\title{
THE INTEGRATION OF CHINESE OPERA TRADITIONS INTO NEW MUSICAL COMPOSITIONS
}

by

SHEN NALIN

Thesis

submitted to the Victoria University of Wellington in fulfilment of the requirements for the degree of Doctor of Philosophy

\section{Volume I: Exegesis}

Victoria University of Wellington 2010 


\section{ABSTRACT}

Almost fifty years ago Chinese composer Chou Wen-chung proposed a musical "re-merger" of East and West. For many Chinese composers of today a sense of historical continuity and an awareness of inherited musical traditions are important contributor to cultural identity, and a basis on which to build the future. The generation that emerged after the Cultural Revolution found new freedoms, and has become, at the beginning of the twentyfirst century, a significant presence on the international musical stage, as the paradigm shifts away from being European-centered, to a culture belonging to the "global village".

As with many other Chinese composers of my generation, the creation of new compositions is both a personal expression and a manifestation of cultural roots. Techniques of "integration" and "translation" of musical elements derived from traditional Chinese music and music-theatre are a part of my musical practice. The use of traditional Chinese instruments, often in combination with Western instruments, is a no longer a novelty.

The written exegesis examines some of the characteristic elements of xiqùे (戏 曲) (the generic term for all provincial Chinese operas), including dă (打) (percussion - an enlarged interpretation of dă, as found in chuānjù gāoqiāng (川剧高腔) Sichuan gāoqiān opera), bănqiāng (板 腔) (The musical style that characterizes Chinese xiqü̆), and niànbái (念 白) (recitation and dialogue), as well as the kuàibănshū (快板书) (storytelling with percussion) of qüỳi (曲 艺) (a term to use to include all folk genres), and shāngē (山 歌) (mountain song). The techniques employed in integrating and translating these elements into original compositions are then analyzed.

In the second volume of the thesis the scores of five compositions are presented, four of the five works are set in Chinese, exploring the dramatic aspects of language, and may be considered music-theatre, one being an opera scene intended for stage production. 


\section{Acknowledgments}

First and foremost, I acknowledge my debt of gratitude to my principal supervisor Jack Body for his patient guidance and unstinting encouragement in all aspects of my study, including the composition of my works, the arranging of performances, and the writing of this thesis, particularly for proper English usage. His insights and understanding of the relationship between Western and Asian musical traditions have been a profound influence on my own musical thinking.

My heartfelt thanks also to Greer Garden, whose meticulous attention to detail and expert advice about the arrangement of material, layout and presentation have been critical in bringing this thesis to its final form.

In the developing my ideas about composition I acknowledge the wise advice of composers John Psathas and Ross Harris, the latter particularly for his knowledge of opera composition and for the study we made together of Alban Berg's Wozzeck.

Duncan Campbell gave me invaluable help as I assembled the libretto of Fatal Desire, by providing me with access to his collection of materials relating to the poet $\mathrm{Gu}$ Cheng, and with his sympathetic English translation of the Chinese text of the Scene of the First Night. I am also indebted to $\mathrm{Gu}$ Xiang, who gave permission to use $\mathrm{Gu}$ Cheng's poems and writings, and supplied me with recordings of Gu Cheng.

Throughout my study I have been helped by numerous NZ School of Music staff besides those mentioned above, but special thanks are reserved for Roy Carr for his expertise in sound and video documentation. I have also received help from many Chinese friends and colleagues who have answered my queries and provided me with important research materials. My great thanks go to Gao Weijie, Tan Dun, Qu Xiaosong, Guo Wenjing, Jia Daqun, Tian Gang and Chang Yingzhong.

I have been privileged to have worked with outstanding musicians and artists for performances of my compositions, including The Song Company of Sydney directed by 
Roland Peelman, the Chinese Music Virtuosi of Hong Kong, the Contemporary Music Ensemble Korea, and the dedicated singers, musicians and production team who collaborated for the realisation of my operatic scene from Fatal Desire.

Completing my composition portfolio and thesis has been a long journey which would have been an impossible undertaking without the significant financial assistance of a Victoria University of Wellington Postgraduate Scholarship for $\mathrm{PhD}$ study, and a Top Achiever Doctoral Scholarship from the New Zealand Tertiary Education Commission. I also had great help from the NZ School of Music to undertake research in Australia and China and the final six months of the writing of this thesis was assisted by a Doctoral Completion grant.

Last but not least, I am eternally grateful to my wife Mingming, and three lovely sons, Brian, Daniel and Frank, for their long-suffering patience and support, without which this thesis and composition portfolio could never even have been begun, much less completed.

Thanks to the following performers of my music:

\section{Xià Sìchuān (下四川) Going Down to Sichuan Province}

The Song Company (Sydney), artistic director Roland Peelman 2010 tour of China: Hangzhou, Suzhou, and Beijing 2011 tour of Australia: Brisbane, Canberra, Wollongong, Sydney, Newcastle and Melbourne

Anna Fraser, soprano

Nicole Thomson, soprano

Lanneke Wallace-Wells, mezzo-soprano

Richard Blank, tenor

Mark Donnelly, baritone

Clive Birch, bass

\section{Wăngēe (輓 歌) Elegy}

Vita Brevis Concert

St Mary of Angels Church, Wellington 
November 26, 2005

Yono Soekarno, gender

Wang Xingxing, zhēng

Robert Easting, voice

Shen Nalin, voice

also

Hunter Council Chamber, Victoria University of Wellington

April 14, 2009

Budi Putra, gender

Wang Xingxing, zhèng

Jack Body, voice

Shen Nalin, voice

\section{Wang}

World Music Days, International Symposium and Festival Dialogue in Music November 1- 4, 2009

The Central Conservatory of Music, Beijing

November 1, 2009, CCOM Recital Hall

Horomona Horo, nguru, kōauau kōiwi, tumutumu, pūkāea and haka

Cui Yanlin, bonang

Liu Jing, zhèng

Zhang Yuwen, saron

Huang Yuting, shēng

Chen Shubo, tenor

Wei Yunxi, soprano

Wang Yang, mezzo-soprano

Wang Yunpeng, baritone

Shen Nalin, conductor

Jiǔ Dé Sòng (酒德颂) Hymn to the Virtue of Wine

Zuì (醉) Drunkenness

Performances in the Project Liù Yingshì (六隐士) Six Hermits

Artistic director, Roland Peelman

The Song Company and the Chinese Music Virtuosi

October 26, 2002, Sydney Conservatorium of Music

October 27, 2002, Riverside Theatres, Parramatta

October 30. 2002, St Paul's Cathedral, Melbourne

November 2, 2006, Loke Yew Hall, University of Hong Kong

Clive Birch, bass

Richard Blank, tenor 
Mark Donnelly, baritone

Ruth Kilpatrick, soprano

Nicole Thomson, soprano

Sze-wang Loo, húqin

Hiu-hung Ng, zhèng

Lok-ting Wong, shēng

Shen Nalin, vocal (Australia only)

Roland Peelman, conductor

\section{Chüyè (初 夜) Scene of the First Night}

Asia Pacific Festival Production, 2007

Te Whaea, National School of Dance and Drama, Wellington

February 12 and 14, 2007

Sara Brodie, director

Gao Ping, conductor

Andrew Brettell, audio-visual designer

Tamsin Lakeman, lighting designer

Judy Huo, costume designer

Laurence Walls, producer

Linden Loader, mezzo-soprano

Wang Xingxing, soprano

James Meng, tenor

Daniel Shen, boy soprano

Contemporary Music Ensemble Korea:

Yi Ji-young, gayageum

Kim Woong-seung, daegeum

Park Chi-wan, piri

Lee Hyang-hee, saenghwang

Kim Woo-jae, guitar

Kim Woong-sik, Korean percussion

Rhee Kyu-bong, Western percussion

Lim Myoung-jin, clarinet

Park Jeung-min, violoncello 


\section{TABLE OF CONTENTS}

Abstract /ii

Acknowledgments /iii

Table of Contents /vii

Volume I: Exegesis

Preface

Background of My Experience in Theatrical Performance /1-5

1 Introduction /6-19

1.1 West-East/East-West /6

1.2 New Chinese Opera /10

1.3 Inspirations for My Musical Creativity: Philosophical Considerations /14

1.4 The Language of the Libretto /15

1.5 Musical "Transcription", “Translation" and "Integration" /16

2 The Sìgōng (四 功) (Four Skills) of Traditional Chinese Xiqü (戏 曲) and Their Wider Application /20-38

2.1 Introduction $/ 20$

2.2 The Skills Sìgōng (四 功) for Chinese Xiqü̆ (戏 曲) Original Concept /22

2.2.1 Chàng (唱) (Singing) /22

2.2.2 Niàn (念) Non-singing vocalizations - (recitation and dialogue) /23

2.2.3 Zuò (做) (Actions or Postures) /25

2.2.4 Dă (打) (Acrobatics) /27

2.3 The Expanded Concept of Sìgōng for the Performance of Chinese Xiqü̈ /28

2.3.1 The Impact of Niàn on the Structure of the Script $/ 28$

2.3.2 Redefining Chàng, Niàn, Zuò, and Dă as Fundamental Principles of Xiqü̆ 
Performance $/ 33$

2.3.3 An Enlarged Interpretation of Dă, as Found in Chuānjù Gāoqiāng /34

2.3.4 Niàn: text -composition and performance $/ 35$

2.3.5 Chàng: music - composition and performance (vocal and instrumental) /35

2.3.6 Zuò: production - stagecraft, action, design (lighting, makeup, costume) /36

2.3.7 Dă: presentation - acrobatics, percussion, production /36

\section{Regional Qǘyì (曲 艺) (Folk Genre) and Chuānjǜ (川 剧) (Sichuan Opera) /39-54}

\subsection{Introduction /39}

\subsection{The Categories of Chuānjǜ (川 剧) (Sichuan Opera) /41}

3.2.1 Chuānjǜ Gāoqiān (川剧高腔) (Sichuan Gāoqiān Opera) with Bāng, Dă and Chàng /42

3.2.2 Chuānjǜ Húqínxì (川剧胡琴戏) (Chuānjǜ Húqín Opera) /44

3.2.3 Chuānjǜ Tánxì (川剧弹戏) (Chuānjù̀ Tán Opera) /45

3.2.4 Chuānjǜ Kūnqiāng (川剧昆腔) (Chuānjü Kūn Opera) /46

3.2.5 Chuānjǜ Huādēngxì (川剧花灯戏) (Chuānjǜ Huādēng Opera) /46

\subsection{Kuàibănshū (快板书) and Shuōshü (说 书) (Folk Storytelling) as Categories} of Qü̈y (曲 艺) /47

3.3.1 Kuàibănshū (Storytelling with Percussion) /47

3.3.2 Shuōshū (Storytelling) /48

\subsection{The Musical Categories of Chinese Xiq $\ddot{\ddot{u}} / 48$}

3.4.1 Qüpái Ti (曲牌体) (Suite Form of Chinese Xiqü) /49

3.4.2 Bănqiāng $T \check{~}$ (板腔体) (A System of Theatrical Musical Forms of Chinese Xiqü) /51

\subsection{Yuèjù̀ (越 剧) (Yuè Opera) /52}

\section{New Compositions (1) /54-117}

\subsection{Introduction $/ 54$}

4.2 Xià Sìchuān (下四川) Going Down to Sichuan Province (for vocal ensemble) /54 4.2.1 Introduction /54

4.2.2 Analysis Shāngē (山 歌) of Going to Sìchuan Province the Transcription of Li Guizhou Performance /59

4.2.3 New Composition: Going Down to Sichuan Province /63

4.2.4 The Structure of Going Down to Sichuan Province /66

4.3 Wăngē (輓 歌) Elegy - for zhēng, gender and voices /72-76 
4.4 Wang - for shèng, zhèng, saron, bonang, vocal quartet and taonga puoro /77-89

4.4.1 The "Non-Text" Concept of Wang /77

4.4.2 The Musical Structure and the Themes of Wang /79

4.4.3 Potential Interpretations of the Meaning of Wang /80

4.4.4 Musical Analysis of Wang /82

4.5 Analysis of Zuì (醉) Drunkeness and Jiǔ Dé Sòng (酒德颂)

Hymn to the Virtue of Wine /90

4.5.1 Introduction $/ 90$

4.5.2 Composition I: Drunkenness - for zhēng solo /92

4.5.3 Composition II: Hymn to the Virtue of Wine (for five singers, zhēng, shēng and two húqín) $/ 97$

4.5.3.1 The Structure of Hymn to the Virtue of Wine/99

4.5.3.2 The Concept of Word Setting in Hymn to the Virtue of Wine /100

4.5.3.3 The Integration of Chuānjù̀ - Niàn, Chàng, Zuò and Dă into

Hymn to the Virtue of Wine /101

4.5.3.4 Analysis of the Music of Hymn to the Virtue of Wine /104

4.5.3.5 Conclusion /116

\section{New Compositions (2)/118-172}

\subsection{Historical Origins of the Opera Zhìmìng de Yùwàng (致命的欲望)} Fatal Desire /118

\subsection{The Libretto /119}

5.2.1 The Novel Ying'er (英儿) The Kingdom of Daughters and

Other Materials / 119

5.2.2 The Arrangement of the Libretto /121

5.2.3 The Structure of the Libretto / 123

5.2.4 The Dramatization of the Libretto /123

5.2.5 The Scenes of the Opera /126

5.2.6 Appendices /129

5.2.6.1 The Story of the Novel Ying'er /129

5.2.6.2 Fatal Desire (Synopsis) /129

\subsection{The Musical Concept /132}

5.3.1 The Musical Inspiration for the Opera /132

5.3.2 The Musico-Dramatic Structure of the Opera /136

5.3.3 The Characters, Motives and Recitation style of the Opera /137

5.3.3.1 The Character, Motives and Recitation Style of Ying'er /137

5.3.3.2 The Character, Motives and Recitation Style of Lei Mi /138

5.3.3.3 The Character, Motives and Recitation Style of Cheng (A \& B) /139

5.3.4 Instruments and Orchestration of the Opera /141

\subsection{Analysis of Chüyè (初 夜) Scene of the First Night /143}

5.4.1 The Concept of Integration as Applied in Scene of the First Night /143 5.4.1.1 Rhythmic Percussive Elements from Qüỳ̀ and Xijù /143 
5.4.1.1.1 Kuàibănshū in Scene of the First Night /144

5.4.1.1.2 Gúnchui Rhythm in Scene of the First Night /146

5.4.1.1.3 Percussion in Scene of the First Night /150

5.4.1.2 Recitation Elements from Qüyì and Xijü /152

5.4.1.3 Material from Plainsong /156

5.4.2 Use of Leitmotifs in Scene of the First Night /158

5.4.2.1 Leitmotif of Ying'er /158

5.4.2.2 Leitmotif of Lei Mi /159

5.4.2.3 Leitmotif of Cheng / 162

5.4.3 Leitmotifs in the Dramaturgical Context of Scene of the First Night /164

5.5 The Stage Production of Scene of the First Night, Asia Pacific

Festival, $2007 / 169$

6 Conclusion /174-177

7 Glossary of Chinese Musical Terms /178-191

8 Bibliography /192-199

9 Appendices $/ 200-217$

9.1 Libretto of the Scene of the First Night in English /200

9.2 Libretto of the Scene of the First Night in Chinese /206

9.3 Asia Pacific Festival Review: Asia-Pacific Music-Theatre /212

9.4 Pīnyīn $/ 216$ 


\section{Volume II: A Portfolio of Compositions}

10 The Scores /217-348

10.1 Xià Sìchuān (下四川) Going Down to Sichuan Province /218

10.2 Wăngēe (輓 歌) Elegy /223

10.3 Wang /231

10.4 Jiǔ Dé Sòng (酒德颂) Hymn to the Virtue of Wine /248

10.4 .1 Zuì (醉) Drunkenness /272

10.5 Chüyè (初 夜) Scene of the First Night $/ 275$

\section{CDs \& DVD}

\section{Audio (I)}

1. Xià Sìchuān (下四川) Going Down to Sichuan Province /6'22”

(The recording was made for the Song Company by Matthew McGuigan and Jacob Craig at the Hunter Baillie Church Hall, Sydney, August 2010)

a. Original Shāngē (山 歌) of Going to Sichuan Province by Li Guizhou 12 '50"

(Studio recording by Roy Carr, 1998)

2. Wăngē (輓 歌) Elegy /8'42”

(Live recording by Roy Carr, November 2005, Church of St Mary of Angels, Wellington)

3. Wang /16'05'

(Live recording by the Musicology Department of the Central Conservatory of Music, November 2009)

4. Jiǔ Dé Sòng (酒德颂) Hymn to the Virtue of Wine /13'38" (including recitation)

a. Zuì (醉) Drunkenness /2'10" (including recitation)

(Live recording was from Sydney Conservatorium, October 2002. Produced by Malcolm Batty for ABC Classic FMABC Radio National, Australia)

\section{Audio (II)}

5. Chüyè (初 夜) Scene of the First Night (9 individual tracks) /42'56"

(Live recording at Te Whaea, National Dance and Drama Centre by Roy Carr, February 2007) 


\section{Video}

1.Wăngē (輓 歌) Elegy /8'42”

(Domestic recording by Brian Shen, in Hunter Council Chamber VUW, April 2009)

2. Wang $/ 16$ ' $05^{\prime \prime}$

(Live recording by the Musicology Department of the Central Conservatory of Music, November 2009)

3. Chüyè (初 夜) Scene of the First Night /42'56"

(Live recording at Te Whaea, National Dance and Drama Centre by Paul Wolffram, February 2007) 


\section{Preface}

\section{Background of My Experience in Theatrical Performance}

I was brought up in Gulin county of

Sichuan province. In the 1970 s, during the Cultural Revolution, I worked in a performing group, Gǔlìn xiàn gémingwěiyuánhuì Măo Zědōng sīxiăng xü̈̄nchuándui (古藏县革命委员会毛泽东思想宣 传队) (Mao Zedong's Thought Propaganda Troupe of Gulin County), later renamed Gǔlìn xiàn wényì gōngzuòtuán (古落县文艺工作团) (The Song and Dance Troupe of Gulin County). When I joined, in 1972, I was 14 years old, the youngest member of the troupe. In the troupe I had opportunities to learn many new skills, and play many different roles hángdang (行当). I learned dance, Sichuan opera acrobatic skills, acting, and musical instruments including the percussion of Sichuan opera.
Because the clarinettist moved away, I was offered the chance to play this instrument and also encouraged to compose songs for the troupe.

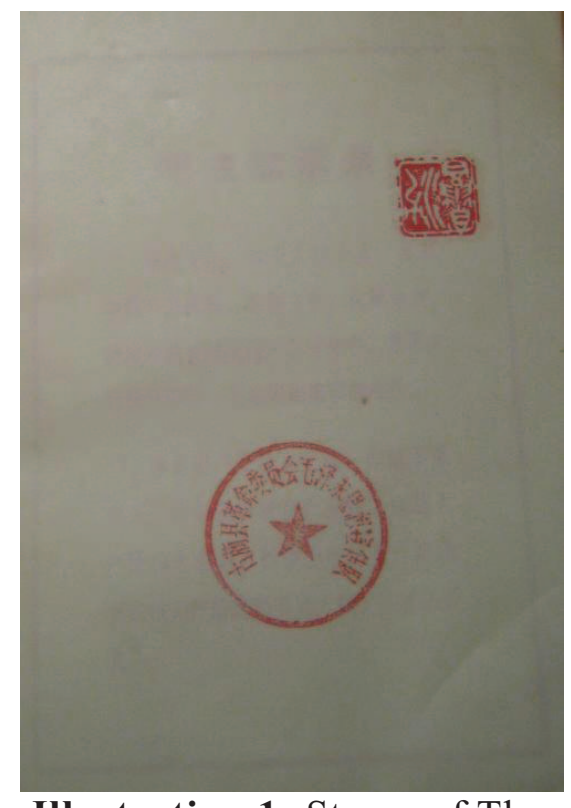

Illustration 1: Stamp of The Song and Dance Troupe of Gulin County

On stage I first played the part of hóng xiăogul̆(红小鬼) (Little Red Devil), in a song and dance sequence entitled Revolutionary Historical Songs. I had to teach myself the clarinet since there was no teacher or instruction book. After six months I was able to perform some popular solo pieces, such as The Joy of a Female Soldier from the ballet The Red Detachment of Women, and Good News from Beijing has come to a Frontier 
Village. As required by Chairman Mao's dictum that literature and art must serve the workers, peasants and soldiers, our performance troupe toured the countryside, factories and army camps for six months every year. I was well-known as a "foreign Suona" (Yáng suǒnà 洋唢呐 i.e. clarinet) player. Then I became interested in composition and taught myself harmony from a Russian text book (translated into Chinese) that had been copied out by hand.

I also participated in excerpts from Gémìng yàngbănxì (革命样板戏) (The Revolutionary Model Plays). These "plays", which included five Beijing Opera two ballets and a symphony ${ }^{1}$, were the only theatrical performances officially permitted and were performed throughout the country during the years of the Cultural Revolution (1966-1976). Our troupe presented excerpts from Hăi

\footnotetext{
1 “The Eight Revolutionary Model Plays" were a series of government-sponsored performances in Beijing for the $25^{\text {th }}$ anniversary celebration of the glorious work, "A Speech of the Yan" an-Literature Symposium" by Mao Zedong. A total of 218 performances over 35 days was watched by a total audience of nearly 330,000 . The

"Eight Revolutionary Model Plays" included five Beijing operas (The Legend of Red Lantern, The Sparks in the Reed Marshes, Takeover by Strategy of Mount Tiger, Raid the White-Tiger Regiment and On the Docks), two ballets (The Red Detachment of Women and White-Haired Girl), and a symphony, The Sparks in the Reed Marshes. Cf. The Xinhua New Agency, A Series of Performances of The "Eight Revolutionary Model Plays" in Beijing, People's Journal, 17/6/ 1967, available from http://news.sina.com.cn/c/144484.html; accessed, 16 July 2010. My translation.
}

Găng (海 港) On the Docks, Shā Jiā

Bāng (沙家浜) The Sparks in the Reed

Marshes, Hǒng Dēng Jì (红灯记) The

Legend of Red Lantern, Zhìqü Wēi-

hǔshān (智取威虎山) Takeover by

Strategy of Mount Tiger, Báimăo Nǚ (白

毛女) The White-Haired Girl and

Hóngsè Niángzijün (红色娘子军) The Red

Detachment of Women.

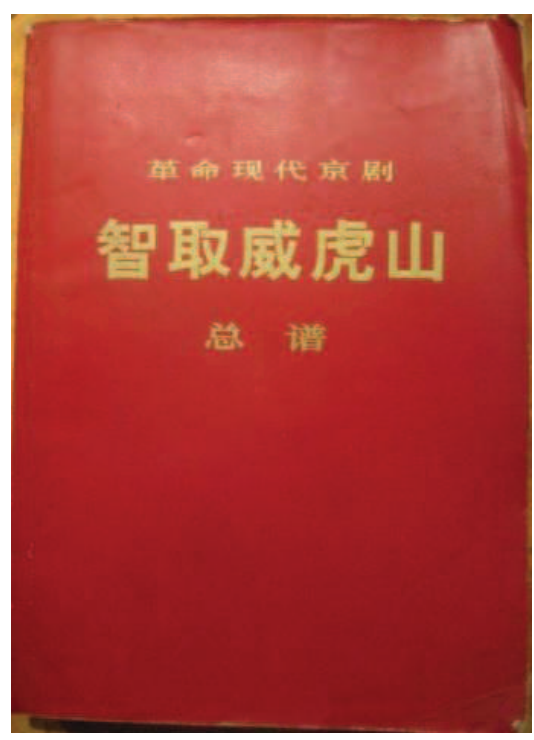

Illustration 2: Full orchestra score of Takeover by Strategy of Mount Tiger 
Later on some other revolutionary works were introduced into the repertoire: there were two Gémìng xiàndài jīngjù̀ (革命现代京剧) (The Modern Revolutionary Beijing Opera) Lóngjiāng Sòng (龙江颂) Ode to Dragon River and Dùjüān Shān (杜鹃山) Mountain Dujuan, and two Gémìng Xiàndài Gejjù̀ (革命现代歌剧) (The Modern Revolutionary Opera) Jiāngjiě (江 姐) Sister Jiang and Hnónghú Chìwèiduì (红湖赤 卫队) The Red Guards on Lake Hong.

With several critical co-related events happening in quick succession in 1976, namely the death of Mao Zedong, the downfall of "The Gang of Four" and the end of the Cultural Revolution, China entered a new era. In the subsequent campaign of Bōluàn Fănzheg (拨乱反正) (bringing order out of chaos) our Song and Dance Troupe of Gulin County took over Gǔlìn Xiàn Chuānjütuán (古萄县 川剧团) (The Gulin County Sichuan Opera Troupe). This expansion provided new personnel and increased our repertoire to include Sichuan Opera. In the following years, many new programmes were created and performed, such as Biānjìng Qindi (边境擒敌) Capturing the Enemy at the Border, Zhuì Bàobiăo (追报 表) Take back the Report Forms. Traditional Chuānjǜ Sichuan Opera material was also performed, such as Sȟ̌wǔ Guàn (十五贯) Fifteen Strings of Coins, Liǔ Yōn $J i$ (柳荫记》Story in the Shade of a Willow, Kăo Hóng (考红) Questions on
Lady Hong, and Sānchā Kǒu (三岔口) At the Cross Roads.

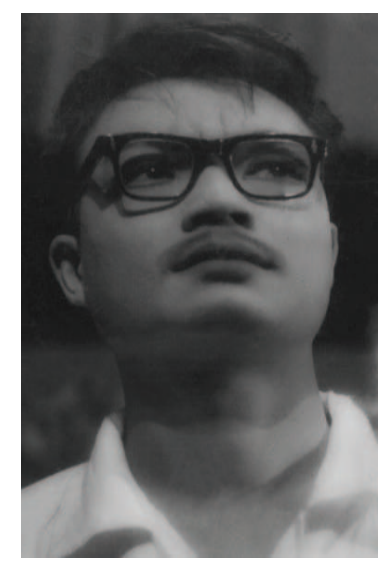

Illustration 3: Protagonist role in From the Silent Quarter

1976-1980 was a time of significant social and political change. Having learned percussion in Sichuan Opera from a traditional master of percussion for a few years, I was assigned a new role in the troupe, in 1977, one of the popular ironical comedies designed to express the public"s indignation towards the Gang of Four. I played the main character in Fēngyè Hóngle de Shíhou (枫叶红了的时 候) When the Maple Leaves Turn Red.In 1978, another popular play Yǘ Wú Shēng 
Chù (于无声处) From the Silent Quarter, it was raised an enthusiastic theatrical response across the country, with 2700 troupes performing this play, I played the protagonist role: Hewei (何为) for our troupe. Then, for the first time we presented a love story of folk opera Liǔ Sānjiě (刘三姐) Third Sister Liu, as well as premiering a new opera Lúshēng Qü (芦笙曲) Song of The Mouth-organ, for which the libretto and music were composed by a group from the Dance and Song Troupe; I was one of the composers.

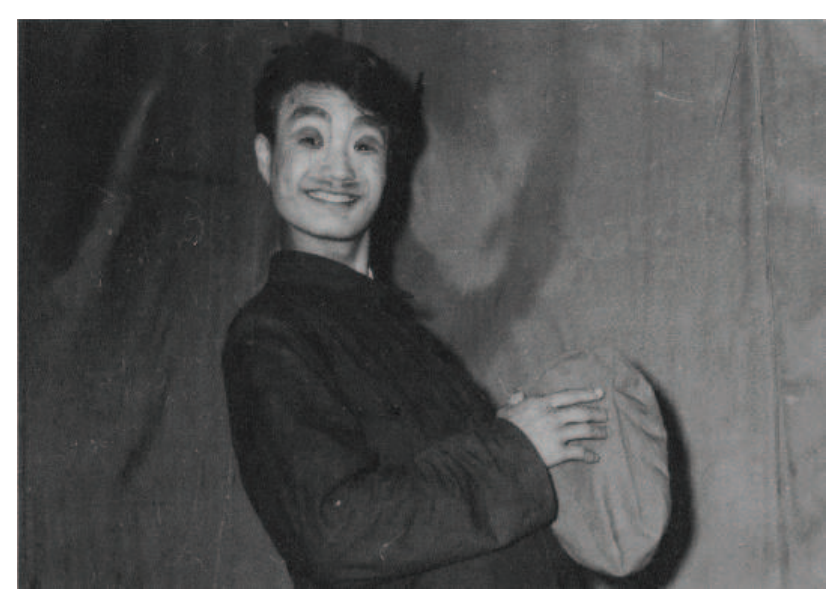

Illustration 4: Protagonist role in When the Maple Leaves Turn Red

After the Song and Dance Troupe of Gulin County was disbanded in 1980, I joined the Song and Dance Troupe of Zigong City where I had three years formal training in acting from Ms Lin Fen 林芬. Lin was a graduate of the Central Academy of Drama in Beijing (now the Central University of Drama). She not only taught us Chinese opera, but also the theory of Western drama, including Bertolt Brecht, and Constantin Sergeyevich Stanislavski, two of most innovative and influential figures in twentieth century Western

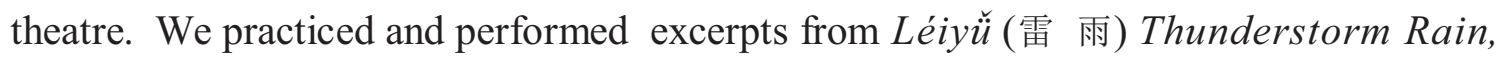
Lóumǐōu Yü Zhūlìyè (罗密欧与朱丽叶) Romeo \& Juliet, with a complete production of Píngguŏ Shùxià (苹果树下) Under the Apple Tree, Yìshuāng Xiùhuāx Xié (一双绣 花鞋) A Pair of Embroidered Shoes, and Pingfă Rénjiāa (平凡人家) The Common Family. During this time I continued to study composition and harmony by myself, and also had lessons on piano. After these three years, with the approval of the Zigong Song

\footnotetext{
${ }^{2}$ Lin Fen 林芬, a lecturer in Acting at the Hebei Institute of Communication.
} 
and Dance Troupe, I entered Sichuan Conservatory of Music having passed their entrance examination in 1982.

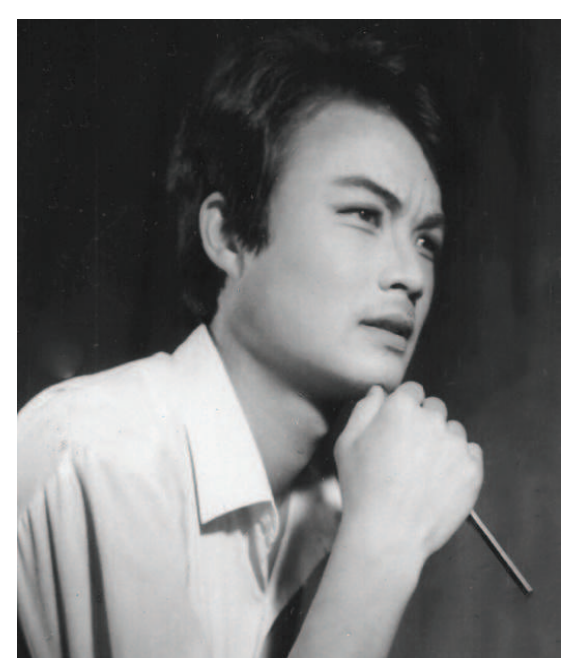

Illustration 5: Protagonist role in The Common Family

My ten years of practical experience laid a solid foundation for my knowledge of Chinese music and theatre. This experience informs my $\mathrm{PhD}$ thesis, especially concerning Beijing opera and Sichuan opera, in both theory and practice. 


\section{Introduction}

\subsection{West-East/East-West ${ }^{3}$}

The history of China's social and cultural contacts with the West stretches back many centuries. Western classical music was first heard in China when Matteo Ricci ${ }^{4}$ gave Emperor Shenzong 神宗 (Wanli 万 历 1563 -1620) a clavichord as a present and composed eight songs in Chinese which he sang in the presence of the court in $1601 . .^{5}$ "Western music was spread through the growing number of missionaries who came to China and by the foreigners who settled in the so-called "treaty ports" that China was forced to create after the first Opium War in 1839". ${ }^{6}$

However, it was only in the early twentieth century that Chinese musicians began to explore Western musical instruments and Western compositional techniques. Composers travelled overseas for musical study, first to Japan and later to Europe and the United States. ${ }^{7}$ This direct contact with Western musical practice equipped Chinese composers

\footnotetext{
${ }^{3}$ This Introduction looks back on both "West-East and East-West" musical influences. West-East focusses on the early time of Western influences on the musical history of China.

4 "He was born in Macerata, Italy, on 6 Oct 1552, and began his studies in a Jesuit school in 1561. In 1578, he left from Lisbon to travel to Goa, on the coast of India. He was ordained a priest in 1582 and left for Macao in China, where the Jesuits had hoped to evangelize from the moment of their foundation in 1534. In 1589, he was transferred to Shao Zhou, in the Province of Guang Dong, leaving two years later for Beijing." Cf. http://www.newsahead.com/preview/2010/05/11/beijing--rome-11-may-2010-catholics-mark-400thanniversary-of-jesuit-matteo-ricci/index.php: accessed Friday, 24 September 2010.
}

${ }^{5}$ Yves Camus SJ, “Matteo Ricci”s legacy: a loving patience”, Journal of British Jesuits, 11 May, 2010, available from http://www.thinkingfaith.org/articles/20100511_1.htm: accessed, 24 September 2010. Cf. also Zhang Xiping 张西平, Following the Steps of Matteo Ricci to China, translation by Ding Deshu \& Ye Jinping, Beijijng: Wuzhou Chuanbo Chubanshe. 2006. pp. 17-20.

${ }^{6}$ Sheila Melvin and Jingdong Cai, "Finding The Right Note: How China Made Western Classical Music its Own", 2004. Available from http: //www.btmbeijing.com/contents/en/btm/2004-08/art/music; accessed Friday, 24 September 2010.

7 “In 1902 Shen Gongxin (1876 - 1947) studied at the Tokyo Hong College. He returned to China 1903 and taught at the Premiere School Nányáng gōngxué füshǔ xiăoxué 南洋公学附属小学 attached to Nanyang College, where he founded the "Song-School", a course in group singing, the earliest such institutionalized music tuition by a Chinese. Xiao Youmei (1884 - 1940) became the first Chinese musician to gain a PhD in music (from the Royal Conservatory of Music in Leipzig, Germany). On returning to Beijing in 1920 he founded the Music department of Beijing High Normal Girls College, and the following year became Dean of the 
with the musical techniques and concepts that enabled them to forge a national music that could speak to an international as well as Chinese audience, in sympathy with the emerging currents of Chinese nationalism. Some foreign musicians who lived and worked in China also had a significant impact on Western style music in China, through their compositions and through their teaching. ${ }^{8}$

During the twentieth century, Western music underwent extraordinary transformations of styles, techniques and aesthetics. The impact of these changes was not felt in China until after the Cultural Revolution (1966-1976), with the opening up to the West after the death of Mao Zedong. Schools and universities reopened. Foreign books, fiction and non-fiction, were translated into Chinese. Among these was Peter S. Hansen"s Introduction to Twentieth Century Music, translated ${ }^{9}$ by Meng Xianfu 孟宪福, a book that gave an insight into the multiplicity of new musical styles and techniques, information that fired the imagination of

faculty of Training Institute of Music attached to Beijing University. ${ }^{7}$ Here he conducted the School"s or-

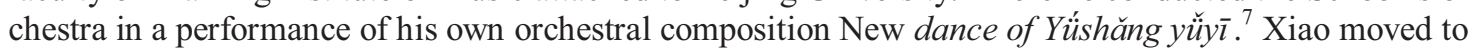
Shanghai and helped found the nation"s first conservatory in 1927. Huang Zi 黄 自 (1904 - 1938) studied music in the United States from 1924, at Oberlin and Yale, where his symphonic work Huáijiù (怀旧) (Reminiscence) was premiered. 1929, he returned to China via Europe, to become Dean of the State Music College of Shanghai. Xian Xinghai 冼星海 (1904 - 1945) studied composition with Paul Dukas in Paris in 1929. He returned to China in 1935, and became Dean of Lu Xun College of Arts in 1939. His most well- known work is the chorus Yellow River, the theme of which was immortalised in the Yellow River Concerto, created by committee during the Cultural Revolution. Ma Sicong 马思聪 (1912 - 1987) became the first Chinese violin student at the Conservatoire de Paris in 1923. He returned to China and established a private conservatory in Guangzhou (with Chen Hong) in 1932, and also as a lecturer in the Century University of Nanjing. In 1949, Ma Sicong was appointed president of the newly established Beijing Central Conservatory of Music until 1967. All information from: Lu Ji 吕 骥 \& Wu Xiaobang 吴晓邦 (et al, ed.), The Great Encyclopaedia of China, Dance and Music Volume, Beijing \& Shanghai: The Great Encyclopaedia of China Press, 1989. (My summary and translation of pp. 578, 745, 284, 278, 422).

${ }^{8}$ Foreign musicians who lived and worked in China also had a significant impact on Western-styled music in China, through their compositions and through their teaching. Most importantly, "In 1934, Russian composer and pianist Alexander Tcherepnin came to Shanghai from Paris as a consultant to the Ministry of Education. In order to encourage the development of new Chinese music, Tcherepnin organized a competition for piano compositions that used both Western and Chinese styles (cf. Huang Xiaohe 黄晓和, “Qiellepunin” The Great Encyclopaedia of China, Dance and Music Volume, p. 526). Russian composer Aaron Avshalomov (18941965) lived 30 years in China from 1918. Besides composing he studied classical Chinese music and worked to create a synthesis of Chinese musical elements and Western techniques of orchestral composition. (Cf. Wang Peiyuan 汪培元. “Afuxialoumufu”, The Great Encyclopaedia of China, Dance and Music Volume, p. 3. (My translation).

${ }^{9}$ Peter S. Hansen, An Introduction to Twentieth Century Music (Fourth edition), Boston: Allyn and Bacon, Inc, 1978. Chinese translated by Meng Xianfu 孟宪福. Èrshí Shìjì Yīnyuè Gàilùn 二十世纪音乐概论, Beijing: Renmin Yinyue Chubanshe, Vol. 1 was first printed in 1981 and Vol. 2 in 1986. 
Chinese composers. "(Music in) the first half of twentieth century has as many shifting patterns and designs as a kaleidoscope". ${ }^{10}$

The many compositional methods and styles of $20^{\text {th }}$-century music which appeared separate and distinct from one another are being synthesized in new ways in the $21^{\text {st }}$ - century. Applicable to this situation, a well known Ming dynasty author Lou Guanzhong 罗贯中 (ca.1330-1400) proposed a general principle which has relevance today: "Separation occurs after a long period of unity, and vice versa; synthesis after a long period of differentiation”. (分久必合，合久必分). ${ }^{11}$ As prominent Chinese composer Tan Dun remarked, “I think that the huge shakeup of the $21^{\text {st }}$-century will be in the blend of East and West. It won't be superficial, as it was before. It will be a true blending of concepts. [...] Now is being created a new concept with the power to change the world". ${ }^{12}$

This "blend" of East and West has become a significant feature of art music in the latter part of the twentieth century, a movement that developed in two directions, ${ }^{13}$ from the West to the East, and from the East to West, producing a blending of ideas and aesthetics, musical instruments and musical materials.

An early promoter of this concept and someone who influenced Tan Dun's generation was composer Chou Wen-chung (b.1923) who left China in 1946 to study in the US, notably at Columbia University where he became an influential member of the faculty in 1964. In his 1971 article "Asian Concepts and Twentieth Century Composers" Chou comments on the growing fascination of Western composers with the music of Asia:

\footnotetext{
${ }^{10}$ Peter S. Hansen, An Introduction to Twentieth Century Music, Preface.

${ }^{11}$ Luo Guanzhong 罗贯中(ac.1330-1400), (Romantic of the Three Kingdoms) 《三国演义》, Beijing : Renmin Wenxue Chubanshe, 1973.

${ }^{12}$ Chen Yanni 陈燕妮, Chen Yanni cáifănglù 陈燕妮采访录: Zāoyù Méigóu 遭遇美国: Tan Dun 谭盾, (“Meeting in with in America: Tan Dun”), Beijing : Zhongguo she hui chu ban she, 1997. p. 21. My translation.
${ }^{13}$ A discussion of the twentieth century interaction between East and West is presented in Frederick Lau"s chapter, "Fusion or Fission The Practice and Politics of Contemporary Chinese Avant-Garde Music" Locat- ing East Asia in Western Art Music. Edited by Yayoi, Uno Everett and Frederick Lau. (Music / Culture) Middletown, CT: Wesleyan University Press, 2004, pp. 22-39. In his consideration of composers, Lau"s focus as in the present thesis is on Chinese composers.
} 
But as we approach the last quarter of our century, more and more on-going events and new perspectives on things past point to the thesis that Asian music has now re-emerged as an influence of growing significance on the development of Western music. The turning point took place almost a century ago. [...] Debussy"s awareness of the values in Asian music was phenomenal, particularly in view of the fact that Asian instruments were still being caricatured as "instruments of torture." [...] Similarly, the sonority that is largely the admixture of a melodic, rhythmic, registral and timbral variants of a single linear movement is a prominent characteristic of the Debussian orchestra.

Chou then discusses "certain Eastern concepts" in the music of Webern and Varèse, but highlights the impact of Asian music and philosophy on the music of Messiaen and of the Americans, Henry Cowell and John Cage:

(Cowell) advocated "world music," firmly believing in a synthesis of East and West; indeed, his early use of tone clusters and his exploration of tone qualities to be obtained inside the piano may have been the result of his early exposure to Asian music. [...] (Cage"s) most important work for prepared piano, Sonatas and Preludes (1946-48), is "an attempt to express in music the "permanent emotions" of Indian tradition." [...] Cage later turned his attention to I Ching and Zen and evolved the chance operations that he first used in 1951 in Music of Changes and Imaginary Landscapes No. 4. [...] Even more intriguing is Messiaen"s penchant for verbal imagery in prescribing the character of his rhythmic, melodic, harmonic, and timbral ideas. This not only echoes the Indian concept of rasa, but also finds a distant precedent in the Chinese Ch'in music. [...] Messiaen"s thinking and teaching must be regarded as another major step forward in the integration of Western and nonWestern musical concepts and techniques. ${ }^{14}$

In Chou Wen-chung's own compositions he attempted the philosophical and musical synthesis of East and West which he proposed as the path to the future:

Exactly thirty years ago, however, I began to advocate publicly for a "remerge" of eastern and western musical concepts and practices. Subsequently, I talked about the music of tomorrow as an era of confluence, during which different traditions intermingle, or better, interpenetrate to bring forth a new mainstream - a vast expanse of musical currents. ${ }^{15}$

\footnotetext{
${ }^{14}$ Chou Wen-chung, "Asian Concepts and Twentieth Century Composers" The Musical Quarterly, Vol. 57, No. 2 April, 1971, pp. 211-229.

${ }^{15}$ Chou Wen-chung, "Music by Asian Composers", Journal of Music in China, Vol. 1, ISSN 1092-1710, USA: KNI. Incorporated, 1999. p. 112.
} 
Yü Ko (1965) is a transcription by Chou Wen-chung for an ensemble of Western instruments of a Yuan dynasty composition for qin (seven string zither) by Mao Min-chung (c.1280). This "translation" for western instruments of the subtleties of sound articulation that are intrinsic to qin technique produced, in this composition, a work of astonishing freshness. It became a model for other Chinese compositions including Zhou Long's Song of the Ch'in (1982).

Chou's Yün (1969) for winds, two pianos and percussion refers to the Taoist concept of art as "the moment when the universe and the individual merge as one" (tiān rén hé $y \bar{\imath}$ 天人合 -), when the macrocosm and microcosm resonate in sympathy. "The title, Yün, is taken from the expression "ch' $i$ yün," the foremost principle in Chinese art, which means reverberation (yün) of the revitalizing force in nature (ch'i)." The work "revels in the resonances of nature", some audible, others inaudible. Chou quotes Chuang Tzu: "When it cannot be heard by the ear, listen with the mind, when it cannot be heard by the mind, listen through ch'i'. 16

\subsection{New Chinese Opera ${ }^{17}$}

At the close of the twentieth century one of the most dramatic developments on the international musical scene has been the appearance of New Chinese opera, exemplified in the operatic and music-theatre works of such composers as Tan Dun 谭 盾 (b. 1957), Qu Xiaosong 篗小松 (b. 1952) and Guo Wenjing 郭文景 (b.1954). Although China has its own opera traditions that predate the creation of a Western operatic tradition, its formalism discouraged experimentation and the creation of new musical material. The opera Kuan Yin by Russian composer Aaron Avshalomov (1894 - 1965) is possibly the first Western-style opera composed and produced in China, premiered in Peking [Beijing] in 1925. This was

\footnotetext{
${ }^{16}$ Cf. Chou Wen-chung, works: Yün, available from http://www.chouwenchung.org/works/1969_yun.php ; accessed 25 September 2010.

${ }^{17}$ Wang Yuehe 汪毓和, “New Chinese Opera” The Great Encyclopaedia of China, Dance and Music Volume, p.756. My translation.
} 
followed by two further Avshalomov operas, The Twilight Hour of Yan Kuei Fei (1933) and The Great Wall (1933-41). ${ }^{18}$

In China the beginnings of a new tradition of opera composed by Chinese composers is commonly credited to Li Jinhui 黎锦晖 who wrote twelve dance and music theatrical works for performance by children between 1921 - 1929, with titles such as The Birds and Child, and The Little Artist. ${ }^{19}$ However, history records another work which may have been the first new opera by a Chinese composer, High Mountain and Flowing Water by Yan Shushi 阎述诗 composed in 1927, which used a Western style of singing, accompanied by a Chinese instrumental ensemble. ${ }^{20}$ Yan composed five further operas all of which were produced on stage. ${ }^{21}$

The composers of new Chinese opera during the 1930s and 40s drew on many sources for their works:

In large cities such as Shanghai, Chongqing and Yan'an, composers began to explore the operatic genre in such works as Qiüzi(1942) by Huang Luoyuan. [...] At the Communist Lu Xun College of Arts, Yan”an, Xian Xinghai 冼星 海 wrote his opera The March of the People and the Soldiers. Under the influence of Maoist ideology, five composers - Ma Ke 马 可, Zhang Lu 张 鲁, $\mathrm{Qu}$ Wei 翟 维, Xiang Yu 向 隅 and Li Huanzhi 李焕之 - collaborated in composing an landmark operatic work, Báimăo Nü̈ (白毛女) The WhiteHaired Girl, in 1945. This work established a new concept for Chinese opera, based on a western opera model, yet drawing musical material from Chinese folk music and song, and traditional Chinese opera (xìqŭ) $[\ldots]$.

\footnotetext{
${ }^{18}$ Neil W. Levin. "Biography: Aaron Avshalomov", available from http://www.milkenarchive.org/people/view/all/630/Aaron+Avshalomov; accessed 24 September 2010; cf. also David Stabler, "Avshalomov Aaron”, in Grove Music Online Oxford Music Online, http://www.oxfordmusiconline.com/subscriber/article/grove/music/50665; accessed 25 September 2010.

${ }^{19}$ Li Quanmin 李全民, “Li Jinhui” 黎锦晖, The Great Encyclopaedia of China, Volume of Dance and Music, Beijing \& Shanghai: The Great Encyclopaedia of China Press, 1989.My translation.

${ }^{20}$ Xue Zongming 薛宗明, “The history of Western Music in Taiwan”,Yuexun, Vol. 88, June, 1998, pp. 14-17.

${ }^{21}$ Lin Ruilan 凌瑞兰, Àigóu Yīnyuèjiā Yan Shushi 爱国音乐家阎述诗 “Yan Shushi: The Patriotic Musician” Journol: Yuè Fǔ Xìnshēng 乐府新声 of Shenyang Conservatory of Music, Vol. 1, 1988.
} 
After 1949, with the many productions of new opera in China, works may be distinguished as being one of three styles: 1) with elements of music derived from Chinese traditional opera (xìqü), such as Hóngxiá (红 霞) by Zhang Rui, and Hóng Shānhú (红珊瑚) by Wang Xiren and Hu Shiping; 2) with elements of folk vocal and instrument music, such as Hónghú Chìwèidù̀ (洪湖赤卫队) by Zhang Jingan and Ouyang Qianshu, or Jiāngjiě (江 姐) By Jin Sha, Yang Ming and Jiang Chunyang, 3) as following the model of Western opera, such as Ayī Gǔlì (阿依古丽) by Shi Fu and Musi Manjiang. ${ }^{22}$

With the mid-1980s came the "Broken Silence"23 generation of Chinese composers, born during the 1950s, who created new operatic forms that used elements of traditional Chinese opera but with a musical language that was aligned to contemporary Western music of the time. Composers such as Tan Dun, Qu Xiaosong and Guo Wenjing all displayed extraordinary talent and musical skill in using Western compositional techniques, and their operatic works had a dramatic impact on Western audiences, even though Chinese audiences were at first baffled and confused.

Tan Dun says: "My experience is different, my time is different, but the method is very much the same. You get some grounding in traditional music, and then you think imaginatively about things you want to create. Your musical language is new, but it also expands tradition. You look for something that's about the past and the future, and you end up creating yourself." 24 Tan Dun's first opera, Nine Songs, is an abstract, non-narrative "ritual opera". "I took the tones and sounds of Chinese dialects, and the declamatory style of local opera, to compose a kind of vocalizing in between chanting, yelling, speaking, and singing. The vocal line $[\ldots]$ is concerned with the relative space between pitches, of single and multiple voices, and develops single lines into more complex patterns, creating a texture similar to Chinese calligraphy"25. Tan's following operas become more eclectic in their sources.

\footnotetext{
${ }^{22}$ Wang Yuehe 汪敏和, "New Chinese Opera” The Great Encyclopaedia of China, Dance and Music Volume, p. 757. My translation.

${ }^{23}$ Eline Flipse (director), film: Broken Silence, this film presents portraits of five Chinese composers: Tan Dun, Chen Qigang, Guo Wenjing, Mo Wuping, Qu Xiaosong, who grew up during the Cultural Revolution and were stunned by the discovery of Western music after China opened up in the late 70s. Goirle, the Netherland: Scarabee Filma, 1990.
}

${ }^{24}$ Matt Dobkin \& Ken Smith, “Tan Dun Operatic Odyssey (2006), available from http://www.metoperafamily.org/metopera/news/features/detail.aspx?id=1945; accessed 7 September 2010.

${ }^{25}$ Tan Dun, program notes “About the Music: Nine Songs”; sound recording: ritual opera / Tan Dun. New York, NY: CRI, p1990. 
Marco Polo (1996) is considered "a wonderful blend of Peking opera and Chinese folk music, Tibetan overtone singing, Puccini, Stravinsky, Strauss and Mahler's Das Lied von der Erde". ${ }^{26}$

Qu Xiaosong's approach to the medium of opera is quite different from Tan Dun's. His Oedipus (1993), The Death of Oedipus (1994), Life on a String (1998), and The Test (2004) are intimate chamber works, rather than opera on the grand scale of Marco Polo. His Life on a String uses stylish speech (in Sichuan dialect) rather than sung arias, and its presentation is as music-theatre rather than an opera, with all musicians present on stage. The "music is characterized by the power of individual notes and the silence between the sounds, as well as the intention to create elementary emotional resonances with quite reduced musical means". ${ }^{27}$

Guo Wenjing's opera Wolf Cub Village (1994) and The Night of Banquet (1998) both show significant influence of the composer's mother-tongue, Chongqing dialect. Poet Li Bai (2007), which "blends post-modern orchestral atmospherics, traditional Beijing Opera and a dreamy, imaginative libretto that paints an impressionistic portrait of one of China's greatest poets". ${ }^{28}$ His recent chamber opera Feng Yi Ting (2004) uses a tenor from the Beijing opera tradition, and a soprano from the Sichuan tradition, in a theatrical "translation" from a traditional to contemporary opera. His Trilogy of War Heroines began with Mu Guiying (2003), was followed by Hua Mulan (2004), and was completed by Liang Hongyu (2008). "The music in Liang Hongyu is a true melting-pot of Chinese regional operas as performers draw on different traditional and contemporary operatic styles including Sichuan, Kun, Peking, Huangmei, even Cultural Revolution model operas and popular

\footnotetext{
${ }^{26}$ Bas van Putten, "East-West divide disappears in global music culture" (2010), English translation by Hilary Staples, Music Centre The Netherland, available from http://www.muziekcentrumnederland.nl/en/contemporary/in-the-spotlight/east-west/; accessed 18 September 2010.

${ }^{27}$ Martin Wilkening, "Salvation for the Narrator Life on a String - an East-West opera by Qu Xiao-song", translated by Klaus Heiliger, The Zeitgenössische (Contemporary) Opera Berlin. 2001. Available from http:/www.zeitgenoessische-oper.de/english/productions.html; accessed 25 September 2010.

${ }^{28}$ Bob Bows, Review: Poet Li Bai, Available from http://www.variety.com/review/VE1117934133.html; categoryid $=33 \& \mathrm{cs}=1$; accessed 25 September 2010 .
} 
music". 29

As an indication of the international context in which these composers have developed their careers almost all of the works were commissioned and premiered outside of China, even though two of them live and work in China.

\subsection{Inspirations for My Musical Creativity: Philosophical Considerations}

Two ancient Chinese philosophical concepts have been inspirational in my musical development. Laozi (571-472 BC), in the well-known Dàodě Jing 道德经, is attributed as describing universals that may be applied to artistic creation, principles that have strongly influenced Chinese arts throughout history, up to the present time. "One is the child of the divine law. After one come two, after two come three, after three come all things". ${ }^{30}$ According to Laozi's teaching "All things change at all moments. They are all different and even conflicting, but Tao (Dao) transforms and harmonises them and combines them into a unity. It is in this stage - of everything following its own nature and yet all forming a harmonious whole - that happiness and freedom are to be found. Therefore, the ideal man, the "true man", does not allow the way of man to interfere with that of Nature, but becomes a "companion of Nature" and forms a unity with Heaven." 31 For me this "companionship with Nature" is the key to creating coherence in my music, to finding natural and meaningful forms and modes of expression.

\footnotetext{
${ }^{29}$ Trilogy of War Heroines, director and librettist Li Liuyi, was co-commissioned by the New Vision Arts Festival and the Holland Festival 2008. Cf. the New Vision Arts Festival, Hong Kong. Available from http://www.lcsd.gov.hk/CE/CulturalService/FestivalOffice/newvision/2008/en/prog/liang.html; accessed 7 September 2010.

${ }^{30}$ Xu Yuanchong 徐渊冲 (translaiton), 道德经与神仙画, Laws Divine and Huamn and Picturesof Deities, (in Chinese and English). Beijing: China Intercontinental Press, 2006, p. 100.

${ }^{31}$ Chan Wing-tsit, "Chinese Philosophy", The New Encyclopedia Britannica, in 30 Volumes, Macropedia, Volume 4, Chicago: The University of Chicago, Helen Hemingway Benton, Publisher, 1973-74. p. 416.
} 
The ancient philosopher Zi Xia (子夏 507 - 420 BC) (the Spring and Autumn Period 721 481BC, Chūnqiū 春 秋) wrote in his "Poetic Preface": "Poetry is the expression of mind; when in the mind it is will, when spoken it is poetry; feelings stir in the heart, so they have to be expressed in words; where words are insufficient, sighs are heard; when sighs are not sufficient to express them, songs are sung; but what the songs find it hard to convey, hands and feet start to dance irrepressibly; feelings emanate from aspirations, when expressed in composition, they become music". ${ }^{33} \mathrm{Zi} \mathrm{Xia's} \mathrm{concept} \mathrm{has} \mathrm{been} \mathrm{a} \mathrm{guiding} \mathrm{principle} \mathrm{in} \mathrm{my}$ work; music grows from the sound of a text, its meaning, its implications, and the ideas and emotions contained within it.

\subsection{The Language of the Libretto}

Since the first opera Dafne, premiered in 1597 at the home of Jacopo Corsi (d.1604) in Florence, Italian opera has had a dominant position on the world stage. However, as the medium spread, composers were moved to write in their own languages, creating rich traditions of French, German, English and Russian opera. The language of these works carries cultural, historical and contextual associations of cultures from which they come.

All my works included in this thesis use the Chinese language, sung and recited. The text of Scene of the First Night is particularly significant, since it was extracted from the writings of the subject of the opera, the poet Gu Cheng, who refused to learn English: "Gu Cheng had vowed never to learn as he feared learning a foreign language would affect his ability to write"34; "If a Chinese person learns another language," he explained, "he will

\footnotetext{
${ }^{32}$ Cihai 辞海 (Chinese Encyclopaedia), Shanghai: Shanghai Cishu Press, 1980, Literature Volume, p.115.

${ }^{33}$ Zi Xia 子夏, Poetic Preface, English translation by Zhang Jige.

${ }^{34}$ Anne-Marie Brady, "Dead in Exile: The Life and Death of Gu Cheng and Xie Ye", China Information, Vol. 11, No. 4, March, 1997, p 129.
} 
then lose his feeling of the existence of the Self, his being." 35 Thus the sounds of the sung and spoken language of Scene of the First Night are essential to the intention of the work. The vocal part in the score is also written in Romanized phonetic pinyin (see Appendix, 7.3) as a pronunciation aid for performers who are not able to read Chinese characters.

The pinnyìn style in this thesis uses the "rules of pronunciation" (hàny̌̌ pīnyìn fāngàn 汉语 拼音方案） which include the indication of vocal intonation, the tones, which in Chinese, as in other tonal languages, are intrinsic to meaning. The one "word" vocal composition Wang (see Chapter 4.4) uses the "tones" as the principle for creating a rich content for the piece. In this thesis, following common practice, the tones are not indicated for proper names or place names.

\subsection{Musical "Transcription", "Translation" and "Integration"}

Having established a context for understanding the background and aspirations of contemporary Chinese composers, including myself, the current situation can be viewed. We enter the "Information Age" ${ }^{, 36}$, and live in the "global village" $" 37$ of the twenty-first century, the internet plunging us into the midst of radical change. Information technology impacts on our daily lives, including how we make music, listen to music and think about music. The new environment of globalisation has opened up the whole world of musical cultures for exploration by composers who can only inherit the past, and proceed to the future. Ancient Chinese philosophical thought encourages us to understand and respond to the changing cultural environment in which we find ourselves.

${ }^{35}$ Eliot Weinberger, "Next stop, the Forbidden City", London Review of Books, Vol. 27, June, 2005, pp. 42.

36 "The Third Wave" is the post industrial society. Toffler says that since the late 1950s most countries have been transitioning from a Second Wave society into a Third Wave society. He coined many words to describe it and mentions names invented by others, such as the Information Age. Cf. "Some Issues on Impacts and Characteristics of Information as Wealth in the New Economy", International Journal of Information Science \& Technology, Vol. 6, July / December, 2008, p. 40.

37 "Global village" is a term coined by Marshall McLuhan in his book The Gutenberg Galaxy (1962). 
The Amsterdam-based contemporary music group Atlas Ensemble is an example of this new "global" concept in music. With the long-established Nieuw Ensemble as its core, the Atlas Ensemble is a pioneer enterprise in integrating a Western musical ensemble with non-Western instruments from China and the Middle East, instruments that are played by musicians drawn from these various traditions. Composers from around the world are encouraged to compose works that integrate these disparate sonorities from different traditions into a coherent sounding ensemble. The Atlas Ensemble has become a model for other such groups, including the Contemporary Music Ensemble Korea (CMEK), an ensemble that I composed for in my Scene of the First Night.

In analysing this blend of ideas and aesthetics, musical instruments and musical materials, it is useful to define the terms "transcription", "translation" and "integration".

Musical "transcription" is a term with many meanings. In composition it has been commonly used for the process of arranging music for a new performing medium, often with elaboration, as in Liszt's numerous piano transcriptions from other composers" orchestral music. As an essential tool in ethnomusicology, transcription is the representation in notation of a music which does not yet exist in notated form or which is transferred from one notational system to another. However, the creative reinterpretation of music between cultures which has become a preoccupation of numerous composers in the latter part of the twentieth century is a concept for which the conventional definition of "transcription" is no longer adequate. As a term borrowed from linguistic studies "translation" is now considered a more appropriate concept for this style of cross-cultural musical transference.

Translation, involving the transposition of thoughts expressed in one language by one social group into the appropriate expression of another group, entails a process of cultural de-coding, re-coding and en-coding. As cultures are increasingly brought into greater contact with one another, multicultural considerations are brought to bear to an ever-increasing degree. [...] We are not just dealing with words written in a certain time, space and socio-political situation; most importantly it is the "cultural" aspect of the text that we should take into account. [...] Multiculturalism, which is a present-day phenomenon, plays a role here, because it has had an impact on almost all peoples worldwide as well as on the international relations emerging from the current new world order. Moreover, as technology develops and grows at a hectic pace, nations and their cultures have, as a result, started a merging 
process whose end (-point?) is difficult to predict. We are at the threshold of a new international paradigm. ${ }^{38}$

Musical "translation" in the twentieth century had its beginnings in the detailed transcription and analysis of folk music, such as in Bartok"s detailed transcriptions of Romanian, Bulgarian and Turkish folk music. As pointed out above, Chou Wen-chung's Yü Ko is a "translation" of qin music, ${ }^{39}$ just as Jack Body's Long-ge a movement from his Three Transcriptions (1987) for string quartet, is a "translation" of a recording of a Chinese Yi (彝) minority Jews harp. ${ }^{40}$

"Integration" has been defined as:

The making up or composition of a whole by adding together or combining the separate parts or elements; combination into an integral whole: a making whole or entire. ${ }^{41}$

This thesis uses the concept of "integration" as a method of musical composition of combining (musical) elements previously separated. The sociological paradigm of integration often deals with the integration of a minority culture within a majority culture. In this thesis, elements of Chinese traditional music are introduced and integrated into compositions based on Western musical compositional practice. These elements may be melodic, rhythmic, structural, textural, stylistic, or as having a defined function, they may be

\footnotetext{
${ }^{38}$ Alejandra Patricia Karamanian, "Translation and Culture", Translation Journal, Vol. 6, No.1, January, 2002. Available from http://accurapid.com/journal/19culture2.htm; accessed 26 September 2010.

${ }^{39}$ Chou Wen-chung, "Yü Ko, or "fisherman's song”, is originally an ancient ch'in (zither) melody in tablature notation composed by Mao Min Chung (c. 1280). The fisherman is a symbol of man in communion with nature. Through the deciphering of the tablature notation, this work produces a modern adaptation that realizes the rich variety in tone production found in the precise ch'in finger technique, one that employs over a hundred symbols to achieve an elusive yet vital expression that is the essence of this art. The composer clarifies: "I have magnified... these inflections in pitch, articulation, timbre, dynamics and rhythm to a more perceptible level by expanding the articulations and timbres possible on each instrument used and by controlling the microtonal modifications in pitch according to the nature of each instrument." Available from http://www.chouwenchung.org/works/1965_yu_ko.php; accessed 25 September 2010.
}

${ }^{40}$ Jack Body, "Long-ge is a multiple jew"s harp of the Yi nationality of Southern China. The instrument is tiny, comprising three thin metal blades. As with other jews harp music the melody is in the harmonics which are reinforced in the mouth cavity of the player. Given the fact that the Long-ge has three fundamental tones the musical texture becomes a charming two-part counterpoint." Cf. Jack Body, Three Transcriptions String Quartet, Wellington: Waiteata Music Press, 1994. (1994 music edition no.5).

${ }^{41}$ The Oxford English Dictionary published by the Oxford University Press, Available from http://dictionary.oed.com/cgi/entry/50118573?single=1\&query_type=word\&queryword=integration\&first=1 \&max_to_show=10; accessed 7 September 2010. 
identified in the instruments used, and methods of playing, the style of singing, and, perhaps most importantly, in the use of Chinese language, including dialects.

My experience during the years 1973-82 as a member of the Gulin Song and Dance Troupe performing chuānjü, and jīngjǜ gave me a practical understanding and appreciation of traditional Chinese music-theatre, and my sixteen years' residence in New Zealand's multicultural society is also a fundamental influence on my musical creative process. In this thesis the "integration" of chuānjì̈, jīngjü and yuèjù styles of percussion, recitation and the musical singing with other musico-dramatic elements, appear in several of my works including Xià Sìchuān (下四川) Going Down to Sichuan Province (for vocal ensemble), is a "translation" composition of mountain song (shāngē) from the central-northern region of Gansu province (see Chapter 4.2.3). Wăngē (輓 歌) Elegy uses the Chinese instrument zhèng, Indonesian gamelan instrument of saron and vocal recitative (see Chapter 4.3). Wang is a cross-culture composition which integrates musical elements and instruments from China, Indonesia and Aotearoa/New Zealand for a vocal quartet, shēng, zhēng, saron, bonang, and taonga pouro (see Chapter 4.4). The following new compositions were part of the project Six Hermits, Jiǔ Dé Sòng (酒德颂) Hymn to the Virtue of Wine is for five singers, zhèng, shēng and two húqin (see Chapter 4.5.3) and Zuì (醉) Drunkenness (for zhēng solo) (see Chapter 4.5.2). A major composition of the thesis integrates a plainsong in the operatic scene Chüyè (初 夜) Scene of the First Night (see Chapter 5.4). In the CD recording of all five works plus original shānge "Going to Sichuan Province" is also included, as well as a DVD of three works, a concert performance of Wăngēe (輓 歌) Elegy, Wang and the stage production of the operatic scene Scene of the First Night. 


\section{The Sìgōng (四 功) (Four Skills) of Traditional Chinese Xiq $\ddot{u}$ (戏 曲) ${ }^{42}$ and Their Wider Application}

\subsection{Introduction}

Chinese xìqü is traditional Chinese opera, which draws on traditions of ancient poetry, song, instrumental music, dance, painting, acrobatics, and martial arts, distilled into a comprehensive, stylised art form. The origin of xiqü can be traced back thousands of years, from the páiyōu (俳 优) (dance-and-music theatre) ${ }^{43}$ of the Qin dynasty (221-206 BC) and the báixì (百 戏) (dance-and-music, acrobatics theatres) ${ }^{44}$ of the Han dynasty (206 BC-AD 220), the cānjü̈nxì (参军戏) (military theatre) ${ }^{45}$ of the Tang dynasty (618-907), the nănxì (南 戏) (Southern theatre) ${ }^{46}$ of the Song dynasty (960-1279) and the zăjù̀ (杂 剧) ${ }^{47}$ of the Yuan dynasty (1279-1368). The long history of Chinese theatre grew from simple forms of en-

\footnotetext{
42 “In English, xiq $\ddot{u}$ (戏曲) (literally, theatre of song) is usually translated as "Chinese opera" or "traditional Chinese theatre". However, this translation easily leads to misunderstanding. The word "opera" might confuse a Westerner who has never seen this Chinese theatrical form as it suggests Western classical grand opera. On the contrary, in contemporary China, there is indeed a dramatic form which blends Chinese and Western forms, and can be called "opera" -gējù (歌剧) (literally, sung drama). Sun Mei, “Xiqqü, the Indigenous Chinese Theatre" Asian Culture, Vol. 16, no. 2 (Summer, 1998), p. 1.
}

${ }^{43}$ Páiyōu were emperor musicians who performed music and dances, comedies, music and acrobatics for the Emperors. .Cf Cihai 辞海 Chinese Encyclopaedia, Shanghai: Shanghai Cishu Chubanshe, 1980, Arts Volume, p. 2. My translation.

${ }^{44}$ Báixì (historically, hundreds of Chinese theatrical arts were once called báixi) is a title for all theatrical performances of music, dances and acrobatics. Cf. ibid, p.2.

${ }^{45}$ The Tang dynasty boasted both song and dance dramas and the cānjün play, which is developed on the basis of the yōu play performed by páiyōu. The Cānjün play was named after a desperado who sued to be a cānjün (military officer). There were two actors on the stage. Cf. Zhang Yihe, Fu Shuyun and Cao Juan, Chinese Theatre, Beijing: Culture and Art Publishing House, 1999, p. 27.

46 "Nánxì was the earliest xìqü form that has completely extant play scripts. In other words, they consider that the earliest full-fleged xìqü form is nánxì than Yuan xìqü". Sun Mei, "Performances of Nánxì", Asian Theatre Journal, Vol.3 no. 2, 1996, p. 143. Nánxì, "profoundly influenced subsequent developments in Xìqü. It influenced the music, role categories, performance techniques, dramatic subject matters as well as script structure". Sun Mei, "Exploring the Historical Development of Nánxì, Southern Theatre", CHINOPERL Papers No. 24, 2002, p. 35.

${ }^{47}$ Yuan zăjǜ (historically, a number of Chinese theatrical arts were once called zăjì̀) the rival of nánxì, another significant form of xiqü, which appeared between the Jin (1115-1234) and Yuan dynasties in North China, has a vital position in the histories of both Chinese theatre and Chinese literature. Cf. Sun Mei, "Xiqü, the Indigenous Chinese Theatre", p.2. 
tertainment involving music and dance, comedy acts, and story-telling, its style and artistic characteristics moulded by the country's many national and folk art traditions into a matured opera tradition in the Song and Yuan dynasties.

Beijing opera (jīngjü 京 剧) has only a short history, having been established in the Qing dynasty. In 1790, the sānqing (三 庆) (opera troupe) from Zhejiang went to Beijing to perform for Emperor Qianlong's 乾隆 (1711-1799) eightieth birthday celebration. The troupe consisted of male and female performers from Anhui (安 徽) province. Soon, three other leading local troupes followed. At the conclusion of the birthday celebrations, the four troupes remained in the capital to offer performances to the local public. To adjust their repertoire and tunes to the tastes of cosmopolitan Beijing audiences, the performers of Anhui Opera adopted elements from other types of opera, notably píhuáng qiāng (皮黄腔) from Hubei (湖 北) province. Eventually, a new kind of opera emerged, called jīngdiào (京 调), later on known as jīngjù̀ (京 剧) (Beijing opera). ${ }^{48}$ The flourishing of numerous local forms during the Qing dynasty created the rich third period of Chinese xiqü. ${ }^{49}$

It should be pointed out that, besides Beijing opera, there are many other regional opera styles still in existence in China, collectively called xìqü. Some references list more than 300 regional opera styles, some no longer extant, but some still popular, including yù̀ejùu (粤 剧) (Cantonese opera), bāngzixì (梆子戏) (Hebei clapper opera), yǜejù̈ (越 剧) (Zhejiang yue opera), chuānjù̀ (川 剧) (Sichuan opera), qínqiāng (秦腔) (Shanxi qín opera), huăngméixì (黄梅戏) Anhui and Hebei (huăngméi opera). Although there are many different regional styles, all xìqü share these similarities:

1. The role system of four categories: male roles Shēng (生) ${ }^{50}$ female roles dàn (旦) ${ }^{51}$, painted-face roles jìn (净) ${ }^{52}$ and comedy roles chǒ $u$ (丑) ${ }^{53}$, also known as partly-painted-face roles xiăo huāliăn (小花脸).

\footnotetext{
${ }^{48}$ For more details, cf. Zhang Yihe, Fu Shuyun and Cao Juan, Chinese Theatre, trans. Kuang Peihua, Beijing : Culture and Art Publishing House, 1999, p. 77.

49 Sun Mei, “Xiqü̈, the Indigenous Chinese Theatre”, p.4.

${ }^{50}$ Cihai 辞海 (Chinese Encyclopaedia), Shanghai: Shanghai Cishu Press, 1980, Arts Volume, p. 1. My translation.
} 
2. The same repertoire of traditional stories.

3. The music of Chinese xiqü is an integral part of "the suite form" qüpái ti (曲牌体) and “a form based on a sectionalised arrangement of varied metres and tempi of chàngqiāng (song)", calls bănqiāng tĭ (板腔体), particularly for the bănzi (梆 子) and pīhuăng (皮黄) styles of regional operas.

4. The performance conventions including techniques of expression, and the functions of singing chàng (唱), recitation niàn (念), actions or postures zuò (做), and acrobatics dă (打).

\subsection{The Skills Sìgōng (四 功) for Chinese Xiqǚ (戏 曲) Original Concept}

Traditionally, singing chàng (唱), recitation niàn (念), actions or postures zuò (做), and acrobatics $d \check{a}$ (打) are the four skills of traditional Chinese xìqü performers. These relate both to the training system and the performance, and are called "four skills" (sigōng 四 功) $)^{54}$. Each of the four has its own rules and conventions.

\subsubsection{Chàng (唱) Singing}

Chàng (唱) is short for chàng gōng (唱 功). Singing skill xìqü (singing) “has established its own unique styles and techniques over a long period of time. It focuses on the relations between words and voices, and between voices and feelings. The prime requirement for singing is how to pronounce words correctly and express their meanings. As a result, a series of singing methods and techniques have developed, with the common purpose of expressing the feelings of the characters". 55

${ }^{51}$ Cihai 辞海 (Chinese Encyclopaedia),p. 15. My translation.

52 Ibid, p. 14.

53 Ibid, p. 15.

${ }^{54}$ Ibid, p. 16.

${ }^{55}$ Zhang Yihe, Fu Shuyun and Cao Juan, Chinese Theatre, p. 146. 
The xiqǚ performers have to practice vocally every morning using the conventions of this unique singing style. Vocal practices unique to xìqü, called: diàosăng (吊嗓 $)^{56}$ : use of vowels on a variety of vibration pitches to free the voice, from middle vibration to slow or fast: and from very low to very high.

1. Breath control (yǜnqi 运气) $)^{57}$

2. Clarity of diction (zìqing 字 清) ${ }^{58}$

3. Singing in the appropriate local style (qiāngchǔn 腔 纯) ${ }^{59}$

4. Singing in the correct metre (bănzhǔn 板 准 $)^{60}$

5. Singing in the right tempo (chřcùn 尺寸 $)^{61}$

\subsubsection{Niàn (念) - Non-singing vocalisations: recitation and dialogue}

Niàn (念) (short for niàn gōng 念 功) is the skill of non-singing vocalisations including recitation and dialogue on stage, which "cannot be expressed naturally, but must be recited with a cadence, focusing on rhythm and metre. The combination of language with music makes the language musical". ${ }^{6}$

The non-singing vocalisations in xìqü include sprechgesang (yünbăi 韵 白) and recitation and dialogue (dàobăi 道 白). Dàobăi may use two different forms of pronunciation of certain words, one being Beijing dialect (jīngbăi 京 白) and the other a local dialect, depending on the traditions inherent in the language and music.

The roles are characterised by the use of different vocal techniques for their non-singing vocalisations, for example “the lăoshēng (老 生) and lăodàn (老 旦) roles use full voice,

\footnotetext{
${ }^{56}$ He Changgao 何长高, Jingjǜ Jīchǔ 京剧基础,(The fundamentals of Beijing Opera), Singapore: Telok Ayer Performing Arts Centre, 1989, p. 56. My translation.

${ }^{57} \mathrm{Ibid}, \mathrm{p} .170$. In this thesis for the sake of phrasal flow I give the English translation first.

${ }^{58}$ Zhang Yihe, Fu Shuyun and Cao Juan, Chinese Theatre,p. 172.

${ }^{59}$ Ibid, p. 175.

${ }^{60}$ Ibid, p. 180 .

${ }^{61}$ Ibid, p. 183.

${ }^{62}$ Ibid, p. 112.
} 
the shèng (生) and dàn (旦) roles use full and falsetto voices, and the jìn (净) roles use a rough voice (cūsăng 粗 嗓)", ${ }^{63}$

In addition, there are some conventions of niàn in the xìqü. These are:

1. Opening (y̌̌nzi 引 子), ${ }^{64}$ which has two parts, the first being recitation and the second sung with instrumental accompaniment.

2. A poem to launch the performance (dingchăng Shī 定场诗) ${ }^{65}$

3. The character introduces him/herself (zibàojiāmén 自报家门) ${ }^{66}$

4. A rhythmic style of yünbăi (shǔbăn 数 板), ${ }^{67}$ couplets with 5,7 , or 10 syllables per line, with wooden percussion (băn) accompaniment.

Yǜnbǎi is a poetic language, a stylized form of declamation similar to Western sprechgesang. It follows the conventions of local styles, in which rhyme dominates, as in a poem.

Regarding rhythm, metre and pitch, it should be noted that there are various techniques available to give expression to certain words.

1) Glissando (huáyīn 滑 音) ${ }^{68}$

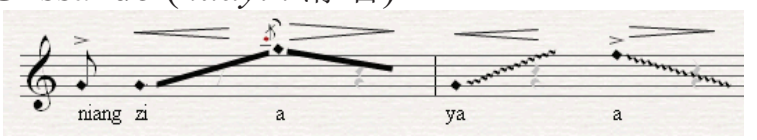

2) Emotional tension (rùnyīn 润 音 $)^{69}$

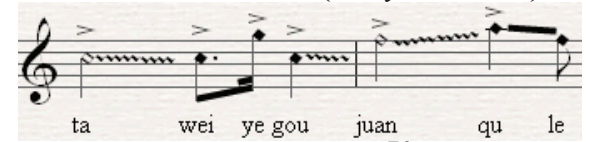

3) Staccato (dùnyīn 顿 音) ${ }^{70}$

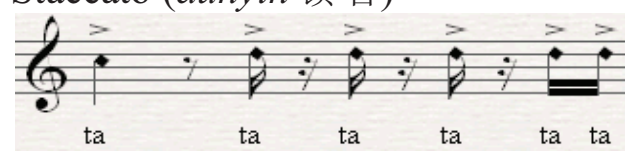

\footnotetext{
${ }^{63}$ 何长高 He Changgao, 京剧基础 (Jinngjù Jīchù), (The fundamentals of Beijing Opera), p. 198. My translation.

${ }^{64}$ Ibid, p. 193.

${ }^{65}$ Ibid, p. 195.

${ }^{66}$ Ibid, p. 197.

${ }^{67}$ Ibid, p. 198.

${ }^{68}$ Ibid, p. 192.

${ }^{69}$ Ibid.

${ }^{70}$ Ibid, p. 193.
} 
4) Prolongation (tuōyin 拖 音) ${ }^{71}$

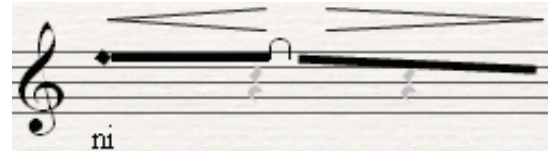

As mentioned above dàobăi (道 白) recitation and dialogue may use different forms of pronunciation of certain words, some being in Beijing dialect, called jingbăi (京 白), others using local dialects called sūbǎi (苏 白) or dàobăi (道 白).

Niàn has some similarities of technique with chàng, including breath control and clarity of diction. Of the several differences, however, one of the most significant is the use of strongly accented plosives pēnkǒu (喷 口). ${ }^{72}$

1. Intonation (tones and register) (yü diào 语 调)

2. Accent (whether accented or gentle) (zhòngyin 重 音)

3. Spaces between syllables (tingdùn 停 顿)

4. Rhythms (fast and slow, with or without metre) (jiézòu 节奏)

\subsubsection{Zuò (做) Actions or Postures}

Zuò (short for zuò gōng 做 功) is the physical action of parts of the body, including dance movements, postures, expressions, acrobatic movements etc, which are stylised and exaggerated. Important basic skills for all xiqqü performance include waist and leg exercises ${ }^{73}$ which are part of a training regime comprising aspects called wŭfă (五 法): ${ }^{74}$

1. Shŏufă (手 法) $)^{75}$ refers to "the posture and movement of hands express joy, anger, sorrow and happiness, that is beauty of dancing" (quoted from famous dàn actor: Mei Lanfang 1894-1961).

\footnotetext{
${ }^{71}$ 何长高 He Changgao, 京剧基础 (Jingjù̀ Jīchǔ), (The fundamentals of Beijing Opera), p. 193.

${ }_{73}^{72}$ Ibid, pp. 200-203.

${ }^{73}$ Ibid, p. 128.

${ }^{74}$ Ibid.

${ }^{75}$ Ibid, pp. 213-29.
} 
1) Gestures of the fingers ( $z h \grave{l} z \bar{l}$ 指 姿)

2) Gestures of the palm (zhăngz $\bar{l}$ 掌姿)

3) Gestures of the fist (quánzi 拳 姿)

4) Postures and hand actions of the male role (男式手, 膀位置及动作).

5) Postures and hand actions of the female role (女式手, 膀位置及动作).

2. Yănfă (眼 法 ${ }^{76}$ refers to the actions and movements of the eyes.
1) Held eye (dingyăn 定 眼)
2) Laughing eye (xiàoyăn 笑 眼)
3) Loving eye (q̌̌ngyăn 情 眼)
4) Mild eye (rǒuyăn 柔眼)
5) Glad eye (mèiyăn 媚 眼)
6) Angry eye (hěnyăn 狠 眼)
7) Thinking eye (hǔ̌s $\bar{l}$ 回 思)
8) Charming eye (chénjǐn 沉吟)

3. Shēnfă (身 法 $)^{77}$ refers to the actions and postures of the upper body.
1) Shoulders (jiān 肩)
2) Waist ( $y \bar{a} o$ 腰)
3) Hips (kuà 胯)

4. Bùfă (步 法 $)^{78}$ refers to the actions and postures of the feet.

1) Postures of the feet (jiăozi $\bar{l}$ 脚 姿)

2) Positions, postures and actions of the feet and legs (jiăowèi 脚 位)

3) Conventions of physical movement, other than walking (bùfă 步 法)

4) Walking styles (bùż̃ 步姿 or táibù 台步), which might convey night patrols or journeys, secret attacks and fleeing. Walking can be by single per-

\footnotetext{
${ }^{76}$ Ibid, pp. 229-33.

${ }^{77}$ Ibid, pp. 234-37.

${ }^{78}$ Ibid, pp. 238-44.
} 
son, two people or a group. Walking while singing is called sound walking, without singing is called silent walking.

5. “Fă" fă ( “法” 法 $)^{79}$ has two meanings, one pertaining to the physical movements of the head, the other to the head as the seat of intellect and the initiator of all physical expression. The body (xing 形) expresses the spirit (shén 神).

\subsubsection{Dă (打)Acrobatics}

$D \check{a}$ (打) (short for dă gōng 打功) is acrobatics, which is a stagecraft version of "gōngfü" martial arts. The basic skills include physical movements and acrobatics often while singing or reciting. There are three categories.

1. Jīndòugōng (筋斗功) ${ }^{80}$ somersaulting, the strongest action in xìqü. It may represent a leap over a wall, river, to or from a hilltop or rooftop.

2. Tănzigōng (建子功) ${ }^{81}$ (carpet skills) for different kinds of somersaults, leaps, jumps and falls, with most leaps and jumps carried out with the hands touching the ground. ${ }^{82}$

3. Băzgōng (把子功) ${ }^{83}$ (bundle skills) are combat techniques usually with stage weapons of many types and sizes. ${ }^{84}$

\footnotetext{
${ }^{79}$ 何长高 He Changgao, 京剧基础 (Jīngjù̀ Jīchǔ), (The fundamentals of Beijing Opera), pp. 244-46. My translation.

${ }^{80}$ Ibid, p. 282.

${ }^{81}$ Zhang Yihe, Fu Shuyun and Cao Juan, Chinese Theatre, p. 282.

${ }^{82}$ Ibid, p. 283.

${ }^{83}$ 何长高 He Changgao, 京剧基础 (Jīngjù̀ Jīchǔ), (The fundamentals of Beijing Opera), p. 128. My translation.

${ }^{84}$ Footnotes: "Bundle" means, in this content of the range stage weapons to be used. Cf. Ibid, p. 128.
} 


\subsection{The Expanded Concept of Sìgōng (四 功) for the Performance of Chinese Xiqü̆ (戏 曲)}

In my view, there are three categories under which an expanded concept of niàn, chàng, $z u o ̀$, and dă can be proposed: the impact of niàn on structure of the script, redefining niàn, chàng, zuò, and dă as fundamental principles of xìqü performance in an enlarged interpretation of $d a$, as found in chuānjù gāoqiāng

\subsubsection{The Impact of Niàn on the Structure of the Script}

A well-known saying is: Jùběn, wéi yī jù zhī běn (剧本, 为一剧之本) (the script is the fundamental root of xiqǚ.) There are no extant zăjǜ scripts from the Song or Jin dynasties, but there are records of the titles of 280 Song zăjü, and 690 Jin yuánběn. In 1920 Ye Gongchuo 叶恭绰 (1881-1968), a Chinese scholar, fortuitously discovered and purchased a copy of Yŏnglè Dà Diăn (永乐大典) The Yong Le Encyclopaedia (Volume 13991) at an antique market in London. This volume contained three complete ancient Nănxi ${ }^{85}$ scripts. One of these is the earliest surviving xìqü script with the title: Zhāngxiè Zhuàngyuán (张 协状元) (Top Scholar Zhangxie), which reveals a fully established theatrical form which included singing and recitation within a drama proper. ${ }^{86}$ The script is extensive, with a total of fifty-three scenes, of various lengths. Here is an example, scene 46, one of the shortest. Square brackets [.] indicate theatrical terms: singing (chàng 唱) and recitation (bái 白). ${ }^{87}$ This shows how song and recitation may be used.

\footnotetext{
${ }^{85}$ Cf. footnote 5 above.

${ }^{86}$ Zhang Yihe, Fu Shuyun and Cao Juan, Chinese Theatre, pp. 33-6.

${ }^{87}$ Qian Nanyang 钱南扬, 永乐大典戏文三种校注 Yongle Dadian Xiwen Sanzhong Xiaozhu, (Notes on Three Dramas from The Yong Le Encyclopaedia), 张协状元 Zhangxie Zhuangyuan (Top Scholer Zhangxie), Biejing: Zhonghua Shuju, 2009. My translation.
} 


\section{张协状元 $^{171}$}

(南宋) “温州九山书会”编撰

第四十六出

[生出唱]【蛮牌令】

一意要读诗书，

一身望改换门问。

一路到京里受钳锤,

一查打得浑身破损，

一妻济不得吾儒。

一举早题雁塔,

第一是张协，

方表勤渠。

[白]韩文公曰：

圣人不世出,

贤人不时出。

且如张协，

独占魁名，

状元及第。

一来仰答天地，

二来感谢圣恩,

三来荷蒙慈父,

今日已成大器。

幸然得到梓州，

择吉日礼上。

十年窗下无人问，

举成名天下知。[生下]

${ }^{171}$ The writers association of Wenzhou, members were called 才人(Cáirén) educated and talent people; they were businessman, doctors, teachers, actors and officers. Cf. Zhanggeng 张庚 and Gou Hancheng 郭汉城, 中国戏曲通史(The History of Chinese Xiqu), Beijing: The drama Publishing House of China, 1980, p. 236. My translation.

\section{Top Scholar Zhang Xie}

(Nan-Sung) by Wenzhou Jiushan book house

Scene 46

[Sheng enters, singing]【Pretty card style ${ }^{172}$

With an ambition to study, With a wish to reach a high position. It was struggle from home to the capital city,

Whole body was injured by bandits, A wife cannot support a scholar. The examination was from early morning at the Wild Goose Tower, The winner was Zhang Xie, This announces his achievement.

[Recitation] Han Wengong said:

Spiritual sages are not of this world, But wise men do appear.

And like Zhang Xie, Monopolizes the honour.

With success for the top scholar.

First, respond to Heaven,

Second, gratitude for the saintly gift, Third, thanks to parental generosity, Become the day"s success Fortunately arrived in Xinzhou, Offer up a lucky day gift.

Ten years' hard study in anonymity, With success comes fame.

[Sheng exits]

(My translation)

\footnotetext{
${ }^{172}$ Footnotes: this term of qüpái shown in 【】 refers to the structure of the song, with regard to the number of lines, the number of syllables per line, tonal sequence and rhyme. (see Chapter 3.4.1).
} 
The Yuan dynasty zăjù was considered the first golden era of Chinese xìqü, in northern China, by which time its theatrical form was fully established. Wang Guowei王国维 (December 2, 1877-June 2, 1927) was a Chinese scholar, writer and poet. He described the structure of yuănjùu (short for Yuan dynasty zăjiù) as follows:

It normally comprises four acts (sizhé 四 折), each characterised by a particular seven note mode of tong gōng (同 宫), with a set of song forms (qüpái ti 曲牌体), some of them with a preludes or interpolations $x \bar{i} z i$ (楔 子). ${ }^{90}$

Each script featured a leading role who performed (singing and reciting) throughout the four acts: if female (dàn 旦), the script is called dànběn (本), if male (mò 末) the script is called mòběn (末 本). All other roles required only recitation. ${ }^{91}$

Another example is Guan Hanqing 关 汉 卿 (late Jin dynasty - after 1279), known as “the Chinese Shakespeare". He composed sixty-eight zăjǜ scripts, of which eighteen have been preserved. Remarkably, twelve of his scripts feature female leading roles drawn from the lives of common people. ${ }^{92}$

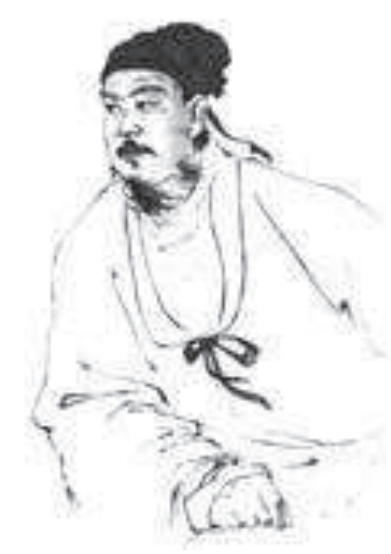

Illustration 6: Guan Hanqing

\footnotetext{
${ }^{90}$ Wang Guowei, 王国维, 宋元戏曲史 (The Chinese Xiqü History of Song and Tuan Dynasties), Shanghai: (Normal University of Huadong Publisher), 1995, p. 114. My translation.

${ }^{91}$ Cihai 辞海 (Chinese Encyclopaedia), Arts Volume, p. 10. My translation.

92 Zhang Yihe, Fu Shuyun and Cao Juan, Chinese Theatre, p. 43.
} 
Guan Hanqing"s best-known tragedy, Dòu Ě Yuān (窦 蛾 冤) ${ }^{93}$ Injustice to Tou $O^{94}$ (The Injustice Done to Dou E) (also known as Liùyuè Xuě (六月雪) Snow in Midsummer, according to a Beijing opera arrangement), is an example of his attention to the tragic life of an ordinary woman. Below is an extract ${ }^{95}$ from Act Three: ${ }^{96}$

\section{《荬 蛾 冤》第三折 (片段)}

(元) 关 汉 卿

[外扮监斩官上，云]

下官监斩是也。

今日处决犯人，

着做公的把住巷口，

休放往来行人闲走。

[净扮公人, 鼓三通, 锣三下科,

刽子磨旗、提刀、押正旦带枷上，刽子云]

行动些, 行动些, 监斩官去法场多时了。

[正旦唱]【正宫 端正好】没来由犯王法，

不提防遭刑宪，

叫声屈动地惊天。

顷刻间游魂先赴森罗殿,

93 “The Injustice Done to Dou E (also known as Snow in Midsummer) is one of Guan Hanqing's representative works. It tells of a girl named Dou E to whom a local tyrant takes a fancy and wishes to marry. On refusing to be his wife, Dou E is falsely charged with murder, and sentenced to death. At her execution, she proclaims her innocence, saying that on being beheaded her blood will spurt high enough to stain a piece of white gauze hanging overhead, that snow will fall in midsummer, and that the region will be hit by drought for three years in succession. All these phenomena occur exactly as she foretells. Three years later, her father comes back as judge and conducts a re-trial of this case, and clears Dou E of the false charge". Huo Jianyi, Yuan Dynasity Zaju, available from: http://www.chinavoc.com/magicn/yzaj.asp; accessed, 15 July 2010

${ }^{94}$ Chung-Wen Shih: Injustice to Tou (Tòu Ó Yuān (Dòu É Yuān)) A Study and Translation, Cambridge: Cambridge University Press, 1972.

${ }^{95}$ Another English translation was made for a literary purpose. It is as Frederick Mote writes in the foreword: "Dr. Shih has drawn upon her skills as a specialist in Chinese and comparative literature. She has translated with grace and fidelity so that the play can be read in English with pleasure and interest". Frederick. W. Mote, "Foreword" of Chung-Wen Shih: Injustice to Tou (Tòu Ó Yuān (Dòu É Yuān)) A Study and Translation, p. x.

${ }^{96}$ For the purpose of this thesis the former translation is preferred since it includes the theatrical instructions, shown in【】, represents the form of the song or poem (qüpái 曲 牌), and represents theatrical instruction. 
怎不将天地也生埋怨。

【滚绣球】有日月朝暮悬，

有鬼神掌着生死权。

天地也只合把清浊分辨,

可怎生糊突了盗跖颜渊：

为善的受贫穷更短命，

造恶的享富贵又寿延。

天地也，做得个怕硬欺软，

却来也这般顺水推船。

地也，你不分好歹何为地。

天也，你错勘贤愚枉做天！

唉，只落得两泪涟涟。

[刽子云] 快行动些, 误了个时辰也。 97

\section{Injustice to Tou $\boldsymbol{O}$ Act III (extract)}

Guan Hanqing (late Jin dynasty - after 1279)

[Wai-role in-make-up-of overseeing

executing official enters; says:]

"Humble official overseeing execution official is $(\mathrm{P})$ ".

Today executive criminal;

order officers to-guard lane entrances,

not let going/coming person idly walk,

[Ching - role in-make-up-of officer, performs-drumming three times, beating-gong three strokes gesture. Executioner waving flag, carrying sword, guarding principal female-role, wearing cangue, enters, Executioner says:]

"Move a-little, move a-little, overseeing executive official has-gone-to execution-ground (L) long time (P)."

\footnotetext{
${ }^{97}$ 关汉卿 Guan Hanqing, Snow in Midsummer (a part of scene three), Wang Jisi 王季思, 中国十大古典悲剧(上) Zhonggou Shiao Gudian Beiju (Shang) (A Collection of Ten Classical Tragedy of China) (book one), Shanghai: The Arts Publishing House, p.19.

${ }^{98}$ Symbols and abbreviations, (P) for particle, (L) for line or locative, cf. Chung-Wen Shih: Injustice to Tou (Tou O Yuan) A Study and Translation, p. 33.
} 
[Principal female-role sings:] 【Cheng-Kung (zhènggōng mode) Proper/Good】

"No reason sinned-against Imperial law, unexpectedly suffered punishment.

Utter (a) cry (M) (of) injustice; stirs Earth, startles Heaven.

Instant-moment (L) drifting soul first goes-to Yama's palace.

How not (Pr) (toward) Heaven/Earth also bigger harboured-resentment?"

\section{【Rolling Embroidered Ball】}

There-are sun (and) moon morning/evening hang;

there are ghosts, spirits control $(\mathrm{P})$ life/death power. Heaven/Earth $(\mathrm{P})$,

only should (Pr) pure, foul distinguish;

instead how confused (P) Bandit Chih, Yen Yuan. Do good (deeds) ones suffer poverty, moreover life short; do evil ones enjoy wealth, nobility; moreover life-span extensive.

Heaven/Earth too have-so-acted-that (there is a) case-of (M) fear the-strong, oppress theweak; contrary [to expectations], after-all, also this way follow current push boat.

Earth (P) (if) you do-not distinguish good, evil, how be Earth?

Heaven (P) (if) you mistakenly examine virtuous, foolish, in-vain be Heaven.

Alas! only reduced-to two (streams of) tears flowing-unceasingly.

[Executioner says:]

"Quickly move some, have-missed (P) time (P) ...

The script indicates the use of the zhènggōng (正 宫) mode, with xiāntiān (先天韵) rhyme scheme, and the inclusion of ten songs. Square brackets ([ ] ) are used for the theatrical term 100 indicating singing (chàng [唱]), recitation (yún [云]) and action (kē [科]). This excerpt demonstrates how the theatrical terms that appear in the script dictate the textual structure of the poems and the recitations. In other words, they are more than mere indications of performing skills. The implications of chàng (唱), yún (云), bái (白) and ke (科) affect the whole development of the production, extending to the contributions of the dramatist, composer, director, designers, etc, as well as the on-stage performers, musicians and actors.

\subsubsection{Redefining Chàng, Nì̀n, Zù̀, and Dă as Fundamental Principles of Xìqü Performance}

\footnotetext{
${ }^{99}$ Chung-Wen Shih: Injustice to Tou (Tou O Yuan) A Study and Translation, p. 186.

${ }^{100}$ Wang Guowei 王国维, 宋元戏曲史 Song Yuan Xìqǔshǐ (Chinese Xiqü̆ History of Song and Tuan Dynasties), p. 114. My translation.
} 
The second point is that the four classes of skills - chàng, niàn, zuò, and dă - become governing principles for the instrumental and percussion accompaniments as much as for the stage performers.

Music accompanies singing, reciting, actions and acrobatics in Chinese opera. It also helps develop the story, personalise the characters, expose their thoughts and feelings, and create a special atmosphere. The orchestra of a typical opera is composed of two parts: the wénchăng (文 场) or "civil” or "literate" section of string and wind instruments, and wǔchăng (武 场) or "military" section, composed of percussion instruments. The former section accompanies singing... [or constitutes the purely instrumental sections, called q $\check{\ddot{u}}$ (曲)]. The latter accompanies the performers' body movements, reciting, singing, dancing and acrobatics. ${ }^{101}$

Thus chàng, niàn, zuò, and dă imply much more than just the performer's skills or techniques, but represent the all-encompassing performing principles of xìqü.

\subsubsection{An Enlarged Interpretation of $D a$, as found in Chuānjù Gāoqiāng}

Finally, in the consideration of xìqü the meaning of dă deserves special attention. In chuānjü gāoqiāng (川剧高腔) (see Chapter 3.2.1) there are three aspects: bāng (帮), chàng (唱), and $d \check{a}$ (打), the last as referring to the acrobatic skills of sigong ${ }^{102}$. In Sichuan opera however dă meaning "hit", refers to the percussion ensemble. Thus it is appropriate and useful to expand the concept of dă to embrace both meanings, viz. acrobatic skills, and the percussion ensemble.

In summary, the concept of sigōng as the overall artistic principle for xiqü̆ may be expanded beyond the four categories of recitation (niàn), singing (chàng), actions/ postures (zuò), and acrobatics (dă) to include the whole processes of creation, production and presentation. There include: niàn (念): text - composition and performance, chàng (唱): music - composition and performance (vocal and instrumental), zuò (做): production stagecraft, action, design (lighting, makeup, costume), dă (打): presentation - acrobatics,

\footnotetext{
${ }^{101}$ Zhang Yihe, Fu Shuyun and Cao Juan, Chinese Theatre, p. 148.

${ }^{102}$ Lu Yingkun 路应昆, 高腔音乐与川剧 Gaoqiang Yinyue yu Chuanju (The Music of Gaoqiang With Chuanju), Beijing: The Music of People Publishing House, 2001, p. 2. My translation.
} 
percussion, promotion. The developmental processes of xiqü̆ run through four steps: the playwright pens the text, the composer marries the melodies and text into a musical score, the production team - including lighting, costume, multimedia and stage design - collaborate, and finally all personnel come together under the director, for rehearsals and performance.

\subsubsection{Niàn (念): text - composition and performance}

Niàn refers to the text, which is primordial. Niàn is one important skill of the roles of Chinese xiqü̈ (as mentioned above). It also has rich connotations relating to the script. Thus, the extended concept of niàn comprises: the skill of the roles of Chinese xiqü̆, the methods used to assemble the text, and the script.

\subsubsection{Chàng (唱): music - composition and performance (vocal and instrumental)}

Chàng not only relates to singing skill, but also refers to the music. Therefore it has two aspects: composition and performance. For the unique style singing of xiqü, it is a part of important performing skills (see Chapter 2.2.1 above). In addition, there is other important part which relates to the music of xiqǚ: the instrumental accompaniment and the composition.

The music of Chinese xiqü, which is integrated with drama, has to meet the dramatic need to demonstrate the characters and create an atmosphere for the development of the story. It has its own special structural form, techniques of expression and artistic skill. It has close relations with dialects, folksongs and the music used to accompany recital-and-song performance. It is not created by specific musicians; it is the outcome of the long period of development of folk music and group creation through of the transmission across the generations and undergoing great changes because of different styles and dialects, deve 
loped into different schools. In the historical process of creation, the performer is himself the composer of the xiqü̈ music drawing on its composing conventions, tune systems, the names of tunes, and the percussion systems. It covers a wide range of singing, reciting, acting and acrobatics of all kinds of xiqü which are connected with the integration and application of musical conventions. ${ }^{103}$ The musical accompaniments were for singing, reciting, acting and acrobatics in Chinese xìqü. They also help to develop the story, personalise the characters, expose their thoughts and feelings, and create a special atmosphere. Each local version of Chinese xìqü has its own ensemble, but in which the principal instrument has the same function for the style of the xìqü. E.g. bamboo flute (zhǔdi 竹笛) for Kun opera (kūnqü 昆 剧), two-string spike fiddle (húqín 胡 琴) for Beijing opera (jīngjùu 京 剧), bănhú (板 胡) for qín opera (qínqiāng 秦 腔), clapper opera (bāngzixì 梆子戏) and chuānjǜ tán opera (tánxì 弹 戏).

\subsubsection{Zuò (做): production - stagecraft, action, design (lighting, makeup, costume)}

This expanded concept of zuò incorporates the process of production, which includes all aspects of stagecraft: directing, designing, performing and performance skills (see Chapter 2.2.3 above). One essential performance element of xìqü is face-painting, by which a character is identified. Historically, before the emergence of theatre proper as a genre, Chinese xiqǚ performers mainly adopted the following methods for facial characterization: masks and face painting. The mask (physical mask or face painting) originated from the ritual song and dance performances of primitive society, such as the dance of nuó wǔ (傩舞), ${ }^{104}$ which contributed to the development of Chinese theatre. Chinese xiqü made full use of masks and other means of projecting character. Physical masks have the advantage over painted faces in that the mask can be frequently changed - this special technique is known as biànliăn (变脸) (changing faces) and is used in many operas, especially chuānjǜ (Si-

\footnotetext{
${ }^{103}$ Zhang Yihe, Fu Shuyun and Cao Juan, Chinese Theatre, pp.141-143.

${ }^{104}$ Cihai 辞海 (Chinese Encyclopaedia), p.488. My translation.
} 
chuan opera). ${ }^{105}$ The limitation of any mask however, physical or painted, is that it has one fixed expression and is incapable of showing subtle changes of emotion.

Chinese xìqü facial painting falls into following categories: decorative makeup (decorated faces), personality makeup (character facial designs), mood makeup (changing facial designs) and pictographic makeup (animal-like facial designs). ${ }^{106}$ In chuānjù̀ liănpǔ (川剧脸 谱) The Facial Paintings of Sichuan Opera there are images of 800 facial paintings. ${ }^{107}$ Another important performance element of Chinese xiqü is costuming, which, "used in the Chinese $x \dot{q} q \ddot{u}$, became more and more elaborate with the passage of time and the constant increase in the variety of repertories [...]; the stage images of some well-known historical figures, such as Guan Yu 关羽, Zhang Fei 张飞 and Zhuge Liang 诸葛亮, were already fixed in the Ming dynasty". ${ }^{108}$ Like the highly-developed performance skills required of the performer, the stylised conventions of face-painting and costume are the result of a long history in the development of xìqü. Therefore, the concept of zuò can be enlarged to encompass all aspects of xiqü̈ production.

\subsubsection{Dă (打): presentation - acrobatics, percussion, production}

The final expanded concept is of $d \check{a}$, concerns three aspects, which involve the three dă: acrobatics (dăgōng 打 功) (see Chapter 2.2.4 above), percussion (dăjīyuè 打击乐) and presentation (dăzào 打 造). The primary reason for including percussion in the expanded concept of dă, is because of its use in chuānjù̀ gāoqiāng (川剧高腔) (see Chapter 3. 2.1). dăzào (打 造) is a word now commonly used to describe the presentation of a major project, event, or production. "In traditional Chinese theatre [xìqü], time, space and setting are mainly represented by means of the performers' singing and, (recitation) and movements.

\footnotetext{
105 Zhang Yihe, Fu Shuyun and Cao Juan, Chinese Theatre, p. 168.

${ }^{106}$ Ibid. p. 168.

${ }^{107}$ Chuānjù Liánpǔ 川剧脸谱 (The Facial Paintings of Sichuan Opera), Chongqing: Xueyuan Publishing House, 2009. p1.

${ }^{108}$ Zhang Yihe, Fu Shuyun and Cao Juan, Chinese Theatre, p. 174. My translation.
} 
The change of time and place is accomplished by the actors frequently entering and leaving the stage" ${ }^{109}$ Today, xìqü has the opportunity to utilise all the facilities of the modern theatre including multimedia and computer-controlled lighting and staging. Thus the concept of dăzào opens xìqü to a new world of possibilities for development.

${ }^{109}$ Zhang Yihe, Fu Shuyun and Cao Juan, Chinese Theatre, p. 177. 


\section{Regional Folk Genre ( $Q \ddot{u ̈ y} i$ 曲 艺) and Sichuan Opera}

\section{(Chuānjǜ 川 剧)}

\subsection{Introduction}

戏出一棚川杂剧

神头鬼面几多般

夜深灯火阑珊甚

应是无人笑倚栏

释道隆 ( 南 宋 1127 1279)

四川涪州人 ${ }^{110}$

"In performance on the open stage is a Sichuan Zăjǜ,

Featured in different masks of grotesque shapes.

In the thick of night where lamps are flickering and dim,

Fascinated beyond the railings are viewers in silence".

Shi Dao Long (Nan-Song dynasty, 1127-1297)

Fuzhou of Sichuan ${ }^{111}$

\footnotetext{
${ }^{110}$ Zhang Jiewen, Poems of Zaju by the Buddhists of Dajiu temple in the Nan-Song Dynasty, Beijing: The culture and Art press, 1983. Cf. Lu Yingkun 路应昆, 高腔音乐与川剧 Gāoqiāng Yīnyuè Yü Chuānjü (Gaoqiang and the Music of Chuānjü), p. 288.

${ }^{111}$ English translation by Zhang Jige, received informally in a letter written to me.
} 
This poem pictures a theatrical performance of Northern zăjù̀ in Sichuan in the Song dynasty, indicating that styles of theatre imported from elsewhere in China, but using the local dialect, were already popular in Sichuan. It is generally acknowledged that Sichuan opera (chuānjî̀) was established in 1912, when the sānqinghuì (三庆会) (sānqìng troupe) formally combined five theatrical styles and fused them into a new form of acting, singing, recitation and instrumental music, in which all the text was written and performed in the Sichuan dialect. The five theatrical traditions were characterized by differing singing styles, instrumentation, musical repertoire, and place of origin: gāoqiān (高 腔), kūnqiāng (昆 腔), húqíngxì (胡琴戏), tánxì (弹 戏) and huādēngxì (花灯戏). All were maintained by their own independent respective troupes until the end of the Qing dynasty (1644-1911). The first four traditions originated outside Sichuan, in the northern and southern provinces. Although all used percussion accompaniment in their original forms, the new synthesis, developed by the sānqing troupe in 1912, adopted the Sichuan percussion ensemble. This form has become chuānjù (川 剧), the Sichuan opera of today. Chuānjǜ has five general categories. chuānjùu gāoqiān (川剧高腔), chuānjù̀ kūnqiāng (川剧昆腔), chuānjù̀ húqíngxì (川剧胡琴戏), chuānjù tánxì (川剧弹戏) and chuānjù̀ huādēngxì (川剧花灯戏).

The variety of chuānjü forms was the result of regional transmigration. During the Ming dynasty, Sichuan was embroiled in the turmoil of war for over 30 years. The first census of the Qing government, in 1661, the eighteenth year of Shunzhi (顺 治), showed that Sichuan had only 16,096 families, giving an estimate of a total population under 90,000 compared with a population estimate of 310,000 in 1578, year six of the Wanli (万 历) in the Ming dynasty. ${ }^{112}$ Sichuan therefore lost almost $64 \%$ of its population over these 83 years. However, after the war, Sichuan received large numbers of immigrant groups organised by the Qing government, during a hundred years of three dynasties of emperors; Kangxi 康熙 (1661-1772), Yongzheng 雍 正 (1722-1735) and Qianlong 乾 隆 (1735-1796). The immi-

\footnotetext{
${ }^{112}$ Lu Yingkun 路应昆, Gāoqiāng Yīnyuè Yǚ Chuānjù 高腔音乐与川剧 (Gaoqiang and the Music of Chuānjü), p. 291.
} 
grants came from Hunan (short as Xiāng 湘), Hubei (Chǔ 楚), Guangdong (Yuè 粤), Jiangxi (Gàn 赣) and Fujian (Min 闽) of the southern China, and from northern Shanxi (Shăn 陕),

Shanxi (Jin 晋), Henaan (Yü 豫). This is represented by the following sentence: Jiāngxī tián hú guăng, hú guăng tián sìchuān (江西填湖广, 湖广填四川) (Jiangxi people fill in Hunan, Hubei and Guangdong provinces, and those provinces people fill Sichuan province) ${ }^{113}$. One of my own ancestors travelled up the Yangtze River from Hubei to Luzhou, Sichuan. From this I know that I come from a family of immigrants. ${ }^{114}$ The immigrants brought with them their own cultures and from this rich variety of traditions Chuānjǜ was born, incorporating both northern and southern theatrical influences.

\subsection{The Categories of Chuānjǜ (川 剧) (Sichuan Opera)}

As a local opera mainly seen in south-west China, Sichuan, Yunnan, and Guizhou provinces, chuānjü is characterized by a unique style of singing, refined acting, rich percussion repertoire, comic roles, lively dialogues, and the use of local dialects. ${ }^{115}$

"Most chuānjù̀ repertoires are adapted from Chinese classical novels, mythologies, legends, and folk tales. Statistics show that the total number of Sichuan Opera plays exceeds 2,000. Its special characteristic, one that distinguishes chuānjü from other theatrical traditions, is

\footnotetext{
${ }^{113}$ Weiyuan 魏源, 魏源集 Wèiyüán Jǐ (Collection of Wei Yuan), Beijing: Zhonghua Shuju, 1976. Cf, Lu Yingkun 路应昆：高腔音乐与川剧 Gãoqiāng Yinnyuè Yü Chuānjü (Gaoqiang and the Music of Chuānjǜ), p. 291.

${ }^{114}$ According to Shěnshì Jiāpǔ (沈氏家谱)(the family book of Shen), in the possession of my uncle Shen Liechun 沈烈春, in which each generation of the Shen family is identified by its sequenced position within a text.

${ }^{115}$ The different dialects used in Chuānjǜ are from different regions: regional river style (Hédào 河道), such as: Ziyang river (Zīyáng Hé 资阳河), which includes the Ziyang, Zigong and Neijiang regions, Luzhou river (Lúzhōu Hé 泸州河), which includes the Luzhou, and Yibing regions, Lower Chiuandong river (Xià Chuāndōng Hé 下川东河), which includes the Chongqing and Waixian regions, Chiuanbei river ( Chuānbéi Hé 川北 河), which includes the Nanchong and Suilin regions, and 川西坝 (Chuānxī Bà) Xia Chiuanxi plain, which includes the Chengdu, and surrounding regions. 缪天瑞等 Miu Tianrui, 中国音乐词典 (Zhōnggóu Yīnyuè Cídiăn), Chinese Music dictionary, Beijing: People’s Music Press, 1985, p. 54. My translation.
} 
its immense vitality and dynamic performances that always strive to bring an individual"s artistic abilities into play to ensure fresh material, and variety of folk songs. Chuānjù reveals an extraordinary flexibility and vitality of expression in its music and performance". 116

\subsubsection{Chuānjù̀ Gāoqiān (川剧高腔) (Sichuan Gāoqiān Opera) with Bāng, Dă and Chàng}

A category of chuānjǜ, Sichuan gāoqiān provided the major inspiration for my composition Hymn the Virtue of Wine, particularly for its melodic style, its style of singing and recitation, as well as the prominent use of percussion.

Sichuan gāoqiān derived from gēyáng musical style gēyángqiān (戈阳腔) of Jiangxi at the end of the Ming dynasty. It absorbed remarkable traditions from both southern and northern China, combining with Sichuan dialect and local folk song, local musical traditions, as well as Taoist music, to become the most significant category of chuānjü.

Chuānjü gāoqiān is noted for the high tessitura of its melodies, accompanied only by percussion, without wind or string instruments. The concept of chàng (singing) ${ }^{\mathbf{1 1 7}}$ in chuānjü gāoqiān is fascinating. It includes two important aspects, bāng (帮) and chàng (唱). Bāng refers to the origin of the dramatic “chorus”(zhònghé 众和), whether it be the leading solo or a group. The music of bāng is fixed and cannot be extended or varied, and is known as “fixed style”(dìngqiāng 定 腔). ${ }^{118}$ Chàng refers to its origin in a style of the unaccompanied singing of a character on stage (túge 徒 歌), in which the music is variable and flexible

\footnotetext{
${ }^{116}$ Cf. Sichuan opera, Available from: http://www.chinaculture.org/gb/en_madeinchina/200512/05/content_76647.htm; accessed 27 July 2010.

${ }^{117}$ Cf. the expanded concept of Chàng (see Chapter 2.3.5).

${ }^{118} \mathrm{Lu}$ Yingkun 路应昆, Gāoqiāng Yīnyuè Yü Chuānjù̀ 高腔音乐与川剧(The Music of Gaoqiang with Sichuan Opera), pp. 40-44.
} 
(huóqiāng 活 腔). ${ }^{119}$ With the inclusion of dă (打), the three important production elements of chuānjǜ gāoqiān are:

1. Bāngqiāng (帮 腔) (or simply bāng 帮) refers to the off-stage “chorus" (two female singers and five percussionists, the latter also joining in the singing of the unison vocal parts). The characters of bāng have three functions ${ }^{120}$ :

1) Bāng represents the character, inner thoughts, what (s) he sees, responses, verbal expressions, and emotions, as well as behaviour.

2) Bāng may also represent the author, when the actor steps out of character, for instance in providing commentary.

3) Bāng may describe the circumstances of the character's situation and state of mind.

2. Dă (打) refers to the percussion ensemble, which provides the accompaniment for chuānjü gāoqiān. The players of the percussion sometimes also perform as singers in the bāngqiāng, which comprises five players, one of whom is the ensemble leader. $^{121}$

1) Ensemble leader (gǔshī 鼓师) playing a single-skin drum (băng ̌̌ 板 鼓). ${ }^{122}$ and wooden clappers (băn 板). ${ }^{123}$

2) Player I: playing dàluó (大 锣), a large chuānjù̀ gong

\footnotetext{
${ }^{119}$ Lu Yingkun 路应昆, (The Music of Gaoqiang with Sichuan Opera), p. 44.

${ }^{120}$ Ibid, pp. 12-3.

${ }^{121}$ Ibid, pp. 19-20.

122 "This instrument is covered with leather on one side only. It has a small drum area (about 5 or $6 \mathrm{~cm}$ in diameter, which is called the Güxin) with a high-pitched timber (the pitch being e or f), about a perfect fourth or fifth higher than the Xiăoluó (small gong). This is the conducting instrument for the ensemble (commonly used in Chinese Xiqu : Peking opera, Sichuan opera and etc.)." Wen Chyouchu 溫秋菊, HouYu-tzung de Píngjù̀ luógǔ 候佑宗的平劇鑼鼓, HouYu-tzung Percussion for Peking Opera. Taipei: Moraity Printing Co. Ltd. 1992, p.40.

${ }^{123}$ Wooden clappers, consisting of three pieces of tán wood, two tightly bound together and struck with the third piece. Played by the ensemble leader gǔshī (鼓师).
} 
3) Player II: playing dàbó (大 钵) large chuānjǜ cymbals

4) Player III: playing xiăoluó (小 锣) small chuānjù̀ gong, and măluó (马 锣) small hand-held chuānjǜ gong

5) Player VI: xiăobó (小 钹) small chuānjǜ cymbals, and tănggǔ (堂 鼓) a middle sized drum

In the music of chuānjǜ gāoqiān, percussion always accompanies bāng, particularly to open a section and mark cadential points, or to make a transition to the next song. A recent development of chuānjù̀ gāoqiān however has seen the addition of other string and wind instruments into the ensemble. Chàng refers to the solo singing of the actors on stage. It is the principal musical element of chuānjù̀ gāoqiān. The musical phrases are dependent on the text according to the principle whereby the singer will adapt the chosen melody yziz xingqiāng (依字行腔), ${ }^{124}$ with repetitions and variations, to match the number of syllables and phrases of the text to achieve a natural and artistic marriage of words and music, according to the role. In this way chuānjù gāoqiān offers audiences great opportunities to appreciate the interpretative artistry of the singers to an even greater degree than is possible in Western opera. "This highly ornamental vocal style is distinguished by brilliantly artful glissando links, skilfully implemented vibrato embellishments around a single tone in the form of a delicately elegant yet energetically melodic ornamentation". ${ }^{125}$

Since chuānjǜ gāoqiān was established in Sichuan, about five hundred qǘpái are known by name, although only three hundred have been notated in the score. ${ }^{126}$ chuānjǜ gāoqiān became the dominant category of chuānjü, and remains the most popular local opera among the gāoqiān style operas in China.

\footnotetext{
${ }^{124} \mathrm{Lu}$ Yingkun 路应昆, Gāoqiāng Yīnyuè Yü Chuānjù̀ 高腔音乐与川剧 (The Music of Gaoqiang with Sichuan Opera), pp. 44-54.

${ }^{125}$ Sichuan opera, Available from: http://www.chinaculture.org/gb/en_madeinchina/200512/05/content_76647.htm ; accessed 27 July 2010.

${ }^{126} \mathrm{Lu}$ Yingkun 路应昆, Gāoqiāng Yīnyuè Y̌̈̌ Chuānjǜ 高腔音乐与川剧(The Music of Gaoqiang with Sichuan Opera), p. 67.
} 


\subsubsection{Chuānjǜ Húqínxì (川剧胡琴戏) (Chuānjù̀ Húqín Opera)}

A category of chuānjǜ, Chuānjǜ Húqín opera refer to the èrhuángqiāng (二黄腔), èrhuáng music style, and the xīpíqiāng (西皮腔), xīpí music style, both also being main musical sources for Beijing opera. In the middle of the Qing Dynasty èrhuángqiāng developed from the huidiào (徽 调) hui mode of Anhui province, and the hàndiào (汉 调) han mode of Hubei and Shanxi provinces, but is performed in Sichuan dialect with the percussion ensemble of chuānjù̈. These two musical traditions, èrhuáng and xīpíqiāng, may be utilised individually or combined together, depending on the dramatic requirements. The principal accompaniment instrument of chuānjü húqin is the high-pitched two string fiddle (xiărhúqín 小胡琴), similar to the jīnghú of Beijing opera, but with a softer tone. Other instruments in the ensemble are the two-string fiddle of Sichuan (chuān èrhú 川二胡), and the four-string plucked zither (yuèqín 月琴). The poetic form of chuānjùu húqin texts comprised two lines, each a complete phrase of seven or ten characters.

\subsubsection{Chuānjù̀ Tánxì (川剧弹戏) (Chuānjǜ Tánxì Opera)}

A category of chuānjü, Chuānjù tánxì opera developed in the Qing dynasty from qín opera of Shanxi (qinqiāng 秦腔), in the period of Kangxi 康 熙 (1661-1772). It belongs to the clapper opera (băngzi 梆 子) tradition, using băngzi (clappers), as well as a two-string spike fiddle (gàibănzi 盖板子) as the principal accompanying instrument ${ }^{127}$. The poetic

\footnotetext{
${ }^{127}$ Gàibănzi: A spike fiddle with two metal strings, originating from the èrxián (二 弦) fiddle of Shanxi qín opera. The neck is $60 \mathrm{~cm}$ long and the sound-board $10 \mathrm{~cm}$ in diameter. It is the principal accompaniment of chuänjü tánxì. The player wears four metal thimbles.
} 
form of tánxì texts is the same as chuānjǜ húqín opera (see Chapter 3.2.2), but musically it uses specific seven-tone modes called tiánpí (甜 皮) and kúpí(苦皮). ${ }^{128}$

\subsubsection{Chuānjǜ̀ Kūnqiāng (川剧昆腔) (Chuānjǜ̀ Kūn Opera)}

A category of chuānjùu, the origin of chuānjù kūn opera was kūnqùu, ${ }^{129}$ from Hunshan of Jiangsu, ${ }^{130}$ Traditionally, kūnqù̀ texts were elaborate poems of high literary quality, and many kūnqù libretti are highly regarded as examples of refined Chinese literature. The music of künqù is regarded as having an almost feminine beauty. Its dominant instrument is the dizi (笛子) bamboo flute. Once kūnqù̀ was imported to Sichuan, it was called chuān$q \bar{u} n$ (short for Sichuan kūnqiāng). At the present time chuānjǜ kūnqiāng is already in decline, and generally only excerpts or selected songs from künqiāng are heard, within the context of a performance of gāoqiān, húqín or tán opera. The bamboo flute is always the principal instrument, although the percussion instruments may changed, the Sichuan xiăobó small cymbals replaced by the softer sūbó cymbals, and the large gong dàluó played away from the centre of the instrument, with its special " $S \bar{u}$ " quality (short for Suzhou), reflecting its origin.

\subsubsection{Chuānjù̀ Huādēngxì (川剧花灯戏) (Chuānjǜ Huādēng Opera)}

A category of chuānjǜ, less developed than other catégories, and regarded as indigenous to Sichuan. The chuānjǜ huādēng opera type has strong associations with my hometown, Gulin huādēng. Traditionally, over the fifteen days of the Chinese New Year holiday, par-

\footnotetext{
${ }^{128} \mathrm{Lu}$ Yingkun 路应昆, Gāoqiāng Yīnyuè Yü Chuānjù̀ 高腔音乐与川剧 (The Music of Gaoqiang with Sichuan Opera ), p. 199.

129 Zheng Lei 郑雷, China”s Traditional Kūnqü Opera, English translated by RB Baron 雨敬然, Beijing: Ministry of Culture of the People's Republic of China, 2001. p. 8.

130"By the end of the 16th century, Künqü spread from the Suzhou region to the rest of China (...)the second half of the sixteenth century marked the beginning of the Chinese Xiq $\ddot{\ddot{u}}$ era, from which all other forms of Chinese theatre performed today evolved. Consequently, many Kūnqü plays have been adapted for other types of Xiqǚ’. Available from: http://www.wtrgreenkunqu.org; accessed, 30 July 2010.
} 
ticularly on the final day, the Lantern Festival, huādēng activities, including singing (chàng huādēng 唱花灯), take place in the town and villages. Some time in the mid-70s, at a time when I was interested in collecting folk songs, the extended family members in my mother's village organised a chàng huādēng in my honour.

In villages in some other Sichuan counties, huādēng activities take place at weddings, funerals or are used as part of exorcism ceremonies. Huādèng is uniquely Sichuan.

Chuānjü huādēng opera uses local percussion, with a particular guttural-sounding twostring fiddle, called “fat fiddle” (pàngtǒngtǒng 胖筒筒), sometimes used to comic effect. When performed in the theatre chuānjǜ huādèng uses Chengdu city dialect and the percussion of chuānjü. However, the repertoire of chuānjǜ huādēng is limited to about twenty plays, making it a sub-category of chuānjü. ${ }^{131}$

\subsection{Kuàibănshū (快板书) and Shuōshū (说 书) Folk Storytelling as Categories of Q⿱艹̈日yyì (曲艺)}

Qǘyi is a general term for a variety of spoken and sung arts in which the performer accompanied him/herself on an instrument. With a history stretching back over millennia qüyi developed an extensive repertoire of oral literature and songs and a rich variety of regional forms and styles of performance, including kuàibănshū and shuōshū story-telling ${ }^{132}$.

\subsubsection{Kuàibănshū (快板书) ${ }^{133}$ (Storytelling with Percussion)}

\footnotetext{
${ }^{131} \mathrm{Lu}$ Yingkun 路应昆, Gāoqiāng Yīnyuè Y̌̈ Chuānjù̀ 高腔音乐与川剧 (The Music of Gaoqiang with Sichuan Opera), pp. 171-72.

${ }^{132}$ Arts of Qüyì, available from: http://www.chinaculture.org/gb/en_madeinchina/200512/08/content_76884.htm; accessed, 30 July 2010.

${ }^{133}$ Kuàishū and Kuàibăn, available from: http://www.chinaculture.org/gb/en madeinchina/200512/08/content_76889.htm; accessed, 30 July 2010.
} 
Kuàibănshū is form of storytelling with rhythmical recitation and singing, with texts having a basic sentence structure of seven-word antithetical couplets, rhyming a-b-c-b. But in practice the sentence pattern is often extended with repetitions and interpolations, provided that the rhyming scheme is not broken.

The performer usually stands while reciting and singing, accompanying himself by the playing of two small percussion instruments held in both hands. ${ }^{134}$

\subsubsection{Shuōsh $\bar{u}$ (说 书) ${ }^{135}$ (Storytelling)}

Shuōshü is another category of qüỳi storytelling, which is popular in many provinces in China. It is spoken and chanted rather than sung. In Beijing it is called Píngshū (评书), but in Sichuan and others provinces it is shuōsh $\bar{u}$. The storyteller shuōshūrěn (说书人), wears a gown and sits behind a table, holding a folded fan and a gavel with which the performer strikes the table to silence the audience or to punctuate sections and create emphasis and tension.

\subsection{The Musical Categories of Chinese Xiq $\ddot{\ddot{u}}$}

The music of Chines xiqǚ is subservient to the text, and has two major categories: qǘpái $t i$ (曲牌体) (the suite form of qüpái), whereby a text is sung with a melody chosen from an existing repertoire, and bănqiāng tı̌ (板腔体) (The system of theatrical musical forms of Chinese $x i q u \ddot{u}$,based on a sectionalised arrangement of varied metres and tempi of arias

\footnotetext{
${ }^{134}$ The small percussions are two pairs of bamboo clapping instruments are used, a big pair and a small pair, the former composed of two bamboo pieces, the latter, of five pieces. The pieces are held together by string.

${ }^{135}$ Cf. Píngshū, Available from http://www.chinaculture.org/gb/en_madeinchina/2005-

12/08/content_76887.htm; accessed 5 August 2010
} 
(chàngqiāng 唱 腔). Beijing opera is an outstanding example of “bănqiāng ť̆”, and the Kun opera is the excellent model of "qü̈pái ti".

The poetic passages of the play are written to fit in a sequence of tunes, known as "qüpái, chosen from an existing repertory. The libretto must conform to the pattern of the particular qüpái in regard to the number of lines, the number of syllables per line, tonal sequence and rhyme". ${ }^{136}$ The text"s poetic form determines the number of characters per line and rhyme scheme.

Each qüpái has a picturesque literary title which is marked in the script by 【】, indicating the structure of the song. Well-known example are【Gǔnxiùqiú (滚绣球)】(Rolling An Embroidered Ball), 【Xīn Shǔ̌ Lìng (新水令)】(New Water Song) and 【Méihuā Jiǔ (梅花 酒)】(Plum Blossom Wine). A famous collection of Qüpái is Jiǔgōng Dàchéng Nánbéi Cí

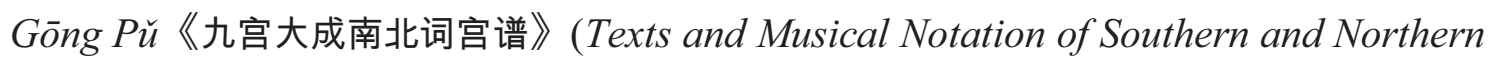
Songs in Nine Modes) which was complied by Zhou Xiangyu 周祥钰, Zou Jinsheng 邹金生, Xu Xinghua 徐兴华, Wang Wenlu 王文禄, Xu Yinglong 徐应龙, Zhu Tingmiao 朱廷缪 in collaboration with a large group of folk musicians in 1746 (the eleven year of Qianlong, the Qing dynasty). This collection of southern and northern songs comprises 2,794 distinct qüpái, although together with variants the total is $4,466 .{ }^{137}$

\footnotetext{
${ }^{136}$ Charles Wilson (based in part on notes by Hans Frankel), What is the Kūnqù̀ Theatre? Available from: http://www.wtrgreenkunqu.org; accessed 30 July 2010.

${ }^{137}$ Yang Yinliu 杨荫汶, Miu Tianrui 缪天瑞 (et al, eds.), Zhōnggóu Yīnyuè Cídiăn 中国音乐词典 (The Dictionary of Chinese Music), p. 203. My translation.
} 


\subsubsection{Qǘpái ti (曲牌体) ${ }^{138}$ (Suite Form of Chinese Xiqü)}

Qüpái $t i$ is a system of grouping of a number of qüpái into a suite form within one scene or act of an opera. A qǘpái ti has three possible forms, called tàoshù (套 数) (the number of qüpái):

1. A selection of different qü̈pái.

2. One qüpái, repeated, with variations.

3. Two qǘpái called mǔzi diào (母子调) (mother and son), which, with their variations, constitute the main body of the scene or act, bounded by an introduction and postlude.

Two important principles govern the qüpái ti system: all qüpái within a suite should be in same gōng mode, and the tempi of qüpái within a suite should progress from slow to fast, for example:

Table 1: shows the tempi of qüpái ti system

\begin{tabular}{||l|l|}
\hline \multicolumn{2}{|c|}{ Tempi of the qǘpái ti system } \\
\hline săn (散) & Rubato \\
\hline màn (慢) & Largo \\
\hline zhông (中) & Andante \\
\hline kuài (快) & Allegro \\
\hline săn (散) & Rubato \\
\hline
\end{tabular}

The following example of the suite form of qüpái is from Guan Hanqing's The Injustice Done to Dou E, Act III uses the zhèng gōng (positive gōng mode) with ten qüpái: ${ }^{139}$

Act III:【Zhèng gōng (正 宫)】 (Positive Gōng mode)

【Duānzhènghăo (端正好)】(Proper and Good)

【Gǔnxiùqiú (滚绣球)】(Rolling An Embroidered Ball)

【Tăngxiùcái (倘秀才)】(Surprised Scholar)

\footnotetext{
${ }^{138}$ Ibid. p. 331.

${ }^{139}$ Chung-Wen Shih: Injustice to Tou (Tou O Yuan) A Study and Translation, p. 29.
} 
【Dāodāoling (叨叨令)】(Chattering Song)

【Kuàihuósān (快活三)】 (Happy third)

【Bāolăotóu (鲍老头)】(Old Man Bao)

【Shuăháier (要孩儿)】(Playing Dolls)

【Èrshā (二 薢】(Secondary Coda)

【Yīshā (一 繁)】(Penultimate Coda)

【Shāwěi (繁尾)】(Coda)

The suite form of qǘpái was used in several types of Chinese xìqǘ, including kūnqŭ and the provincial styles of gāoqiāng operas, such as chuānjù gāoqiāng of Sichuan, xiāngjü gāoqiāng of Hunan, yuèxī gāoqiāng of Anhui and Duchang, Hukuo and Penze gāoqiāng of Jiangxi. I used chuānjù style of percussion and elements of chuānjù gāoqiāng music, particular its syntax of phrases, in my opera Fatal Desire.

\subsubsection{Bănqiāng $T \grave{\text { ( }}$ (板腔体) ${ }^{140}$ (The System of Theatrical Musical Forms of Chinese Xiq $\ddot{u})$}

Bănqiāng ť̆ is a system of theatrical musical forms of Chinese xìqü, translated as (a form based on a sectionalised arrangement of varied metres and tempi of chàngqiāng (song)) comprising a sequence of two sentences of equal length (qiyán 齐 言) with metres that change from time to time (bănshi 板 式). Tempo and metre are dictated by the percussion leader gǔsh ${ }^{141}$ The first beat (strong beat) băn (板) is played with wooden clappers băn, and the following weak beats, yăn (眼) played with small high-pitched drum băngǔ (板 鼓). The following table shows the metres băn yăn (板 眼), the names of bănshì and the time signatures from Beijing opera jīngjùt:

\footnotetext{
${ }^{140}$ Yang Yinliu 杨荫汶, Miu Tianrui 缪天瑞 (et.al.eds.), 中国音乐词典 Zhōnggóu Yīnyuè Cídiăn (The Dictionary of Chinese Music), p. 15. My translation.

${ }^{141}$ See Chapter 3.2.2. the percussion of Chuānjǜ Gāoqiāng.
} 
Table 2: The system of metre identified by strong \& weak, the name of tempi of bănshì and equivalent time-signatures of bănqiāng $t i$ system $^{142}$

\begin{tabular}{|l|l|l|}
\hline $\begin{array}{l}\text { Băn Yăn (板 眼) Metre Identi- } \\
\text { fied by strong \& weak beats }\end{array}$ & $\begin{array}{l}\text { Bănshì (板 式) Name of Bănshì Identified by } \\
\text { tempo }\end{array}$ & $\begin{array}{l}\text { Equivalent } \\
\text { time-signatures }\end{array}$ \\
\hline without băn yăn (无板无眼) & dăobăn (导板), sănbăn (散板) & free metre \\
\hline only băn (有板无眼) & liúshur (流水), kuàibăn (快板), yáobăn (摇板) & $1 / 4$ \\
\hline one băn one yăn (一板一眼) & yuánbăn (原板), èrliù (二六) & $2 / 4$ \\
\hline one băn three yăn (一板三眼) & mànbăn (慢板 ), kuài sānyăn (快三眼) & $4 / 4$ \\
\hline one băn two yăn (一板二眼 ) & new compositions metre & $3 / 4$ \\
\hline
\end{tabular}

The bănqiāng tı̆ system is used in many opera traditions, such as Beijing opera (jīngjüu), Shanxi qín opera (qín qiāng), qhuānjù̀ húqín opera and tánxì opera of Sichuan.

Table 3: Example of the use of Bănqiāng Tĭ is from Beijing opera ${ }^{143}$

\begin{tabular}{|l|l|l|l|}
\hline $\begin{array}{l}\text { 板 眼 (Băn Yăn) Metre identified } \\
\text { by strong \& weak beats }\end{array}$ & $\begin{array}{l}\text { 板 式 (Bănshi) Name } \\
\text { of Bănshì }\end{array}$ & $\begin{array}{l}\text { Identified by } \\
\text { tempo }\end{array}$ & $\begin{array}{l}\text { Equivlent time- } \\
\text { signatures }\end{array}$ \\
\hline without băn yăn (无板无眼) & dăobăn (导 板) & Introduction & Free metre \\
\hline one băn three yăn (一板三眼) & mànbăn (慢 板) & Largo & $4 / 4$ \\
\hline one băn three yăn (一板三眼) & kuàisânyăn (快三眼) & Adagio & $4 / 4$ \\
\hline one băn one yăn (一板一眼) & yuánbăn (原 板) & Moderato & $2 / 4$ \\
\hline one băn one yăn (一板一眼) & èrliù (二 六) & Allegro & $2 / 4$ \\
\hline only băn (有板无眼) & liúshur (流 水) & Vivace & $1 / 4$ \\
\hline without băn yăn (无板无眼) & sănbăn (散板) & Rubato & Free metre \\
\hline
\end{tabular}

In practice, this selection of bănshì is subject to variation, dependent on the size of the text and the dramatic requirements.

\subsection{Yuèjù̀ (越 剧) Yuè Opera}

\footnotetext{
${ }^{142}$ He Changgao 何长高, Jīngjǜ Jīchǔ 京剧基础,(The fundamentals of Beijing Opera), p. 70.

${ }^{143}$ Yang Yinliu 杨荫浏, Miu Tianrui 缪天瑞 (et.al.eds.), 中国音乐词典 Zhōnggóu Yīnyuè Cídiăn (The Dictionary of Chinese Music), p. 15.
} 
Yuè opera is "popular in the region south of the Yangtze River, and is especially popular in Zhejiang, Shanghai, and Jiangsu. It originated in Shaoxing County, Zhejiang Province in the early $20^{\text {th }}$-century". ${ }^{144}$ It was named yuèjù after the ancient State of Yue (Spring and Autumn period, 721-841BC) which is the Zhejiang Provence of today.

Yuè opera was begun with only narration and singing. As the performers sang to the accompaniment of a rhythmic $d \bar{l} d u d \bar{\imath} d u$ sound made by a drum and sandalwood clappers, they were also called $d \bar{\imath} d u$ troupes. In the late 1920 s, with the emergence of a large number of female performers, a dì $d u$ troupe with only female performers appeared; it was called the women's refined opera. In the autumn of 1938, it formally adopted the name of yuèjù. Later, orchestral accompaniment was added. ${ }^{145}$

The structure of qǘpái (arias) of yuèjǜ has a specified form, comprising two pairs of phrases of the text, each phrase with seven or ten characters. While always using the gonng mode, second pair of phrases moves to a new tonic. This principle of "alternating modes", which is found in others forms of Chinese classical music, is a particular characteristic of yuèjù̀. Within its short history, yuèjù has rapidly grown in popularity.

All of the musical compositions in this thesis integrate in some way elements from Chinese xìqŭ, folk-song (specifically shāngē), and qü̈yì story-telling. I used chuānjù̈, jīngjǜ and yuèjù styles of percussion, nianbai recitation, and gāoqiāng music "yùzān jì" in the ensemble works Jiǔ Dé Sòng (酒德颂) Hymn to the Virtue of Wine (for five singers, zhēng, shēng and two húqín) and Zuì (醉) Drunkenness (for zhēng solo). Xià Sìchuān (下四川) Down to Sichuan Province (for vocal ensemble), Wang (for shēng, zhēng, saron, bonang, four singers and Maori taonga puoro) and Wăngē (輓 歌) Elegy (for zhēng, saron and voices). In the operatic scene Chüyè (初 夜) Scene of the First Night I use the bănqiāng tĭ musical style of chuānjǜ gāoqiāng, and rhythmical patterns derived from kuàibănshū.

\footnotetext{
${ }^{144}$ Yuèjù̀ Gàishù 越剧概述 (A summary of Yuè opera), available from http://www.godpp.gov.cn/zlzx_/200704/04/content_9695745.htm; accessed 24 August 2010.

${ }^{145}$ Yuè Opera, available from http://www1.chinaculture.org/focus/2006-11/21/content_90006.htm; accessed 24 August 2010.
} 


\section{New Compositions (1)}

\subsection{Introduction}

The works described under New Compositions (1) explore in different ways the setting of Chinese texts, as well as different approaches to the concept of music-theatre. These shorter works may be considered preparatory to the composition of my opera Fatal Desire. They all draw inspiration from traditional Chinese styles of vocalization and adopt principles of musical "translation” and “integration”. Xià Sìchuān (下四川) Going Down to Sichuan Province is a "translation" composition of a shānge (mountain song) from Gansu province. Other compositions Wăngē (輓 歌) Elegy, Wang, Jiǔ Dé Sòng (酒德颂) Hymn to the Virtue of Wine with Zui (醉) Drunkenness - both composition elements integrating from xìqü, including percussion styles, vocal styles, and other cross-cultural components.

\subsection{Xià Sichuān (下四川) Going Down to Sichuan Province (for vocal ensemble)}

\subsubsection{Introduction}

This is an arrangement of a folksong, which based on the "translation" concept. It was composed for and dedicated to The Song Company, a professional group of vocal soloists based in Sydney, Australia, who visited New Zealand in July 2008 at the invitation of Chamber Music New Zealand. (I had previously worked with the Song Company in 2002, and composed Zui (醉) Drunkenness, a short solo for zhēng (21 string Chinese zither), and Jiǔ Dé Sòng (酒德颂) Hymn to the virtue of wine a poem of Liu Ling (c.225-280) for them as part of their Liù Y̌ngshì (六隐士) Six Hermits project). During their visit the artistic 
director of The Song Company, Roland Peelman, asked me to write an arrangement of a Chinese folksong for their tour to China in May, 2010. The piece needed to be based on a song widely known in China, and so I chose Going to Sichuan Province a shāngē from the central-northern region of Gansu province. It had always been one of my personal favourite folk songs, and I was thrilled to be involved in a new recording on which to base my arrangement.

In 1998, Jack Body's opera Alley, based on the life of New Zealander Rewi Alley ${ }^{146}$, was performed in Asia Pacific festival. He invited Du Yaxiong, a well-known ethnomusicologist from the China Conservatory, Beijing, who accompanied two authentic folk singers from central-northern Gansu province Yongjing County. The two singers, Li Guizhou and Ji Zhengzhu, appeared as soloists in the production. During their stay in Wellington Jack Body arranged a recording session in the Adam Concert Room at the School of Music at Victoria University, when Li Guizhou and Ji Zhengzhu recorded 23 songs from their repertoire. This recording (recording engineer Roy Carr) was later published by the School of Asian Studies of VUW, accompanying a booklet with an essay by Du Yaxiong with Jack Body, and musical notations transcribed by Mathieu Fraser. English translations of the songs were made by Du Yaxiong. I contributed to this project at a later stage by writing in the Chinese text and the Romanisation (pinyin $)^{147}$ into the musical score.

In viewing the notation and listening to Li Guizhou's unique version on the recording I was fascinated not only by the disjunct intervals of the beautiful melody, and its multi-pentatonic modality, but also by the singer's unique interpretation, his individual style of vocal ornamentation, and the emotional power of his performance, so characteristic of the highland genre: forceful, wild, stirring yet tinged with melancholy. Moreover, it interested me that this recording had been made in New Zealand.

\footnotetext{
146 "Rewi Alley (December 2, 1897. Springfield. NZ - December 27, 1987 Beijing, China) is one of New Zealand"s distinguished sons, as well as one of the best-known friends of Chinese people". See, Rewi Alley, An Autobiography, third edition Beijing: New World Press, 1997, inside back cover page.

147“"Romanised phonetics representation of the sounds".
} 
The genre of this song is shàonián. As described by Du Yaxiong in his essay: ${ }^{148}$

During summer festival held in villages across parts of Northwest China, the impressive high-pitched sounds of shàonián may be heard. These are courtship dialogue songs with improvised lyrics. Men and women gather in the mountains, dressed their best clothes, to engage in the singing and to celebrate the festival with food and with visits to local temples.

Shàonián are unusual in that they are not confined to one particular area or one ethnic group only. They are sung in four different provinces and autonomous regions (Gansu, Qinghai, Ningxia, and Xinjiang) by as many as eight different nationalities (Han, Tibetan, Hui, Salar, Uighur, Dongxiang, Bao'an and Tu). They have become a particularly famous genre of shāngé..$^{149}$

This recording of Going to Sichuan Province has three verses with a short coda. Here is the text, in Chinese and English:

十八马站的（哟哟哎）下四川

没一站叫阿哥留恋

（喔哟哟）没一站叫阿哥留恋

三站路踏成（吆喔）两站半

心牵着家乡的红牡丹

(喔哟哟) 心牵着家乡的红牡丹

今个子牵来着（哟哟唉）明个子盼呀

天天盼, 夜夜的晚夕里梦见（喔哟哟）

夜夜的晚夕里梦见（呃嘿哟, 呃嘿哟, 阿哈呀) I dream of you every night (ei hei yo, ei hei yo, a ha ya)

Eighteen posts from here (yo yo ai)

to Sichuan

None of them attracts me

(wo yo yo)Three day"s distance

I pass over in (wo yo) two days

I miss the peony in my homeland

(wo yo yo)I miss the peony in my homeland

I miss you today(yo yo ai) and

tomorrow

I dream of you every night (wo yo yo)

${ }^{148} \mathrm{Du}$ Yaxiong 杜亚雄 with Jack Body, Shàonián: Courtship Songs from Northwest China- The Singers, the Songs and the Music, Wellington: Victoria University of Wellington 2000. (Asia Studies Institute Working Paper 15), p. 1.

${ }^{149}$ “Generally speaking, musicologists in China classify Chinese folksongs in three categories, according to their performance contexts. The first category is called hàozi (work song), which are sung when people do some form of physical labour, for example, pushing a ship into water, or building a house. The second category, called shange (mountain song), covers songs which are sung in the field or in the mountains. The third category Xiăodiào(ditties) comprises all songs not included in the other two categories". See Du Yaxiong with Jack Body, ibid. p. 1. 


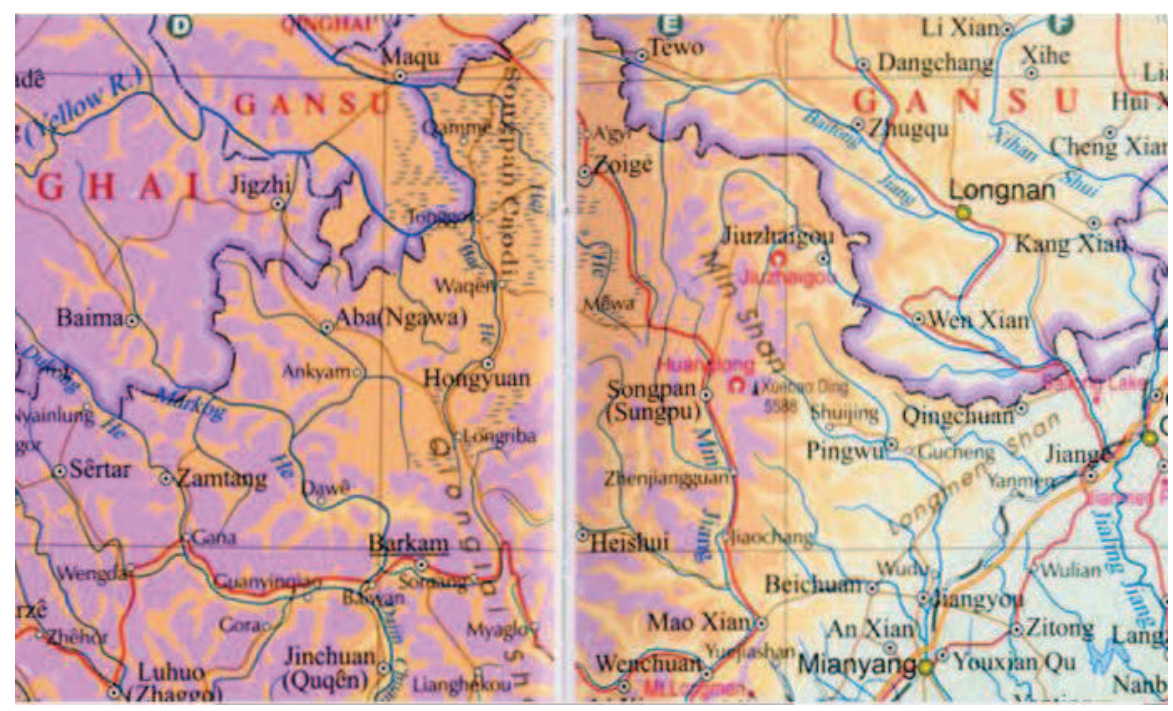

Illustration 7: A map of Northern Sichuan Province ${ }^{150}$

Gansu is known as huángtǔ gāopō (黄土高坡) (yellow earth highlands) because of its dry, arid landscape. Traditionally many goods such as tea, fabric and salt had to be imported by foot from neighbouring northern Sichuan, on Gansu's southern border Maqu County, over the the mountain and river, and from the Hongyuan Plateau up to Songpan Plateau of Ruo'ergai region. It is a long and arduous journey, and became part of Mao Zedong's famous “long march”. There is such well-known Tang dynasty’s poem Shǔdào Nán (蜀道 难) (Hard Road in Shu) by 李白 (Li Bai, 701-762). ${ }^{151}$ Three times the same sentence is repeated: Shǔdào nán, nányú shàng qīngtiān “蜀道难, 难于上青天” “"travelling is harder than scaling the blue sky") in the poem. Here is the beginning of the poem:

“噫吁戏，危乎高哉！ 蜀道之难难于上青天! 蚕从及鱼包, 开国何茫然。 尔来四万八千岁, 始与秦塞通人烟。 西当太白有鸟道, 可以横绝峨眉巅...”
Oh, but it is high and very dangerous!

Such travelling is harder than scaling the blue sky.

Until two rulers of this region

Pushed their way through in the misty ages,

Forty-eight thousand years had passed

With nobody arriving across the Qin border.

And the Great White Mountain,

Westward, still has only a bird"s path...

\footnotetext{
${ }^{150}$ Available from htt://www.chinatouristsmaps.com/provinces/sjchuan/full-map.html; Accessed 19 April 2010.

${ }^{151}$ Wang Yanju 汪艳菊 (ed.). Zhōnggóu Gǔdiăn Shīcí Xīnshăng 中国古典诗词欣赏 - Li Bai 李 白. (Enjoy of Chinese Classical Poems - Li Bai). Beijing: Wuzhou Chuanbo Chubanshe, 2005, p. 9.
} 
The original song Going to Sichuan Province is a Hànzú shāngē (汉族山歌) (the mountain song of Han), also known as jiăohù ling (脚户令) (porter's song), and is one of the songs from this work tradition. The form of the text and melodies of these songs is known as zhănduànyāo (斩断腰) (back breaking), having two phrases, separated by a short inserted phrase. The melodies are considered ${ }^{152}$ to express the arduousness of the journey and the desolate beauty of the landscape.

Mathieu Fraser's transcription of the recording is a detailed representation of Li Guizhou's performance, and includes portamenti and short rests.

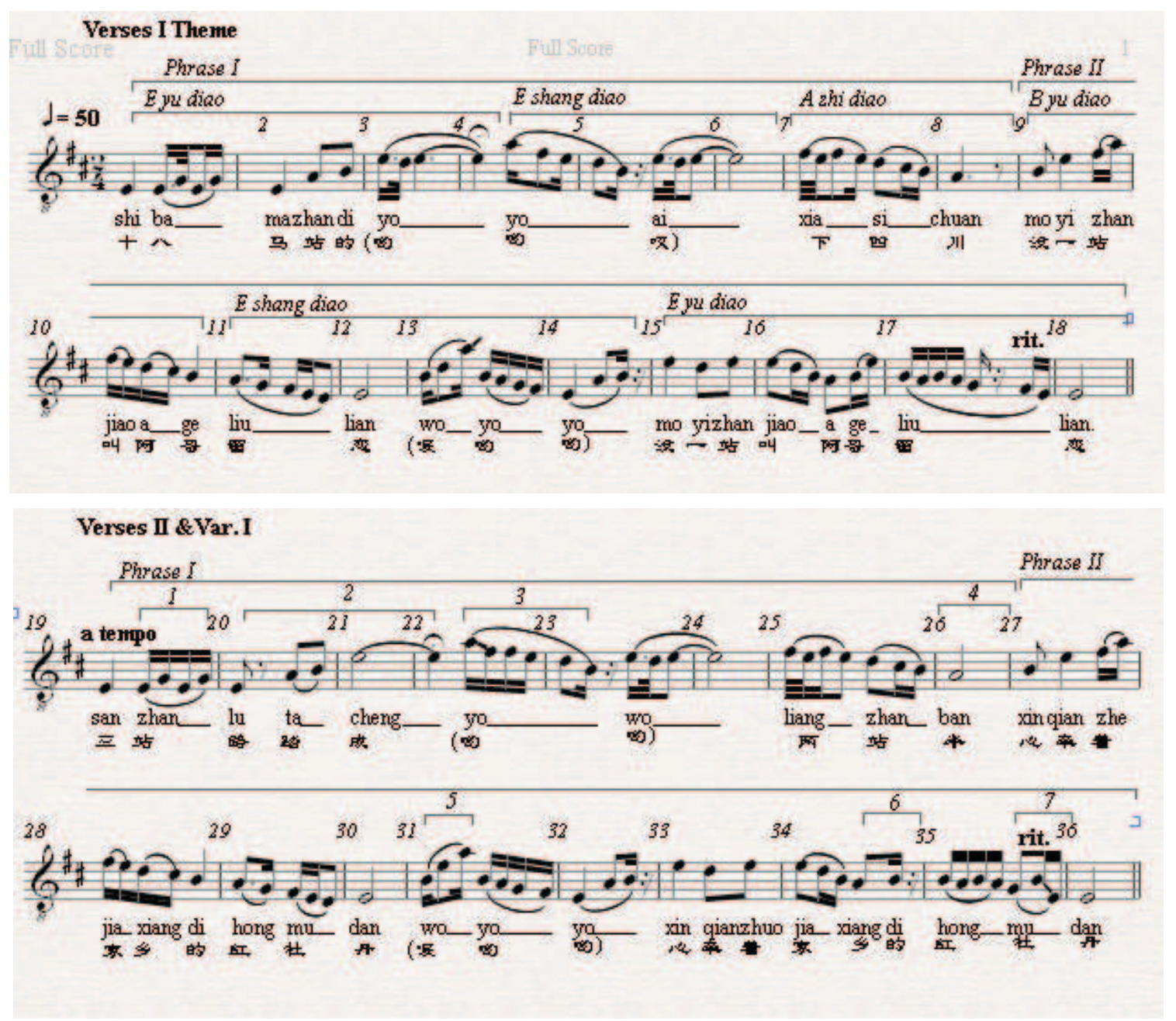

${ }^{152}$ Yīnyuè xīnshăng shǒucè (xùjî)《音乐欣赏手册》续集 (The Handbook of Understanding Music), Shanghai: Shanghai Music Press, p. 388. My translation. 


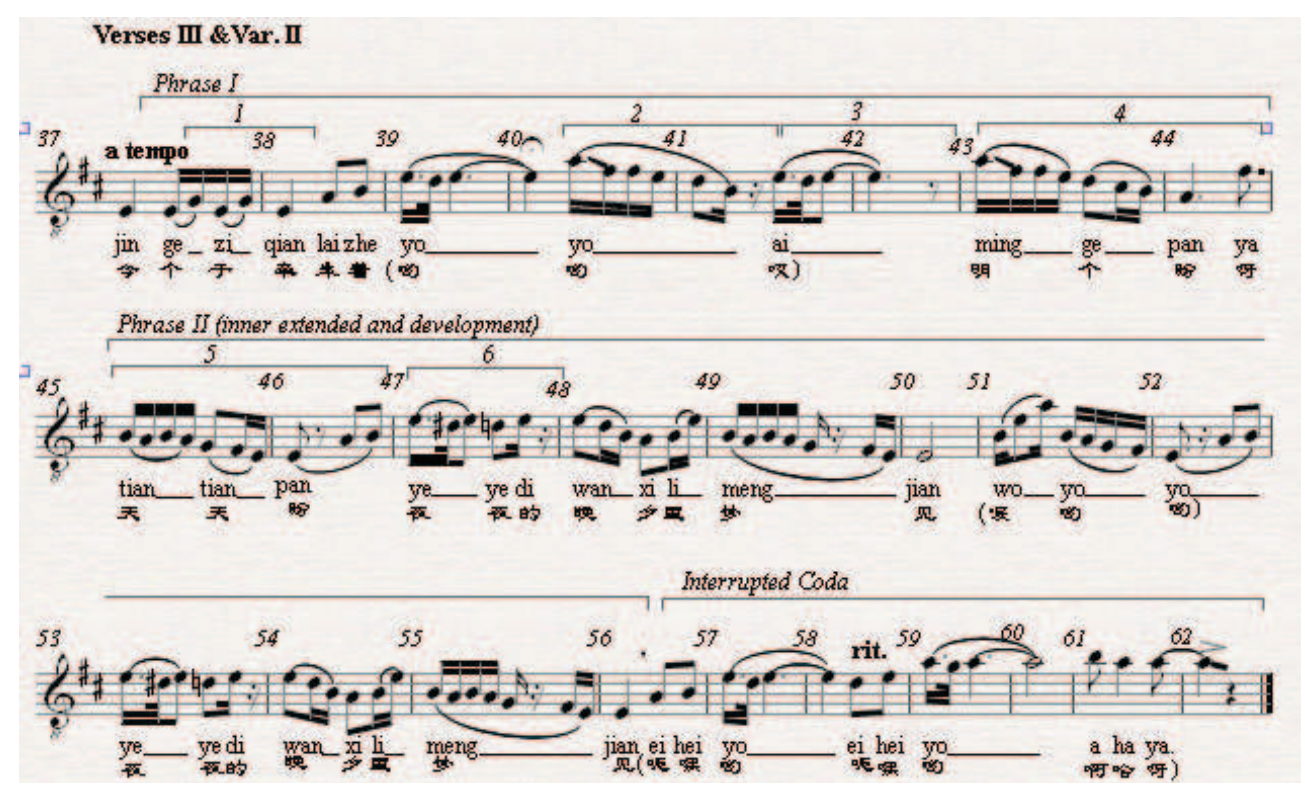

Example 1: Analysis of the original transcription of Going to Sichuan Province

Xià Sìchuān was transcribed in 1956 by Zhou Zhonglu, who worked in the Song and Dance Troupe of Xi'an, and was known as the “King of hua'er”. His numerical notation jiănpǔ (简谱) (simplified score) has of course many differences from Fraser's transcription, and the text is likewise dissimilar, except for the second half of the first verse which is the same as the third verse in Li Guizhou's version. In the same year, composer Liu Feng made an arrangement of Xia Sichuan for four parts chorus, based on Li Guizhou's notation. This work was performed that year at the Nie $\mathrm{Er}^{153}$ festival and subsequently became well-known throughout China. ${ }^{154}$

\subsubsection{Analysis of Going to Sichuan Province the Transcription of Li Guizhou Performance}

The song is strophic, with three verses and a coda. The melodic line is characterised by

\footnotetext{
153، Nie Er 聂尔 (1912-1935), who is a Chinese composer and an organiser of music events”. Cf. Lu Ji 吕 䩀 and He Luding 贺绿丁, the Music and Dance Vol. The Encyclopaedia of China, Beijing and Shanghai: The Encyclopaedia of China Publisher, 1989, p. 484. My translation.

${ }^{154}$ Huai zi 槐子, “Xià sìchuān lìng běnshi” (下四川令本事) (About Xià sìchuān), Beijing: Chinese Cultural Publishing Cooperation, Vol. 2, 2007, p 10. My translation.
} 
disjunct intervals, most striking of which is the recurring interval of perfect $5^{\text {th }}$ and $4^{\text {th }}$. Verse I has two phrases of different lengths (bb.1-8+9-18). The text talks about the eighteen posting-stations in the descent to Sichuan, during which time the singer moves on, without distraction. The opening emphasizes shiba (十八) (eighteen), the long distance that must be travelled.

The mode of this song may be considered heptatonic according to Chinese musical theory, ${ }^{155}$ the qīshēng qīngjüé diàoshì (七声调式), since, overall, it uses seven tones. However, in the first six bars the mode is pentatonic (wǔshēng diàoshì 五声调式), and from bar 8 to the end it is hexatonic (liùshēng diàoshì 六声调式). Looking more closely, I discover that within the 18 bars of the verse the pitch groups have multiple modes, they are $E$ shāng, $A$ zȟ̆ and $B$ y $\check{u}$, and are also two gōng modal systems (D gōng and G gōng) shifting, passing through various forms:

${ }^{155}$ According to Chinese musical theory:

Wǔshēng Diàoshì (五声调式) (pentatonic mode) Chinese pentatonic mode, consists of five principal notes: gōng, shāng, jüé, zhǐ and yüu(宫商角徵羽) it has five pentatonic modes. E.g. G gōng wǔshēng-E yü diàoshì as follows:

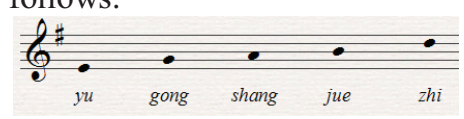

Liùshēng diàoshì (六声调式) Hexatonic mode, a six-note mode that is based on the wǔshēng diàoshì, with the addition of either piān yīn (偏音) (additional note) biàn gōng (变宫) note (a minor second lower from the note of gōng) (sofège syllable ti) or qingjüé (清 角) note (a minor second higher from the note of jüé) (sofège syllable $f a$ ). Liùshēng diàoshì has ten hexatonic variants.

E.g. G gōng liùshēng -E yü diàoshì as follows:

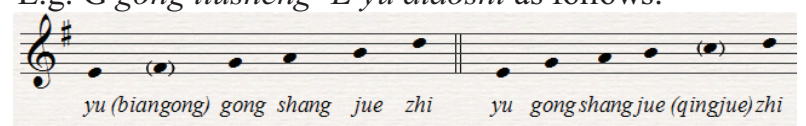

Qīshēng diàoshì (七声调式) Heptatonic mode. A seven-note mode that is based on the wǔshēng diàoshì, with the addition of the pair piān yīn (偏 音) (additional note). It has three categories of mode, qīshēng diàoshì thus has fifteen heptatonic variant modes. E.g. G gōng qīshēng - E qīng yuè yīnjiē (清乐音阶) as follows:

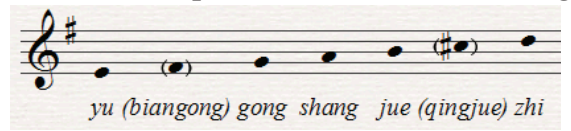

Cf. Li Chongguang 李重光, Chapter 5 "The varieties of Pentatonic Modes that are based on Wǔshēng Diàoshi”, Yinnyuè lìlùn jīchǔ (音乐理论基础) (Basic Music Theory). Beijing: ren min yin yue chubanshe, 1984, pp. 45-57. My translation. 


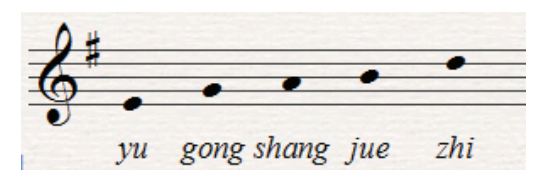

G gōng: (bb. 1-4) wǔshēng E yǘdiào

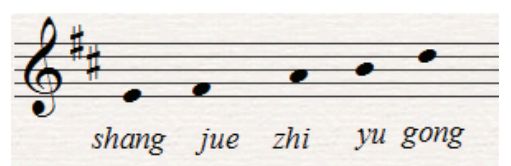

D gōng: (bb. 5-6) wǔshēng E shāngdiào

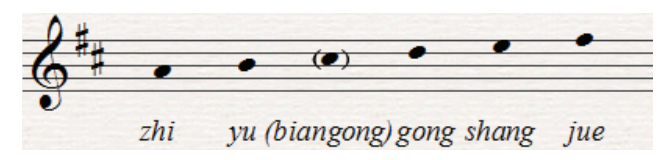

D gōng: (bb. 7-8) liùshēng A zhìdiào

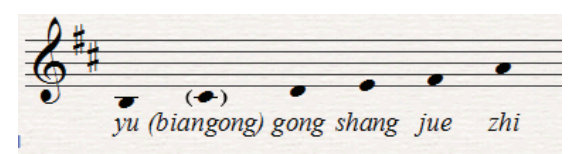

D gōng: (bb. 9-10) liùshēng B yǘdiào

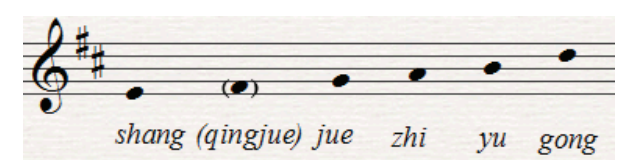

D gōng: (bb. 11-14) liùshēng E shāngdiào

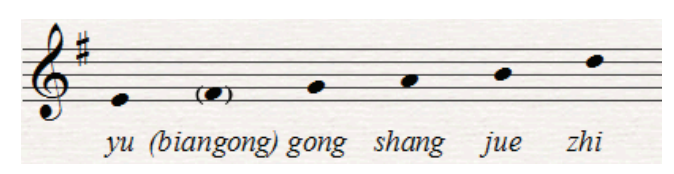

G gōng: (bb. 15-18) liùshēng E yǘdiào

Verse II (bb. 19-26 + 27-36) follows the same basic melodic shape with some minor variations, such as a break in the opening phrase, where the singer catches a breath before ascending strongly to the top E. This might be interpreted as expressing the enthusiasm of the singer on his journey home. Also of interest is the portamento over a $5^{\text {th }}$ at the cadence (b. 17), emphasizing the word Hóng mǔdān (peony = sweetheart). 
Verse III (bb. 37-44 + 45-56), is a more extended version of the basic melody. Bars 45-46 are an insertion derived from the recurring cadential figure (bb. 17-18, bb. 35-36, bb. 49-50, and bb. 55-56). The chromatic inflexions at bars 47 and 53 - Yèyède wănxīli mèngjiàn (dreamed of every night) - are examples of expressive word-painting by the performer.

The coda (bb. 56-62) begins impetuously, with no lingering on the cadential E, as the melody moves upwards to the climatic high point of the song, leading to a strongly emotional conclusion.

Table 4: The details of analysis

\begin{tabular}{|c|c|c|c|}
\hline $\begin{array}{l}\text { V. I } \\
\text { Two phrases of different } \\
\text { lengths }\end{array}$ & $\begin{array}{l}\text { V. II } \\
\text { Two phrases of different lengths }\end{array}$ & $\begin{array}{l}\text { V. III } \\
\text { Two phrases of different } \\
\text { length }\end{array}$ & Coda \\
\hline $\begin{array}{l}\text { phrase I (bb. 1-4+5-8) } \\
\text { modes changes: } \\
\text { bb.1-4 is wǔshēng E yüdiào } \\
\text { bb. 5-6 is wǔshēng E shāng- } \\
\text { diào } \\
\text { bb. 7-8 is liùshēng A zhǐdiào }\end{array}$ & $\begin{array}{l}\text { phrase I (bb. 19-26) variations: } \\
\text { 1. a break in the opening } \\
\text { phrase } \\
\text { 2. the portamento over a } 5^{\text {th }} \\
\text { at the cadence (b.17) }\end{array}$ & phrase I (bb.37-44) & $\begin{array}{l}\text { it is inter- } \\
\text { rupted final } \\
\text { tonic note } \\
\text { and leading } \\
\text { to a short } \\
\text { coda }\end{array}$ \\
\hline $\begin{array}{l}\text { phrase II (bb. 9-12+13-18) } \\
\text { bb. 9-12 is liùshēng B yǘdiào } \\
\text { bb. 11-14 is liùshēng E } \\
\text { shāngdiào } \\
\text { bb. 15-18 is liù shēng E yǔ } \\
\text { diào }\end{array}$ & phrase II (bars 27-30+31-36) & $\begin{array}{l}\text { phrase II (bb. } 45-50+51- \\
56) \\
\text { bb. } 45-46 \text { are an insertion } \\
\text { derived from the recur- } \\
\text { ring cadential figure } \\
\text { the chromatic inflexions } \\
\text { at bb. } 47 \text { and } 53\end{array}$ & $\begin{array}{l}\text { it is the } \\
\text { climax of } \\
\text { the song } \\
\text { (bb. 56-62) }\end{array}$ \\
\hline
\end{tabular}

I noticed and appreciated that those three beginning phrases were all sung differently:

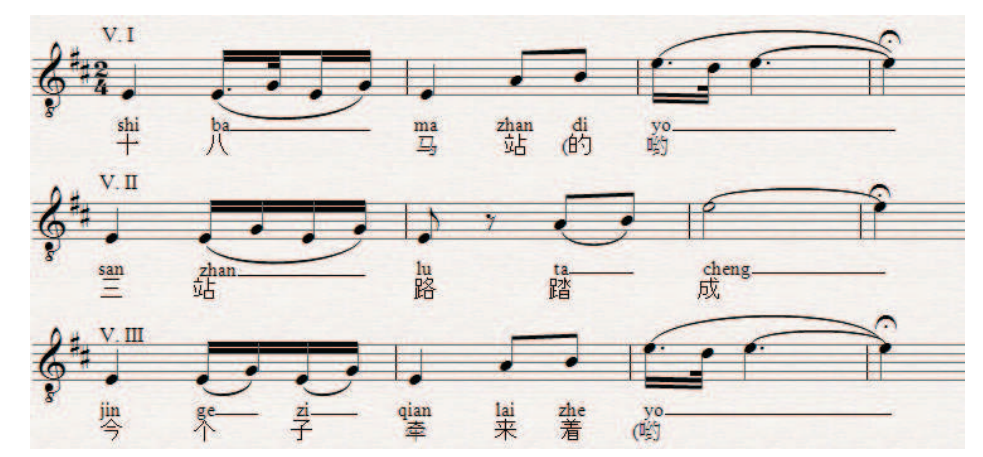

Example 2: Extract from the original transcription of Going to Sichuan Province 


\subsubsection{New Composition: Xià Sìchuān (下四川) Going Down to Sichuan Province}

All the material of this composition was developed from the transcription of Li Guizhou's performance, and from shàonián traditions.

As mentioned above, shàonián are heard "during (the) summer festivals held in villages across parts of Northwest China", when "men and women gather in the mountains, dressed their best clothes, to engage in the singing...” The character of shàonián, with its high tessitura, long phrases, flexible rhythm and disjunct, leaping intervals place it within the category of shāngē (山 歌) (mountain song or mountain airs). ${ }^{156}$

Li Guizhou's vivid performance inspired me to compose this new arrangement of Xi⿳亠 Sichuān. Writing for the Song Company, an ensemble of vocal soloists, gave me the possibility to treat the singers both as an ensemble and as solo voices, as expressing collective moods and personal emotions. My composition takes the original material, but develops it into a new expressive space, combining the voices in various combinations, such as the tenor solo (A, bars 7-10), tenor and baritone duet (A1, bb. 11-24), the two sopranos in unison (A2, bb. 25-28) and chorus (Coda, bb. 29-31).

My concept in this composition was to extrapolate new material from the original song, for instance, to develop quartal harmony ${ }^{157}$ derived from the overlap of perfect $5^{\text {ths }} \& 4^{\text {ths of }}$ the melody.

\footnotetext{
${ }^{156} \mathrm{Lu} \mathrm{J}$ 吕簧 and He Luding 贺绿丁 (et. Al.), The Encyclopaedia of China, Music and Dance Volume, p. 570.

${ }^{157}$ Vincent Persichetti, Twentieth Century Harmony-Creative Aspect and Practice, London, W. W. Norton \& Company, 1961. Chinese translated by: Liu Liewu 刘烈武, Beijing: Renmin Yinyue Chubanshe, 1989, p. 85 .
} 


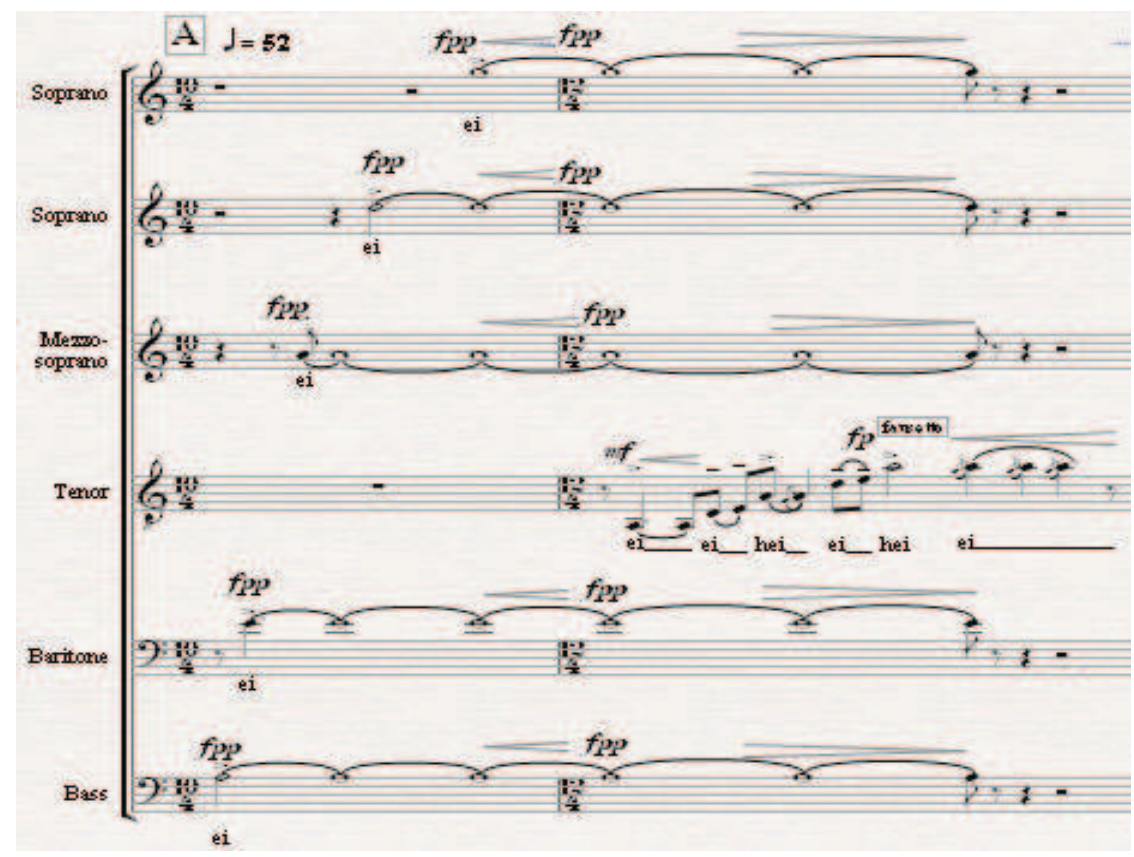

Example 3: Going Down to Sichuan Province (b. 1)

Some short phrases of the melody become motives which may be repeated or developed.

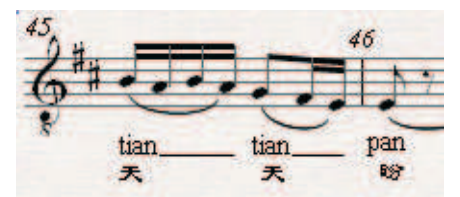

Example 4: A short phrase from (bb. 45-46) of the original transcription

Each verse of the original song ended with this cadential figure, but it was also used in bar 34 for important word Tiāntiānpàn (天天盼) (waiting for days and days).

This figure was developed as an "ostinato" motive, in the A1 section for the two sopranos and mezzo-soprano. 


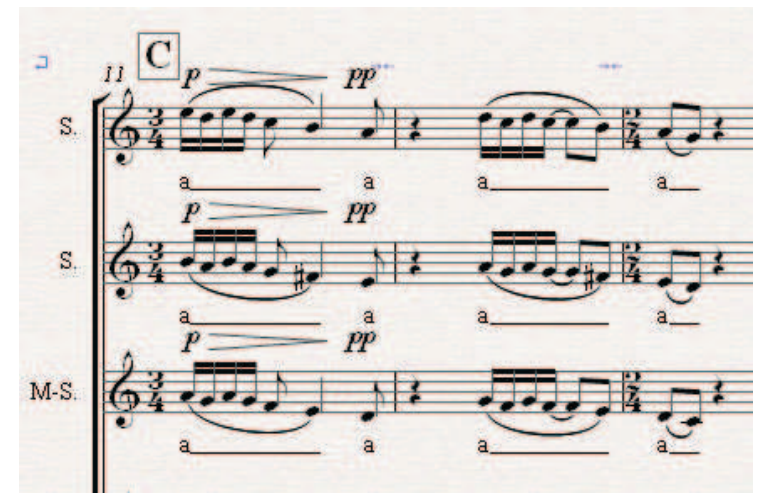

Example 5: Going Down to Sichuan Province (b. 11)

Another motive occurring at this same point is derived from the extraordinary leaps in bar 13 of the original song.

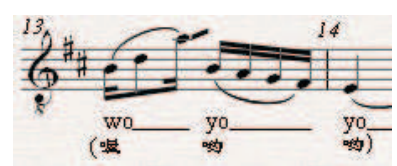

Example 6: A short phrase from (bb. 13-14) of the original transcription

Although there is no meaningful text for this short phrase wo-yo-yo (喔哟哟), its disjunct intervals of $4^{\text {th }}, 5^{\text {th }}$ and $7^{\text {th }}$ give a strikingly vivid character to the melody. In my composition, this motive becomes a bass voice motive, repeated in counterpoint with the female voices, as a kind of call and response.

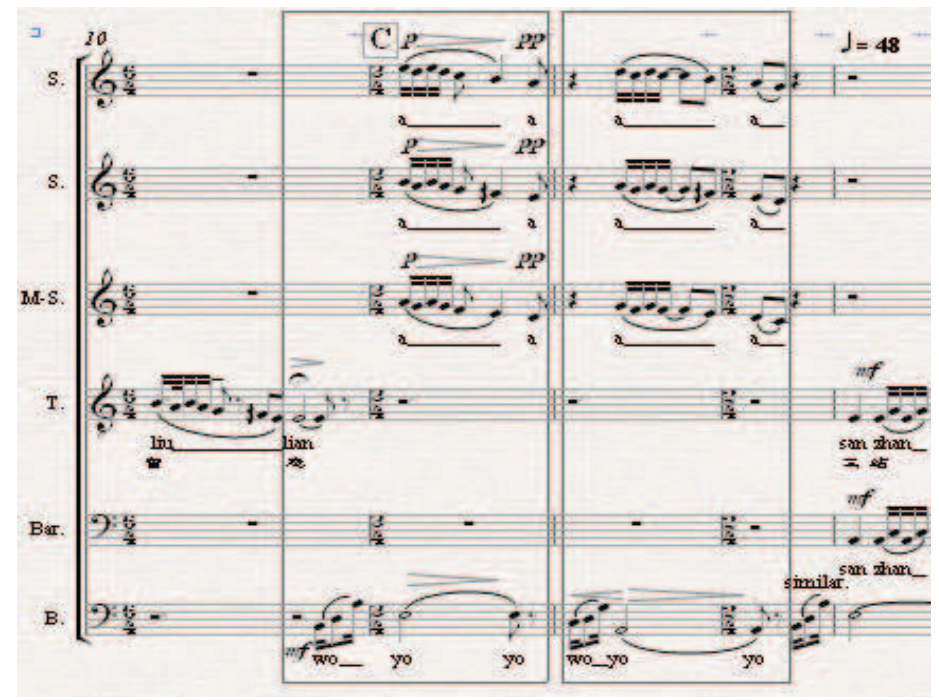


Example 7: Going Down to Sichuan Province (bb.15 - 18)

\subsubsection{The Structure of Xià Sìchuān (下四川) Going Down to Sichuan Province}

The form of my composition is in five sections:

Introduction $+\mathrm{A}+\mathrm{A} 1+\mathrm{A} 2+$ Coda.

Table 5: The structure of my Going Down to Sichuan Province

\begin{tabular}{|c|c|c|c|c|}
\hline $\begin{array}{l}\text { Introduction } \\
\text { bb. } 1-6\end{array}$ & $\begin{array}{l}\text { Verse I } \\
\text { bb. } 7-10\end{array}$ & $\begin{array}{l}\text { Verse II } \\
\text { bb.11-24 }\end{array}$ & $\begin{array}{l}\text { Verse III \& develop- } \\
\text { ment } \\
\text { bb. } 25-28\end{array}$ & $\begin{array}{l}\text { Coda } \\
\text { bb. } 29-31\end{array}$ \\
\hline $\begin{array}{l}\text { bb. 1-3 } \\
\text { chords back- } \\
\text { ground } \\
\text { T. \& M. S. solo }\end{array}$ & $\begin{array}{l}\text { bb. } 7-10 \\
\text { chorus (throat sing- } \\
\text { ing quartal har- } \\
\text { mony background) } \\
\text { T. solo } \\
\text { S. I \& II counter- } \\
\text { point echo part }\end{array}$ & $\begin{array}{l}\text { bb. 11-23 } \\
\text { S. I \& II and M.S. } \\
\text { short phrase is as } \\
\text { ostinato section } \\
\text { bb. } 11-23 \\
\text { B. repeated in coun- } \\
\text { terpoint with the fe- } \\
\text { male voices }\end{array}$ & $\begin{array}{l}\text { bb. } 25-28 \\
\text { S. I \& II and M.S. } \\
\text { chorus in perfect } 5^{\text {th }} \text {, } \\
\text { but unsynchronized }\end{array}$ & $\begin{array}{l}\text { b. } 29 \\
\text { bass solo }\end{array}$ \\
\hline $\begin{array}{l}\text { B. bb. 4-6 } \\
\text { bridged short } \\
\text { phrases }\end{array}$ & & $\begin{array}{l}\text { bb. 13-24 } \\
\text { T. \& Bar. in Perfect } \\
\text { 5th }\end{array}$ & $\begin{array}{l}\text { bb. 26-28 } \\
\text { T. B. \& bass. chorus } \\
\text { counterpoint echo } \\
\text { parts in perfect double } \\
4^{\text {th }}\end{array}$ & $\begin{array}{l}\text { bb. } 20-31 \\
\text { M. S. solo with } \\
\text { chorus }\end{array}$ \\
\hline
\end{tabular}

The introduction (bb.1-6 bars) comprises overlapped perfect $5^{\text {ths }} \& 4^{\text {ths }}$ built into a vertical chord. Material derived from the coda of the original transcription is then presented by the tenor (bb. 2-3), with the mezzo- soprano solo responding (bb. 3-4). Bars 4-6 consist of two short phrases as a transition.

Bars 7-10, Verse I: The tenor presents the main melody, but with a flexible rhythm, suggestive of the free rhythm of shāngēe. Accompanying the main melody, the two spranos sing in parallel $4^{\text {ths }}$, echoing the tenor. Meanwhile the baritone, mezzo-soprano and bass sing a throat singing background of quartal harmony; suggestive of Mongolian vocal styles, since Inner Mongolia is the Chinese province bordering on Gansu, from where Xià Sìchuān originates. 
In Chinese music the term zhissheng füdiào refers to a style of polyphony whereby melodic material in one voice is used to generate the material in other voices, similar in some ways to melodic imitation in Western polyphonic music of the $16^{\text {th }}$ century. In zhīshēng fùdiào the derived melodies are not regarded as independent, but rather as branches growing out of a main trunk (the principal melody). This is the concept I used in composing the line for the sopranos in bars 7-10 in relation to the tenor.

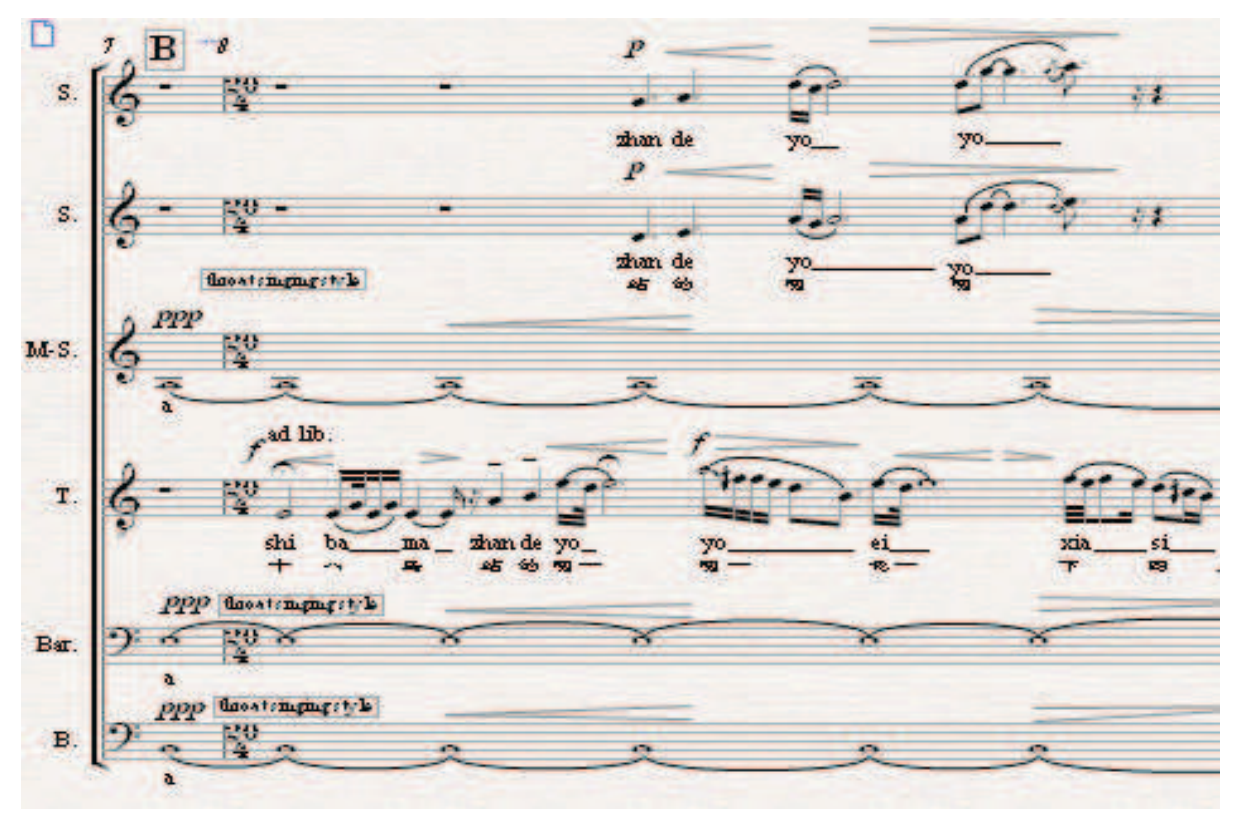

Example 8: Going Down to Sichuan Province (bb. 7-8)

Bars 11-24, Verse II begins with a series of layered ostinati, with the bass and sopranos in dialogue with each other, as call and response. The tenor and baritone present the main melody in parallel perfect $5^{\text {ths }}$. By way of contrast with verse I, the tempo increases and a stronger sense of dynamics is established. 


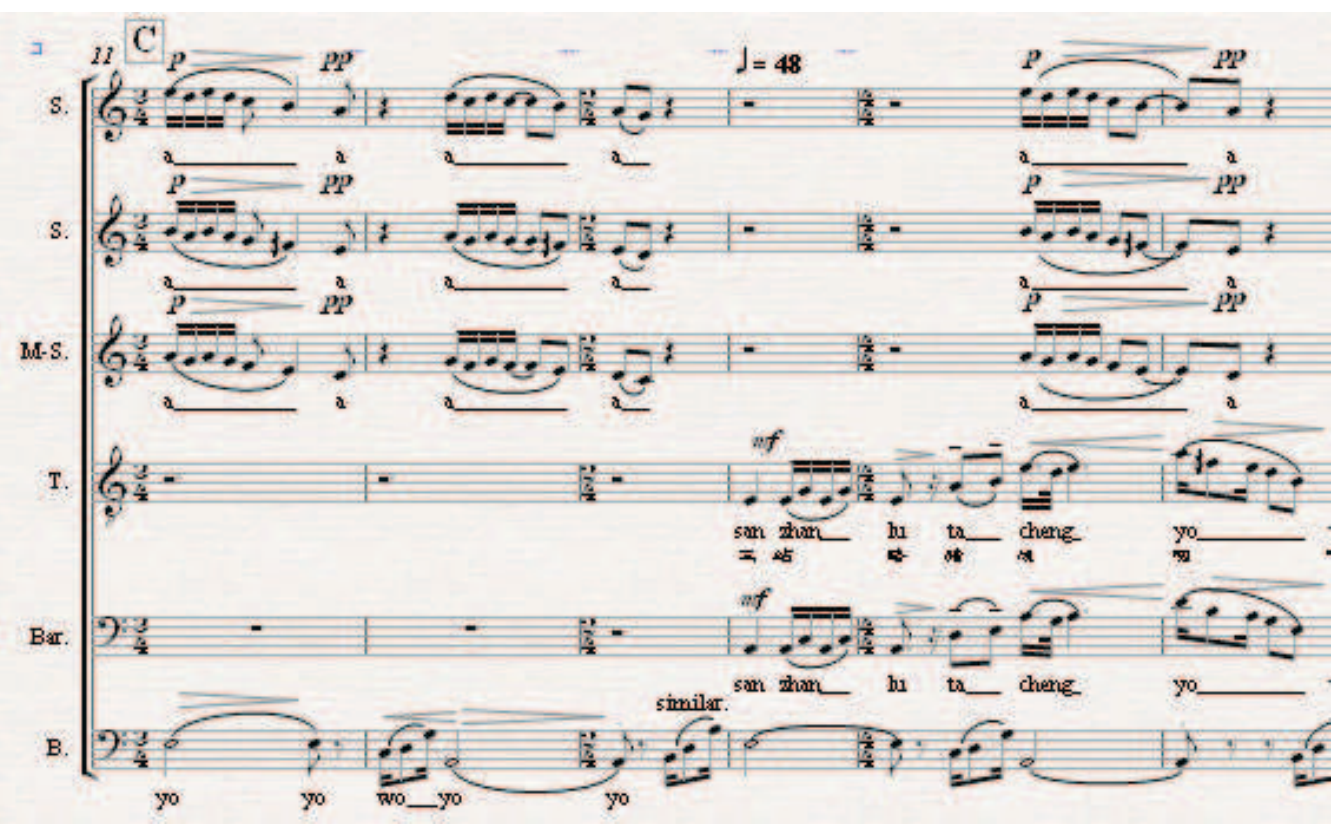

Example 9: Going Down to Sichuan Province (bb. 11 - 16)

In bars 25-28, Verse III there is a return to the first tempo $(\cdot=\mathbf{4 4})$ and the shāngē style of the first verse. The three female voices are required to sing in an unsynchronized manner, creating a rhythmic heterophony, the mezzo-soprano singing a $5^{\text {th }}$ lower than the two sopranos. Meanwhile, the tenor, baritone and bass echo the upper voices in parallel quartal chords.

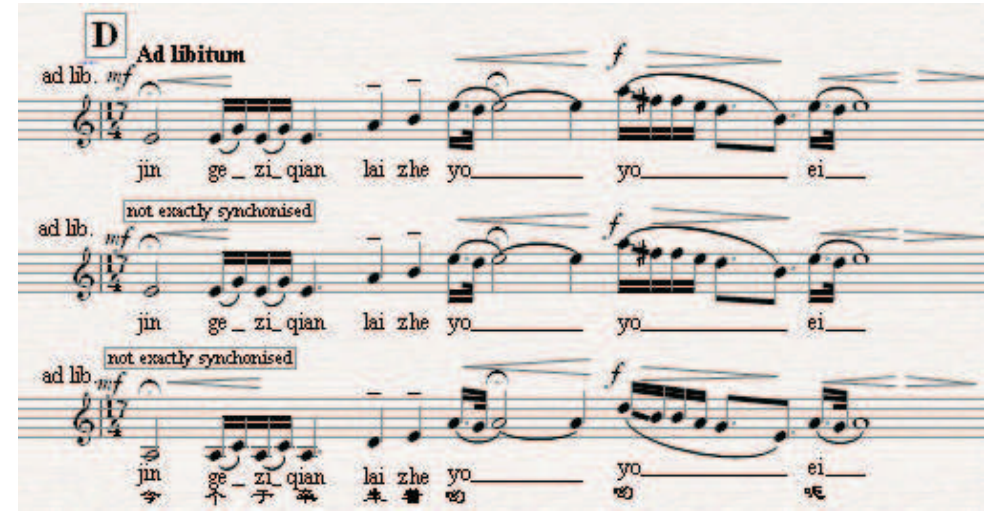

Example 10: Going Down to Sichuan Province (b. 25)

In the second half of this verse, all parts are again together, and the harmony builds in tension towards the climax at the beginning of bar 28 . 


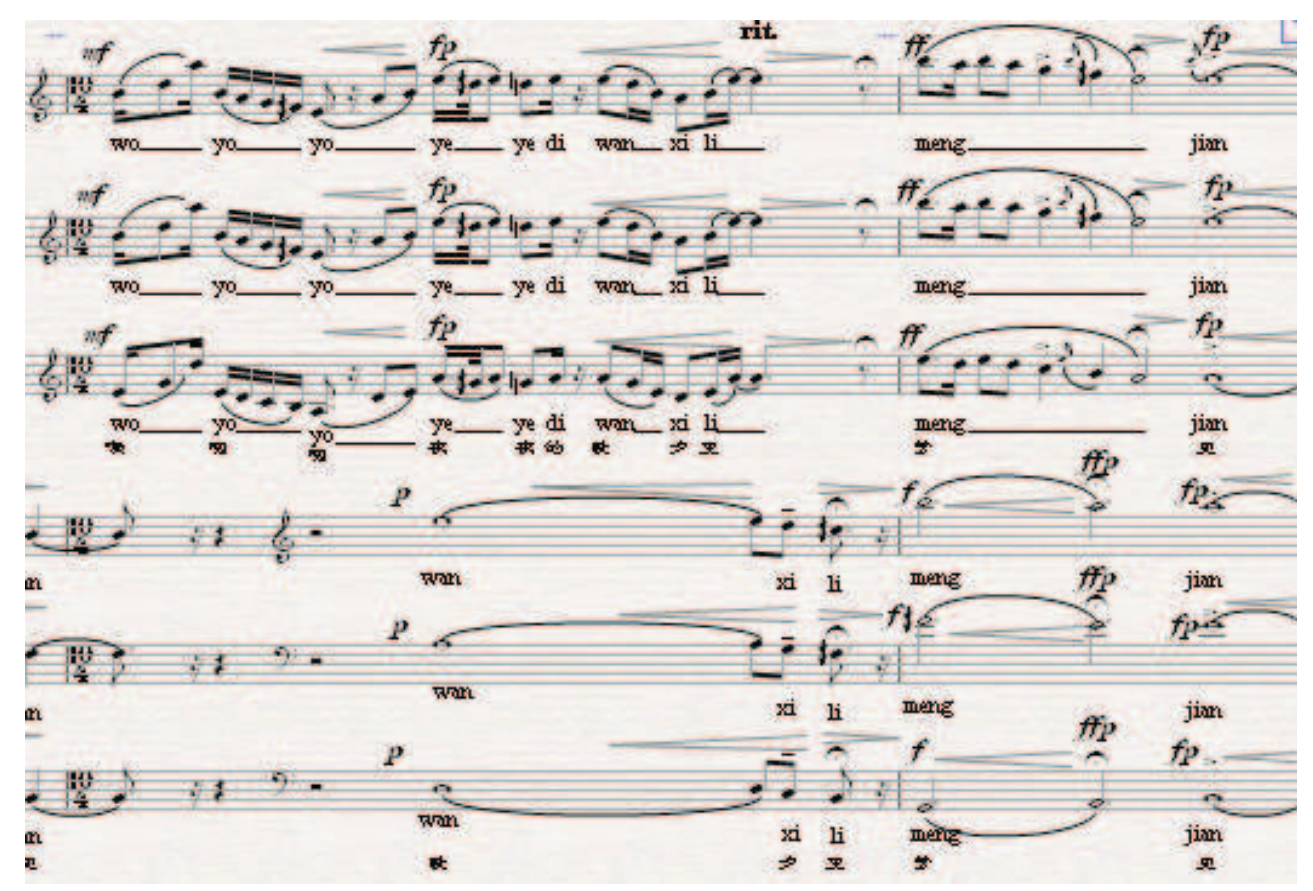

Example 11: Going Down to Sichuan Province (bb. 27 - 28)

The coda (bb. 29-31), begins with melodic variation for the bass, with a same pitch tremolo technique, characteristic of the mùge (牧歌) (highland pastoral) style. This technique is used by Li Guizhou and Ji Zhengzhu in several songs on the recording shàonián: Courtship Songs from Northwest China, such as No. 3. Going to Sichuan Province by Li Guizhou and No.7. The First Melody of Linxia by Ji Zhengzhu. ${ }^{158}$

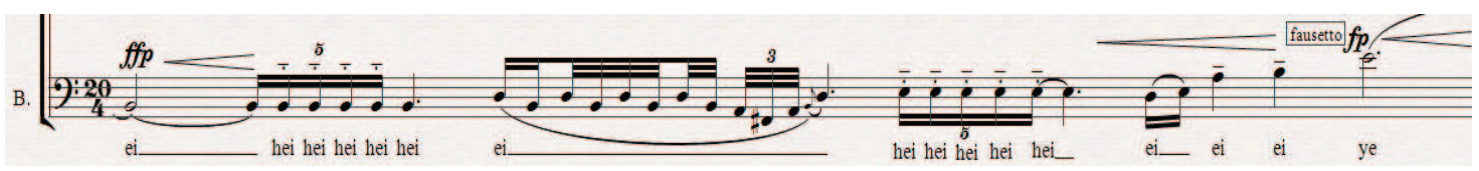

Example 12: Going Down to Sichuan Province (b. 29)

The second phrase of the solo line passes from the bass to the mezzo-soprano, ornamented with grace notes figures such as those found in Chinese opera. This is not as inappropriate

\footnotetext{
${ }^{158}$ Du Yaxiong 杜亚雄 with Jack Body, Shàonián: Courtship Songs from Northwest China- The Singers, the Songs and the Music, p. 33.
} 
as might first appear since we know that origins of Chinese opera are to be found in folk music. $^{159}$

The final bar of Xià Sìchuān reviews the essential melodic material of the whole work.

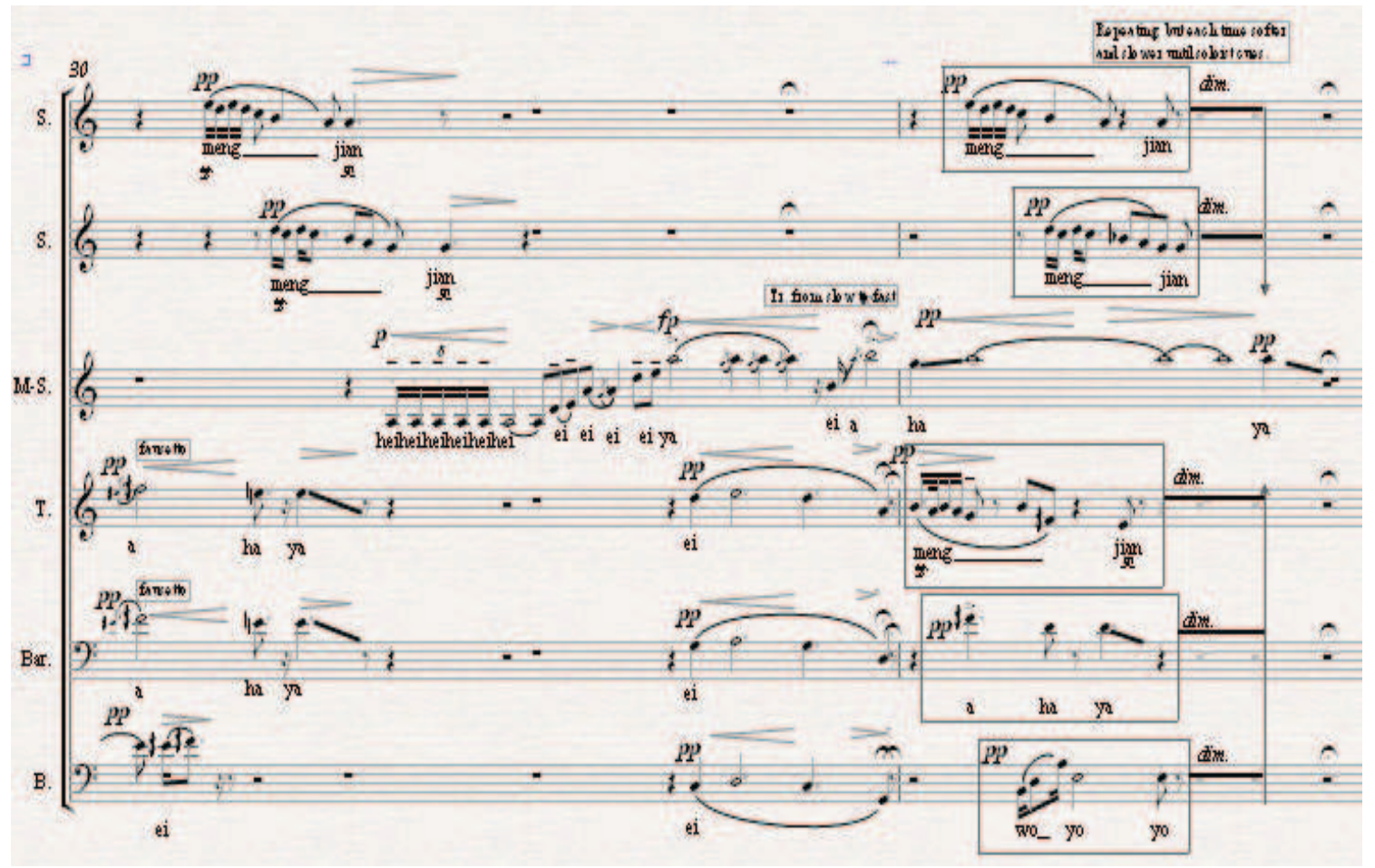

Example 13: from Going Down to Sichuan Province (bb. 30 - 31)

In summary, in this work, a Chinese folk song originally sung by an authentic Chinese folk singer has been transformed into a composition for an ensemble of six professional Western singers.

After studying and analysing Mathieu Fraser's notation I reassembled and structured the material for six voices in five sections:

\footnotetext{
159 “In the early 南戏 (Nánxi) The Southern Theatre, its music comprised local tunes.” Cf. Lu Ji 吕骥 and He Luding 贺绿丁, The Encyclopaedia of China, Music and Dance Volume, p. 419. My translation.
} 
Table 6: The Structure of Going Down to Sichuan Province

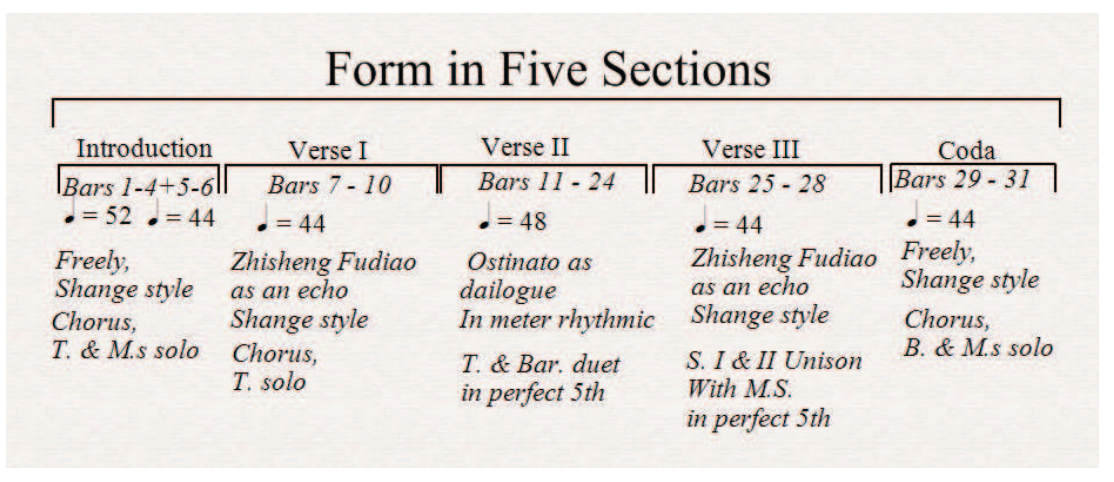

In dramatic terms, this composition draws together the moods of several characters, with a common feeling of longing and desire, representing the roles of shàonián (少 年) (young man) and hóng mǔdān (红牡丹) (peony = sweetheart), While not "music theatre" in the strictest sense, I intended this work to be performed and perceived as a quasi erotic exchange between the male and female performer.

I ask the singers to listen very carefully to the recording of Li Guizhou's performance and to assimilate and reproduce as closely as possible his singing style and the vocal techniques which he uses. 


\subsection{Wănge (輓 歌) Elegy}

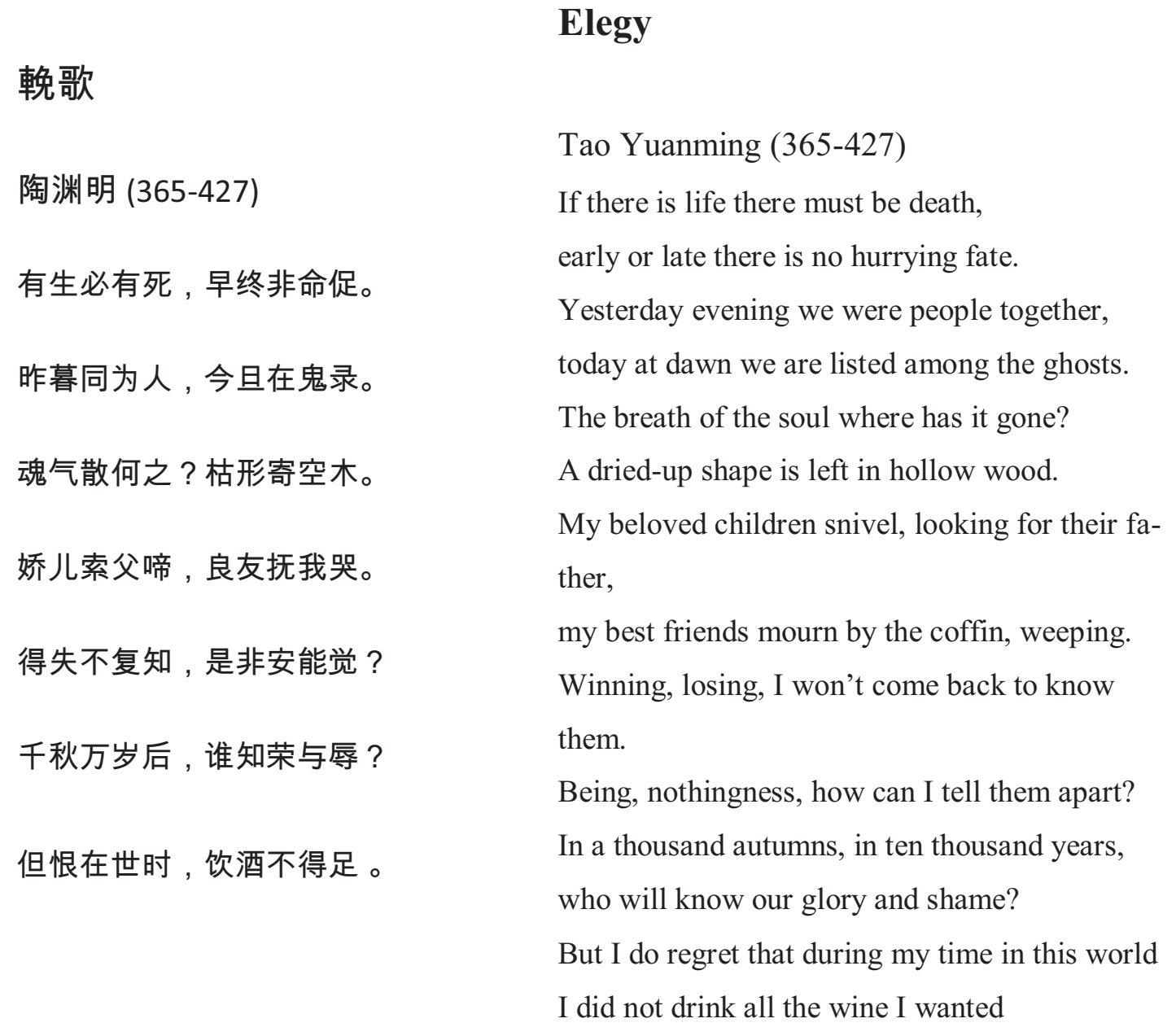

This work was composed for inclusion in a programme called "Vita Brevis", a concert in memory of the victims of the 2004 Asian tsunami.

Wăngē (Elegy) uses a poem by Tao Qian (Tao Yuanming) (365-427), who is one of the greatest poets in the Weijing (魏晋) period of China. His famous poem and essay Táohuā Yuán Ji Bìng Shī (桃花源记并诗) (The Garden of Peach Blossoms) ${ }^{160}$ describes an imaginary "ideal world" which became an inspiration for following generations who came to

\footnotetext{
${ }^{160}$ Chen Qiaosheng 陈桥生, Tao Yuanming 陶洲明 (The Poem of Tao Yuanming), Beijing: Wuzhou Chuanbo Chubanshe, 2006, p. 90.
} 
admire his works and his life. The poem Wăngē (Elegy) expresses the poet's attitudes towards life and death, about honour and disgrace, and his love of wine.

The composition Elegy is for zhēng (zither), two gender metalophones from a Javanese gamelan and vocalist/speaker. The technique for the zheng includes playing the strings on both the right- and left-hand sides of the bridge. Both instrumentalists also sing in the latter part of the work. The poem is presented in the performance in both English and Chinese.

While the 21 strings of the zheng are usually tuned in a pentatonic mode of five notes per-octave, Elegy requires a special tuning of six notes per octave, matched with the gender, each of which have themselves slightly different tuning, as indicated below:

Table 7: The tuning of the zheng

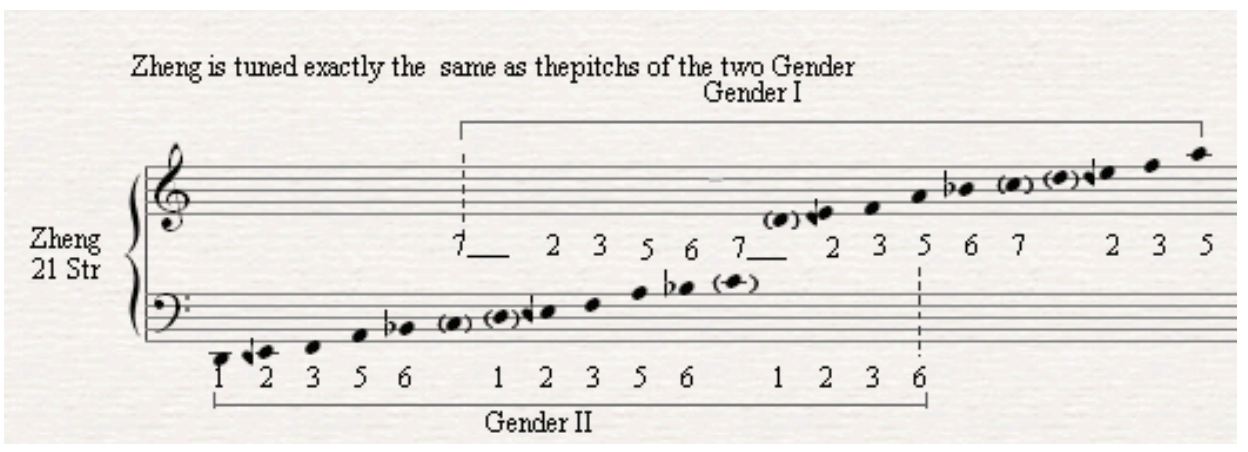

The gender is played in an unconventional way, with both soft and hard beaters, and sometimes with the base of the beater handle in imitation of the "bent pitch" of the depressed strings of the zheng.

The musical material of the work is derived from a short motive from a classical Chinese qín composition, the second theme of Méihuā sān nòng (梅花三开) (Plam Blossom triparted variation): ${ }^{161}$

\footnotetext{
${ }^{161}$ Zhu Zhou 朱舟, Zhonggou Chuantong Mingqu Xinshang (The most remarkable traditional compositions of China), Chengdu, Sichuan Renmin Chubanshe,1982, p.26.
} 


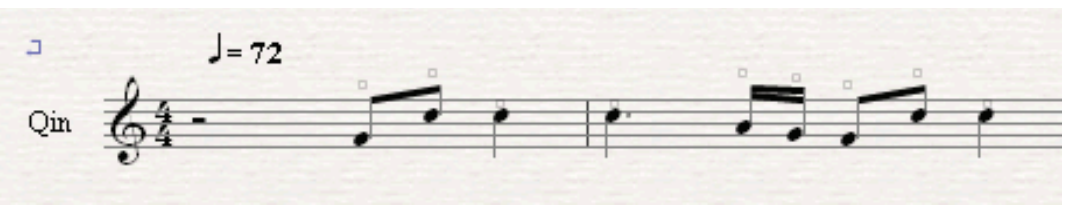

Example 14: A motive from Méihuā sān nòng for qín

The structure of Elegy is in two parts with an introduction and a coda. Part I is instrumental, and Part II is for voices with instruments. In the introduction the poem is recited in English, and in the short coda the instrumentalists also sing while playing.

Table 8: The musical structure of Elegy

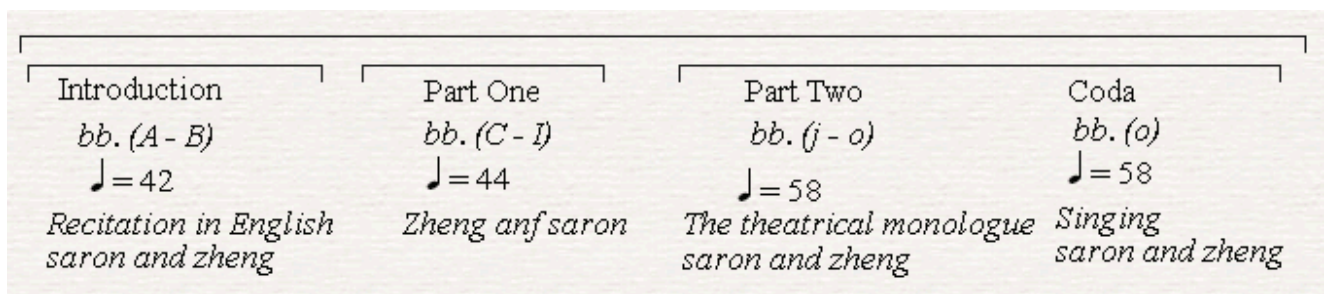

In Part I, the two instruments are from different parts of Asia, and then echo single notes, conveying a sense of aloneness in death.

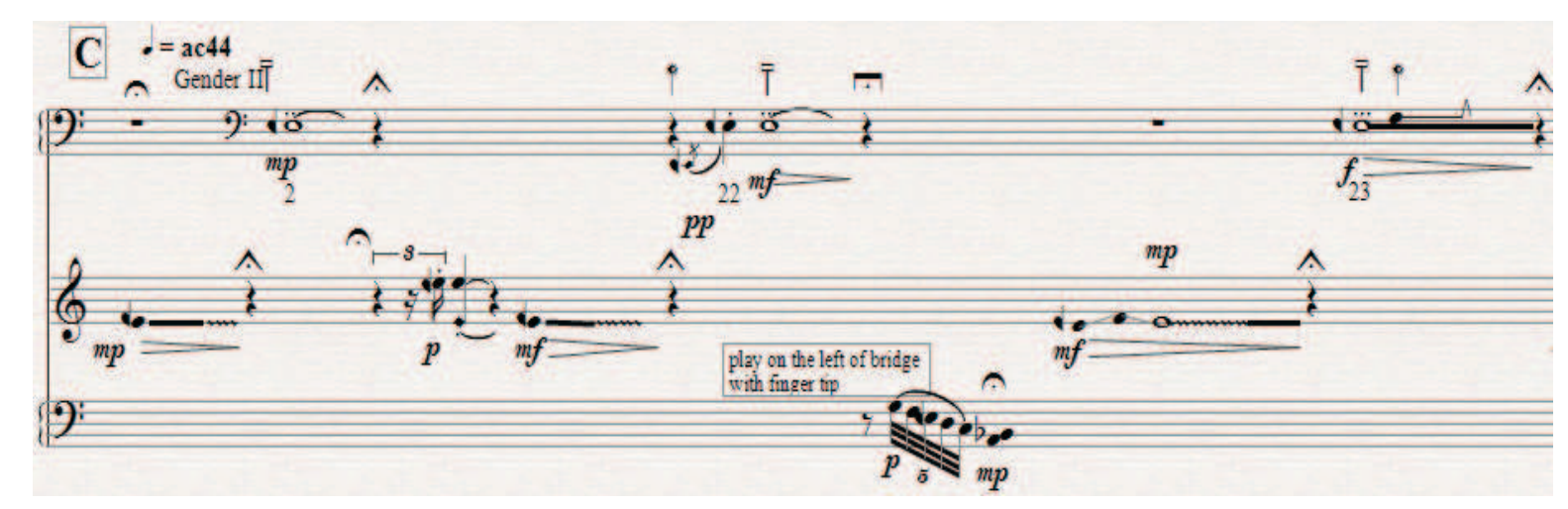

Example 15: The opening of Part I

Part II integrates the Chinese xìqü performance style in a setting of Tao Yuanming's poem as a kind of theatrical sprechgesang monologue, with the vocalist enacting the character of Tao Yuanming. 


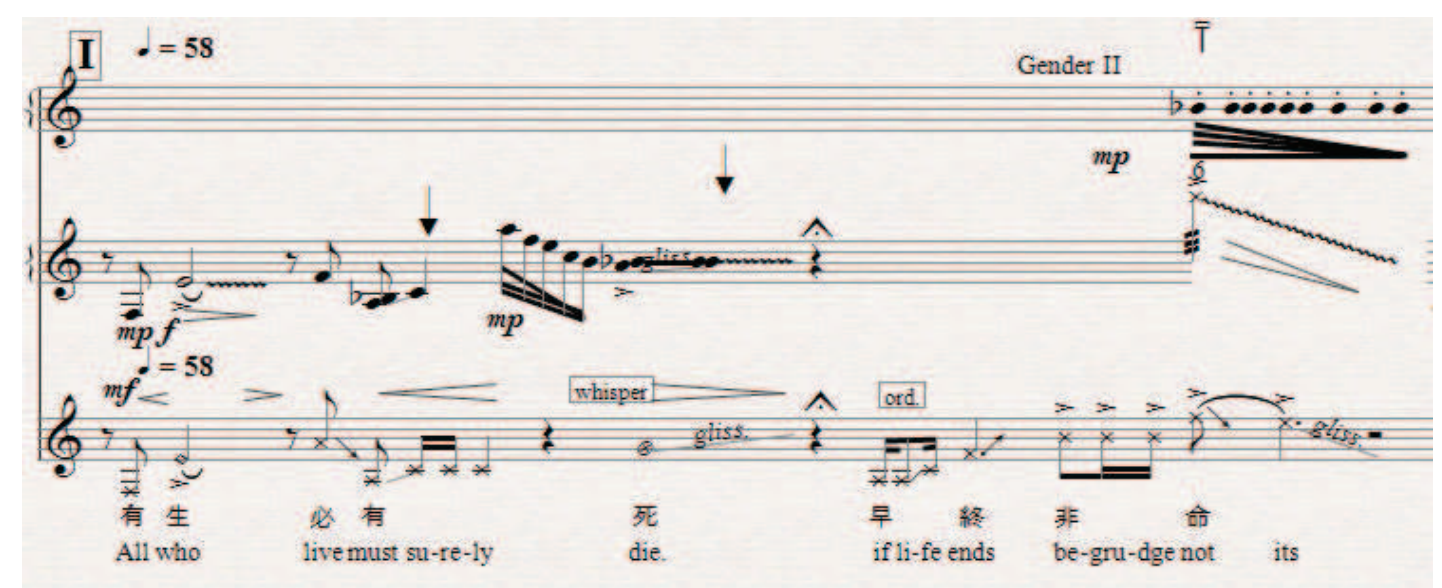

Example 16: The opening of Part II

In the coda, the three musicians play and sing together the sung motive based on the pelog mode of the gender. At the time of composition this ending took into consideration the venue of the first performance and its resonant acoustic (St Mary of the Angels Church, Wellington) to suggest a hymn-like tribute to the memory of this great poet.

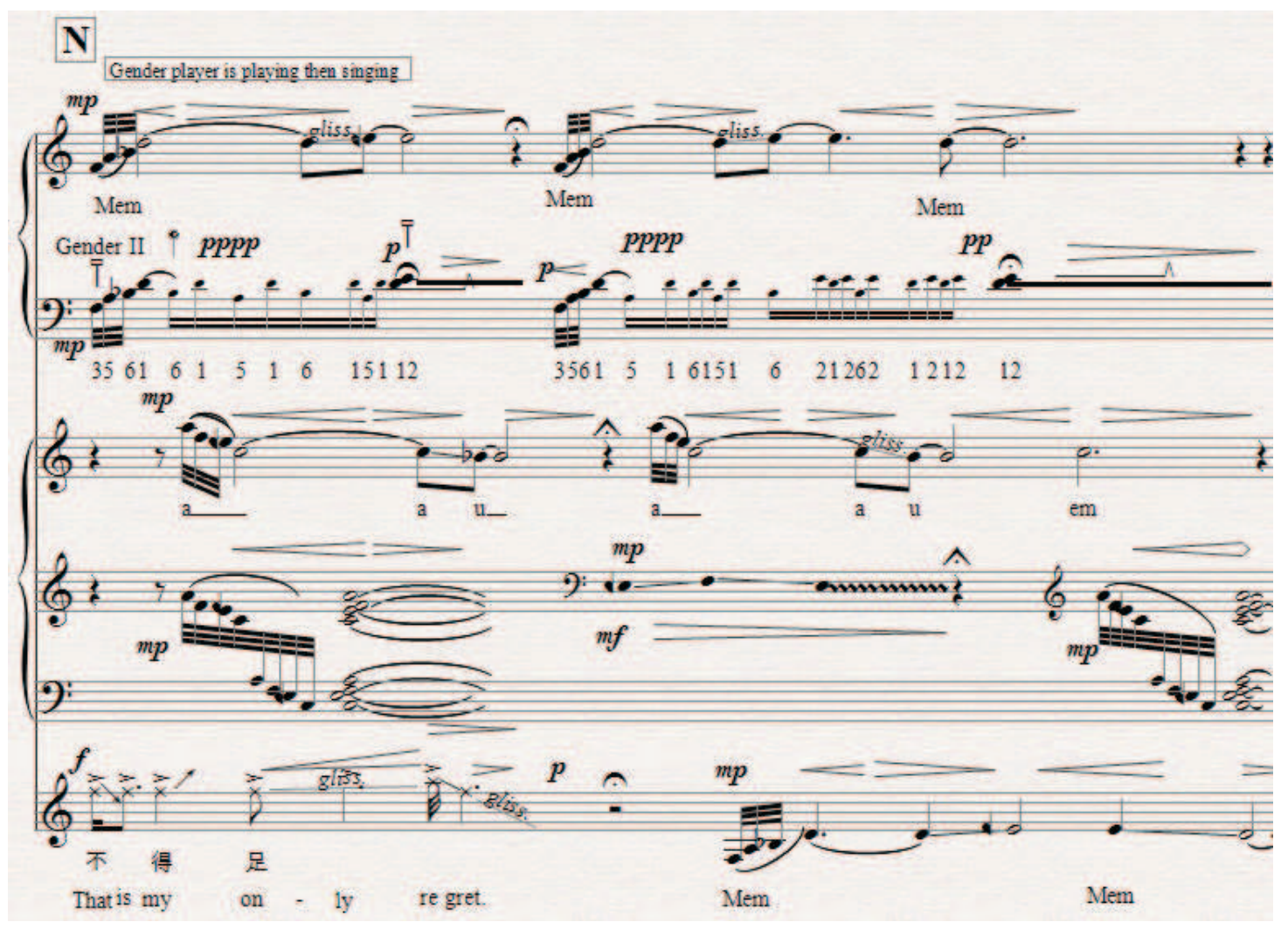

Example 17: The coda of Elegy 
This was the first time I derived materials from different cultural traditions, and integrated them into a new work. This new musical sound world became a fascination in my compositional practice.

I had pleasure in dedicating the work to Jack Body who organized the "Vita Brevis" performance, who is known to appreciate wine, and who I believe shares with Tao Yuanming a similar attitude to mortality and the necessity of living life to the full. 


\subsection{Wang}

"To Western ears, spoken Chinese is already music"

- Jack Body

Wang was composed for the World Music Days, International Symposium and Festival Dialogue in Music, 2009: an annual conference and festival hosted by the musicology department of the Central Conservatory of Music, Beijing. The 2009 festival/conference ${ }^{162}$ focused on the musical cultures of Aotearoa/New Zealand. Wang had its premiere on $1^{\text {st }}$ November in the Recital Hall. The work integrates three different instrumental traditions: Chinese, Javanese and Maori. It is scored for a vocal quartet, a shēng (mouth organ), a zhēng (21-string zither), two qing (temple bowls), a saron, bonang and gongs from a West Javanese gamelan, and a Maori instruments: nguru (small nose flute), koauau koiwi (bone flute), pukaea (large wooden trumpet) and tuтитити (percussion). Both in conceiving the work and in its performance I collaborated with Maori musician Horomoro Horo.

\subsubsection{The "Non-Text" Concept of Wang}

Jack Body's comment about the "musicality" of Chinese language was the inspiration for this work. The text consists of a single sound, "wang" which takes on an impressive raft of different meanings when articulated using different expressions, and the different intonations available in the various "tones" of spoken Chinese.

\footnotetext{
${ }^{162}$ Curated by Jack Body, this conference/festival was held in Beijing to explore Maori and Pacific Island music and practice in a multi-cultural Pacific/Asian context. A delegation of 27 musicians, composers, scholars, film makers and other artists representing New Zealand, Maori and Pacific Island cultures, gave papers, lectures, demonstrations and performances. Each of the four conference days concluded with a concert of New Zealand, Maori and Pacific music. The four conference sessions and associated concerts were divided into themes:

Sunday 1 November: Multicultural NZ

Monday 2 November: Tangata Whenua: People of the land

Tuesday 3 November: Visual Art and Music

Wednesday 4 November: Dialogue between Chinese and Pacific Music
} 
Tones have always been intrinsic to most Chinese languages. The writer of the Southern,

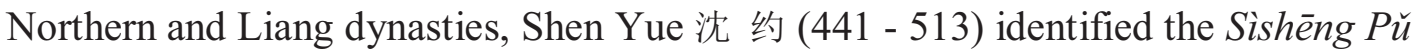
(四声谱) (Four Tones Spectrum). ${ }^{163}$ In 1958 the Chinese government issued Hànyǔ Pīnyīn Fāngàn 汉语拼音方案 (Chinese Phonetic Alphabet) which formalized a standard for the Romanisation of the sounds of Chinese as well as indications of tone.

The sound "wang", spoken with these different expressions and intonations and placed in various contexts can have up to 20 different meanings, and written with up to 48 different characters. There are nouns, verbs, adjectives, prepositions, quantifiers, and onomatopoeia. Some characters are obsolete, but exist in ancient texts, while others are slang or obscene and are seldom written.

Some of the meanings are similar and sometimes they are completely opposite, as seen in the following examples: 1) The first tone of wāng, as a word such has 龙, means “feeble" or "lame", while the same sound and tone may be written as 汪, and is a surname (wāng), an "expanse of water" or "an ooze from underground". 2) The second tone of wáng, if written as 亡, means “to die” or “to perish", while 王 means "King” or is a surname (wáng). 3) The third tone of wăng written as 往 means “to go" (in a diretion/past/previous/towards), while 枉 means “unjustly wronged” or “in vain”. 4) The fourth tone of wàng 旺 means “prosperous”, “flourishing”, “to prosper”, “to flourish”, and 望 is similarly positive, meaning "hope", "expect", "to visit" "to gaze (into the distance)", "look towards/towards". On the other hand 妄 means "absurd", “fantastic", and 忘 means "to forget”, "to overlook", or "to neglect".

The monosyllable "wang", as a sound, has potential to endlessly stimulate the imagination.

\footnotetext{
${ }^{163}$ Shen Yue 沈约 (441 - 513) was a prominent scholar of the Liang dynasty and the author of Song Shu (the book of Song) a historical work covering the history of the previous Liu Song dynasty. He is probably best known as the originator of the first deliberately applied rules of tonal Euphony in the history of Chinese prosody. Cf. Ci Hai 辞海, Chinese Encyclopaedia, Literature volume, 1980, p. 41.
} 
This is the concept behind this composition, which has no coherent "text", but which leaves it up to the listener to explore the multifarious and multilayered meanings of "wang".

\subsubsection{The Musical Structure and the Themes of Wang}

The musical structure of Wang consists of compound variations, which are based on two themes and variants of there two sections, plus an introduction and a coda.

Table 9: The Musical Structure of Wang

\begin{tabular}{|c|c|c|c|}
\hline Introduction & A & B & Coda \\
\hline bb. $1-43$ & bb. $44-118$ & bb. $119-195$ & bb. $196-232$ \\
\hline$\bullet=54$ & $\bullet=54$ & $\cdot=72 / 78 / 48$ & $\cdot=48$ \\
\hline $\begin{array}{l}\text { Recitation } \\
\text { and singing }\end{array}$ & $\begin{array}{l}\text { Theme I and five variations, } \\
\text { based on variant intervals } \\
\text { and melodic omaments }\end{array}$ & $\begin{array}{l}\text { Theme II and six variations, } \\
\text { based on extention the length } \\
\text { of theme II and imitations }\end{array}$ & $\begin{array}{l}\text { Recitation } \\
\text { and singing }\end{array}$ \\
\hline
\end{tabular}

Theme I is constructed from four repetitions of "wang", using the four tones, producing a melodic contour born out of the embryonic shape of the spoken syllables.

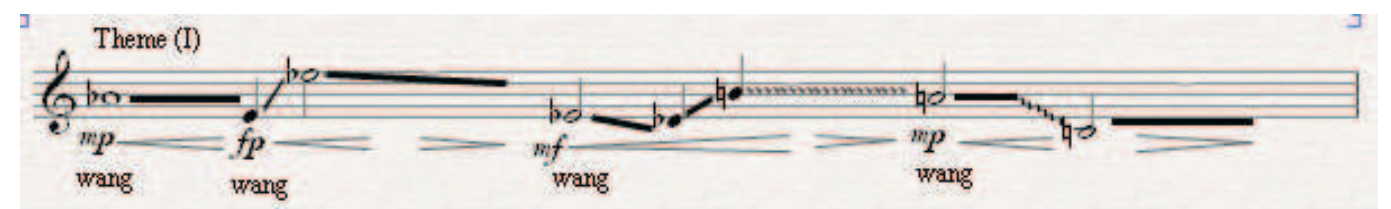

Example 18: The four tones melodic contours of theme I

Theme II uses a specific pentatonic mode, in two complementary contrapuntal lines, one of 8 beats and the other of 7 beats. The pitches of this theme are derived from the pitches of the specific gamelan used for the premiere of Wang, a set of instruments from Sunda (West Java) and tuned in pelog mode. 


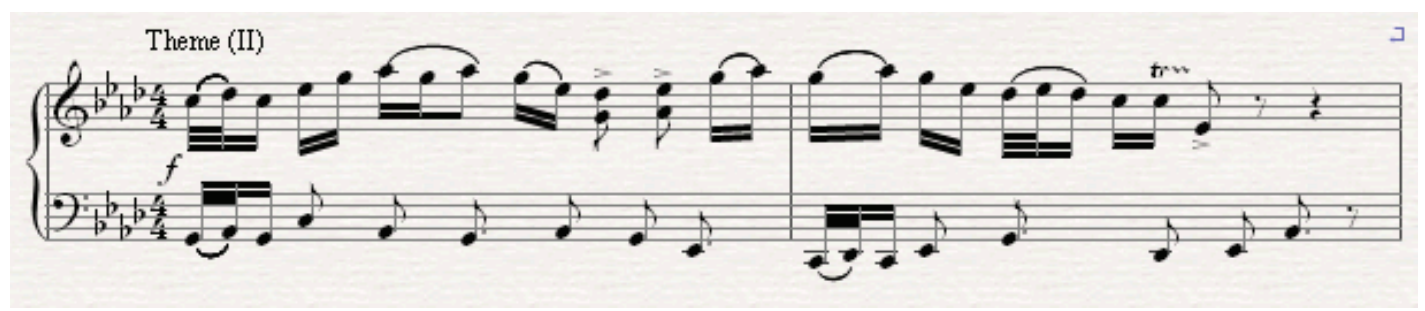

Example 19: Theme II

The score calls for two complementary gamelan Saron (metalophone) and one bonang (horizontally mounted gong chimes), providing ranges of three and two octaves respectively.

\subsubsection{Potential Interpretations of the Meaning of Wang}

As mentioned above, a Chinese-speaking audience listening to Wang may interpret the meaning of the different presentations of the word according to the contours of the vocal line, that is, the direction of the tone. However, an audience unfamiliar with Chinese language may interpret meanings of the word Wang through their imaginative response to the music itself, to its textures, dynamics and tempi, and especially to the expressive qualities of the voices. Here are four examples of suggested interpretations.

In my first example, bb.14-38, is a series of long crescendi-diminuendi "waves". Over four phrases the note durations, at the beginning semibreves, gradually become shorter. The word "wang" is sung on a single pitch, $\mathrm{Ab}$, but is broken down into four discrete phonems - w (u), a, n, ng - which the singers merge slowly one into another. Phrase one is a single, very elongated presentation of the word. Phrase two presents the word twice within the same number of bars. Phrase three has two repetitions, each concluding with a rapidly repeated "echo-effect" ("wang, wang, wang..."). The Maori performer meanwhile sings a gentle ori-ori. The instrumental writing throughout the section includes sustained notes that slowly rise in pitch on the bowed zhèng, and the shēng, with occasional, though increasingly active flutterings from the percussion. The fact that "wang" spoken in tone 1 means "ocean", should by this time be self-evident to all listeners. 
In phrase four the singers depart from a single note A flat building a sequence of ascending perfect 4ths, suggesting the rising intonation of tone 2 . The music builds in its dynamics and activity and the pitch rises towards the first climactic point of the work as Maori musician blows the putatara conch shell. The water symbolism by now has changed into something more ambiguous.

In my second example, the descending cries in the vocal parts at b.115 and bb.168-169, suggest self-pity, of someone suffering psychological hurt, as sung by a dan (且) (young lady) character in xiqü. The instrumental ensemble plays a loud insistent chord that suddenly stops. The voices here would be interpreted as a "wang" spoken in tone 3 (falling and rising), meaning "unjustly wronged", the archetypical opera character for which would be the pitiable Dou E, in Dòu E Yuān (窦娥冤) (The Injustice Done to Dou E), who was falsely accused of murder and executed because she refused a marriage proposal (see footnote 89$)$.

In bb.131-151, my third example, the meaning of "wang" in this section is deliberately ambiguous. The colourful and rhythmically lively music, a variation of Theme II, is played by the full ensemble including gamelan instruments accompanied by a percussive pulse. The voices chant all four tones of "wang" but in a melodic contour that is strongly reminiscent of a revolutionary song from the Cultural Revolution, Wúchănjiējí wénhuà dàgěmìng jiùshihăo 无产阶级文化大革命就是好 (The Proletarian Great Cultural Revolution is good), the original pentatonic mode now "bent" into pelog.

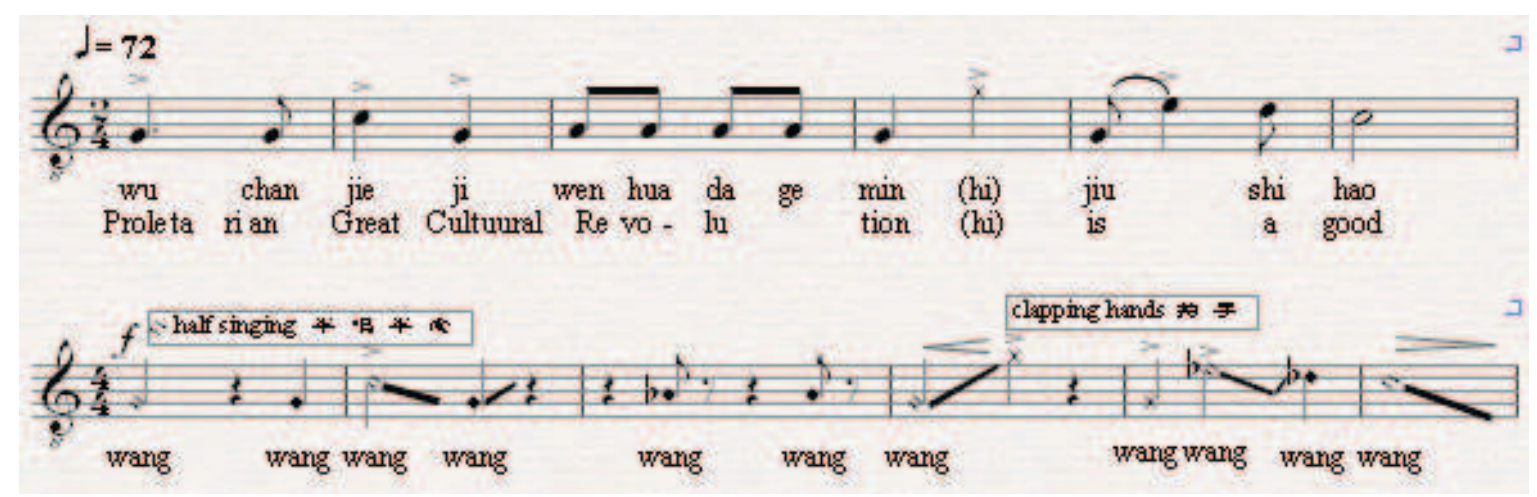

Example 20: The revolutionary song adapted for the Wang 
Since all four tones are heard, a Chinese audience can draw on many interpretations of "wang" including negative associations such as "death", "absurdity" and "injustice". Thus the joyful character of the music suggests an ironic meaning for a Chinese audience, especially for those who lived through the dark times of the Cultural Revolution.

Four times in my fourth example, (bb 116-118, 122-124, 128-130, 181-183) the vocal style imitates the mămén qiāng style of declamation, used by a warrior character such as wǔshēng (武 生) (samurai) in Sichuan opera. Hearing this, a Chinese audience imagines a powerful, heroic figure announcing his imminent entry onto the stage. The interpretation of "wang" with tone 2 (ascending from low to high) implies "King", a symbol of power, which is reinforced on hearing (and seeing!) a Haka, a Maori war chant (bb.176-183). Throughout the section an instrumental pulsation combines with vocalists" clapping in the rhythm of a slow march while also periodically chanting "wang" in a loud whisper. The "power" image is hereby enriched by associations engendered by the falling intonation (tone 4) of the vocalists" whispered "wang", meaning "death".

\subsubsection{Musical Analysis of Wang}

Wang is focussed on the compositional technique of variations. The theme of section A is based on a melodic contour. The variations of it expand and contracte its intervals, which serves to ornament its melodic contour. This variation principle derives from the music tradition of chuānjǜ gāoqiāng.

As mentioned above (see Chapter 3.2.1), the singing style tradition of chuānjù̀ gāoqiāng allows the singer to introduce variations of the given melody, to extend or contract the phrase lengths, and to ornament expressively according to the particular text which is being sung.

This principle is reflected in the score of Wang, where the theme is subject to variations, (albeit composed rather than improvised) which intended to convey the spirit of chuānjü 
gāoqiāng through variation. The singers are "introduced" one by one by the shēng (mouth organ), each having their own variants which follow the same melodic contour of the theme, albeit with expanded and contracted intervals.

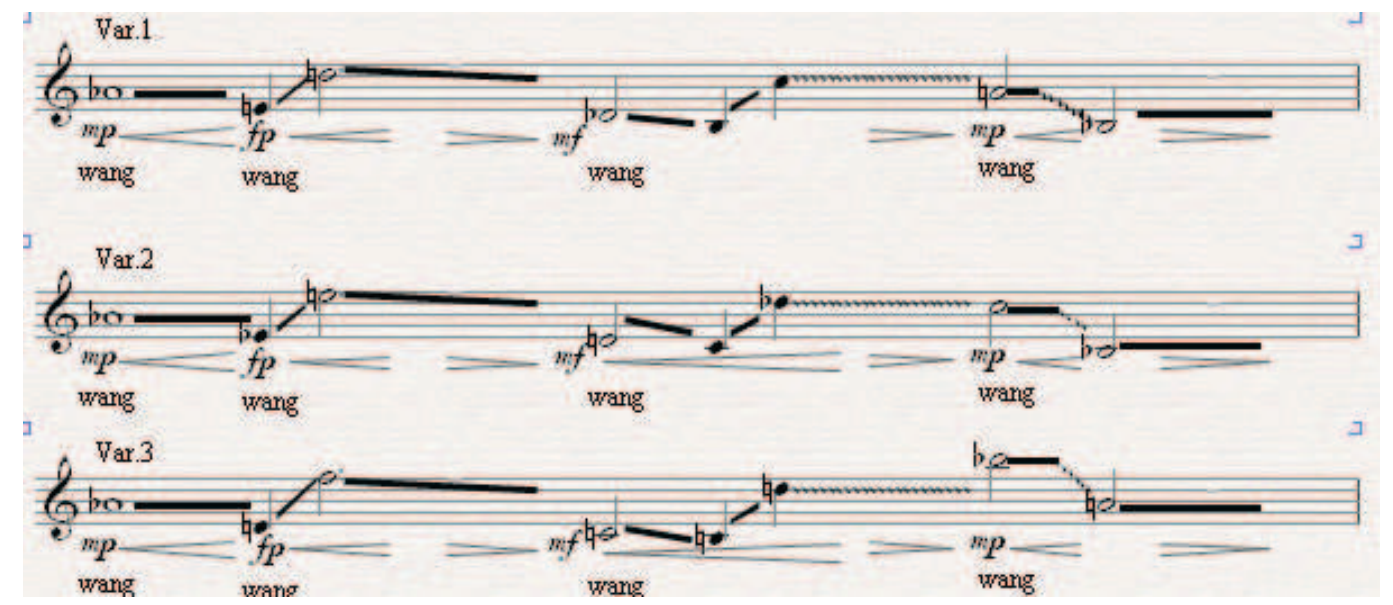

Example 21: Section A: Three variations of the melodic contours of Theme I

The theme is subject to further variation, but always following the same melodic contour, though sometimes in retrograde.

Table 10: Variations of "wang"

\begin{tabular}{|l|c|c|c|c|c|c|c|c|}
\hline Theme A & $\mathrm{Ab}$ & $\mathrm{E}$ & $\mathrm{Eb}$ & $\mathrm{Eb}$ & $\mathrm{Db}$ & $\mathrm{B}$ & $\mathrm{A}$ & $\mathrm{B}$ \\
\hline $\mathrm{A} 1$ & $\mathrm{Ab}$ & $\mathrm{E}$ & $\mathrm{D}$ & $\mathrm{Db}$ & $\mathrm{B}$ & $\mathrm{C}$ & $\mathrm{A}$ & $\mathrm{Bb}$ \\
\hline $\mathrm{A} 2$ & $\mathrm{Ab}$ & $\mathrm{Eb}$ & $\mathrm{E}$ & $\mathrm{D}$ & $\mathrm{C}$ & $\mathrm{Db}$ & $\mathrm{C}$ & $\mathrm{Bb}$ \\
\hline $\mathrm{A} 3$ & $\mathrm{Ab}$ & $\mathrm{D}$ & $\mathrm{F}$ & $\mathrm{C}$ & $\mathrm{B}$ & $\mathrm{D}$ & $\mathrm{Bb}$ & $\mathrm{A}$ \\
\hline A retrograde & $\mathrm{B}$ & $\mathrm{A}$ & $\mathrm{B}$ & $\mathrm{Db}$ & $\mathrm{Eb}$ & $\mathrm{Eb}$ & $\mathrm{E}$ & $\mathrm{Ab}$ \\
\hline A1 retrograde & $\mathrm{Bb}$ & $\mathrm{A}$ & $\mathrm{C}$ & $\mathrm{B}$ & $\mathrm{Db}$ & $\mathrm{D}$ & $\mathrm{E}$ & $\mathrm{Ab}$ \\
\hline $\mathrm{A} 2$ retrograde & $\mathrm{Bb}$ & $\mathrm{C}$ & $\mathrm{Db}$ & $\mathrm{C}$ & $\mathrm{D}$ & $\mathrm{E}$ & $\mathrm{Eb}$ & $\mathrm{Ab}$ \\
\hline A3 retrograde & $\mathrm{A}$ & $\mathrm{Bb}$ & $\mathrm{D}$ & $\mathrm{B}$ & $\mathrm{C}$ & $\mathrm{F}$ & $\mathrm{D}$ & $\mathrm{Ab}$ \\
\hline A 4 transposition of A & $\mathrm{Eb}$ & $\mathrm{B}$ & $\mathrm{Bb}$ & $\mathrm{Bb}$ & $\mathrm{Ab}$ & $\mathrm{F}$ & $\mathrm{E}$ & $\mathrm{F}$ \\
\hline A 5 transposition of A3 & $\mathrm{Eb}$ & $\mathrm{A}$ & $\mathrm{C}$ & $\mathrm{G}$ & $\mathrm{F} \#$ & $\mathrm{~A}$ & $\mathrm{~F}$ & $\mathrm{E})$ \\
\hline
\end{tabular}

In turning these pitch sequences into vocal lines chuānjǜ gāoqiāng principles of variation and ornamentation are kept in mind. The Maori musician, playing the koauau koiwi, is required to apply these principles in following the contour of the given line when improvising a response to Theme I (A) sung by the mezzo-soprano. 


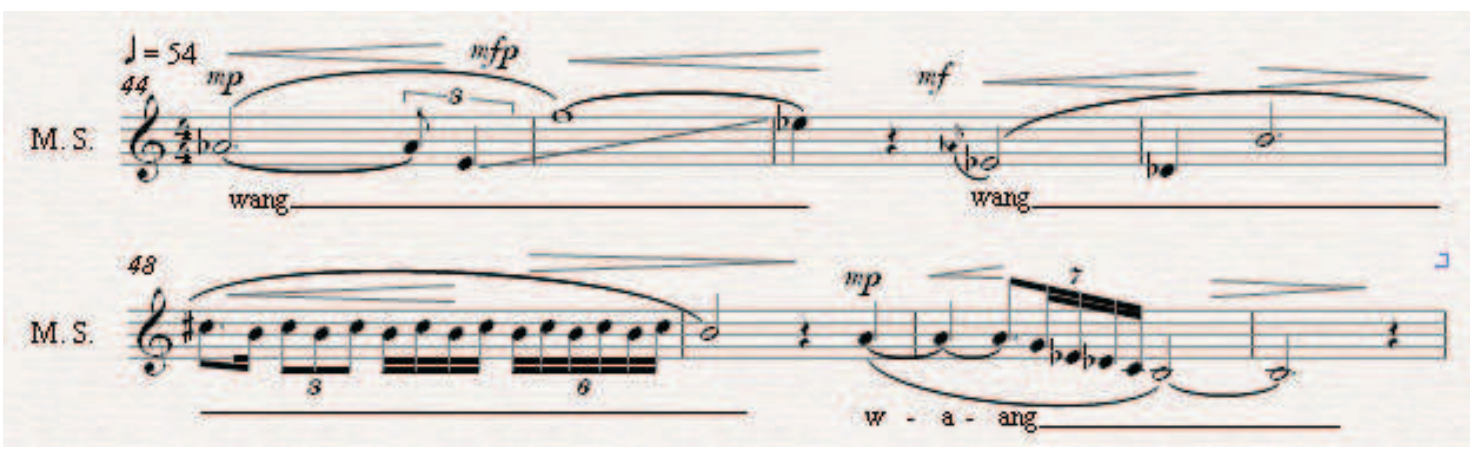

Example 22: Theme I (mezzo-soprano) and the melodic contour supplied to the improvising Maori instrument player)

After the soprano's singing of Theme I above, the shenng plays a motive announcing the next singer.

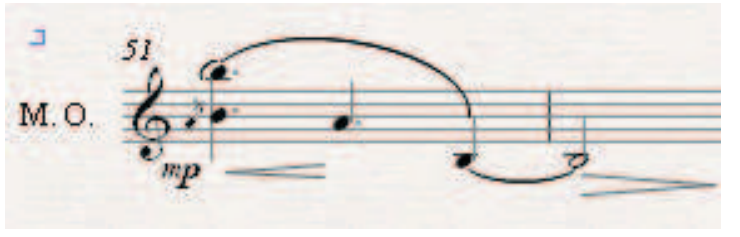

Example 23: Theme I of Wang

A variation I of Theme (A1) is sung by the baritone:

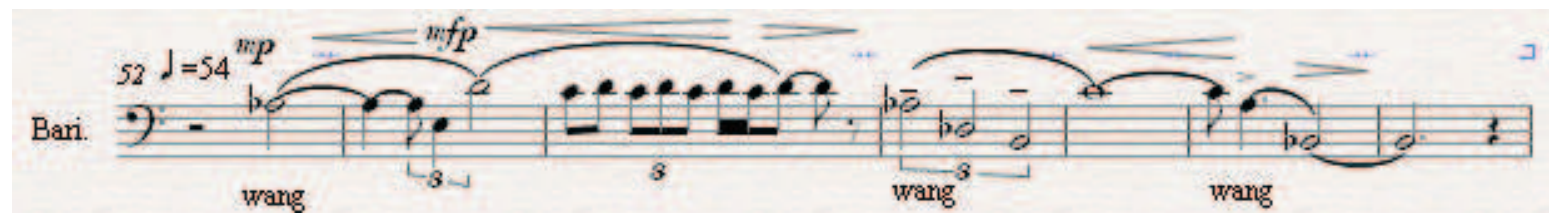

Example 24: Variation I

The shēng repeats the announcing motive, introducing the soprano (A1):

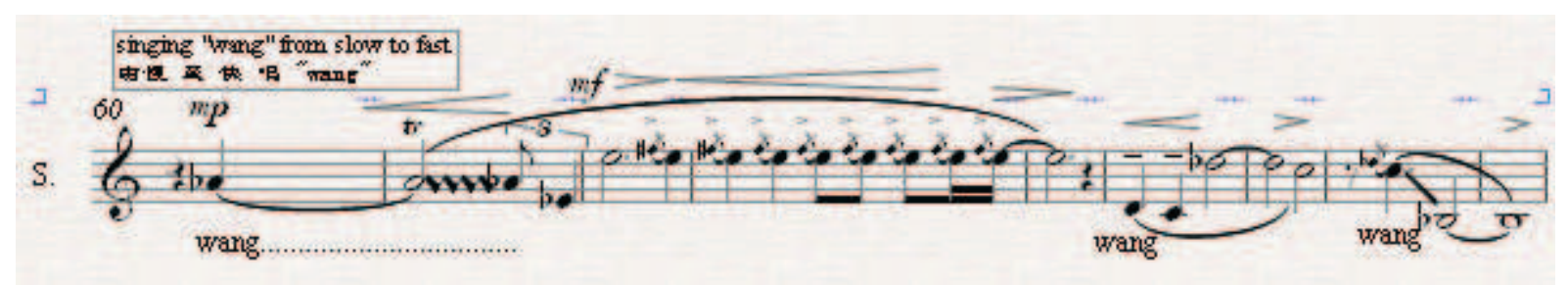

Example 25: Variation II 
The final variation, Variation III, is sung by the tenor (A3):

T.
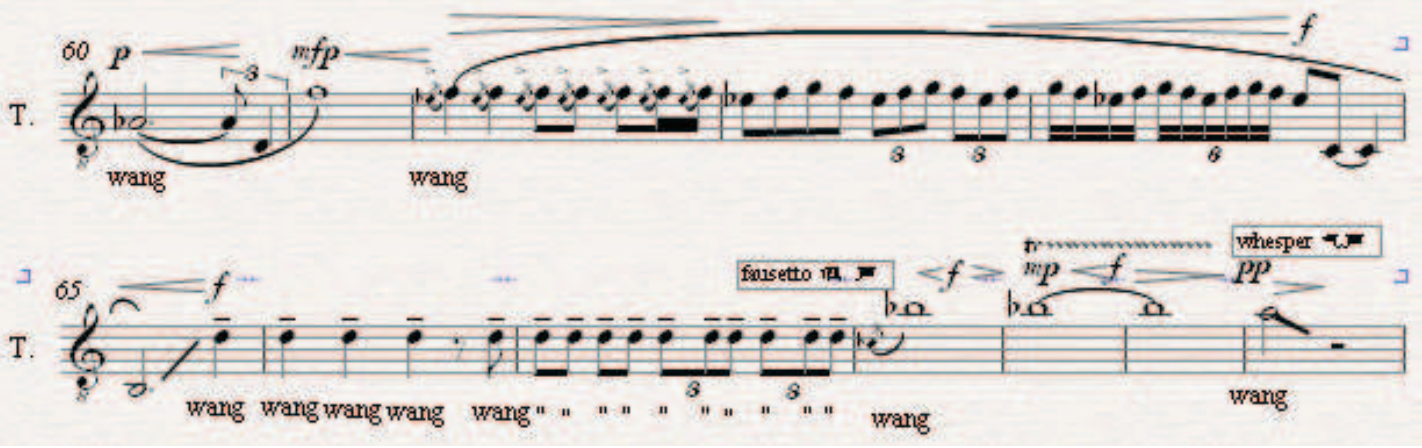

Example 26: Variation III

The shèng again plays the invitation motive, but, since all four singers have already been introduced, there is no response. The sheng steps into the breach (bb. 83-85) and with a little flourish, invites the ensemble to join, playing Variation IV of Theme I (A), in two-part imitation with its transposition (A4) at the interval of a $4^{\text {th }}$.

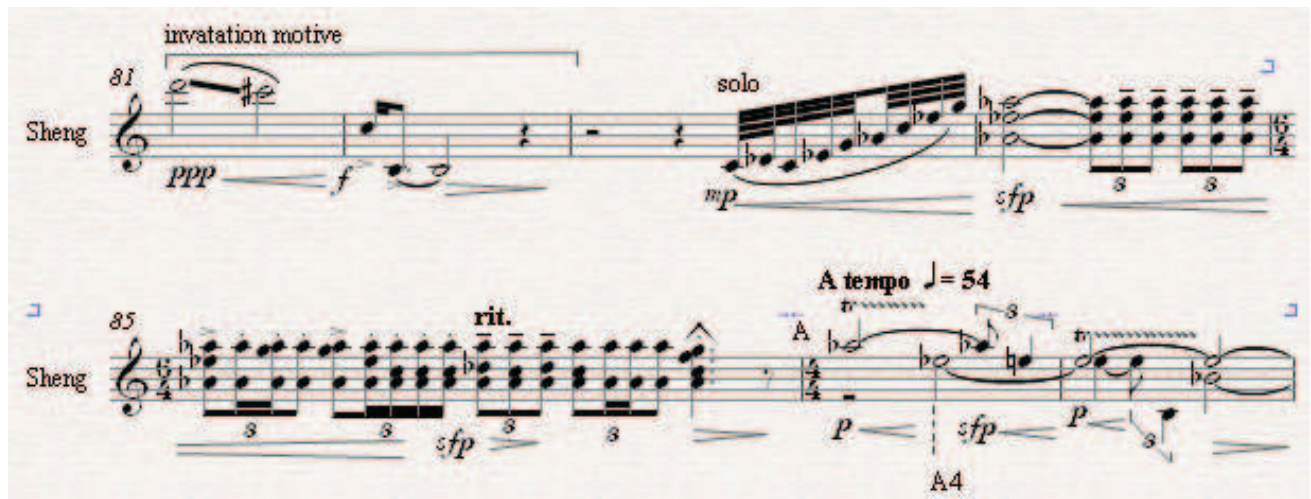

Example 27: Variation IV

The shēng, by introducing counterpoint, encourages the singers to follow the example, the mezzo-soprano (A) and baritone (A4) first joining in a duet (Variation V), and then all four singers, shēng and zhèng get into the climax section (Variation VI, bb.105-115). 


\begin{tabular}{|l|l|}
\hline soprano & A2 \\
\hline mezzo-soprano & A in retrograde \\
\hline tenor & A3 \\
\hline baritone & A2 in retrograde \\
\hline shēng & A5 (transposition of A3) \\
\hline zhēng & A1 \\
\hline
\end{tabular}

Unlike variation A which explored interval expansion and contraction and ornamentation within the melodic contour, Variation B explores the length of Theme II with the variety of imitation techniques.

It is in three sections. The first section introduces Theme II (bb.119-130), in two phases: 1) the theme's archetype, played by shēng and zhèng (bb.120-121), followed by three bars of "wāng" sung in tone one, and 2) Variation I, in which the melody line of the theme, played twice by the saron, is counterpointed by the second line (bonang and zheng). Because this line is almost two beats longer than the saron's melody, the parts take on a different contrapuntal relationship in the repetition (bb.125-127). Then follows three connecting bars with "wáng" sung in tone two. 


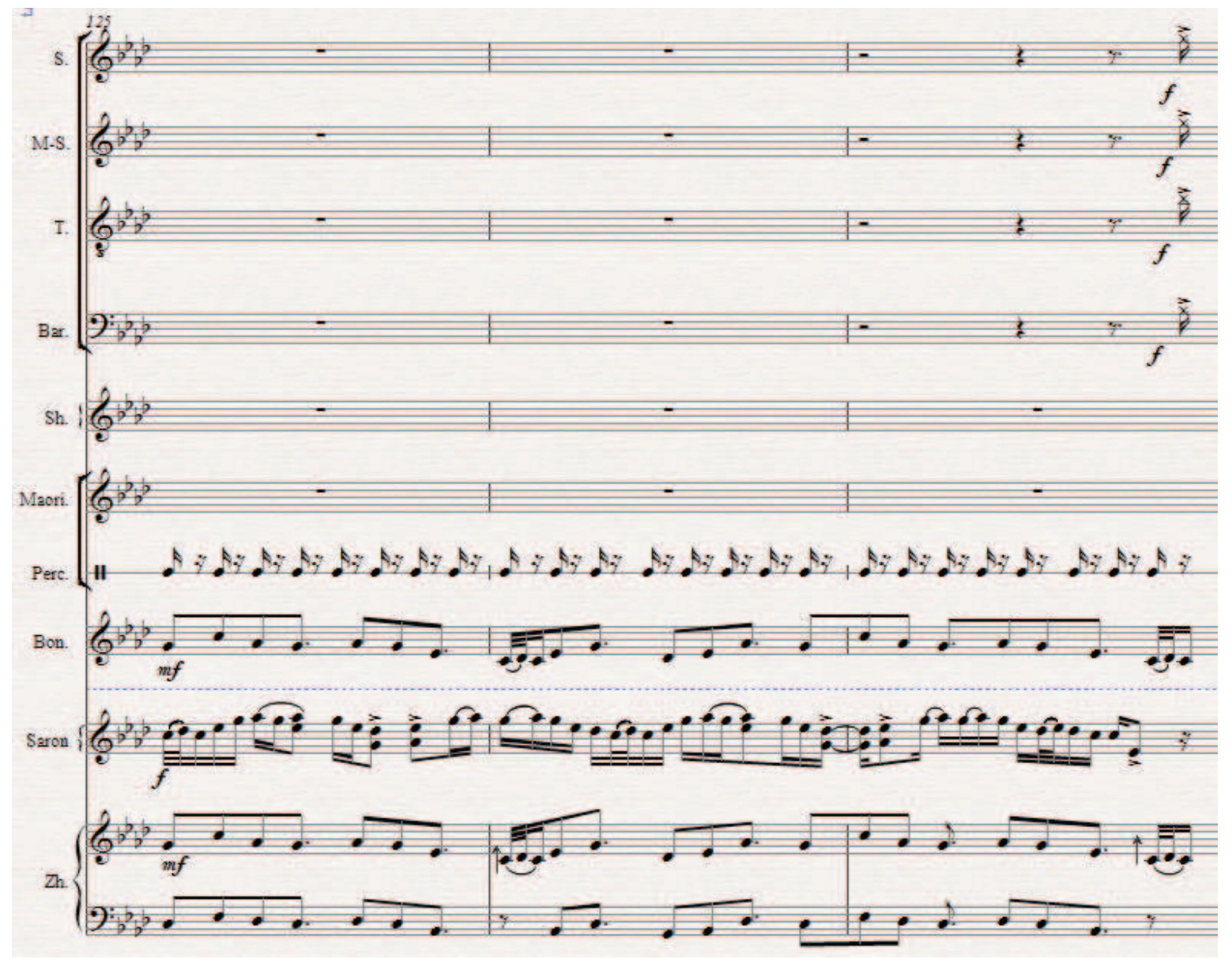

Example 28: Variation I of Theme II (bb.125-127)

In the second section, beginning with Variation II, the theme is played three times by the zheng, while the accompanying bonang line is only played twice, the contrapuntal relationship having changed, as previously (bb.133-136).

In Variation III, the melody line is played against itself in a canon at the octave by the saron and zhēng (bb.139-142).

In Variation IV (bb.143-147) the saron and shèng play the melody in canon by inversion, beginning on $\mathrm{G}$ and $\mathrm{D}$ respectively.

Variation $\mathrm{V}$ is a three-part canon, played on zhēng, shēng and saron all beginning on the same pitch, although the saron plays an inversion of the melody as follows: 


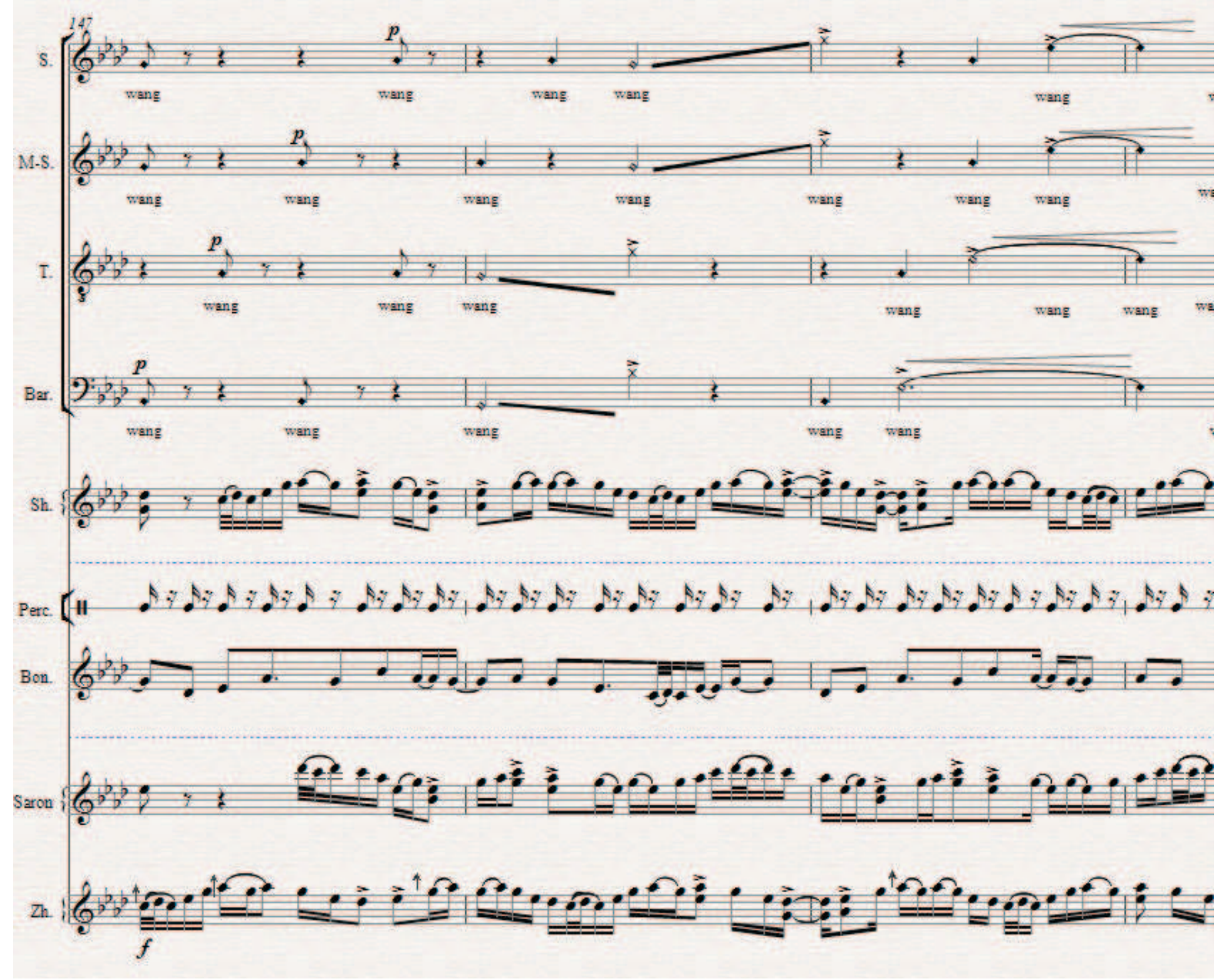

Example 29: Variation V of Theme II (bb.147 -150)

Throughout the section Variation II to V, the vocal quartet chants the "bent" version of the revolutionary song ${ }^{164}$ mentioned above (see also Chapter 4.4.3).

The third section of B builds towards the climax of the composition. The melody line of Theme II is extended by three beats.

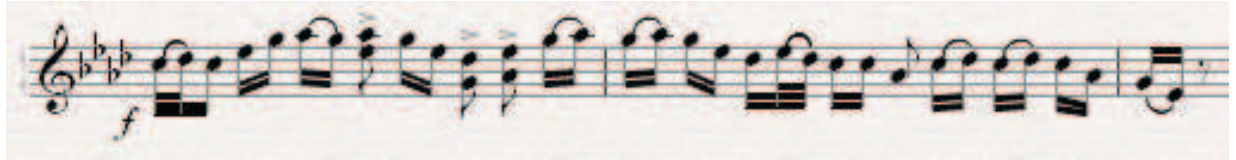

Example 30: the extended Theme II

\footnotetext{
${ }^{164}$ This revolutionary song was not performed in the premiere on $1^{\text {st }}$ November, 2009 in the Recital Hall of the Central Conservatory of Music, Beijing.
} 
Variation VI is based on the extended Theme II, in a three part canon, played by the shèng, zhèng and saron, starting on $\mathrm{C}, \mathrm{G}$ and $\mathrm{C}$ respectively. The bonang plays the secondary contrapuntal line, the notes of which are periodically accented by the vocal quartet.

The tempo quickens and the ensemble plays Theme II in unison. The vocalists sing the melodic contours of Theme I before finally concluding with the "descending cries" of "wang" (see Volume II, pp. 214-215).

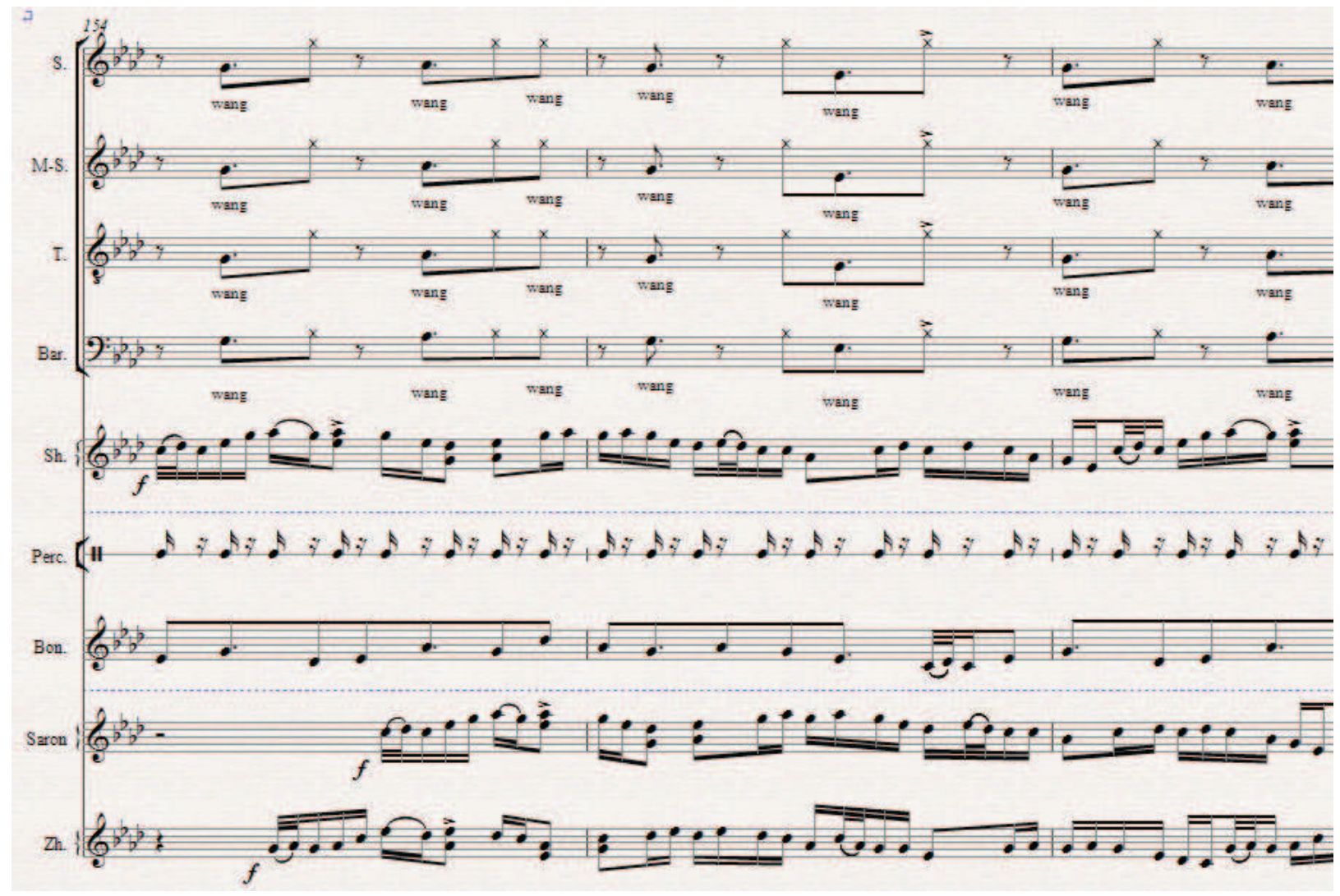

Example 31: Variation VI of Theme II (bb.154-156)

$\mathrm{A}$ and $\mathrm{B}$ sections are contrasted in several ways by means of the compositional techniques employed (interval expansion/contraction), the pitch material used (chromatic/modal), and in the character of the music itself. The vocal music, however, in both sections use the monosyllable "wang" as a unifying principle. 


\subsection{Analysis of Zù̀ (醉) Drunkenness and Jiǔ Dé Sòng (酒德颂) Hymn to the Virtue of Wine}

\subsubsection{Introduction}

In 2001 The Song Company of Sydney, Australia, commissioned seven composers to contribute to a project, based on the life and works of the so-called Zhǔlin Qìxián (竹林七贤) ${ }^{165}$ (The Seven Sages of the Bamboo Grove), a very famous group of Chinese literati of the Wei dynasty. ${ }^{166}$ For this project entitled Liù Yĩngshì (六隐士) (Six Hermits). I composed Zuì (醉) (Drunkenness), a short solo for zhēng (21-string Chinese zither), and Jiǔ Dé Sòng (酒德颂) (Hymn to the Virtue of Wine), a poem of Liu Ling (c.225-280). Both works were performed by The Song Company and premiered on 26 October 2002 at the Sydney Conservatorium of Music. Subsequent performances took place at the Riverside Theatres, Parramatta on 27 October, at St Paul's Cathedral in Melbourne on 30 October as part of the 2002 Melbourne International Festival, and at the Loke Yer Hall, University of Hong Kong, on 2 November 2006.

The seven composers who contributed to the Six Hermits project were chosen because of their Chinese ancestry or their strong attachment to Chinese music and culture: Giulio Castagnoli (Torino), Hing-yan Chan (Hong Kong), Liza Lim (Brisbane), Joyce Bee Tuan Koh (Singapore/Paris), Bun-ching Lam (Macau/New York), Shen Nalin (Wellington), and Qin Yi (Shanghai). The six singers of The Song Company were joined by an ensemble playing Chinese instruments, the Chinese Music Virtuosi from Hong Kong.

The programme note for the project describes eloquently the literary background to the project:

Six Hermits is based on the life and work of the Seven Sages of the Bamboo Grove - seven legendary Chinese figures from the end of the Wei dynasty (is also known as Cao Wei, $220-265$ ). The seventh figure, Wang Rong (234-205) known for his wealth and avarice, is not included, as

\footnotetext{
${ }^{165}$ Ci Hai 辞海, (Chinese Encyclopaedia), Literature Volume, p. 259.

166 The New Encyclopedia Britannica, Macropedia, Volume 4, Chicago: Helen Hemingway Benton, $1973-$ 1974 , p. 315.
} 
none his work was preserved. The fascinating tales of their regular gatherings under the bamboo grove tell a story of drunken revelry, irreverent humor and daring provocation, as well as a love of art and nature, and freedom of expression. Their refusal to partake in the affairs of the world and their constant state of inebriation protected them from the harsh reality of a repressive regime. Only one of them, Xi Kang, was tragically executed in the Marketplace of Luoyang in $262 .{ }^{167}$

It should be pointed out that many of the literati of ancient China belonged to the class of civil servants who had passed the requisite examinations and had entered the Imperial administration. The Six Hermits included poets, philosophers and musicians, all but one of whom enjoyed drinking wine.

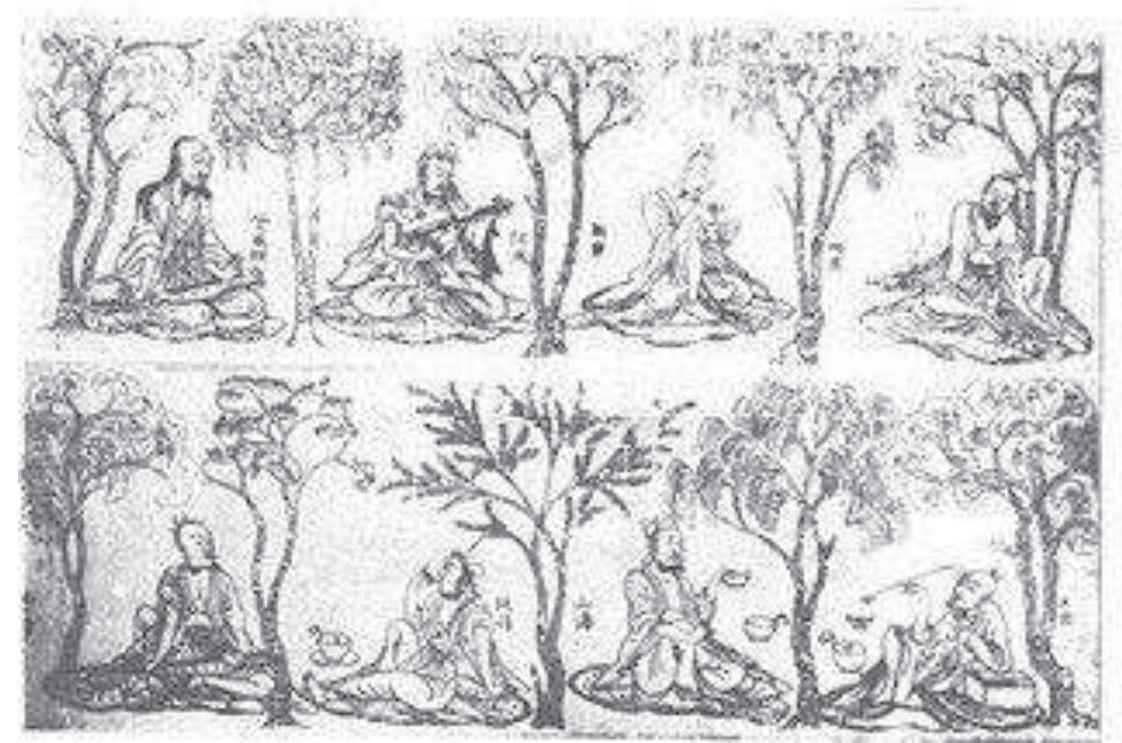

Illustration 8: Picture of Rong Qiqi and the Seven Sages of the Bamboo Grove ${ }^{168}$. Top row from left: Rong Qiqi, and the Seven Sages: Ruan Xian, Liu Ling, Xiang Xie. Lower row from left: Xi Kang, Ruan Ji, Shan Tao and Wang Rong.

\footnotetext{
${ }^{167}$ Melbourne Festival programme notes, Six Hermits, Melbourne Festival, 17 Oct. - 2 Nov. 2002, p. 1.

${ }^{168}$ Picture on moulage of brick 竹林七贤砖印模画, the Seven Sages of the Bamboo Grove in the Bamboo Forest and Rong Qiqi, pressed tiles, unearthed from the Southern-dynasty tomb at (1960) Xishanqiao, now in the museum of Nanjing. Luo Shiping, 罗世平, Masterworks of Chinese Figure Painting from Wei, Jin to Northern and Southern dynasties (AD 220-285), Beijing: Culture Relic Publishing House, 2005, Vol. 1, p. 52.
} 
Ruan Xian (234-305), one of the youngest members of the group, was the nephew of Ruan Ji, and also a musician. The Chinese fretted lute, the ruăn (阮), was named after him. He usually played this instrument when the group gathered under the bamboo. ${ }^{169}$

Liu Ling (c.225-280) was fond of liquor, his name being a poetic substitute for the term “drunk". He wrote Jiŭ Dé Sòng (酒德颂) (Hymn to the Virtue of Wine).

Xiang Xiu (c.221-300) was the teetotaler of the group. As an academic figure he was famous for his writings on The Book of Changes and on Taoism. He also wrote Sijjiù Fŭ (思 旧赋) (Ode on Retrospection) on Xi Kang”s death.

Xi Kang (223-262) was one of the important spiritual leaders. The group usually gathered at his place. He composed four outstanding works for Qin which was adopted as test pieces for the Imperial examination. The qin "Melody of Guăngling" is said to memorialize the tragic death of Xi Hang, beheaded by one of the political clans who had been offended by Xi's intransigence.

Ruan Jí (210-263) in his professional life was a military commander, and a prolific writer on political matters. Within the Bamboo Grove he was the other spiritual leader of the group, and was also a renowned musician. The remarkable piece for qin ( 7 string zither), called Jiŭ Kuáng (酒 狂) (Drunken Ecstasy), is believed to have been composed by him.

Shan Tao (205-283) was an orphan who by the time he was 17 was already well known among political circles for his abilities and profound character, but who, resenting the pressures of his official position, resigned. He was the oldest member of the Bamboo Grove. At the age of 47 he reluctantly rejoined the civil service.

\subsubsection{Composition I: Zuì (醉) Drunkenness}

$$
\text { (for zhēng solo) }
$$

In the programme of Six Hermits, each of the seven composers was asked to compose a short piece for a solo Chinese instrument selected from the ensemble, inspired by Ruan Jí's piece Jiǔ Kuáng (酒 狂) (Drunken Ecstasy). These were performed as interludes between those vocal compositions. I chose to write a short piece for a 21 -stringed zhēng.

In this piece, the soloist is required to play on the strings on both the right- and left-hand sides of the bridge. The 21 strings of the zheng are usually tuned with five notes per octave, i.e. pentatonic, using one gōng system throughout. Drunkenness requires a special tuning.

${ }^{169}$ Ci Hai 辞海, (Chinese Encyclopaedia), Literature Volume, p. 359. 
The right-hand side of the bridge (where the strings are normally sounded) is tuned consecutively in four pentatonic scales: D juédaiò, D\# yǔdiào E zhĭdiào \& Eb gōngdiào. All twelve chromatic notes are used within this tuning, although the character of the Chinese pentatonic modes (wǔshēng diàoshi) is still present (see footnote 150).

The tuning of the strings on the left-hand side of the zhēng is somewhat arbitrary, ${ }^{170}$ allowing for flexibility in the actual pitch chosen. In order to achieve the approximate tunings I want for my piece, the bridges have to be shifted and the tuning pegs readjusted; from low to high the first 3 strings should be more or less at the same low pitch, and strings 4 to 18 tuned microtonally within an octave (approximately 15 pitches), and strings 19 to 21 tuned to the same high pitch, which must be a semitone higher than string 18:

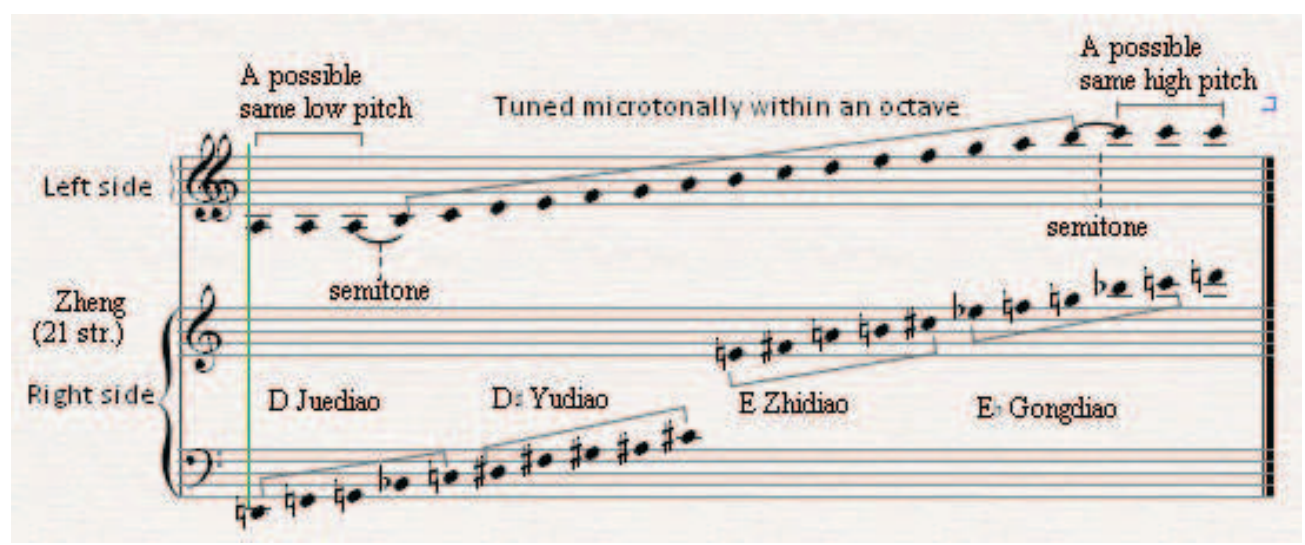

Example 32: Sample tuning for solo zhēng

Drunkenness consists of three sections: Introduction $+\mathrm{A}+\mathrm{B}+\mathrm{A} 1+$ Coda.

In Ruan Ji's composition for qin, Jiǔ Kuáng, there is a remarkable brief comment written in the score at the beginning of the coda of the piece xiānrén tùjiǔ sēng (仙人吐酒声) ${ }^{171}$ (the sound of the hermit vomiting). The two grace note figures appear for the first and only time:

\footnotetext{
${ }^{170}$ The zhēng is one of my favorite Chinese instruments. In 1987 I composed a chamber piece Chénjiè (尘界) (The Boundary between Earth and Heaven), in which I used for the first time the strings on both the left- and right-hand sides of the bridge. I was happy with the result, but the use of the zheng in this way caused controversy at the time.

${ }^{171}$ Zhu Zhou 朱 舟, Zhōnggóu Chuántǒng Mingqü Xïnshăng 中国名曲欣赏 (The Most Remarkable Traditional Music of China), pp.32-34.
} 


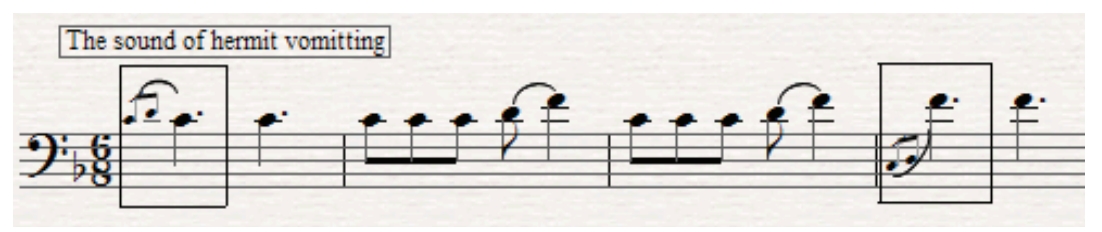

Example 33: Ruan Ji: Drunken Ecstasy (bb. 49-52)

This image of vomiting from intoxication I took as the germ for the short introduction of my piece Drunkenness:

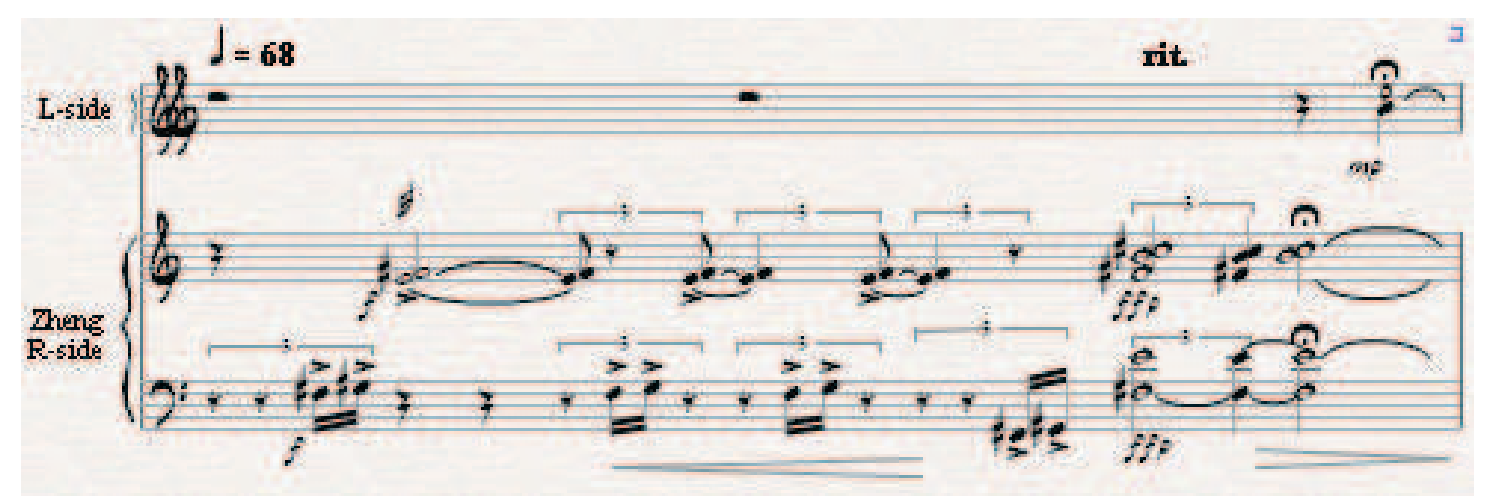

Example 34: Drunkenness for zhēng solo (b.1)

However, another motive is also derived from Jiǔ Kuáng.

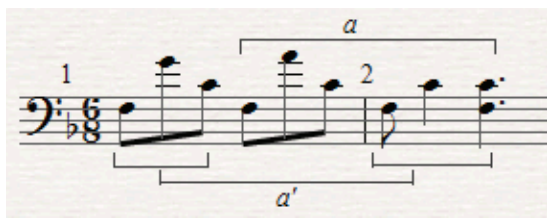

Example 35: Ruan Ji: Drunken Ecstasy (bb. 1-2)

The A section has two phrases (the notes of the motive are bracketed). Motive $a$ in the first phrase is played on the right-hand side of the bridge, and is thus heard at the notated pitch. When the motive $a$ " appears in phrase two however, it is played on the left-hand side, and sounds unpredictably microtonal. 


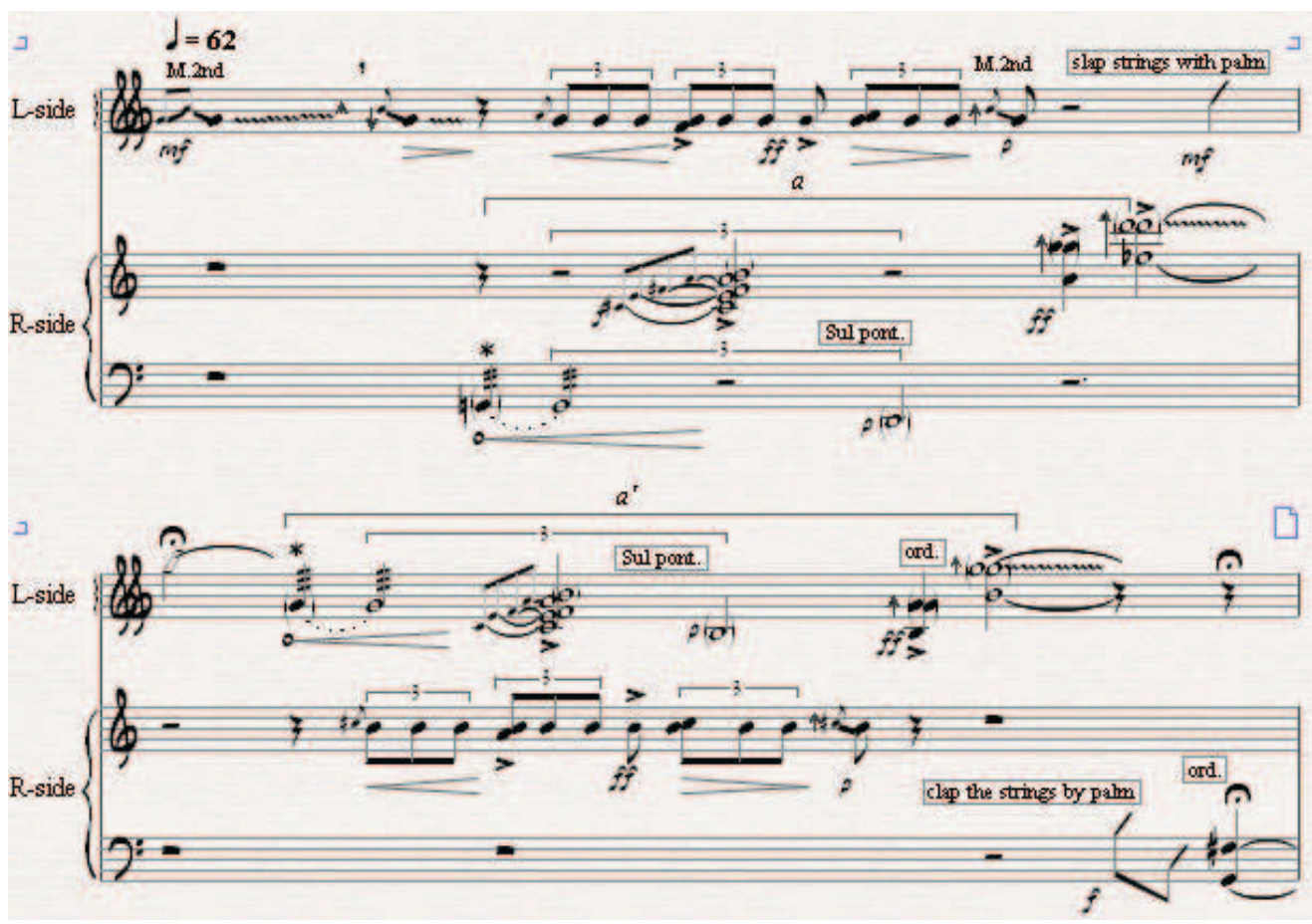

Example 36: Drunkenness for zhēng solo (bb.2-3)

Another motive also is derived from Jiǔ Kuáng (bb.9-10) which is in a bar of my section B a short "quasi stretto".

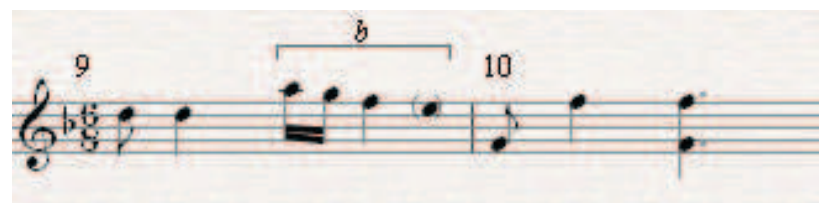

Example 37: Ruan Ji: Drunken Ecstasy (bb. 9-10)

Motive $b$ for this stretto is derived from the second half of b.9 of Jiǔ Kuáng with the first, discarded E reinserted (b.4 of my work). Each of the twelve entries (some fragmentary) is different in pitch: the eight that are played on the right-hand side are in different $g \bar{o} n g$, while the two played on the right-hand side are indeterminately pitched. 


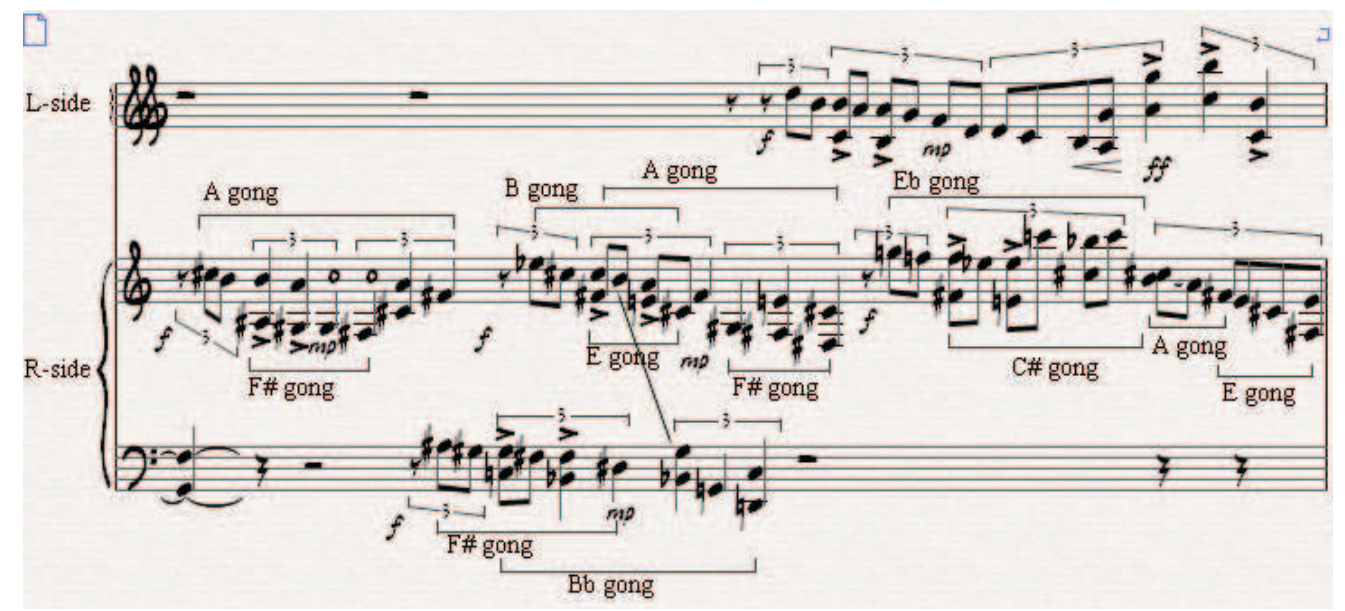

Example 38: Drunkenness for zhēng solo (b.4)

A1 recalls only the second phrase $\left(a^{\prime \prime}\right)$ of A, in which a dramatic flourish constitutes the coda of the piece.

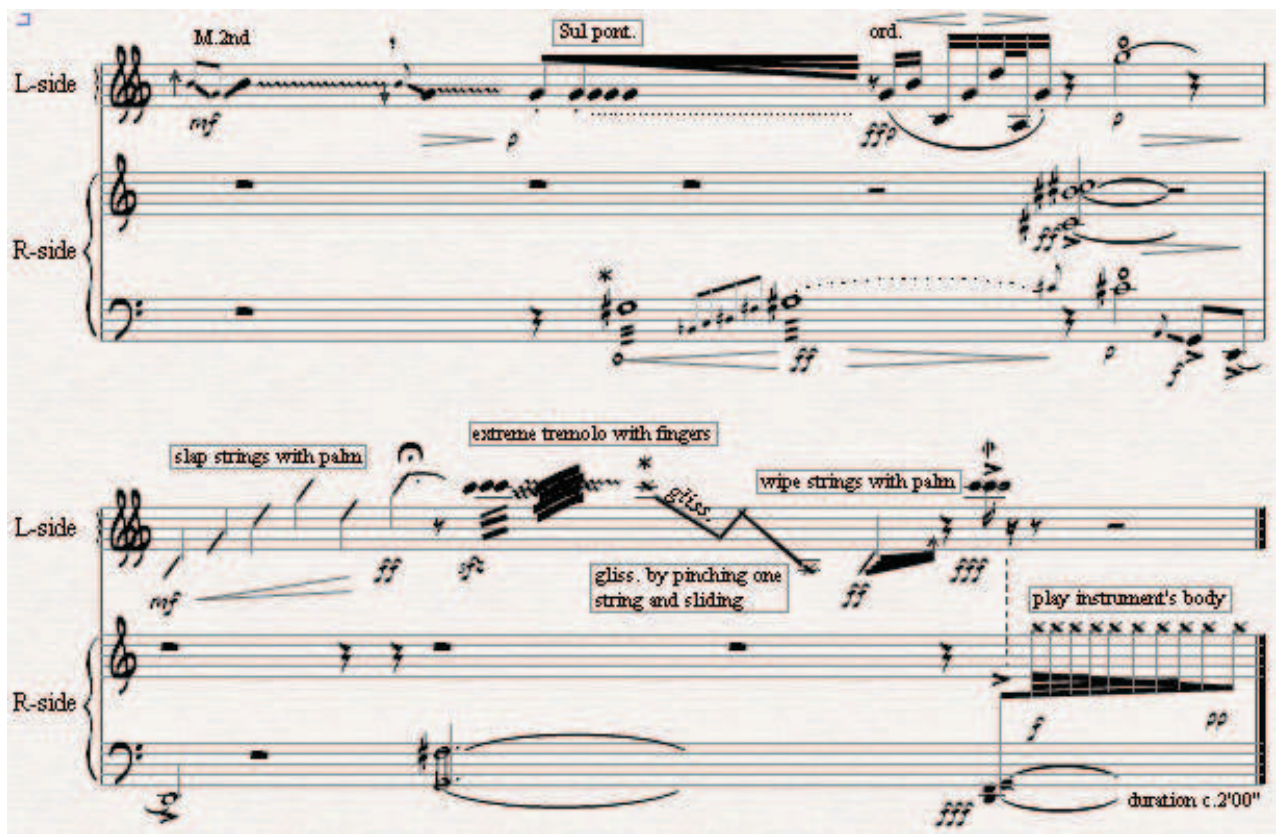

Example 39: Drunkenness for zhēng solo (bb.6-7)

I ask the soloist to play the work with a flexible tempo, with numerous fermatas, particularly in the short "quasi stretto" section. This faltering quality is intended to express the "short memory lapses" of the drunken state. 


\subsubsection{Composition II: Jiǔ Dé Sòng (酒德颂) Hymn to the Virtue of Wine}

(for five singers, zhēng, shēng and two húqín)

A work that sets a text marries the genres of literature and music. Generally speaking the composer first focuses on the text in order to compose the music; simply stated, he sets the words to music. However, the setting of a Chinese text to music is more complicated.

Liu Ling"s Hymn to the Virtue of Wine is an extended Ode, which uses some ancient Chinese characters which are no longer in common use. I present the text below in the original Chinese, and in a transliteration into pinnyin with tones, and in an English translation.

\section{Jiǔ Dé Sòng (酒德颂)}

刘伶 (c.225-280)

有大人先生者, (yǒu dàren xiānshen zhě)

以天地为一朝, (y̌̀ tiāndì wéi ȳ̄zhāo)

万期为须臾, (wànqī wéi xüyú)

日月为局㸠, (rìyuè wèi jióng yǒu)

八荒为庭眭。(bāhuāng wèi tíngqú)

行无辙迹, (xing wú zhéji)

居无室庐, (jüü wú shilú)

暮天席地, (mùtiān xídì)

纵意所如。(zòngyì suǒrú)

止则操后执䚜, (zhì zé cāozhì zhígǔ)

动则挈榼提壶, (dòng zé qièkē tíhǔ)

唯酒是务, (wěi jiǔ shìwù)

焉知其余? (yān zhī qíyú)

有贵介公子,(yǒuguì jiè gōngzĩ)

缙绅处士, (jìn shēn chù shi)

闻吾风声, (wén wú fēng shēng)

议其所以。(yì qí suǒ yì)

乃奋袂攮襟, (năi fènměi năngjīn)

怒目切齿, (nùmù qìechì)

陈说礼法, (chénshuō lǐfá) 是非锋起。(shìfēi fēngqū)

先生于是方捧罂承槽, (xiānsheng yúshì fāng pěngyīng chéngcáo)

衔杯漱醪。(xiánbēi shùláo)

奋䯿箕踞, (fènrán jījūiu)

枕麴藉糟, (zhěnqü jìcāo)

无思无虑, (wú sī wú lì)

其乐陶陶。(qí lè tāo tāo)

兀然而醉, (wùrán érzui)

豁尔而醒。(huòer érxǐng)

静听不闻雷霆之声, (jìngtīng búwén léitíng zhì shēng)

熟视不睹泰山之形, (shǔshì bùdǔ tàishān zhī xing)

不觉寒暑之切肌, (bùujüé hánshǔ zhī qièjī)

利欲之感情。(lìyù zhī gănqíng)

俯观万物, (fŭguān wànwù)

扰扰焉如江汉之载浮萍; (răo răo yānrú jiānghàn zhī zài fúpíng)

二豪侍侧焉, (érháo shìcè yān)

如蜾蜆之与螟蛉。(rú gǒuluó zhī yú

mingling) 


\section{Hymn to the Virtue of Wine}

by Liú Líng (c.225-280)

There was a certain Mr. Great Man, for whom

Heaven and earth were but a morning's span, A myriad ages but a flash of time;

The sun and moon, a door and window's eye, The eight directions like a country lane.

He travelled without leaving a track or trace, And domiciled in neither room nor hut;

For curtain — sky, and for a mat - the earth; He let his fancy wander where it would. At rest he grasped a goblet or a cup, And moving, always carried jug or pot. For wine, and wine alone, was all his lot.

How should he know about the rest?

Now there was

A certain noble duke, Lord High-and-Great, And a retired scholar, Sir Silk Sash,

Who, hearing rumors of our hero's ways, Came to discuss with him the hows and whys. Waving their sleeves and baring wide their breasts,

With wildly glaring eyes and gnashing teeth, They lectured loud and long on rites and laws,
While rights and wrongs rose up like spears. At this the Great Man

Took the jar and filled it at the vat, Put cup to mouth and quaffed the lees;

Shook out his beard and sat, legs sprawled apart,

Pillowed on barm and cushioned on the dregs, Without a thought, without anxiety,

His happiness lighthearted and carefree.

Now utterly bemused with wine,

Now absently awake,

He calmly listened, deaf to thunder's crashing roar,

Or fixed his gaze, unseeing of Mt. Tai's great hulk.

Of cold or heat he felt no fleshly pangs, Of profit or desire no sensual stir;

He looked down on the myriad things, with all their fuss,

As on the Jiang or Han with floating weeds. And those two stalwarts, waiting by his side-

How like to blacktail flies their busy buzz!

(English translation by Richard Mather) 


\subsubsection{The Structure of Hymn to the Virtue of Wine}

Because of the length and complexity of this poem I divided it into six sections, with an additional introduction, and a reprise at the conclusion.

Table 11: Sections of Hymn to the Virtue of Wine

\begin{tabular}{|l|l|l|l|l|l|}
\hline $\begin{array}{l}\text { I: } \\
\text { the virtue of } \\
\text { detachment }\end{array}$ & $\begin{array}{l}\text { II: } \\
\text { his place in } \\
\text { the world } \\
\text { (Taoist) }\end{array}$ & $\begin{array}{l}\text { III: } \\
\text { social } \\
\text { status }\end{array}$ & $\begin{array}{l}\text { IV: } \\
\text { serious } \\
\text { debate }\end{array}$ & $\begin{array}{l}\text { V: } \\
\text { his favourite } \\
\text { activity: } \\
\text { drinking } \\
\text { wine }\end{array}$ & $\begin{array}{l}\text { VI: } \\
\text { transcenden- } \\
\text { tal intoxica- } \\
\text { tion }\end{array}$ \\
\hline $\begin{array}{l}\text { bangqiang } \\
\text { and } \\
\text { sprechgesang } \\
\text { yunbai in } \\
\text { chuanju } \text { style }\end{array}$ & $\begin{array}{l}\text { play with } \\
\text { tongue and } \\
\text { slap hands } \\
\text { half sing } \\
\text { and half } \\
\text { nainbai }\end{array}$ & $\begin{array}{l}\text { sing- } \\
\text { ing }\end{array}$ & $\begin{array}{l}\text { rhyth- } \\
\text { mical } \\
\text { nianbai } \\
\text { and sing }\end{array}$ & $\begin{array}{l}\text { bangqiang } \\
\text { recitation in } \\
\text { English; } \\
\text { play bottle } \\
\text { of wine }\end{array}$ & $\begin{array}{l}\text { sprechge- } \\
\text { sang as the } \\
\text { yunbai and } \\
\text { humming } \\
\text { then singing }\end{array}$ \\
\hline
\end{tabular}

The musical structure of my composition Hymn to the Virtue of Wine is in quasi rondo form. The main features of the composition are the grouping of the voices, where the sopranos sing in bāngqiāng style while the men perform in niàn style, and strong textural and timbre contrasts.

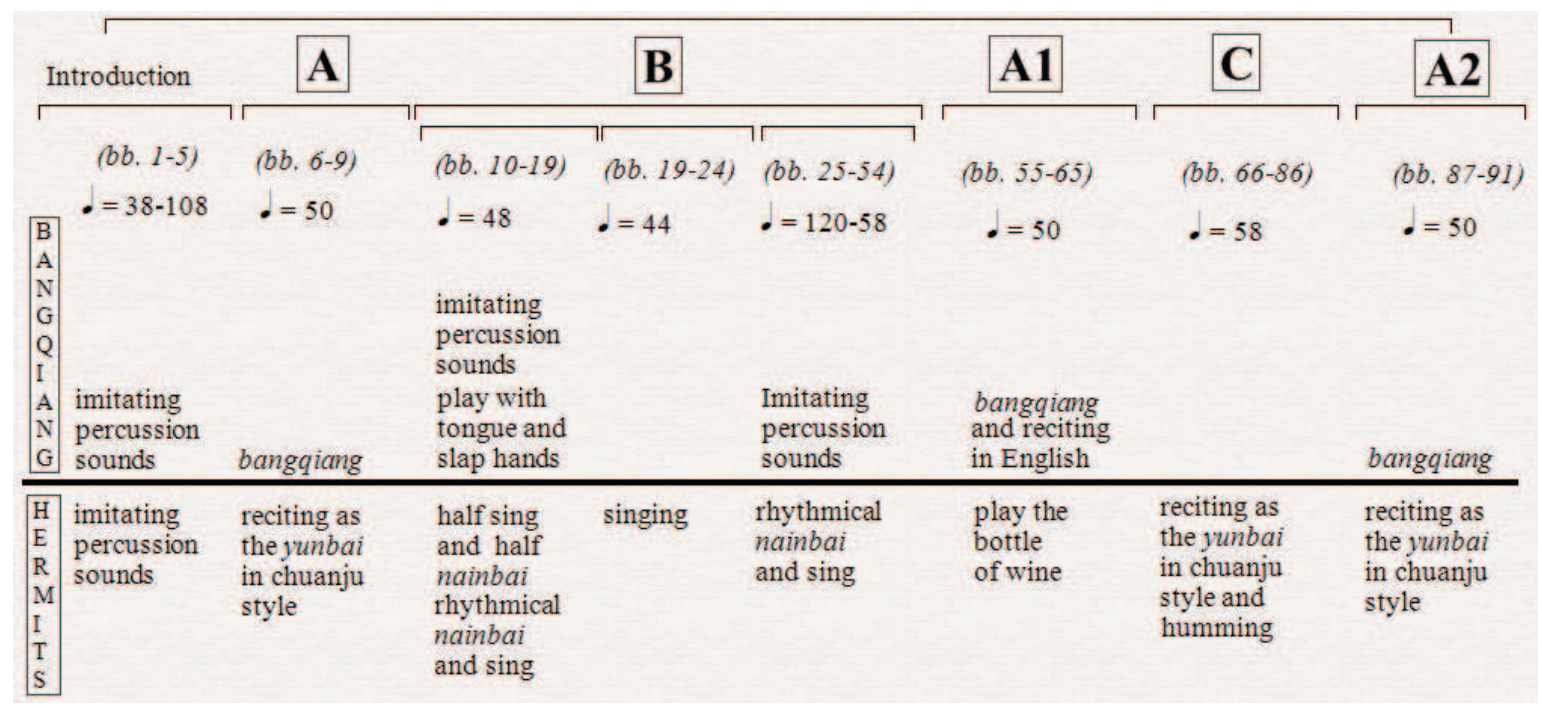

Illustration 9: Musical structure of Hymn to the Virtue of Wine 
In section A the sopranos sing the principal melodic parts in bāngqiāng Sichuan opera style. At the same time, the three male voices perform in yùnbái (sprechgesang) representing the roles (chuānjǜ gāoqiāng) of the Three Hermits. In section A1, soprano I sings in bāngqiāng style, while soprano II performs niànbái recitation in English, and three males, as the Three Hermits, blow bottles, signifying their progressive intoxication. At the conclusion of the composition the refrain reappears (A2) as a variation of A.

In the contrasting section $B$, the most extended part of the work consisting of 44 bars, the Hermits become the focus, performing rhythmic niànbái and singing, while the sopranos imitate percussion sounds, with tongue clicks and hand claps.

Section $\mathrm{C}$ is another contrast, in which the principal part is taken up by one Hermit (the tenor), performing a yùnbái recitation, accompanied by a léiqìn (a moderately large twostring spike fiddle) ${ }^{172}$ which imitates the tenor's yùnbái intonations. Other Hermits hum in a befuddled manner; the female voices are silent.

\subsubsection{The Concept of Word Setting in Hymn to the Virtue of Wine}

In the setting of Chinese words to music, the tones of the characters must be taken into account. For instance, melodic movement upward on a word/character that has a falling tone (tone 4) destroys its meaning, or more often, creates a completely different meaning.

For instance, section A starts from the first phrase of text of Jiǔ Dé Sòng (酒德颂). The pǔtōnghuàn (Mandarin) pīnyīn for the phrase “有大人先生” is yǒu dàren xiānsheng. But, if this phrase is spoken in Sichuan dialect its tones are very different: yòu dázen xiānsēn.

Table 12: Comparison of different tones between mandarin and Sichuan dialect

\begin{tabular}{|l|l|l|l|}
\hline chinese character & 有 & 大人 & 先生 \\
\hline
\end{tabular}

\footnotetext{
${ }^{172}$ Chinese two-string spike fiddle. This particular string fiddle can imitate voices, birdsong as well as opera singing and Niànbái. Cf. Yang Yinliu 杨荫汶, Miu Tianrui 缪天瑞 (et al, ed.), Zhōnggóu Yīnyuè Cídiăn 中国音 乐词典, (The Dictionary of Chinese Music), p. 221.
} 


\begin{tabular}{|l|l|l|l|}
\hline tones & 3 & $4 / 5$ & $1 / 5$ \\
\hline mandarin & yŏu & dàren & xiānsheng \\
\hline tones & 4 & $2 / 5$ & $1 / 5$ \\
\hline sichuan dialect & yòu & dázen & xiānsēn \\
\hline
\end{tabular}

Notating the phrase yǒu dàrend xiānsheng (有大人先生) in musical terms depends on whether standard Mandarin (pǔtōnghuàn), or another Chinese dialect, such as Sichuan, is used. If Mandarin as follows:

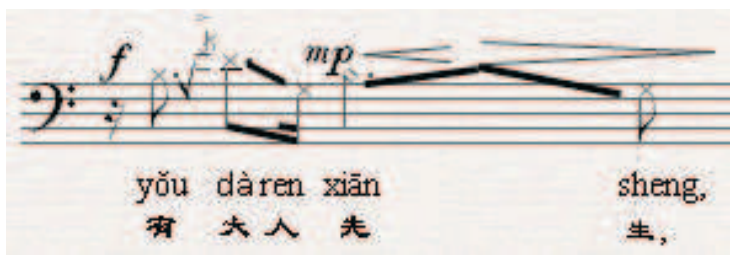

Example 40: in Mandarin pīnyìn with tones indicated

If Sichuan dialect:

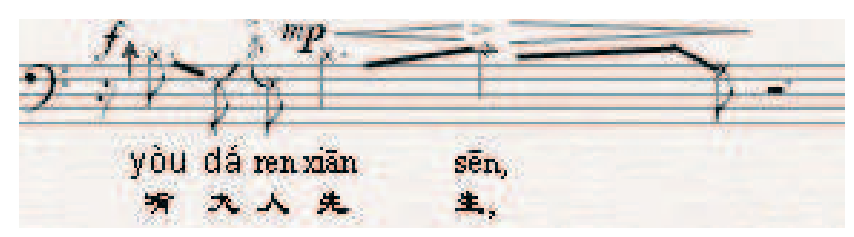

Example 41: in Sichuan dialect with tones indicated

\subsubsection{The Integration of Chuānjǜ - Niàn, Chàng, Zuò and Dă into Hymn to the Virtue of Wine}

Chuānjù (川 剧) (Sichuan opera) has four significant performance elements: niàn (念) speaking, reciting (intoned or rhythmical), chàng (唱) - singing (accompanied or unaccompanied), zuò (做) - bodily gestures, costume and make-up, dă (打) - acting, percussion. ${ }^{173}$

The musical style and compositional concepts of Hymn to the Virtue of Wine were strongly influenced by chuānjǜ, specifically, the three important production elements of chuānjǜ gāoqiāng: bāng (帮), Dă (打) and chàng (唱).

\footnotetext{
${ }^{173}$ For more information about Chuānjǜ, see chapter: 2.2 The Skills Sigōng (四功) for Chinese Xìqü (戏曲).
} 
By way of example here is a transcription of a chuānjǜ gāoqiāng, named Yùzān jì (玉輴 记 $)^{174}$ Song of the Jade Barrette.

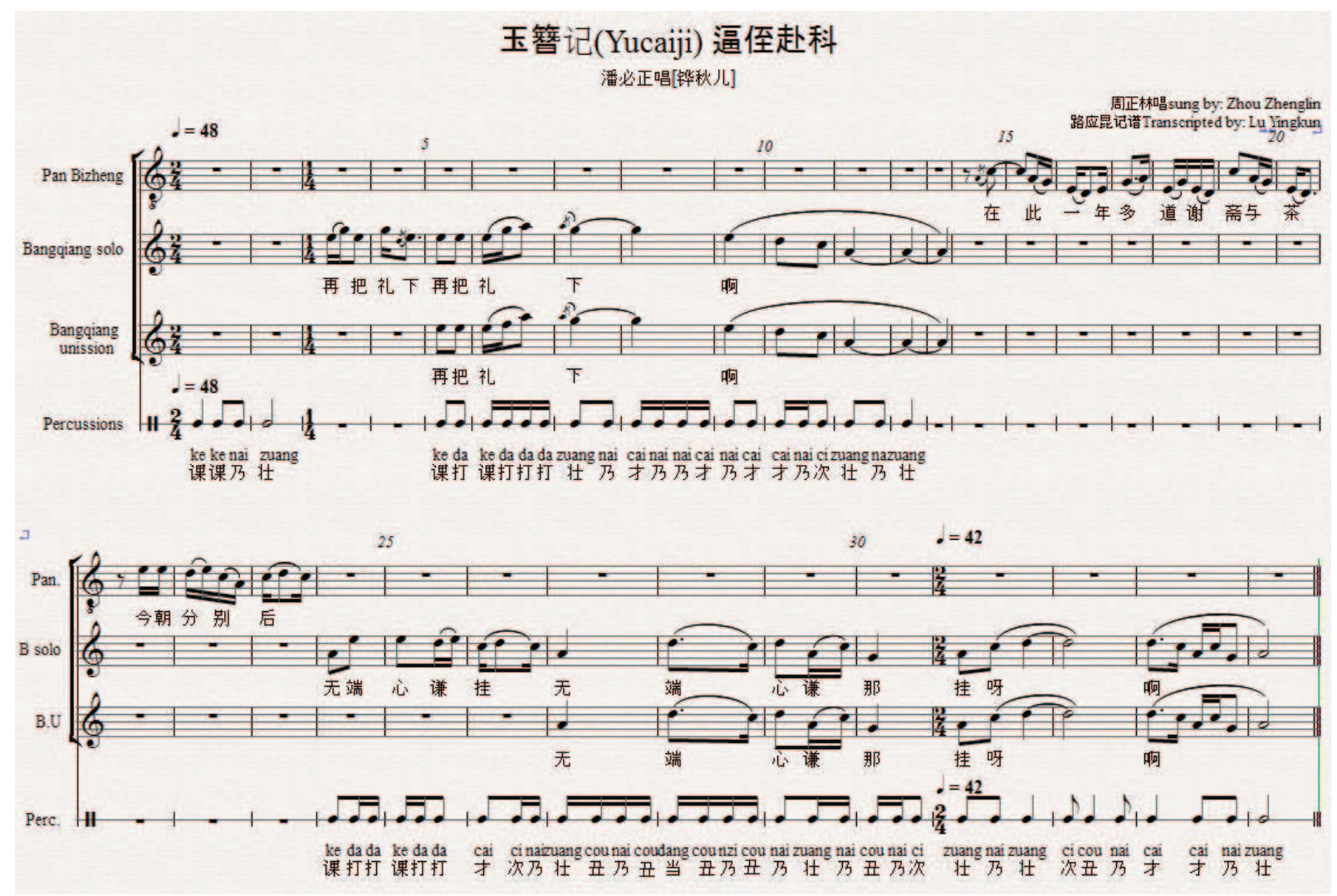

Example 42: Transcribed score of chuānjü gāoqiāng: Yùzān jì (玉箬记)

This example shows the three elements of chuānjù gāoqiāng. The first line (tenor) is for the solo role which represents chàng. The second line is the bāngqiāng (soprano) solo and the third line is the bāngqiāng chorus (in unison); both parts are representing Bang. In the bottom line is the percussion part which represents dă. The Chinese characters are onomatopoeic notations of the percussion sounds.

The theatrical concepts which constitute chuānjǜ - niàn, chàng, zuò and dă (see Chapter 2.3.2) I utilize in the music for the five singers in my composition. Specifically, Soprano I performs tongue clicks, hand claps and plays Chinese percussion băn (板) (wood percus-

\footnotetext{
${ }^{174} \mathrm{Lu}$ Yingkun transcribed a score that was based on Zhou Zhilin”s song. Lu Yingkun 路应昆, Gāoqiāng Yīnyuè Yü Chuānjù̀ 高腔音乐与川剧 (The Music of Gaoqiang with Sichuan Opera), p. 4.
} 


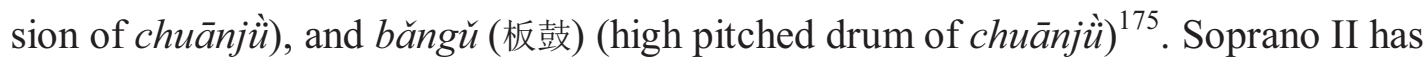
tongue clicks, hand claps and plays manjira (small cup cymbals). Both function, at the back of the stage, as bāngqiāng (chàng), as niàn (recitation) and as dă (percussion).

The tenor, baritone and bass have recitation (niàn), costume and make-up (zuò), play a bottle of wine (dă), as well as sing (chàng). They play the roles of the Hermits, both sober and drunk, and perform at the front of the stage.

Table 13: Niàn, Chàng, Zuò and Dă in Hymn to the virtue of wine

\begin{tabular}{|c|c|c|c|c|c|}
\hline Singers & $\begin{array}{l}\text { Niàn } \\
\text { Yùnbái, rhythmical Niànbái }\end{array}$ & $\begin{array}{l}\text { Chàng } \\
\text { Bāngqiāng }\end{array}$ & Sing & $\begin{array}{l}\text { Zòu } \\
\text { Costume and } \\
\text { make-up }\end{array}$ & $\begin{array}{l}\text { Dă } \\
\text { Percussion }\end{array}$ \\
\hline soprano I & $\begin{array}{l}\text { imitate the percussion } \\
\text { (bb. } 1-5,10-19,25-54)\end{array}$ & $\begin{array}{l}\text { bāngqiāng } \\
\text { (bb. 5-9, } \\
55-65,87- \\
91 \text { ) }\end{array}$ & & & $\begin{array}{l}\text { click tongue and } \\
\text { clap hands (bb. 10- } \\
\text { 19) play băn and } \\
\text { băngǔ (bb. 55-65) }\end{array}$ \\
\hline soprano II & $\begin{array}{l}\text { imitate the percussion } \\
\text { (bb. 1-5, 10-19, 25-54) } \\
\text { recitation in English } \\
\text { (bb. 55-65) }\end{array}$ & $\begin{array}{l}\text { bāngqiāng } \\
\text { (bb. 5-9, } \\
55-65,87- \\
91 \text { ) }\end{array}$ & & & $\begin{array}{l}\text { click tongue and } \\
\text { clap hands (bb. 10- } \\
\text { 19) play manjira } \\
\text { (bb. 55-65) }\end{array}$ \\
\hline tenor & $\begin{array}{l}\text { imitate the percussion (bb.1-5) } \\
\text { perform the yùnbái in sprechge- } \\
\text { sang (bb. 5-9) } \\
\text { half singing and half niànbái } \\
\text { (bb. 10-19) } \\
\text { rhythmical niànbái and sing } \\
\text { (bb25-54) } \\
\text { perform the yùnbái in sprechge- } \\
\text { sang (bb. 66-86, 87-91) }\end{array}$ & & $\begin{array}{l}\text { singing } \\
\text { as a } \\
\text { role } \\
\text { (bb. 19- } \\
\text { 24) }\end{array}$ & $\begin{array}{l}\text { dress of an- } \\
\text { cient China } \\
\text { or Western } \\
\text { hermit }\end{array}$ & $\begin{array}{l}\text { play a pitched }(\mathrm{H}) \\
\text { bottle of wine }(\mathrm{bb} \text {. } \\
55-65)\end{array}$ \\
\hline baritone & $\begin{array}{l}\text { imitate the percussion (bb.1-5) } \\
\text { recital the yunbai (bb. 5-9) } \\
\text { half singing and half niànbái } \\
\text { (bb. 10-19) } \\
\text { rhythmical Niànbái and sing- } \\
\text { ing (bb25-54) } \\
\text { humming (bb. 66-86,) } \\
\text { perform the yùnbái in sprechge- } \\
\text { sang (bb. 87-91) }\end{array}$ & & $\begin{array}{l}\text { singing } \\
\text { as a } \\
\text { role } \\
\text { (bb. 19- } \\
24 \text { ) }\end{array}$ & $\begin{array}{l}\text { dress of an- } \\
\text { cient China } \\
\text { or Western } \\
\text { hermit }\end{array}$ & $\begin{array}{l}\text { play a pitched }(\mathrm{M}) \\
\text { bottle of wine }\end{array}$ \\
\hline bass & $\begin{array}{l}\text { imitate the percussion (bb.1-5) } \\
\text { recite the yunbai (bb. 5-9) } \\
\text { half singing and half niànbái } \\
\text { (bb. 10-19) } \\
\text { rhythmical niànbái and sing- } \\
\text { ing (bb25-54) } \\
\text { humming (bb. 66-86,) }\end{array}$ & & $\begin{array}{l}\text { singing } \\
\text { as a } \\
\text { role } \\
\text { (bb. 19- } \\
24 \text { ) }\end{array}$ & $\begin{array}{l}\text { dress of an- } \\
\text { cient China } \\
\text { or Western } \\
\text { hermit }\end{array}$ & $\begin{array}{l}\text { playing a pitched (B) } \\
\text { bottle of wine }\end{array}$ \\
\hline
\end{tabular}

175 "Both Ban and Bangu are played by the percussion ensemble leader who is as the conductor in Chinese opera”. Cf. Yang Yinliu 杨荫汶, Miu Tianrui 缪天瑞 (et.al.eds.), Zhōnggóu Yinnyuè Cídiăn 中国音乐词典, (The Dictionary of Chinese Music) Arts Volume, p. 15. 
Niànbái (niàn for short) is a stylized form of recitation or sprechgesang, and is an important element in chuānjǜ performance. There are various categories of niàn: fast, slow, accented, gentle, ecstatic and rhythmic. I have used those appropriate to the particular character of the Hermits.

\subsubsection{Analysis of the Music of Hymn to the Virtue of Wine}

\section{Introduction (bb. 1-5)}

The introductory section integrates niàn and dă, all the singers and léiq̌n imitating the percussion sounds of kāichăng luógŭ (开场锣鼓) (the percussion overture) that normally opens a chuānjǜ performance. I based my introduction on the kāichăng luógǔ notated below, called Fānshān yăo (翻山鹞) (Snipe over the Mountain). ${ }^{176}$

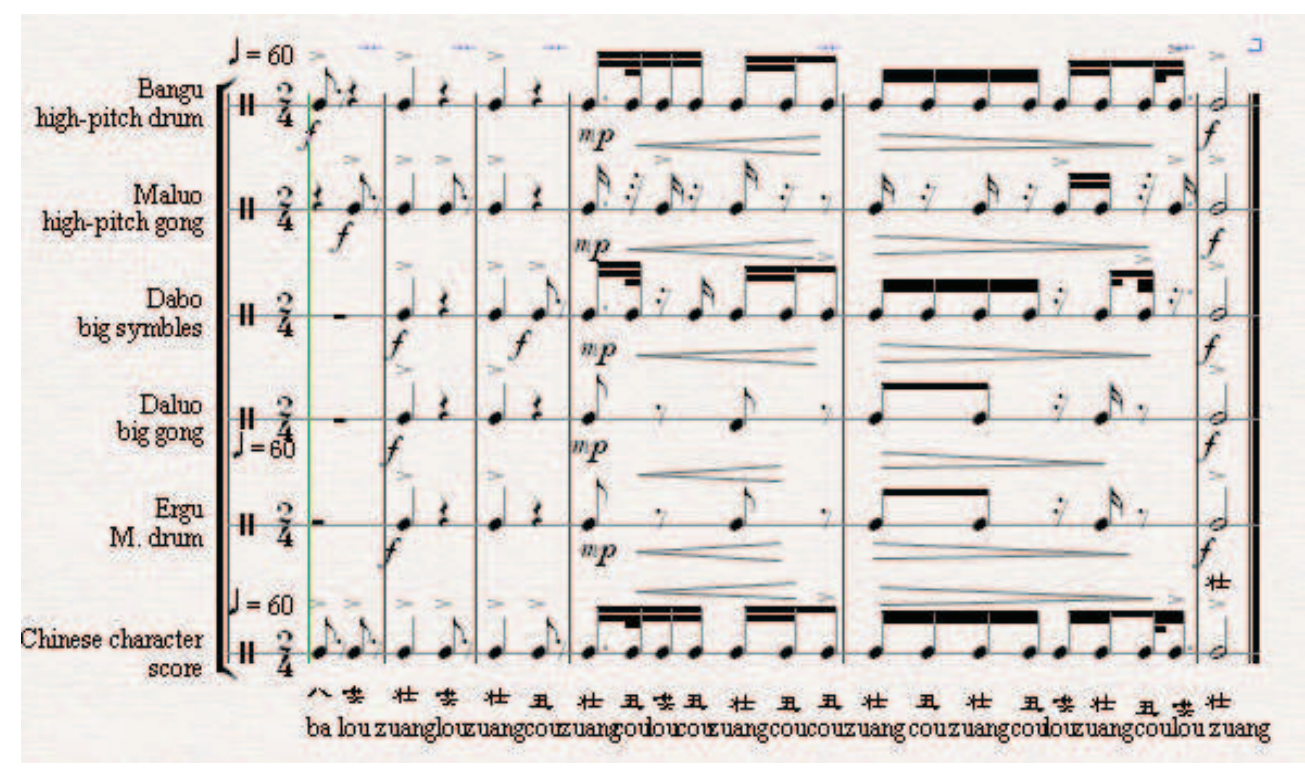

Example 43: A transcription of chuanju percussion Fānshān yăo (翻山鹞)

\footnotetext{
176 This Kāichăng Luógǔ I learnt through aural transmission from a traditional percussionist in 1976.
} 
The first three bars of Fānshān yăo, I developed into two short phrases of my introduction, with vocalised onomatopoeic percussion in a free rhythm. However, Soprano I performs niàn (recitation) while, at the same time, playing bángǔ drum (dă).

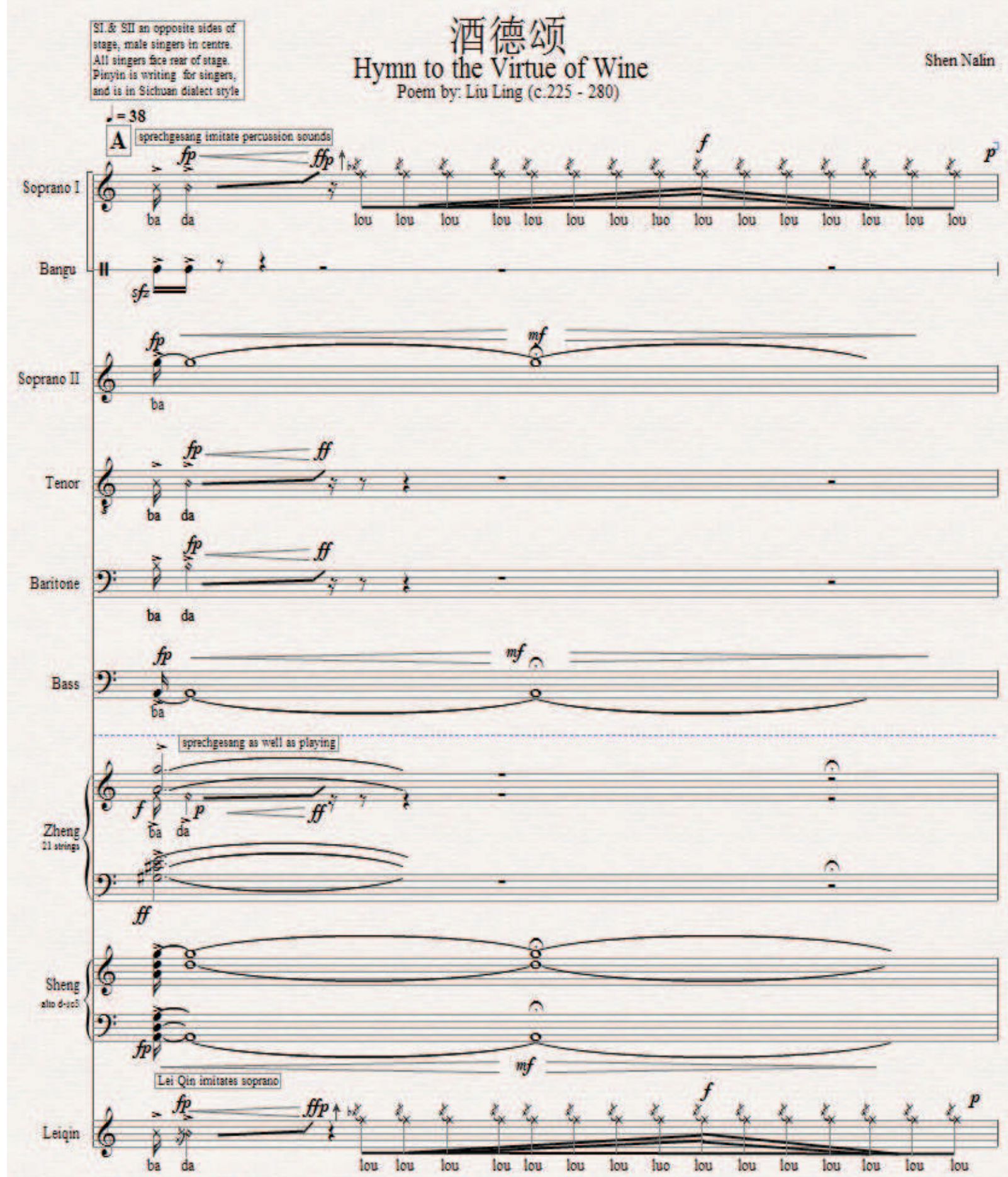

Example 44: Hymn to the Virtue of Wine (b. 1) 
The last three bars of Fānshān yăo, which I keep in metered rhythm, are divided between the choral parts:

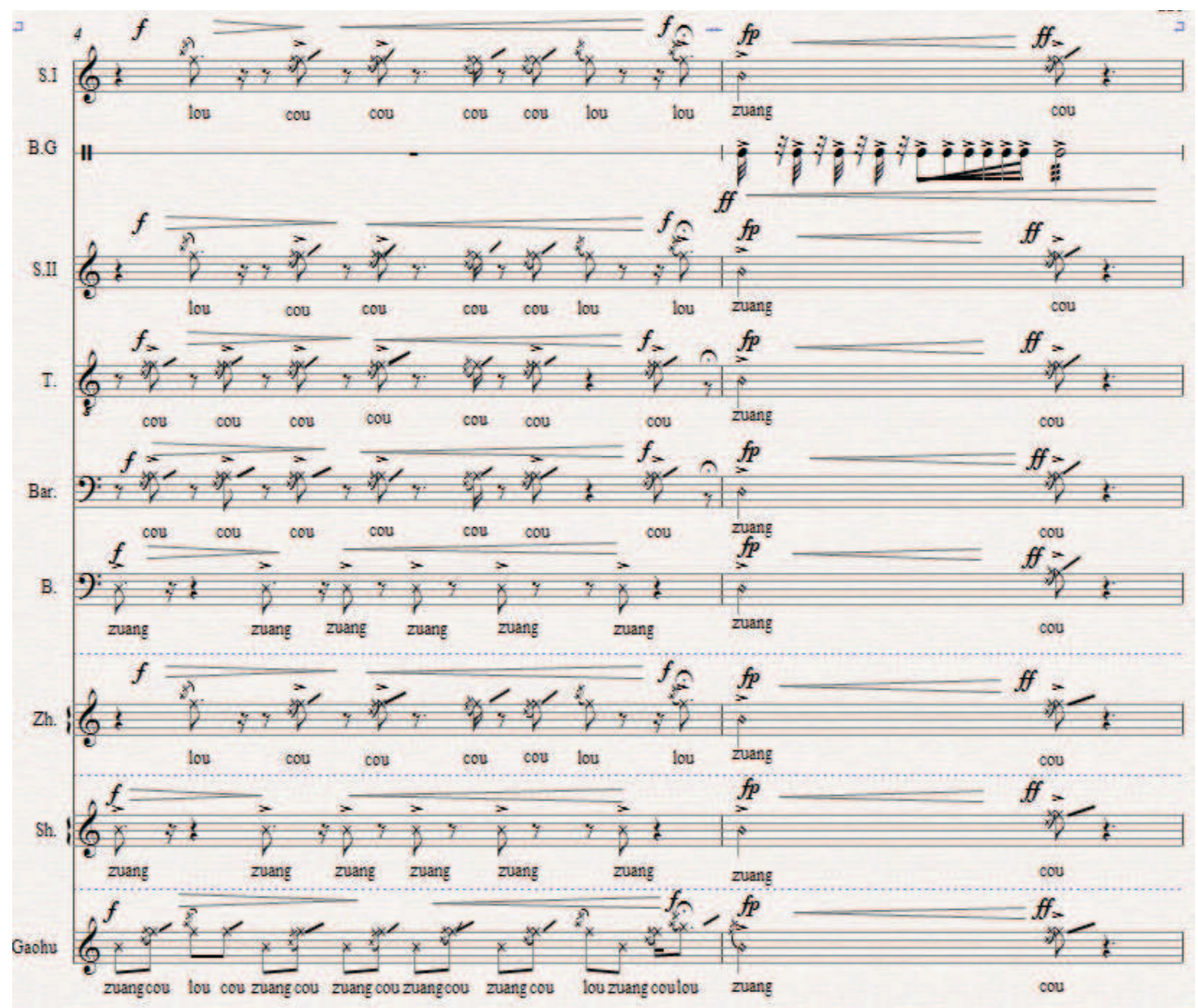

Example 45: Hymn to the Virtue of Wine (bb. 4-5)

Section A (Theme) (bb. 6-9)

As mentioned above, I am influenced by Zi Xia's concepts of the arts, particularly regarding the relationship of music and text. In this work the music and sounds needed to comply with the speech tones of Sichuan local dialect (see Chapter above 4.3.3.2). 
The pitch material of the first phrase for the sopranos' bāngqiāng has been integrated with the traditional Yùzān jì (玉篧记) (Song for the Jade Barrette) (mentioned above). I believe I subconsciously modelled my setting on a melodic shape of a bāngqiāng that was embedded in my memory from my days of playing in the chuānjù percussion ensemble, as might be seen in the following comparison:

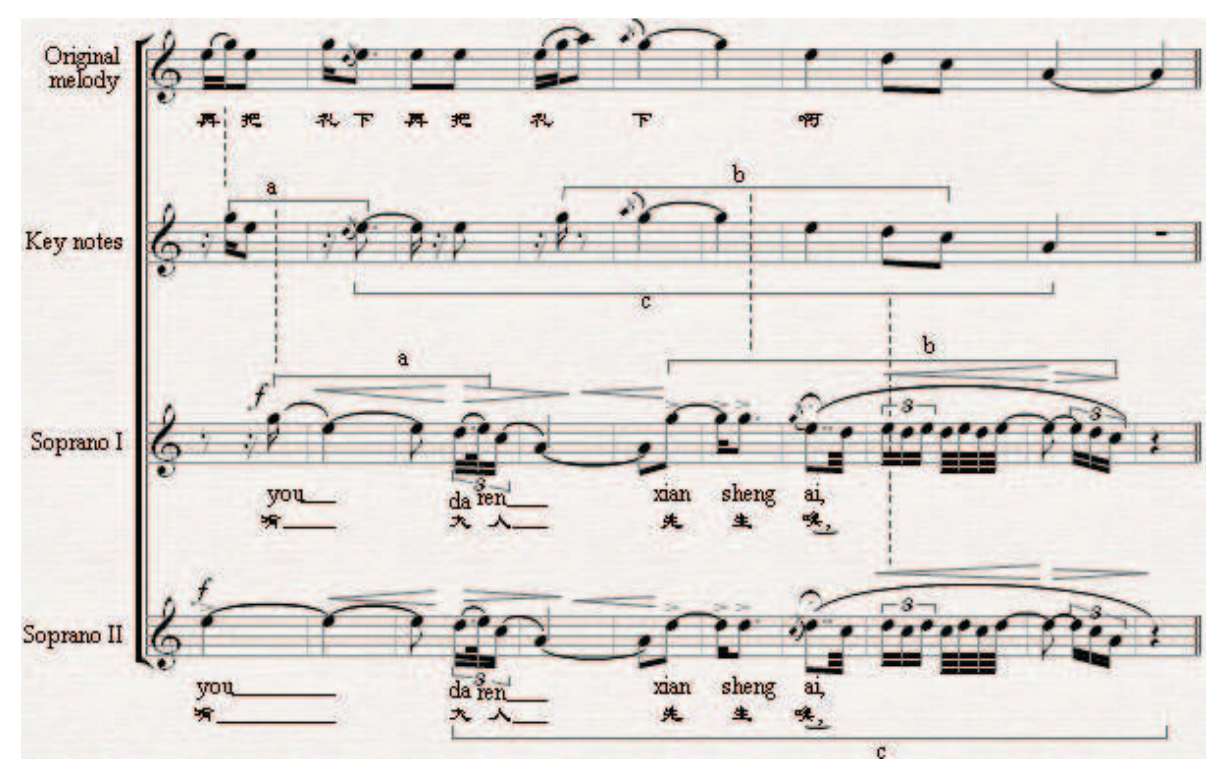

Example 46: Contours of original melody, and its integration in Hymn to the Virtue of Wine (S. I \& II)

In the first sentence of the text yǒu dàren xiānshen (有大人先生) (There was a certain Mr. Great Man) the characters introduce themselves, in traditional fashion zibào jiāmén (自报家 门). ${ }^{177}$ The words are important, since the people's titles are so elevated. Therefore, I employ both niàn (recitation) and chàng- bāngqiāng (singing) in a complementary way, to express these important words.

${ }^{177}$ Ci Hai 辞海, (Chinese Encyclopaedia), Literature Volume, p. 17. 


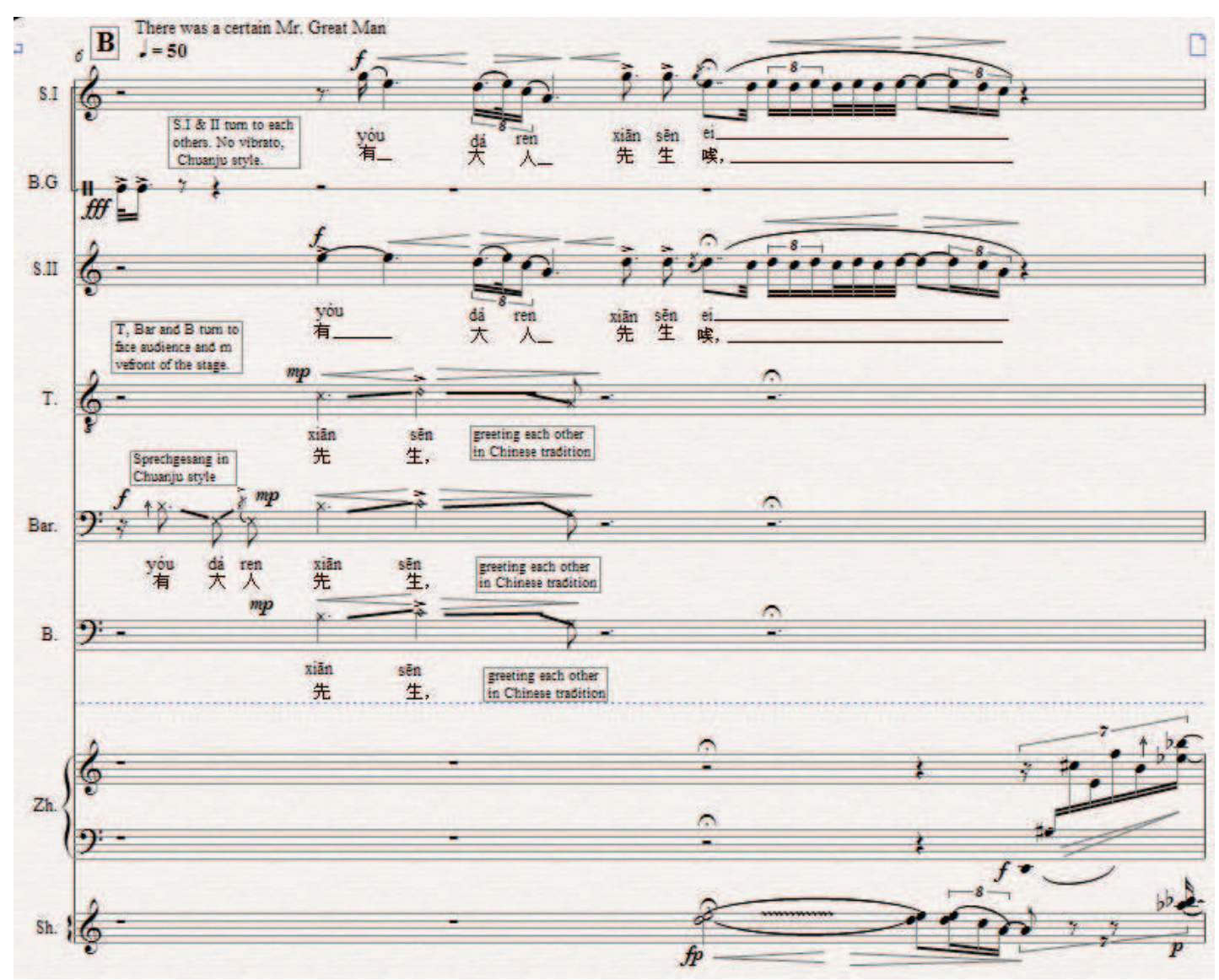

Example 47: Hymn to the Virtue of Wine (b. 6)

\section{Section B (bb. 10-54)}

The contrasting B section, consisting of 44 bars, has a three-part structure (a niànbái $+\boldsymbol{b}$ chàng $+\boldsymbol{c}$ niànbái $)$. The Hermits here play the principal parts, perform rhythmic niànbái (rhythmic recitation) and chàng. Meanwhile the sopranos imitate percussion sounds, and for one section are silent.

The first part $\boldsymbol{a}$ (bb.10-19) begins with a one-bar transitional phrase played by zhèng. Then two sopranos imitate percussion sounds, bars 11-12, and then perform tongue clicks and hand claps, bars 13-18. This percussion-like sound may be categorized as dă, and it brings a new and important timbre to my composition. 
However, the sopranos form an accompaniment to the main part, which is performed by the Hermits. Their half sung, half rhythmic recitation, fills this section.

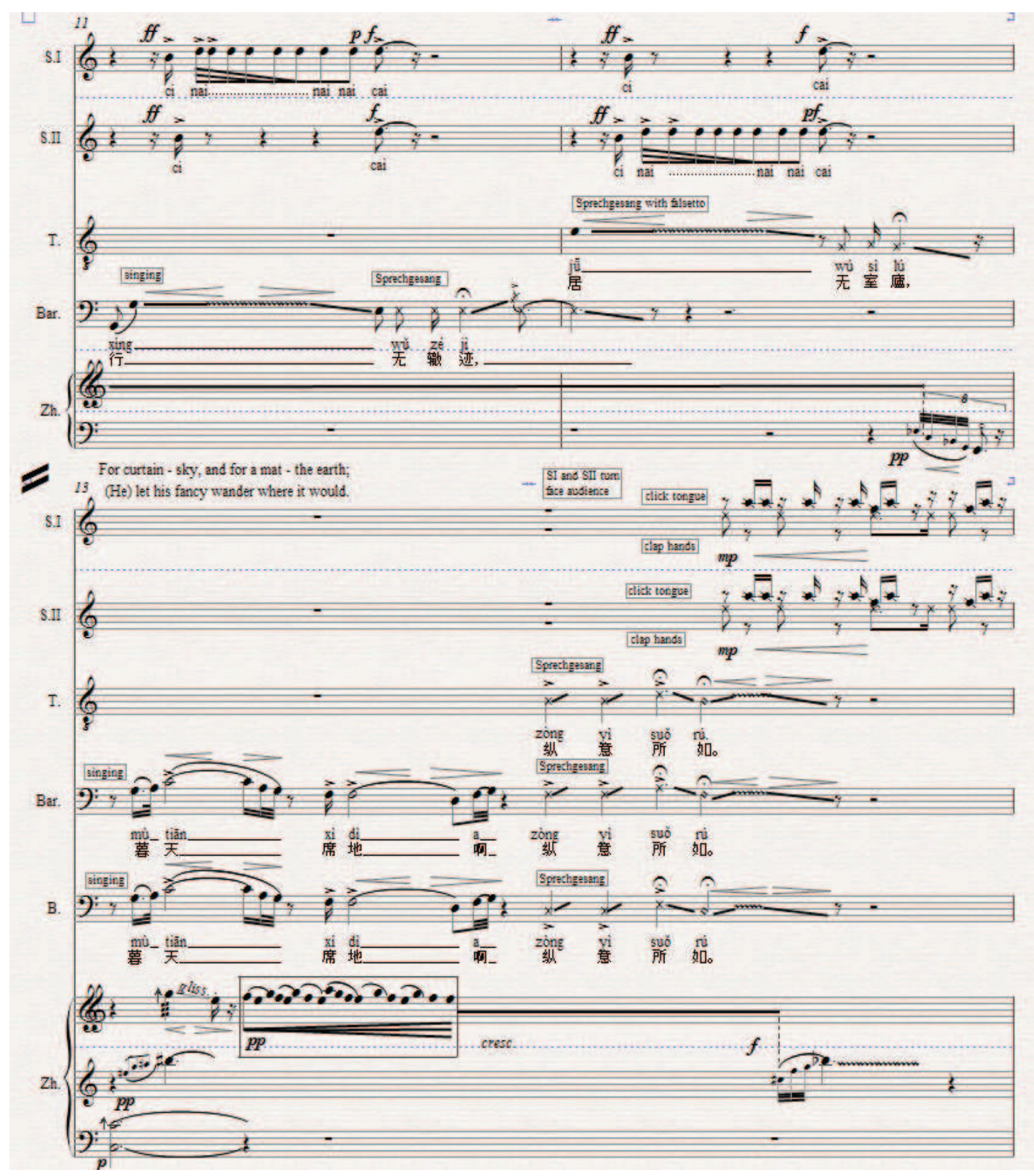

Example 48: Hymn to the Virtue of Wine (bb. 11-13) 
The second part $\boldsymbol{b}$ (bb.19-24) consists entirely of chàng by the Hermits with the instrumental ensemble. The sopranos are silent:

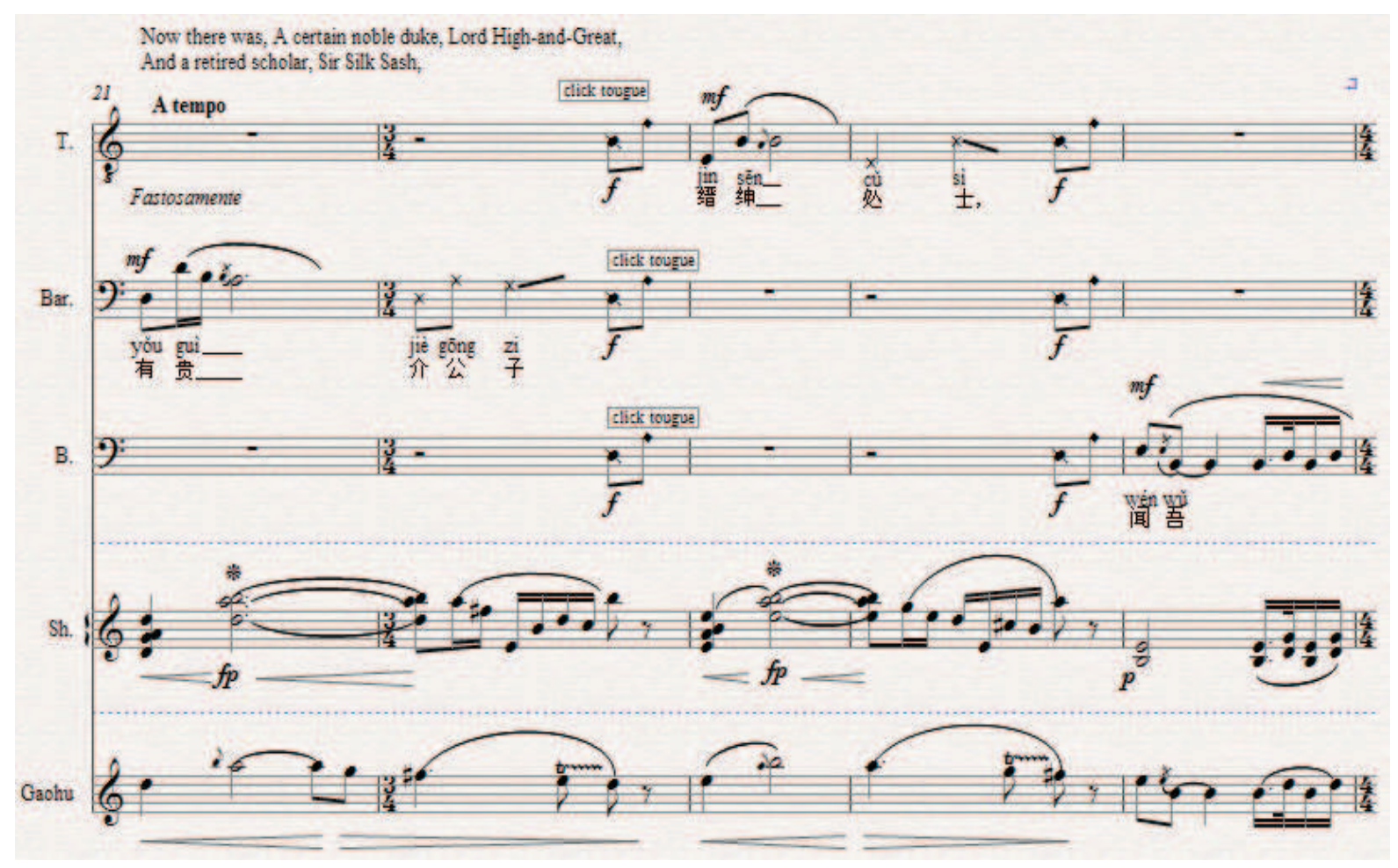

Example 49: Hymn to the Virtue of Wine (bb. 21-25)

The second part $c$ of B (bb. 25-54), in strong contrast is one of the climaxes of the composition. The text presents a powerful moment when the Hermits, debating aloud, express deeply-held convictions on serious matters:

Waving their sleeves and baring wide their breasts,

With wildly glaring eyes and gnashing teeth,

They lectured loud and long on rites and laws,

While rights and wrongs rose up like spears.

The tempo speeds up from $d=\mathbf{5 8}$ to $d=\mathbf{1 2 0}$, as if summoned by the short ensemble introduction which leads to a continuously rhythmical section: 


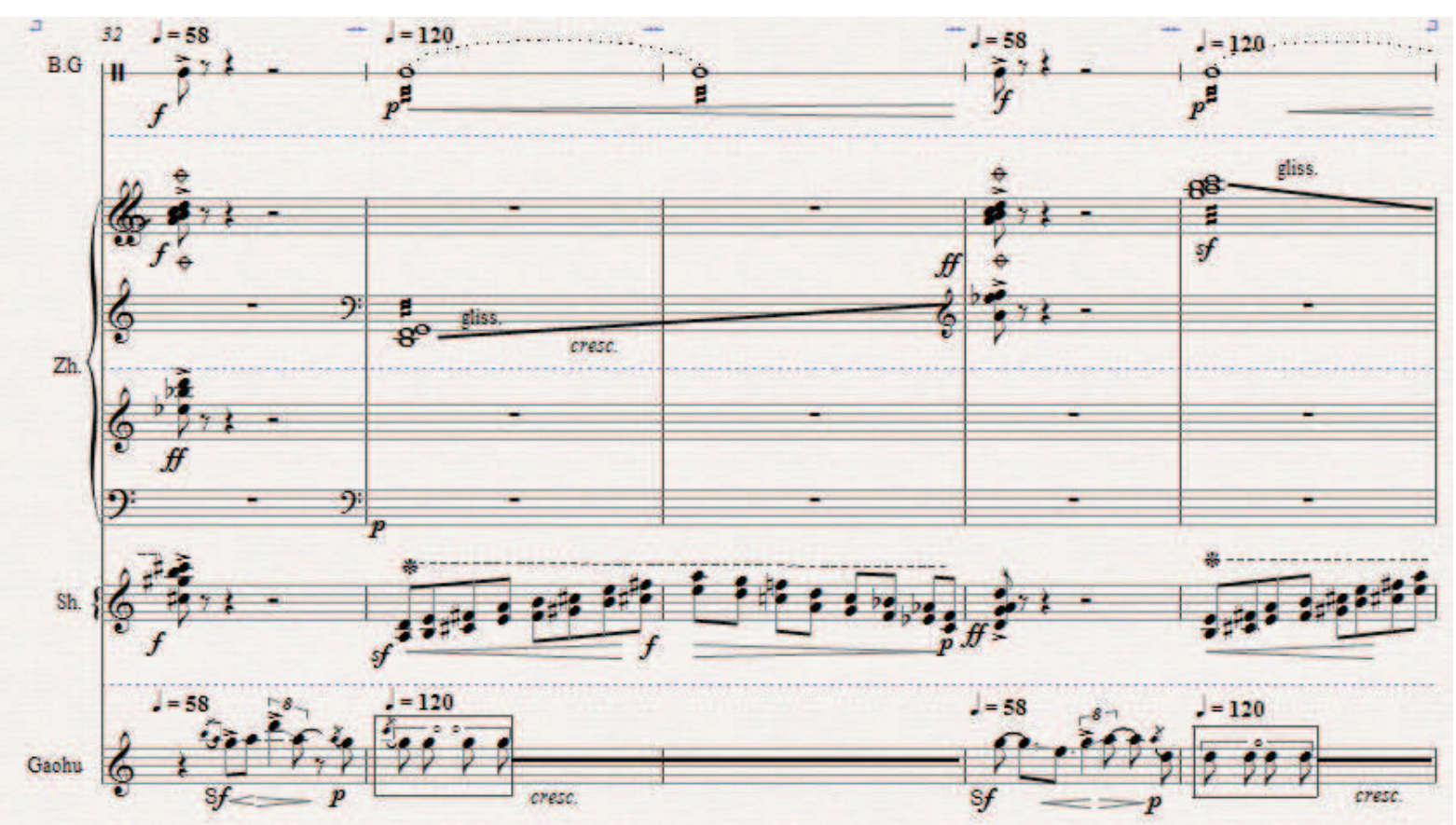

Example 50: Hymn to the Virtue of Wine (bb. 32-36)

The Hermits are performing niànbái for the first half. Then, they perform half singing and half niànbái, and gradually build up to a chàng phrase, which is the climax of the piece. At the same time, sopranos imitate percussion sounds to join with them. 


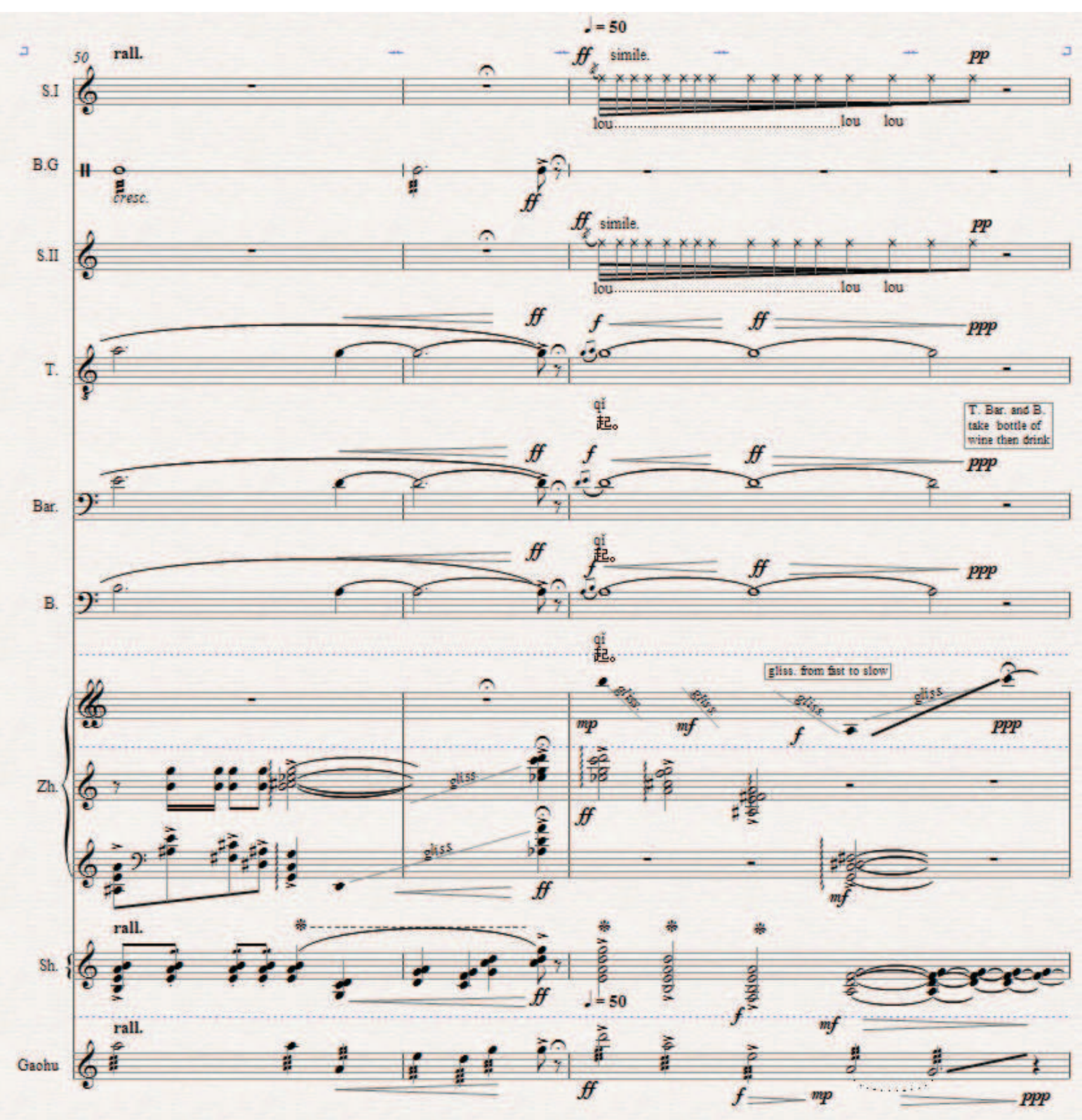

Example 51: Hymn to the Virtue of Wine (bb. 50-52)

In A1 the return of the refrain, a development of A, soprano I is bāngqiāng solo, while soprano II performs a niànbái which is a recitation in English for the same text as soprano I who is singing in Chinese. However, the three Hermits dramatically play the bottles as a background of sounds, and perform with body gesture movements as the element of zòu, to express the behavior of the Hermits, as showing their drunken state: 


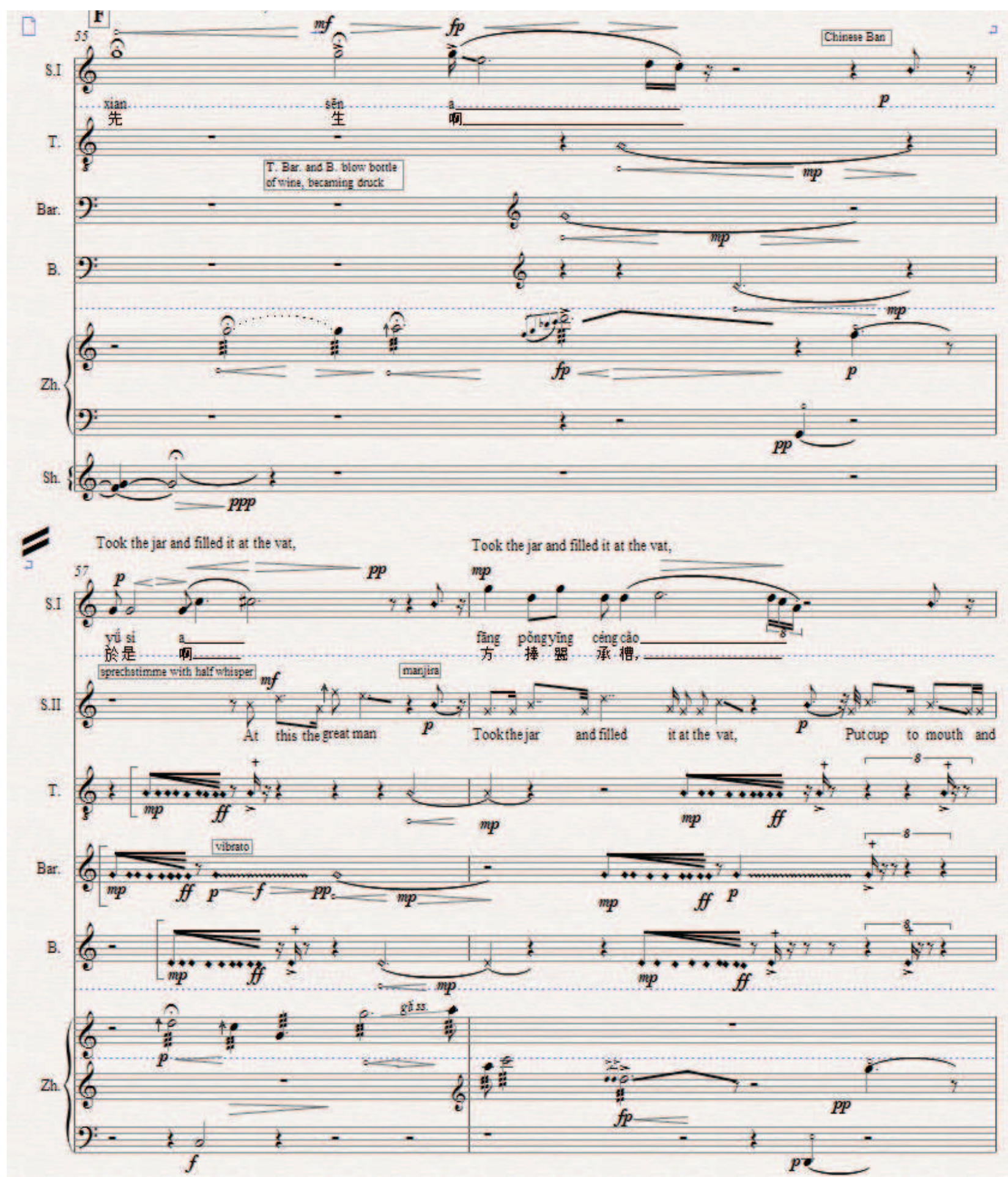

Example 52: Hymn to the Virtue of Wine (bb. 55-57)

In the other contrasting section $\mathrm{C}$, the principal part is given to one hermit (tenor) yùnbái recital and a léiq̌̌n (double string Chinese spike fiddle) to imitate his yùnbái sounds. Other hermits are again blowing across the mouths of wine bottles; the sopranos are silent. 
There is another instance, using yùnbái and chàng, in which the tenor performs in sprechgesang the text; it is a rhythmical setting, playing along with léiqinn, which imitates the tenor's sprechgesang. The baritone and bass hum, using simple melodic pattern that mimics the sound of the drunken state.

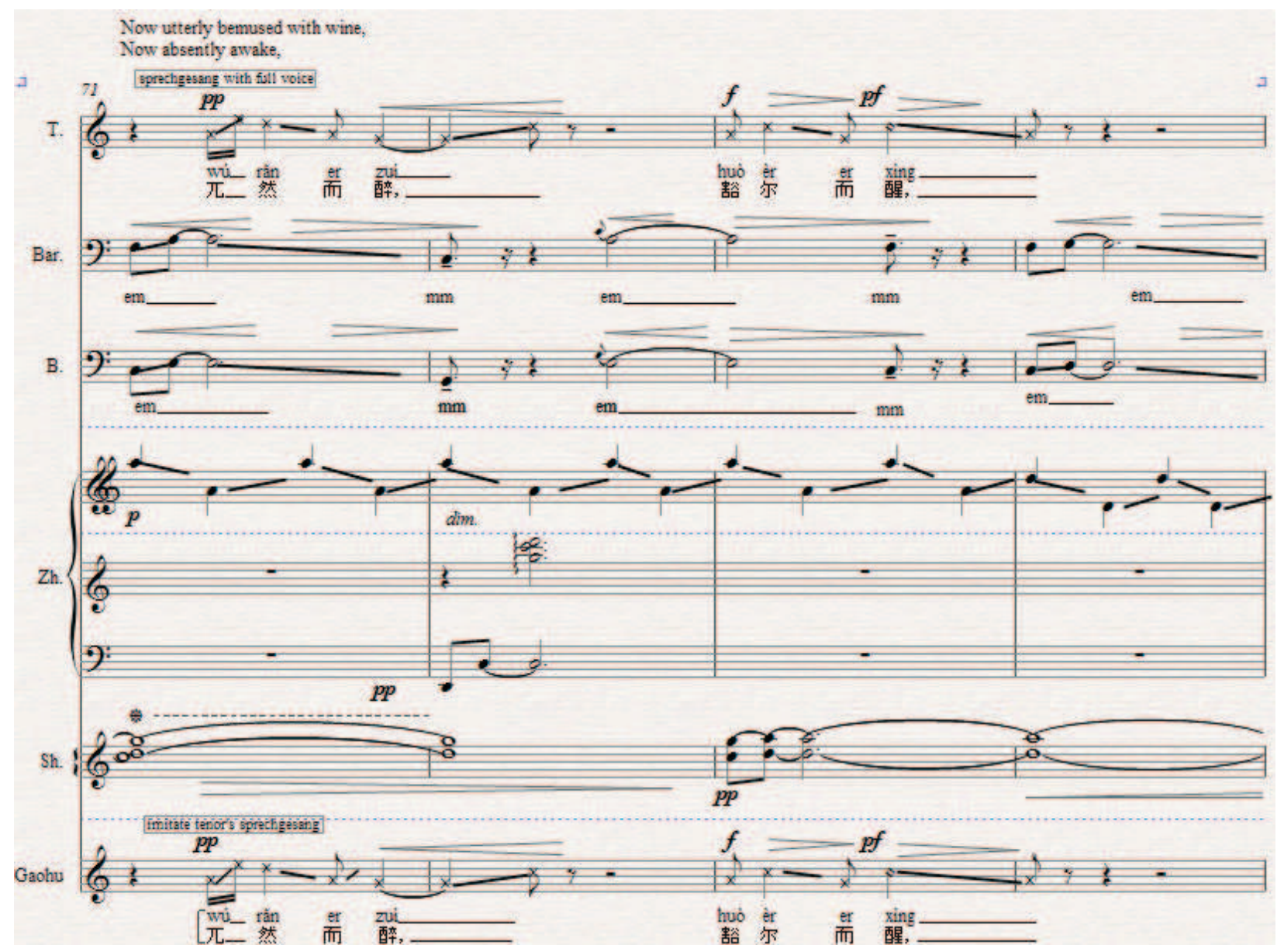

Example 53: Hymn to the Virtue of Wine (bb. 71-74)

Section A2 is a refrain that repeats a variation of A. It has a different musical expression. The niànbái of the Hermits parts are composed in a canonic style, as if echoing each other with even-decreasing dynamics (from $f-m f-m p-p-\mathrm{pp}$, of silence). 


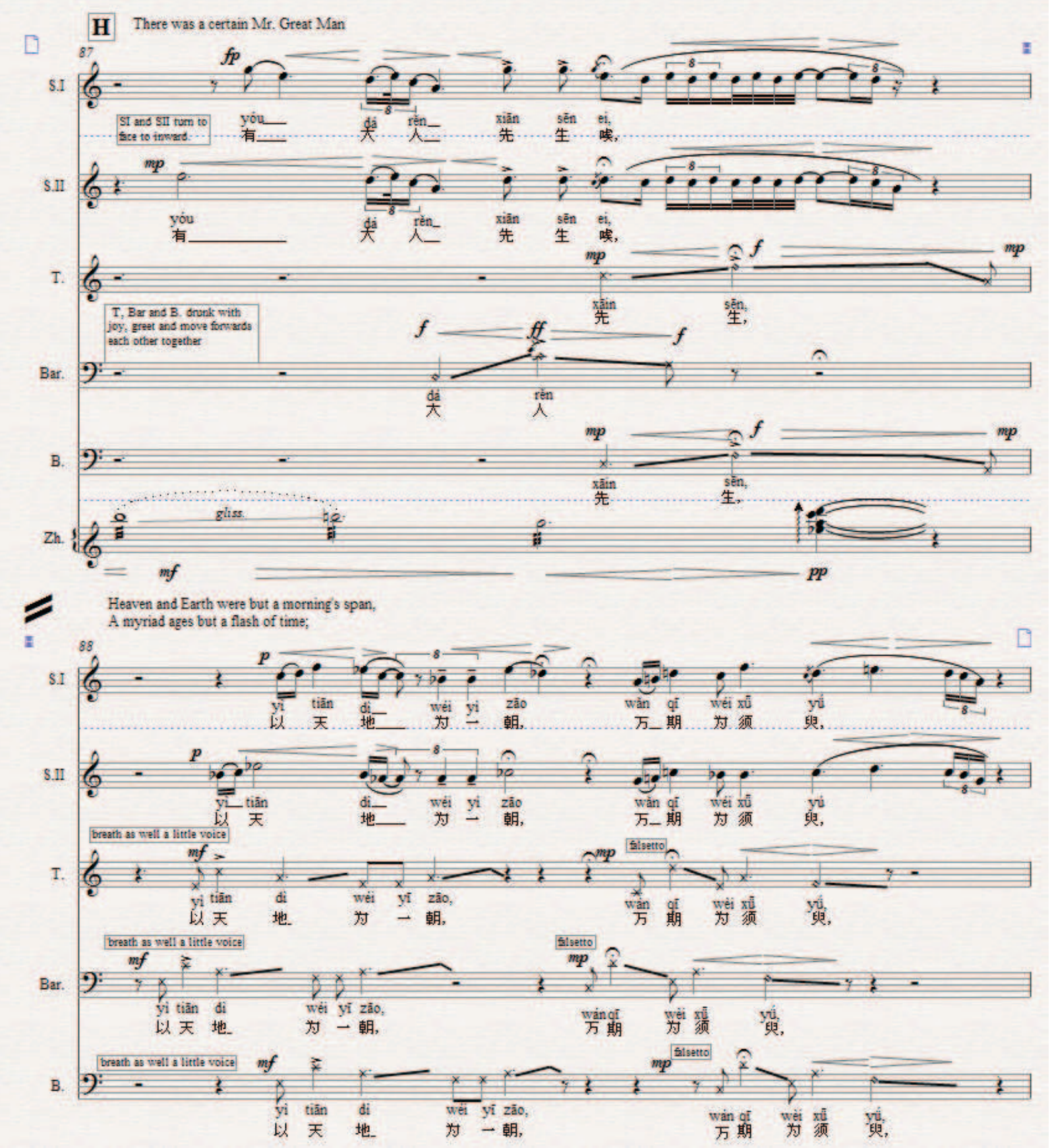

Example 54: Hymn to the Virtue of Wine (bb. 87-88) 


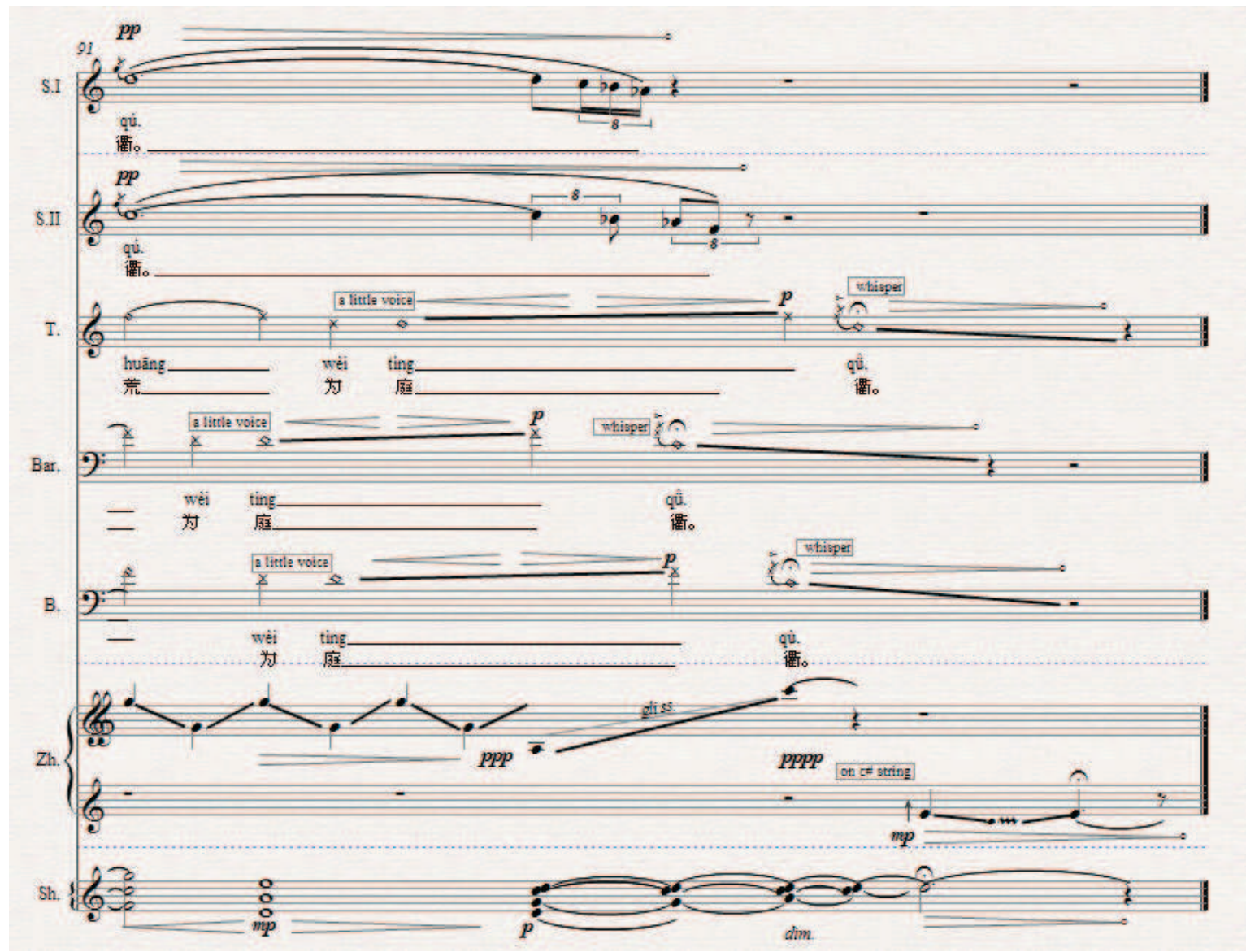

Example 55: Hymn to the Virtue of Wine (b. 91)

\subsubsection{Conclusion}

For the production of Hymn to the Virtue of Wine, to resolve the problems of the language for the performers, such as pinyin of tones and the pronunciation, I made a recording of each section, giving examples of the sounds, to send to The Song Company so that the singers could practice. Later on I went to Sydney for sectional rehearsals, and I demonstrated Chinese pronunciation, as well as the Sichuan dialect, to the singers.

The instrumentalists have an extra task, in that they are sometimes required to sing and speak as well as play their instruments. I myself participated in the Sydney premiere performances, as well as in subsequent performances at the Riverside Theatres, Parramatta, 
and St Paul's Cathedral in Melbourne, playing băngǔ (板 鼓) (the high pitched drum of chuānjì̀) and performing niànbái for a long section of recitation in Sichuan dialect in section $\mathrm{C}$.

In my composition Hymn to the Virtue of Wine, my aim was to employ from Sichuan opera the concepts of niàn, chàng, zòu and dă, and I also derived my musical materials from chuānjǜ gāoqiān music, such as onomatopoeic vocalizations imitating percussion sounds, the counterpoint of bāngqiāng (singing) and yùnbái (sprechgesang) in chuānjù̀ style, and the diverse niànbái (recitation) both in Chinese and English, used rhythmically, or with percussion and instruments (léiqin) together. Incorporating those techniques, I conceived a contemporary vocal work, semi-opera almost, which was to develop my composing methods, techniques and capabilities for writing the opera later on.

At the same time that I was composing Drunkenness, and Hymn to the Virtue of Wine, I was also developing the libretto of my opera Fatal Desire, based on a confessional quasibiographical novel Ying'er, by Gu Cheng, co-authored by Lei Mi (Gu Cheng's wife, whose real name was Xie Ye). In facing the prospect of composing music for an opera, I viewed the composition of Hymn to the Virtue of Wine, a setting of the words of an ancient poem, as ideal preparation for this bigger task. 


\title{
5. New Compositions (2)
}

\subsection{Historical Origins of the Opera Zhìmìng de Yùwàng (致命的欲望) Fatal Desire}

\author{
黑夜给了我黑色的眼睛 \\ 我却用它寻找光明 \\ Even with these dark eyes, a gift of the dark night \\ I go to seek the shining light \\ Gu Cheng (Yìdài Rén) (One Generation) (1979) ${ }^{381}$
}

Gu Cheng 顾 城, son of the well-known army poet Gu Gong 顾 工 (born in 1928), was born in Beijing on 24 September 1956. During the "re-education campaign" started in 1969, he was sent to a remote salt desert in Shandong Province where he laboured as a pig shepherd. That was an experience in which he claimed that he had learned poetry directly from nature. He would always write poems in the sand with a twig. Poems composed during this period include "The Nameless Little Flower" and "The Dream of the White Cloud". He returned to Beijing in 1974 and worked in a factory. Later, he became associated with a unofficial and underground journal called Jingtiā (今 天) (Today) that was to initiate a style of poetic writing, later known as Ménglóngshī (朦胧诗) (The Misty Poem). The work of the modernist poets concerned was published in the journal. ${ }^{382}$

In 1983, Gu Cheng married Xie Ye in Shanghai and began to travel around the world as an international celebrity, particularly in Germany and the Netherlands. ${ }^{383}$ His short poem

\footnotetext{
${ }^{381}$ Joseph Allen, Sea of Dreams: The Selected Writings of Gu Cheng, New York: New Directions, 2005, http://www.cipherjournal.com/html/allen_gu_cheng.html; accessed 11 May 2010.

${ }^{382}$ Gu Cheng 顾城 \& Lei Mi 雷米, the Postscript - Ying'er 英儿, Beijing, Zuojia Chubanshe, 1993, inner page. My translation.

${ }^{383} \mathrm{Gu}$ Cheng was invited by Prof. Wolfgang Kubin in 1987 to visit Germany and Europe. See Li Xia: Essays, Interviews, Recollections and Unpublished Material of Gu Cheng, 20th Century Chinese Poet: The Poetics of Death (with a supporting preface by Goran E. Malmqvist). New York: The Edwin Mellen Press, 1999, p. 1.
} 
“One Generation" was printed on a trip to Holland. His wife accompanied him on all their trips. In 1987, they settled in Auckland, where Gu Cheng taught Chinese literature at the University of Auckland. In 1990, Li Ying, Gu Cheng's mistress, better known as Ying'er, arrived in Waiheke Island and lived with them. ${ }^{384}$ In 1992, Gu Cheng went to Berlin on a DAAD fellowship with his wife Xie Ye. They returned to New Zealand on 24 September 1993. On 8 October, he assaulted his wife, Xie Ye with an axe, she died later in hospital, and he then hanged himself. ${ }^{385}$

I came to know Gu Cheng's work through the short poem quoted above. Containing eighteen characters under the title of "One Generation", this poem was included in a handcopied book which was very popular among university students in the early 1980's. I belong to the same generation as Gu Cheng and went through the same dark age known as the Cultural Revolution that lasted ten years. The eighteen-character poem, with each of its character as a catalyst, served as an encouragement for the whole generation to strive for a better life, to "seek the shining light".

In 1993, when I was working for the music channel of the Guangdong Provincial Radio Station, I read in the newspaper an article entitled Juéchàng Xīnxīlán (绝唱新西兰) (The Swansong from New Zealand) and learned that Gu Cheng ended his life after killing his wife. The whole of China seemed to be immersed in grief at the sad news. It occurred to me then that I should take this story as the theme of an opera.

\subsection{The Libretto}

\section{2. 1 The Novel Ying'er (英 儿) (The Kingdom of Daughters) and Other Materials}

\footnotetext{
${ }^{384}$ About this extraordinary circumstance cf. the novel Ying'er for more information.

${ }^{385}$ Chen Zishan 陈子善 (ed.), Shiren Gu Cheng Zhi Si (诗人顾城之死), (The Death of Poet Gu Cheng), Shanghai: Shanghai Renmin Chubanshe, 1993, inside cover page. My translation.
} 
Ying'er is a prose novel by Gu Cheng, co-authored by Lei Mi (pseudonym of Xie Ye, Gu Cheng's wife) in Berlin 1992 while he was on a DAAD fellowship, "Gu Cheng wrote one of the strangest books ever written: Ying'er, which he called his 'dream of the Gu Cheng chamber', a barely fictionalised account, with long passages of physical details of the love affair and its break-up. It is obsessive and hallucinated, narcissistic and self-pitying, precise and incoherent, kitschy and terrifying - in the end perhaps more of a document than a piece of literature, and now impossible to read at a purely aesthetic distance. Gu Cheng dictated the book on tape, and Xie Ye transcribed it, adding some paragraphs and chapters of her own"386 . They finished the first draft in May 1993 in Berlin, the second draft in August 1993 in "the little house in Langenbroich", ${ }^{387}$ Eifei, Germany.

An original manuscript of the novel Ying'er (英儿) was sold to an anonymous buyer at the “93 Shenzhen Auction of Manuscripts (93 Shenzhen wéngăo pāimài hui 深圳文稿拍卖会) on 9 October, one day after Gu Cheng's death. This version of the novel was published by the Beijing Zuojia Chūbănshè (Beijing Writers Press) in November 1993. On the cover were the words, "the present edition is the only legal completed edition authorized by the authors". In the postscript to this edition the owner of the manuscript declared that he was not seeking royalties from this publication ${ }^{388}$. The English translation of the novel, $G u$ Cheng and Lie Mi, Ying'er: The Kingdom of Daughters ${ }^{389}$, was the work of Li Xia. Another draft of the novel was published by Beijing Hauyi Chūbănshè (Beijing Huayi Press) on 5 November 1993, in a version that found a publisher through the services of his friend Liu Zhenyun 刘震云 who had met Gu Cheng and Xie Ye at a conference in Berlin in June 1993. The order of some chapters is different and some descriptions are missing in this

\footnotetext{
${ }^{386}$ Eliot Weinberger, "Next stop, the Forbidden City", London Review of Books, Vol. 27, June, 2005, p. 42. Available from http://www.lrb.co.uk/v27/n12/eliot-weinberger/next-stop-forbidden-city: accessed 11 May 2010.

${ }^{387}$ Gu Cheng 顾城 and Lei Mi 雷米, the Postscript - Ying'er 英儿, Beijing, Zuojia Chubanshe (Zuojia Press), 1993, p. 366.

${ }^{388}$ Cf. A postscript by the anonymous owner, Ài de Kuānróng (爱的宽容), (“The Tolerance of Love”), Gu Cheng and Lei Mi, Ying'er 英 ル, Beijing: Zuojia Chubanshe (Zuojia Press), 1993, p. 367

${ }^{389}$ Li Xia 李侠, Gu Cheng and Lei Mi, Ying'er: The Kingdom of Daughters, translation by Li Xia, Dortmund: Project verlag, 1995, p. 309.
} 
version. ${ }^{390}$ The text of my libretto was derived from both versions of the novel and from some of Gu Cheng's poems.

In addition, I also used as a source for my libretto two other related books: Wǒ Moiànduì Gù Chéng de Zuihòu Shísitiān (我面对顾城的最后十四天) (Gu Cheng's Last Fourteen Days with $\mathrm{Me}$ ) by 顾 乡 $\mathrm{Gu}$ Xiang (the elder sister of Gu Cheng), published by International Culture Press (Guoji Wenhua Chūbănshè, Beijing, 1994), and Shīrén Gù Chéng Zhīshǐ (诗人顾 城之死) (The Death of Poet Gu Cheng), an essay collection edited by Chen Zishan 陈子善 and published by Shanghai People’s Press (Shanghai Renmin Chūbănshè).

Before I started work on the libretto, I made contact with Gu Xiang, who is the copyright guardian of Gu Cheng's works. I paid several visits to her at her home and came to a formal agreement with her in respect of the copyright. According to this agreement, I was given the freedom to use Gu Cheng's poems, novel and sound recordings for the purpose of my research.

\subsubsection{The Arrangement of the Libretto}

There were some compelling reasons for me to take the opportunity to work on this subject. $\mathrm{Gu}$ Cheng and I are of the same generation. We grew up in the same social and political milieu. These factors enabled me to understand him and his work. What is more, we have the same "black eyes" with which we read history and "seek the shining light".

In addition, I feel a strong personal attachment to Gu Cheng's works, his poetry, his essays, his prose and novels, and especially his interviews, lectures and articles, and recordings of his reciting his poetry, one accompanied by his own improvisations on the piano.

\footnotetext{
${ }^{390}$ Cf. Raoul David Findeison, “Two Works - Hong (1930) and Ying'er (1993) as Indeterminate Joint Ventures" in Essays, Interviews, Recollections and Unpublished Material of Gu Cheng, 20th Century Chinese Poet: The Poetics of Death, ed. with an introduction, essays and translations by Li Xia, New York: The Edwin Mellen Press, 1999, p. 151.
} 
Commenting on the poet's life, Raoul David Findeisen, in the conclusion of his thesis, Two Works - Hong (1930) and Ying'er (1993) - as Indeterminate Joint Ventures, states: "The technique and procedures traced above may complement, if not slightly modify the conventional image of somebody who truly 'made his living by writing' (wèi shēng ér xiě,, 为生 而写)”.391

Indeed, Gu Cheng was not living by his writing shēngcún (生 存), but rather through and within his writing shēngming (生 命). As he himself wrote in his novel Ying'er: "Life is saturated by writing, thought up page after page. Longer than life. People (life) just print books. It is up to you read them". ${ }^{392} \mathrm{Gu}$ Cheng was living his novel The Kingdom of Daughters. "I can only madly build my wall, my city, the borders of my heavenly world... this is a crazy idea. But I did it, in that split second." 393

Some readers complain of the "long passages of physical detail" 394 describing sexual intercourse, but I appreciate the quality of poetical writing in Ying'er, expressing the author"s honest feelings and reflecting his inner conflicts.

Most significantly this tragic story took place in New Zealand and contains both New Zealand and Chinese elements, which have taken on special personal meaning for me as a Chinese immigrant to this country.

My projected opera, based on Gu Cheng's writings, particularly his novel Ying'er, I titled Zhìming de Yǜwàng (致命的欲望) Fatal Desire.

\footnotetext{
${ }^{391}$ Raoul David Findeison, “Two Works - Hong (1930) and Ying'er (1993) as Indeterminate Joint Ventures”, p. 135.

${ }^{392} \mathrm{Gu}$ Cheng and Lei Mi, Ying'er, The Kingdom of Daughters, p.18.

${ }^{393}$ Ibid, p. 87.

${ }^{394}$ Eliot Weinberger, "Next stop, the Forbidden City", p.42.
} 


\subsubsection{The Structure of the Libretto}

Wu Sijing 吴思敬 395 considers Gu Cheng’s novel a psychological novel, “(whose) strength lies in its psychological explorations and its weakness is in its structural composition" 396. In the arrangement of the libretto, the story of the opera has no specific time sequence. Any event in the opera can be viewed as an independent episode and can be performed as such.

By having an open structure, the scenes of Part Two of Fatal Desire offer different possibilities for performance. This can be explained in the following three ways:

1. Each scene of the opera can be performed independently and as a separate work.

2. Several scenes of the opera can be performed as a whole and

3. All scenes can be swapped in any permutation and combination (with the exception of the Epilogue, of course).

\subsubsection{The Dramatisation of the Libretto}

It took me one and a half years to arrange the first draft of the libretto Fatal Desire In arranging the libretto, I observed the following principles:

1. All excerpts from the original text were used verbatim, even if the sequence was sometimes changed.

2. Separate episodes of the novel were sometimes brought together to create dramatic unity, but always in accordance with the spirit of the original novel.

\footnotetext{
${ }^{395} \mathrm{Wu}$ Sijing 吴思敬 is a poetry critic and Professor of Chinese at the Capital University of Pedagogical studies in Beijing.

${ }^{396}$ Wu Sijing 吴思敬, “Some Biographical Notes on Ying’er and Gu Cheng's Death” Cf. Li Xia 李 侠 (ed. with an introduction, essays and translations), Essays, Interviews, Recollections and Unpublished Material of Gu Cheng, 20th Century Chinese Poet: The Poetics of Death, New York: The Edwin Mellen Press, 1999, p. 305.
} 
3. The original subtitles of the chapters of the novel were also kept for the scenes of the opera.

Gu Cheng and Lei Mi's Ying'er is considered a autobiographical psychological novel in which Gu Cheng's thoughts and feelings are filtered through his wife, who acted as his transcriber, and later as his co-author. The reader is led in a circular fashion through Gu Cheng's "psychological explorations", as his inner unconscious world is channelled to the surface of awareness. ${ }^{397}$

In constructing the role of Cheng in my opera, I created two characters: Cheng A, inhabiting the conscious world, and Cheng B, who expresses the unconscious world of the soul. I felt this "split personality" was needed in order to adequately reflect the complex and often dark world that the poet expressed in his writings.

A Dream of Red Mansions, a novel by Cao Xueqin 曹雪琴 (ca. 1715-1763) ${ }^{398}$, was wellknown by Gu Cheng's generation as a Yuè opera, popularized in a film version. ${ }^{399} \mathrm{Gu}$ Cheng in his writings dreamed of his personal "Kingdom" inspired by A Dream of Red Mansions. He discussed this subject with Marián Gálik, when he was in Berlin (1992) “A heavenly kingdom on earth has twice appeared in Chinese literature, one created by Tao

\footnotetext{
${ }^{397}$ In Freud"s theory of the Ego, "people have three levels of awareness: the conscious, the preconscious, and the unconscious." $[\ldots]$ "The conscious consists of whatever one is aware of at a particular point of time $[\ldots]$ the preconscious contains material just beneath the surface of awareness that can easily be retrieved $[\ldots]$ the unconscious contains thoughts, memories, and desires that are well below the surface of conscious awareness but nonetheless exerts great influence on behaviour." Fc. Wayne Weiten, Psychology Themes \& Variations, $6^{\text {th }}$ ed., USA: Thomson Wadswonth, 2004, p. 481.

398 "Cao Xueqin is considered to be China's greatest novelist, but little is known of his life. An unconventional, versatile man, he came from an eminent and wealthy family which suffered a reversal of fortune in 1728 after the death of the Kangxi Emperor and a power struggle between his sons. Cao seems to have spent about ten years writing and revising his novel, from roughly 1740 to 1750 , but the last 40 of the 120 chapters were completed by a different author, probably after his death. He also worked for a period of time in the Imperial Clan's school for the children of the nobility and banner men, but eventually settled in the countryside west of Peking. He earned some money by selling his own paintings, but his family seems to have been perpetually in poverty. The novel, now generally recognised as a masterpiece, was not published until 1791, nearly 30 years after Cao's death". Cf. Renditions, available from:

http://www.renditions.org/renditions/authors/caoxue.html; accessed 22 August 2010.

${ }^{399}$ A film of Yuè opera: A Dream of Red Mansions is a special Xijù̀ film, directed by Cen Fan with the leading actress Xu Yulan and Wang Wenjuan from the Shanghai Yuè opera house, was produced by The Shanghai Film (Group) Corporation in 1962. However, it was suppressed during the Cultural Revolution.
} 
Yuanming 陶波明 (365 or 372-427) in the Garden of Peach Blossoms ${ }^{400}$ with indistinct characters, and the other by Cao Xueqing in the Grand View Garden of his A Dream of Red Mansions. As soon as the gate of the Grand View Garden was opened, there was compensation for the lack of soul in modern poetry. People then began to realise that the omnipresent moon on the spring river had turned into the pure and unique Kingdom of Daughters". ${ }^{401}$ My opera uses his idea, derived from Gu Cheng's fantasy world as found in several chapters of the novel Ying'er. One scene of the libretto is derived from Gu Cheng's Ying'er, performed in Yuè opera style, and is called A Dream of Red Mansions.

\section{Characters of the opera}

The names of the three main characters in the opera, the poet Cheng, his wife Lei Mi and his lover Ying'er, are drawn from the novel Ying'er, and should not be interpreted as representing real people, living or dead.

Cheng A (tenor I) - a Chinese Poet

Cheng B (baritone) - a second aspect of Cheng

Lei Mi (mezzo-soprano) - the Poet's Wife

Ying'er (soprano I) - the Poet's Lover

A Woman Poet (soprano II) - a female Chinese Poet

An Editor (tenor II) - the Editor of a Journal of Contemporary Poetry

An Elder (bass) - a Western Scholar of Contemporary Chinese Literature

\footnotetext{
${ }^{400}$ Chen Qiaosheng 陈桥生, Tao Yuanming 陶渊明 (The Poem of Tao Yuanming), Beijing: Wuzhou Chuanbo Chubanshe, 2006, p. 90.

${ }^{401}$ For more information on this point, cf. Gu Cheng, "Da suo wen - Questions and Answers", in Essays, Interviews, Recollections and Unpublished Material of Gu Cheng, 20th Century Chinese Poet: The Poetics of Death, p. 345.
} 


\subsubsection{The Scenes of the Opera}

The opera comprises three parts with a total of nine scenes. Part One is the prelude, in two sections, the first integrating the actual text of an interview with Gu Cheng, and the second with recitations of Gu Cheng's poetry. Part Two, comprising seven scenes, one being an Interlude, constitutes the main body of the opera. Its material is derived from $\mathrm{Gu}$ Cheng and Lei Mi's novel Ying'er. Part Three is the Epilogue, and is based on other writings of Gu Cheng.

\section{Part One of Fatal Desire: The Poet and His Poems}

The Prelude includes a short biography of Gu Cheng, spoken by a character named The Elder (a Western scholar). The interview section of the Prelude is an edited version from The Aimless I - An Interview with Gu Cheng, by Suizi Zhang-Kubin. ${ }^{402}$ For the opera production the voice of the interviewer is conceived as having been pre-recorded, with the character Cheng A responding on stage. The poetry readings are made by both "aspects" of the poet, Cheng A \& Cheng B.

\section{Part Two of Fatal Desire: The Poet and His Kingdom}

\section{Scene of the Novel}

“Fragment” Duànzhāng (断章)

“After the Letter is Sent” Fāxìn Yǐhòu (发信以后)

“Letters from the Island” Dăoshàng Láixìn (岛上来信)

“The Wound” Shāngkǒu (伤口)

“The Reef” Jiāo Shř (礁石)

\footnotetext{
${ }^{402}$ Suizi Zhang-Kubin, "The Aimless I-An Interview with Gu Cheng”, in Essays, Interviews, Recollections and Unpublished Material of Gu Cheng, 20th Century Chinese Poet: The Poetics of Death, pp. 335-340
} 
As in the novel, the scene begins with the words: "You are both my wives; I have loved you both and I still do" ${ }^{\prime 403}$. This scene focuses on the events surrounding the writing of a novel by the two characters, Cheng and his wife Lei Mi. "Cheng was mad with grief. He began to write to Ying'er as an outlet for his pain with Lei.",404

\section{Scene of Two Wives (in a xìqü comedy style)}

“Go Home and Ask Your Husband” Huíqù Wènwen Nìde Zhàngfu (回去问问你的丈夫)

“Miaow" Mī (咪)

“Princess Ye"gōngzhu (叶公主)

The scene represents Cheng's fantasy life ("the Kingdom of Girls"405) as enjoying a harmonious relationship with two wives. It is a collection of episodes presented in both xijù comedy style, and shuōshū style.

\section{Scene of the First Night ${ }^{406}$}

“Missing You from Not So Far Away”Bìngbù Yáoyuănde Sìniàn (并不遥远的思念)

“The First Month” Dìȳge Yuè (第一个月)

“The First Night” Chū Yè (初夜)

This scene is a "parallel drama", in which the three characters express themselves simultaneously, but without interaction, in separate theatrical spaces: in one room Lei Mi is longing for her absent son, while in another Cheng expresses his desire for Ying'er, who, upon waking next morning, reveals her feelings for Cheng. ${ }^{407}$

\footnotetext{
${ }^{403} \mathrm{Gu}$ Cheng and Lei Mi, Ying'er, The Kingdom of Daughters, inside of cover page.

404 Anne-Marie Brady, "Dead in Exile: The life and Death of Gu Cheng and Xie Ye", China Information, 11, no. 4, 1997, p.131.

${ }^{405}$ It would be more accurate to translate it as "Kingdom of Girls". Cf. Anne-Marie Brady, an excerpt from "Dead in Exile: The life and Death of Gu Cheng and Xie Ye", China Information, 11, no. 4, 1997, p. 137.

${ }^{406}$ Scene of the First Night for a production of the $26^{\text {th }}$ Asia Pacific festival 2007, in Wellington. For more information cf. chapter: 5.5 below, on the stage production.

407 The libretto of the Scene of the First Night, with an English translation kindly provided by Duncan Campbell, is given in Appendix 8.1 \& 8.2 below.
} 


\section{Scene of A Dream of Red Mansions (in yuèjù̀ style)}

“The Nature of Maidenhood” Nü”erXing (女儿性)

“Epilogue”Huíjiā (回 家)

Cheng's "heavenly kingdom" is a world where women are adored, but who remain pure and remote. He fantasizes women sleeping together, making love. He imagines himself within Cao Xueqin's Honglou Meng (A Dream of Red Mansions) and this becomes an important key to the personal myths of all three characters in drama with Cheng thinks of himself as a modern Jia Baoyu, with Lei Mi (his wife) as Xue Baochai, and Ying'er (his lover) as the Lin Daiyu. In my opera Lei Mi, Ying'er, and Cheng B take on the roles of Xue Baochai, Lin Daiyu and Jia Baoyu, performing in yuèjù̀ style.

\section{Scene of Love-making}

“In the Bush” Zài Guànmù Cóng (在灌木丛)

This scene takes place on the bushy mountainside, and mixes singing, dancing and declamation. The text contains many erotic details of Cheng's love-making, expressed in singing and recitation by Cheng A, overlapping descriptions by Cheng (B) and Ying'er of their first meeting.

\section{Interlude (in a xìqü comedy style)}

“Deranged” Cuòluàn (错乱)

“Disappearance” Shīzōng (失踪)

Cheng discovers evidence of his wife's infidelity, that she had fallen in love with a man named Dayü, whom she had met in Germany. Cheng also finds that his lover, Ying'er, has eloped from the island with a man "whom she and Cheng had always referred to derisively as lăo tǒuzi (the old man), a martial arts instructor". 408

\footnotetext{
${ }^{408}$ Anne-Marie Brady, an excerpt from "Dead in Exile: The life and Death of Gu Cheng and Xie Ye", pp. $135-36$.
} 
Scene of the Poet's Declaration of Love, and Death

"July" Qīyuè (七月)

“Snow Mountain” Xuéshān (雪山)

“The Farm” Mùchăng (牧场)

Cheng, still in love with both Lei Mi \& Ying'er, begins to believe both women are waiting for him to die. Cheng, distraught over his loss of Ying'er and also driven wild by Lei Mi's affair and the imminent arrival of her lover, violently assaults her. At the end of this scene a radio report is heard and images from newspapers tell of the tragic death of Lei Mi and of Cheng's suicide by hanging.

\section{Part Three}

\section{Epilogue. The Poet as Genius}

“The Return Home” Huijiā (回 家)

In Lie Mi"s eyes Cheng was a genius, not only for his poetry, but for his many other talents, such as calligraphy, drawing, and piano improvisation. Before the final curtain Cheng's final poem, Huijiā (回 家) “Return Home” is recited. Although written for his son, it has special poignancy as the poet's swan song at the end of his short and tragic life.

\subsubsection{Appendix}

\subsubsection{The Story of the Novel Ying'er ${ }^{409}$}

Ying'er is a convoluted mix of Gu Cheng's philosophical fantasies plus the facts and the attack on the character of Li Ying, the woman he once loved. In Gu Cheng's fantasy world he lives in a "heavenly kingdom", a world of adoration of women who "must not love a man". He fantasizes his women sleeping together, making love, whom he matches with Cao Xueqin's Honglou Meng, is an important key to the personal myths of all three characters in drama: $\mathrm{Gu}$ Cheng had long fantasized himself as a modern Jia Baoyu; Xie Ye or Lei (his wife) is his Xue Baochai, beautiful, talented but somehow unable to complete-

${ }^{409}$ Ibid. 
ly satisfy his spiritual needs; Ying'er (his mistress) is the Lin Daiyu he desires but is unable ultimately to obtain.

Ying'er's real name is Li Ying, but in discussing Gu Cheng's writings on her, we should distinguish the real person from the fictional character $\mathrm{Gu}$ Cheng created. Li Ying and Gu Cheng met in Beijing, she was a young university student of Chinese language and literature. They only met a few times, but each meeting made a profound impression on the other. Gu Cheng believed that in Li Ying he had discovered a woman who shared his deepest fantasies, who would help him create a "kingdom of girls". After Gu Cheng and Xie Ye left China in 1987, Li Ying and Gu Cheng kept contact with each other through correspondence. Soon after Gu Cheng and Xie Ye arrived in New Zealand did they decide to invite Li Ying to come and live with them. When Li Ying finally arrived in New Zealand in 1990 after three years of correspondence with Gu Cheng. He found her different from what he had imagined. Gone was the sky. In Gu Cheng's eyes Li Ying had become materialistic; she "wanted to lead a normal life ... and liked to sit in a coffee shop like others". After a few days together on Waiheke Island, Gu Cheng found that their "mutual disappointment" was obvious. Neither of them had imagined that things would turn out like that. The couple"s life in an old house in the bush of Waiheke did not appeal to Li Ying at all. She was long accustomed to the cosmopolitan life of Beijing. This was not the extravagant West she had fantasized.

Nevertheless, in Gu Cheng's prose, Ying'er despite her materialism desired him and his body. The text is dominated by detailed erotic descriptions of $\mathrm{Gu}$ Cheng's love-making with her. Later, they were in love with each other.

In $1992 \mathrm{Gu}$ Cheng and Lei Mi went to Berlin on a DAAD cultural exchange. Gu Cheng only agreed to go to Berlin after Ying'er persuaded him, to earn the money to repair the house on Waiheke Island.

While Gu Cheng and Lei were in Berlin, Ying'er eloped from the Island with a man whom she and Gu Cheng had always referred to derisively as "the old man" (lăo tǒuzi), a martial arts instructor. Gu Cheng was mad with grief. At the suggestion of a friend in Germany, he began to write Ying'er as an outlet for his pain. Not long after beginning the book he realised that Lei, his wife, was having an affair with a friend of his in Berlin, and was thinking of leaving him. This sent him into further depths of despair and loss. He began to believe that Lei and her lover, as well as Ying'er, were "waiting for him to die".

\subsubsection{Fatal Desire (Synopsis) ${ }^{410}$}

In exile upon a small island and in search of his idyll, a Chinese poet lives with his wife (Lei Mi) and his lover (Ying'er); the couple's infant son stays nearby with a neighbour. Returning from a trip overseas, the poet discovers that Ying'er has fled the ramshackle seaside bach the three of them share, apparently with another man. The poet immediately sits down to write a

\footnotetext{
${ }^{410}$ Duncan Campbell, "Synopsis of Fatal Desire" was written for the production of The Asia Pacific Festival, 2007.
} 
novel narrating the story of their love - a novel, in the poet's mind, both for and by her. As has been the case in the past with his poetry, his novel is transcribed for him, word by word, by Lei Mi. (Scene of the First Night), performed tonight, presents the poet's account of his first sexual encounter with his lover, juxtaposed with Xiang Yu's longing for her absent son. The opera ends with reports of the tragic outcome of the imminent departure of Xiang $\mathrm{Yu}$ also from their home - her murder at the hands of her husband and his suicide. ${ }^{411}$

${ }^{411}$ Duncan Campbell, "Synopsis of Fatal Desire", Program of Asia-Pacific Music-Theatre, Wellington: The Asia Pacific Festival, 2007. (This production had an agreement with Gu Xiang that all characters names would be changed for the performance to avoid any media attention). 


\subsection{The Musical Concept}

\subsubsection{The Musical Inspiration for the Opera}

In China there has always been lively discussion about the best direction for the development of a Chinese style of modern opera, what elements it should take from traditional Chinese opera styles, and what it should borrow from Western operatic models. ${ }^{412}$

My experience in the performance of chuānjǜ and also jīngjì̀ gave me an understanding and appreciation of traditional Chinese music-theatre, but as a contemporary composer I also became interested in new operatic compositions by such composers Tan Dun, Qu Xiaosong and Guo Wenjing all of whom are highly skilled in using Western compositional techniques, but share a similar background as myself of having performed in Song and Dance Troupes during the 1970s. As with these composers my opera Fatal Desire used elements from Chinese tradition but within the context of a contemporary musical style. The "flavour" of my work is different from the operas of other Chinese composers, but I believe we are part of a movement to develop a new style of contemporary Chinese opera.

In my opera I decided to use elements of chuānjǜ gāoqiāng music, particularly its syntax of phrases, and the chuānjü, jīngjùi and yüèjù̀ styles of percussion and recitation, the lastnamed becoming the model for all aspects of the Scene of A Dream of Red Mansions. As well, I drew upon the rhythmic styles of kuàibănshū and shuōshū of qǘyì in both the sung and spoken settings of my opera. In addition, I began to consider its relationship with techniques such as niànbái (念 白) and the dàobái (道 白) in Chinese xìqù̆. In my opera, I follow both Western and Chinese music-theatre traditions, incorporating elements of singing (chàng), recitation (dàobái), and sprechstimme (niànbái) into my musical language.

\footnotetext{
${ }^{412}$ Man Xinying 满新颖, Èr shí shìjì shàng bàn yè zhōngguó gējù yícún de lìshì wèntí (二十世纪上半叶中国歌剧 遗存的历史问题) (Historical Problems of Opera in the First Half of 20th Century in China). Shanghai: Theatre Arts. Vol. 4, 2009. pp. 94-103.
} 
In my work I borrowed from the unique style of Chinese xiqqü and the folk elements of q $\ddot{u} y \dot{i}$, to create an integration of Western and traditional Chinese theatrical musical styles. It follows the principle established by Zi Xia (子夏 507 - 420BC): “when spoken, it is poetry; feelings stir in the heart, so they have to be expressed in words; where words are insufficient, sighs are heard; when sighs are not sufficient to express them, songs are sung." With this in mind, I recognized the early $20^{\text {th }}$-century the technique of sprechgesang, ${ }^{413}$ as a valuable technique in music-theatre. Its primary exponent was Arnold Schoenberg, who, in his description of hwo he intended the voice part should be performed in his Pierrot Lunaire, states that the singer "should give the (the pitch) exactly, but then immediately leave it in a fall or rise". 414 The quality of sprechgesang as a form of "vocal enunciation intermediate between speech and song" 415 is particularly applicable to Chinese (Han) language, which is tonal (cf. Appendix 8.4) meaning that the pitch level and direction of all syllables (written as single characters) are precisely prescribed. This has led to the common perception among Westerners of spoken Chinese as having a "sing-song" character.

While working on the draft libretto of the projected opera Fatal Desire, I studied Alban Berg's opera Wozzeck with my co-supervisor Ross Harris. We analysed its structure and the way the composer used various musical forms. I was impressed by the sense of continuity of Berg's musical language which served so effectively the drama of the play. As Peter Gutman notes, Berg's language is expressionist and mostly atonal, "without the burdens of melodic development and harmonic progression, or the disruption of pausing for arias, ensembles and other typical means of displaying performers and gratifying audiences, the music is free to track the exact demands of the drama and enrich the text more subtly." ${ }^{416}$ I came to admire the composer's sense of theatricality in his music. I was inspired by the composer's "A word about Wozzeck", written ten years after the completion of the opera,

\footnotetext{
413 "Sprechgesang (Sprechstimme) (Ger. "speech-song” ("speech-voice”)). Cf. Paul Griffiths, Sprechgesang, The New Grove Dictionary of Music and Musicians, London: Macamillan Publishers Limited 1980, Vol. 18, p.27.

414 Ibid.

415 Ibid.

${ }^{416}$ Peter Gutmann, Alban Berg's Wozzeck (copyright 2003), available from http://www.classicalnotes.net/classics/wozzeck.html; accessed Wednesday, 18 August 2010. On Berg's style cf. Douglas Jarman, Alban Berg: Wozzeck, Cambridge: Cambridge University Press, 1989.
} 
in which he states: "I simply wanted to compose good music to develop musically the content of Georg Büchner's immortal drama; to translate his poetical language into music.

Other than that, when I decided to write an opera, my only intention, as related to the technique of composition, was to give the theatre what belong to the theatre". 417

Taking a cue from Berg's Wozzeck, ${ }^{418}$ (who of course inherited Wagner's legacy), I decided to adopt the principle of leitmotifs in order to obtain a unity of material for each character in the opera, a potent musical-dramatic technique. I developed the principle in both in the vocal and instrumental parts. As John Warrack observed in relation to Wagner "the function of the motif is dramatic as well as structural". ${ }^{419}$

Alban Berg's Wozzeck is a good example of the usefulness of sprechgesang, as Peter Gutdmann says: "Nearly all the text is presented in sprechstimme (sprechgesang). This bizarre technique, introduced by Berg's mentor Arnold Schoenberg in his 1912 Pierrot Lunaire, inhabits a world between talk and song, with more emphatic cadence and pitch than speech but without the stylized tonal precision and metric regularity of singing. As a result, it reflects the realism of the story and characters, but with an overlay of fantasy and just enough stylization to raise the narrative from the commonplace into the realm of art". ${ }^{420}$ And also, Berg use sprechgesang in another opera his well known opera Lulu. In both operas Berg "introduced a new shade, "half sung”, between sprechgesang and song". 421

\footnotetext{
${ }^{417}$ Alban Berg, "A word about Wozzeck", Modern Music (November- December 1927), Cita in Douglas Jarman, Alban Berg Wozzeck, p.152.

418 "Most of the leitmotives in Wozzeck are themes that have a clear melodic and rhythmic shape and that are immediately recognizable when they recur. On occasion, however, some of these are transformed in such a way that their clear melodic and rhythmic identities are destroyed. In such cases the link between the different versions of a leitmotiv is their common relative pitch content - that is to say that the different versions define the same harmonic unit." Cf. Douglas Jarman, Alban Berg: Wozzeck, 1989, p. 46.

${ }^{419}$ John Warrack, "Leitmotif", The New Grove Dictionary of Music and Musicians, (Vol. 10), London: Macamillan Publishers Limited 1980, p. 645.

${ }^{420}$ Peter Gutmann, Alban Berg's Wozzeck. http://www.classicalnotes.net/classics/wozzeck.html; accessed 18 August 2010.

${ }^{421}$ Paul Griffiths, "Sprechgesang”.
} 
Sprechgesang may be considered as having an affinity with the new theatrical style invented in the early opera Florentine Camerata at the end of the $16^{\text {th }}$ century: both are forms of "heightened speech", where natural speech rhythms and intonations are enhanced and dramatized with the addition of accompaniment. Jacopo Peri, writing in his preface to Dafne, claimed the invention of recitar cantando:

I knew also that in our speech we intone certain syllables in such a way that harmony can be built upon them, and in the course of speaking we pass through many that are not so intoned until we reach another that permits a movement to a new consonance. Keeping in mind those manners and accents that serve us in our grief and joy, and similar states, I made the bass move in time with these, faster or slower according to the affections. I held it fixed through both dissonance and consonance, until the voice of the speaker, having run through various notes, arrived at a syllable that, being intoned in ordinary speech, opened the way to a new harmony. ${ }^{422}$

"Monteverdi described two lettere amorose in his seventh book of madrigals (1619), which are in the simplest form of recitative, as being "in genere rappresentivo", ("the theatrical style"): "si canta senza battuta" ("to be sung without a beat")". 423

In 2002 I had a chance to attend a live performance ${ }^{424}$ of L'Orfeo by Claudio Monteverdi. ${ }^{425}$ I was very struck by the effectiveness of the "recitative" with orchestral accompaniment.

In my opera, I follow both Western and Chinese music-theatre traditions, incorporating elements of singing (chàng), recitation (dàobái), and sprechgesang (niànbái) into an integrated musical language. Each scene has a unique character within itself, but the scenes have connecting interrelationships which help create a sense of overall coherence.

\footnotetext{
${ }^{422}$ Cited in Claude Palisca, Baroque Music, $2^{\text {nd }}$ ed. Englewood Cliffs, N. J.: Practice-Hall, c1981, p. 32.

${ }^{423}$ Jack Westrup, "Recitative”, The New Grove Dictionary of Music and Musicians, $6^{\text {th }}$ ed. Vol. 15, p. 643.

${ }^{424}$ It was produced by the School of Music of Victoria of Wellington, under conductor Peter Walls, in the Adam Concert Room in 2003.

${ }^{425}$ L'Orfeo (Mantua, 1607), called by the composer, "Favola in Musica" (libretto by Alessandro Striggio, after Ovid's Metamorphoses). It was commissioned by the Academy of the Invaghiti, whose patron was Francesco, son of Duke Vincenzo Gonzaga.
} 


\subsubsection{The Musico-dramatic Structure of the Opera}

The music of the opera follows the structure of the libretto, which is open-form and nonsequential. This open structure offers different possibilities for sequencing the individual scenes or groups of scene within Part Two, concluding with Part, Three the "poet"s" diverse talents. The macro-structure of the work comprises two parts. Part One, "The Poet and his Poems", is a prelude of two sections, "introduction" and "interview". Part Two, "The Poet and his Kingdom", has eight scenes, and holds the main content of the opera.

Table 14: Musical structure of the opera Fatal Desire

\begin{tabular}{|c|c|c|c|}
\hline $\begin{array}{l}\text { Dramatis } \\
\text { Personae }\end{array}$ & Name of Scene & Form & Music \\
\hline \multicolumn{4}{|c|}{ Part One: The Poet and his Poems } \\
\hline $\begin{array}{l}\text { elder (bass) } \\
\text { soprano I } \\
\text { soprano II } \\
\text { mezzo-soprano } \\
\text { tenor II } \\
\text { voice of Huizi } \\
\text { Cheng A \& B }\end{array}$ & $\begin{array}{l}\text { (introduction) } \\
\text { (interview) }\end{array}$ & $\begin{array}{l}\text { Prelude } \\
\text { in two } \\
\text { sections } \\
\text { (ca. 40') }\end{array}$ & $\begin{array}{l}\text { choir } \\
\text { solo recitation } \\
\text { recorded poem } \\
\text { recorded voice of "Suizi" } \\
\text { recitation } \\
\text { kuàibănshū }\end{array}$ \\
\hline \multicolumn{4}{|c|}{ Part Two: The Poet and his Kingdom } \\
\hline $\begin{array}{l}\text { Cheng A } \\
\text { Lei Mi }\end{array}$ & Scene of the Novel & $\begin{array}{l}\text { A } \\
\text { Largo } \\
\text { (ca. 30') }\end{array}$ & $\begin{array}{l}\text { Sichuan opera style } \\
\text { arialduetlchoir }\end{array}$ \\
\hline $\begin{array}{l}\text { Cheng A } \\
\text { Lei Mi } \\
\text { Ying'er }\end{array}$ & Scene of Two Wives & $\begin{array}{l}\text { B } \\
\text { Allegro } \\
\text { (ca. 22') }\end{array}$ & $\begin{array}{l}\text { comedy style (Beijing opera) } \\
\text { arialduet lchoir } \\
\text { shuōsh } \bar{u}\end{array}$ \\
\hline $\begin{array}{l}\text { Cheng A } \\
\text { Lei Mi } \\
\text { Ying'er } \\
\text { Voice of the son }\end{array}$ & $\begin{array}{l}\text { Scene of the First } \\
\text { Night }\end{array}$ & $\begin{array}{l}\text { A } \\
\text { Largo } \\
\text { (ca. 43') }\end{array}$ & $\begin{array}{l}\text { Sichuan opera style } \\
\text { arialduet|choir } \\
\text { kuàibănshū } \\
\text { recorded voice of son }\end{array}$ \\
\hline $\begin{array}{l}\text { Cheng A \& B } \\
\text { Lei Mi } \\
\text { Ying'er }\end{array}$ & $\begin{array}{l}\text { Scene of A Dream of } \\
\text { Red Mansions }\end{array}$ & $\begin{array}{l}\text { B } \\
\text { Allegro } \\
\text { (ca. 20') }\end{array}$ & $\begin{array}{l}\text { performing, singing, reciting } \\
\text { and costume in yüè opera } \\
\text { style }\end{array}$ \\
\hline $\begin{array}{l}\text { Cheng A } \\
\text { Ying'er } \\
\text { two dancers } \\
\text { two recitsrs }\end{array}$ & Scene of Love-making & $\begin{array}{l}\text { C } \\
\text { Allegretto } \\
\text { (ca. 22') }\end{array}$ & $\begin{array}{l}\text { aria } \\
\text { choir } \\
\text { recitation } \\
\text { dance }\end{array}$ \\
\hline $\begin{array}{l}\text { Cheng A \& B } \\
\text { A woman poet } \\
\text { An editor } \\
\text { An elder }\end{array}$ & Interlude & $\begin{array}{l}\text { Interlude } \\
\text { Allegro } \\
\text { (ca. 16') }\end{array}$ & $\begin{array}{l}\text { comedy style } \\
\text { aria } \\
\text { choir } \\
\text { recitation }\end{array}$ \\
\hline
\end{tabular}




\begin{tabular}{|c|c|c|c|}
\hline $\begin{array}{l}\text { Cheng A } \\
\text { Lei Mi } \\
\text { Ying'er }\end{array}$ & $\begin{array}{l}\text { Scene of the Poet's } \\
\text { Decluration of Love } \\
\text { with Death }\end{array}$ & $\begin{array}{l}\text { A } \\
\text { Largo } \\
\text { (ca. 44') }\end{array}$ & $\begin{array}{l}\text { Sichuan opera style } \\
\text { arialduetchoir } \\
\text { recitation }\end{array}$ \\
\hline \multicolumn{4}{|l|}{ Part Three: Epilogue } \\
\hline $\begin{array}{l}\text { Cheng A \& B } \\
\text { Lei Mi / Ying'er } \\
\text { A woman poet } \\
\text { An editor / An elder }\end{array}$ & The Poet as Genius & $\begin{array}{l}\text { Epilogue } \\
\text { (ca.18') }\end{array}$ & $\begin{array}{l}\text { transcription of Cheng's pi- } \\
\text { ano improvisation } \\
\text { choir } \\
\text { recitation }\end{array}$ \\
\hline
\end{tabular}

\subsubsection{The Characters, Motives and Recitation Styles of the Opera}

I designed motives for the three main characters: Cheng (although Cheng A and Cheng B are two actors, dramatically this is one role), Lei Mi (Cheng's wife) and Ying'er (Cheng's lover). These motives identify musically the characters within the drama, their personalities and the contexts in which they operate. As mentioned above, the motives unify the musical material for each character in the opera. Non-sung recitation is a significant element in the opera, with each character having his/her unique style, relating to their personal background within the context of the novel.

\subsubsection{The Character, Motives and Recitation Style of Ying'er}

The music for Ying'er, a dramatic soprano, leans toward the Beijing opera style in her manner of singing and reciting. In the drama she is 26 years old, and the "ideal lover" in the mind of Gu Cheng. As a character she sows the seed of the tragedy, represented in the music by a descending minor second. She is pretty, clever, bright, intense, sexy and passionate, but, on the negative side, her personality has elements of discord and uncertainty. Her motives emphasize the intervals of minor second, minor third, perfect fifth, consistent with her character.

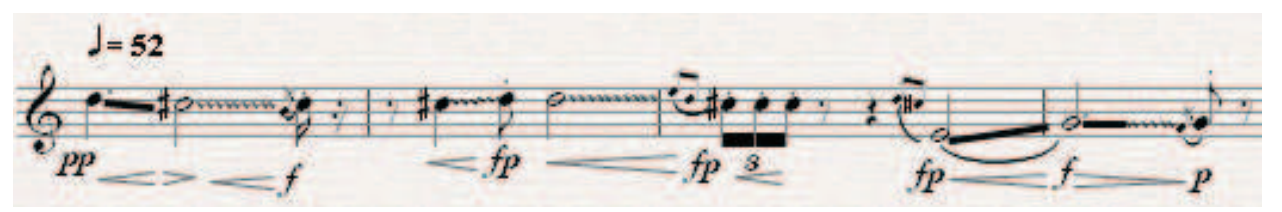

Example 56: Motive I of Ying'er 


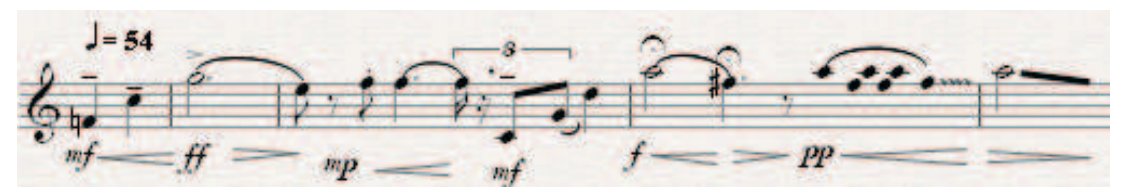

Example 57: Motive II (love) of Ying'er

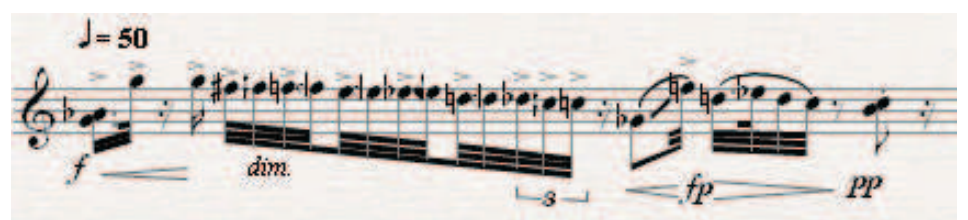

Example 58: Motive III of Ying'er

\subsubsection{The Character, Motives and Recitation Style of Lei Mi}

Lei Mi is a mezzo soprano. In his novel Ying'er: The Kingdom of Daughters, Cheng wrote of Lei Mi "You are my Empress, I want to be governed by you" ${ }^{426}$. In their time together, she looks after Cheng like a mother. She has a rather docile personality. She is beautiful, intelligent, virtuous, peace-loving, relaxed, feminine and respectful, but perhaps conceals beneath her exterior secret motivations. She is characterised by the interval of a major second, which, if repeated as a sequence of three whole-tones, creates a tritone, suggesting impending tragedy (motive I):

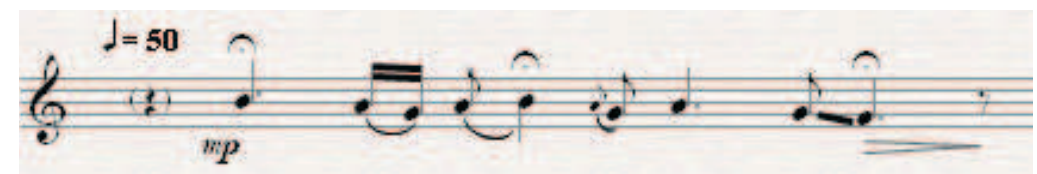

Example 59: Motive I of Lei Mi

The motive associated with Lei Mi's character includes a major second, minor seventh and perfect fourth.

\footnotetext{
${ }^{426}$ Gu Cheng 顾城 \& Lei Mi 雷米, Ying'er 英儿, Beijing: Hauyi chubanshe (Beijing Huayi Press), 1992, p. 20. My translation.
} 
Lei Mi's motive II is the "love motive", which is related to, or derives from Cheng's motive; the first short phrase is from Cheng's motive I (see Example 9), but with two notes (G $\&$ F) omitted. The second short phrase emphasizes leaping perfect fourth intervals:

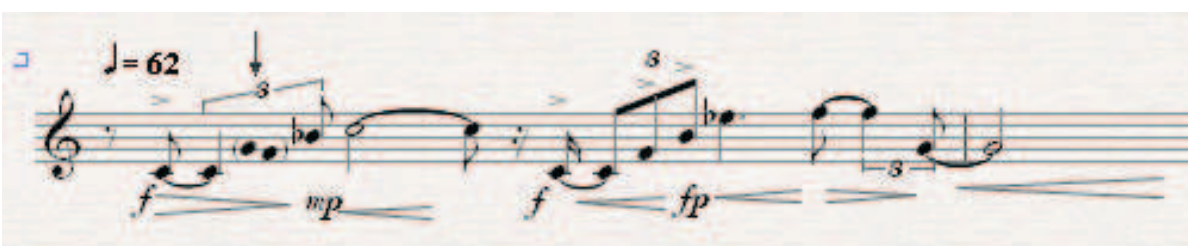

Example 60: Motive II (love) of Lei Mi

As mentioned above (see Chapter 5.3.1) I used the style of yüè opera as a model for the scene of A Dream of Red Mansions. In addition, because Lei Mi originally came from Shanghai, I decided that her role should use the yüè opera style, both in her style of singing and recitation, and also in her pronunciation, a dialect different from standard Mandarin (yǔtōnghuà).

\subsubsection{The Motives and Recitation Style of Cheng}

As can be seen from the libretto (see Chapter 5.2.4 above), in my opera the poet Cheng has two dramatic characters, A and B. The A character is a tenor, and the B character a baritone. In the drama Cheng is 33 years old. He is talented, idiosyncratic, nature-loving, with a personality that is by turns childish, fantastic, dreamy, courageous and passionate, but also cruel, self-obsessed, and tragic. The motive of Cheng A uses the intervals of a perfect fourth \& fifth, major and minor second, minor third (major six) and minor seventh.

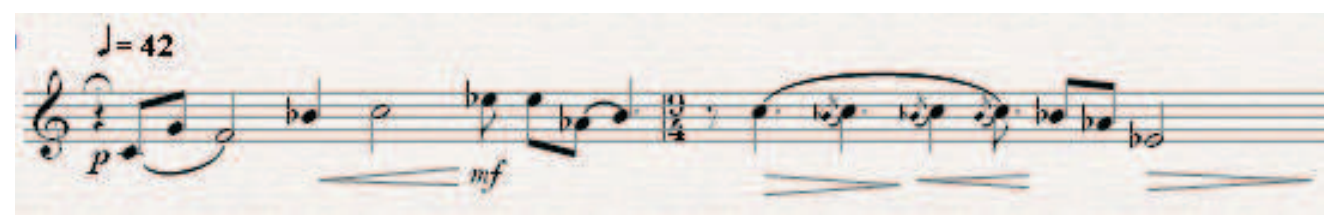

Example 61: Motive I of Cheng 
Cheng's motive II is a "love motive". Its first perfect fifth (a) is from the "love motive" of Ying'er, the second ascending interval (b), a perfect fourth, is from the "love motive" of Lei Mi:

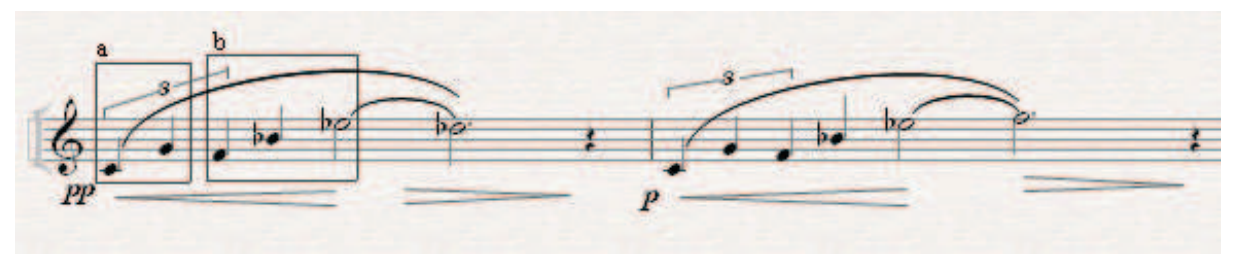

Example 62: Motive II (Love) of Cheng

Dramatically, intervals of a second relate to Cheng's "wives" "427. For example, the descending major (a) and minor (b) second in the "tragic motive" relate to his wife Lei Mi, and his lover Ying'er, representing the "seed" of the tragedy. Here it is integrated with a characteristic gúnchuí rhythm from the Chinese xìqù (see Chapter 5.4.1.1.2):

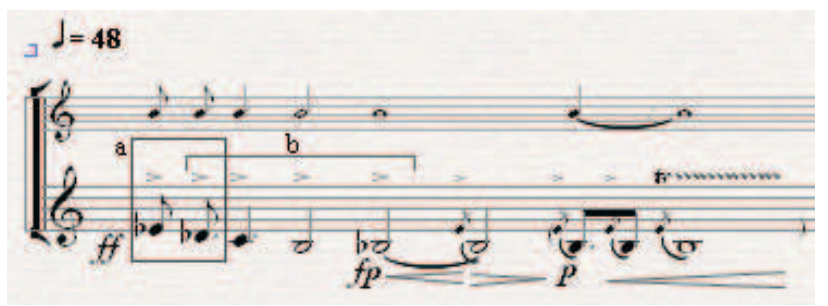

Example 63: Motive III (Tragic) of Cheng

Cheng B's role is not included in the novel. It represents him as a dramatic figure, an incarnation of Cheng's soul or inner consciousness. In the drama this B character presents Cheng's humanity and his desire; it reflects the story's darkness. Cheng B's motive uses intervals of an augmented fourth in addition to the intervals of the two motives of Cheng A:

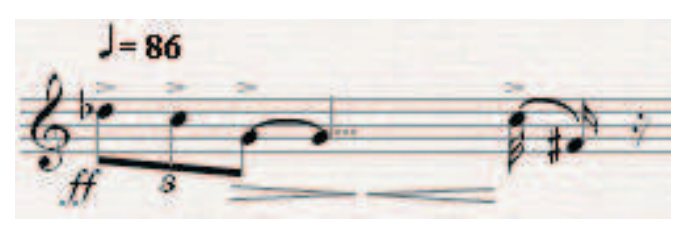

Example 64: Motive of Cheng B

427 "You are both my wives; I have loved you both and still do." Gu Cheng \& Lei Mi, Ying'er, The Kingdom of Daughters, title page. 
I have listened to Cheng's reading of his own poems many times. The sound of his voice has a special character that brings to mind some of the dialogues from his novel. He always used a poetical language, and his voice has a rare poetical quality. For this reason I prefer for this role - Cheng A - to be performed in a dialect, both in his singing and recitation, depending on the singer's background and fluency. However, when Cheng A and B perform are at the same time, as in reciting a poem, then, of necessity, they both use standard Mandarin (pǔtōnghuà).

\subsubsection{Instruments and Orchestration of the Opera}

The editorial allocation of the instruments for the live performance I witnessed of Monteverdi's L'Orfeo in 2003 impressed me. The full orchestra accompanied choral items and provided ritonelli (refrains) between vocal items, or between verses of the vocal items. Solos, duos, trios were accompanied by "a bass line", ${ }^{428}$ which required to be "realised". ${ }^{429}$ In the original score, Monteverdi did not always specify the instrumentation and never the orchestration, since "the intermedio tradition provides help: trombones, regal, bass viol represent Hell and magic; harp, lute and strings represent Heaven; wind instruments represent Pastoral scenes" ${ }^{430}$ Consequently the orchestration enhanced the drama by characterising the roles, and defining the dramatic situations.

Adapting Monteverdi's idea, I allocated instruments to specific characters of drama: the clarinet ( $\mathrm{Bb} \&$ bass) to Cheng $\mathrm{A} / \mathrm{B}$, cello to Lei Mi, and piri to Ying'er. Thus, "musical characterisation of the dramatic roles' became an orchestration principle for the work. The percussion ensemble of chuānjǜ (Sichuan opera) (see Chapter. 3.2.1) has a unique sonic character. I utilized many of these instruments in the opera ensemble, including: bangǔ (板 鼓), dàbó (大 钵) large chuānjù̀ cymbals and wooden clappers, xiăoluó (小 锣) small

\footnotetext{
${ }^{428}$ Concerning the instruments cf. Jane Glover, "Recreating Orfeo for the modern stage: solving the musical problems", in Claudio Monteverdi, Orfeo, ed. John Whenham, Cambridge: Cambridge University Press, 1986 (Cambridge Opera Handbooks), pp. 141-146.

${ }^{429}$ Ibid.

${ }^{430}$ Ibid.
} 
chuānjù̀ gong, xiǎobó (小 钹) small chuānjǜ cymbals, and măluó (马 锣) small hand-held chuānjù̀ gong.

Scene of the First Night was produced at the Asia Pacific Festival in Wellington in February 2007. As the accompanying ensemble for this occasion I had been offered the services of the Contemporary Music Ensemble of Korea (CMEK), since it was the featured ensemble of the festival. A mixed Korean and Western ensemble, it comprised five members playing traditional Korean instruments, ands four playing Western instruments.

\section{Contemporary Music Ensemble Korea}

1 Gayageum (25 string)

1 Daegeum (flute)

1 Piri (double reeds wind)

1 Saenghwang (17 pipe mouthorgan)

Korean percussion

Western percussion

1 Guitar

1 Clarinet ( $\mathrm{Bb} \&$ bass)

1 Violoncello

I was excited to do this orchestration for the unusual ensemble, knowing that the Korean instruments bore an historical relationship with Chinese instruments that I was already familiar with, some of them originally having come from China to the Korea in the Goryeo dynasty (913-1392). In my mind, I matched up the Korean instruments with Chinese instruments: dízi (笛子) - daegeum (bamboo flute), guănzi (管 子) - piri (double reeds wind), shēng (笙) - saenghwang (bamboo mouth organ), and zhēng (筝) - gayageum (25 string zither). Although I had access to recordings of the sounds of the instruments while I worked on the score, the uniquely Korean character of the sounds was something that I confronted only in the first rehearsal. It was altogether a stimulating exercise in "cultural translation". 


\subsection{Musical Analysis of Chüyè (初 夜) Scene of the First Night}

The following analysis will focus on three aspects: 1) the composition practice of "integration", ${ }^{431}$ by which musical elements, materials, as well the performance style of traditional Chinese xìqü and qüỳ̀ are integrated into the work. 2) the leitmotivs used in the instrumental and vocal writing, and 3) the development of leitmotivs in the dramaturgical context.

\subsubsection{The Concept of Integration as Applied in Scene of the First Night}

In this scene, the concept of integration has been applied on several levels. I have already alluded to the work's orchestration, inspired by a production of Monteverdi's L'Orfeo which I saw in 2003. Two other dimensions of this scene had other origins. One of these dimensions concerns rhythmic techniques deriving mainly, though not exclusively, from Chinese opera, integrated into the work at different levels ranging from literal quotation to full absorption and consequent transformation in their new context. Western plainchant conditioned one episode. The other dimension concerns the characterisation of the protagonists and their interactions; this was achieved through the use of the Western operatic leitmotiv.

\subsubsection{Rhythmic Percussive Elements from Qǚyì and Xiquì}

An important dimension in which the integration of musical elements is applied and achieved in my opera concerns rhythms.

\footnotetext{
${ }^{431}$ This thesis uses the concept of "integration" as a method of musical composition of combining (musical) elements previously separated. The sociological paradigm of integration often deals with the integration of a minority culture within a majority culture. In this thesis, elements of Chinese traditional music are introduced and integrated into compositions based on Western musical compositional practice (for more information see Chapter 1.5).
} 


\subsection{Kuàibănshū in Scene of the First Night}

A specific rhythmic element I used was inspired by a poem of Gu Cheng, Sīxiāng Q Qü (思乡曲) ${ }^{432}$ (Homesick) from Drawings and Texts from Waiheke Island (Jīliú dăo huà huà běn 激流岛画话本). The style of the poem is in folk kuàibănshū (see Chapter 3.3.1), using the idiomatic language of a story-teller, a kind of poetic form Cheng fondly described at 1991 conference in London ${ }^{433}$. He stated, “shīde yüyán shì yīzhǒng zìrándeyüyán (诗的语言 是一种自然的语言) (the language of poem is a kind of natural language)." Kuàibănshū is popular in China, particular in Shandong province where Cheng spent a few of his childhood years. I adopted the musical element directly from Cheng's poem, kuàibănshū, thus becoming an important rhythmic element of the operatic scene, integrated with the music of Lei Mi, as well as the voice of the Son.

Musically, kuàibănshū is vocal chant with a percussion accompaniment playing a characteristic rhythm (see Chapter 3.3.1):

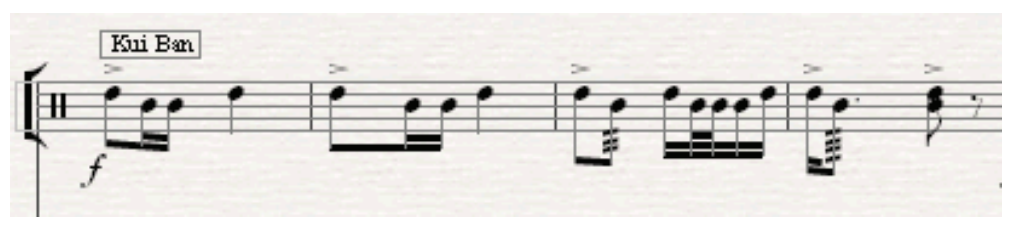

Example 65: A basic rhythm of Kuàibănshū from (bb.343-46) Scene of the First Night

In the Scene of the First Night, the text is derived from the novel Ying'er, whose concluding chapters were written by Lei Mi, addressed to her son, Samuel. "Missing you from not so far away":

\footnotetext{
${ }^{432}$ Gu Cheng, “Homesick” (Sīxiāngqŭ 思乡曲) - (Drawings and Texts from Waiheke island) (Jïliú Dăo Huà Huà Bèn 激流岛画话本), from 顾城诗全编 Gu Cheng Shì Qüánbiān (Complete poems of Gu Cheng), Shanghai: Shanghai sanlian shudian, 1996, P. 808.

${ }^{433}$ Gu Cheng, A speech title : 《我在等待死亡的声音》Wǒ Zài Děngdài Š̌wáng de Shēngyīn “I am waiting for the voice of death" (5/6/1991) Conference of Chinese Contemporary poetry in London 1991. For more information on this "Natural Philosophy" idea, cf. Gu Cheng, 《没有 目的 的 “我”》 Méiyǒu Mùdè de “Wó” (nonobjective of "Me"), available from http://www.gucheng.net/gc/gczp/gczx/200502/164.html; accessed $30 \mathrm{Au}$ gust 2010.
} 
You sing many songs, in the voice you have just learnt to manage. They are not songs taught by adults. They are not songs that you can hear elsewhere either. In the beginning, you sang: "One man good; one man not good. One two three men good; one two three men not good. You tended to lose track of the tune. People couldn"t help laughing and feeling heartfelt affection for you. Later you reached five: One two three four five men good; one two three four five men not good. You also like Mummy sing. ${ }^{434}$

In Scene of the First Night this "Children's Chant" is presented in Chinese with kuàibănshī style. To enhance the drama, the Son's voice is heard, responding to Lei Mi.

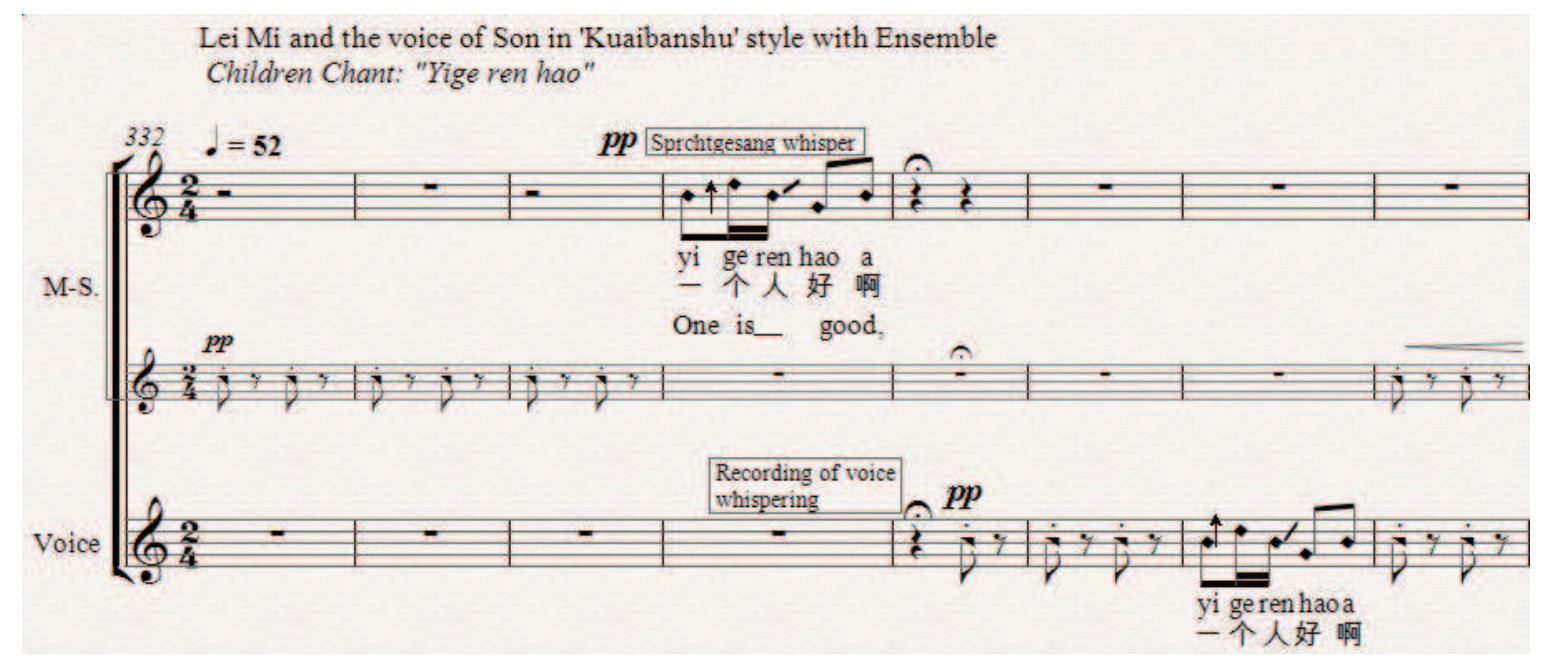

Example 66: Kuàibănshū: "Children's Chant" from Scene of the First Night (bb.332-39)

In developing the rhythmical element of this vocal chant, the ensemble musicians imitate each other, canonically, and increase the tempo by degrees: crotchet $=52,63,72,80,84$, $88,92,96$ and finally 100 . The strong rhythmic vocal chant with percussion as well as hand clapping creates a climax to the section.

${ }^{434}$ Li Xia 李 侠 (trans.), Gu Cheng \& Lei Mi, Ying'er, The Kingdom of Daughters, p. 238. 


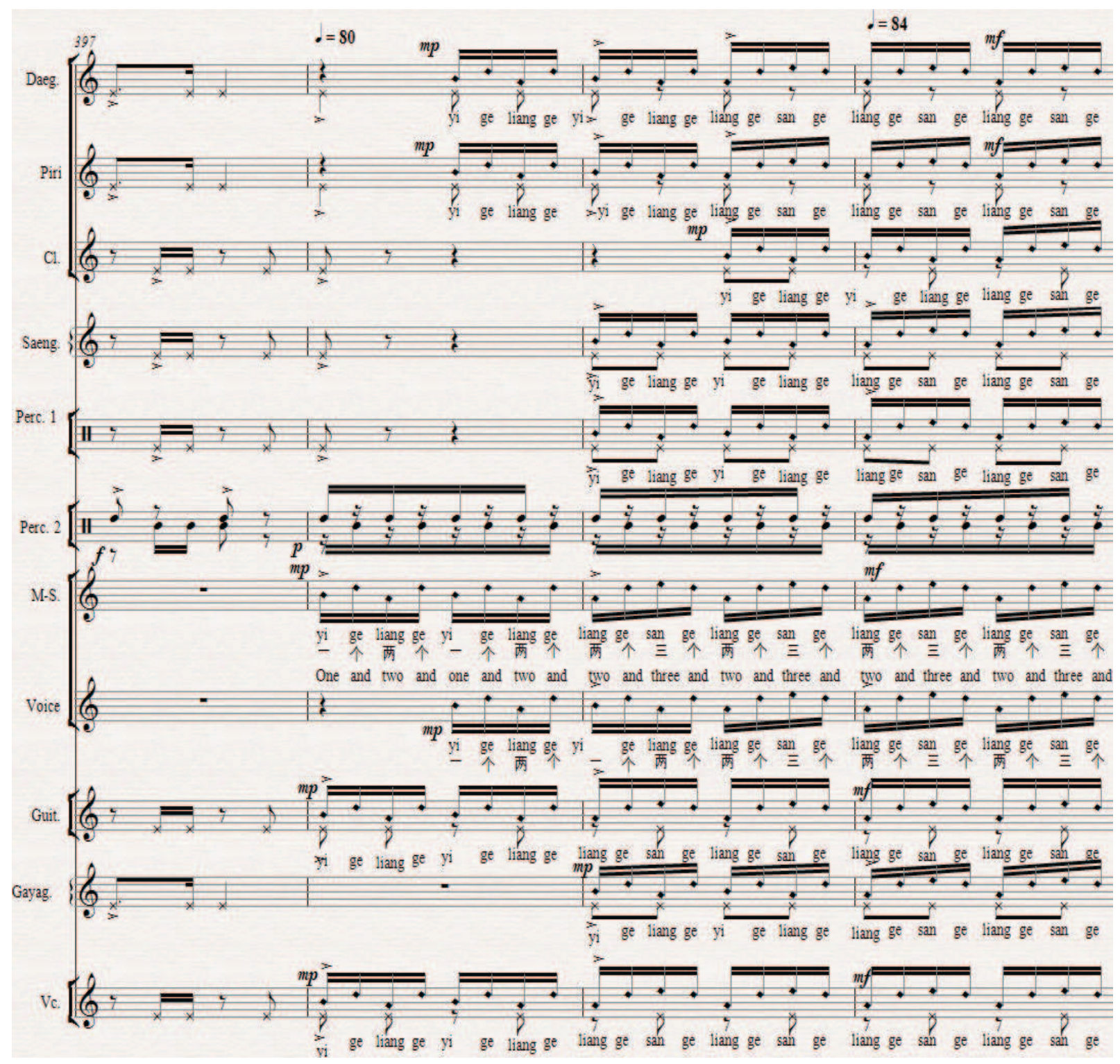

Example 67: Kuàibănshū: "Children Chant"

from Scene of the First Night (bb.397-100)

\subsection{Gúnchuí Rhythm in Scene of the First Night}

A particular rhythm commonly heard in Chinese xìqü is called gúnchui (滚 捶) (rolling of the drum) of the bángǔ. It comprises repeated beats gradually changing from slow to fast or in reverse, notated as: 


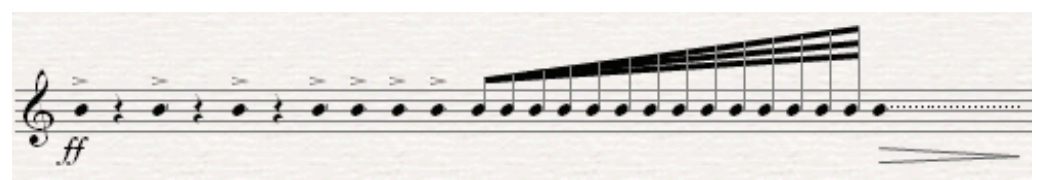

Example 68: The Gúnchuí rhythm

This rhythm is used in many places in the opera, including, in its reversed fast to slow version, in the "tragedy motive", mentioned above (see Example 63).

At a primary level of integration, the element or material retains its original form within the new context. An example is in the introduction section of Scene of the First Night, where the gúnchui rhythm is played on a Cook Island pate "slit drum"435 (b. 1), and then echoed on Korean yongge drum (b. 3). This effect is reminiscent of the sounds of a Chinese village at night, in the tradition of a watchman called dăjēng (打 更), who announces the time at various periods through the night. ${ }^{436}$ It is heard over a long pedal chord, suggestive of the sea, an image of a calm surface with turbulent currents beneath:

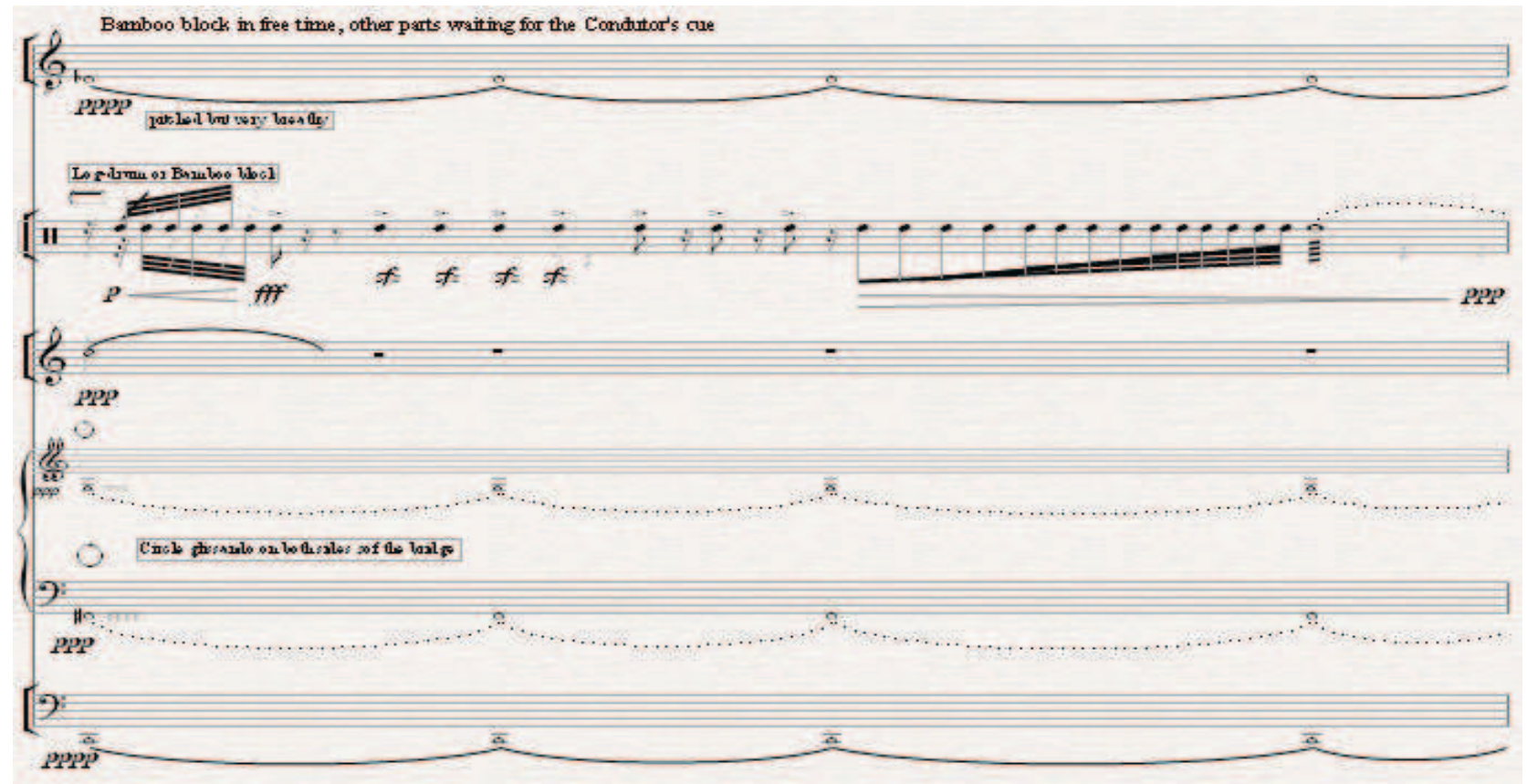

Example 69: Gúnchuí rhythm playing by Slit drum (b.1)

\footnotetext{
${ }^{435}$ Cook Islands wooden percussion instrument.

${ }^{436}$ Dăjēng (打 更) (time announcer on the streets at night) In ancient China, the town people were always told time by percussion (bangzi, gong and drums) instruments.
} 
This gúnchui rhythm appears later in the scene, combined with Ying'er's motive I played by piri. (bb. 17- 19) and the love motive of Cheng plays by the clarinet (bb. 20-24).
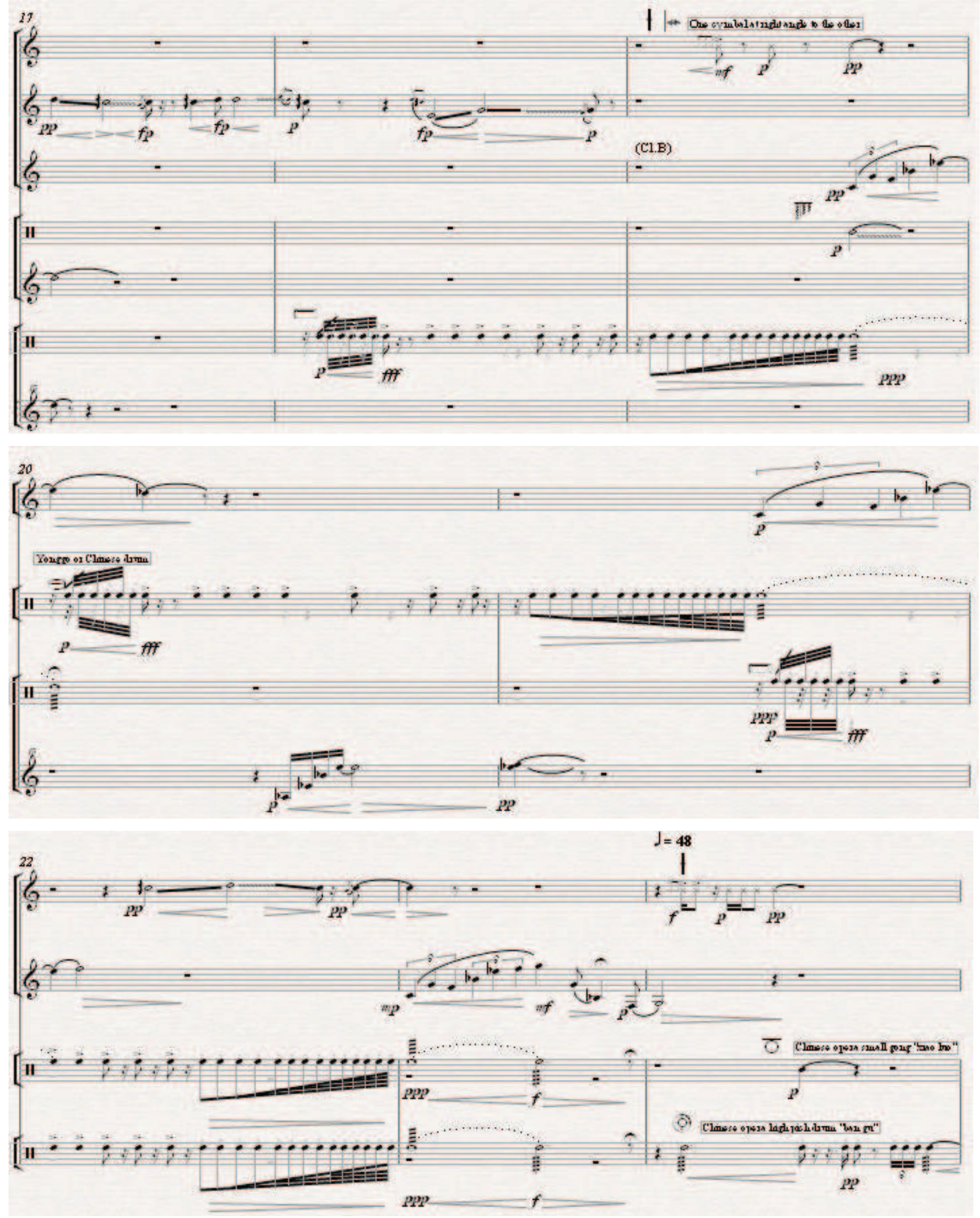

Example 70: Gúnchuí rhythm played by Yongge and Slit drum (bb. 17-24) 
At a higher level of integration the borrowed material is developed or transformed in the new composition. In the following examples the gúnchui rhythm is integrated into both Cheng and Lei Mi's arias.

This rhythm is found in the vocal part of Cheng's aria: "Such a dark night", in which is singing a free trill of two notes from slow to fast. It creates tension on the word "wǒ zhìdào (我知道) (I know)”.

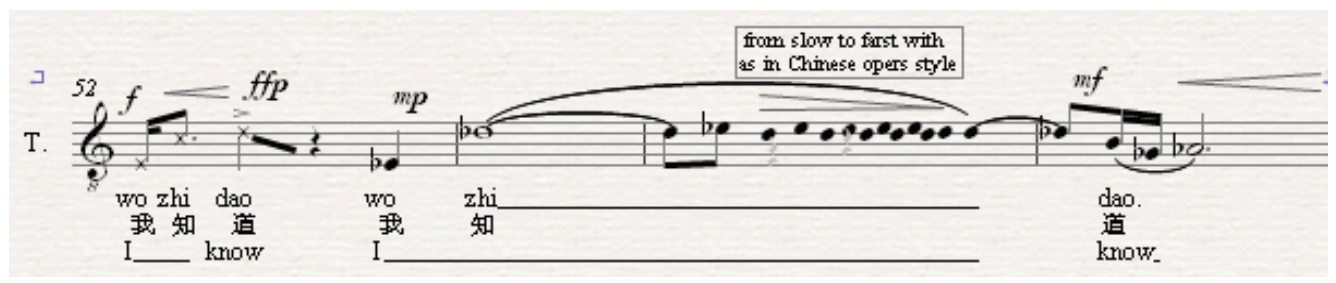

Example 71: Gúnchuí rhythm in Cheng's aria (bb. 52-54)

The same singing style for this rhythm is used, in the Duet: "My precious son, my sweetheart" where Lei Mi, and Cheng sing the rhythm simultaneously, but unsynchronised, as a free trill:

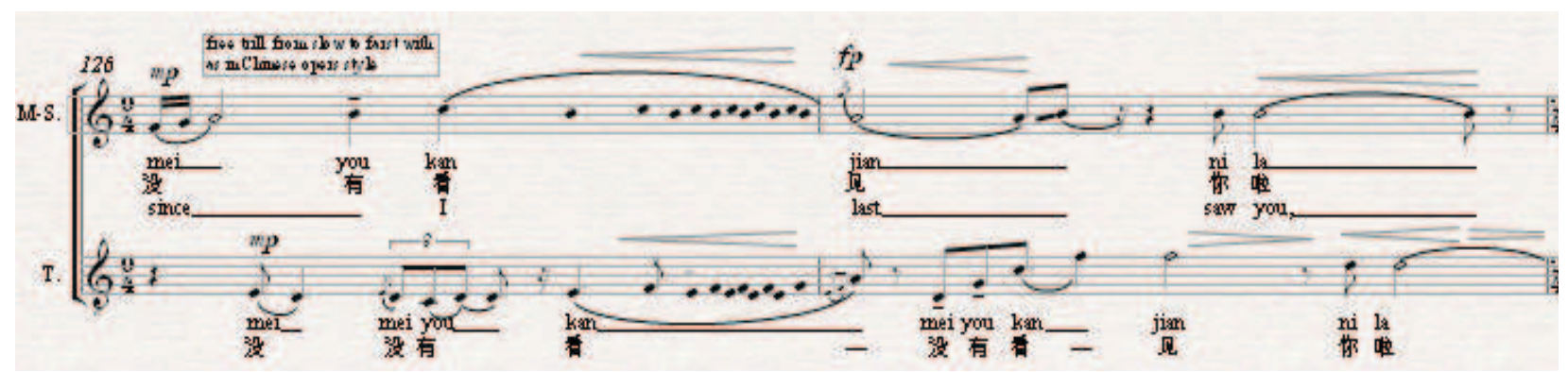

Example 72: Gúnchui rhythm in the duet of Lei Mi and Cheng's (b. 126-27)

This gúnchui rhythm is integrated into the instrumental part, in the introduction to the scene the clarinet plays from slow to fast, and then reversed.

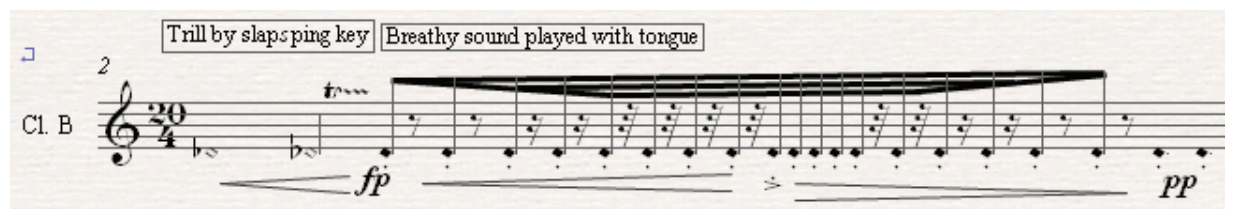

Example 73: Gúnchuí rhythm plays by clarinet (b. 2) 
In the climax section of the Duet, the gúnchuí rhythm on the bángǔ creates emotional tension in the accompaniment of Lei Mi's sprechgesang, much as Monteverdi intended with his tremolo on the strings in his stile concitato of his late works.

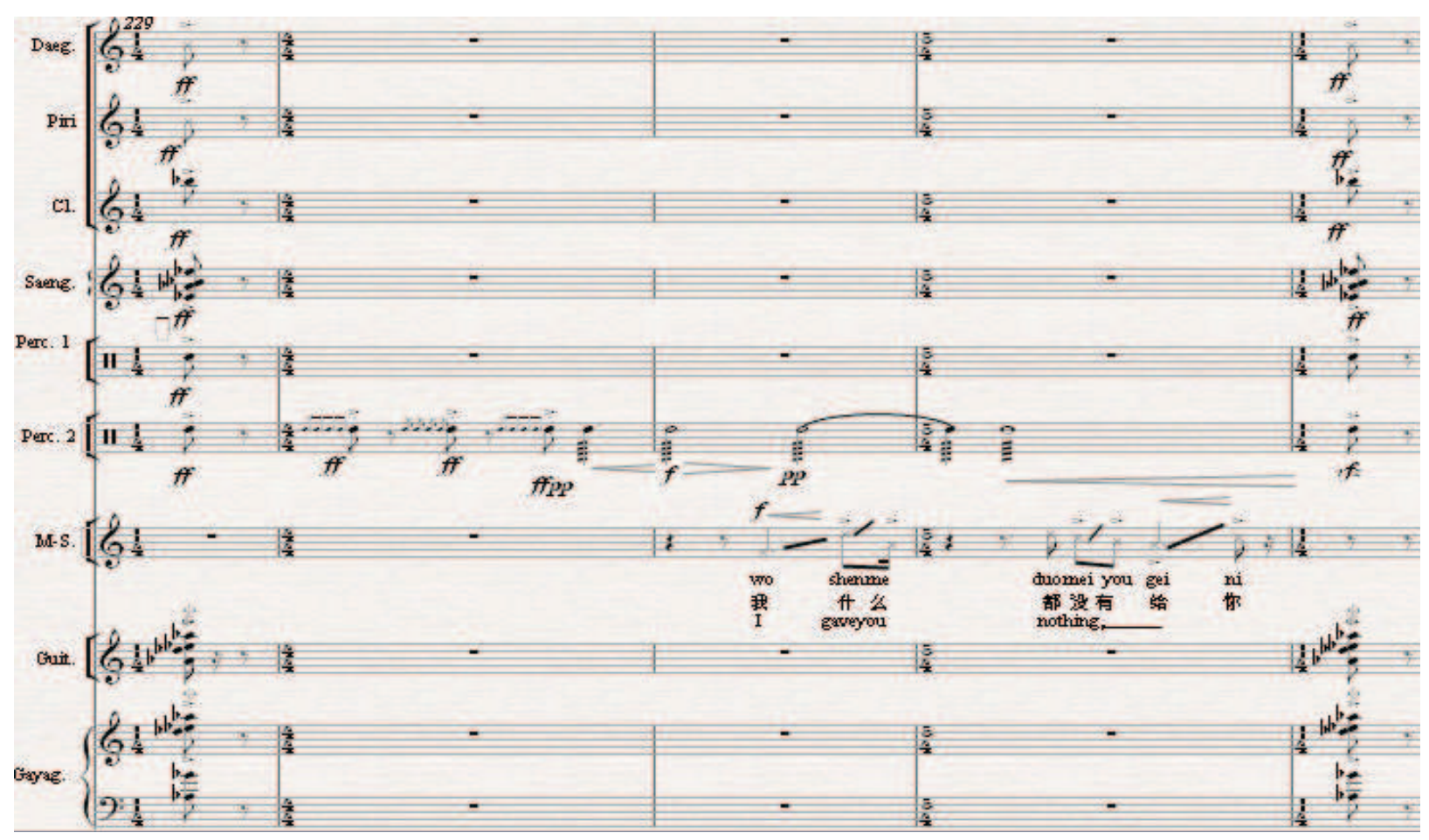

Example 74: Gúnchuí rhythm play by Bángǔ (bb. 229-33)

\subsection{Percussion in Scene of the First Night}

$D \check{a}($ 打) is the name of the percussion ensemble of chuānjì̈ gāoqiān, which accompanies singing and the stage action. It also plays music for the opening and closing of a scene and for the transitions between scenes or acts. This same function of the percussion is employed in the Scene of the First Night.

A wénchăng xiăodá luógǔ (文场小打锣鼓) (percussion ensemble), used for intimate wénxì style of chuānjǜ is integrated into the scene to accompany Lei Mi as she removes her son's toys from a box, and holds them to her that instead of instrument ensemble. 


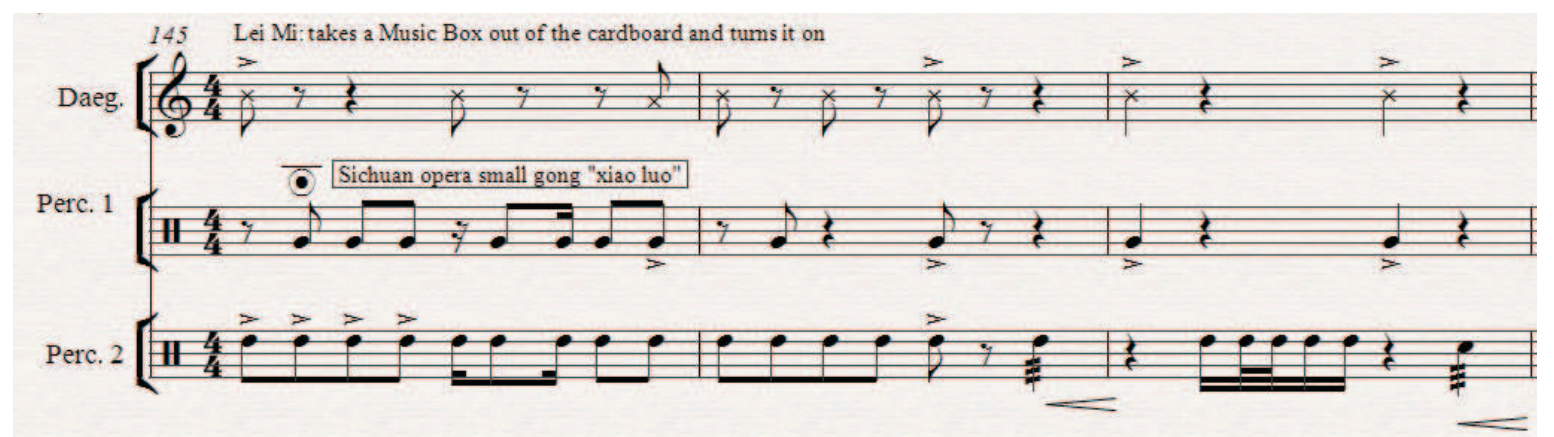

Example 75: Percussion rhythmic phrase from Wénxì of Chuānjǜ Scene of the First Night (bb. 145-47)

The following example of percussion accompanies the actions of Ying'er:

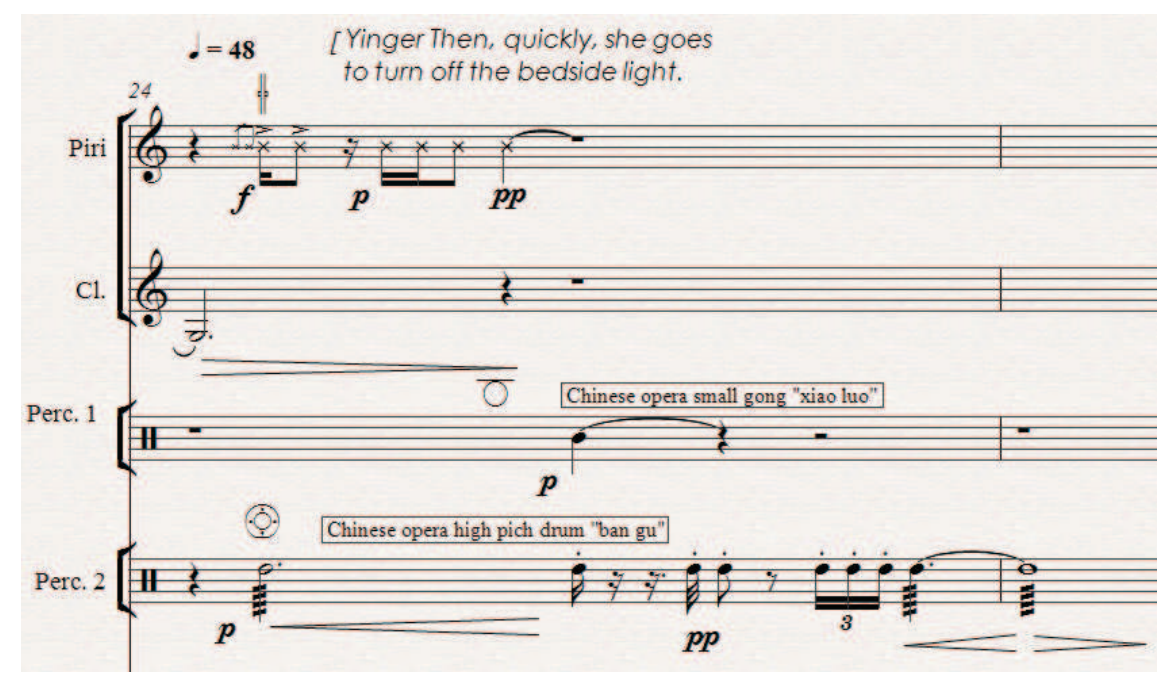

Example 76: Percussion rhythmic phrase from

Scene of the First Night (b. 24)

After Cheng’s recitation “Lěi Mĩ gēiwǒ zuò shǒushì (雷米给我做手势) (Lei Mi pointed in that direction gesture, Yinger's bedroom) he imitates Lei Mi's pointing gesture, with the percussion and piri accompaniment, the latter echoing Cheng's voice: 


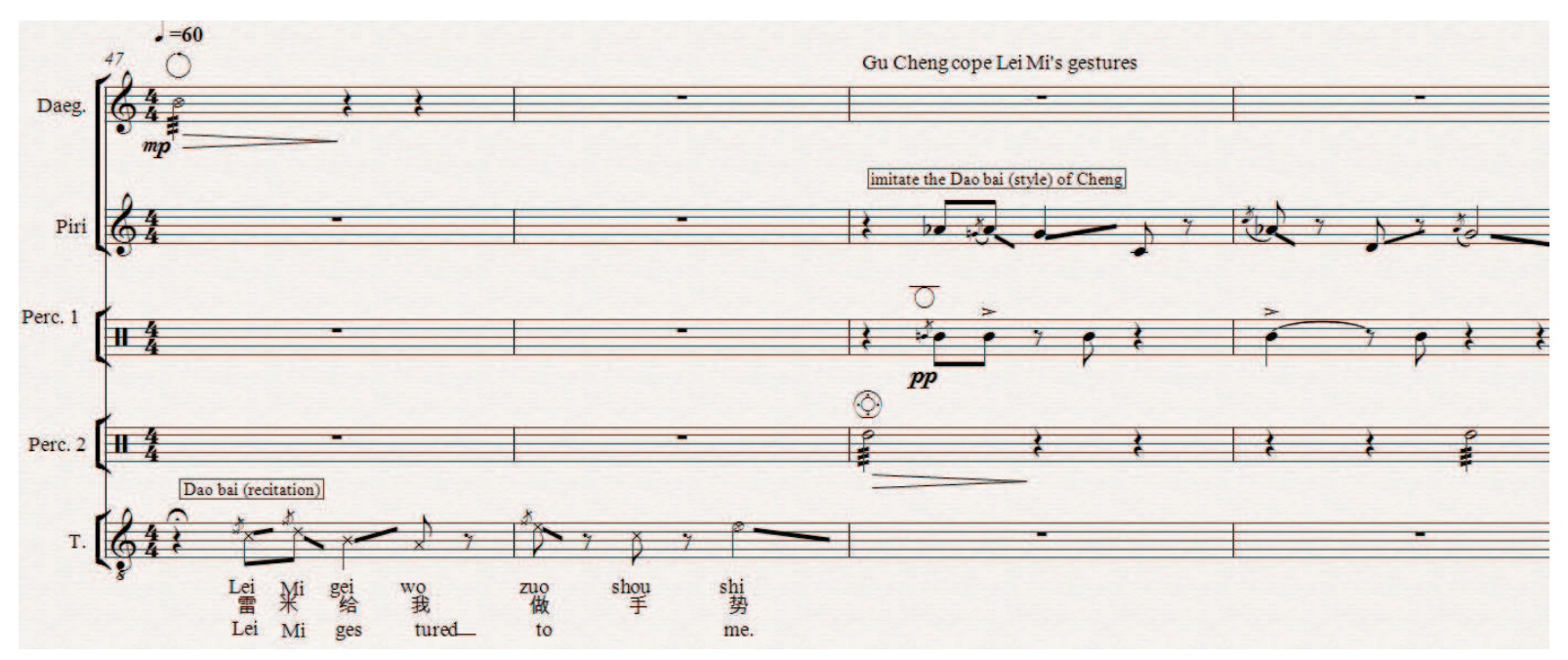

Example 77: Percussion rhythmic phrase from

Scene of the First Night (bb. 47-50)

\subsubsection{Recitation Elements from Qǘyì and Xijüì}

As previously outlined, there are four performance skills ${ }^{437}$ in chuānjù (川剧), niànspeaking, reciting (intoned or rhythmical), with non-singing vocalisations including sprechgesang (yù̀nbăi 韵 白) and recitation and dialogue dàobăi (道 白). In my iǔ Dé Sòng (酒德颂) Hymn to the Virtue of Wine, which largely integrated niàn into the composition (see also Chapter 4.5.3.3). All of these elements are absorbed into Scene of the First Night, in the music written for both characters, Cheng and Lie Mi.

The following examples show three different styles of vocal writing which stem from niàn recitation techniques. Lei Mi and Cheng's Duet "My precious son, my sweetheart”, uses recitation only. Lei Mi expresses her longing for her son, and suddenly remembers “Wǒhái bùcén wèinǐ jübàngò shēngrì qìngdiăn (我还不曾为你举办过一个生日的庆典) (but I never even had a birthday party for you)":

${ }^{437}$ For more information refer to chapter 2.2 The Skills Sigōng (四 功) of Chinese xìqü (戏 曲) 


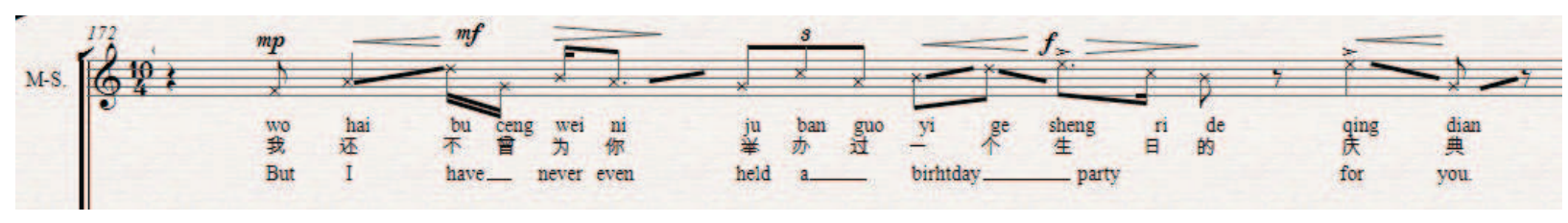

Example 78: Lei Mi and Cheng's Duet: “My precious son, my sweetheart” (b. 172)

In the following example, the first half of the sentence is in sprechgesang, and the second is sung. This technique is used frequently through the scene. Cheng's aria "Such a dark night” begins with hèi (黑) (darkness), a significant word from Gu Cheng's poem One Generation, a work that has many deep connotations. Musically, its importance is emphasized by use of a combination of sprechgesang and singing:

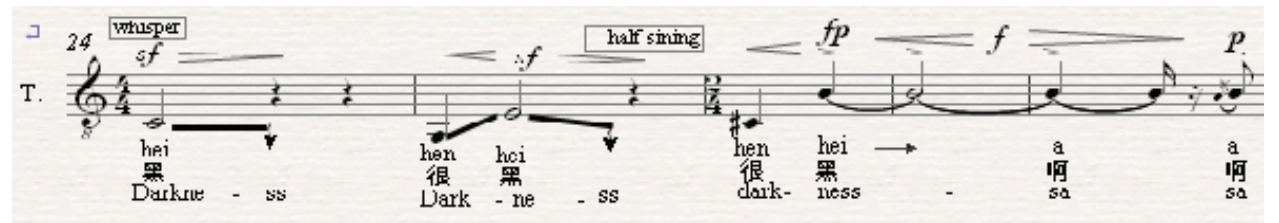

Example 79: Cheng's aria: "Such a dark night" (bb. 24-28)

Likewise, a little later in Cheng's aria, the recitation gives way to singing in triplets with a minor second (Ying'er's characteristic interval), building to a high point for the words rè wàng (热 望) (unquenched desire).

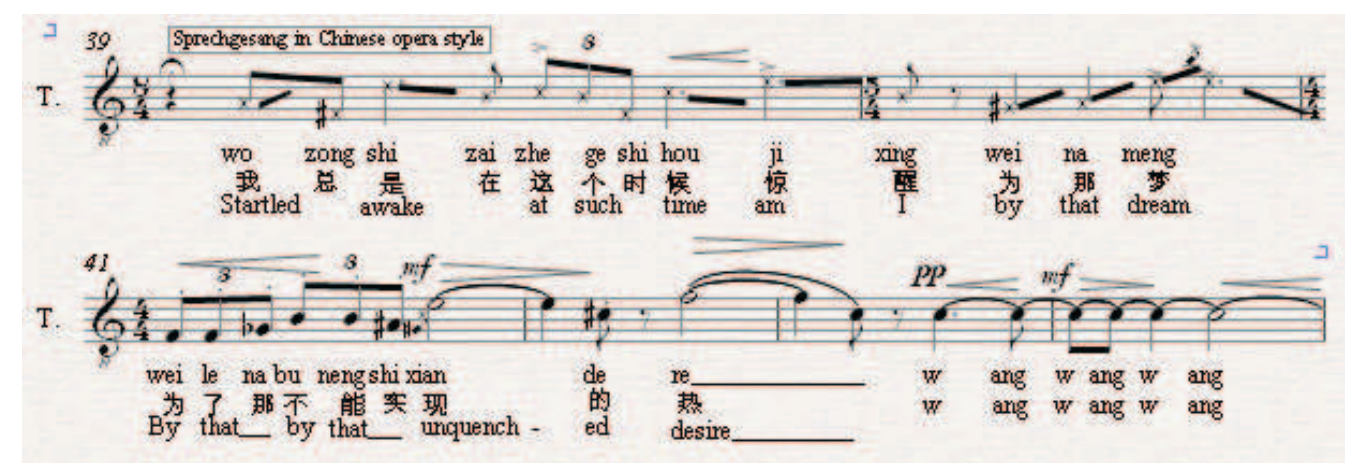

Example 80: Cheng's aria "Such a dark night" (bb. 24-28)

The following two examples provide a contrast with the previous examples. In Lei Mi and Cheng's Duet: "My precious son, my sweetheart" layers singing with sprechgesang, with 
each of the two characters expressing their individual and unrelated thoughts, Lei Mi singing with longing for her son, and Cheng expressing his desire with whispers and declamations.

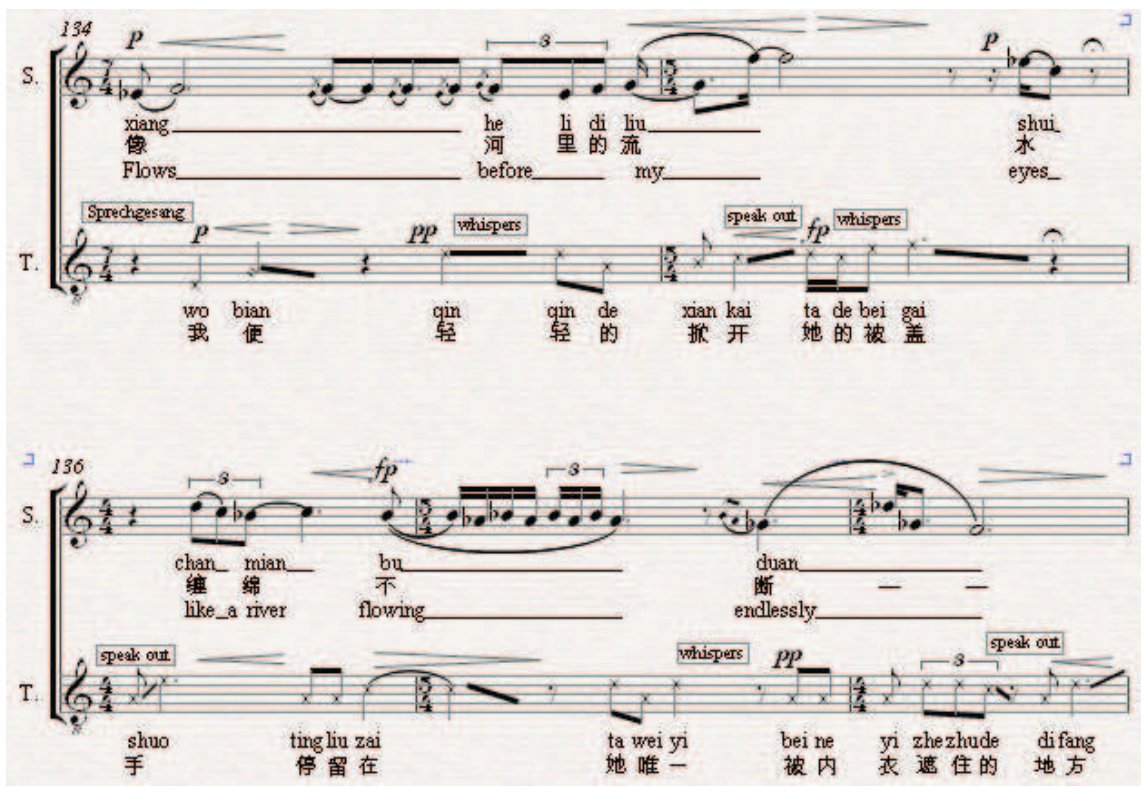

Example 81: Lei Mi and Cheng's

Duet: "My precious son, my sweetheart" (bb. 134-38)

In the next example Cheng sings while Lei Mi performs sprechgesang, their reversed style of performance suggesting a musical interaction, even though they inhabit different spaces on the stage, and their Duet is serendipitous.

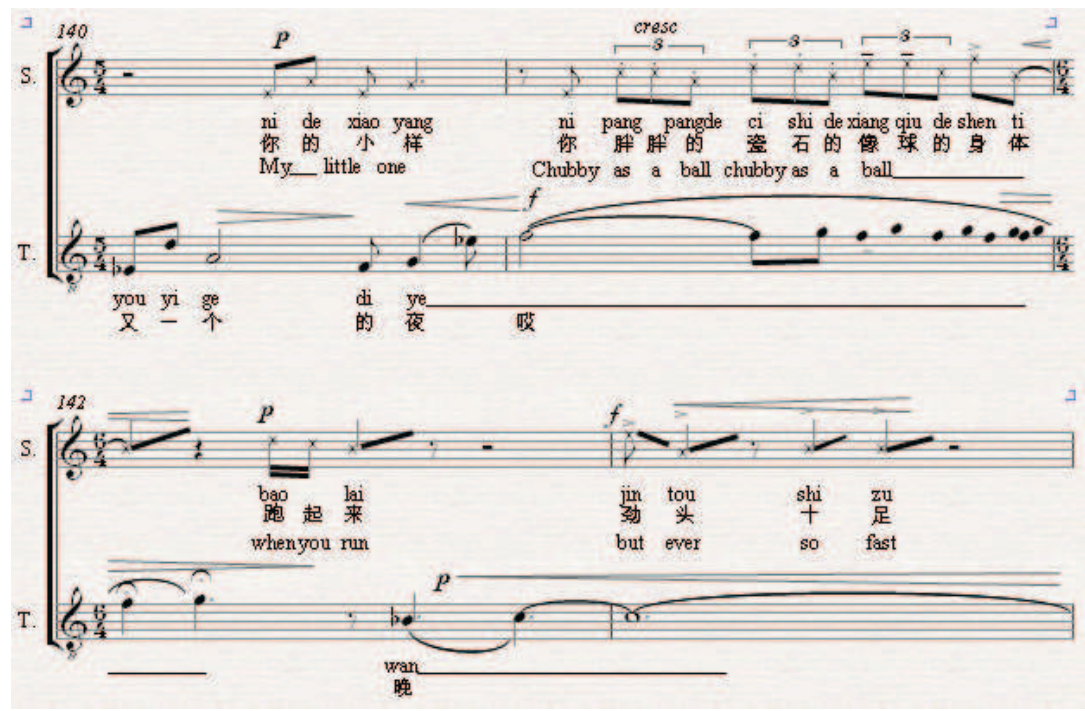


Example 82: Lei Mi and Cheng's Duet: "My precious son, my sweetheart" (bb. 140-43) The next example of niàn is complex, for it combines singing and sprechgesang. èrhuáng yăobăn (二黄摇板) (lit. “shifting rhythm of metre”), a particular musical texture found in traditional Chinese opera. It comprises a fast rhythmic instrumental pulsation that accompanies slow or sustained singing. Ėrhuáng yăobăn is integrated into the middle section (bb. 181-224) of the Duet. There are four components of the music in the following example. The guitar and gayageum plays the ǰnla (the fast rhythmic pulsation, while Cheng sings long notes in mànchàng style. In addition the soprano, Lei Mi, chants rhythmically accompanied by a percussion group:

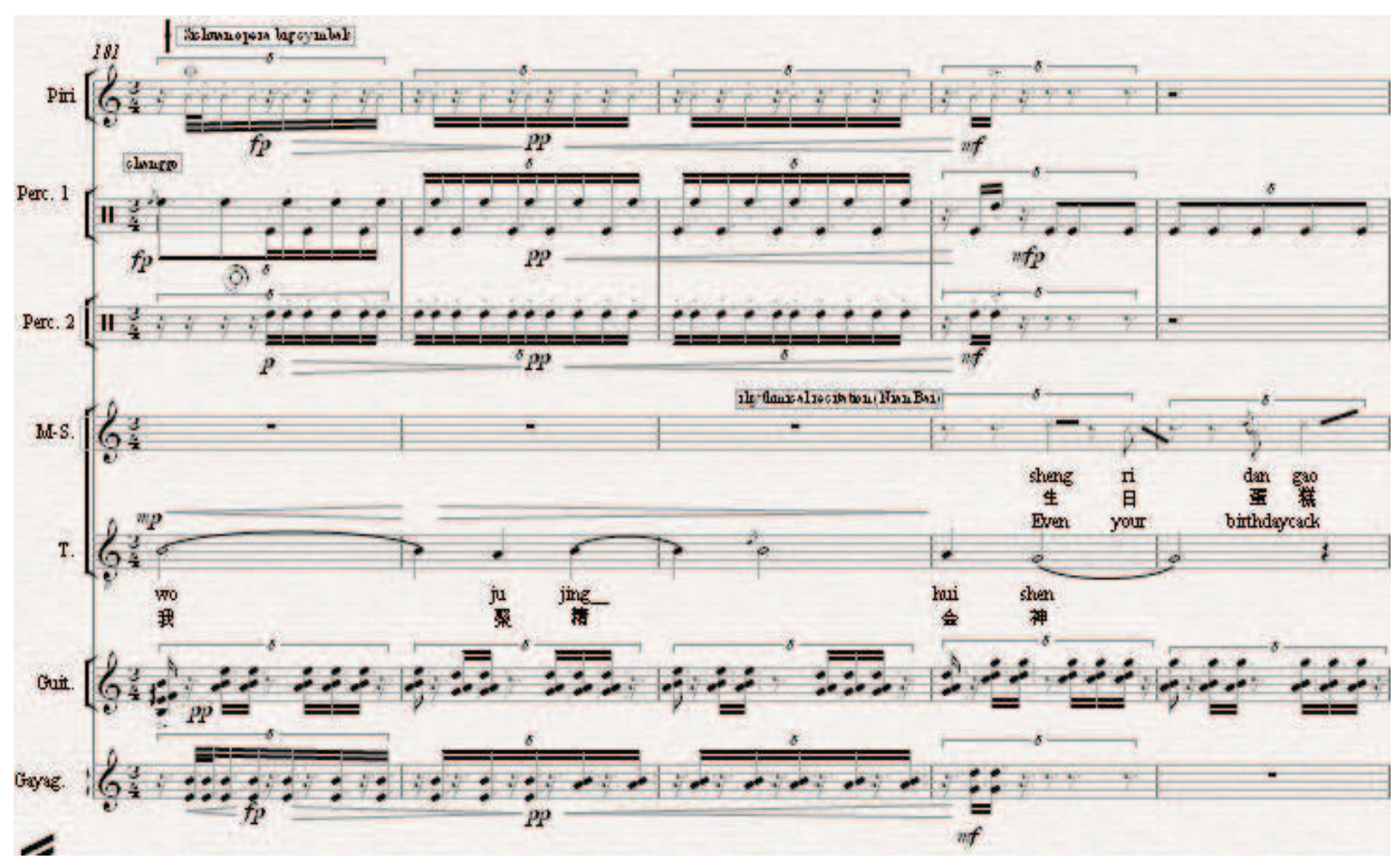

Example 83: J̌̌nlā Mànchàng in Lei Mi and Cheng's

Duet: "My precious son, my sweetheart" (bb. 181-85)

The integration of recitation and dialogue (dàobăi 道 白) can be found in the dramatic “serendipitous duet" of Lei Mi and Cheng: 


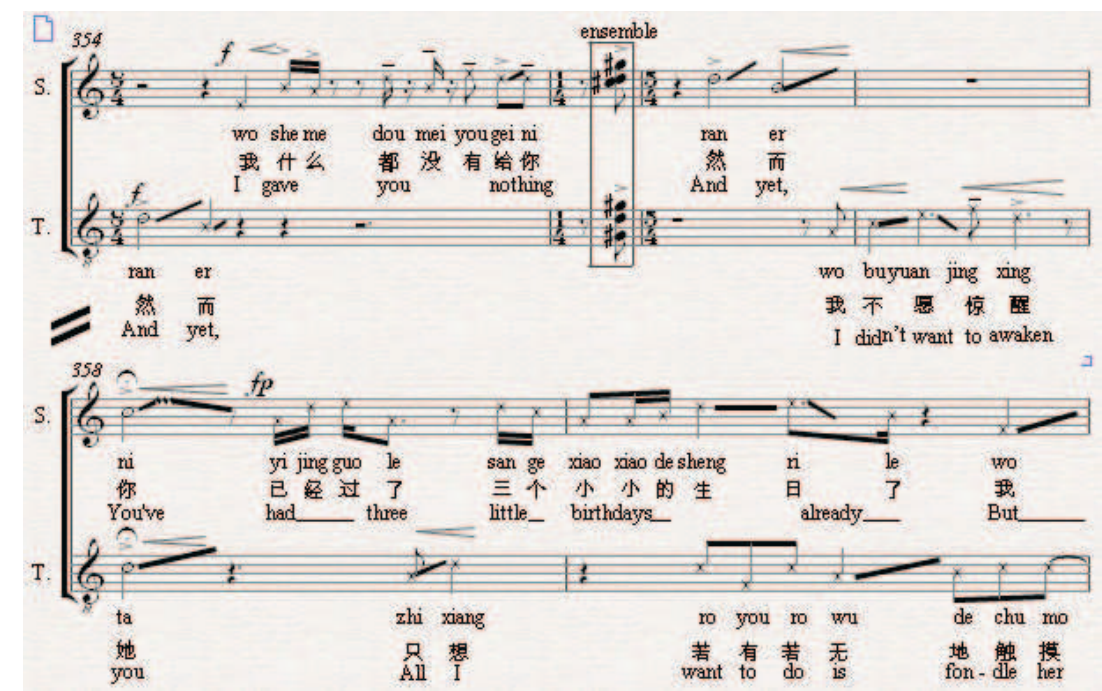

Example 84: Recitation and dialogue (dàobăi) in Lei Mi and Cheng's Duet: "My precious son, my sweetheart" (bb. 354-85)

\subsubsection{Material from Plainsong}

This extract from the novel Ying'er opens the chapter "The First Month":

第一个月

我轻轻地转向你

我还没有醒来, 她那急秘之处就呈现在我的面前, 那么细致饱满，像博物馆菊石 的图案, 又像无花果逐渐变得甘 美柔 和把一切细小的籽粒蕴涵其中。

\section{The First Month}

\section{I gently turned towards you}

"I was not awake and her secret past was already in front of my eyes. I was still emerging from my sleep, so elegant, so slender and rich, like the pattern of ammonites in museums, like figs turning sweet and soft enveloping the seeds deep inside". ${ }^{438}$

In the libretto of Scene of the First Night operatic scene this text is adapted in an arrangement for chorus:

${ }^{438}$ Li Xia 李侠 (trans.), Gu Cheng \& Lei Mi, Ying'er, The Kingdom of Daughters, p.45. 


$\begin{array}{ll}\text { 晨曦初露, 万物苏醒 } & \text { The first light of dawn } \\ \text { 神秘的隐处再苒呈痕现 } & \text { Awakens the myriad creatures } \\ \text { 像博物馆菊石的图案 } & \text { There in the mysterious hidden } \\ \text { 那么细致饱满 } & \text { recesses is revealed, } \\ \text { 像无花果逐渐变得柔和 } & \text { As fine and as ripe } \\ \text { 那么滋润甘甜 } & \text { As the pattern of the ammonites } \\ \text { 把一切细小的籽粒蕴涵 淫秽 } & \text { in a museum, }\end{array}$

The beauty of Cheng's poetical language required a musical setting that was equally beautiful and delicate, creating an image of sanctity, avoiding salaciousness. To achieve this, contours of the music are modelled on the graceful lines of plainsong. The Dorian mode of the opening changes to the hypodorian mode, suggestive of the time change from night to morning. The visual imagery I associated with this new dawn was of the female genitalia, although this was not realised in the Asia Pacific Festival production.

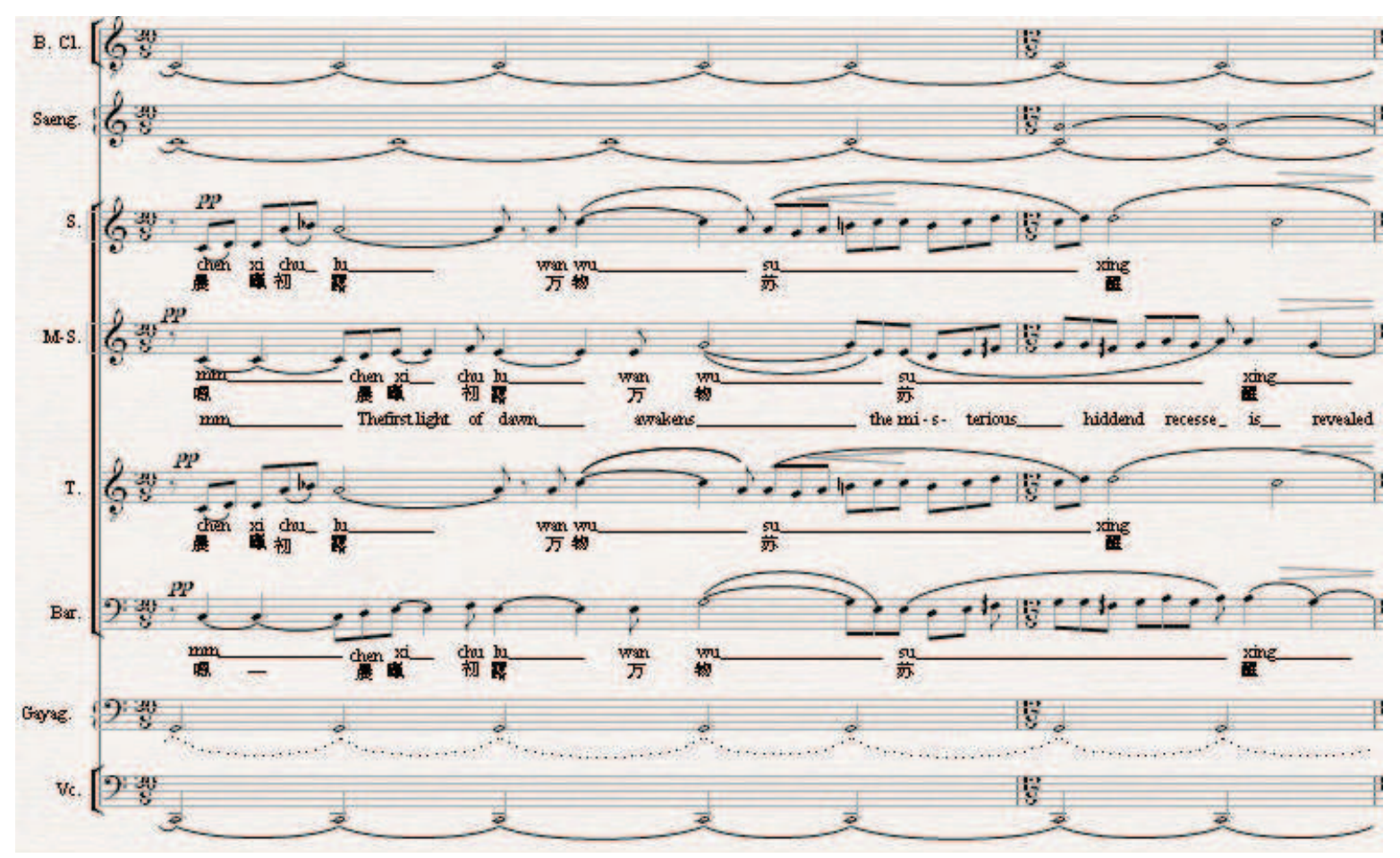

Example 85: The beginning of Chorus in Scene of the First Night (bb. 423-24) 


\subsubsection{Use of Leitmotifs in of Scene of the First Night}

Wagner and Berg adopted the leitmotif principle in order to unify the music for each character in the drama. There has never been an equivalent concept in Chinese operatic traditions. I recognized leitmotifs as a potent musico-dramatic tool and used this principle throughout Scene of the First Night, in both the vocal and instrumental writing.

\subsubsection{Leitmotif of Ying'er}

In terms of instrumentation, the piri represents the character of Ying'er. Her first motive I is initially heard in bb. 17-18, when Ying'er appears on the stage.

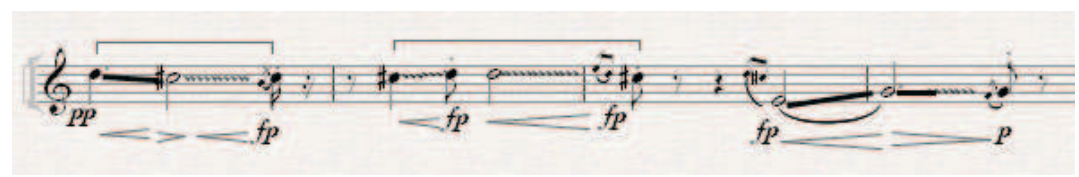

Example 86: Ying'er's motive I, in the opera

Scene of the First Night (bb.17-18)

When Cheng finally enters Ying'er's bedroom, she pretends to be asleep. Cheng stands looking, gazing longingly for a long time at Ying'er, He questioned himself. “Wǒ bùnéng xiăngxiàng zhèshì tā? zhèjiùshì wǒ suó yàodenühái? Wǒde mèng? (我不能想象这是她? 这 (就) 是我所要的女孩? 我的梦?) (I can”t believe that this is her, this is the girl of my heart”s desire, my dreams)". Cheng's questioning of his relationship with Ying'er is reflected in the changing instrumentation of her motive, now played by the daegeum flute instead of the piri.

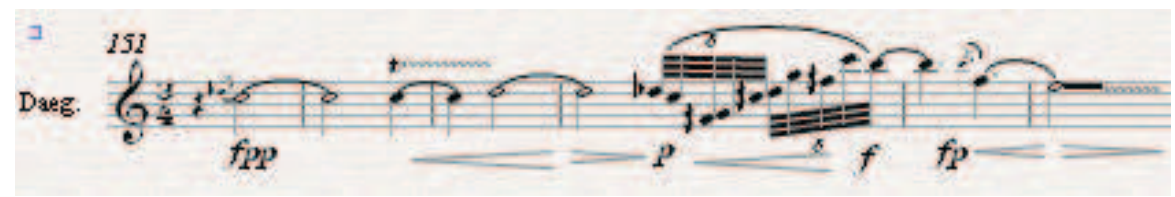

Example 87: Ying'er's motive I, in the operaScene of the First Night (bb.151-56) 
Cheng did not disturb Ying'er, but remained in her room throughout the night. In the morning Ying'er wakes, and observing Cheng asleep, sings her aria "I love you", with the motive as first played on the piri:

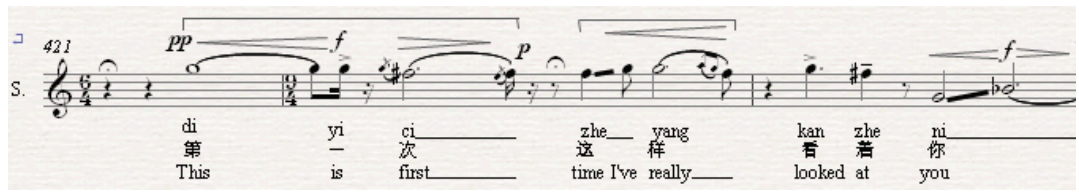

Example 88: Ying'er's motive I, in the aria "I love you"(bb. 421-23)

In the second verse of the aria, Ying'er's motive I changes its rhythms in synchronization with the choir, demonstrating the constancy of her love for Gu Cheng:

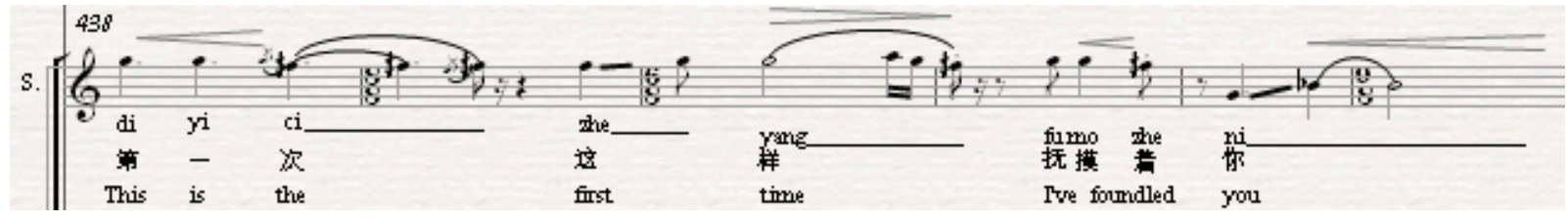

Example 89: Ying'er's motive I, in the aria "I love you" (bb. 438-43)

Ying'er's motive II, the "love motive", based on the characteristic perfect fifth interval, a sequence of ascending perfect fifths representing her passion and desire, as in her aria "I Love You":

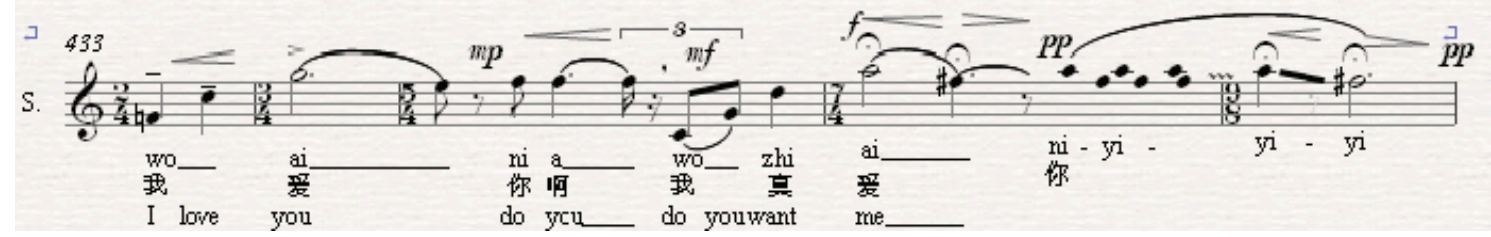

Example 90: Ying'er's motive II, in the opera Scene of the First Night (bb. 433-47)

\subsubsection{Leitmotif of Lei Mi}


Lei Mi's leitmotifs in the Scene of the First Night appears in the singing and instrumental parts. Motive I has a major second as the characteristic interval, which is repeated as a descending sequence of three whole-tones, creating a tritone scale as in the Lullaby: "Dearest son":

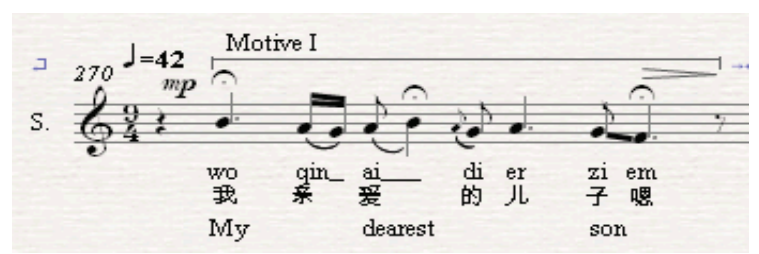

Example 91: Lei Mi's motive I, in the Lullaby: "Dearest son" (b. 270)

This motive is extended by a retrograde version of itself. This "mirror" technique is used frequently in developing Lei Mi's vocal line, as, for example in her duet with Cheng, which is extended with the addition of a major $2^{\text {nd }}$ :

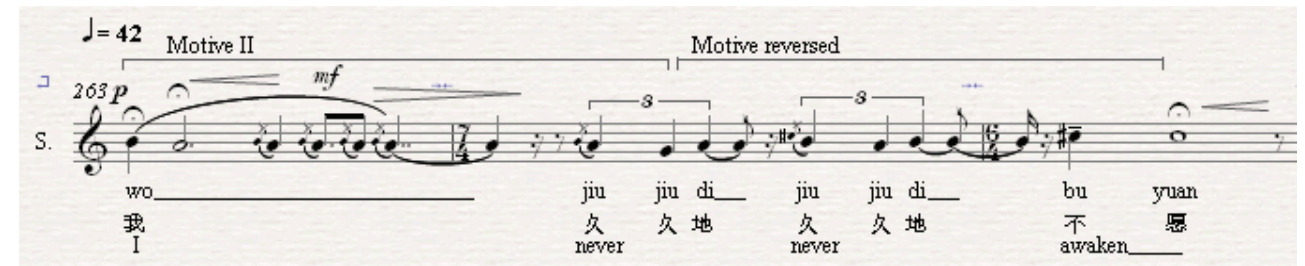

Example 92: Lei Mi's motive I, in the Duet

"My precious son, my sweetheart" (bb. 263-68)

The next example has a similar mirror shape but then rises a minor $2^{\text {nd }}$ (A\# to B) for the text: zài wǒmén kéyľ yìqǔ shēnghuóde rìzilı̌ (在我们可以一起生活的日子里) (When we live together), implies the "seed" of tragedy in her life, the fact they will not be able to live together.

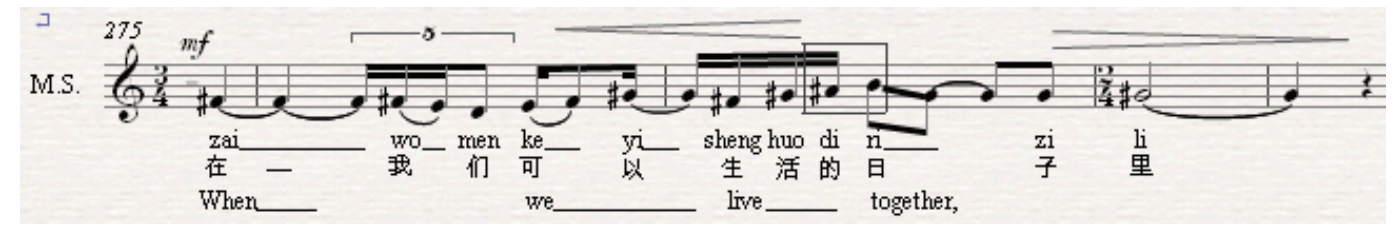

Example 93: Lei Mi’s motive I, in the Lullaby: "Dearest son” (bb. 275-79) 
Motive I also appears in the instrumental interlude, after Lei Mi's singing of the lullaby. In a heterophonic texture played by the daegeum and gayageum, the music represents Lei Mi's loneliness which seeks comfort in her attachment to her son. This transitional interlude leads to the "Children chant", a rhythmic recitation chant in which she is joined by the "Voice of the son":

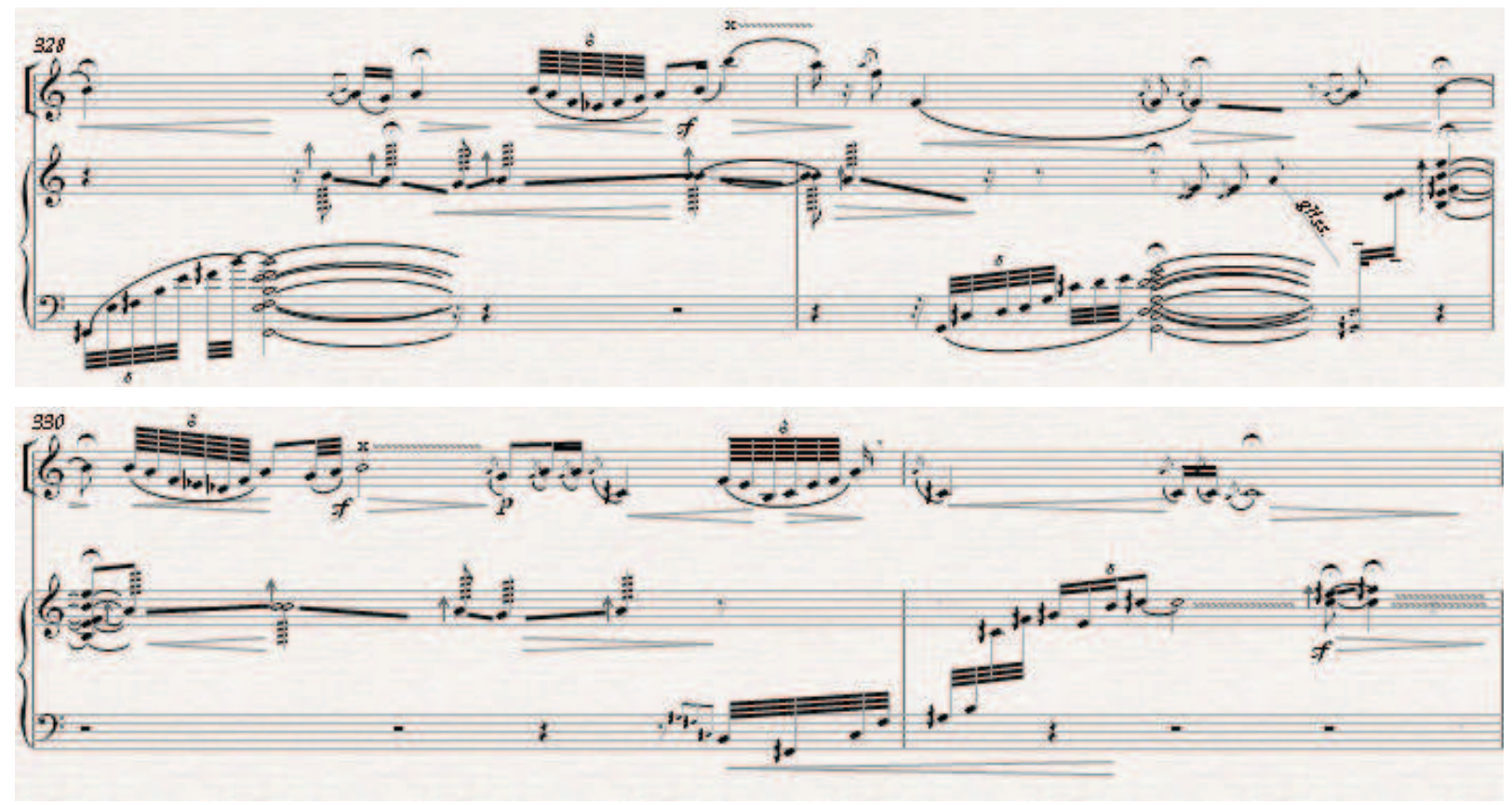

Example 94: Lei Mi's motive I, in the opera

Scene of the First Night (bb. 328-31)

Lei Mi's motive II is the "love motive", which, in the following example, played by the cello, relates in its first phrase to Cheng's "love motive" (see Example 62). The second phrase is characterized by a chain of ascending perfect $4^{\text {ths }}$, representing the heightened emotion of being in love. The motive then segues into Lei Mi's motive I. The whole passage accompanies Lei Mi’s Sprechgesang as she thinks lovingly about her son - "Ň̌ y̌jīing guòle sāngè xiăoxiăode shēngrìle, wǒ juéde nǔ xiàng yīgè mèng (你已经过了三个小小的生日 了, 我觉得你象一个梦) (You've had three birthdays already, but I think of you as a dream really encircles me)". 


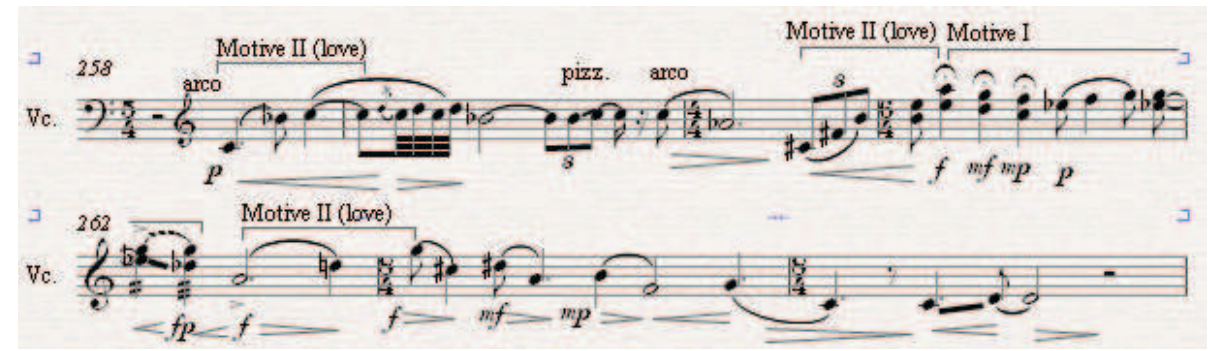

Example 95: Lei Mi's motive II, in the opera Scene of the First Night (bb. 258-64)

Li Mei"s singing of the lullaby "Dearest son" also combines the motives I and II, but, in this case, reverses the sequence of the two intervals. The second half of the phrase combines a version of motive I with its mirror and an extension up to the tritone.

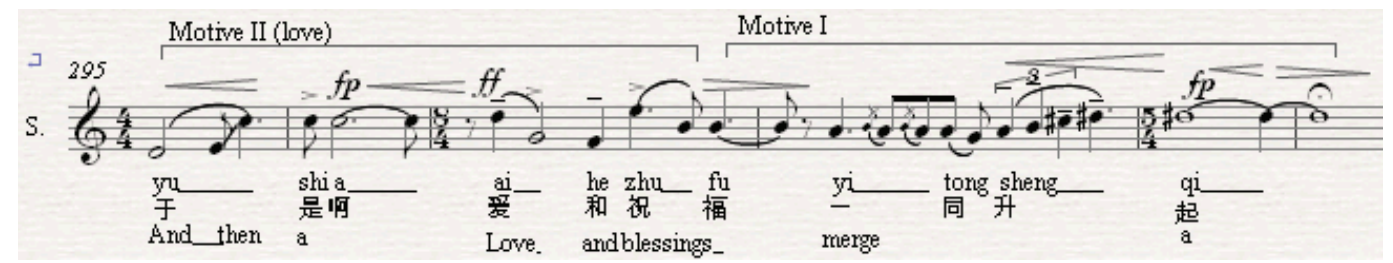

Example 96: Lei Mi's motive I \&II, in the opera Scene of the First Night (bb. 295-300)

\subsubsection{Leitmotif of Cheng}

Cheng's "love motive" is first heard on the clarinet, the instrument with which his character is associated. Appearing after the scene"s introduction, it is repeated twice, introducing Cheng on to the stage.

Cl. B

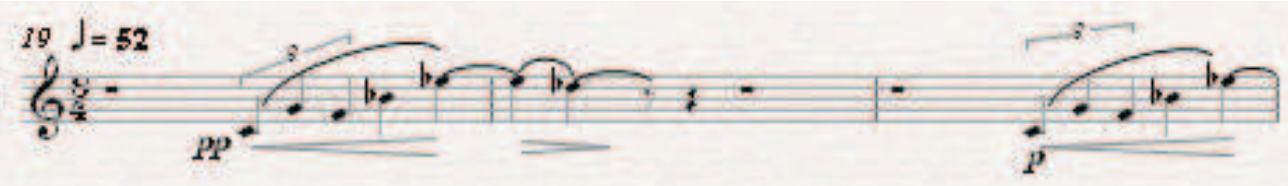

c1. B

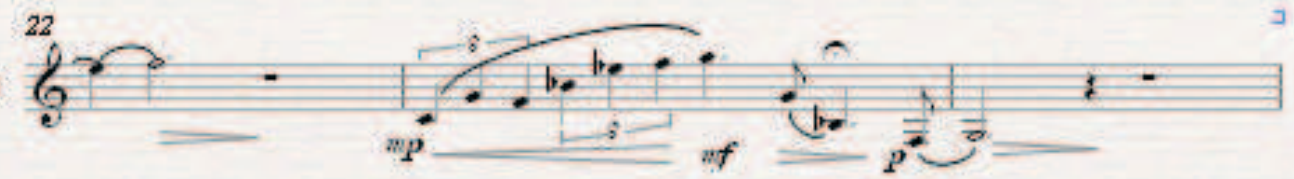

Example 97: Cheng's "love motive" II, in the opera Scene of the First Night (bb. 19-24) 
In Cheng's aria "Voice of the son", the shape of his "love motive" is inverted and the second pitches displaced to the end of the motive.

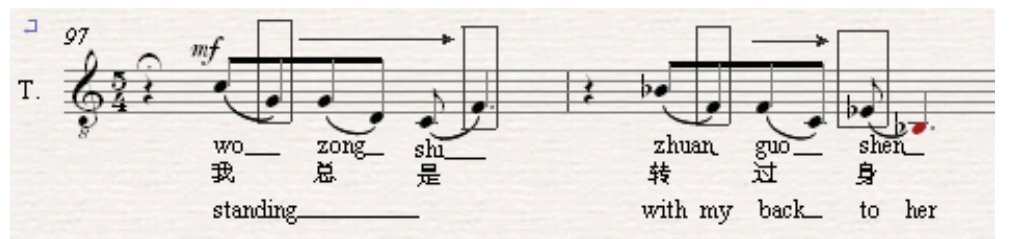

Example 98: Cheng's motive II, in the opera Scene of the First Night (bb. 97-98)

Cheng's motive III is his “tragic motive", incorporating Lei Mi's interval of a major $2^{\text {nd }}$ and Ying'er interval of a minor $2^{\text {nd }}$ in a descending direction using the gúnchui rhythm. In the following example from his aria "Such a dark night" the text is "Nà báitiān Liúxiàde Y̌̃nyuēde Xìnqing (那白天留下的隐约的心情) (By the indistinct feelings that linger from the day before)":

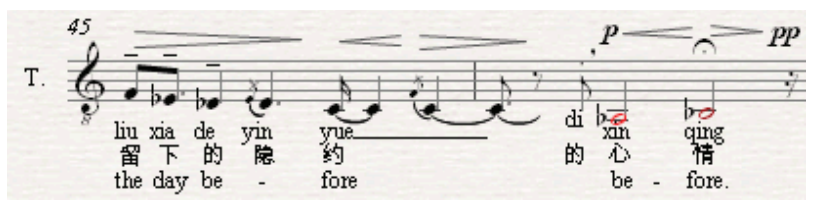

Example 99: Cheng's "tragic motive" in the opera Scene of the First Night (bb. 45-46)

At the end of this aria this motive reappears with the words “Mèngxiăng hé qīdài (梦想和期 待) (Like the dreams and hopes of so many years)". While the words are full of optimism the music intimates the tragedy that is to come. This sense of doom is echoed by the clarinet.

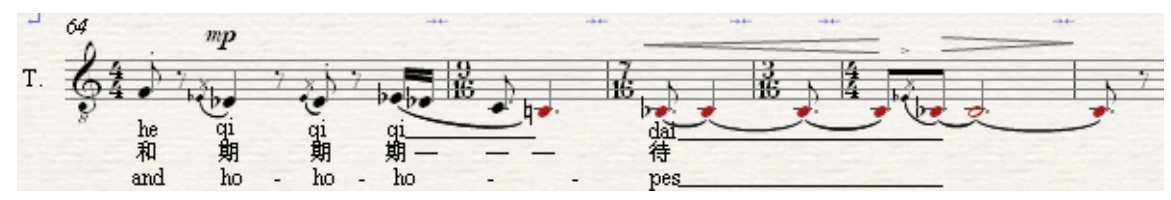

Example 100: Cheng's "tragic motive" in the Scene of the First Night (bb. 64-69) 


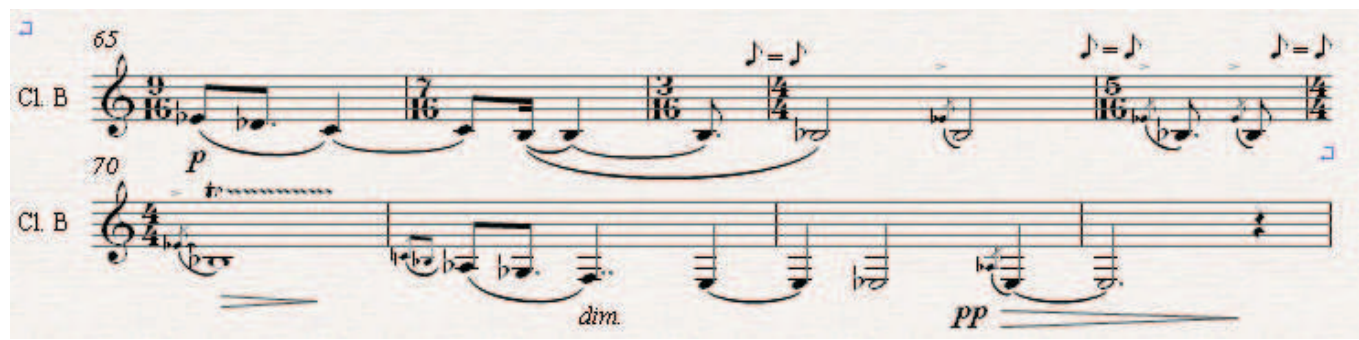

Example 101: Cheng's "tragic motive" in the Scene of the First Night (bb. 65-73)

\subsubsection{Leitmotifs within their Dramaturgical Context}

The juxtapositions of the various leitmotifs and the transformations they undergo enhance the unfolding drama and reflect the relationships between the various theatrical personae.

In the libretto, the chorus "The first light of dawn" marks the transition of time to the next morning. Ying'er wakes and expresses her love for Cheng, who is himself asleep. In the aria "I love you", sung by Ying'er, her "love motive" (1) is combined with Cheng's "tragic motive" (2) (with a quasi retrograde of itself (3)). Then follows the "love motive" again, in an expanded form (4), and an inverted fragment of the "tragic motive" (5):

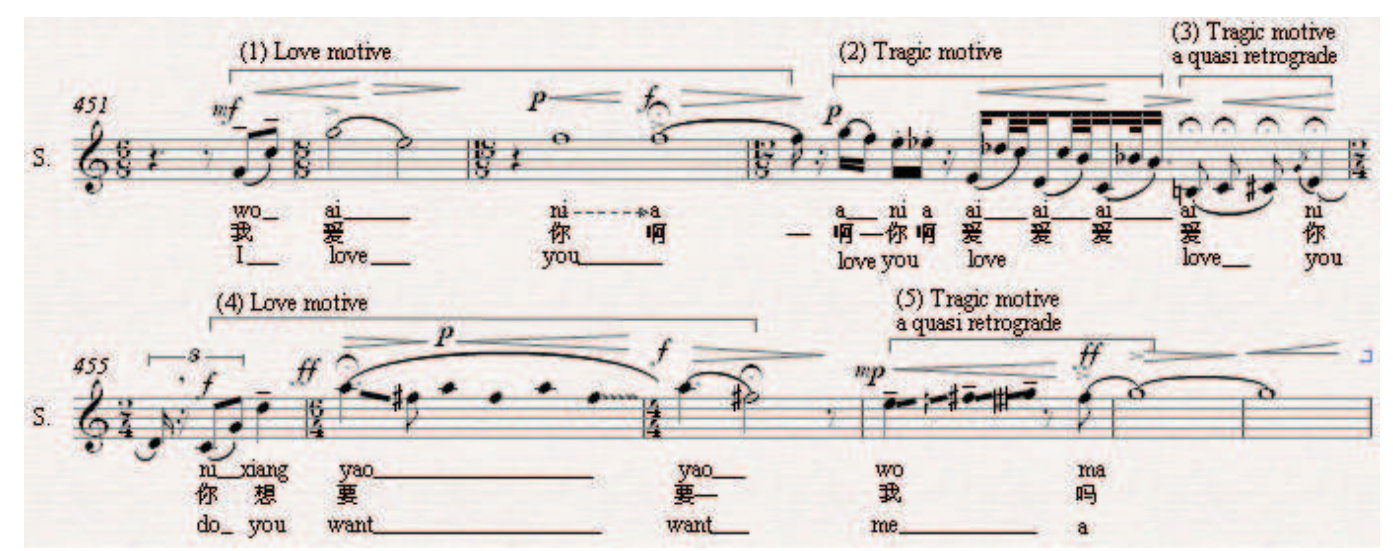

Example 102: Ying'er's “love motive" combination of Cheng's

"tragic motive" in the aria of "I love you"(bb. 451-60)

In the following example, two characters express themselves simultaneously, but without interaction, existing in separate theatrical spaces: in one room Lei Mi's sings of her long- 
ing for her absent son while in another Cheng expresses his desire for Ying'er. This "parallel drama" is reflected in Lei Mi singing "My precious son" while Cheng sings "My sweetheart". As can be seen in the first three bars of this serendipitous duet, it begins with Lei Mi's motive I (a) while Cheng sings an inversion of the first three notes of Lei Mi's phrase (a1). The initial major $2^{\text {nd }}$ becomes a major $9^{\text {th }}$ leading to Lei Mi's characteristic interval (b), the perfect $4^{\text {th }}$ (b.135). Lei Mi's second phrase echoes Cheng's inversion (a1), but, most significantly, contains within it the "seed of tragedy" (c), the minor $2^{\text {nd }}$ of Ying'er. This motive is echoed, in turn, by Cheng, whose line then blossoms into the "love motive" (d).

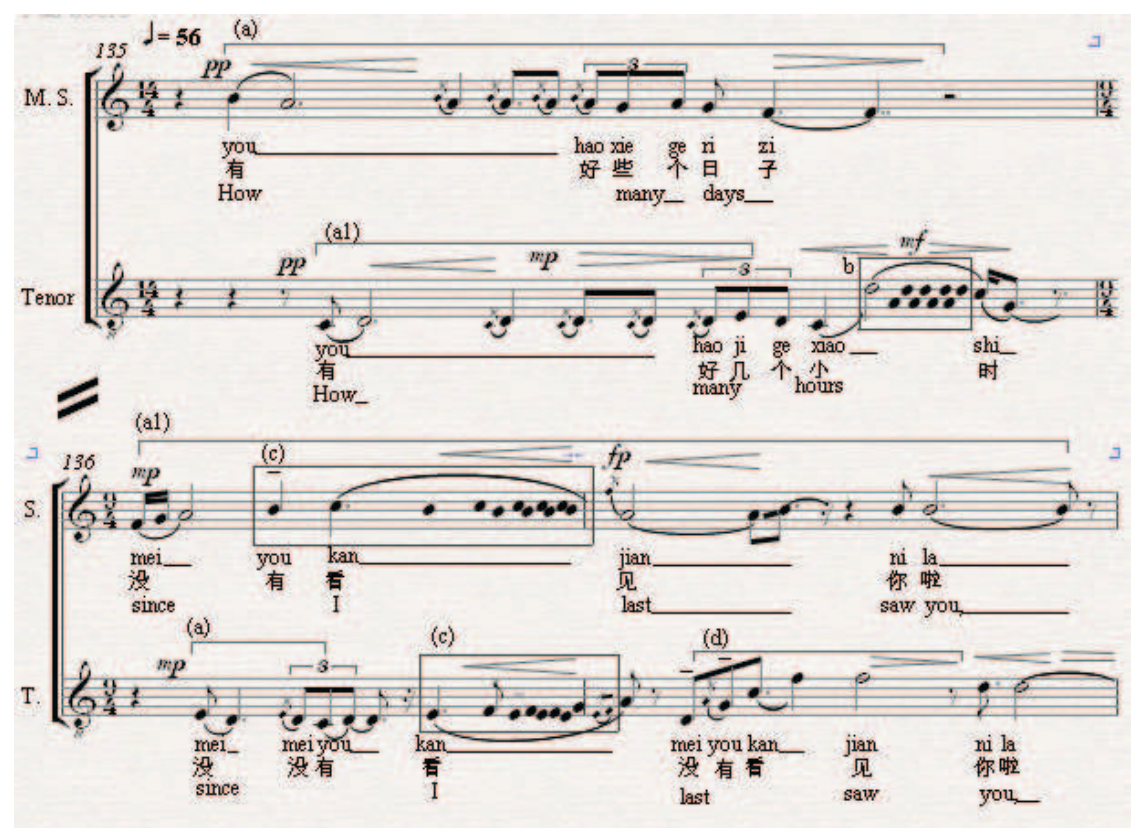

Example 103: The "seed of tragedy" minor $2^{\text {nd }}$ in Lei Mi and Cheng's Duet: "My precious son, my sweetheart" (bb. 135-36)

The "seed of tragedy" is found in Lei Mi's Lullaby, "Dearest son", where her motive I is inverted and repeated in sequence, leading to the "seed of tragedy" (3) with the word: “bēiāi (悲哀) (tragedy)":

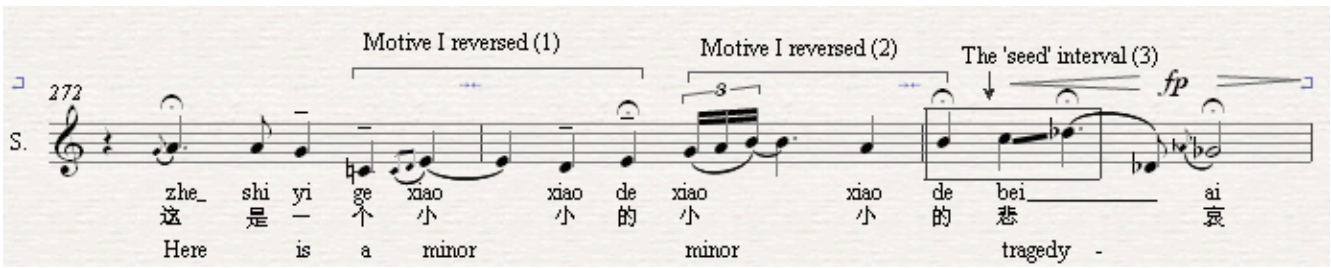

Example 104: The "seed of tragedy" in Lei Mi's Lullaby: "Dearest son" (bb.272-74) 
Later in the Lullaby she recalls, with pained emotion, the time when she lived with her son:

我亲爱的儿子，

(唱) 这不是一个 (有趣的) 故事，

这是一份小小的悲哀。

我不能为你挡住世界，

挡住你小小的心需要承担的伤害。

在这丑陃和痛苦面前

我和你柔弱相差无几。

我在深深的忧伤中想你，
Dearest son

This is not an (interesting) story

Here's a minor tragedy.

I cannot keep the world at bay,

Protect your tiny heart from the wounds it must bear.

In the face of such ugliness and suffering,

The two of us are far too weak.

In the midst of my grief I think of you,

The tritone compass of Lei Mi's motive 1 also signals impending tragedy and its combination with Ying'er's "seed of tragedy" interval reveals the depth of Lei Mi's pain in the midst of her loving reminiscence of her son:

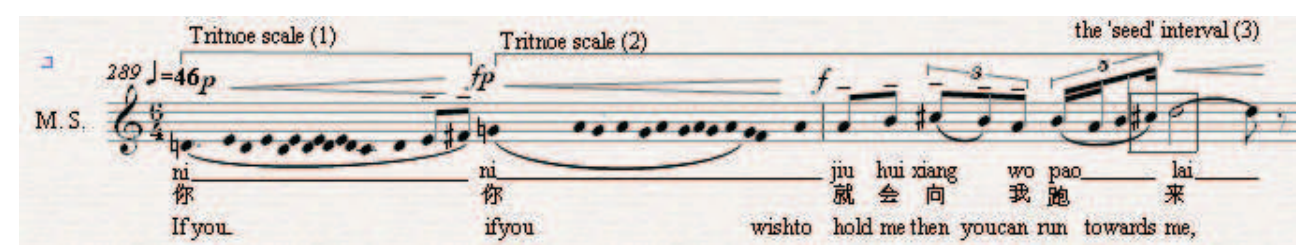

Example 105: Lei Mi's motive I combined with the tragic "seed" interval of

Ying'er in the Lullaby: "Dearest son" (bb. 289-31)

Central to the drama of Scene of the First Night is Cheng's emotionally complex relationship with his wife and his lover. His musical motive contains their characteristic intervals, a perfect $5^{\text {th }}$ (Ying'er), and a major $2^{\text {nd }}$ and a perfect $4^{\text {th }}$ (Lei Mi). In his aria "Voice of the son", Cheng's motive I begins with a perfect $5^{\text {th }}(1)$, followed by a perfect $4^{\text {th }}(2)$, followed by a descending $5^{\text {th }}(3)$, joining with a phrase based on major $2^{\text {nds }}$, a version Lei Mi's motive 1 (4):

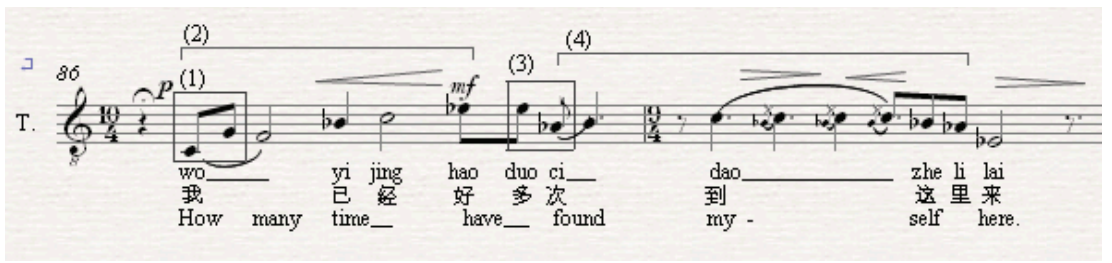

Example 106: Integrated Lei Mi's motive I and Ying'er's "love motive" in the aria of Cheng (bb. 86-87) 
In the same aria, Cheng sings “Wǒ zhǒngshì bèiguòshēn, kàn chuāngwàide yuèsè (我总是 背过身,看窗外的月色) (Standing with my back to her, Gazing at the moon through the window)". He stands in Ying'er bedroom, entranced, looking at "the moon through the window". The integration of Lei Mi and Ying'er's musical motives into his aria represents the complexity of his inner thoughts. In the following example, Lei Mi's motive I is inverted (encompassing a tritone, b. 99), before it is clearly stated in the next two bars (bb. 100-101). Then follows "love motive" of Ying'er in inversion (bb102 -103), and Lei Mi's motive I, this time interrupted by a perfect $5^{\text {th }}$ (squared), from the "love motive" of Ying'er (bb. 104105):

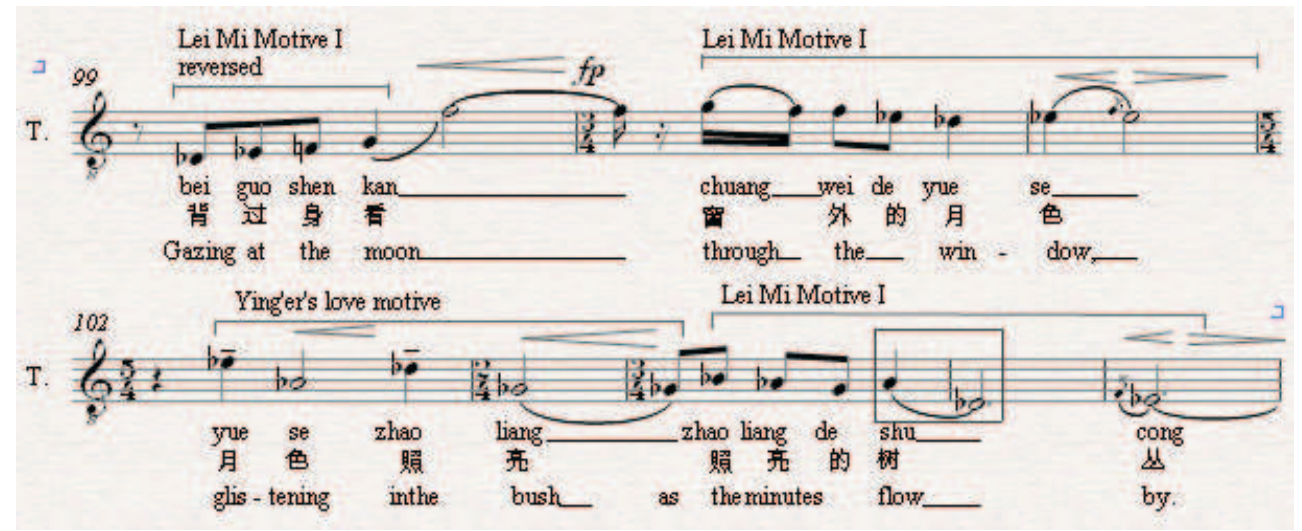

Example 107: Lei Mi’s motive I and Ying'er's “love motive” in Cheng's aria (bb. 99-105)

Cheng's state of mind is reflected in the text:

$\begin{array}{ll}\text { 我已经好多次到这里来 } & \text { How many times } \\ \text { 可是每次来的时候 } & \text { have I found myself here, } \\ \text { 依旧恍惚 } & \text { Only to be entranced }\end{array}$

This entrancement is portrayed by Cheng B's motive, representing Cheng's unconscious world. Embedded within it are several "seeds of tragedy", minor $2^{\text {nds }}$ (squared), as for the words “Yìrán huănghù (依旧恍惚) (Only to be entranced)" in the aria "Voice of the son": 


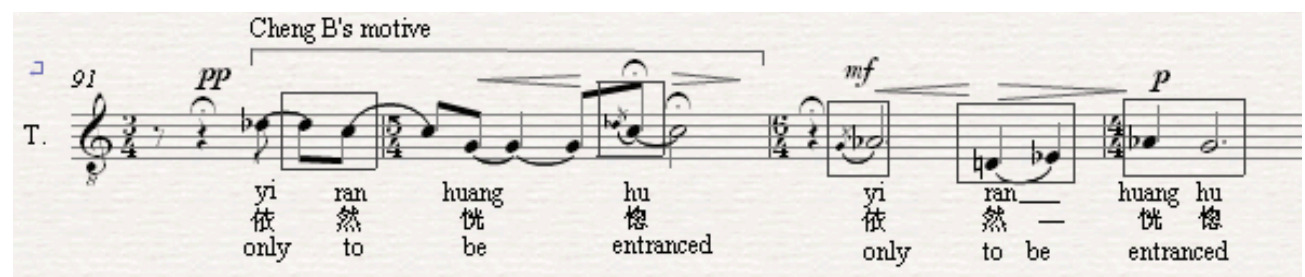

Example 108: Integrated Ying'er's "seed" interval in the aria of Cheng (bb.91-94)

The final example is instrumental, and combines three motives representing the three protagonists, and played by the three characterizing instruments, the piri, the cello and the clarinet. The music represents the dramatic love triangle:

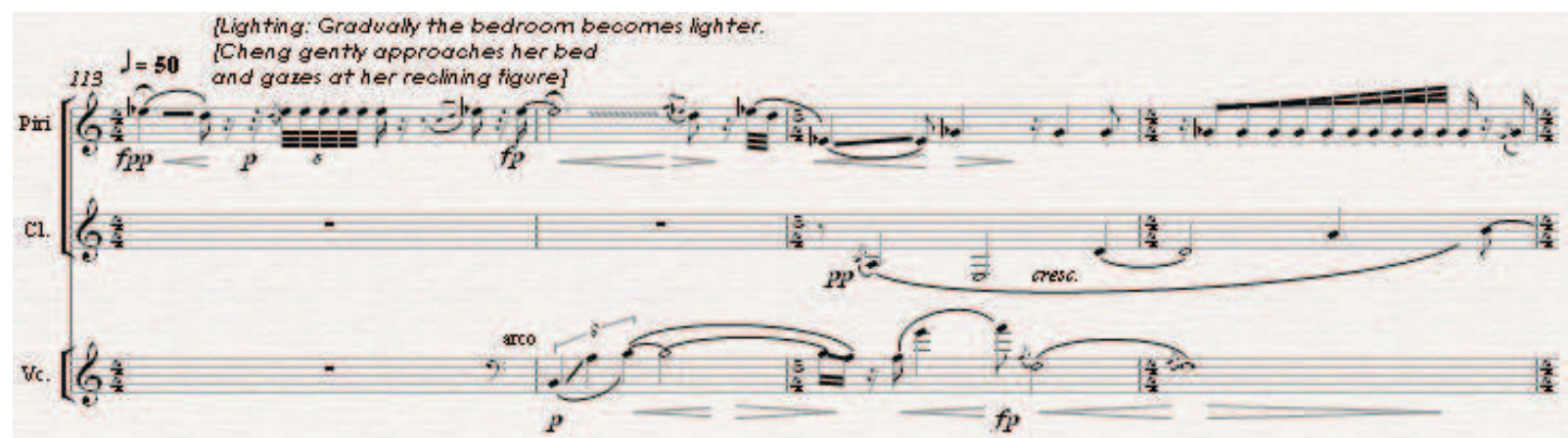

$=$
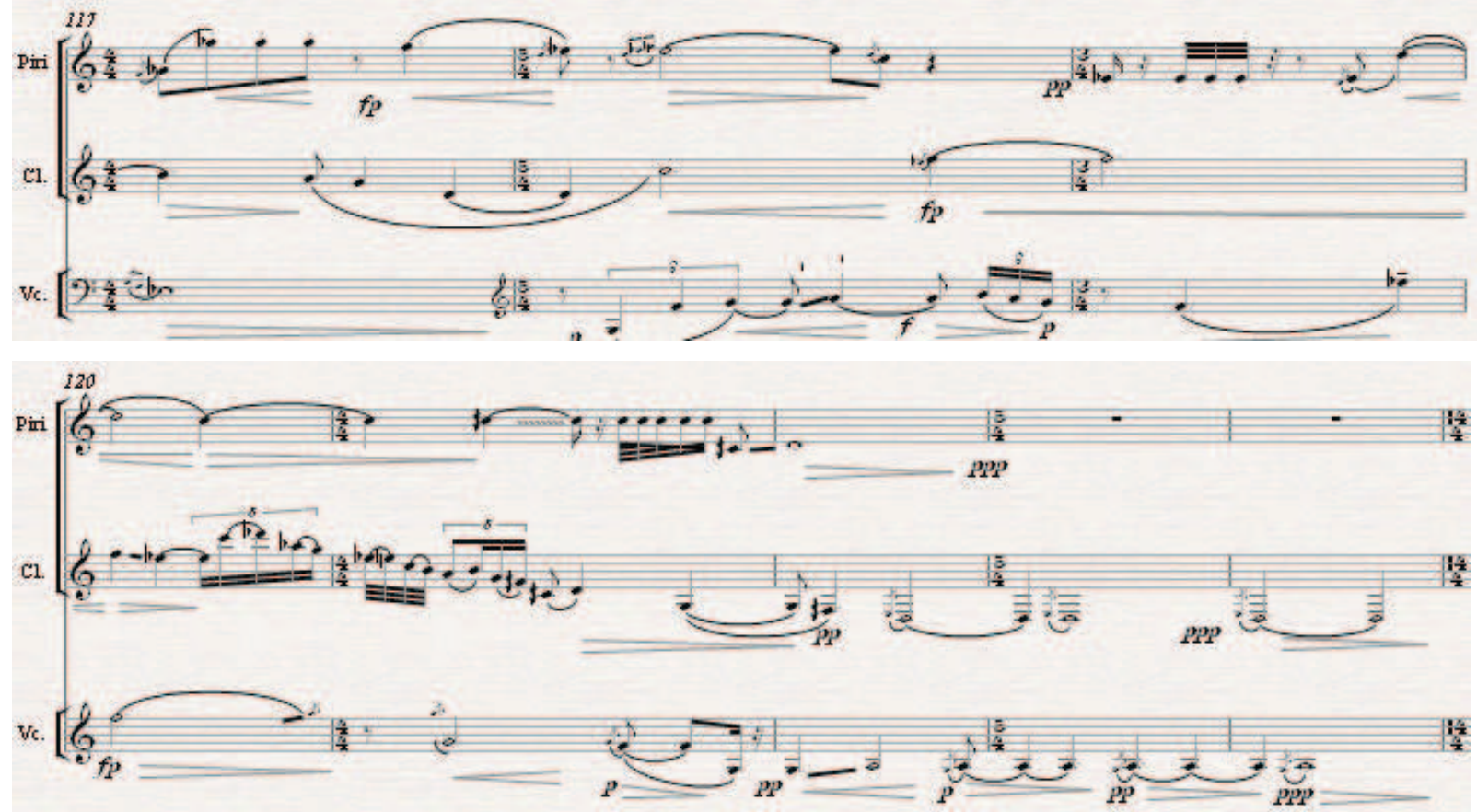

Example 109: Interlude section in the Scene of the First Night (bb.113-24) 


\subsection{Stage Production of Scene of the First Night in the 2007 Asia Pacific Festival}

The 2007 Wellington Asia Pacific Festival featured musical concerts, opera and puppetry performances as well as a four-day composers' conference. Scene of the First Night was produced on February 12th and 14th, at Te Whaea National Dance and Drama Centre, in a programme of three music-theatre productions, called Asia-Pacific Music-Theatre. On this occasion my work was given the title Fatal Desire, being the third scene of a projected nine-scene opera of this title.

This Fatal Desire excerpt, Scene of the First Night, was an exceptional opportunity for me to collaborate with director Sara Brodie, musical director Gao Ping, audio-visual designer Andrew Brettell, costume design Judy Huo, lighting design Tamsin Lakeman and producer Laurence Walls.

Chinese tenor James Meng sang the role of the Poet (Cheng). Wang Xingxing, at that time a first year student at the NZ School of Music, made her debut as an opera soloist in the role of Qing'er (Ying'er). As native Chinese speakers both these artists had no difficulty in singing in Chinese. The role of Xiang Yu (Li Mei) was sung by Linden Loader, a former winner of the Mobil Song Quest who had had wide experience throughout New Zealand in opera, oratorio and recital performances. Singing in Chinese was a new experience for her, a challenge that she overcame magnificently; she learned to read the sounds of the characters by reading pinyin, and to memorize them by listening to a demonstration recording I had made for her. Her role required her to learn the particular recitation and sprechgesang styles of Chinese xìqü.

The rehearsal period for the singers lasted two weeks, under the direction of Gao Ping, a well-known Chinese pianist, composer and lecturer, now resident in New Zealand. This was his debut as a conductor. The Contemporary Music Ensemble Korea arrived four days before the opening night, providing opportunity for only three days of intensive rehearsal with the singers. The period was particularly intense for me as the composer, since this was the first time that I was able to hear live this unique ensemble that combined Western instruments with Korean traditional instruments whose sonorities I was not familiar with. 
I appreciated the professional expertise and imagination of the director Sara Brodie and of the audio-visual designer Andrew Brettell. Sara's concept was to translate the character of The Poet's "desire" into a theatrical and visual form as poetic as the (Chinese) character. To do this I decided to incorporate an audio-visula element (visual projections) into the stage design as a means of alluding to the imagery generated and alluded to in the score. She studied carefully the dynamics of the drama, where the three characters never actually interact face to face with one other. In the libretto Lei Mi follows Cheng onto the stage, but they inhabit different rooms. When Cheng enters Ying'er's bedroom, she feigns sleep. Next morning Ying'er wakes and expresses her love for Cheng who is himself asleep. However, in the production, Sara created three "imaginary encounters".

Imaginary encounter I. While Cheng is standing in Ying'er room looking at her asleep, he sings a "parallel duet" with Lei Mi who is in the adjacent room. (shuōbái) "Wó biàn qīngqingde xiānkāi tāde bèigài, shǒu tíngliǔzài tā wéiyì bèi nèiȳi zhēyănde difāng, (chàng) Yígè yòu yígède yièwăn (说白) (我便轻轻的揭开她的被盖, 手停留她唯一被内衣遮掩的地方, (唱) 一个又一个的夜晚) (sprechgesang) Ever so gently I pull back the covers. My hand lingering above that place covered by her panties, (singing) night after night". In the production, Ying'er, in this imaginary encounter, wakes up and responds to Cheng, even though he does not acknowledge or interact with her.

Imaginary encounter II. In the libretto the voice of the Son is intended to be heard only from a recording, but in this imaginary encounter the voice becomes an "actual child" responding to his mother Lei Mi. A review of the production describes this encounter as follows:

The tone of the piece changes as the Wife imagines a counting game with her son (his answering voice provided by an actual child skipping adorably through the orchestra) and the vocal clicking rhythm of the game extends through the orchestra in an escalating canon (Lyndon Hood, Appendix 9.3 below). 
Imaginary encounter III. In the libretto, after her climatic aria "I love you" at the end of the scene, Ying'er moves up-stage, and slowly removes her nightgown accompanied by a chorus that gradually fades as the curtain falls.

In the production, however, as Ying'er finishes her aria, Cheng stands and the two of them face each other, embrace, and lie down together on the bed. The action is symbolic, an imaginary encounter, rather than an actual coming together:

Finally a new voice is added as the Lover sings, inviting the Poet to her bed. The ominous buildup in music that heralds their laying down is intriguing, causing us to reflect that the relationship of this reminiscence has ended, and hinting at the tragic conclusion of the opera (Ibid.).

The original music after this climatic point is a short transition, which eventually dissolves into the choral conclusion: 


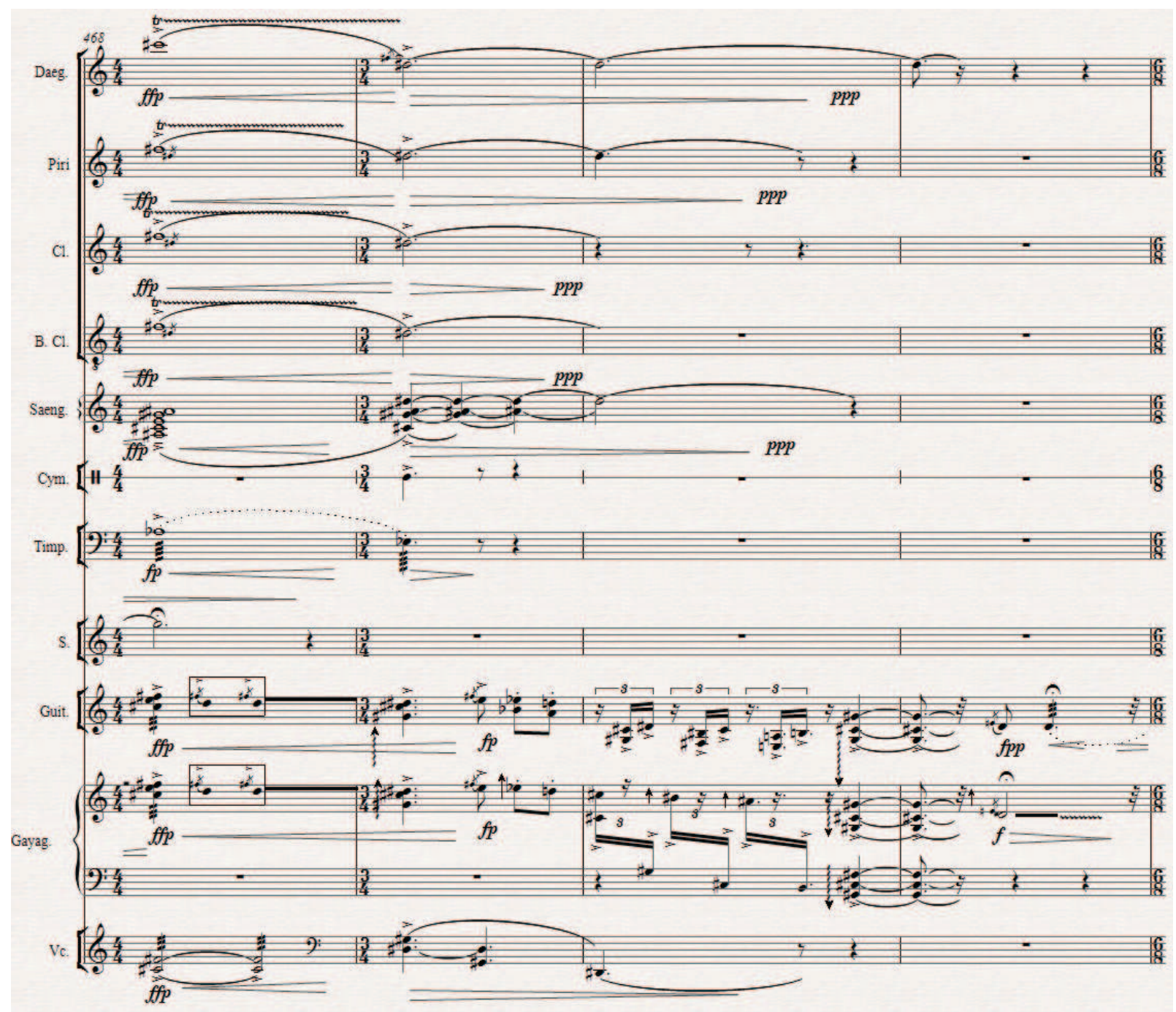

Example 110: A short transition phrase from the original score (bb.468-71)

In the production Sara envisaged this "imaginary encounter" as a visual and emotional extension of the climax which, in the event, seemed to call out for music of a similarly sustained intensity. After the production was over I decided to revise this section, extending the original four bars to fourteen bars, with a music that I feel provides a stronger, more dramatically satisfying conclusion to the work. 


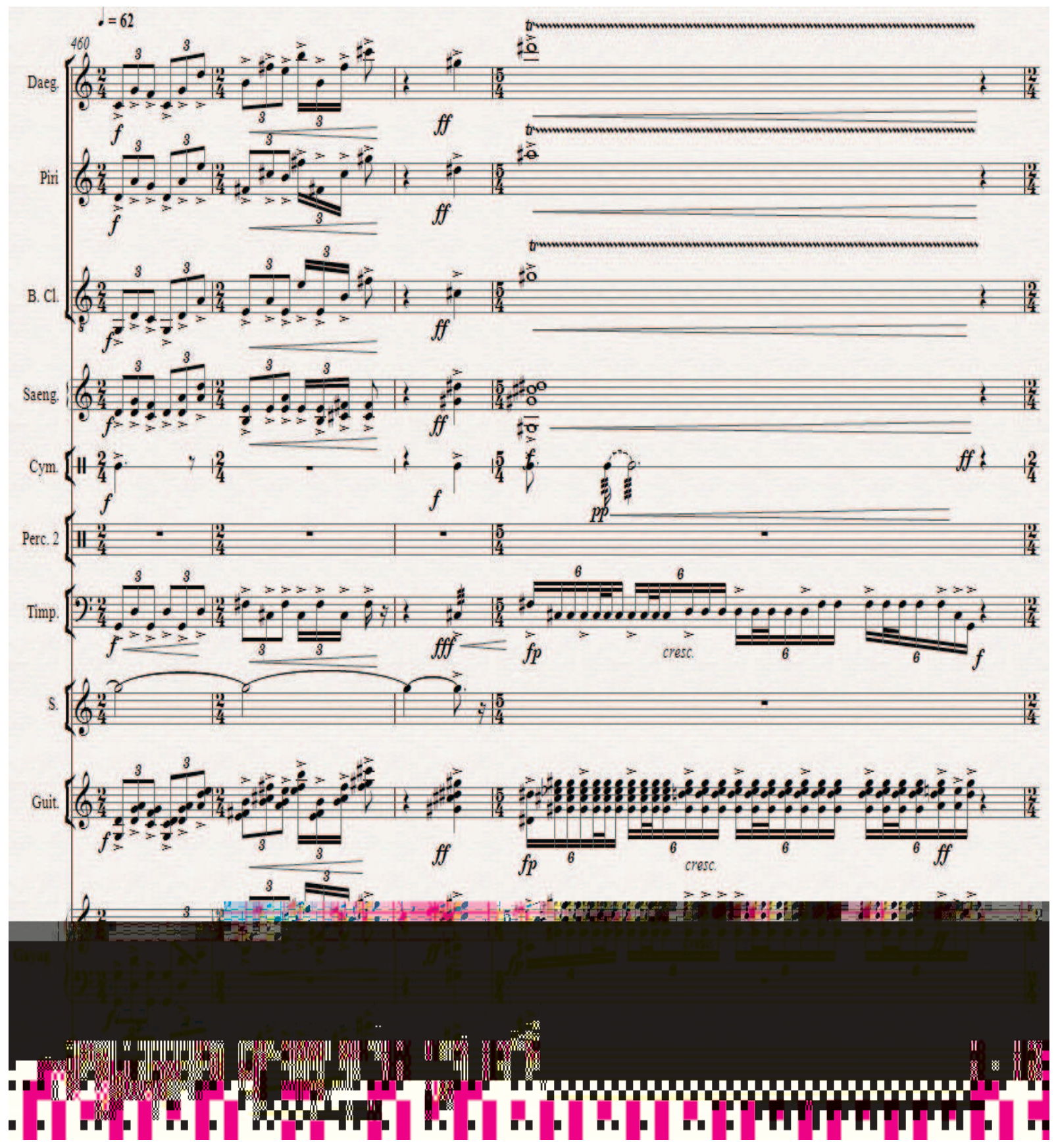

Example 111: Beginning of the revised score (bb.460-64) 


\section{Conclusion}

This thesis has traced the twentieth century concept of compositional practice that has moved from West to East and from East to West, or, as propounded by Chou Wen-chung (b.1923), a "re-merger" of oriental and occidental musical practice. The vast variety of musical currents that developed during the twentieth century is undergoing a process of synthesis in the twenty-first century as the world redefines itself as a "global village".

I myself have lived in New Zealand for sixteen years and the multicultural character of this society has become a fundamental influence on my creative process, as can be seen in the concept behind my works Wăngē (輓 歌) Elegy, and Wang, both of which integrate multicultural musical elements from China, Indonesia and New Zealand.

At the same time, as a Chinese composer I identify deeply with the aspirations of the group of Chinese artists who, like myself, emerged after the Cultural Revolution. Operas and other music-theatre works have been among the most important contributions to contemporary musical repertoire maby by the composers of my generation, works that have introduced into the international arena new concepts and musical ideas. These compositions were often inspired by Chinese musical traditions and particularly by our experiences during the years 1967-77.

Chinese language, the form and style of Chinese opera (xìqü) and of Chinese folk music have been especially important in my work. The five works included in volume two of this thesis all use Chinese language. Four of the five exploring different aspects of language may be considered music-theatre, one being an opera scene intended for stage production. Several works use Chinese instruments (as well as traditional Korean, Indonesian and Maori taonga puoru).

The regional styles of qüyì (曲 艺) and Sichuan opera chuānjù̀ (川 剧) are particularly relevant to my work, this fact having necessitated a brief survey of the history of the forms and a description of their structure and character. In describing the four skills required of a 
xìqü performer - niàn, chàng, zuò, dă - an expanded definition is proposed to encompass other aspects of the production including performance directions in the text, the writing of the music (since traditionally there was no "composed score"), and in certain of the musical elements, particularly the use of percussion. A wide range of vocalisation techniques are used in xìqü along a continuum between stylized recitation and pure song; many of these bear similarities to Schoenbergian sprechgesang.

The works included in this thesis have explored in different ways the setting of Chinese texts, as well as different approaches to the concept of music-theatre. Drawing inspiration from traditional Chinese styles of vocalization, they have used the principles of musical translation and integration, as discussed in the introduction of this thesis.

The vocal Xià Sìchuān (下四川) Going Down Sichuan Province, scored for vocal ensemble, may be considered a translation of a mountain song (shāngēe from the central-northern region of Gansu province. Although the material is drawn from a notated transcription, the original recording upon which this transcription is based was used as the reference for capturing the style and character in the "translation". The challenge for the singers for whom the work was written (The Song Company of Sydney) was to reproduce the authentic singing style of folksinger Ji Zhengzhu, both the style of vocal production and the special character of the ornamentation. In doing so, the Song Company singers participated in this process of "translation". The concept of the composition was to reveal the imlied drama within the folk text, and to distribute "roles" among the singers, as in the courtship exchanges characteristic of huā'er (flower - young girls' - song) and shàonián (young men's song).

In Wăngē (輓 歌) Elegy, a work for Chinese zhēng, Indonesian gender and voices, Tao Yuanming's poem is presented as a xìqü recitation, integrating the Chinese xìqü style of performance as a kind of theatrical monologue. The gender plays in an unconventional way, with the intention of imitating the "bent pitch" of the depressed strings of the zheng. The echoing of single notes by these two instruments from different parts of Asia is a 
crosscultural dialogue that attempts to portray the sense of aloneness found in the "death" theme of the poem.

The musical setting of Chinese texts requires consideration of the "tones" of the spoken language, the prescribed intonation of each syllable (character). The ambiguities and multifaceted meanings of Chinese as "sound" are exploited in Wang, a quasi-theatrical work which, ironically, cannot have a text in Chinese written form. The "integration" of the prescribed intonation of spoken Chinese - the tones - into a this quasi music-theatre explores the potential of a single sound. The work conjures up for the Chinese speaker a rich and ambiguous world of meaning, while for the non-Chinese speaker it explores a totally abstract sound-world of "wang". On another level of integration, the exotic instrumentation of Wang blends timbral sonorities from China, Indonesia, and indigenous New Zealand with Western-styled singing.

Jiǔ Dé Sòng (酒德颂) Hymn to the Virtue of Wine, scored for five singers, zhēng, shēng and two húqin, was part of the Six Hermits project involving seven composers from different countries. My work integrated the dynamic concepts of niàn, chàng, zòu and dă of Sichuan opera into a music-theatre composition. The work also derived musical materials from chuānjü gāoqiān, such as onomatopoeic vocalizations imitating percussion sounds, from bāngqiāng (singing) and yùnbái (sprechgesang) in chuānjù̀ style, and from the niànbái (recitation), in both Chinese and English. Incorporating these techniques into a work of music-theatre, prepared me for the task of composing Scene of the First Night, where I extended further this principle of integration. 醉 (Zui) Drunkenness, a work for solo zhèng, was originally performed as an interlude between the major sections of the Six Hermits project,

The operatic scene Chüyè (初 夜), Scene of the First Night, one section of a very large projected opera Fatal Desire can be superficially described as sitting within the tradition of Western opera, even though the sung language is Chinese and the accompanying ensemble mixed Western and non-Western instruments. The use of the leitmotif as a unifying 
principle is a technique borrowed from a Wagnerian tradition, and the staging conceived in a style that would not be unfamiliar to a Western audience. However there are numerous musical elements that have been embedded at varying levels, which have their origins in Chinese theatre, and Chinese folk traditions. The use of jǐnglā mànchàng Chinese percussion rhythms accompanying a free-flowing vocal line is designed to merge naturally into the drama, and the niànbái recitation style borrowed from xìqü enhances the emotional quality of the vocalist. The incorporation of folk vocal chant, kuàibănshī, shapes the musical structure of the climax section. This deep level of integration of elements of chuānjǜ musical style, including bănqiāng (music style of xìqü), bănshì (the metres of xìqü) is combined with the leitmotif principle, opening up an array of options for developing the music dramatically, in ways not possible in traditional Chinese theatre.

The adoption of multicultural elements integrated into the fabric of a new work, at several levels, and informed by the various aesthetic philosophies behind these elements, represents a rich resource for the contemporary composer, as well as a creative challenge. Alongside my Chinese heritage, the multicultural character of New Zealand, with its indigenous people and people of diverse origins, has also exerted a fundamental influence on my creative processes, as can be seen in the concept behind my works represented here. The works in this thesis represent a consolidation of my musical practice, and an affirmation of my belief that the music of the twenty-first century will be vastly enriched by the many musical traditions which are available to all of us who inhabit this global village. I believe the once considered dichotomies of East versus West, nationalism versus internationalism, modernism versus tradition are no longer relevant issues for the composer of today. 


\section{Glossary of Chinese Musical Terms}

bái (白) Short for niànbái (念 白), stylized dialogue in Chinese xìqü.

băn (板)

- Wooden clappers, consisting of three pieces of tán wood, two tightly bound together and struck with the third piece. Played by the gŭshī (鼓师), ensemble leader.

- The strong first beat, played with the wooden clappers (băn).

bāng (帮) The music sung by the “chorus” (zhònghé 众和) in chuānjǜ gāoqiān, performed by a soloist or a group or a combination of both.

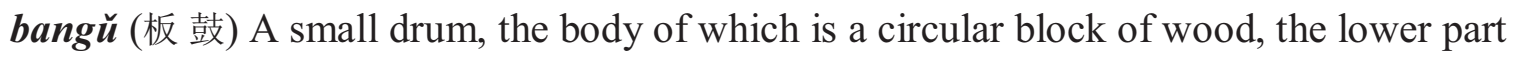
of which is hollowed towards an small opening (5 to $6 \mathrm{~cm}$ in diameter) in the centre of the upper surface. Taut leather covers the whole of the upper surface. The ensemble leader gŭshī beats the centre of the drum gŭxīn (鼓 心) to produce a sharp high-pitched sound.

băngzi (梆 子) Wooden clappers comprising two pieces beaten together.

bāngzixì (梆子戏) Clapper opera, using băngzi.

bănhú (板 胡) A two-string sptke fiddle, with a coconut-shell body and thin wooden soundboard.

bănqiāng (板 腔) The musical style that characterizes Chinese xìqü.

bănqiāng ť̆ (板腔体) A system of theatrical musical forms of Chinese xìqü̆, based on a sectionalised arrangement of varied metres and tempi of arias (chàngqiāng 唱 腔). 
bănshì (板 式) Tempo and metre, as dictated by the percussion leader, the gŭshī.

băn yăn (板 眼) The metre, defined by the distribution of strong and weak beats.

bănzhŭn (板 准) Singing in time, on the beat.

bāolăotóu (鲍老头) Old Man Bao, a particular musical-poetic form (qü̆pái).

biàn gōng (变 宫) An additional note to Chinese pentatonic mode system. A biàn gōng note is a minor second lower (solfa syllable $t i$ ) from the $\boldsymbol{g} \overline{\boldsymbol{o}} \boldsymbol{\text { ng note. }}$

biàn zhř (变 徵) As above Chinese pentatonic mode system. A biàn zhǐ note is a minor second lower (solfa syllable $f e i$ ) from the zhı̆ note.

chàng (唱)

- Short for chàng gōng (唱 功), the specific skill of singing Chinese xìqü.

- On-stage solo singing in Sichuan gāoqiān opera, whose origin is in túg $\overline{\boldsymbol{e}}$ (徒 歌), a style of the unaccompanied solo singing.

- In this thesis the concept of chàng is expanded to include music (both as composition and performance) as well as the singing skill.

chàng huādēng (唱花灯) To sing a style of regional song called huādēng.

cȟ̆cùn (尺寸) In Chinese xìqü, to sing in the appropriate tempo

chuān èrhú (川二胡) A slightly larger version of the èrhú two-string spike fiddle used in chuānjǜ húqúnxì.

chuānjù (川 剧) The regional style of opera found in south-west China - Sichuan, Yunnan, and Guizhou. Chuānjǜ has five categories.

chuānjù̀ gāoqiān (川剧高腔) A category of chuānjǜu, noted for its high vocal tessitura, 
and a percussion-only accompaniment.

chuānjù̀ huādēngxì (川剧花灯戏) A category of chuānjǜ, less developed than other categories, and regarded as indigenous to Sichuan. Besides percussion, its accompaniment uses a guttural-sounding two-string “fat fiddle" (pàngtǒngtǒng 胖筒筒), sometimes for comic effect.

chuānjǜ húqínxì (川剧胡琴戏) A category of chuānjǜ characterized by the use of the xiăohúqín (小胡琴) high-pitched two-string spike fiddle. Other instruments in the ensemble are the two-string fiddle of Sichuan (chuān èrhú 川二胡), and the fourstring plucked zither (yuèqín 月 琴). Chuānjü húqínxì draws on two musical styles - èrhuángqiāng (二黄腔) and xīpíqiāng (西皮腔) - which may be utilised individually or in combination, depending on the dramatic requirements.

chuānjù̀ kūnqiāng (川剧昆腔) A category of chuānjùu, with origins in $\boldsymbol{k} \bar{u} n q \grave{u}$. The dominant accompanying instrument is the $\boldsymbol{d i} \boldsymbol{i} \boldsymbol{i}$ (笛子) (bamboo flute). Once $\boldsymbol{k} \overline{\boldsymbol{u}} \boldsymbol{n} \boldsymbol{q} \dot{\boldsymbol{u}}$ had been imported to Sichuan, it became known as chuānqūn (short for Sichuan kūnqiāng).

chuānjù̀ tánxì (川剧弹戏) A category of chuānjǜ, with Qing dynasty origins from qin opera of Shanxi (qínqiāng 秦 腔). It belongs to the clapper opera (băngzi 梆 子) tradition, using băngzi (clappers), as well as a two-string fiddle (gàibănżi 盖板子) as the principal accompanying instrument. The poetic form of tánxì texts is the same as chuānjü húqín opera, but musically it uses specific seven-tone modes called tiánpí (甜 皮) and kŭpí (苦 皮).

cūsăng (粗 嗓) The rough style of vocal production used by jìn (净) (painted-face) roles.

dц̌ (打).

- Short for dă gōng (打 功), acrobatic skills, a stagecraft version of gōngfū (功夫) martial arts. 


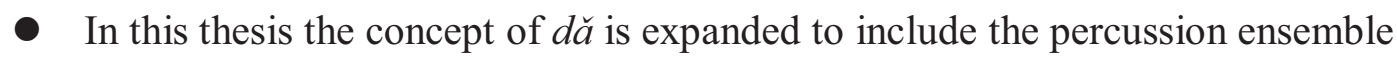
which provides the accompaniment for chuānjǜ gāoqiāan. The concept also encompasses aspects of presentation (dăzào 打造).

dàbó (大 钵) Large cymbals used in chuānjǜ.

dàluó (大锣) A large gong used in chuānjǜ.

dàobăi (道 白) Recitation and dialogue in Chinese xìqü̆ which uses local dialect.

dăobăn (导 板) A name of bănshì (板 式), an introductory phrase that is always in free metre, and a free tempo.

dāodāolìng (叨叨令) A Chattering Song, a particular musical-poetic form (qü̆pái).

diàosăng (吊嗓) A technique of voice production where vowels are extended through a variety of pitches, particularly from low to high, often as an exaggerated vibrato.

dingchăng shī (定场诗) A poem to open the performance.

dingqiāng (定 腔) Known as a “fixed style" of bāng (see bāng) whereby a section of music is always of the same structure. This style is found in chuānjü gāoqiān.

$\boldsymbol{d i z} \boldsymbol{i} \boldsymbol{i}$ (笛子) A side-blown bamboo flute, with one hole covered with a resonating membrane.

duānzhènghăo (端正好) Proper and Good, a particular musical-poetic form (qǘpái).

dùnȳ̄n (顿 音) Staccato.

èrhú (二 胡) A double-string spike fiddle, the most popular of the family of huqin family of traditional Chinese bowed string instruments.

èrhuáng yăobăn (二黄摇板) Lit. "shifting the rhythm of metre”. A musical texture found 
particularly in traditional Chinese operas. This is a bănshì (板 式) of èrhuáng.

èrhuángqiāng (二黄腔) ל̀rhuáng music style, one of the two types of aria in

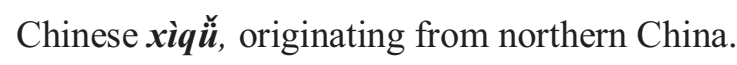

èrliù (二 六) A bănshì (板 式), equivalent to Western simple duple time, always in a moderate to lively tempo (allegro).

èrshāa (二 鞄) Secondary Coda, a particular musical-poetic form (qü̆pái).

gàibănzi (盖板子) A spike fiddle with two metal strings, originating from the èrxián (二 弦) fiddle of Shanxi qin opera. The neck is $60 \mathrm{~cm}$ long and the sound-board $10 \mathrm{~cm}$ in diameter. It is the principal accompaniment of chuānjǜ tánxì. The player wears four metal thimbles.

gāoqiān (高 腔) High vocal tessitura.

gémìng xiàndài gējù̀ (革命现代歌剧) Modern revolutionary operas, such as Jiāngjiě (江 姐) Sister Jiang and Hónghú Chìwèiduì (红湖赤卫队) The Red Guards on Lake Hong.

gémìng xiàndài jīngjù (革命现代京剧) Modern revolutionary Beijing operas, such as Lóngjiāng Sòng (龙江颂) Ode to Dragon River and Dùjüān Shān (杜鹃山) Mountain Dujuan.

gémìng yàngbănxì (革命样板戏) Revolutionary model plays. The so-called "Eight Revolutionary Model Plays" include five Beijing operas (The Legend of Red Lantern, The Sparks in the Reed Marshes, Takeover by Strategy of Mount Tiger, Raid the White-Tiger Regiment and On the Docks), two ballets (The Red Detachment of Women and White-Haired Girl), and a symphony, The Sparks in the Reed Marshes.

gēyángqiān (戈阳腔) The musical style of Jiangxi. 
Gŭlìn huāēeng (古萄花灯) A type of performance (music and dance) local to Gulin county traditionally performed during the Chinese New Year holiday, particularly on the Lantern Festival, the final day of the holiday.

gōng (宫) One of the principle notes of wŭshēng diàoshì (五声调式) (pentatonic mode).

gúnchuí (滚 捶) A drum roll.

gǔnxiùqiú (滚绣球) Rolling An Embroidered Ball, a particular musical-poetic form (qǘpái).

gǔxīn (鼓 心) The centre of the drum head.

hàndiào (汉 调) A theatrical musical style from Hubei and Shanxi provinces.

$\boldsymbol{h u} \bar{a} d \bar{e} n g$ (花 灯) A local music style that is always performed in the Lantern Festival.

huáȳ̄n (滑 音) Glissando.

huīdiào (徽 调) A theatrical musical style from Anhui province.

huóqiāng (活 腔) Known as a "flexible style" of bāng whereby a section of music is always variable and flexible. This style is found in chuānjù gàaoqiān.

húqín (胡 琴) Generic name for all Chinese spike fiddles, almost all two-string.

jiéżòu (节 奏) Rhythms.

jīngbăi (京 白) In the opera, the Beijing dialect is used as the spoken dialogue.

jīnghú (京 胡) A high-pitched two-string spike fiddle, the principal accompanying instrument in Beijing opera. 
jǐnlā (紧 拉) A special musical texture involving rhythmic pulsation, while the vocal sings long notes in mànchàng (慢 唱) style.

\section{Jiǔgōng Dàchéng Nánbéi Cí Gōng Pǔ 《九宫大成南北词宫谱》(Texts and Musical} Notations of Southern and Northern Songs in Nine Modes) A collection of southern and northern songs comprising of 2,794 distinct qüpái (although together with variants the total would be 4,466), compiled by Zhou Xiangyu 周祥钰, Zou Jinsheng 邹 金生, Xu Xinghua 徐兴华, Wang Wenlu 王文禄, Xu Yinglong 徐应龙, and Zhu Tingmiao 朱廷缪 in collaboration with many folk musicians in 1746 (the eleventh year of Qianlong's rule, of the Qing dynasty).

jüé (角) One of the principal notes of wŭshēng diàoshì (五声调式) (pentatonic mode).

kuàibănshū (快板书) A category of qǚỳi, is a form of storytelling with rhythmical percussion accompaniment.

kuàihuósān (快活三) Happy third, a particular musical-poetic form (qüpái).

kuàisânyăn (快三眼) A bănshì, equivalent to Western simple quadruple time, always in a moderate tempo (moderato).

$\boldsymbol{k} \overline{\boldsymbol{u}} \boldsymbol{n} \boldsymbol{q} \breve{\boldsymbol{u}}$ (昆 剧) $\boldsymbol{K} \overline{\boldsymbol{u}} \boldsymbol{n}$ opera. By the end of the sixteenth century, $\boldsymbol{k} \overline{\boldsymbol{u}} \boldsymbol{n} \boldsymbol{q} \ddot{\boldsymbol{u}}$ spread from the Suzhou region to the rest of China. The second half of the sixteenth century marked the beginning of the Chinese xiqqü era, from which all other forms of Chinese theatre performed today evolved. Consequently, many $\boldsymbol{k} \overline{\boldsymbol{u}} \boldsymbol{n} q \ddot{\boldsymbol{u}}$ plays have been adapted for other types of xìqü.

kŭpí (苦 皮) One of two aria types from chuānjù̀ tán opera. It uses qīshēng diàoshì (heptatonic mode), but with emphasis on piān ȳ̄n (偏 音) (additional notes) biàn gōng (变 宫) a minor second below the gōng), and qīngjüé (清 角) a minor second above the jüié). Musically, it is slow and sorrowful. 
léiqǔn (雷 琴) A moderately large two-string spike fiddle, known for its mimicry of birdsong and the opera singer's voice.

liùshēng diàoshì (六声调式) Hexatonic mode, a six-note mode that is based on the wŭshēng diàoshì, with the addition of either piān ȳ̄n (偏 音) (additional note) biàn gōng (变 宫) note (a minor second lower from the note of gōng) (solfa syllable $t i$ ) or qīngjüé (清 角) note (a minor second higher from the note of jüée (solfa syllable fa). Liùshēng diàoshì has ten hexatonic variants.

liúshuı̌ (流 水) A bănshì (板 式), equivalent to Western simple 1/4 time, always in in a fast tempo (vivace).

lúshēng q苔 (芦笙曲) Songs of the lúshēng (a folk mouth-organ, comprising generally six bamboo pipes, each containing a free reed).

măluó (马 锣) A small hand-held chuānjǜ gong.

mànbăn (慢 板) A bănshì, equivalent to Western simple quadruple time, always in a slow tempo (largo).

mànchàng (慢 唱) Slow singing that is always accompanied by ǰ̌nlä (紧 拉), a fast rhythmic pulsation.

mànsânyăn (慢三眼) A bănshì , equivalent to Western simple quadruple time and always in a slow tempo (adagio).

Măo Zědōng sīxiăng xüānchuánduì (毛泽东思想宣传队) The Song and Dance Propaganda Troupe of Mao Zedong's “Thought”, during the Cultural Revolution.

mǔzi diào (母子调) A binary form of qü̆pái, called mǔzi diào (“mother and son”). 
niàn (念)

- Short for niàn gōng (念 功): the skill of non-singing vocalisations including recitation and dialogue.

- In this thesis the concept of niàn is expanded to include the text, both as the method used to assemble the libretto as well as the skill of the roles of Chinese xìqü.

niànbái (念 白) Non-singing vocalisations including recitation and dialogue.

pàngtǒngtǒng (胖筒筒) A two-string spike fiddle with a large resonator, also called "fat fiddle".

pēnkŏu (喷口) A significant technique of dàobăi, using strongly accented plosives.

piān ȳ̄n (偏 音) An additional note of Chinese pentatonic mode, such as rùn

(闰) (solfa syllable te), a major second lower from the note of $\boldsymbol{g} \overline{\boldsymbol{o}} \boldsymbol{n g}$, qīngjüié (清 角) (solfa syllable $f a$ ), a minor second higher from the note of jüé.

pīhuăng (皮黄) A contraction of xīpíqiāng (西皮腔) and èrhuángqiāng (二黄腔), representative styles of regional operas in China.

píngshī (评 书) A term used in Beijing for the category of qü̆ỳ storytelling.

qín (琴) Short for gǔqin (古 琴), an ancient Chinese seven-string zither, one of the qín qi shū huà (琴棋书画) “Four Arts” of the Chinese scholar.

qiāngchŭn (腔 纯) Singing in the appropriate local style

qīngjüé (清 角) An additional note to Chinese pentatonic mode system. A qīngjüé note is a minor second higher from the note of $j u ̈ i e ́$ (solfa syllable $f a$ ).

qūng yuè yīnjiē (清乐音阶) One of the three categories of qūshēng diàoshì. It is based on 
the wǔshēng diàoshì, with additions of both biàn gōng (变 宫) and qīngjüé (清 角) notes.

qínqiāng (秦 腔) An original qín opera of Shanxi province.

qūshēng diàoshì (七声调式) Heptatonic mode. A seven-note mode that is based on the wǔshēng diàoshì, with the addition of the pair piān yīn (偏 音) (additional note). It has three categories of mode:

- qūngyuè yīnjiē (清乐音阶) with the addition of the pair biàn gōng (变 宫) (solfa syllable $t i$ ), a minor second lower from the note gōng, and qīngjüié (清 角) (solfa syllable $f a$ ), a minor second higher from the note jüé.

- yăyuè yīnjiēe (雅乐音阶) the pair qīngjüé (清 角) and rùn (闰) (solfa syllable te), a major second lower from the note gōng.

- yànyuè yīnjiē (燕乐音阶) the pair biàn gōng (变 宫) and biàn zhǐ (变 徵) (solfa syllable $f e i$ ), a minor second lower from the note $\boldsymbol{z h}$.

Qīshēng diàoshì thus has fifteen heptatonic variant modes.

qúyán (齐 言) A couplet comprising two phrases of equal length and metre.

qüpái (曲 牌) Arias of Chinese xìqü̈, comprising two phrases of text, each with seven or ten

characters. While always in the "positive" gōng mode, the following pair of phrases generally moves to a new tonic.

qǘpái ti (曲牌体) The music of Chinese xìqü. It is an integral part of the suite form bănqiāng ť̆ (板腔体), a form based on a sectionalised arrangement of varied metres and tempi of chàngqiāng (song), particularly for the bănzi (梆 子) and pīhuăng (皮 黄) styles of regional operas.

ruăn (阮) A moon-shaped Chinese fretted lute, named after the poet-musician Ruan Xian (234-305). 
rùn (闰) An additional note to Chinese pentatonic mode system. A rùn note is a major second lower from the note of $\boldsymbol{g} \overline{\boldsymbol{o}} \boldsymbol{n}$ (solfa syllable te).

rùnyīn (润 音) The technique of vocal expressivity.

sănbăn (散 板) A bănshì (板 式) that is always in free tempo and without metre.

shāwěi (慜 尾) Coda, a particular musical-poetic form (qǘpái).

shāng (商) One of the principle notes of wǔshēng diàoshì (五声调式) (pentatonic mode).

shuăháier (要孩儿) Playing Dolls, a particular musical-poetic form (qǘpái).

shǔbăn (数 板) Rhythmical recitation.

$\boldsymbol{s h} \boldsymbol{u} \overline{\boldsymbol{o s h}} \overline{\boldsymbol{u}}$ (说 书) A category of qü̆ỳ storytelling, popular in many Chinese provinces.

shuōshürěn (说书人) Storyteller.

$\boldsymbol{s} \bar{u} \boldsymbol{b} a \check{i}$ (苏 白) The use of Suzhou dialect in spoken dialogue, in Chinese xìqü

$\boldsymbol{s} \overline{\boldsymbol{u}} \boldsymbol{b} \boldsymbol{o}$ (苏 钵) Small cymbals originating from Suzhou, “s̄u” being short for Suzhou.

suǒnà (吵 呐) A double-reed woodwind instrument, having a sharp sound.

tăngg й (堂 鼓) A medium-sized double-headed drum.

tăngxiùcái (倘秀才) Surprised Scholar, a particular musical-poetic form (qǘpái).

tàoshù (套 数) A suite of qǘpái.

tiánpí (甜 皮) One of two aria types from chuānjǜ tán opera, using qīshēng diàoshì. 
Musically, it is fast, sweet and cheerful.

tíngdùn (停 顿) The silence between syllables.

túge (徒 歌) Unaccompanied singing style.

tū̄ȳ̄n (拖 音) Prolongation of a sung note.

wénchăng xiăodá luóğ̌ (文场小打锣鼓) One of two types of percussion styles used in chuānjǜ. It is specifically for the "literary play" style. It employs soft sound instruments, such as: small cymbals and small gong.

wényì gōngzuòtuán (文艺工作团) Song and dance troupes that existed in most cities of China during the Cultural Revolution.

wú băn wú yăn (无板无眼) A phrase of music without metre in b̆ănshì, e.g. dăobăn (导 板). wǔshēng diàoshì (五声调式) Chinese pentatonic mode, consists of five principle notes:

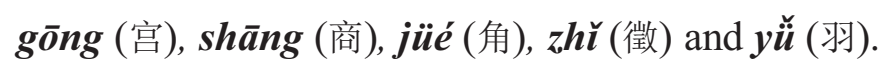

xiäntiān (先天韵) Rhyme scheme.

xiaobo (小 钹) Small cymbals used in chuānjǜ.

xiăoluó (小 锣) Small gong used in chuānjǜ.

xiărhúqín(小胡琴) A high-pitched two string spike fiddle, similar to jīnghú.

xīpíqiāng (西皮腔) A theatrical music style origining from southern China, and one of the two types of aria in Chinese xìqü.

xìq $\breve{\ddot{u}}$ (戏 曲) The generic term for all provincial Chinese operas. 
yăn (眼) The weak beats, played with a small high-pitched drum băngŭ (板 鼓).

yáng suǒnà (洋唢呐) A “foreign” suǒnà (e.g. clarinet).

yīănèryăn (一板二眼) A bănshì.

yībănsānyy̆n (一板三眼) A bănshì equivalent to Western simple quadruple time, e.g. mànbăn (慢 板) and kuàisânyăn (快三眼).

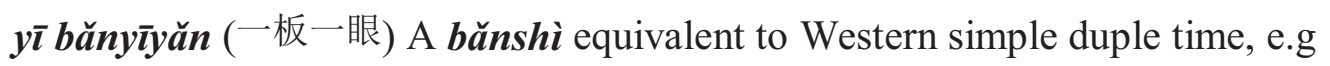
yuánbăn (原 板) and èrliù (二 六).

y̌nzi (引子) The opening part (overture) of a performance. It has two parts, the first being recitation and the second sung with accompaniment.

$\boldsymbol{y} \overline{\boldsymbol{i}} \boldsymbol{s} \boldsymbol{\overline { a }}$ (一 繁) Penultimate Coda, a particular musical-poetic form (qǘpái).

yǒubănwúyăn (有板无眼) A bănshì, a metre of single beats, e.g. kuàibăn (快 板), liúshuǔ (流 水) and yáobăn (摇 板).

$\boldsymbol{y} \breve{u}$ (羽) A principal note of wǔshēng diàoshì (五声调式) (pentatonic mode).

yuèyü diào (语 调) The intonation (tones and register) of dàobăi (recitation).

yuèjù̀ (越 剧) Yuè opera, popular in the south of the region Yangtze River, originated in Shaoxing County, Zhejiang Province, in the early $20^{\text {th }}$-century.

yuánbăn (原 板) A bănshì (板 式), equivalent to Western simple duple time and always in a moderate tempo (andante).

yuèqín (月 琴) A moon-shaped four-string plucked lute. 
yún (云) A ancient term for dàobăi (recitation).

yǜnbăi (韵 白) Rhyming recitation, in couplets of 5, 7, or 10 syllables per line, accompanied by percussion (shŭbăn 数 板).

yù̀nqì (运气) Control of breathing.

zhēng (筝) A 21-string Chinese zither with raised movable bridges.

zhènggōng (正 宫) A “positive” gōng in a pentatonic mode.

zhǔ (徵) A principal note of wŭshēng diàoshì (五声调式) (pentatonic mode).

$\boldsymbol{z} \boldsymbol{h}$ ŭdi (竹 笛) Another name for the dízi (bamboo flute).

zhònghé (众 和) The music sung by the “chorus" in chuānjù̀ gāoqiān.

zhòngyīn (重 音) Accent.

zìqīng (字 清) Clarity of diction. 


\section{Bibliography}

Allen, Joseph. "Translation Gu Cheng". An "Introduction” to Sea of Dreams: The Selected Writings of Gu Cheng. New York: New Directions, 2005. Available from http://www.cipherjournal.com/html/allen_gu_cheng.html: accessed, 11 May 2010.

Berg, Alban. “A word about Wozzeck”. Modern Music, November- December, 1927, pp. $22 \mathrm{ff}$.

Berg, Alban. Georg Buechner"s Wozzeck. Op. 7. Score (486 p.), revised by Apostel, H.E. English translation by Eric Blackall and Vida Harford. Vienna: Universal Edition, c1955.

Berg, Alban. Wozzeck, Opera libretto. London: J. Calder, 1990.

Bi Minghui 毕明辉. Èrshi Shìji Xīfāng Yīnyuè Zhōng de Zhōnggóu Yīnsì (20 世纪西方音乐中的 “中国因素”). ("Chinese Elements" in Western $20^{\text {th }}$ century Music). Shanghai: Shanghai Conservatory of Music Publishing House, 2007.

Body, Jack. "Sex, Politics, Religion - And Music". Massey University Composer Address. Edited by Robert Hoskins, School of English and Media Studies, College of Humanities and Social Sciences. Palmerston North: Massey University, 1999.

Brady, Anne-Marie. "Dead in Exile: The Life and Death of Gu Cheng and Xie Ye". China Information. Vol. 11, no. 4, March, 1997, pp. 126-148.

Camus SJ, Yves. "Matteo Ricci”s legacy: a loving patience". Online Journal of British Jesuits, 2010. Available from http://www.thinkingfaith.org/articles/20100511_1.htm: accessed 24 September 2010.

Chan Wing-tsit. "Chinese Philosophy". The New Encyclopedia Britannica . Macropedia Chicago: The University of Chicago, Helen Hemingway Benton, Publisher. Vol. 4, 1973-1974.

Chen Qiaosheng 陈桥生 (ed.). Zhōnggóu Gǔdiăn Shīcí Xìnshăng 中国古典诗词欣赏 - Tao Yuanming 陶料明. (The Enjoyment of Chinese Classical Poems - Tao Yuanming). Beijing: Wuzhou Chuanbo Chubanshe, 2006.

Chen Yanni 陈燕妮. Chen Yanni cáifănglù 陈燕妮采访录: Zāoyù Méigóu 遭遇美国: “Tan Dun 谭盾. Meeting in America: Tan Dun”. Beijing : Zhongguo she hui chu ban she. 1997. 
Chen Zishan 陈子善 (ed.). Shìrén Gù Chéng Zhīshı̌ 诗人顾城之死. (The Death of Poet Gu Cheng). Shanghai: Shanghai Renmin Chubanshe, 1993.

Chou Wen-chung. "Music by Asian Composers". Journal of Music in China, Vol. 1, 1999. pp. 111-115.

Chuānjù Liánpǔ 川剧脸谱. (The Facial Paintings of Sichuan Opera). Chongqing: Xueyuan Publishing House, 2009.

Chung-Wen Shih. Injustice to Tou (Tòu Ó Yuān (Dòu É Yuān)) A Study and Translation. Cambridge: Cambridge University Press, 1972.

Cihai 辞 海 (Chinese Encyclopaedia). Shanghai: Shanghai Cishu Press. Literature Volume, 1980.

Dai Weihou 戴維后. Messiaen de Yīnyuè - Fēnxī “Shijiān de Sècăì” 梅湘的音樂-分析”時間的色彩”. (Analysis of Chronochromie of Messiaen). Taipei: Quanyin Yinyue Chubanshe Youxian Gongsi, 1990.

Dobkin, Matt \& Smith, Ken. "Tan Dun Operatic Odyssey" (2006). Available from http://www.metoperafamily.org/metopera/news/features/detail.aspx?id=1945; accessed 7 September 2010.

Findeison, Raoul D. “Two Works - Hong (1930) and Ying'er (1993) as Indeterminate Joint Ventures”. Li Xia 李 侠 (Trans.) Essays, Interviews, Recollections and Unpublished Material of Gu Cheng, 20th Century Chinese Poet: The Poetics of Death. New York: The Edwin Mellen Press, 1999.

Finley, Michael. "Alvin Toffler"s and the Third Wave". Available from http://www.skypoint.com/members/mfinley/toffler.htm; accessed 7 September 2010.

Forte, Allen. "The Mask of Tonanity: Berg's Symphonic Epilogue to Wozzeck". Alban Berg: Historical and Analytical Perspectives, ed. by David Gable and Robert P. Morgan. New York: Oxford University Press, 1991.

Gálik, Marián. "Gu Cheng and Xie Ye: Contemporary Chinese Poets Who Died Too Early". Asian and African Studies, Vol. 3, no. 2, 1994, pp. 116-139.

Glover, Jane. "Recreating Orfeo for the modern stage: solving the musical problems", in Claudio Monteverdi, Orfeo, ed. John Whenham. Cambridge: Cambridge University Press, 1986 (Cambridge Opera Handbooks), pp. 138-155. 
Griffiths, Paul. "Sprechgesang”. The New Grove Dictionary of Music and Musicians, Vol.18. London: Macmillan Publishers Limited, 1980.

Guan Hanqing 关汉卿, Snow in Midsummer. Wang Jisi 王季思. 中国十大古典悲剧(上) Zhōnggóu Shídà Gǔdaìn Bēijù̀ (Shàng). (A Collection of Ten Classical Tragedies of China). Vol. I, Shanghai: The Arts Publishing House, 1990.

Gu Cheng. Wǒ Zài Děngdài Š̌wáng de Shēngyīn “我在等待死亡的声音” . (“I Am Waiting for the Voice of Death"). Speech made at a conference on Chinese contemporary poetry. London, In June 1991.

Gu Cheng 顾 城. \& Lei Mi 雷 米.Ying'er 英 儿. Beijing: Zuojia Chubanshe (Zuojia Press), 1993.

Gu Cheng 顾 城. \& Lei Mi 雷 米.Ying'er 英 儿. Beijing: Huayi Chubanshe (Huayi Press), 1993.

Gu Cheng 顾城. Méiyǒn Mùdè de “Wǒ”没有目的的 “我”. (“Non-objective of “Me” ”). Available from http://www.gucheng.net/gc/gczp/gczx/200502/164.html; accessed 30 August 2010.

Gu Cheng 顾 城. “Sixxiāngqǚ”思乡曲. (“Homesick”). Jīliú Dăo Huà Huà Běn 激流岛画话本. (Drawings and Texts from Waiheke Island). Shanghai: Shanghai Sanlian Shudian, 1996.

Gu Cheng 顾 城. Gu Cheng Shī Qüánbiān 顾城诗全编. (The Complete Poems of Gu Cheng). Shanghai: Shanghai San lian shu dian, 1996.

Gu Xiang 顾 乡. Wǒ Moiànduì Gù Chéng de Zuihòu Shisitiān 我面对顾城的最后十四天. (Gu Cheng's Last Fourteen Days with Me). Beijing: Guoji Wenhua Chubanshe, 1994.

Guo Wenjing 郭文景. Kuángrén Riji 狂人日记. Wolf Cub Village. Manuscript score of opera donated to Jack Body by the composer, 1994.

Gutmann, Peter. Alban Berg's Wozzeck (2003). Available from http://www.classicalnotes.net/classics/wozzeck.html; accessed 18 August 2010.

He Changgao 何长高. Jìngjü Jīcȟ̌ 京剧基础. (The fundamentals of Beijing Opera). Singapore: Telok Ayer Performing Arts Centre, 1989.

Hansen, Peter S. An Introduction to Twentieth Century Music. $4^{\text {th }}$ ed. Boston: Allyn and Bacon, Inc, 1978. Chinese translated by Meng Xianfu 孟宪福. Ėrshí Shìjì Yīnyuè Gàilùn二十世纪音乐概 
论. Beijing: Renmin Yinyue Chubanshe, Vol. 1 was first printed in 1981 and Vol. 2 in 1986.

Huang Shizhong 黄仕忠, Jin Wenjing 金文京, Qiao Xiuyan 喬秀岩 (ed.), Riben suo cang: xi jian Zhongguo xi qu wen xian cong kan 日本所藏：稀見中國戲曲文獻叢刊. (The Collection of Japan: Rare Scripts of Chinese Xiqu Literature). Volume 1, No. 16. Guilin: Guangxi shi fan da xue chu ban she, 2006.

Huai zi 槐子. “Xià sìchuān lìng běnshi” (下四川令本事). (Music Works). Beijing: Chinese Cultural Publishing Cooperation, Vol. 2, 2007.

Jarman, Douglas. Alban Berg: Wozzeck. Cambridge: Cambridge University Press, 1989.

Ji Liankang 吉联抗 (ed.). YùeJi 乐记. (Musical Ideology of Ancient China). Beijing: Renmin Yinyue Chubanshe, 1987.

Jia Daqun 贾大群. Shǔyùn-Gāoqiāng, Yánwén, Liănqu 蜀 韵 - 高 腔, 岩 纹, 脸 谱. (Flavour of Bashu). Manuscript score of opera donated to Jack Body by the composer, 1995.

Kobbe, Gustav. The Complete Opera Book. Chinese translation by Zhang Hongdao 张洪岛. X̄̄yáng Gējǜ Gùshì Qüánjí 歌剧故事全集. Shanghai: Wanye Shudian Yinxing, 1952.

Kouwenhoven, Frank. "Composer Tan Dun: the Ritual Fire Dancer of Mainland China's New Music”. China Information. 1996. Vol. 6, no. 1, pp. 1-24.

Kouwenhoven, Frank \& Schimmelpenninck, Antoinet.”Gou Wenjing - A Composer's Portrait: The string going hong hong hong and the percussion bong Kèèh - that's my voice!”. The Chime Journal. (Spring/Autumn), 1997. Leiden: European Foundation for Chinese Music Research. Vol.1, no. 11, 1997, pp. 8-49.

Lau, Frederick. "Fusion or Fission: The Practice and Politics of Contemporary Chinese Avant-Garde Music". Locating East Asia in Western Art Music. Edited by Yayoi, Uno Everett and Frederick Lau. (Music / Culture) Middletown, CT: Wesleyan University Press, 2004. pp 22- 39.

Li Chongguang 李重光. Chapter 5 “The varieties of Pentatonic Modes that based on Wǔshēng Diàoshi”, Yīnyuè lǐlùn jīchǔ (音乐理论基础) (Basic Music Theory). Beijing: ren min yin yue chubanshe, 1984. pp. 45-57.

Lin Ruilan 凌瑞兰. Àigóu Yīnyuèjiā YanShushi 爱国音乐家阎述诗. (“Yan Shushi: The Patriotic Musician”). Journol: Yuè Fǔ Xīnshēng 乐府新声. Shenyang: Shenyang Conservatory of Music, Vol. 1, 1988.

Liu Jidian 刘吉典. Jingyjù Yinyuè Jièshào 京剧音乐介绍. (Introduction to the Music of Beijing Opera). Beijing: 
Yinyue Chubanshe, 1959.

$\mathrm{Li} \mathrm{Xia}$ 李侠 (ed. with an introduction, essays and translations). Essays, Interviews, Recollections and Unpublished Material of Gu Cheng, 20th Century Chinese Poet: The Poetics of Death. New York: The Edwin Mellen Press, 1999.

Li Xia 李 侠(Trans). Gu Cheng \& Lei Mi: Ying'er, The Kingdom of Daughters. Dortmund: Project Verlag, 1995.

Luo Guanzhong 罗贯中 (ac.1330-1400). Sān Góu Yănyì 三国演义. (Romance of the Three Kingdoms). Beijing: Zuojia Chubanshe, 1953.

Luo Shiping, 罗世平. Masterworks of Chinese Figure Painting from Wei, Jin to Northern and Southern Dynasties (AD 220-285). Beijing: Culture Relic Publishing House. Vol. I, 2005.

Lu Yingkun 路应昆. Gōuqiāng Yīnyuè Yü Chuānjǜ 高腔音乐与川剧满新颖. (The Music of Gaoqiang with Sichuan Opera). Beijing: Renmin Yinyue Chubanshe, 2001.

Madell, Geoffrey. Philosophy, Music and Emotion. Edinburgh: Edinburgh University Press. 2002.

Man Xinying 满新颖. Èr shí shìjì shàng bàn yè zhōngguó gējù yícún de lìshì wèntí二十世纪上半叶中国歌剧遗存 的历史问题 (Historical Problems of Opera in the First Half the of 20th Century in China). Shanghai: Theatre Arts. Vol. 4, 2009. pp. 94-103.

Minford, John and Joseph S. M. Lau. Classical Chinese Literature, An Anthology of Translations. New York: Columbia University Press/Hong Kong: The Chinese University Press, 2000.

Minford, John. "The Chinese Garden: Death of a Symbol”. Studies in the History of Gardens \& Designed Landscapes. Vol. 18, no. 3, 1998, pp. 257-68.

Monteverdi, Claudio. L'Orfeo. Farola in musica, ed. G. F. Malipiclo. Claudio Monteverdi: Tutte le opere. $2^{\text {nd }}$ ed., Asolo, 1954, Vol. 11/1.

Mohammadi \& Moghaddam, A. R. Isfandyari. Some Issues on Impacts and Characteristics of Information as Wealth in the New Economy. International Journal of Information Science \& Technology. Volume 6, Number 2 July / December, 2008.

Palisca, Claude V. Baroque Music. $2^{\text {nd }}$ ed, Englewood Cliffs, N. J.: Prentice-Hall, c1981. 
Persichetti, Vincent. Twentieth Century Harmony-Creative Aspect and Practice. London: Norton, 1961. Chinese trans. by: Liu Liewu 刘烈武, Beijing: Renmin Yinyue Chubanshe, 1989.

Qian Nanyang 钱南扬 (Annotate). Yǒnglè Dàdiăn Xìwén Sānzhŏng Xiàozhù 永乐大典戏文三种校注. (Notes on Three Dramas from The Yong Le Encyclopaedia). Beijing: Zhonghua Shuju, 2009.

Qu Xiaosong 翟小松. Shì Qī 试 妻. (The Test). Opera in one Act. New York: Peermusic Classical, 2004.

Qu Xiaosong 翟小松. Opera: Ming Ruò Qín Xián 命若琴弦. (Life on a String). Manuscript score of opera donated to Jack Body by the composer, 1998.

Renmin Ribao 人民日报. Bāgè Gémìng Yàngbănxì Zài Jìng Huìyăn “1967.6.17 八个革命样板戏在京会演”. (A Series of Performances of The "Eight Revolutionary Model Plays" in Beijing), 17/6/ 1967. Available from http://news.sina.com.cn/c/144484.html; accessed 16 July 2010.

Schmalfeldt, Janet. Berg's Wozzeck: Harmonic Language and Dramatic Design. New Haven: Yale University Press, c1983.

Stuckenschmidt, H. H. Twentieth Century Music. London: Weidenfeld \& Nicolson,1969. Chinese translation by Tang Yating 汤亚汀. Beijing: Renmin Yinyue Chubanshe, 1992.

Sun Mei 孙 玫. Dōngxīfāng Xìjü Zònghéng 东西方戏剧纵横. (A Collection Essays of Western and Eastern Theater Art). Nanjing: Jiangsu Wenyi Chubanshe, 1991.

Sun Mei 孙 玫. "Exploring the Historical Development of Nánxì, Southern Theatre”. CHINOPERL Papers No. 24. 2002, pp. 35-63.

Sun Mei 孙 玫. “Performances of Nánxi”. Asian Theatre Journal, Vol.3, No. 2, 1996, pp. 141-166.

Sun Mei 孙 玫. “Xiqü̆, the Indigenous Chinese Theatre". Asian Culture, Vol.16, no. 2, 1998. pp.1-12.

Tan Dun 谭盾. Chá 茶, Tea: A Mirror of Soul. New Yolk: G. Schirmer. Inc. and Parnassus, 2002.

Tan Dun 谭 盾. String Quartet: Eight Colours. Manuscript score of opera donated to Jack Body by the composer, 1998.

Toffler, Alvin. The Third Wave, USA: William Collins \& Co. Ltd, 1980. Chinese trans. by Zhu Zhiyan 
朱志炎. Dìsāncì Làngcháo 第三次浪潮. Beijing: Shenhuo, Dushu he Xinzhi Chubanshe, 1983.

Walker, Thomas. "Opera II, 1: Italy - up to Scarlatti”, The New Grove Dictionary of Music and Musicians. London: Macmillan Publishers Limited. Vol. 15, 1980.

Wang Guowei 王国维. Song Yuan Xiqü Shi 宋元戏曲史. (The Chinese Xiqü History of Song and Tuan Dynasties). Shanghai: Huadong Shifan Daxue Chubanshe, 1995.

Wang Anguo 王安国. Xiàndài Héshēng yü Zhōnggóu Zuòpǐng Yánjiū 现代和声与中国作品研究. (A Study of the Comtemporary Harmony and Composition of China). Beijing: Zhonggou Wenlian Chuban Gongsi, 1987.

Wang Yanju 汪艳菊 (ed.). Zhōnggóu Gǔdiăn Shīcí Xīnshăng 中国古典诗词欣赏 - Li Bai 李 白. (Enjomenty of Chinese Classical Poems - Li Bai). Beijing: Wuzhou Chuanbo Chubanshe, 2005.

Wang Yuehe 汪毓和. “New Chinese Opera”. The Great Encyclopedia of China. Lu Ji 吕䩀 \& Wu Xiaobang 吴晓邦 (et al, eds.). Beijing \& Shanghai: The Great Encyclopaedia of China Press. Dance and Music Volume, 1989, P.756.

Warrack, John. "Leitmotif”. The New Grove Dictionary of Music and Musicians, London: Macmillan Publishers Limited. Vol. 10, 1980.

Wei Minglun 魏明伦. Hăo Nürrén yu Huài Nü̈́wn - Wei Minglun Nǚxìng Jǜzuò Xüăn 好女人与 坏女人 - 魏明 伦女性剧作选. (Good Woman and Bad Woman: a Selection of Wei Minglun's Drama). Ed. By Wei Wan \& Yang Rong 魏 完 \& 杨 嵘. Beijing: Zuojia Chubanshe, 1976.

Weinberger, Eliot. "Next stop, the Forbidden City". London Review of Books. Vol. 27, June, 2005, pp. 42-49.

Weiten, Wayne. Psychology Themes \& Variations. $6^{\text {th }}$ ed. Belmont, California: Thomson Wadsworth, 2004.

Weiyuan 魏 源. Wèiyüán J̌ 魏源集. (Collection of Wei Yuan). Beijing: Zhonghua Shuju, 1976.

Wen Chyouchu 溫秋菊. HouYu-tzung de Píngjü luógǔ 候佑宗的平劇鑼鼓. (HouYu-tzung Percussion for Peking Opera). Taipei: Moraity Printing Co. Ltd. 1992.

Westrup, Jack. "Recitative”. The New Grove Dictionary of Music and Musicians. London: Macmillan Pub lishers Limited. Vol. 15, 1980.

Wilkening, Martin. Review: "Salvation for the Narrator Life on a String - an East-West opera by Qu Xiao- 
Song”. English trans. by Klaus Heiliger, The Zeitgenössische (Contemporary) Oper Berlin, 2001.

Xu Chengbei 徐诚北. 中国京剧. China's Beijing Opera. Guangzhou: Guangdong Nuyou Chubanshe, 2004.

Xu Yuanchong 徐洲冲 (trans.). 道德经与神仙画. Laws Divine and Human and Pictures of Deities. (in Chinese and English). Beijing: China Intercontinental Press. 2006.

Xuē zongming 薛宗明. (The History of Western Music in Taiwan). Taipei: Yuexun of Taiwan Symphony Orchestra (Journal 88), 1988.

Yang Liqing 杨立青. Song Yuan Xìqü Shi 梅西安作曲技法初探. (The Elementary Techniques of Composition of Olivier Messiean). Xiapu: Fujian Jiaoyu Chubanshe, 1989.

Yang Yinliu 杨荫测, Miu Tianrui 缪天瑞 (et al, eds.). Zhōnggóu Yinnyuè Cídiăn 中国音乐词典. (Dictionary of Chinese Music).Beijing: Peoples Music Publishing House, 1985.

Zhang Hongdao 张洪岛. Ōuzhōu Yĩnyuè Shř 欧洲音乐史. (The History of Western Music). Beijing: Renmin Yinyue Chubanshe, 1983.

Zhanggeng 张庚 and Gou Hancheng 郭汉城. ZhōnggóuTōngshĭ 中国戏曲通史. (The History of Chinese Xìqü). Beijing: The Drama Publishing House of China, 1980.

Zheng Lei 郑 雷. China's Traditional Kunqu Opera. English trans. by RB Baron . Beijing: Ministry of Culture of the People's Republic of China, 2001.

Zhang Xiping 张西平. Following the Steps of Matteo Ricci to China. translation by Ding Deshu \& Ye Jinping. Beijijng: Wuzhou Chuanbo Chubanshe, 2006.

Zhang Yihe, Fu Shuyun \& Cao Juan. Chinese Theatre. English trans. by Kuang Peihua. Beijing: Culture and Art Publishing House, 1999.

Zhu Zhou 朱 舟. Zhōnggóu Chuántǒng Míngqü Xïnshăng 中国名曲欣赏. (The Most Remarkable Traditional Music of China). Chengdu: Sichuan Renmin Chubanshe, 1982. 


\title{
9 Appendices
}

\subsection{Libretto of the Scene of the First Night in English}

\author{
"The First Night" \\ "The First Month", \\ "Missing You from Not So Far Away"
}

[Scene: Cheng \& Lei Mi's home. A sitting room in the middle; bedrooms to left and right. The walls of both the sitting room and the two bedrooms are covered by a mural, upon which is depicted an astonished young woman dressed in a cheongsam with a deer-horn like hawthorn tree growing out of her head and upon which can be seen, here and there, a red berry or two. The mural stradles the two windows and stretches into the bedrooms. Dark red clouds and smoke circle round and round, and in the sky there is a fire-spouting dragon who is attacking God's wings. God, for his part, is standing upon a small green snake, beneath which spreads a huge expanse of land upon which people are chasing leopards, tigers and a mounted elephant races towards the mouth of a dragon that looks like a huge butterfly. The mural bears the inscription: "This dragon too was once a great beauty, with a hawthorn tree on its head"]

[Staging: Cheng A is in the bedroom to stage left]

[Sound effects: Evening music begins]

[Music: Cheng aria: "Such a dark night"]

Cheng A: (sings)

Such a dark night,

But as dawn approaches,

The moon appears, as if suspended above

the tips of the branches.

I'm always startled awake at times like this

By that dream

By that unquenched desire

(speaks)

By the indistinct feelings that linger from the day before.

Lei Mi pointed in that direction

(sings)

(he imitates Lei Mi's gesture of pointing to Yinger's bedroom)

I know that there in that room,

Behind the long curtain

Lie the dreams and hopes of so many years.

[Staging: Cheng A sings as he opens the door and enters the sitting room, walking over to the door to Yinger's bedroom, but then retreating before turning again to approach her door. Ever so gently he pushes the door open and enters] 
[Lighting: Gradually the lighting in the room increases]

[Staging: Yinger pretends to be asleep, in a most fetching pose. Cheng A gently approaches her bed and gazes at her reclining figure]

[Music: Cheng aria: "Voice of the son"]

Cheng A: (sings)

How many times have I found myself here,

Only to be entranced

Each time.

Standing with my back to her,

Gazing at the moon

through the window,

glistening in the bush,

As the minutes flow by?

[Lighting: Forcefully, Lei Mi lights up a candle and her room too gradually lights up. Lei Mi comes on stage and rushes towards the door to Yinger's bedroom. In an instant, however, she appears to calm down somewhat and begins to retreat, step by step...Hearing the movement, $\mathrm{Gu}$ Cheng goes to the door and listens intently]

[Staging: Lei Mi opens up a cardboard box and begins to look intently at a number of her son's toys and some photographs of the three of them together]

[Staging: Ever so carefully, Cheng A draws closer to Yinger's bed, and slowly he sits down]

[Staging: Lei Mi addresses the photographs of her son as she looks through them]

[Sound Effects: Samuel's Voice]

[Music: Cheng and Lei Mi Duet: "My precious son, my sweetheart"]

Lei Mi: (sing together)

How many days (hours) since I last saw you?

Cheng A: (speaks)

My precious son?

Cheng A: (sings)

My sweet heart? Dide dedi!

Lei Mi: (sings)

How peacefully she breathes

Cheng A: (speaks)

(Each and every moment that we have spent together)

Flows before my eyes, so moist.

Ever so gently I pull back the covers.

My hand lingering above that place covered by her panties,

Lei Mi: (sings)

Night after night after...

Like a river endlessly flowing

(Looking at the photographs, she speaks, joyfully)

(speaks)

My little one, 
Chubby as a ball,

But ever so fast when you run.

[Staging: Lei Mi picks up a music box from the cardboard box. As she winds it slowly, the distinct and melodious sound of the music plunges her deeply into her memories]

Cheng A: (Staring at Yinger intently, he speaks, joyfully)

I can"t believe that this is her,

Lei MI: (sings)

This is the girl of my heart"s desire, my dreams

On your third birthday,

Cheng A: (speaks)

How I hugged you.

Lei Mi: (sings)

And now is the most dangerous moment

Cheng A: (speaks)

You love to place your arms around my neck,

But I've never even held a birthday party for you.

Lei MI: (speaks)

Like carefully turning the combination lock of a safe

The birthday cake

Was given to us by your Auntie Xiang

Perhaps

From now on she will bake a cake

Cheng A: (sings)

Every birthday

I'll summon up my innermost desires with all my mind,

Like that first moment, boundless longing

Lei Mi: (speaks)

The three candles

Were lit by Auntie Ying

Perhaps

Some time in the future

Cheng A: (sings)

You will become part of one of her stories

Lei Mi: (speaks)

It seems as if this is not her,

But a fountain surging upwards slowly

Cheng A:(speaks)

I gave you nothing,

Just sat in a trance by the pillar

Lei Mi: (speaks)

Panic swept through my heart

Perhaps,

Only you understood

Cheng A: (speaks)

How many times has my desire for you made me erect

Lei Mi: (speaks)

You needed a satchel and a few coloured crayons

Cheng A: (speaks)

I'll slip off her panties

Lei Mi: (speaks) 
Cheng A: (speaks)

All you needed was a small ordinary bed
I stand still here besides her

Lei Mi \& Cheng A:(together)

You need me to sleep

Cheng A: (speaks)

beside you all night to protect you

Lei Mi: (speaks)

For that brief moment I almost did that most vulgar of things

Cheng A: (speaks)
And yet,
I gave you nothing

And yet,

I didn't want to awaken you

Lei Mi: (speaks)

You've had three birthdays already,

But I think of you as a dream

Cheng A: (speaks)

All I want to do is fondle her indistinctly
And to take her slowly from one dream

Lei Mi: (speaks)

Lei Mi \& Cheng A: (sing together)

Let me (her) never, never awaken

[Staging: Gently Cheng A rests upon the bed, staring at the sleeping Yinger. Lei Mi hugs her son's toys as if she was hugging him.]

[Lighting: The spotlights in Yinger's room gradually dim]

[Music: Lei Mi Lullaby: "Dearest son"]

Lei Mi: (sings)

\begin{tabular}{|c|c|}
\hline & Dearest son \\
\hline & Here's an (interesting) story, \\
\hline & Here's a minor tragedy. \\
\hline & When we live together, \\
\hline & Everyone who sees you knows my joy \\
\hline & Wherever we are, whenever it is, \\
\hline & If you wish to hold me, \\
\hline (recitation) & Then you can run towards me, \\
\hline & And I will pick you up, so gently, \\
\hline & Place a hand on your head. \\
\hline & Your hair, so soft and shiny, \\
\hline & Against my palm. \\
\hline (sings) & \\
\hline & And then, \\
\hline & Love and blessings merge. \\
\hline & Dearest son \\
\hline
\end{tabular}




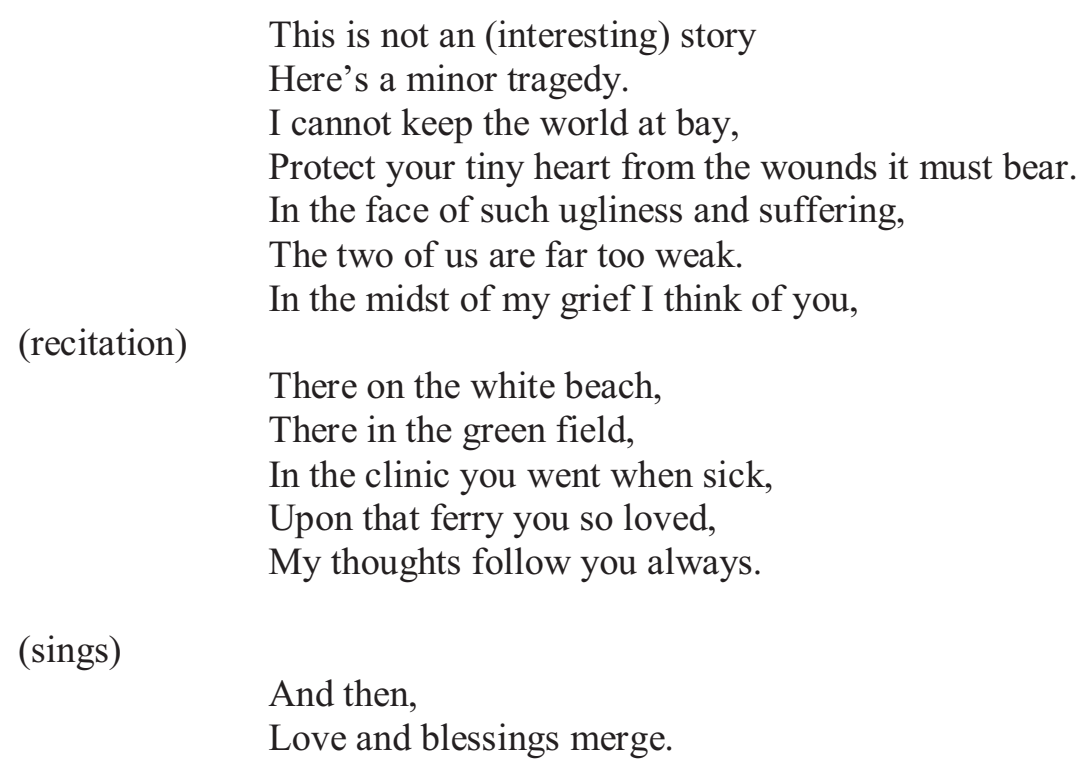

[Staging: From amongst her son's toys, Lei Mi picks up a wooden fish and begins to beat it, softly but rhythmically, humming to herself a song invented by her son]

[Music: Lei Mi \& the Voice of the Son: "Children's Chant"]

Lei Mi: (chants)

One's good,

One's not so good,

One and two and three are good,

One and two and three are not so good,

One and two and three and four and five are good

One and two and three and four and five are not so good

[Lighting: The spotlights in Lei Mi's bedroom gradually dim. Dawn begins to break. A dazzling but warm ray of light shines into Yinger's bedroom through the window]

[Staging: Deftly, Yinger turns over and gets out of bed. She is wearing a soft and transparent pyjamas that reveal her beautiful and slender body]

[Chorus : "The First Light of Dawn"]

Chorus : $\quad$ (The first light of dawn

Awakens the myriad creatures)

There in the mysterious hidden recesses is revealed,

As fine and as ripe

As the pattern of the ammonites in a museum,

Like a fig made sweet and soft,

Enveloping all the tiniest seeds.

[Yinger sings, Aria: "I Love You”]

Yinger: (sings)

This is the first time I've really looked at you,

This is the first time that I've kissed you with 
my sweet girl's lips,

Wanting to tell you that,

I love you, I really love you.

(sings, at the same time as the chorus)

This is the first time I've fondled you,

This is the first time I've called out to you with my heart,

Wanting to tell you that,

I love you, do you want me?

Chorus : $\quad$ (The first light of dawn

Awakens the myriad creatures)

There in the mysterious hidden recesses is revealed,

As fine and as ripe

As the pattern of the ammonites in a museum,

Like a fig made sweet and soft,

Enveloping all the tiniest seeds.

[Staging: In the midst of the music and the singing, Yinger stands in front of Gu Cheng, gently fondling his head and body. Then, holding his head in both her hands and looking at him intently, she kisses him softly...Then, slowly, she unbuttons her white pyjamas and pulls them off with her slender hands and they float to the floor...]

[Lighting: The light becomes more intense as the tempo of the music increases.Then, the spotlights begin gradually to dim and to focus upon Yinger, and then fade out...] 


\title{
9.2 Libretto of the Scene of the First Night in Chinese
}

\author{
Chūyè \\ “初 夜” \\ “第一个月” 和 \\ “并不遥远的思念”
}

[地点: 城和雷的家。舞台左边是客厅的一角, 靠窗前有一书柜, 有沙发、

茶几和三张小孩坐的小椅子，右边是英儿的睡房，有一张单人床和一只床头灯，其间用

“穷子” 隔开。整个客厅的连着睡房的墙上是一幅巨大的壁画。一个神气惊讶穿着旗袍的 姑娘, 头上长着鹿角一样的山楂树, 一点点红色的果子依答 $7 \mathrm{~d}$ 可见辩。壁画跨过两个窗户

一直伸到睡房。暗红色的云和烟气纵横翻卷, 天上有飞着的龙吐着火, 击毁了上帝的翅膀, 上帝的脚下踩着一条小青蛇, 再下边是大片大片的土地, 有人赶着豹子、老虎和大象的车, 向着一个巨大的蝴蝶虫一样的龙的嘴里奔跑。并有题款: ” 龙本来是个美人, 头上有山楂 树。”

[音效：夜晚音乐起。

[灯光：幽兰月光从窗外照进客厅和英儿的睡房，使垂立在窗前的英儿像”雕塑”一样 的剪影。

[舞台：英儿身着白色的睡衣，垂立在窗前，眺望远方，思绪万千。

[舞台: 英儿发现了客厅里有声音, 轻轻地走向门窝, 侧耳探听。又快步走向床边 关上床头灯。

[舞台：城 A 身披白祄衣，头戴” 古城帽” (剪下牛仔裤的一段裤腿而成)。从舞台左边的 “睡房”上场。城 A 唱咏叹调: “黑”。

城 A:（唱）黑, 很黑

(在)很黑的夜晚

接近黎明的时候

月亮悬浮在树冠之上

我总是这个时候警醒

为那梦

为那不能实现的热望

(和) 那白天留下的隐约的心情

（白）（雷米给我做手势）

(学雷米的手势指向英儿睡房)

(唱) 我知道 (在) 那个房间里

长长的垂幕后面

有我多少年的梦想和期待

[舞台：城 $\mathrm{A}$ 一边唱一边走向英儿的睡房门窝前, 侧耳探听。又退回来, 看看右边的 睡房, 反复几次。 
[舞台: 英儿听到客厅里城的声音, 一阵惊喜, 轻轻地走向门帘, 侧耳倾听。期望 城进来, 又怕被发现, 在床和门帘之间来回, 反复几次。

[舞台：城 A 终于掀开英儿的睡房门窝, 轻轻地走进睡房,

[灯光: 英儿室内灯光渐亮。

[舞台: 英儿以优美睡姿假睡在床上。城 A 轻轻地走向床前, 看着熟睡的英儿。

[音乐：城 A 唱咏叹调：“看窗外的月色, 照亮的树丛”。

城 A：(唱) 我已经好多次到这里来

可是每次来的时候

依旧恍惚

(舞台: 雷米从舞台左边的” 睡房” 上场。冲向英儿的睡房门窝前。片刻, 镇静下来, 一步一步地退了回来。

城 $A$ ：（唱）我总是背过身

看窗外的月色, 照亮的树从

时间在一刻一刻地过去...

[灯光: 雷米点燃一支蜡烛, 室内灯光渐亮。

[舞台：城 $\mathrm{A}$ 听见响动，走向门窝前，侧耳倾听。

[舞台：雷米打开一个纸箱子, 拿出一些她和城的儿子的玩具和照片仔细的看着。

[音效：小孩说话和笑声。

[舞台：城 A 小心翼翼地走向英儿的床，慢慢的坐下。

[舞台: 雷米一边看他们儿子的照片, 一边对这照片说话。

[音乐：城和雷米的二重唱：“我亲爱的儿子，我亲爱的人儿”。

雷米: (同城 A, 唱) 有好些日子没有看见你了

我亲爱的儿子

城 A: (同雷米, 唱) 有好几个小时没有看见你了

城 A:（说白）我亲爱的人儿, 滴的里滴

城 A：（唱）她依旧在沉静地呼吸

雷米:（说白）(每次和你见面的情景，还都）

都历历在目, 是潮湿的 
城 A:（说白）我便轻轻的揭开她的被盖 手停留她唯一被内衣遮掩的地方

（唱）一个又一个的夜晚

雷米: (唱) 像河里的水流缠绵不断

（看着照片，幸福地：说白）

你的小样

你胖胖的瓷实的像球儿的身体

跑起来劲头十足

(舞台: 雷米从纸箱子里, 拿出一个” 音乐盒”, 慢慢地打开, 清脆, 悠扬的音乐把她 带入深

深地回忆之中...... 。

城 A:（深情地注视着英儿, 幸福地: 说白）

我不能想象这是她

这 (就) 是我所要的女孩、我的梦

雷米: (唱) 你三岁那天

我抱了抱你

城 $A$ :（说白）这是最危险的一刻

雷米: 你喜欢地搂住我的脖子

我还不曾为你举办过一个生日的庆典

城 A：（说白）好像深夜轻轻转动保险柜的号码

[舞台: 雷米想自己给儿子一个生日庆典, 她从纸箱子里, 找出一个” 园型玩具” 放在茶几 上, 当作蛋糕。再找出三个玩具人放在左右和前面, 代表英儿, 乡阿姨和她儿子。

雷米：（念白）生日蛋糕

是乡阿姨为你做的

也许

她会在所有以后的生日

都为你做一个蛋糕

城 A：（唱）我聚精会神想唤起我心中的热望

好像那起动一刻, 无限遥远

（舞台：雷米点燃蛋糕上的蜡烛

雷米：（念白）三支小蜡烛

是英子阿姨为你点的

也许

会有那么一天 
你将成为她的故事

[舞台: 雷米合上双手, 代表儿子许愿。然后吹蜡烛, 欣喜地鼓掌。

城 A：（唱）好像这不是她

只是一个渐渐涌起的水花

雷米:（说白）我什么都没有给你

只是靠在一根柱子上发愣

城 A：（说白）我心里掠过一阵惊慌

雷米: 也许,

只有我才知道

城 $A$ : 我无数次真立的渴望

雷米: 你需要一个书包几只彩色的小蜡笔

城 $A$ : 我退下她唯一的那件内衣

雷米: 你需要一张普通的小床

城 $A$ ：身体依旧停留在床边

雷米、顾城 A：（合) 需要我在床边守护你的夜晚

城 A：那一慜那我真想做最粗鲁的事

雷米: 然而

我什么也没有给你

城 $A$ : 然而

我不愿惊醒她

雷米： 你已经过了三个小小的生日了 我觉得你象一个梦

城 $A$ : 我只想若有若无的触摸 使她从一个梦

雷米: 真实的围绕着我

城 A：缓缓的落进另一个梦

雷米、顾城 A:（合唱）使我 (她) 久久地，久久地不愿醒来 
[舞台: 城 $\mathrm{A}$ 轻轻地靠在床上。看着熟睡的英儿。雷米抱着儿子的玩具, 就象抱着熟 睡的儿子一样。给他唱摇篮曲: “我亲爱的儿子”。

[灯光: 英儿睡房的追光渐收。

雷米：（唱）亲爱的儿子

这不是一个（有趣的）故事, 这是一份小小的悲哀。

在我们可以一起生活的日子里,

所有看见你的人都知道我的幸福。

不论何时何地,

只有思念牵动着我,

你就会向我跑来,

（白）我把你轻轻的抱起,

把一只手放在你的头上。

你光洁而柔软的头发,

温和地触及我的手心,

(唱) 于是，

爱和祝福一同升起。

我亲爱的儿子，

（唱）这不是一个（有趣的）故事,

这是一份小小的悲哀。

我不能为你挡住世界,

挡住你小小的心需要承担的伤害。

在这丑陃和痛苦面前

我和你柔弱相差无几。

我在深深的忧伤中想你,

（白）在白色的沙滩、

在绿色的草地、

在你生病时去过的诊所,

和那艘你无比喜爱的渡轮上,

无时无刻的思念围绕着你,

（唱）于是，

爱和祝福一同升起。

[舞台: 雷米拿起儿子的玩具中的一只小木鱼, 并轻轻, 有节奏地敲越来, 同时哼 唱儿子自己编的儿歌。

雷米：（念唱）一个人好啊,

一个人不太好

一个两个三个人好啊,

一个两个三个人不太好。

一个两个三个四个五个人好啊,

一个两个三个四个五个人不太好。 
[声效: 雷米哼唱的同时, 叠进 Samue1 的儿歌的声音, 再叠进雷米的的声音。形成 多声部的 Canon, 逐渐达到高潮。

[灯光: 旭日东升。一束耀眼而温暖的阳光透过窗户射进英儿的睡房。雷米睡房的 追光渐收。

[舞台: 英儿轻手轻脚翻身而起。身上穿着柔软、透明的睡衣, 显透出她修长、美丽的身躯。

合唱:（晨曦初露,

万物苏醒。)

神秘的隐处申冉呈现

像博物馆菊石的图案

那么细致饱满,

像无花果逐渐变得柔和

那么滋润甘甜

把一切细小的籽粒蕴涵

（音乐：英儿唱咏叹调 : “我爱你”

英儿:（唱）城啊，

第一次这样看着你,

第一次我用女孩子温和的嘴唇亲吻着你

我想对你说

我爱你了，真的爱你了

城啊

(唱，与合唱同时)

第一次这样抚摸着你

第一次在我的心里呼喊着你

我想对你说

我爱你了，你想要我吗

合唱:（晨曦初露,

万物苏醒。）

神秘的隐处冉苒呈痕现

像博物馆菊石的图案

那么细致饱满

像无花果逐渐变得柔和

那么滋润甘甜

把一切细小的籽粒蕴涵

[舞台: 音乐与歌声中, 英儿站在城的面前, 温柔地抚摸着城的头和身体, 双手捧 起他的脸仔细看, 温柔地亲吻着 $\cdots$ 。然后, 慢慢地解开自己睡衣的扣子，柔软的 细手慢慢地抽出袖筒, 白色的睡衣轻盈地飘落在地上…

[灯光: 灯光随着音乐越来越强烈。尔后, 追光渐渐的收束, 聚在英儿的身上。越 来越小…。 


\title{
9.3 Asia Pacific Festival Review: Asia-Pacific Music-Theatre
}

\author{
Scoop Review
}

Wednesday, 14 February 2007, 10:45 am

\section{Asia Pacific Festival Review: Asia-Pacific Music-Theatre}

Review by Lyndon Hood

\author{
Asia-Pacific Music-Theatre \\ Spinning Mountain - Balinese shadow puppet theatre \\ Simcheong-ga - scene from Pansori Korean Opera \\ Fatal Desire - opera scene \\ Te Whaea, National Dance and Drama Centre \\ 12 Feb (8pm), 14 Feb (6.30)
}

Asia-Pacific Music-Theatre gives Wellington audiences a rare chance to sample musical theatre works based on three different traditions - two of them using forms that UNESCO has declared Masterpieces of Oral and Intangible Heritage of Humanity.

Spinning mountain is one of these, working in the Indonesian shadow puppetry (Wayang Kulit) tradition. The performance was an extract from an hour-long piece being created for the coming children's festival at Capital E. Talented artists from the Balinese tradition - composer Wayan Yudane, puppeteer Kadek Setwain and librettist Ketut Yuliarsa - are working with New Zealand composer Gareth Farr and Director Nina Nawalowalo (as well as a number of other performers) to present a tradition Balinese story for a New Zealand audience.

Judging from their advertising image, the presentation here was a simplified staging. On on side of the stage, four musicians and the instruments (percussion ranging from the metallophones and gongs of gamelan to rock drums and including a few hanging flower pots). On the other, the screen on which the puppetry was projected.

First and last to appear in the puppetry - as is traditional - was the "Tree of life" (Kayonan), a shape that seemed not unlike a feather or leaf as it leapt and spun, forming a link between the gods and the performance. The title of the production could bring to mind shadow-theatre tradition as a whole - the Kayonan can also represent a mountian. 
There is a specific mountain (Mount Mandara) at the centre of the story, which judging by their publicity is the "churning of the ocean of milk" episode from the Puranas. However, what we saw was primarily setting the scene.

A father and son - engagingly characterised both in their movement and voice provided a frame as the old man began a once-upon-a-time story inspired by the sight of a lunar eclipse. The scenes that followed showed the inhabitants of this golden age - gods, demons and an impressive range of animals - doing their thing. For the gods and demons, this didn't include talking in English, but then it didn't seem that any plot was occuring for us to miss. The widely varied vocal tones of the puppeteer conveyed attitude nicely, and what we could see was testament to his skill.

The shadows of Kadek Setwain"s puppet displayed a remarkable degree of liveliness. The father"s turning to send a perfectly-placed glare at his lippy son, a giraffe shaking itself, a rabbit's lope - some of the puppets are clearly quite intricate (many, for example, have moving mouths) but the degree of animation is unexpected even considering that.

Fans of gamelan music and of Gareth Farr, will probably not be surprised that the music tended to the driving, a wall of sound built out of tuned percussion, augmented only occasionally by vocals from the pupeteer (and sometimes the clap of puppet's rod on board) and one English-language scene-setting song from a musician.

Especially in the main theme, the music also had a startling speed. The rolling patterns for the metallophones, played on the with a single hammer, demanded a pace and precision that was impressive, especially with two players (Farr himself being one) working in perfect sychronisation.

The full production of Spinning Mountain will premiere at the Capital E National Arts Festival on March 21 and 22.

If you can imagine a vocally-animated storyteller whose changes in pitch and timing reached the point where they were actually singing, you'll have some sense of the way Pansori works. Described variously as "Korean Opera" or "Epic chant", the performance is limited to a singer/actor/orator (in this case, Park Aeri) collaborating with a drummer (Kim Woong-sik), to tell one of the five extant story cycles of the tradition.

This performance was of a scene known as "Sim Cheong throws herself in the water" from Simcheong-ga. Sim Cheong sacrifices herself to a sea god knowing her blind father will receive rice for a temple donation that he has been assured will restore his sight (this devotion does not go unrewarded in the rest of the story). 
Both performers are dressed in traditional costume, and make a simple and attractive stage picture. The singer stands and sings or speaks narrative or dialogue from the stories. The drummer sits, playing one face of his drum with a hand and beating the other face, and tapping the drum's wooden body, with a stick.

It"s perhaps indicative of the rhythmic skill demanded of the singer that the percussion is used simply as a kind of punctuation or emphasis, rather than actually thumping out a beat in the way someone of the Western tradition might expect. The drummer also vocalises ("Hm!" "Aah!") and these noises also fall precisely in their rhythmic place, at the same as giving explicit reaction or encouragement to the singer. Given that a full performance usually lasts hours, the support is no doubt welcome.

It also seems to be a useful device for leading audience reaction. The drummer, as well as performing, is part of the singer's audience. At times Park Aeri was delivering her performance to Kim Woong-Sik, which enhanced the sense of intimacy she had developed with the charming personality of her storytelling. I don"t know how accurate it was, but I was left with the impression of a form with roots in a folk tradition rather than a more formal one.

This attractive sense of informality despite (or probably, in fact, as one facet of) a performance of great technical skill. From the theatrical ability to simply hold the attention of the audience (many of whom, if I'm any example, had no knowledge of the language and had only the vaguest sense of the action) to some remarkable musical and vocal ornamentation (onomatopoeia feature strongly at one point) to the sudden and precise fall of her fan at the end (I cannot but assume to represent Sim Cheong"s descent into the ocean) - it was all remarkably well executed.

The style of the music began with the singer pulling back and forth across a slow beat - giving a highly maritime effect. Other moments put me in mind of the vocals in American folk-rock or the rhythmic singing of hip-hop - without the need for the addition of a beat.

These elements all combined into a compelling example of traditional storytelling.

The last performance was a scene from Chinese composer/NZ resident Shen Nalin"s opera Fatal Desire, directed by Sara Brodie. In the scene a Poet (James Meng, tenor) recalls the beginnings of his sexual relationship with a lost Lover (Wang Xing-Xing, soprano), which is contrasted with his Wife (Linden Loader, mezzo) and he longing for their absent son - sometimes using something close to the same phrases or similar sounds.

The orchestral music had something of an echo of the surging rhythms and sudden, isolated sounds of the Pansori drums, and made a discordant, uneasy background over which the vocals ran more smoothly. The music was performed by the Con- 
temporary Music Ensemble Korea, conducted by Gao Ping. The players used a mixture of western and traditional Chinese instruments - often swapping between the two - to what I assume was often a quite non-traditional effect.

English surtitles were projected over the stage as part of an ongoing video projection above the simple set (platforms, a bed, a chest) that was placed upstage of the orchestra. Images, many based around water, such as ripples on a woman's skin or a child playing on a beach change to compliment or reflect the contrast being presented in the performance. The simplicity of the libretto, and a, possibly deliberate, unclearness in the surtitles as to which character's line was which during duets reinforced in my mind the idea that, in opera, the words are not the main thing.

The tone of the piece changes as the Wife imagines a counting game with her son (his answering voice provided by an actual child skipping adorably through the orchestra) and the vocal clicking rhythm of the game extends through the orchestra in an escalating canon.

Finally a new voice is added as the Lover sings, inviting the Poet to her bed. The ominous buildup in music that heralds their laying down is intriguing, causing us to reflect that the relationship of this reminiscence has ended, and hinting at the tragic conclusion of the opera. In the context of this morning-tinged scene, the intriguing image of a rather striking line (from memory) "Dawn reveals hidden crevices, as delicate as ammonites in a museum" actually does resonate. Its uneasiness also seems to sit well with the tone of the production. 


\subsection{Pīnyīn}

The majority of Chinese languages are tonal, that is, the intonation of the spoken word is intrinsic to meaning. In standard Chinese, Mandarin (pǔtōnghuà), there are five standard tones. The first tone is a straight, high pitch, represented by a macron added to a vowel, in the pinyin style of phonetic writing (in Romanized script). The second tone is a rising pitch, middle to high, and is denoted by an acute accent, as in " $m a$ ". The third tone falls from middle to low and then rises sharply to high, is marked by a caron (mă). The fourth tone falls from high to low, represented by a grave accent $(m a \grave{)}$. And the fifth tone is neutral tone without any mark $(m a)$.

Table 1: Pīnyīn " $m a$ " with five tones for different meaning and characters

\begin{tabular}{|l|l|l|l|l|}
\hline Chart of tones & Character & Pinyīn & Tones & Meaning \\
\hline 5 & 妈 & $m \bar{a}$ & $1^{\text {st }}$ & mother \\
\cline { 2 - 5 } & 马 & $m a ́$ & $2^{\text {nd }}$ & horse \\
\cline { 2 - 5 } & 麻 & $m a \check{a}$ & $3^{\text {rd }}$ & hemp \\
\cline { 2 - 5 } & 骂 & $m \dot{a}$ & $4^{\text {th }}$ & scold \\
\cline { 2 - 5 } & 吗 & $m a$ & $5^{\text {th }}$ & $\begin{array}{l}\text { question } \\
\text { particle }\end{array}$ \\
\hline
\end{tabular}

Pinyin, the phonetic representation of the sound of the language, seldom indicates the tones, even though the system exists. Pinyin, without the tones, is therefore of very limited use for understanding the proper pronunciation of Chinese. For Chinese readers pinyin is confusing, and often meaningless.

In the setting of Chinese words to music, the tones of the characters must be taken into account. For instance, melodic movement upward on a word/character that has a falling tone (tone 4) destroys its meaning, or more often, creates a completely different meaning.

In technical terms, the music and sound needed to comply with the tones of the language (the specific pitch attenuations characteristic of spoken Chinese, see table below), in some case, a local dialect rather than standard Mandarin (pǔtōnghuà). The tones (pitch attenuations) of spoken Chinese are intrinsic to meaning. 


\title{
THE INTEGRATION OF CHINESE OPERA TRADITIONS INTO NEW MUSICAL COMPOSITIONS
}

\author{
by
}

\section{SHEN NALIN}

\author{
Thesis \\ submitted to the Victoria University of Wellington \\ in fulfilment of the \\ requirements for the degree of \\ Doctor of Philosophy
}

Volume II: Portfolio of Compositions

Victoria University of Wellington

2010 


\subsection{Xià Sìchuān (下四川) \\ Going Down to Sichuan Province}

The Song Company of Australia

2010 China Tour

Hangzhou, Suzhou, Shanghai and Beijing

2011 tour of Australia

Brisbane, Canberra, Wollongong, Sydney,

Newcastle and Melbourne,

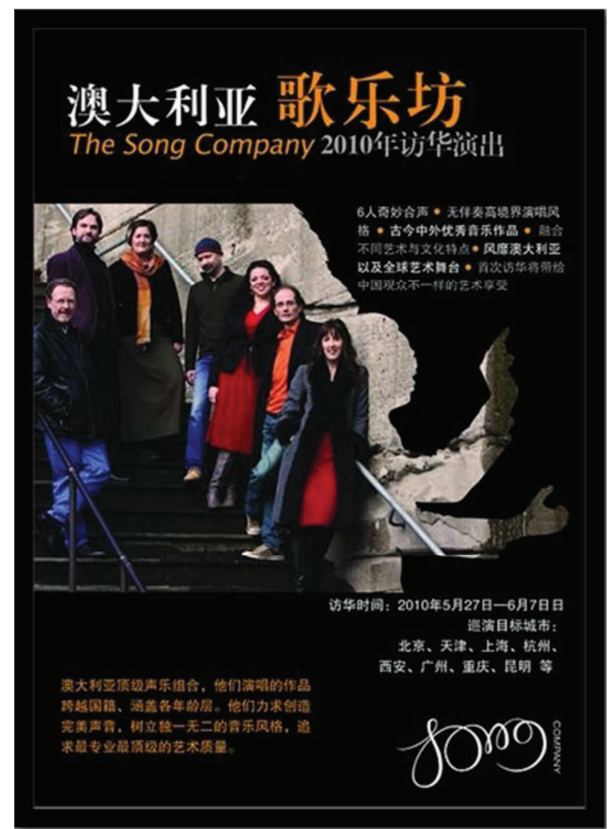

Programme

The Song Company of Australia

$\begin{array}{ll}\text { Clive Birch } & \text { bass } \\ \text { Richard Blank } & \text { tenor } \\ \text { Mark Donnelly } & \text { baritone } \\ \text { Ruth McCall } & \text { soprano } \\ \text { Anna Fraser, } & \text { soprano } \\ \text { Lauren Easton } & \text { mezzo-soprano } \\ \text { Roland Peelmen } & \text { artistic director }\end{array}$

(The recording was made for the Song Company by Matthew McGuigan and Jacob Craig at the Hunter Baillie Church Hall, Sydney, August 2010) 

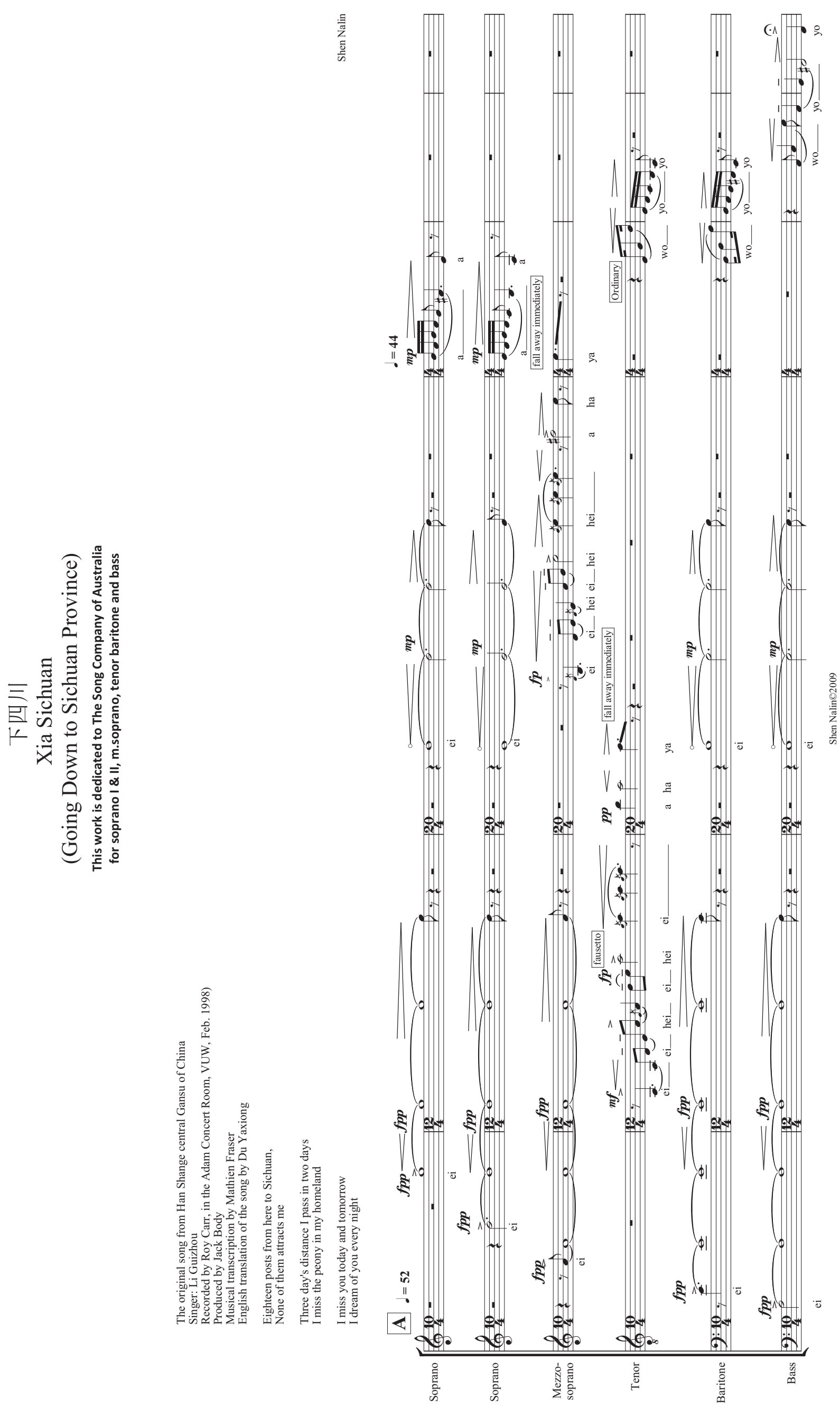


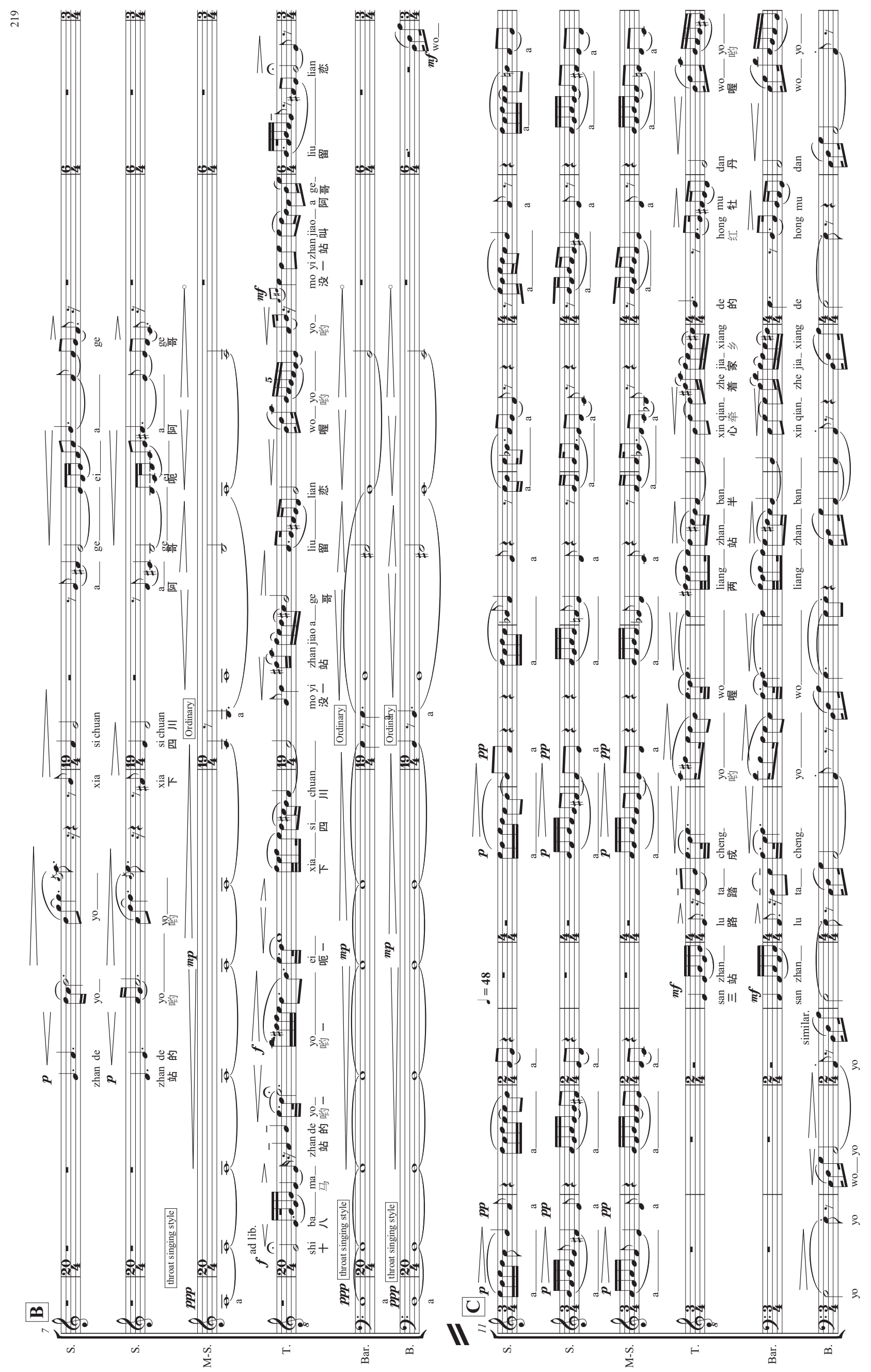




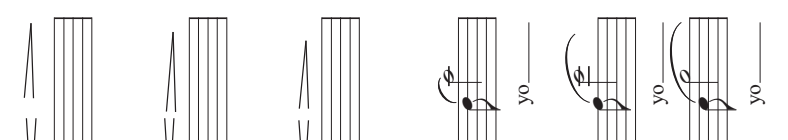

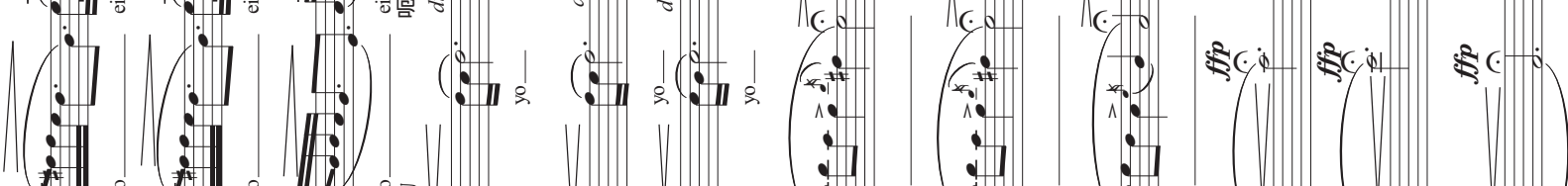
(i) (1) (I) 1.

1 . 1 . 1 .

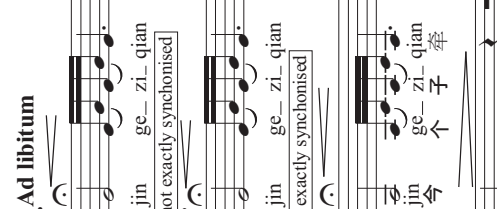

$\because$

11.

(1)

倠

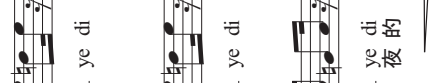

(1)

(2) (2) (19) 192$)^{\circ}$

(1).) (15) (1)

(n)

₹.

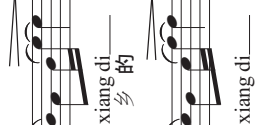

(i)

(7) $=0$

(.)

ही हो

$\therefore$ 네

18.

(5) [5. [5] (i) (i)

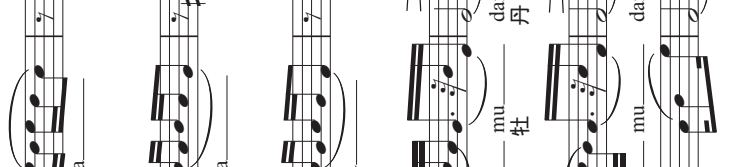

(II) II: II:

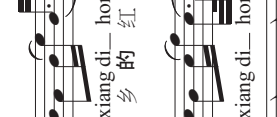

(1)

(1)

[i:) (i) $\because 4$

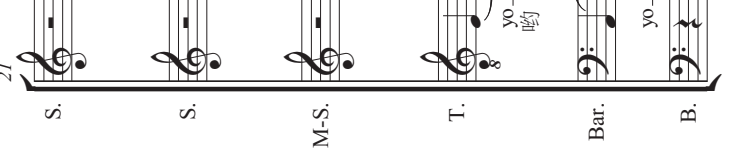

(1)

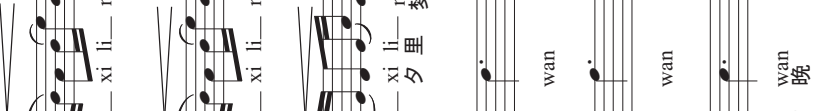
\& (.

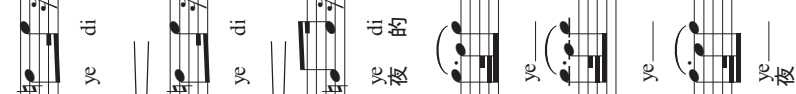

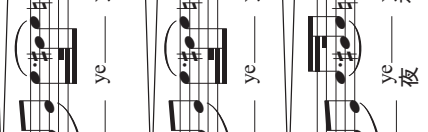

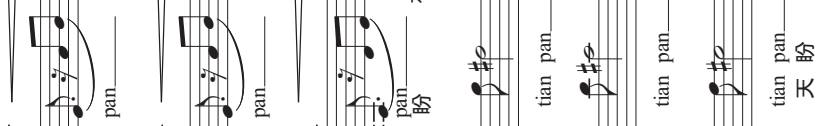

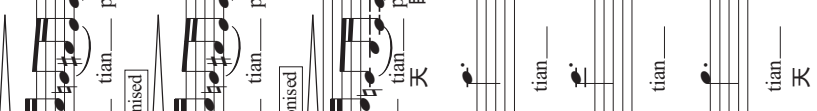

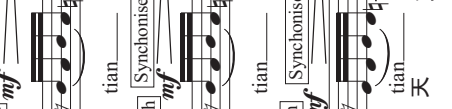

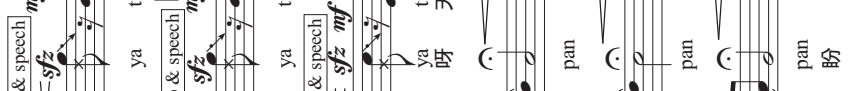
或

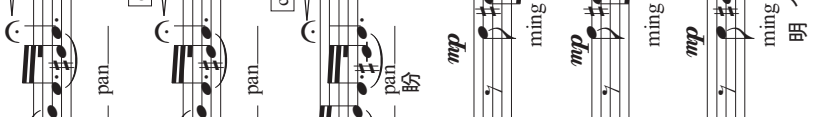

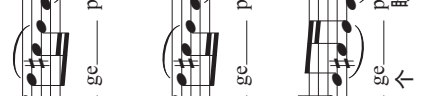

(i) (i) (i) (i) 


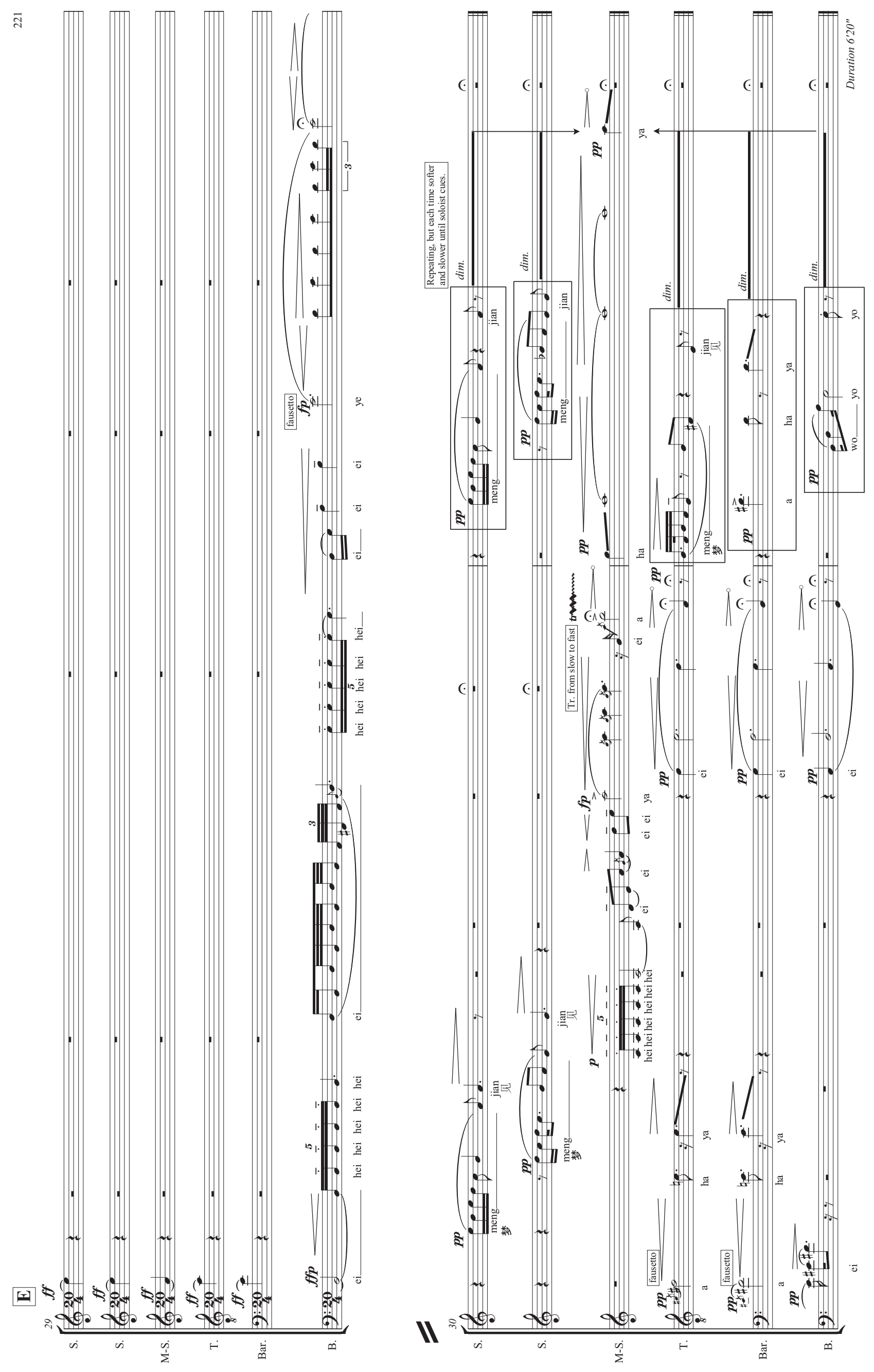




\subsection{Wănge (輓 歌) Elegy}

The work dedicated to Jack Body

Premiered, The Vita Brevis Concert

26 November 2005 Church of St Mary of the Angels, Wellington

Performed, 14 April 2009 Hunter Council Chamber, VUW

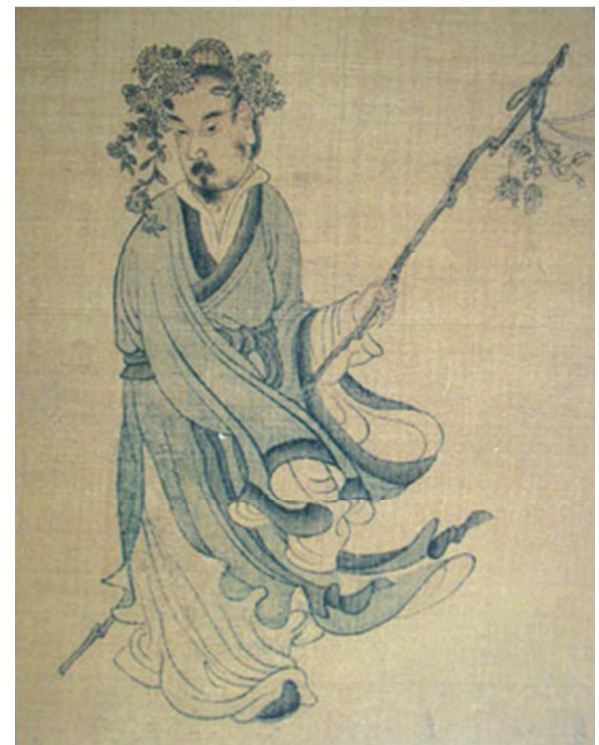

Portrait of Tao Qian by Chen Hongshou (1599-1652)

The Vita Brevis Concert Performers

Yono genders

Wang Xingxing zhèng

Robert voice

Shen Nalin voice

(Live recording by Roy Carr, 26 November 2005, iChurch of St Marry of the Angels, Wellington)

\section{Hunter Council Chamber Performers}

Budi Putra genders

Wang Xingxing zhēng

Jack Body voice/gong

Shen Nalin voice

(Domestic recording by Brian Shen, on 14 April 2009, Hunter Council Chamber, VUW) 

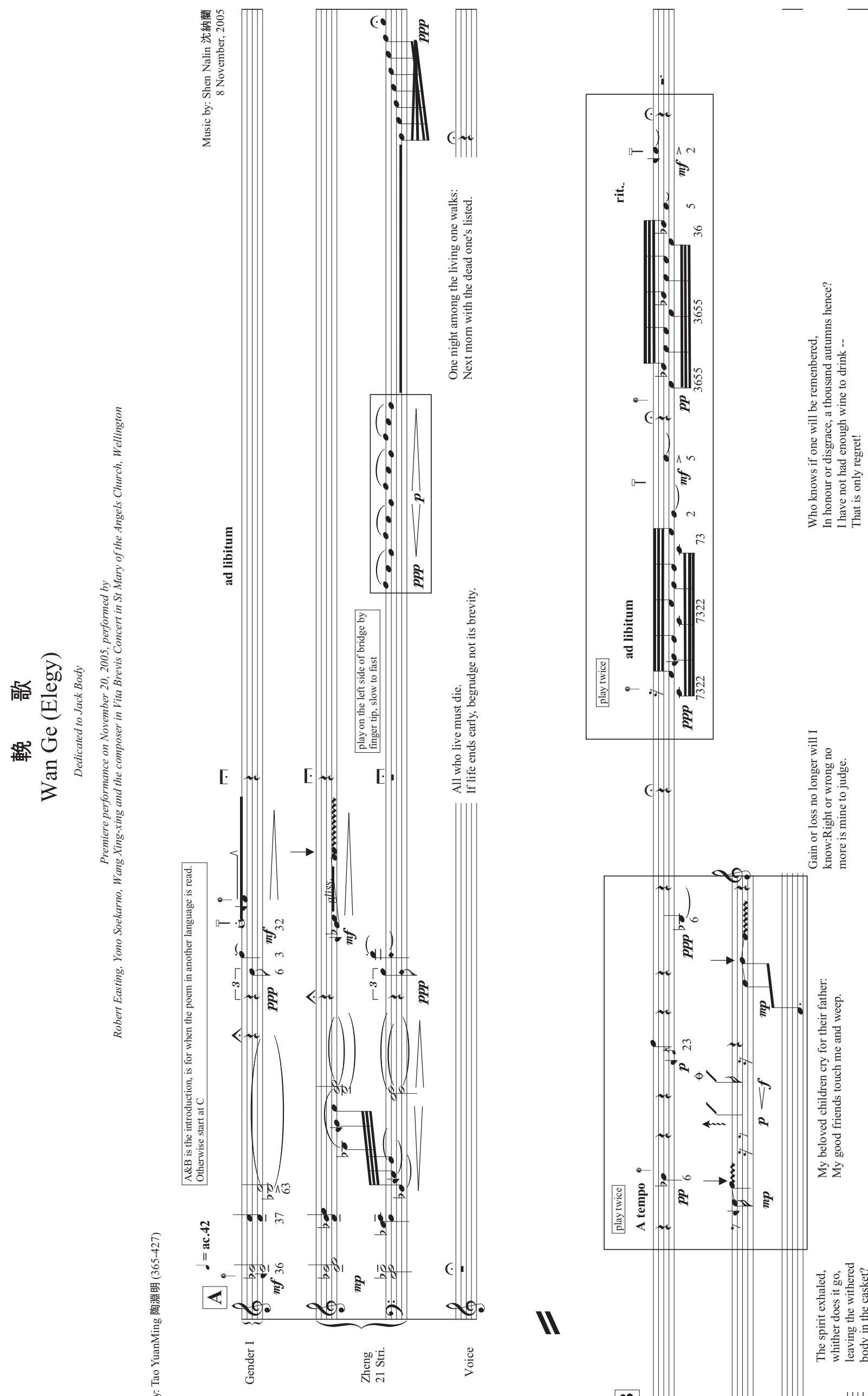

言。
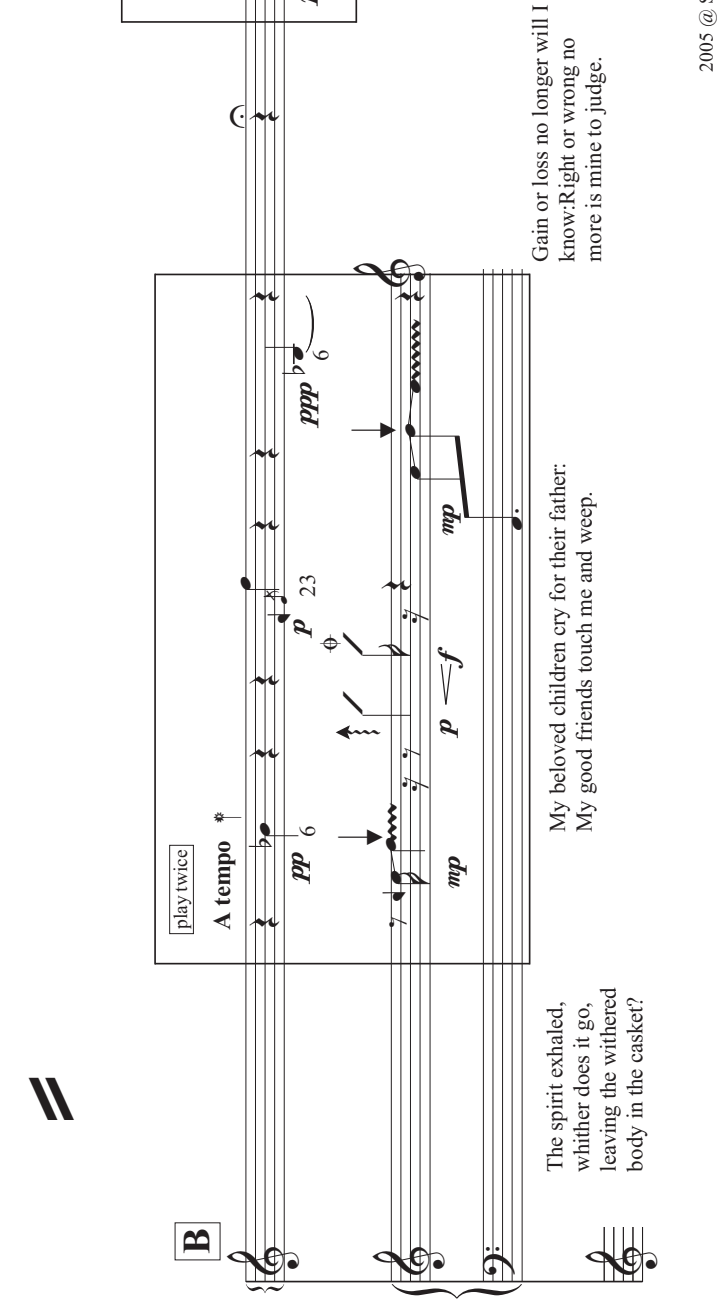


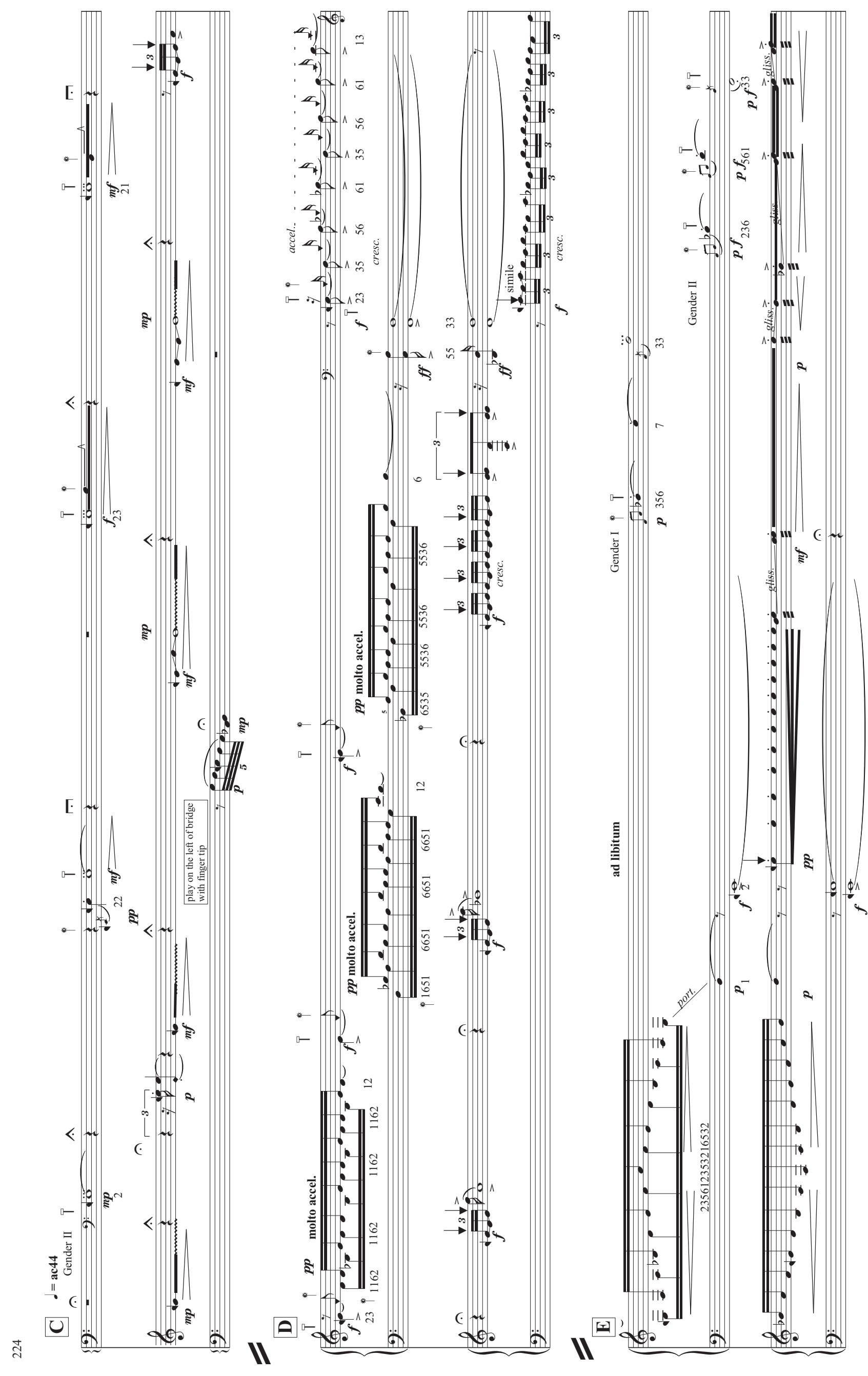


ส

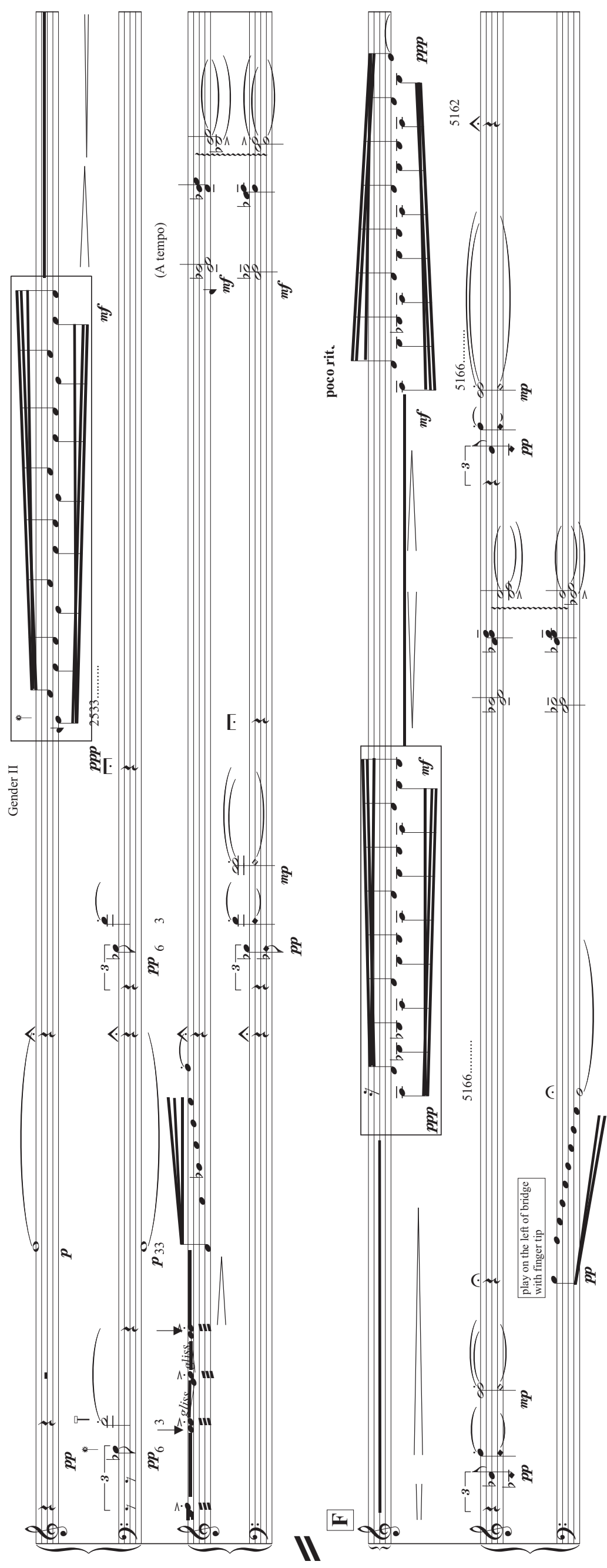

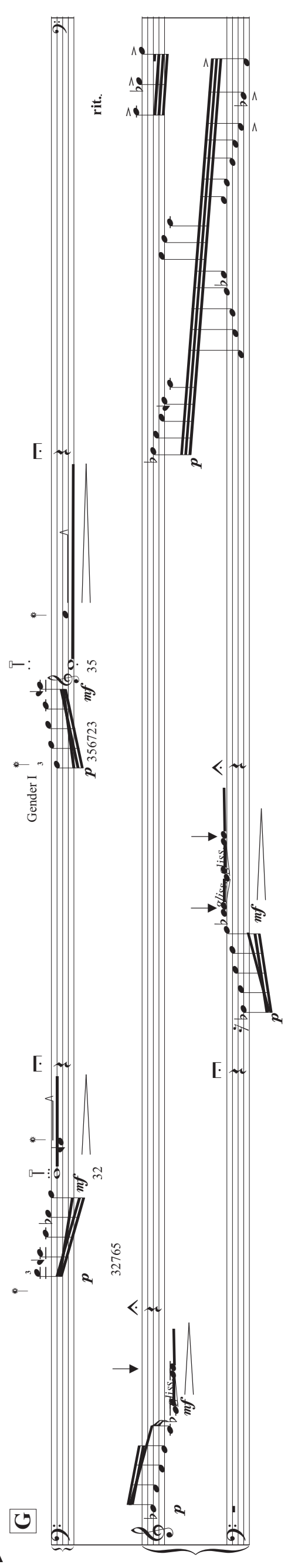




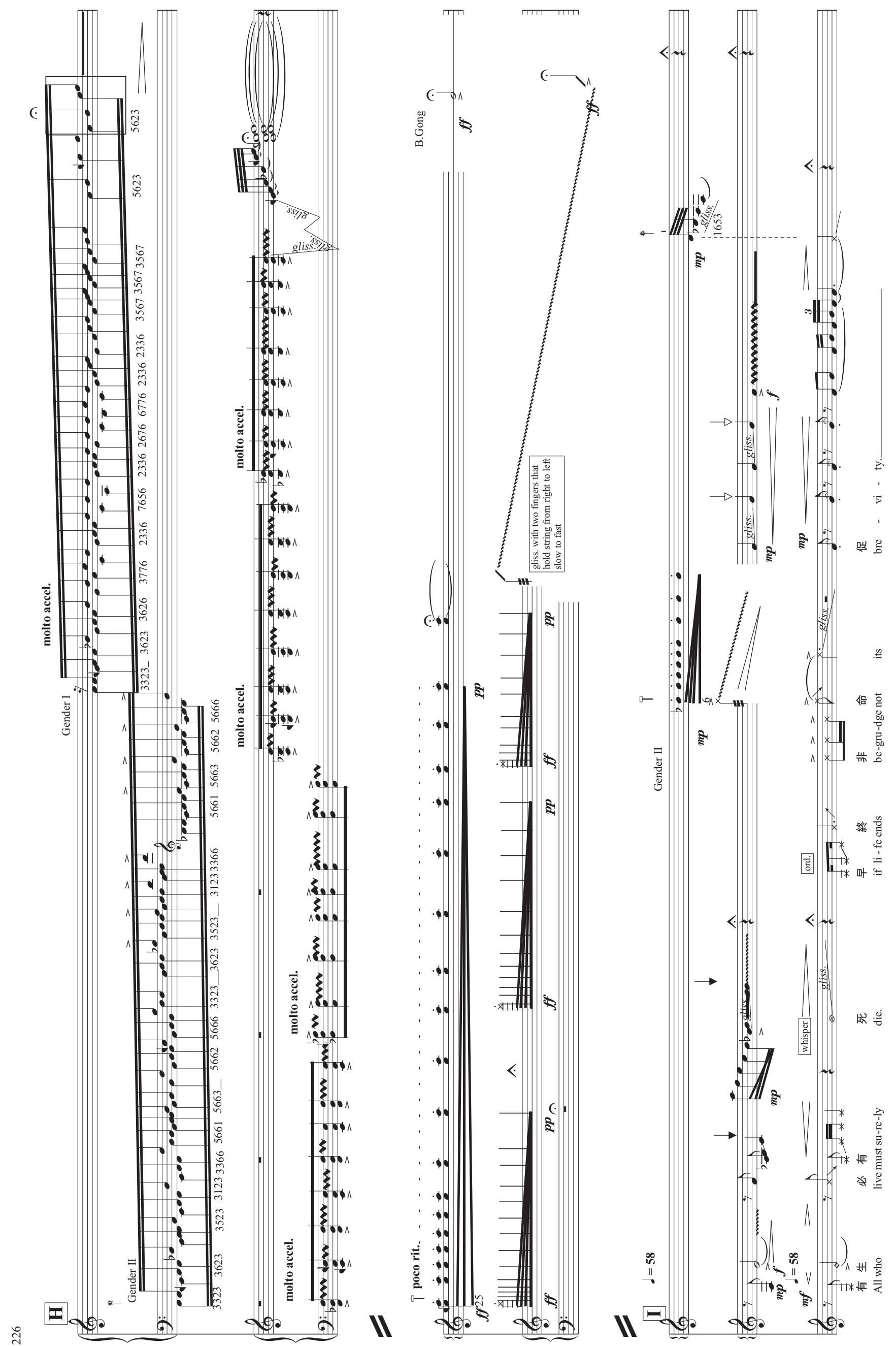




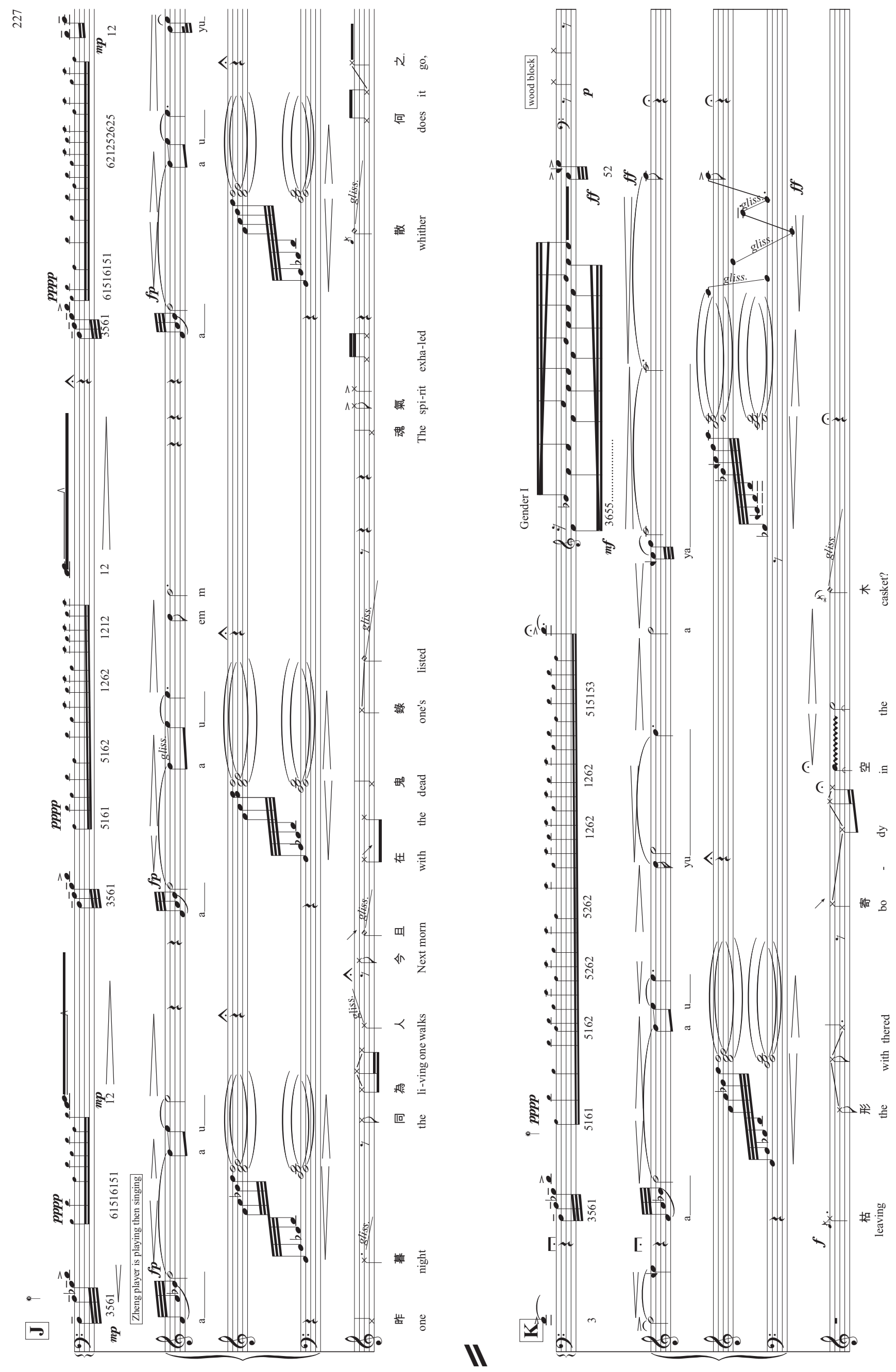




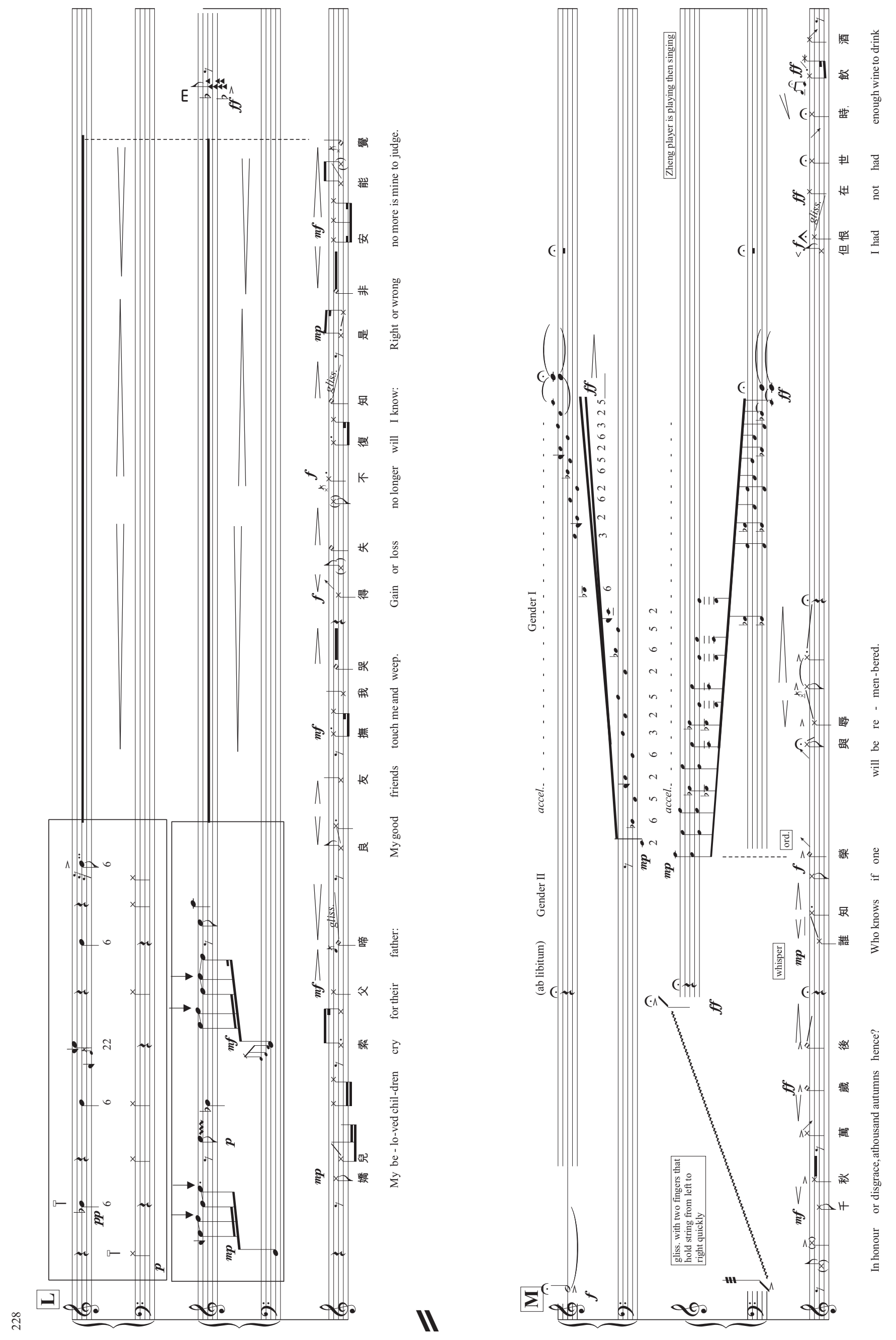




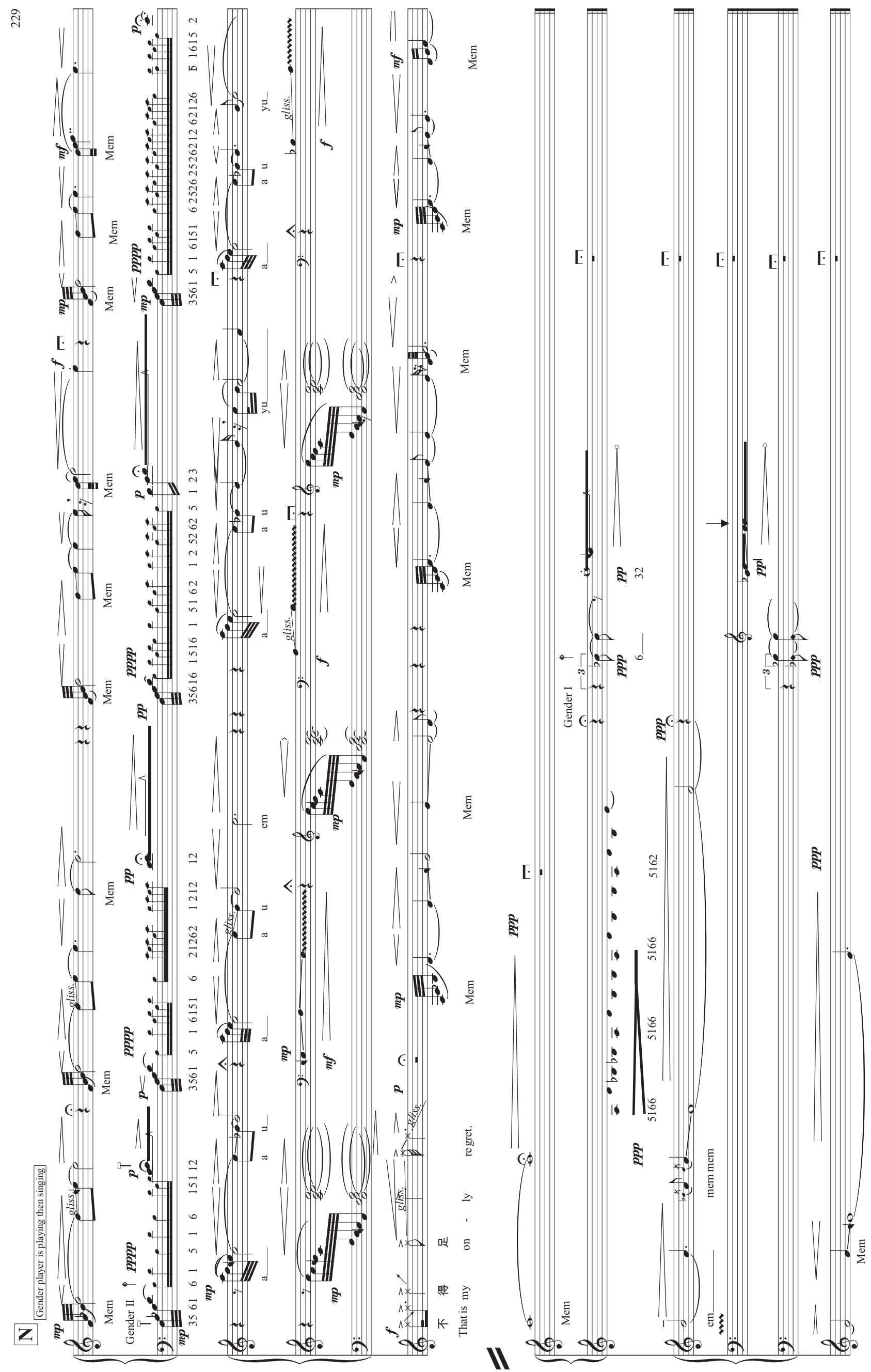




\subsection{Wang}

Premiered: The World Music Days 2009

International Symposium and Festival Dialogue in Music Central Conservatory of Music, Beijing

Concert I: Multicultural New Zealand

On $1^{\text {st }}$ November 2009, at 19:30 CCOM Recital Hall

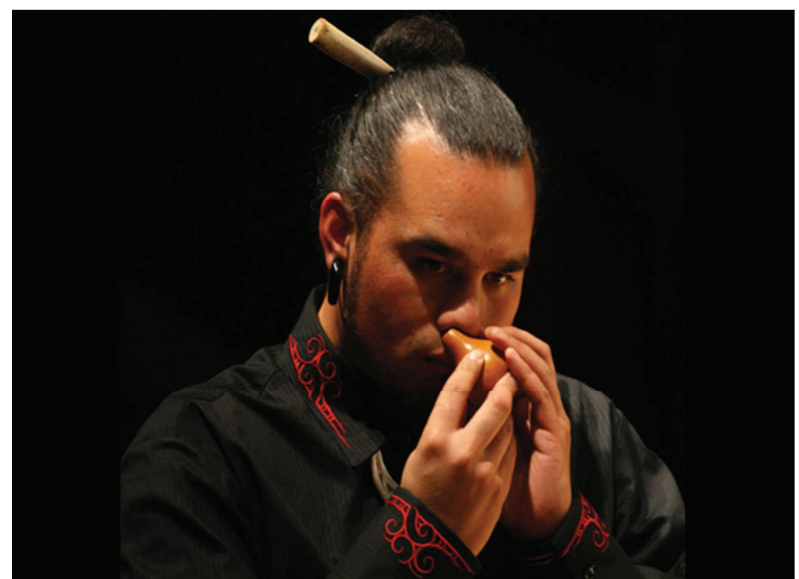

Horomona Horo

(Photographer Wang Xianyan)

Musician of the Central Conservatory of Music, Beijing

Cui Yanlin

Liu Jing

Zhang Yuwen

Huang Yuting

Chen Shubo

Wang Yang

Wei Yunxi

Wang Yunpeng

Horomona Horo

Shen Nalin

\author{
bonang \\ zhèng \\ saron \\ shèng \\ tenor \\ mezzo soprano \\ soprano \\ baritone \\ nguru, kōanau kōiwi, \\ tumutumu, pūkāea and haka \\ conductor
}

(Live recording by the Musicology Department of the Central Conservatory of Music, November 2009) 


\section{WANG}

for sheng, zheng, saron, bonang, four singers and taonga puoro
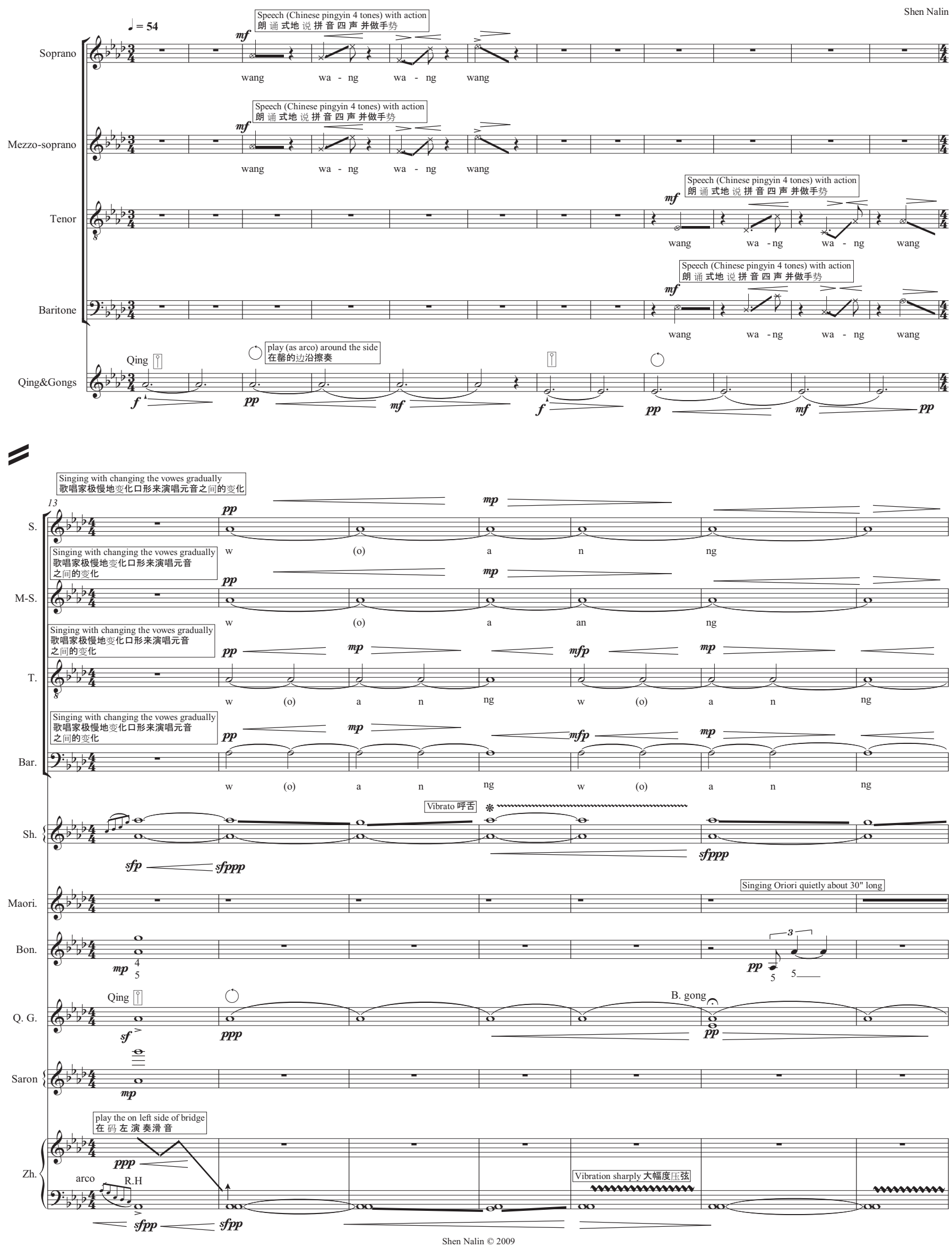

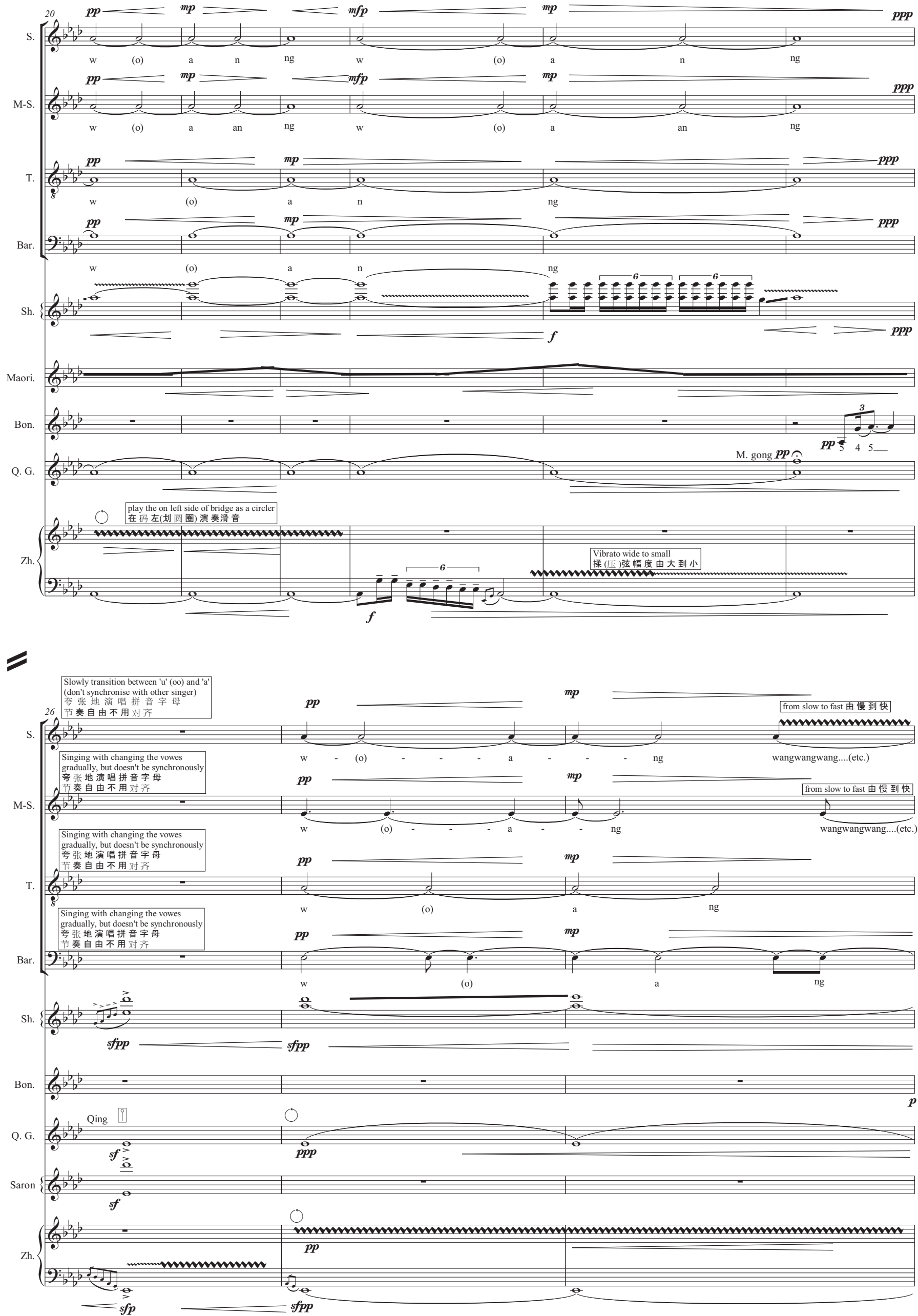


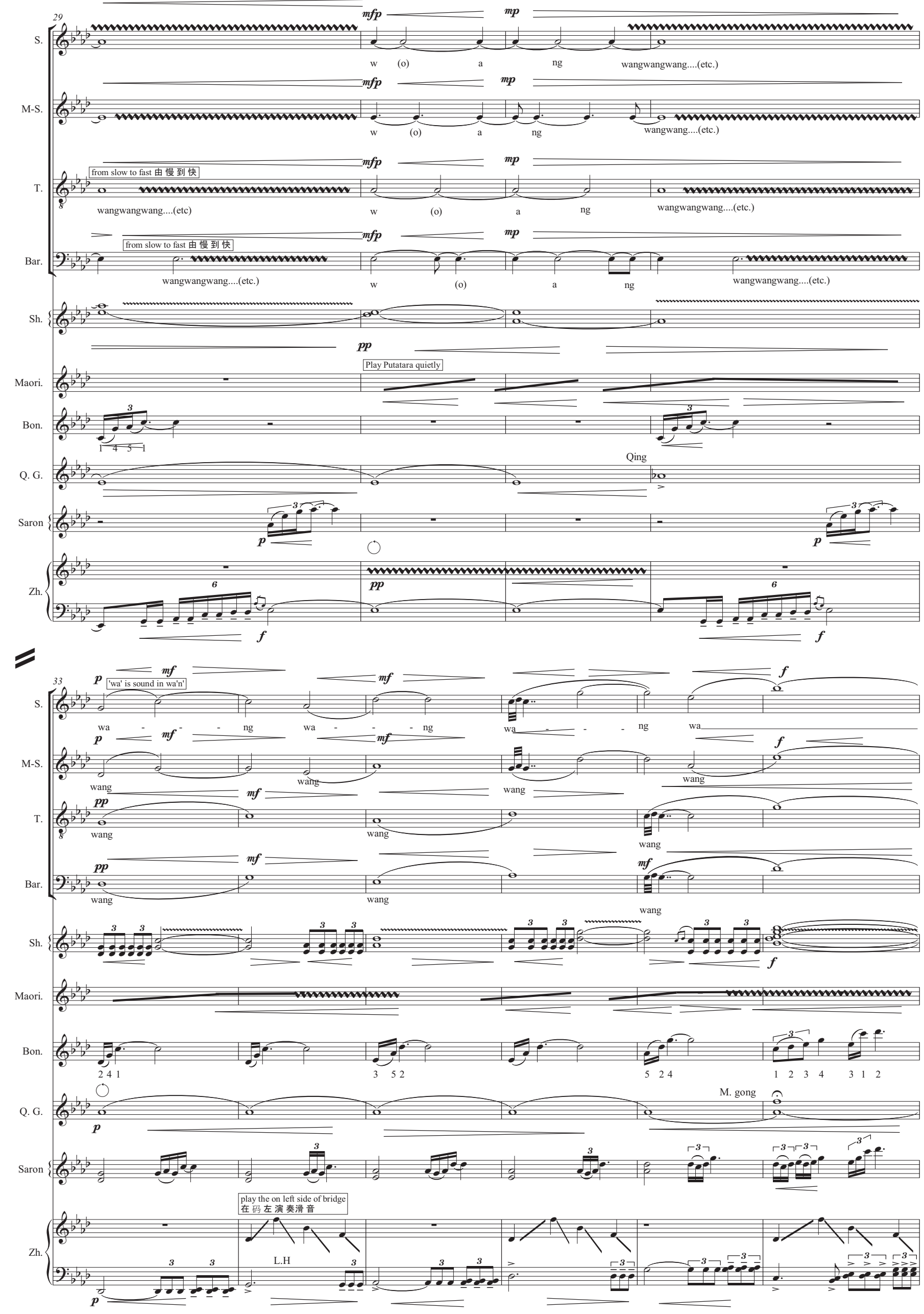



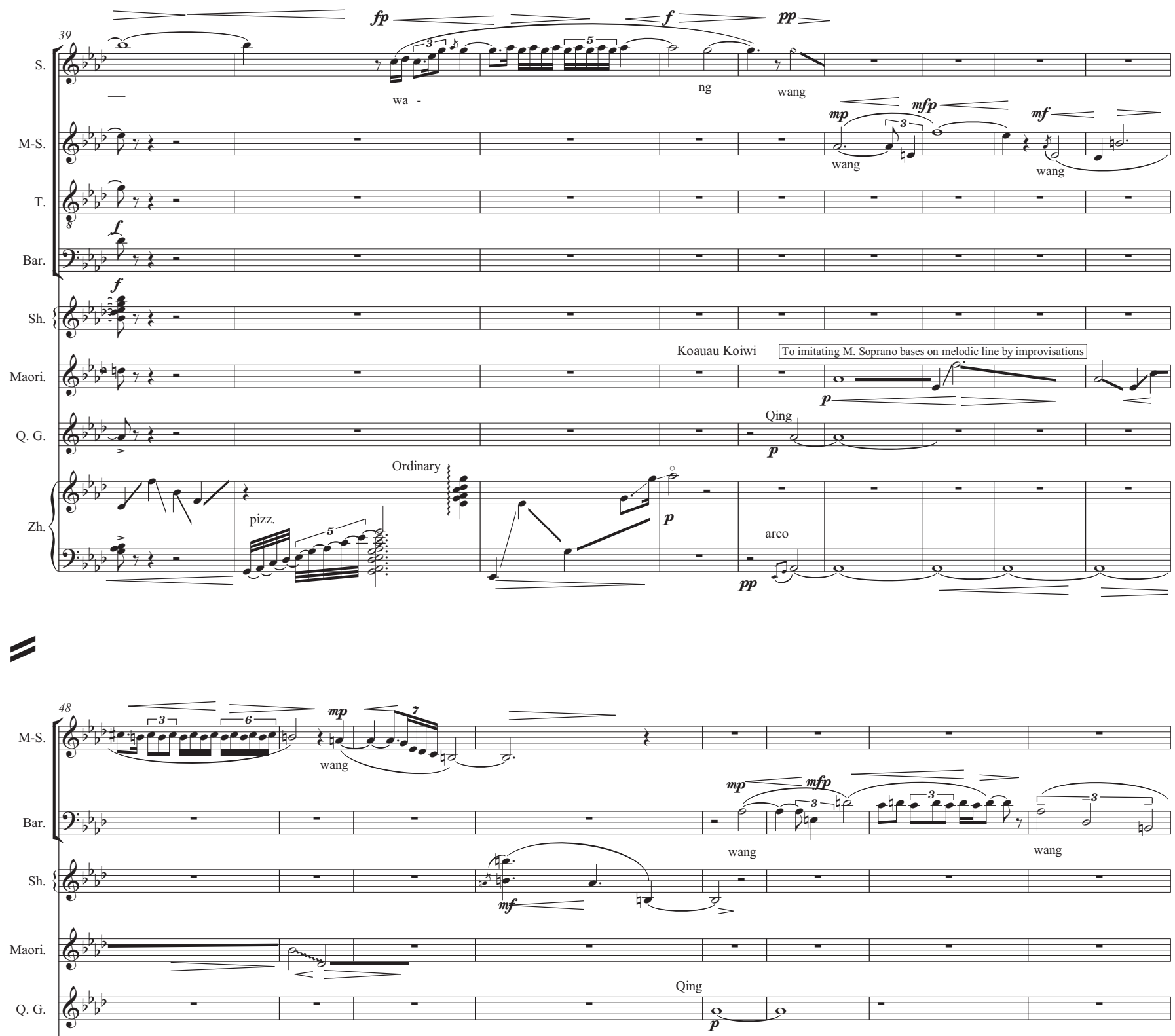

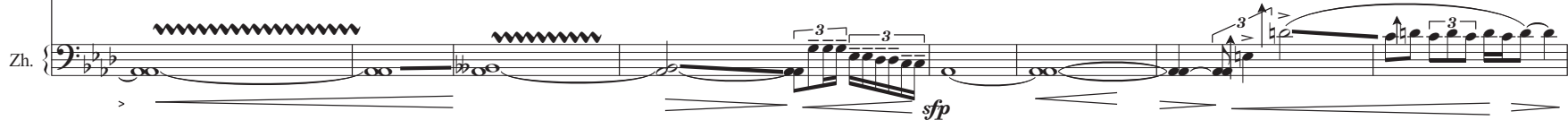

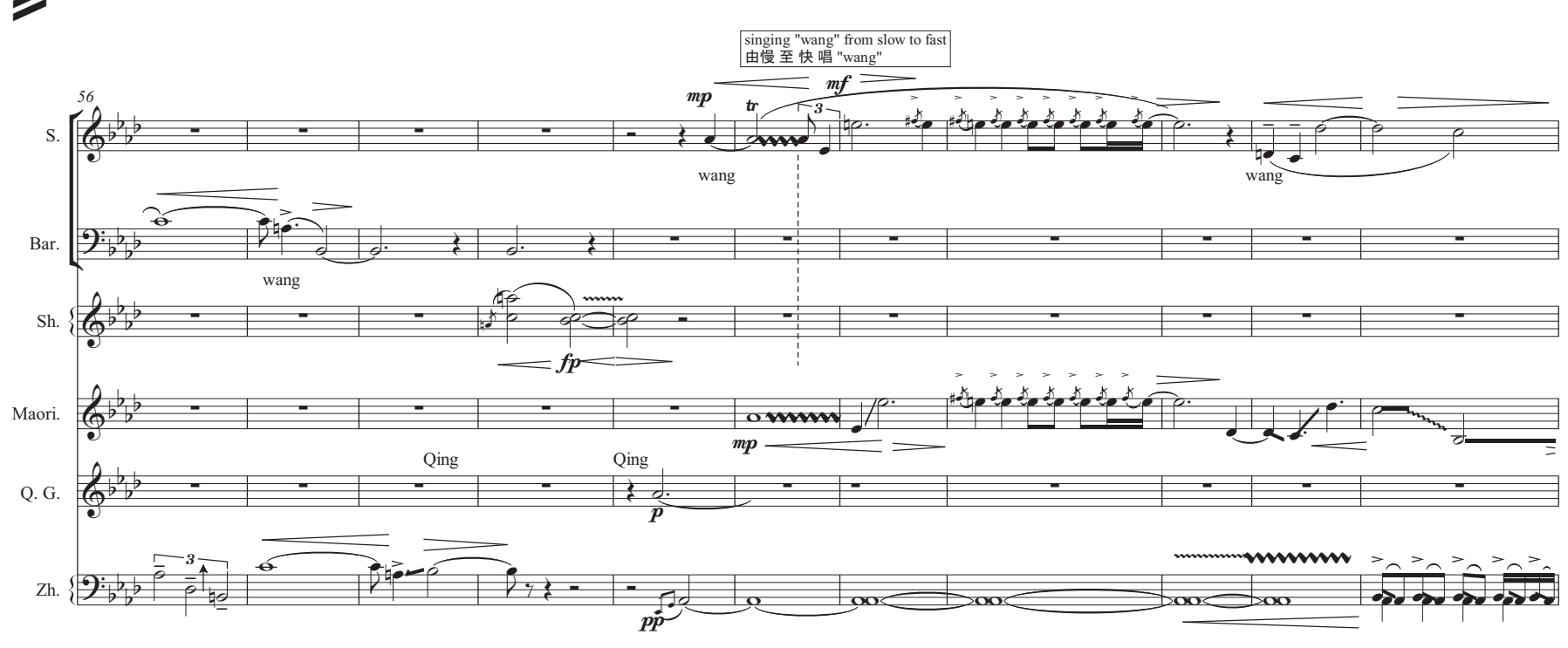




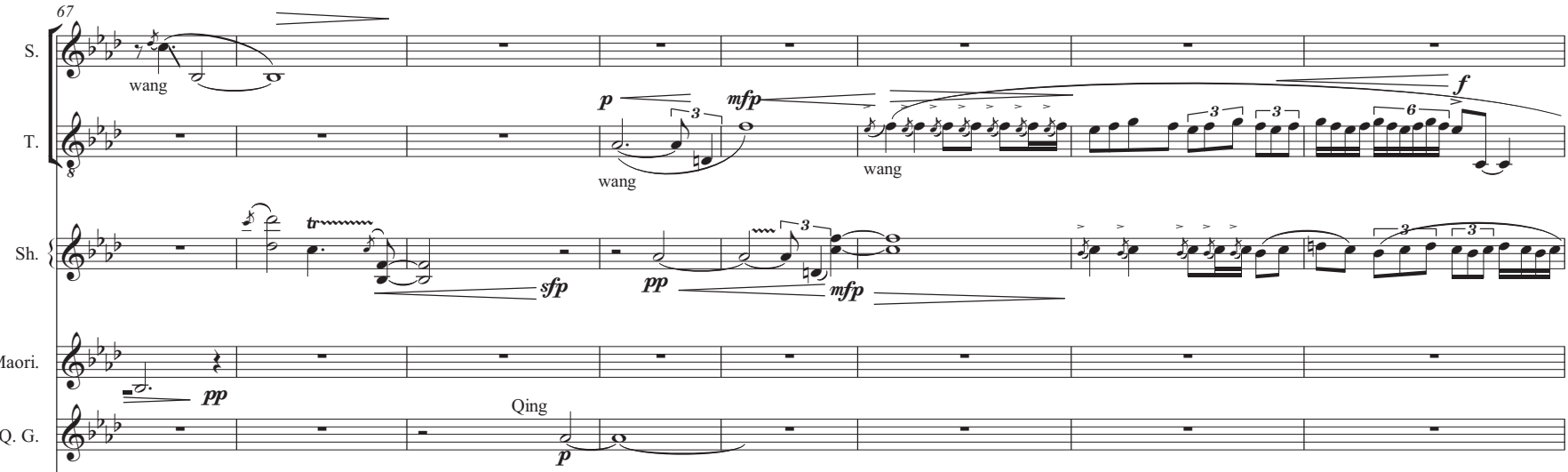

Zh. $\left\{\sum_{2, b, 000}\right.$ 2

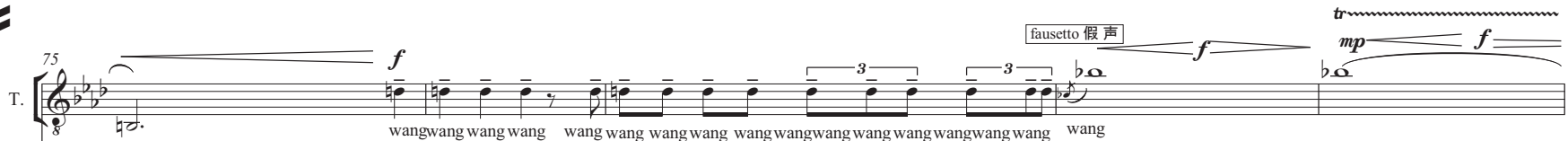

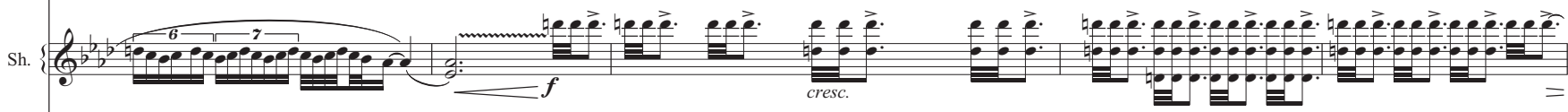
Zh. $\left\{\sum_{0,000}^{\infty}\right.$

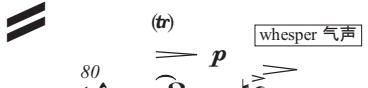
rit.
A tempo $\cdot \mathbf{5 4}$
т.

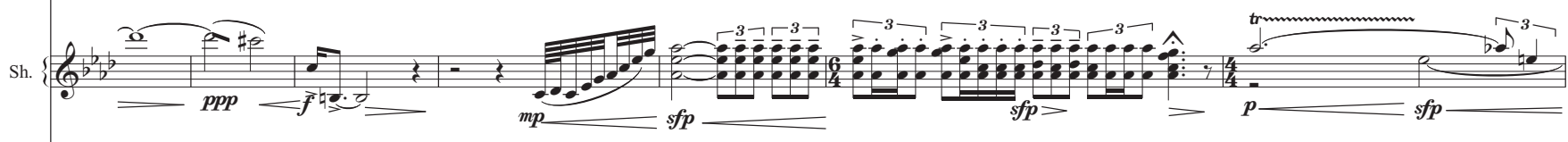

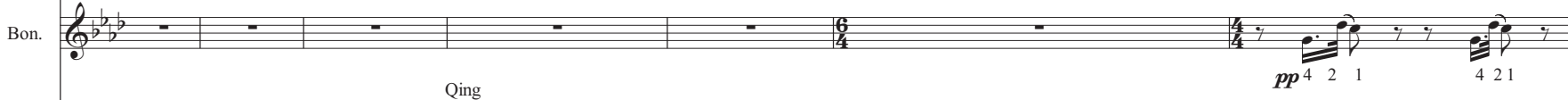

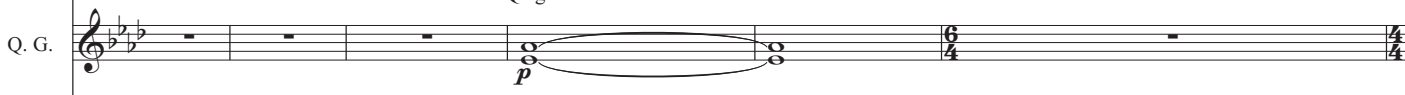

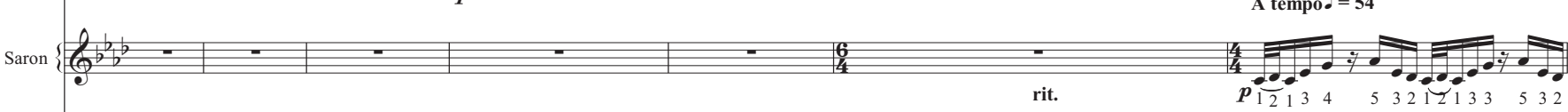

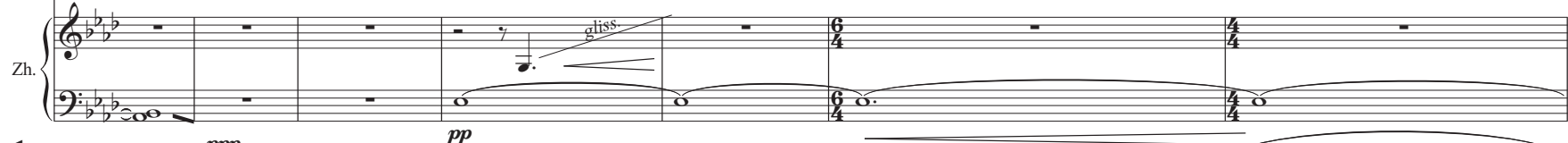

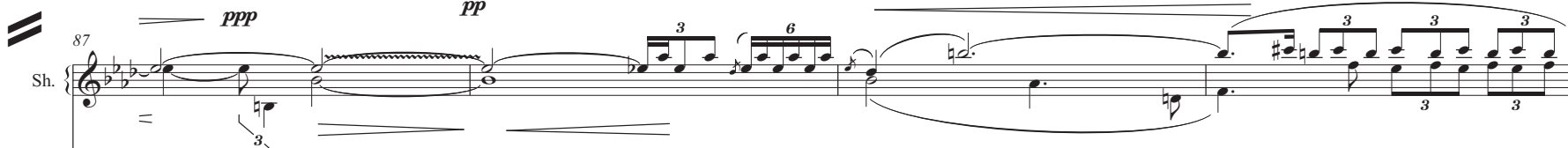 Bon.

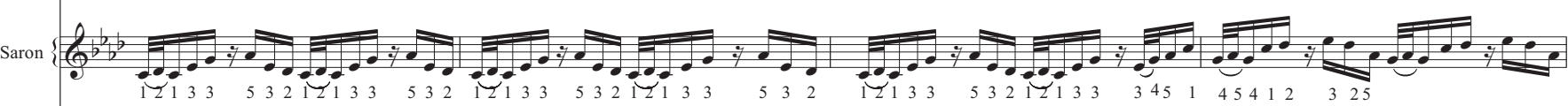

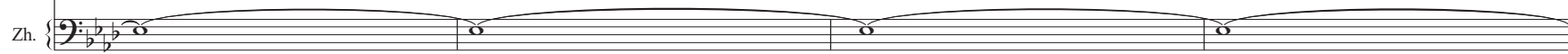




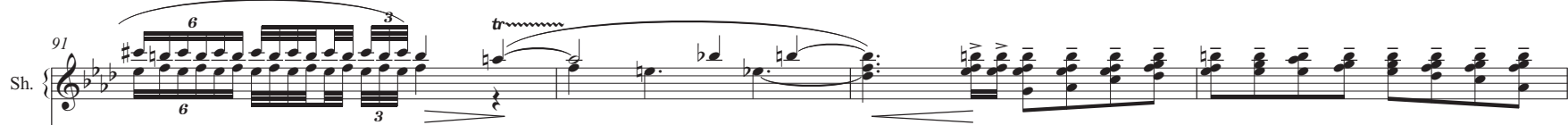

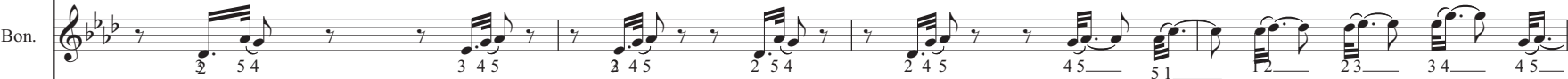

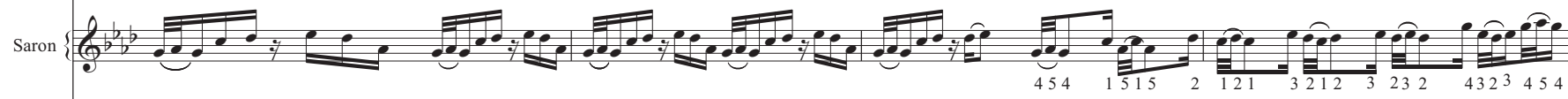

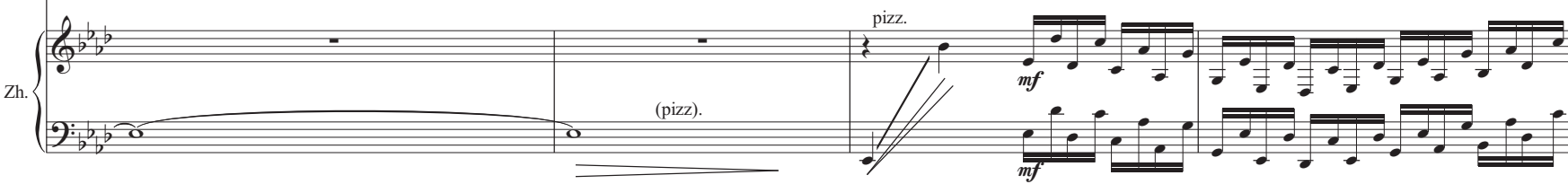
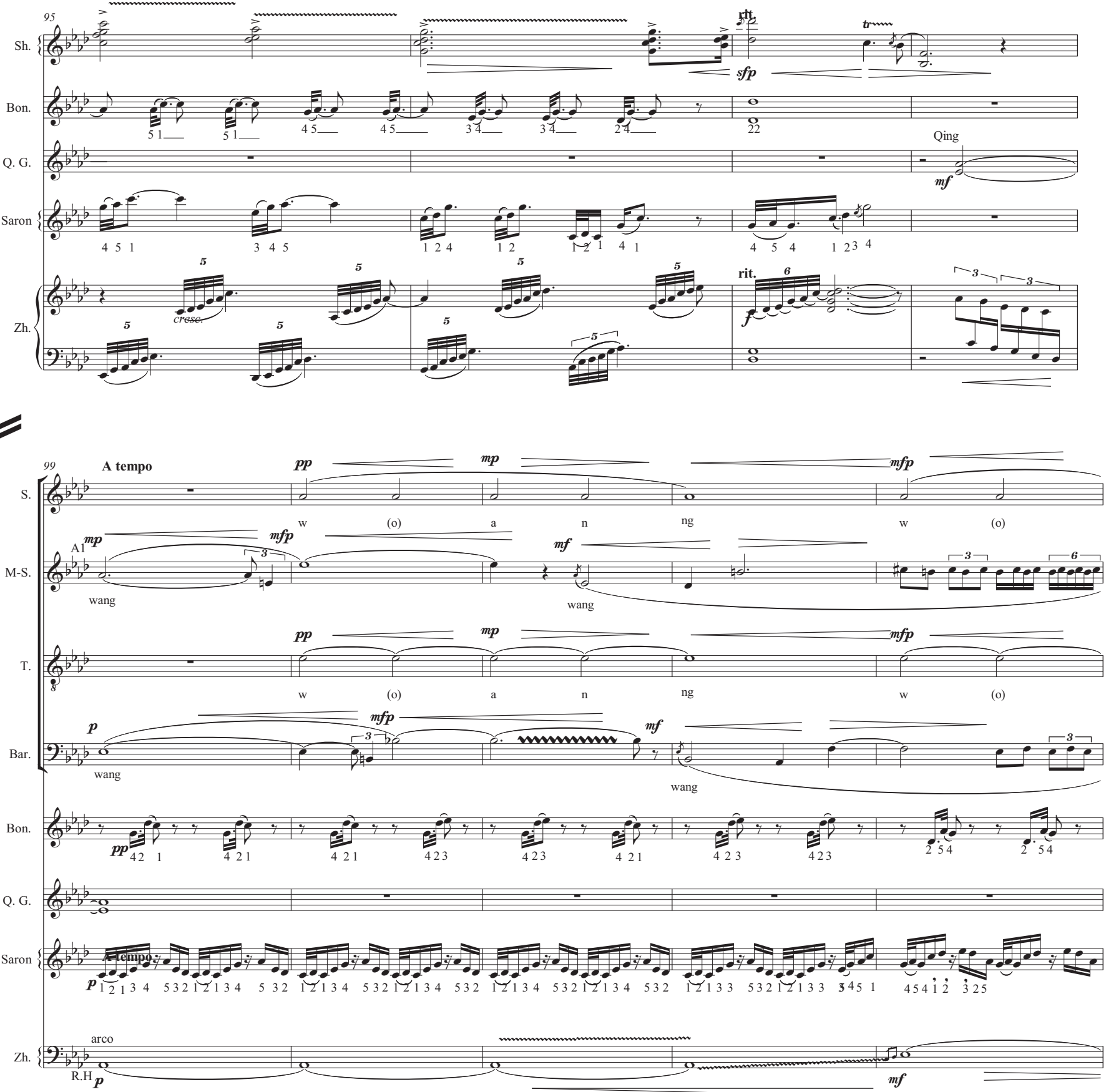

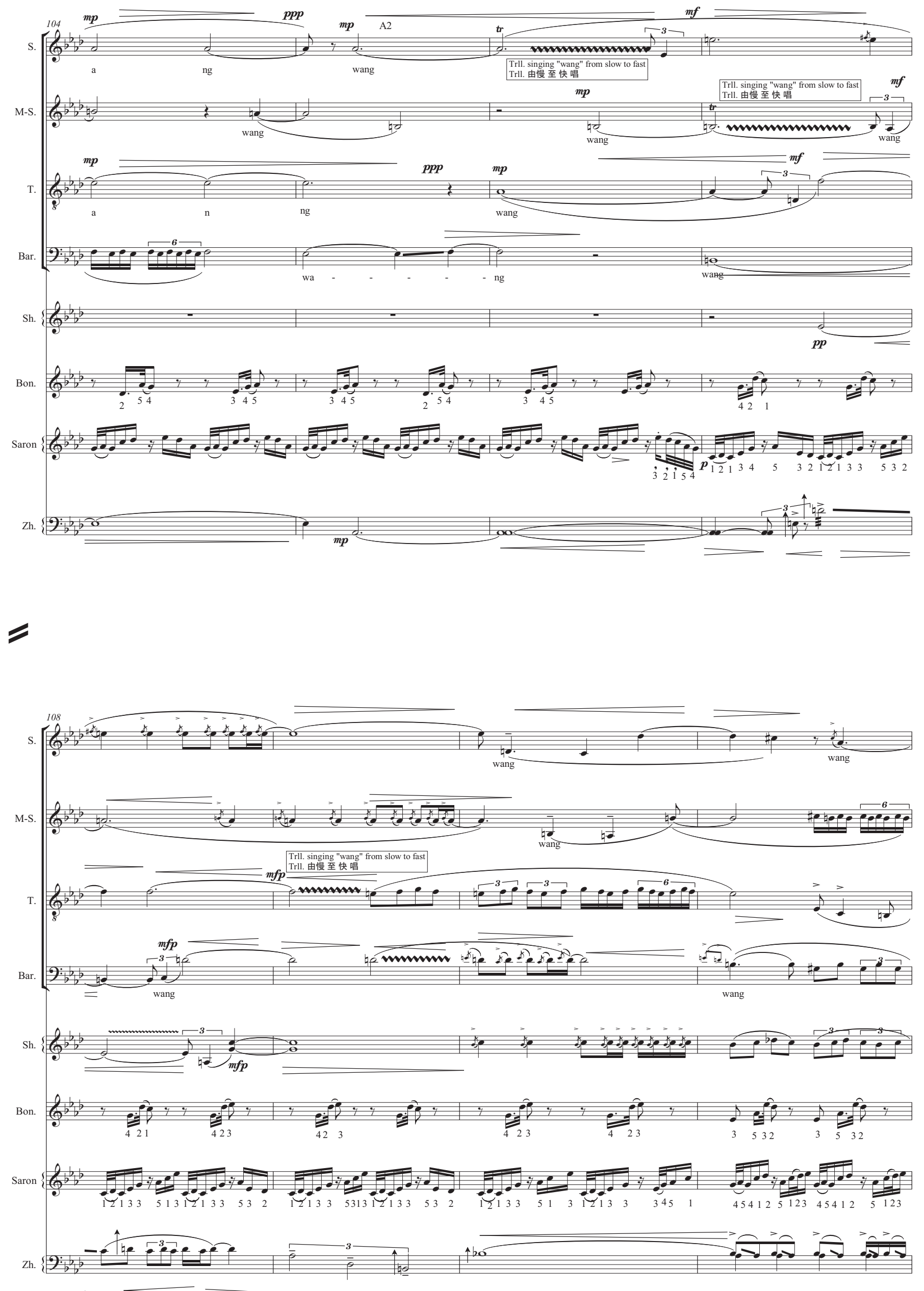


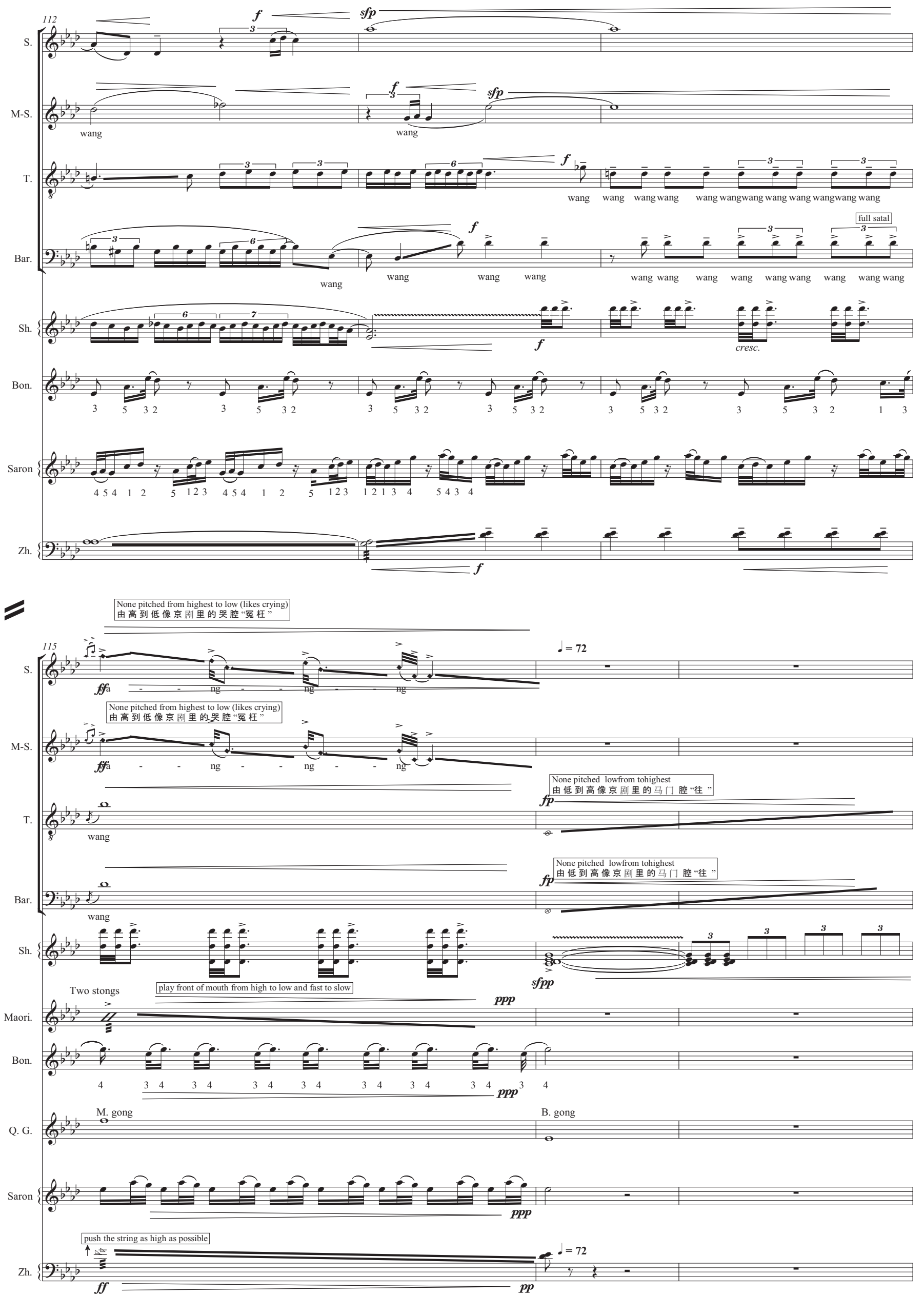




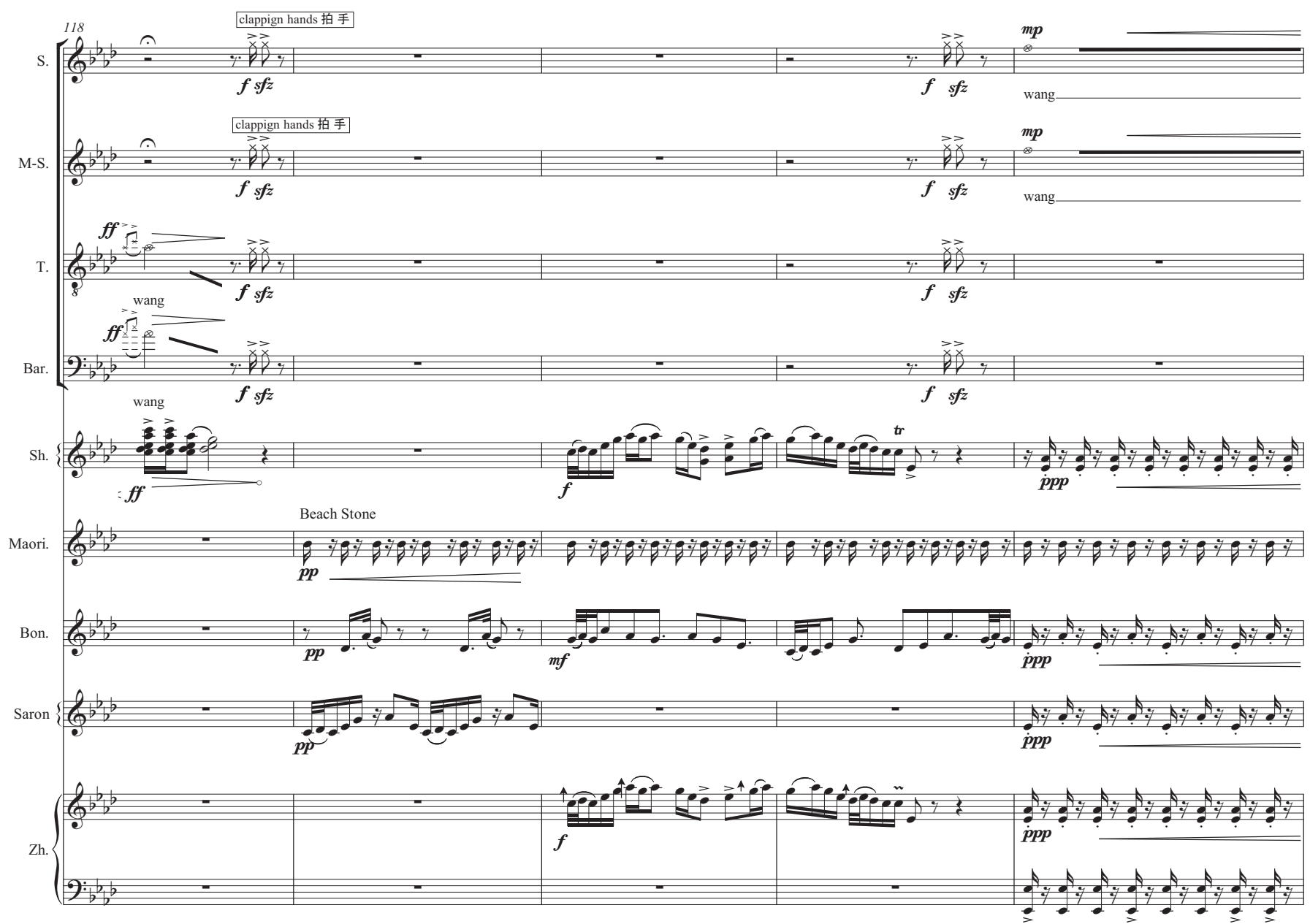

₹

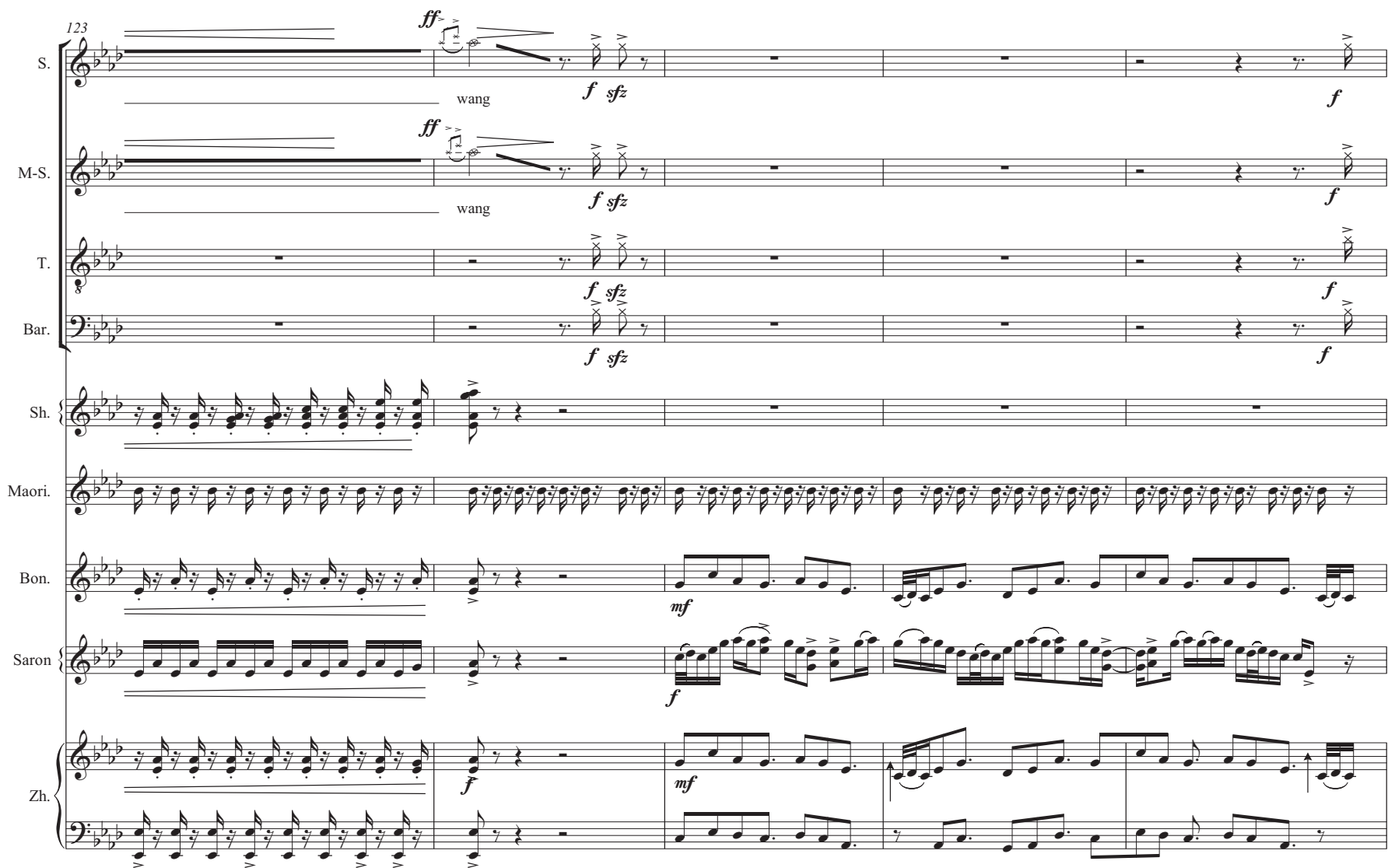



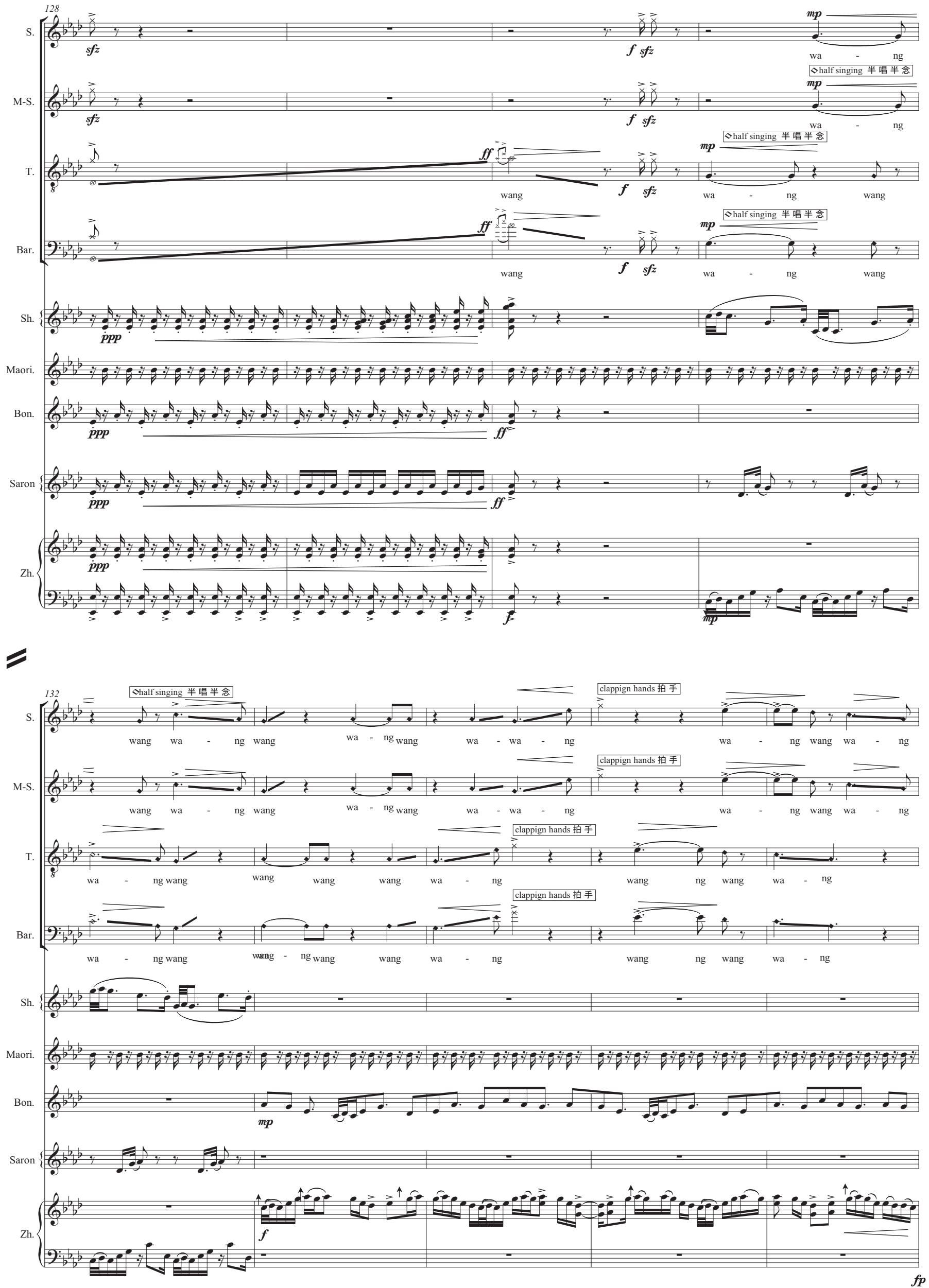


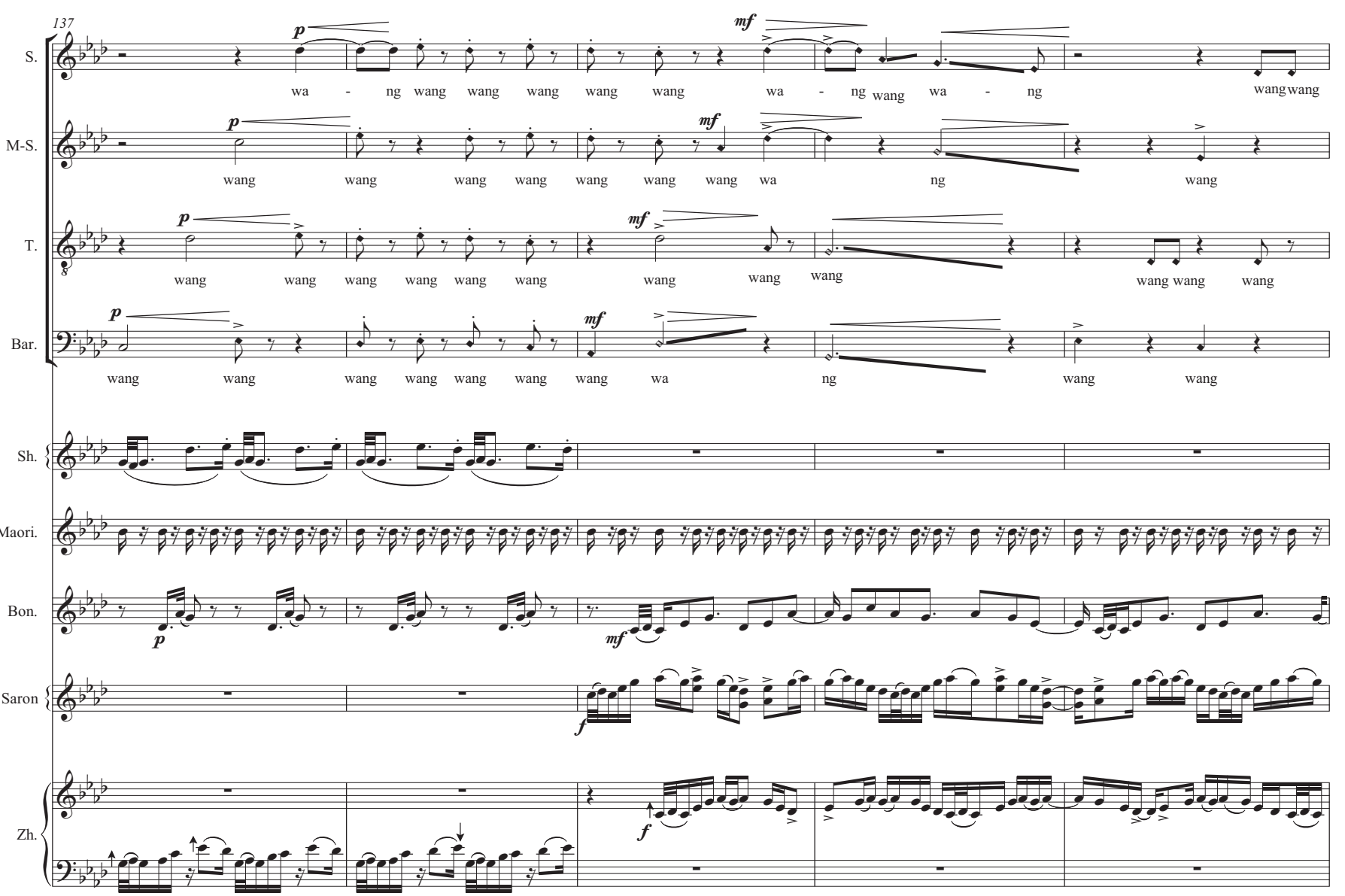

1

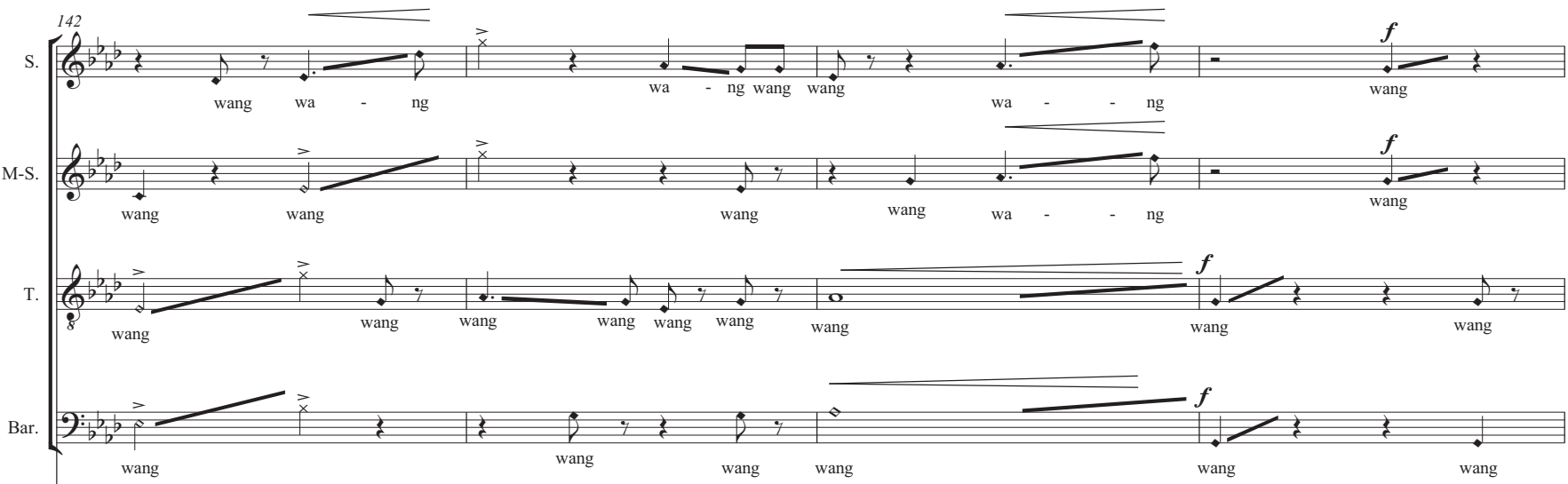

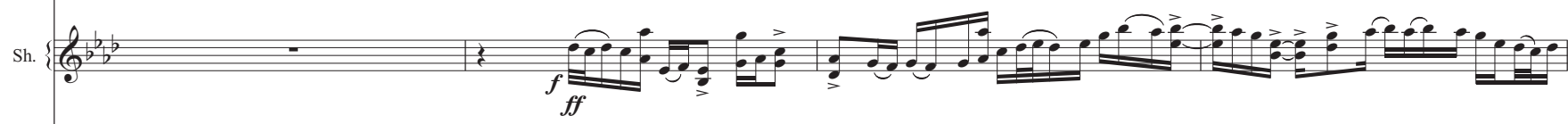

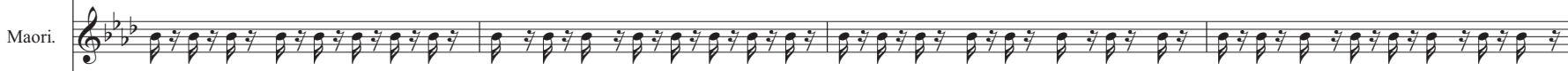

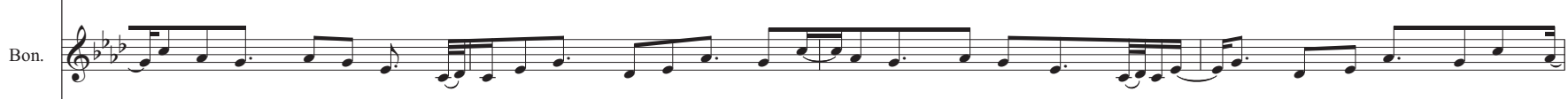

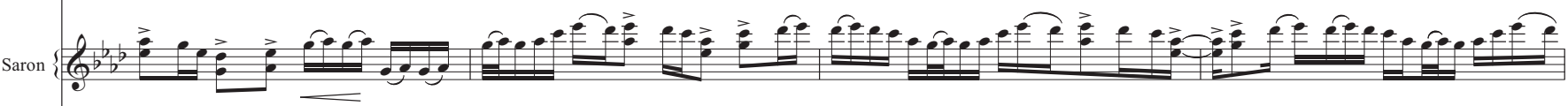

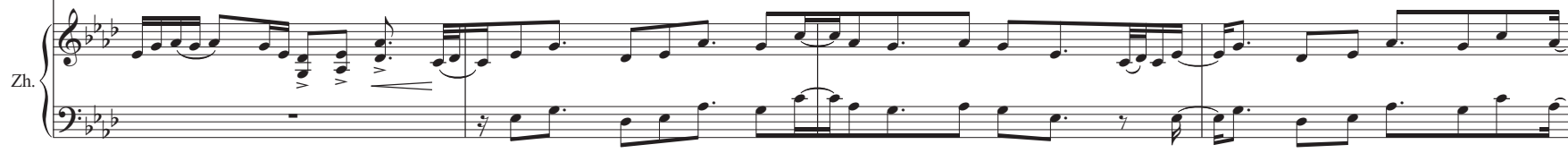




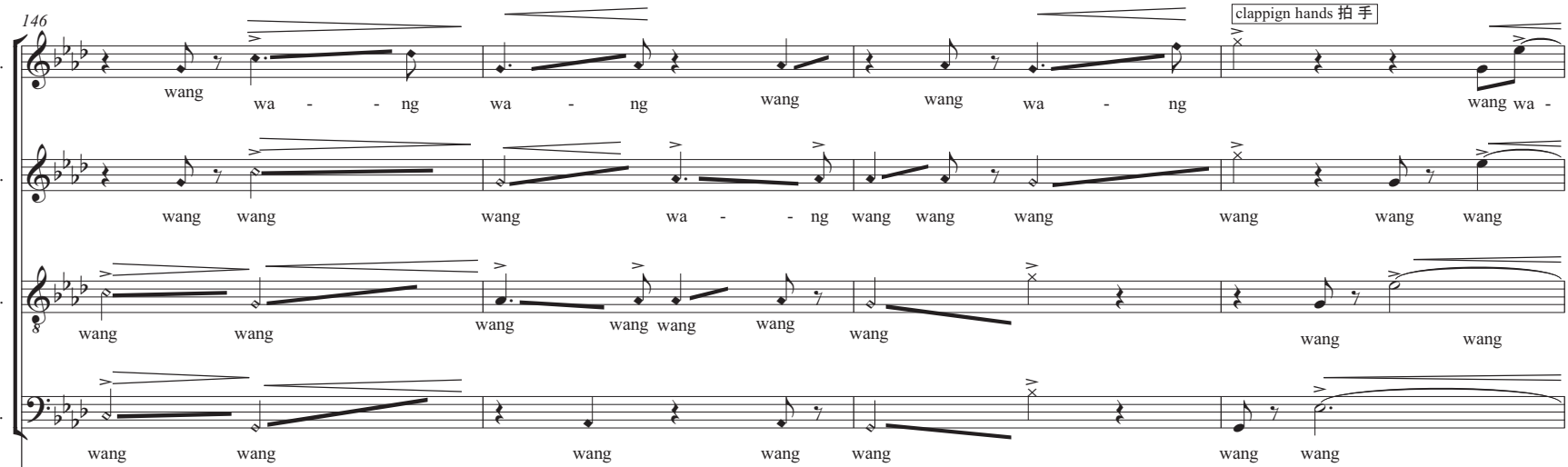

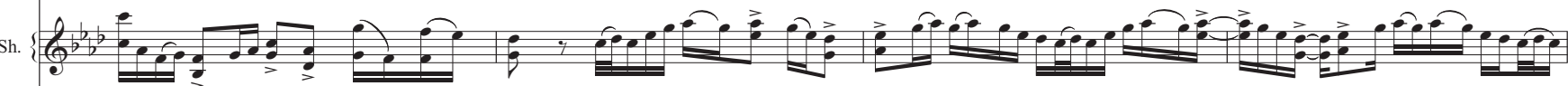

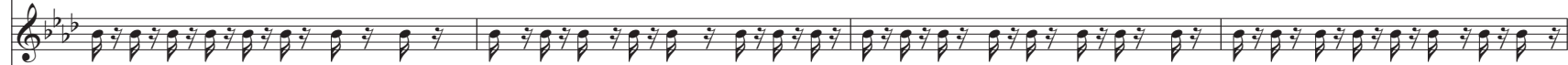

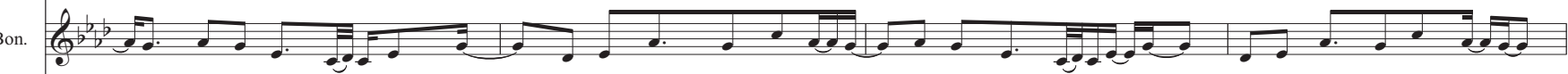

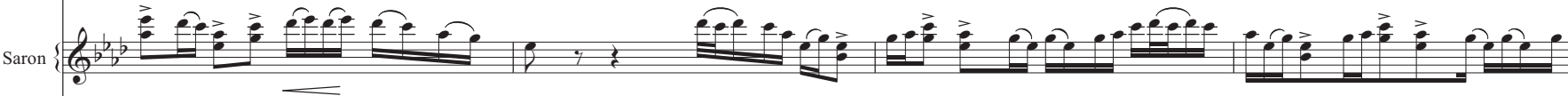

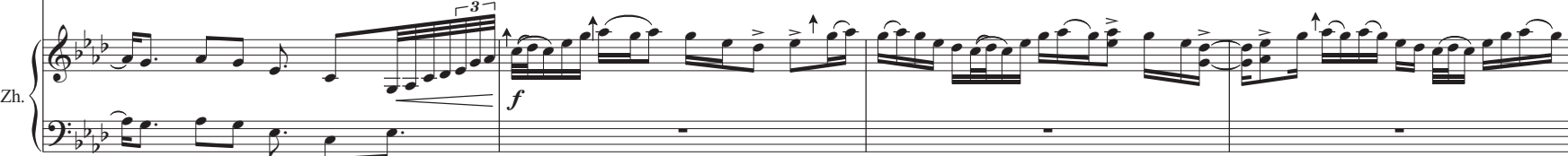

2

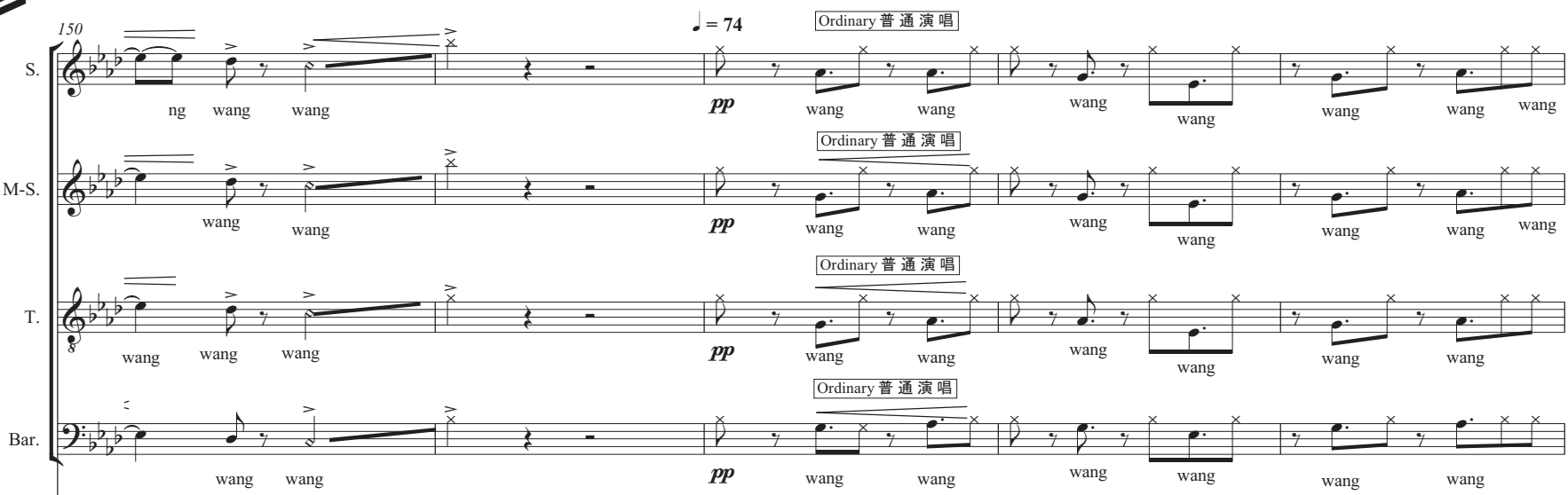

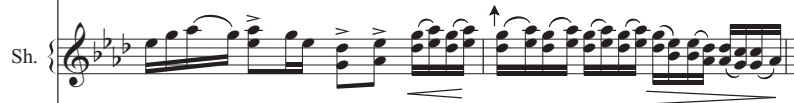

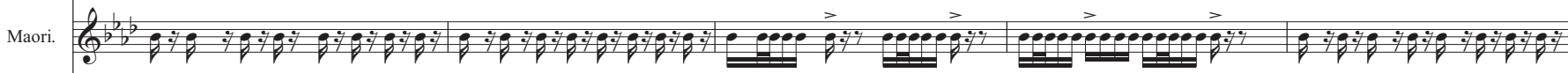

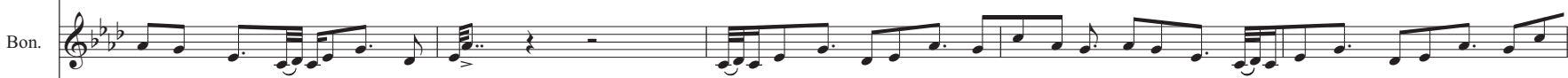
Q. G. $\underset{2}{2}$

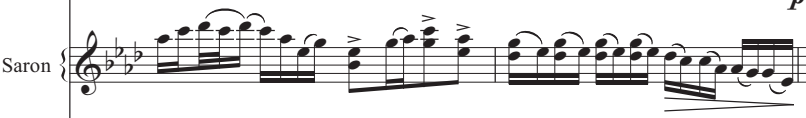

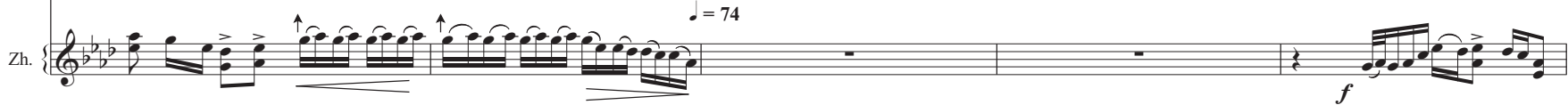




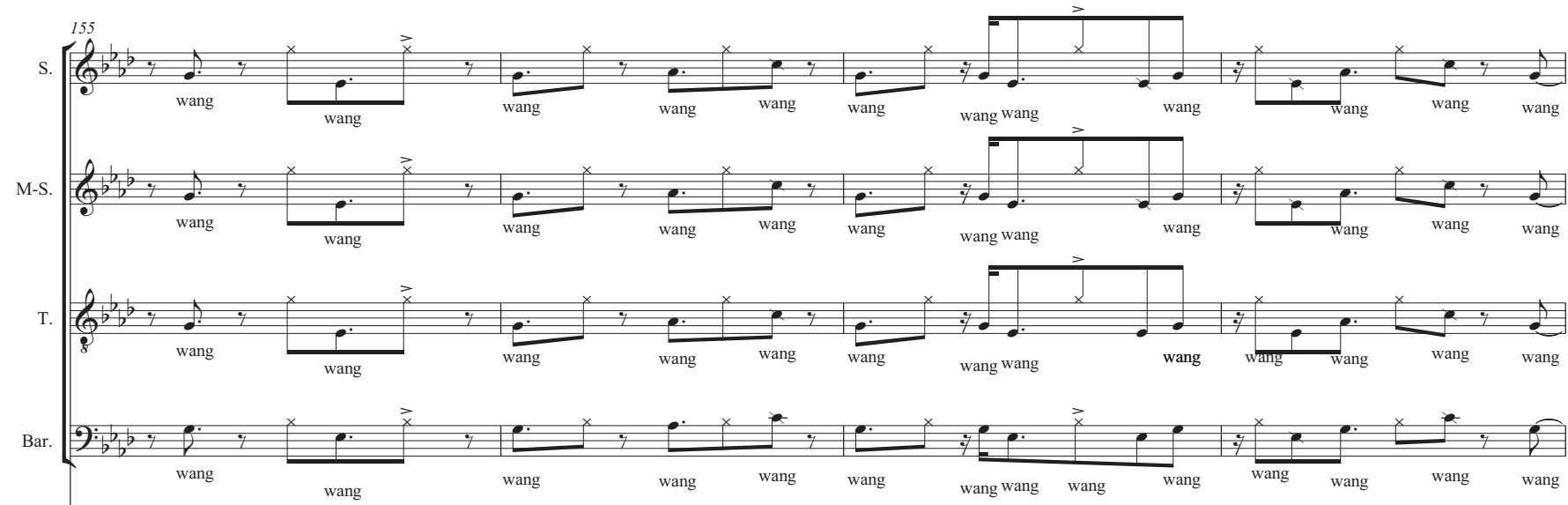

Sh

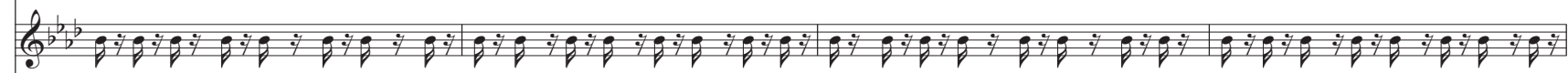

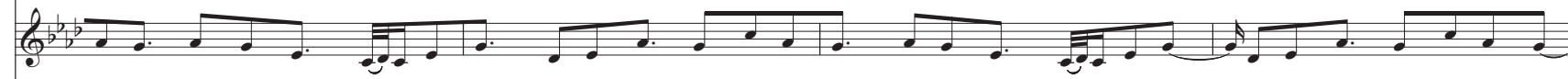

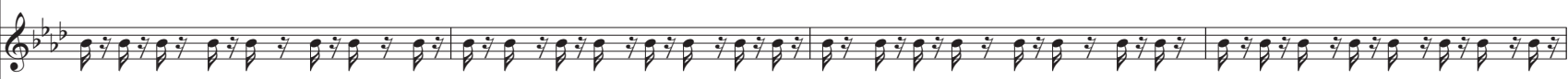

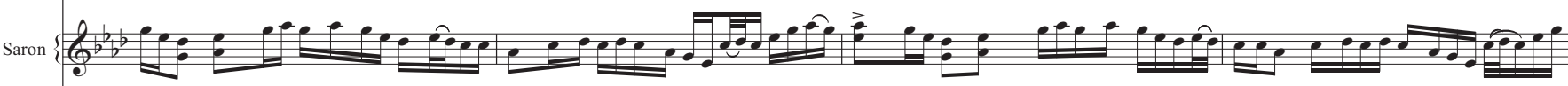

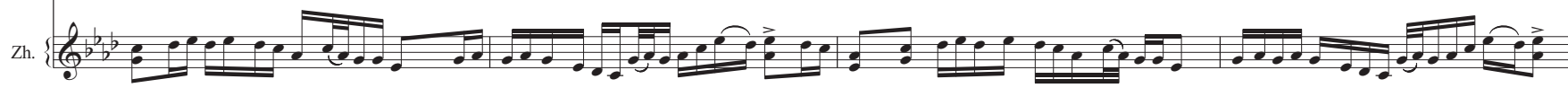

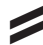
Mar.

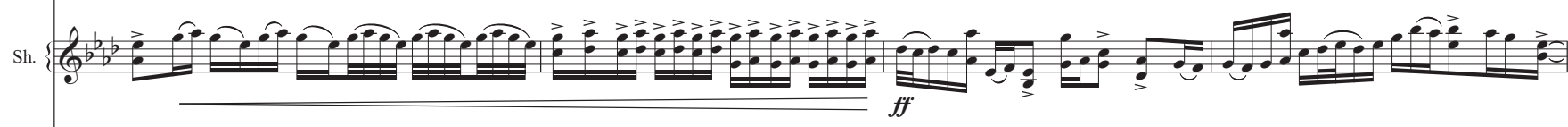
Marri.

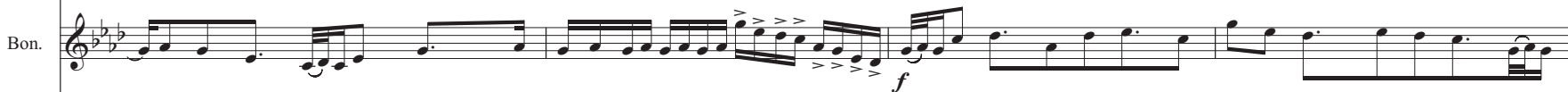
Q.

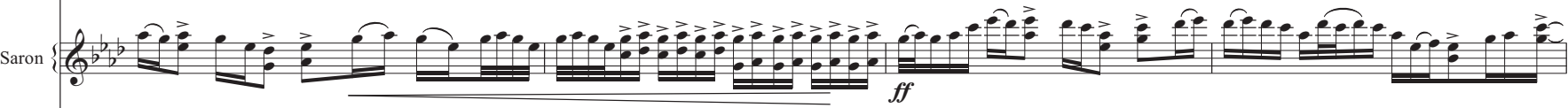

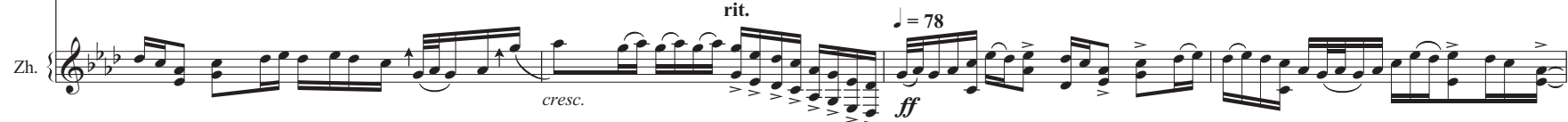




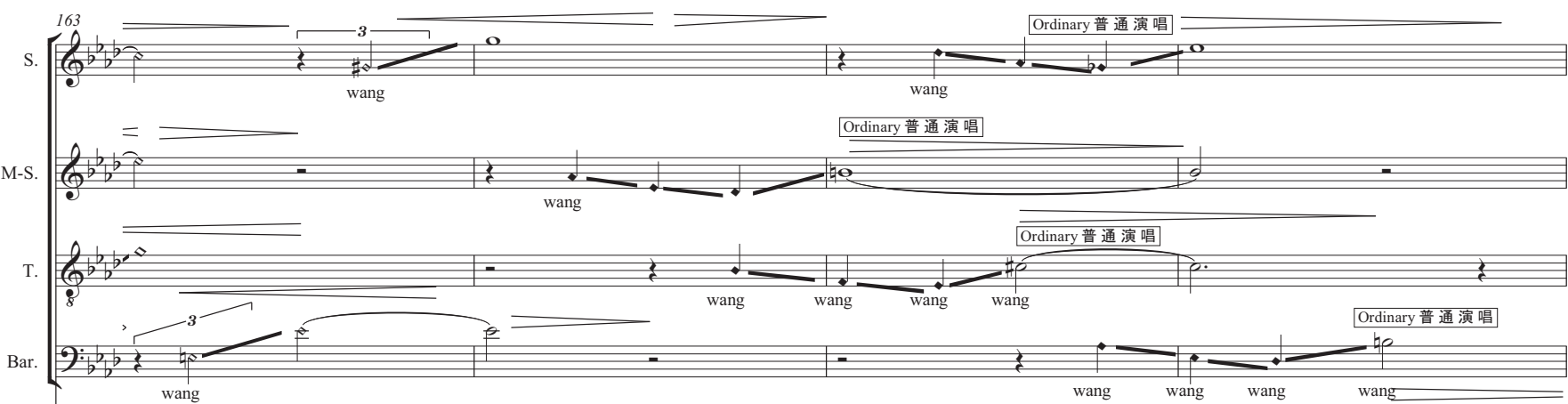

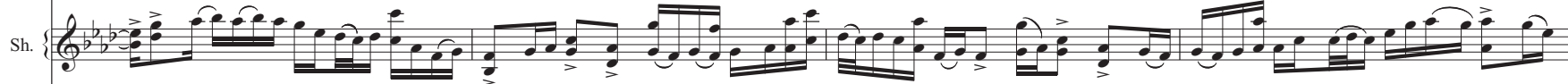
Marri. Bon. Q. G. Saron $\left\{b_{0}\right.$

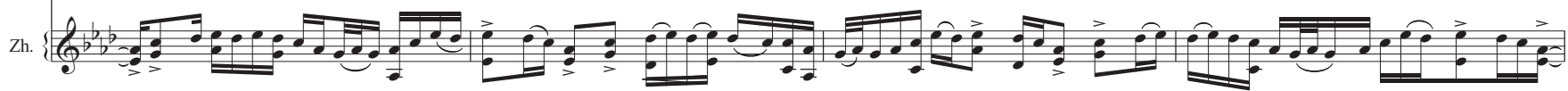

₹

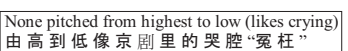
Q. G. 

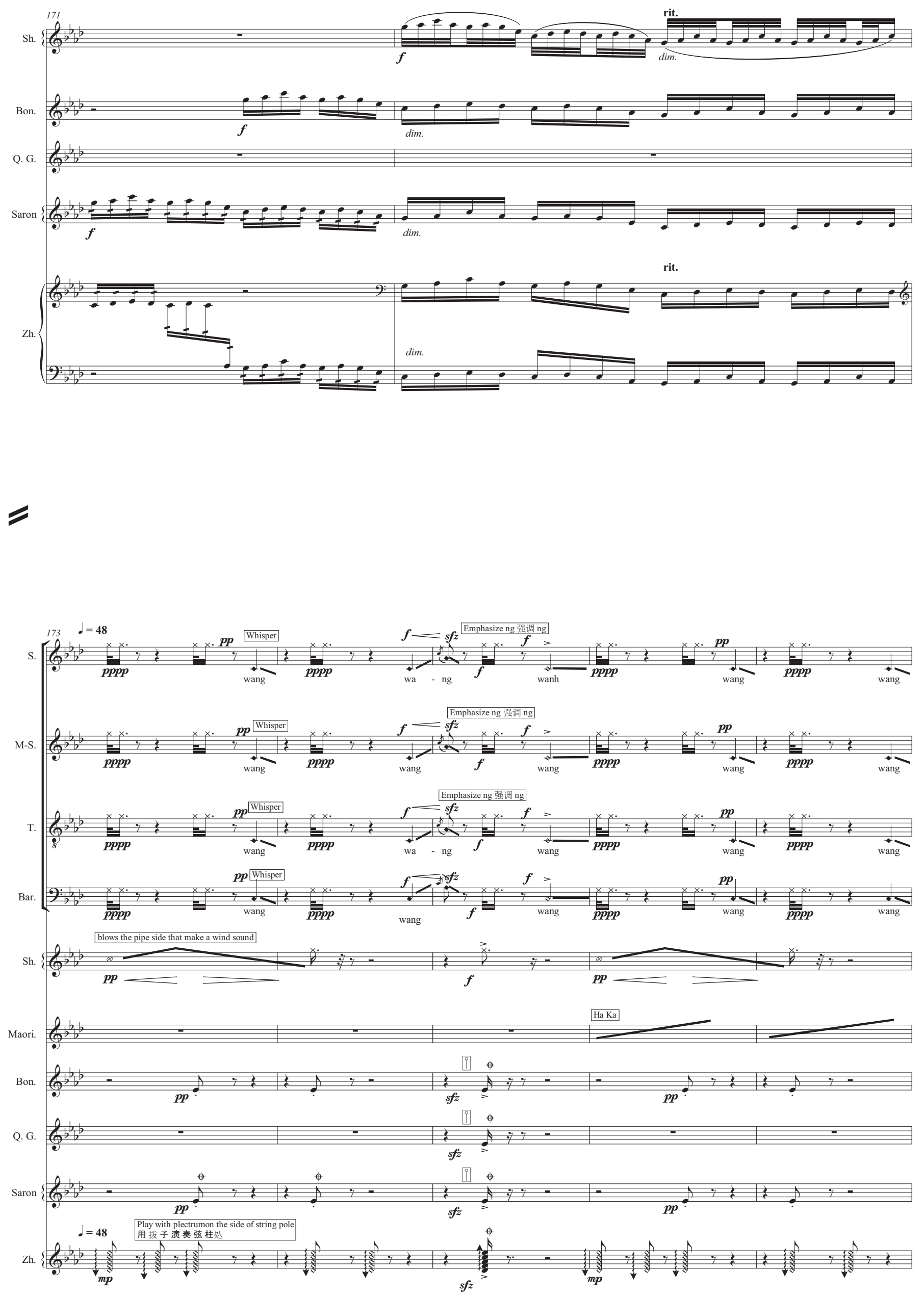


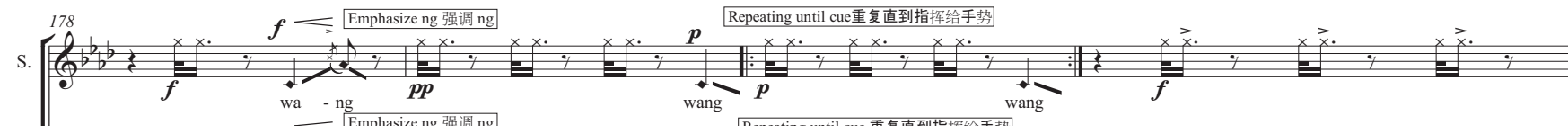

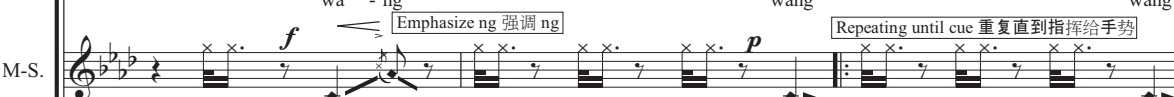

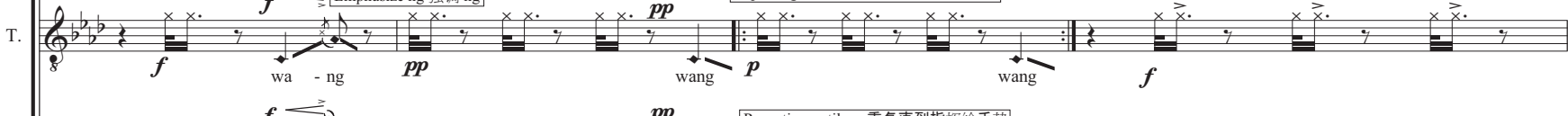

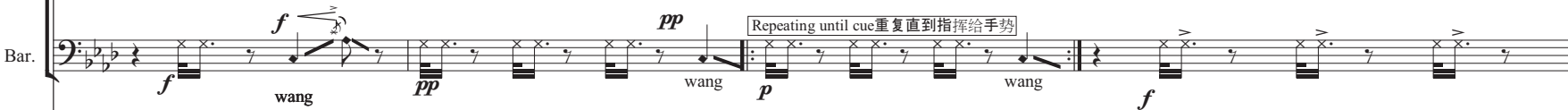

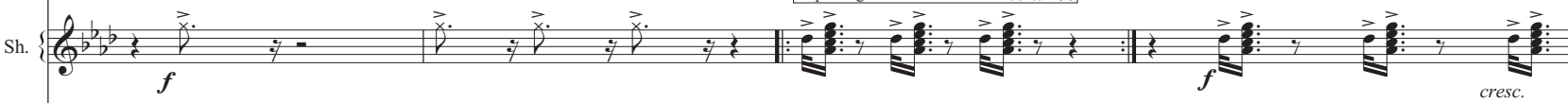
Maori. $\frac{1}{3}$ Bon. Q. G. Saron Zh. Marri 

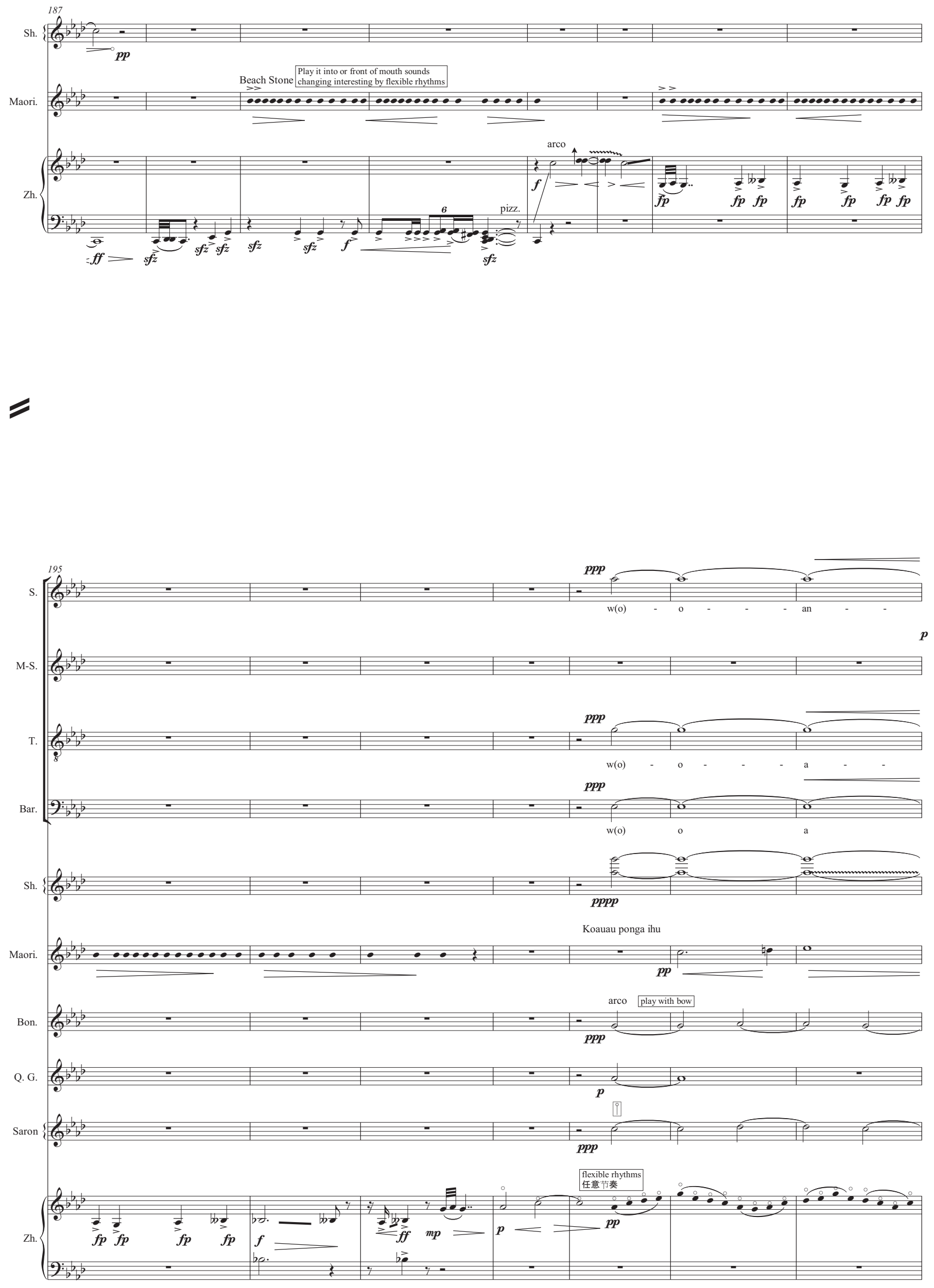

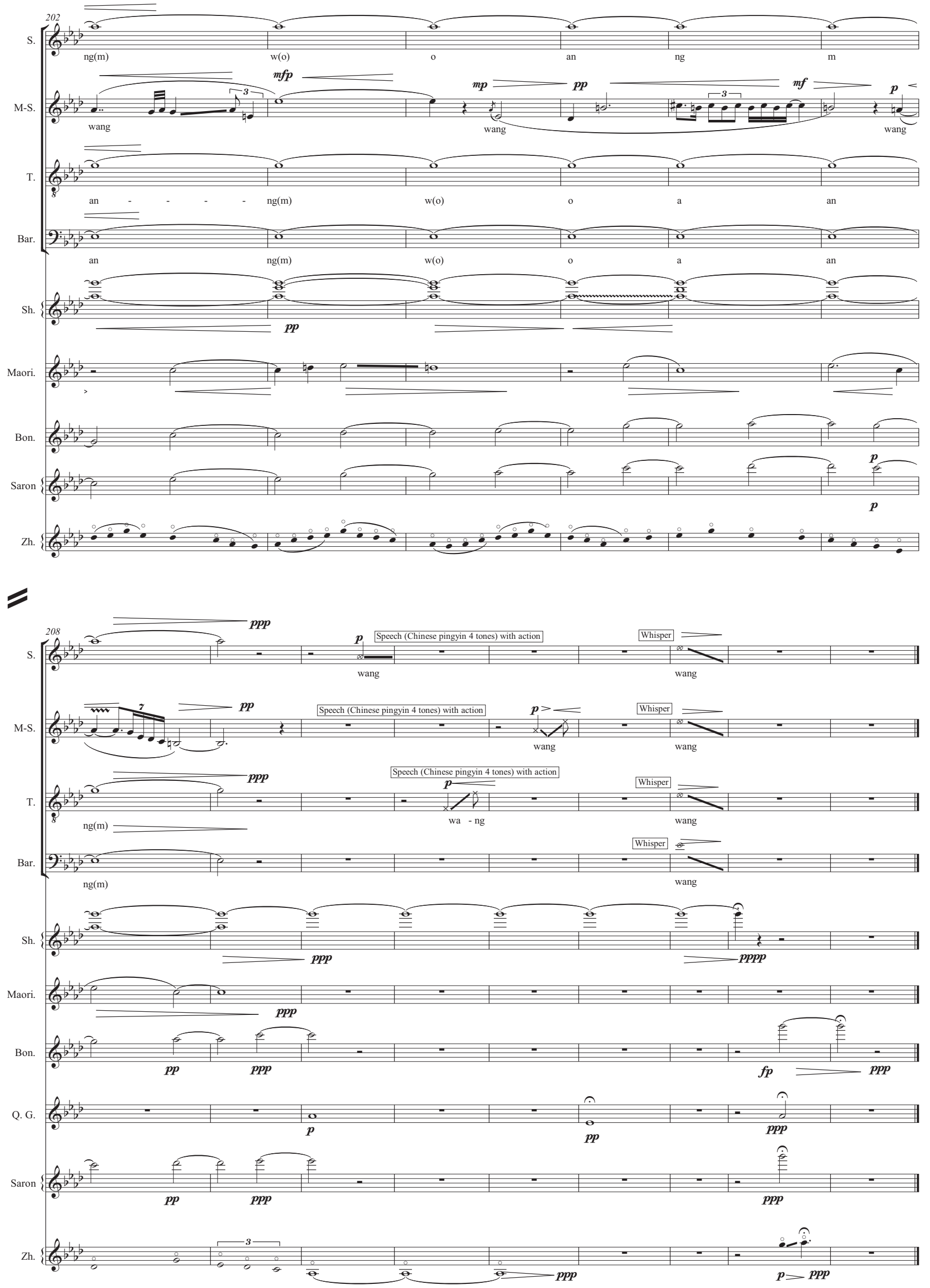


\subsection{Jiǔ Dé Sòng (酒德颂) \\ Hymn to the Virtue of Wine}

Premiere and performances by Song Company of Australia Liù Y̌̌ngshì (六隐士) Six Hermits concert

26 October 2002 Sydney Conservatorium of Music

27 October 2002 Reriverside Theatres Parramatta

27 October 2002 St Paul's Cathedral Melbourne

2 November 2007 Loke Yew hall, The University of Hong Kong

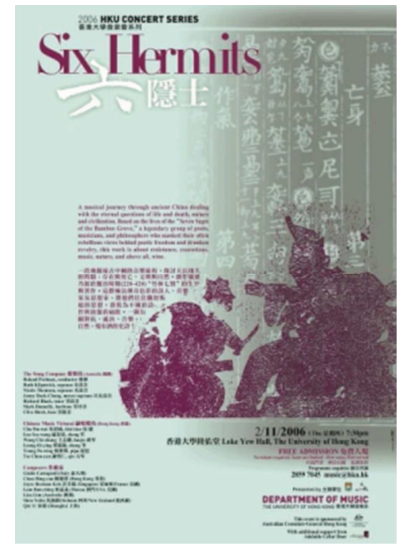

Hong Kong performance

The Song Company of Australia

Clive Birch

Richard Blank

Mark Donnell

Ruth Kilpatrick

Nicole Thomson

Roland Peelmen

\section{Chinese Music Virtuosi}

(Australia)

Sze-wang Loo

Hiu-hung $\mathrm{Ng}$

Lok-ting Wong

Shen Nalin

(Hong Kong)

Sze-wang Loo

Leung Oi-Ying

Wong Chi-chung bass

tenor

baritone

soprano

soprano

artistic director

húqins

zhēng

shēng

vocal

shēng

zhēng

húqins

(Live recording was from Sydney Conservatorium, October 2002. Produced by Malcolm Batty for ABC Classic FMABC Radio National, Australia) 


\section{酒德颂}

Hymn to the Virtue of Wine

Poem by: Liu Ling (c.225 - 280)

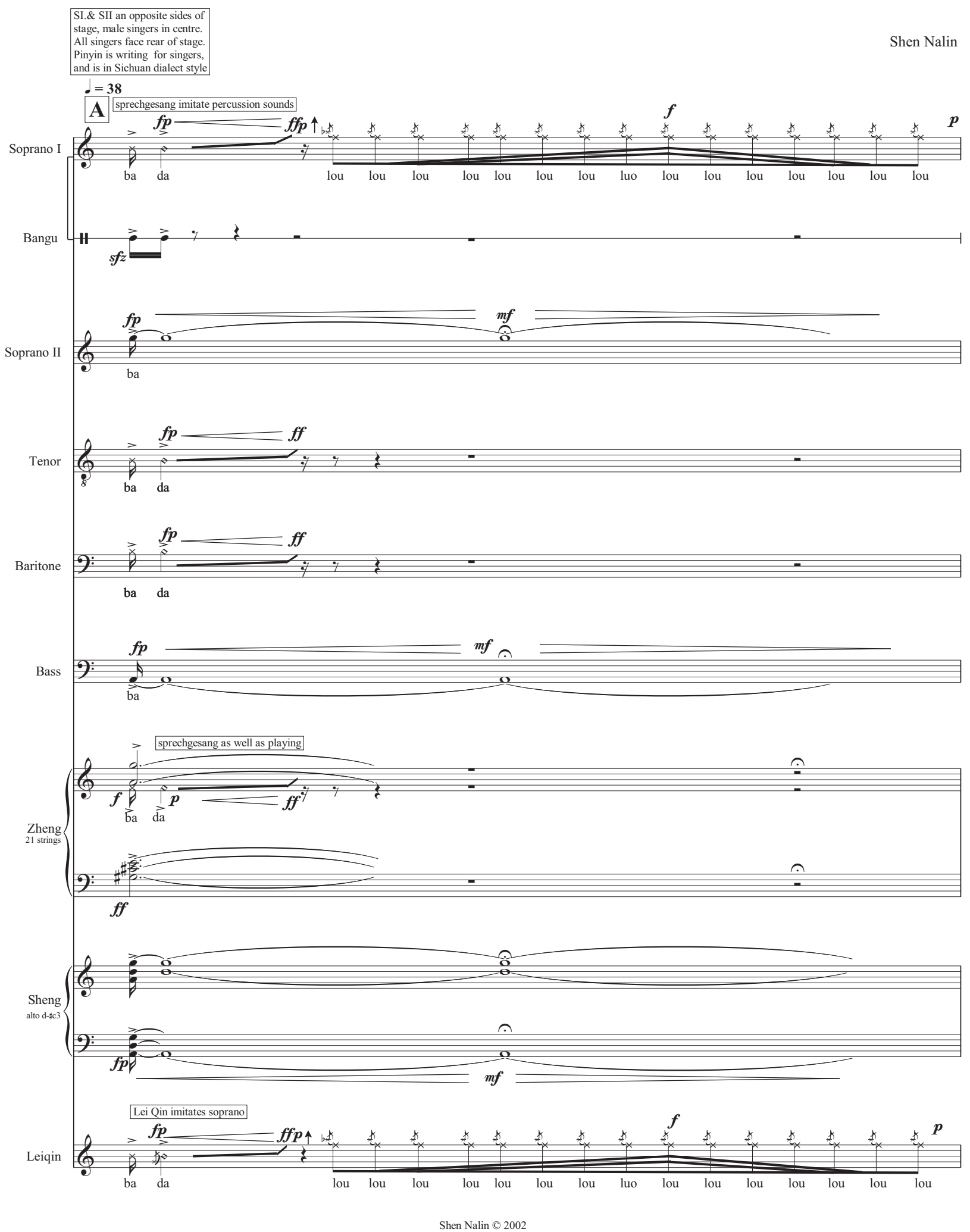



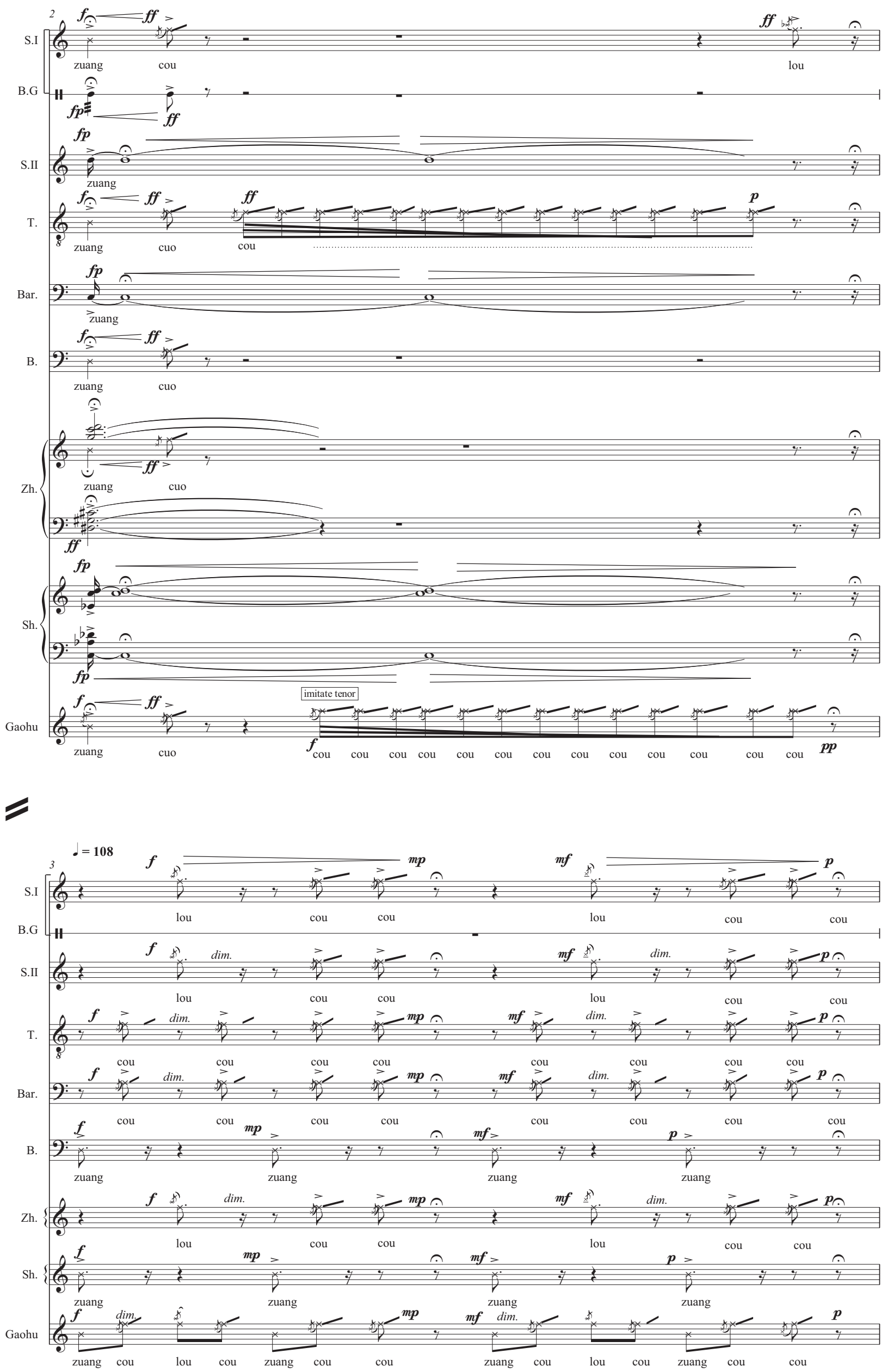

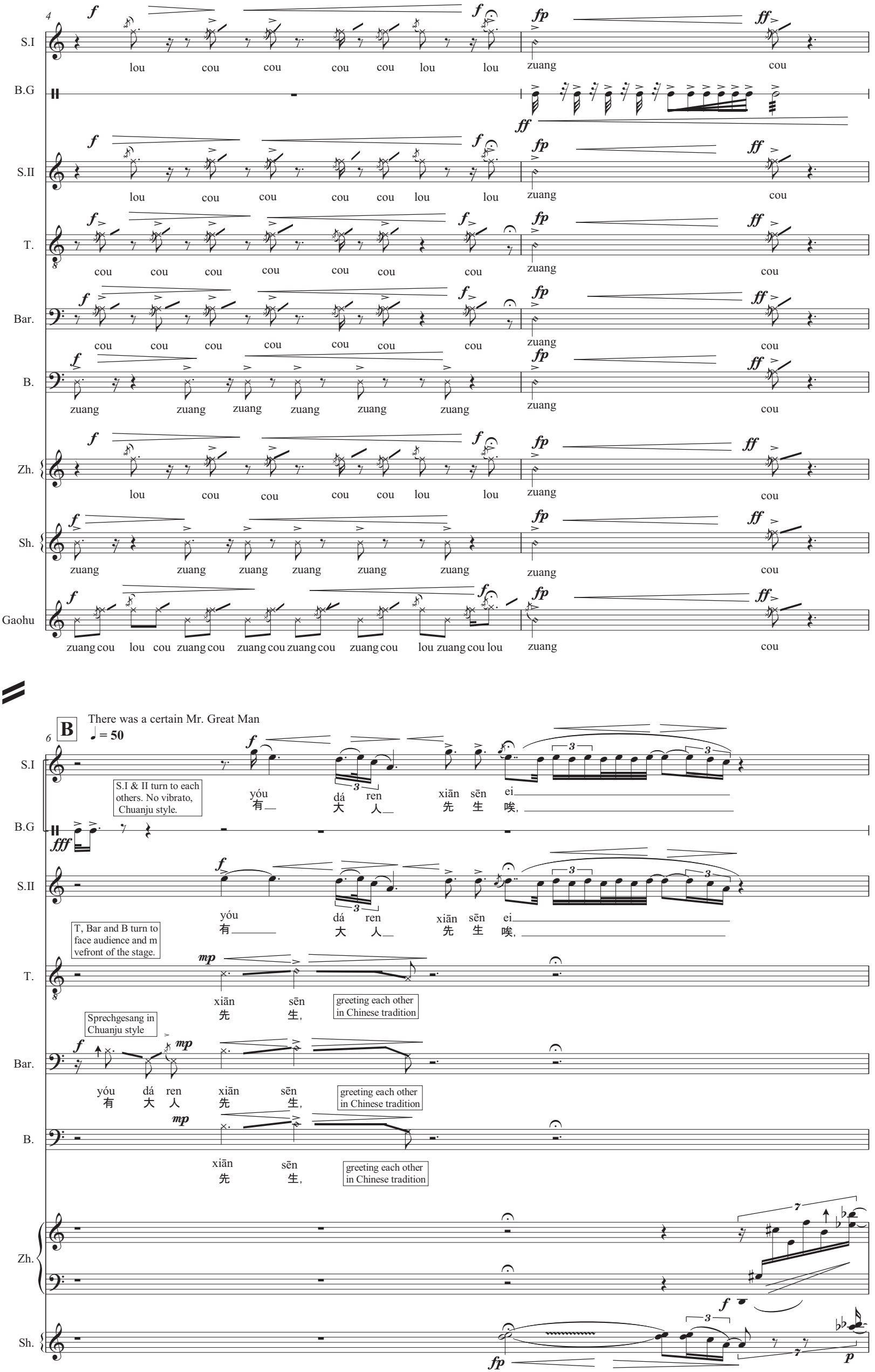
Heaven and Earth were but a morning's span,

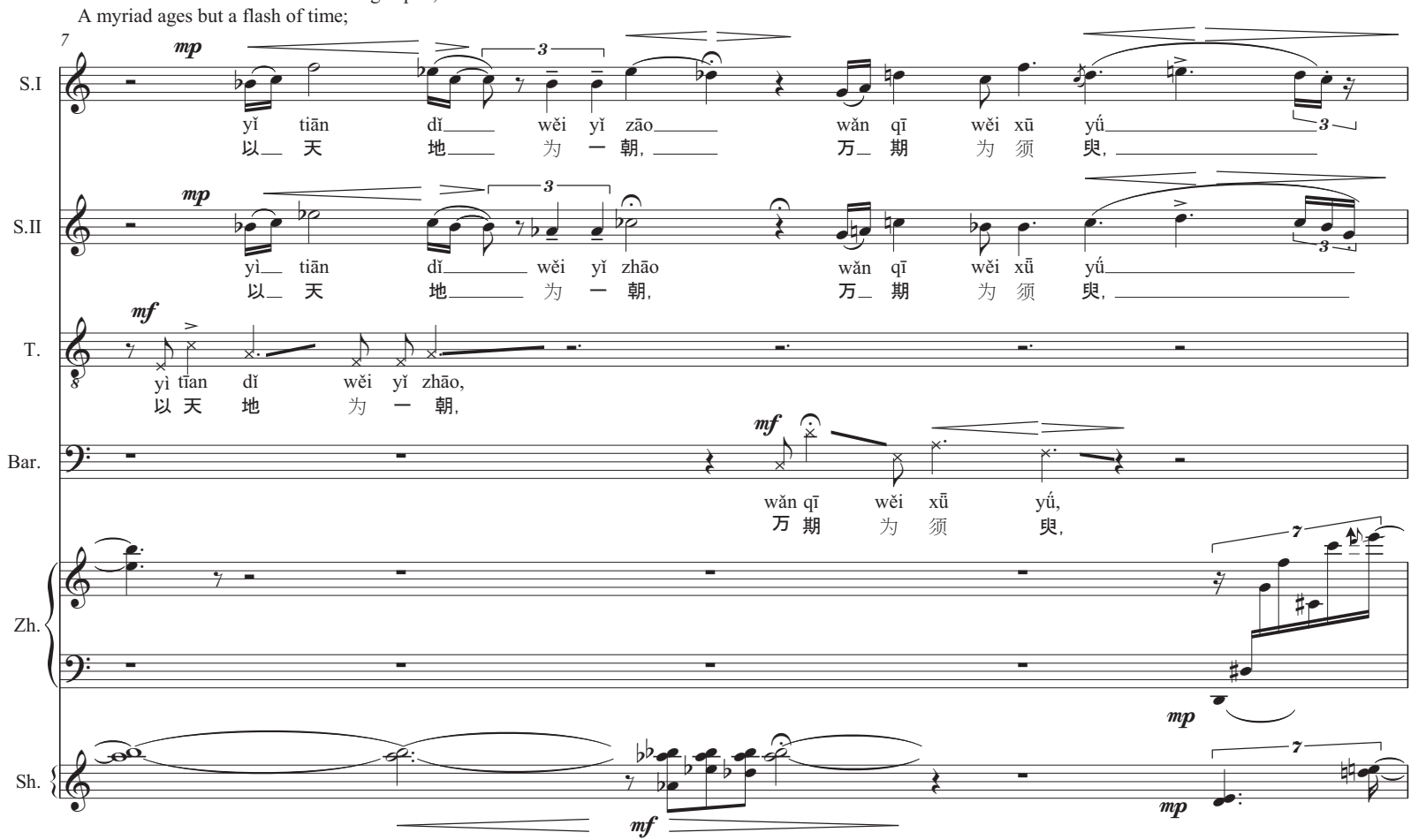

The sun and moon, a door and window's eye,

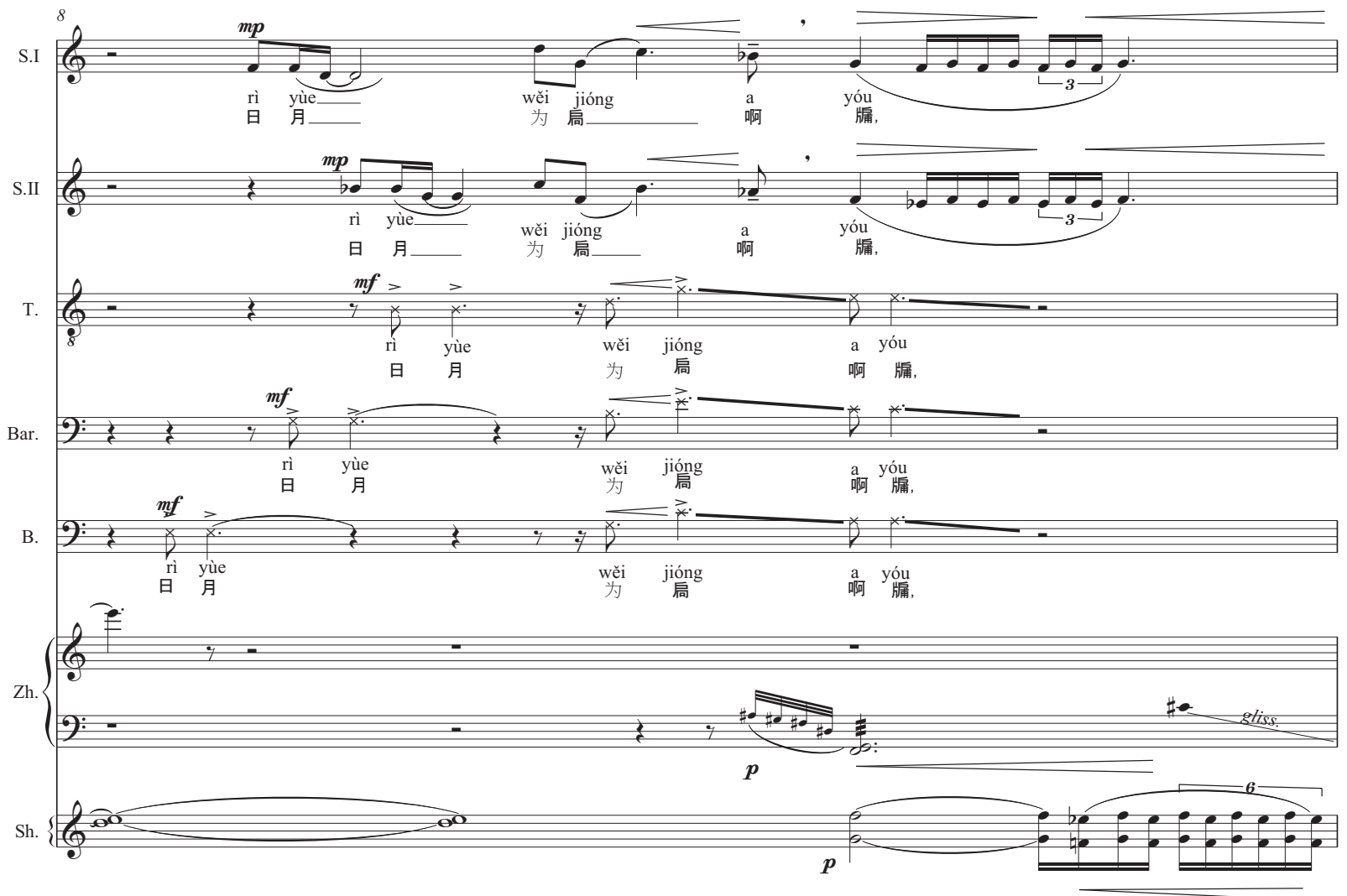


the eight directions like a country lane.
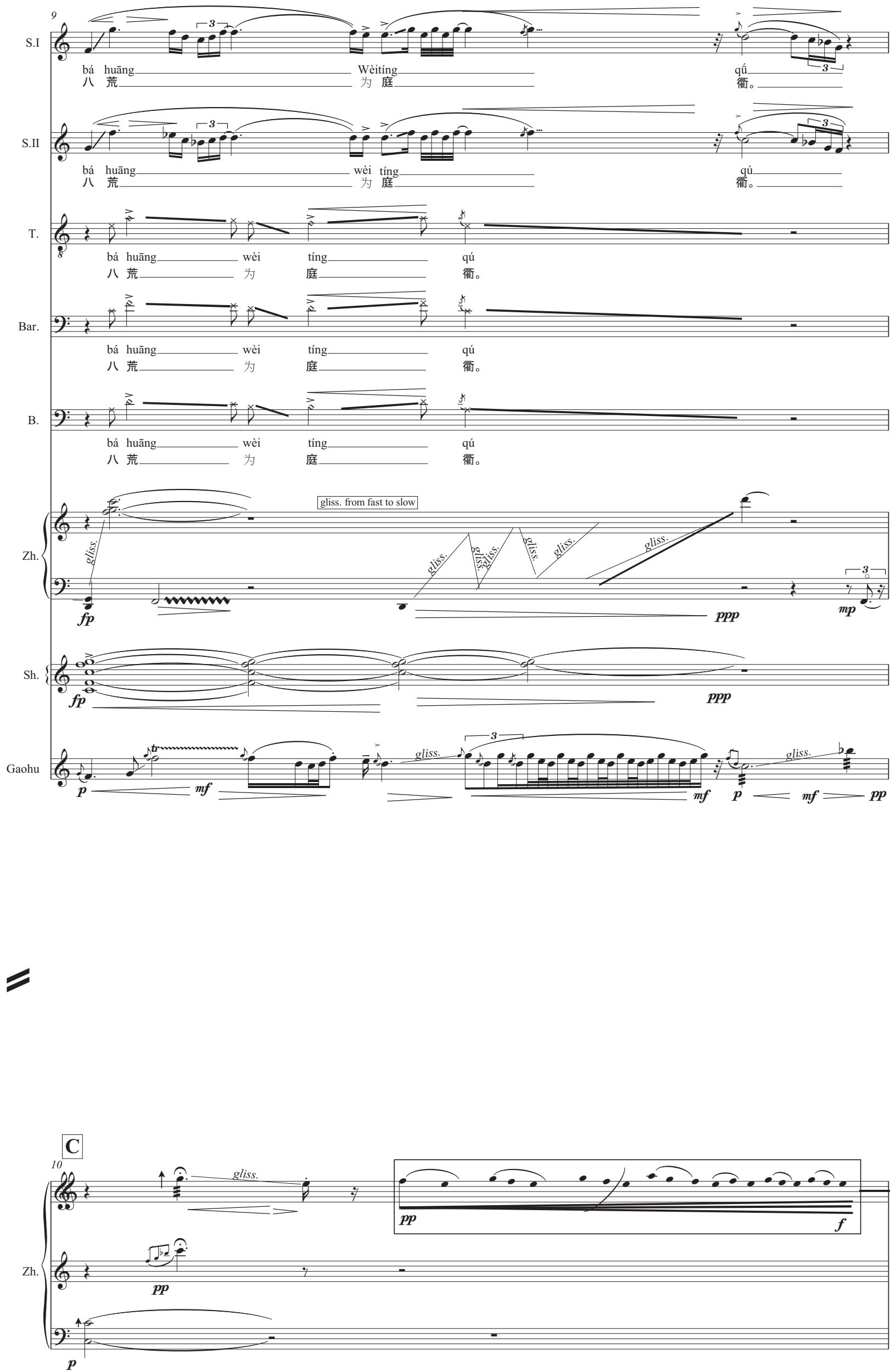
(He) Traveled without leaving track or trace,

And domiciled in nether room nor hut;
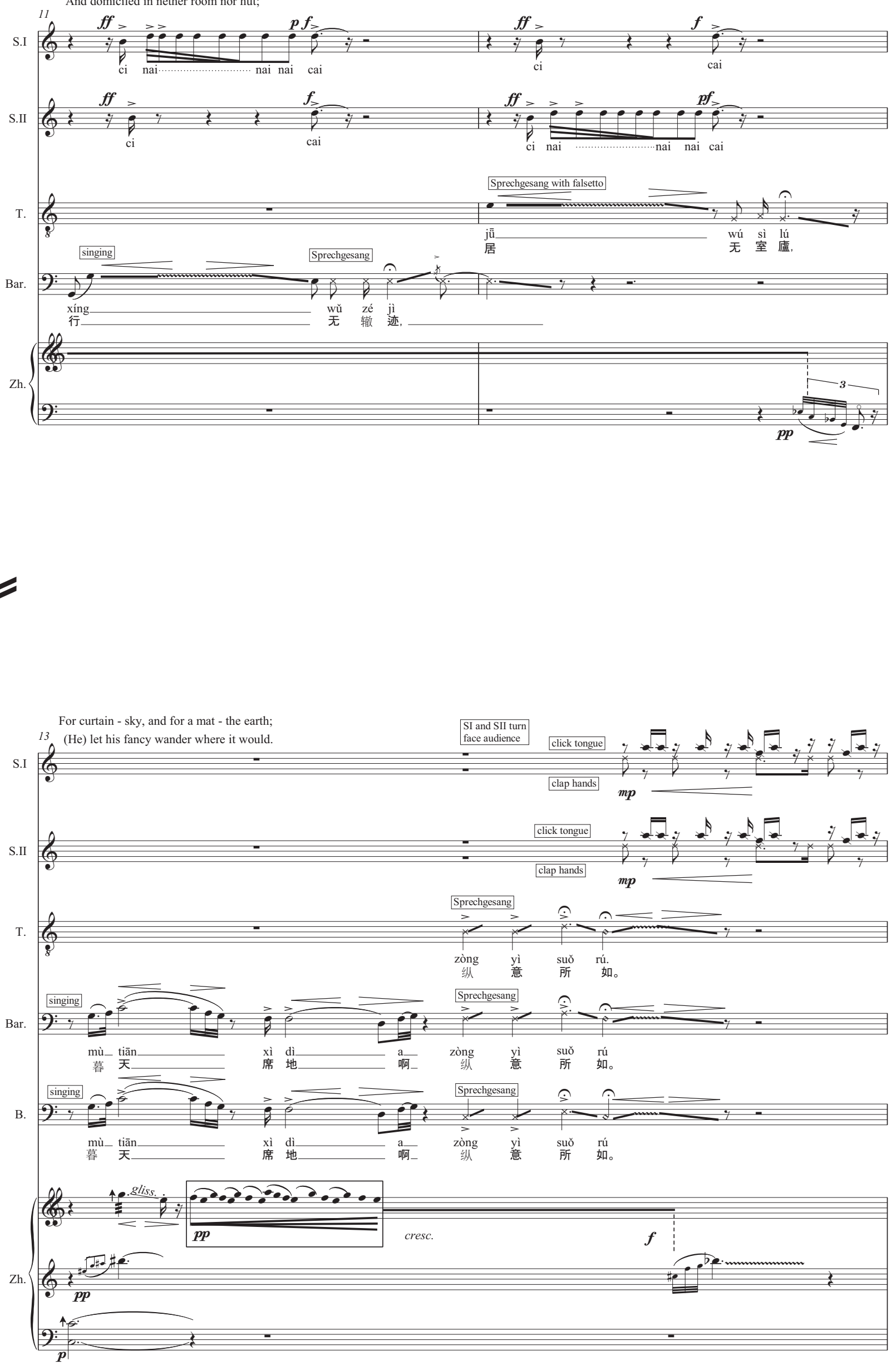
At rest (he) grasped a goblet or a cup,

And moving, always carried jug (ro) pot

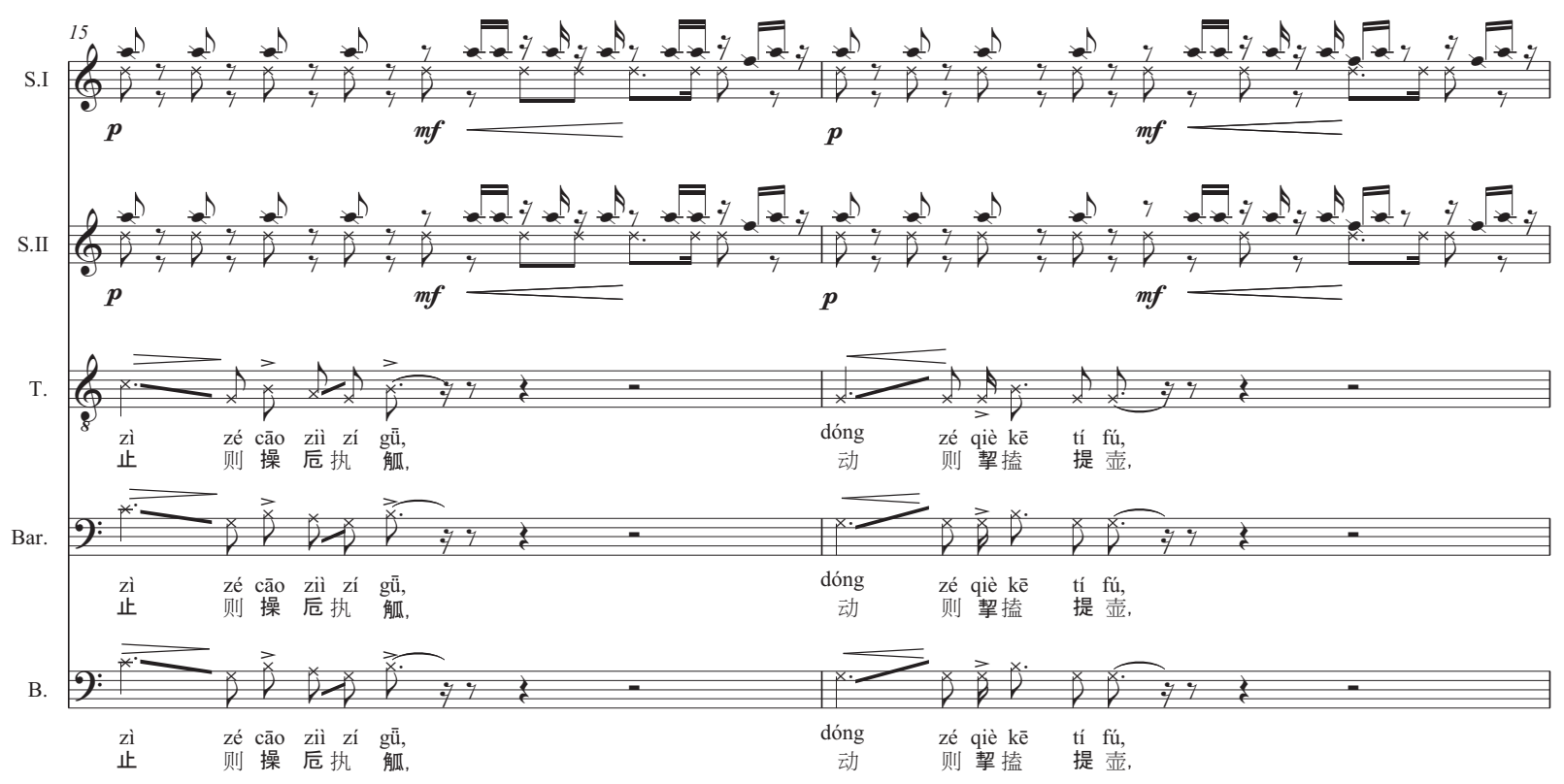

For wine, and wine along, was all his lot. How should he know about the rest?

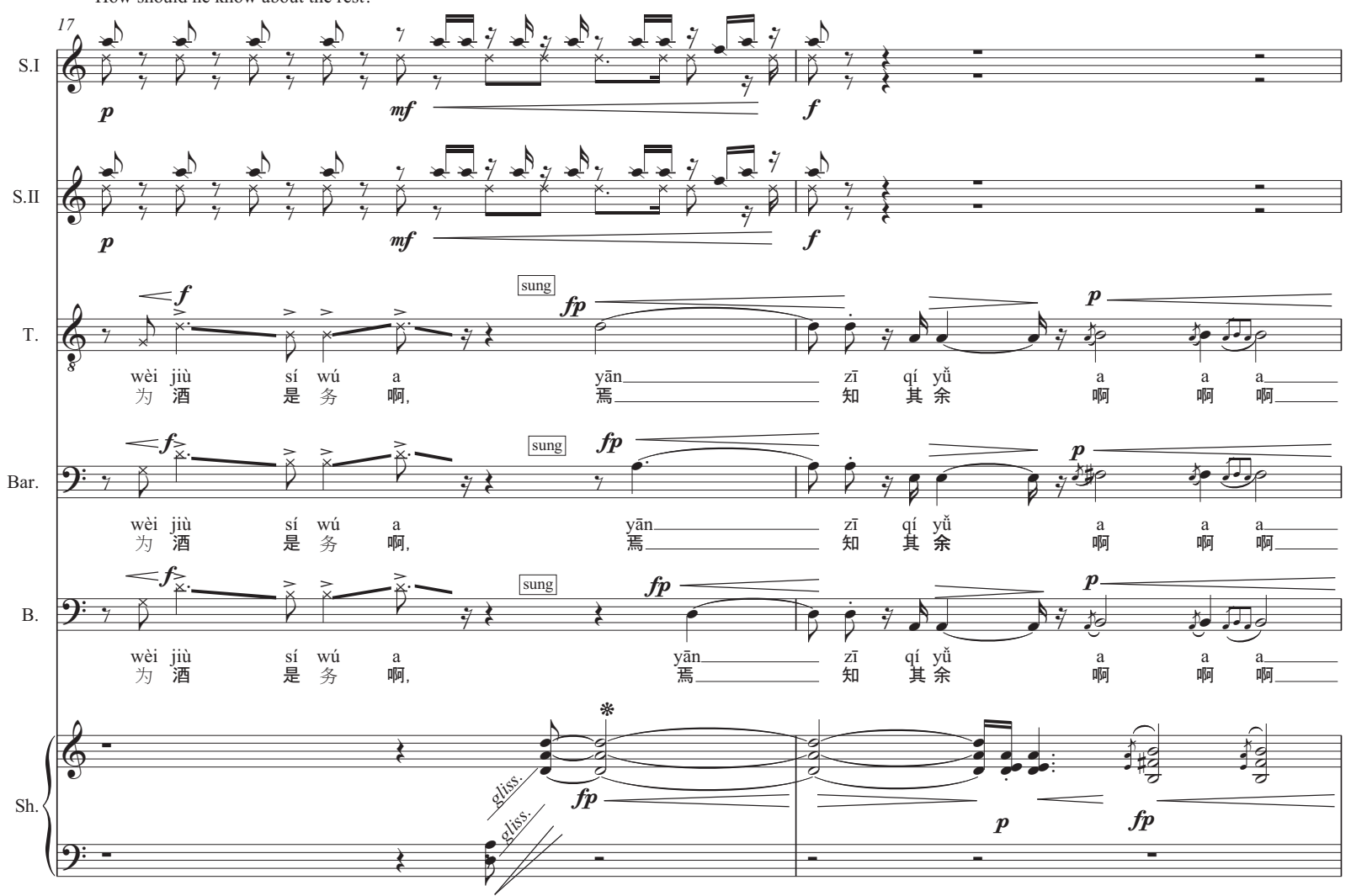


D

rit.

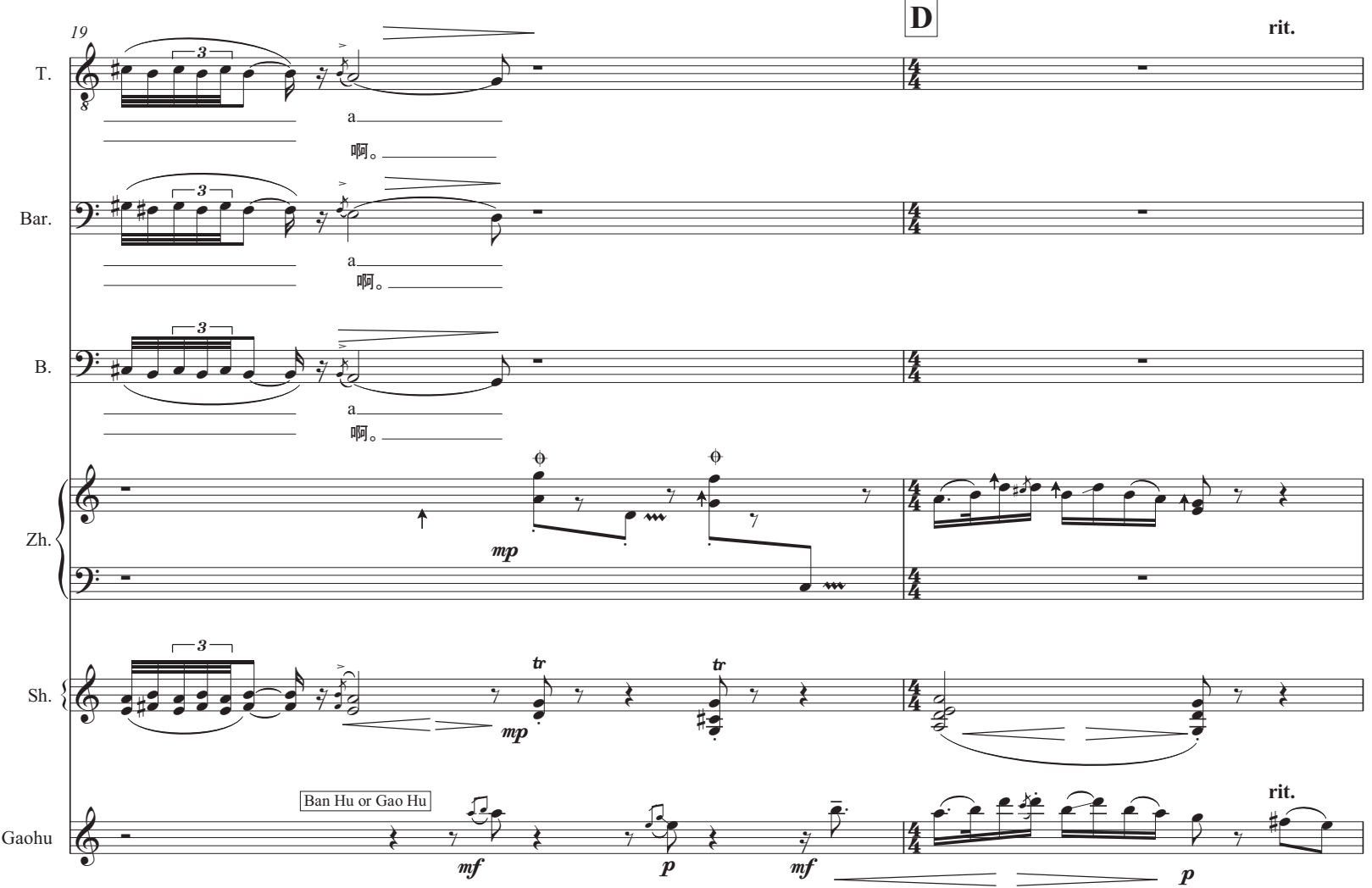

Now there was, A certain noble duke, Lord High-and-Great,

And a retired scholar, Sir Silk Sash,

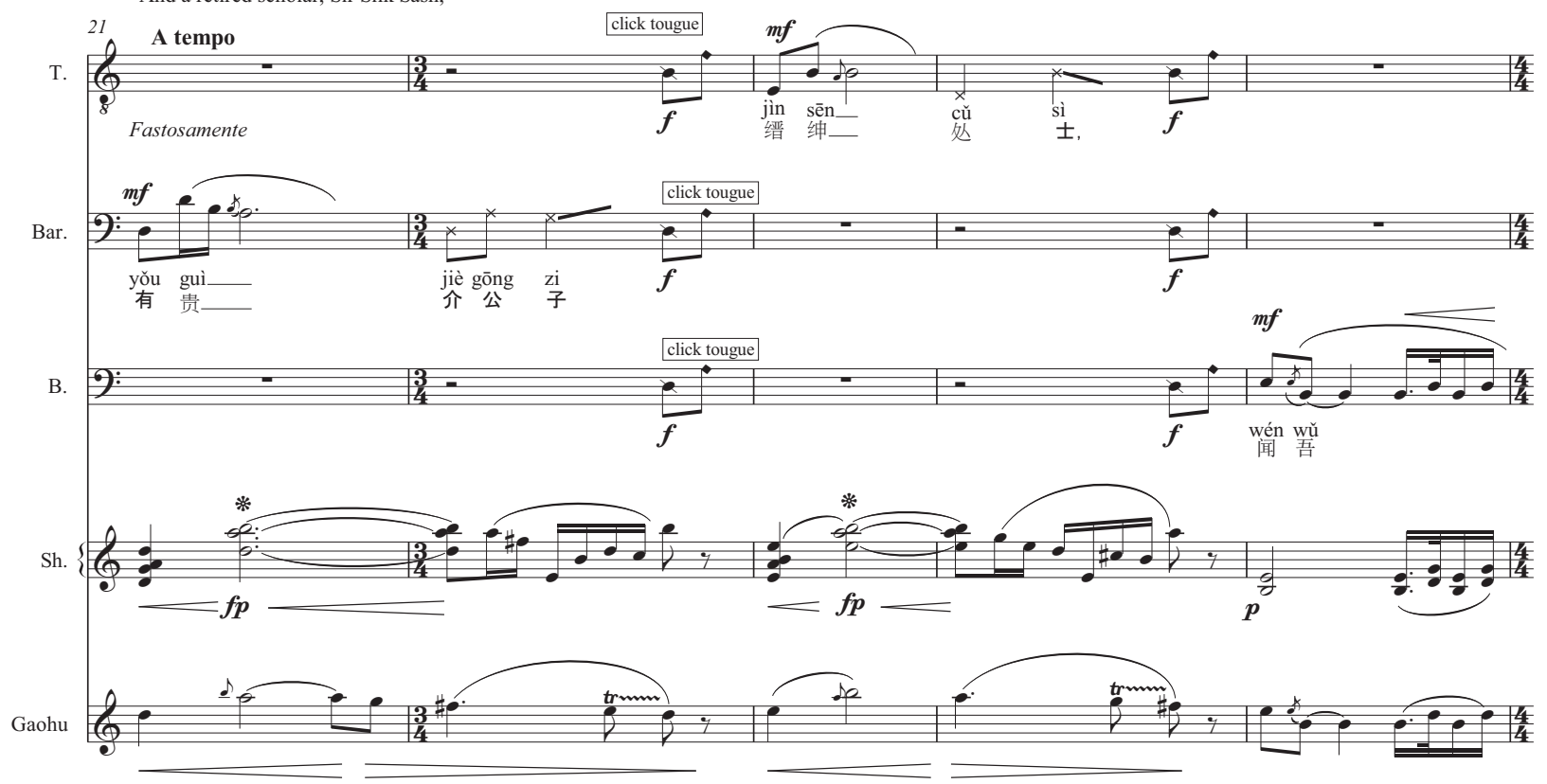


Who hearing rumors of our hero's ways,

26 Came to discuss with him the hows and whys,

.$=120$

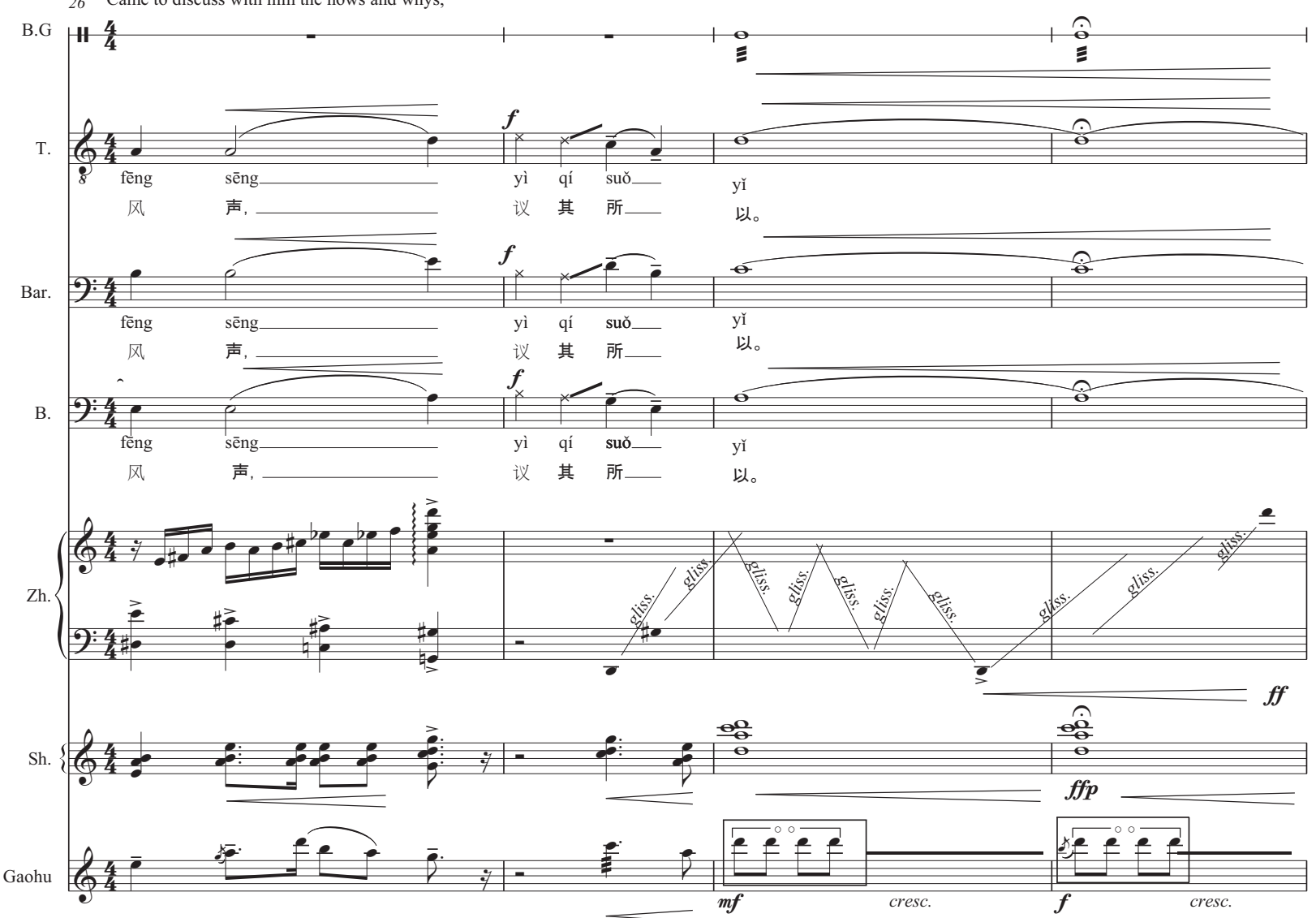

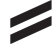

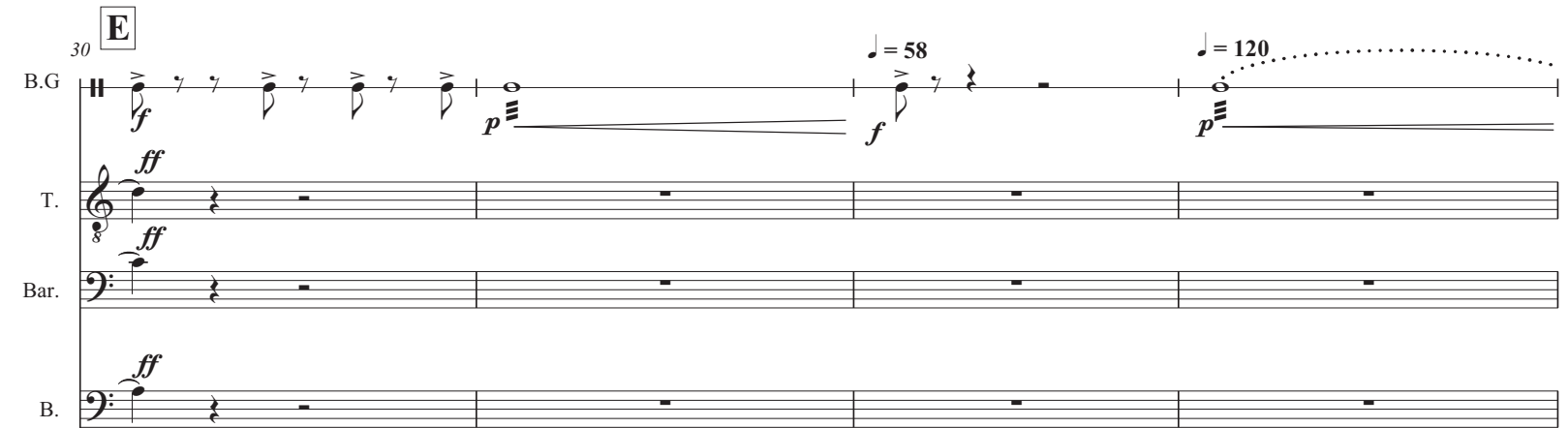

Zh.

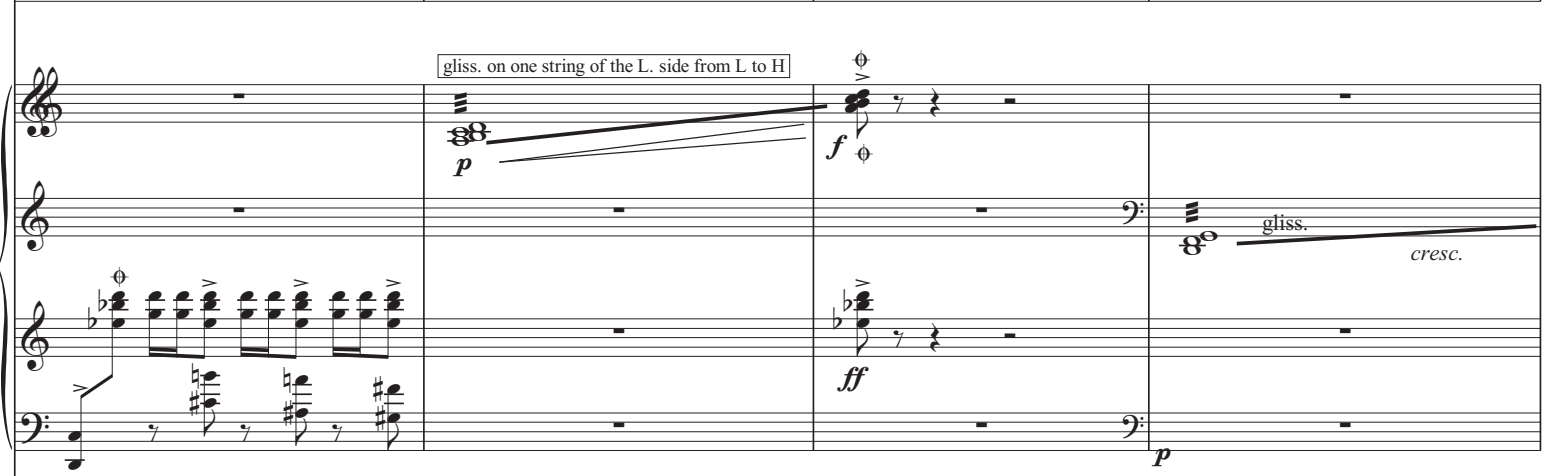

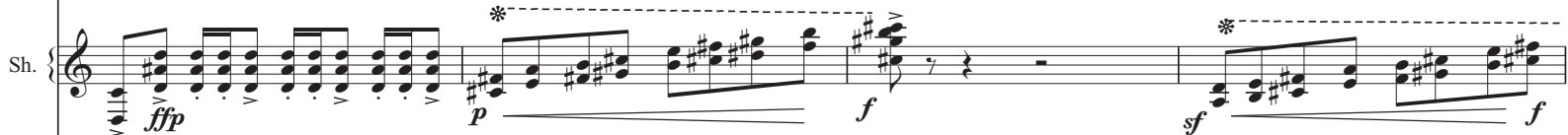

Gaohu

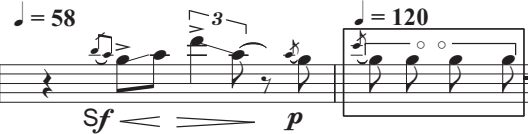




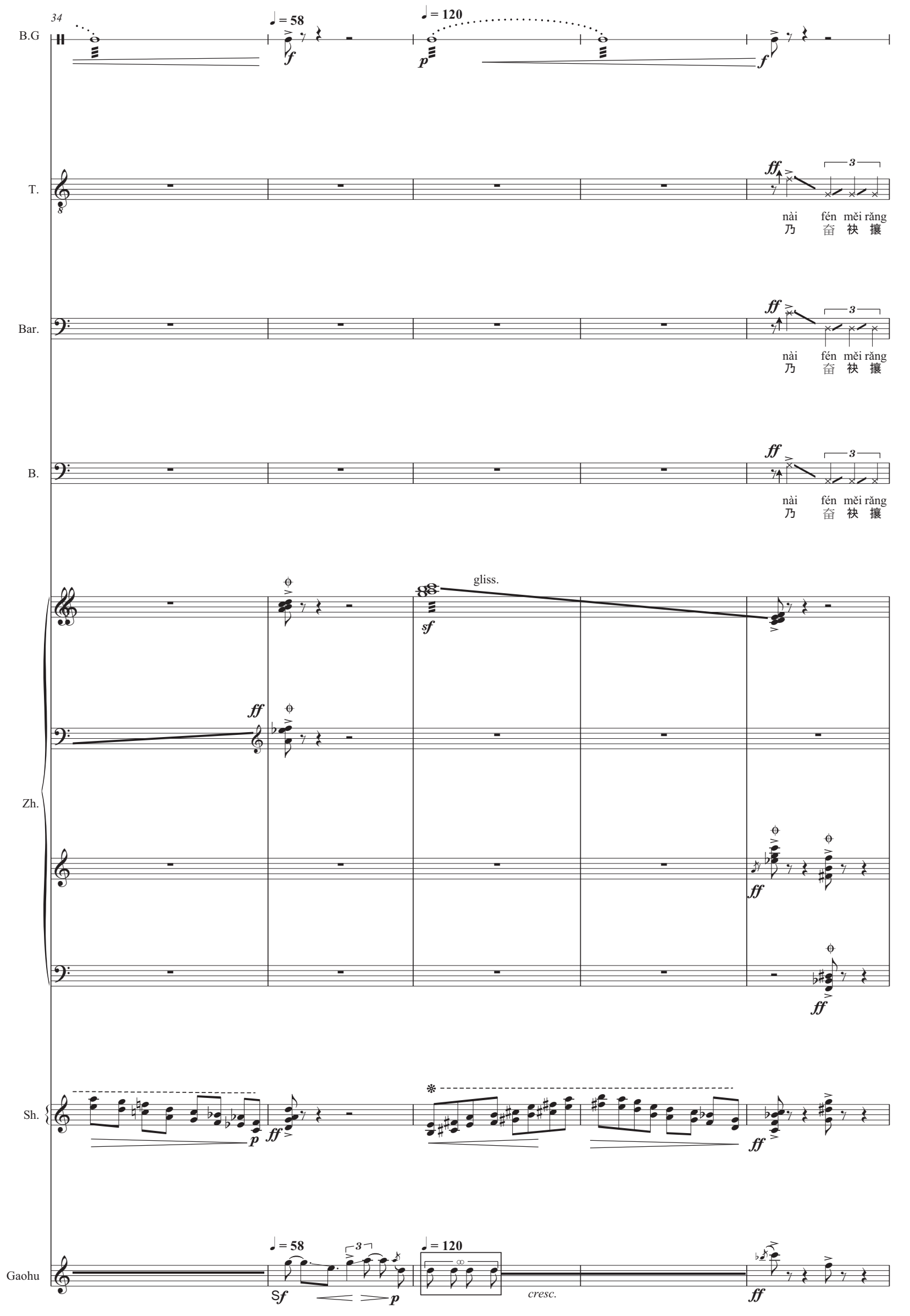



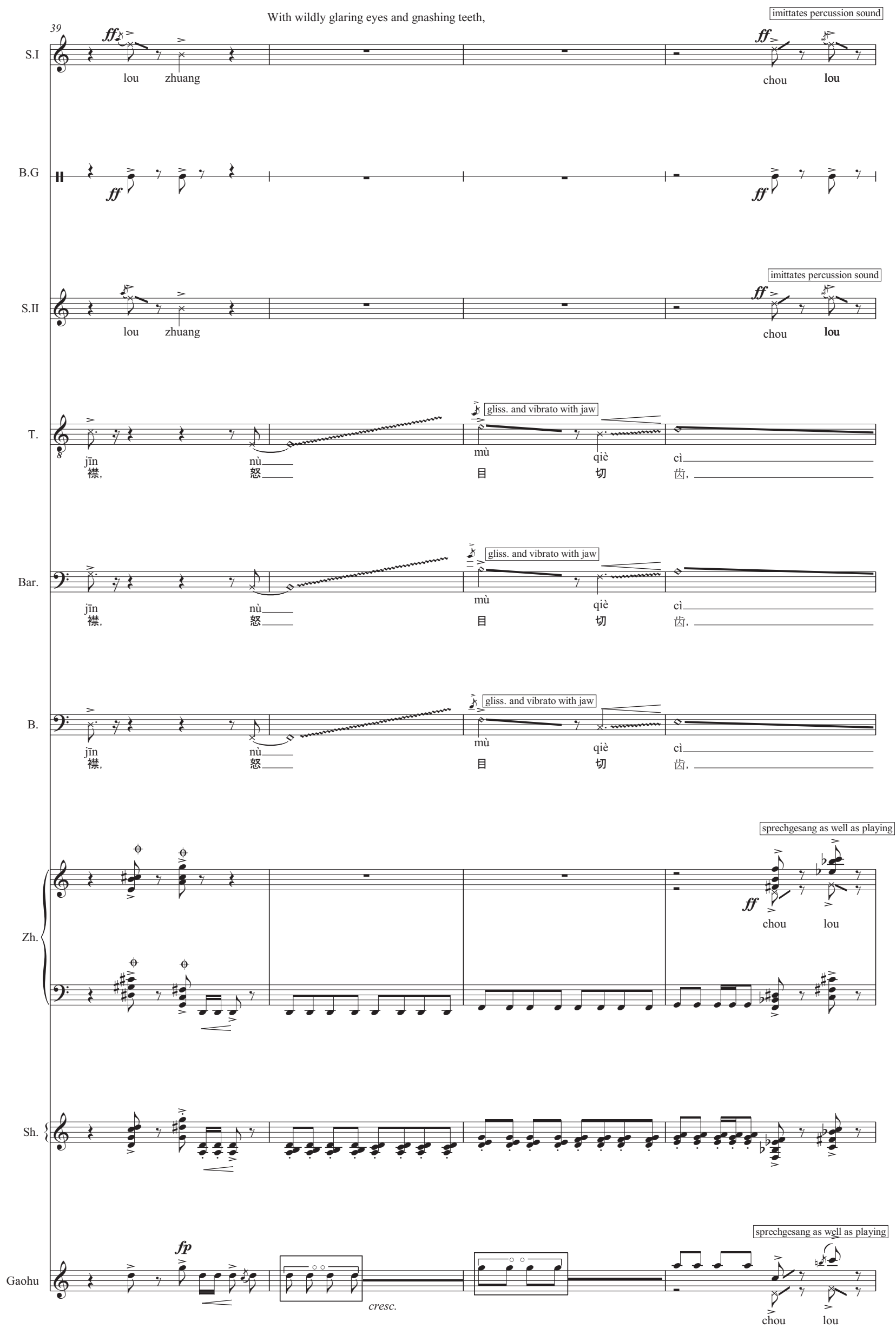

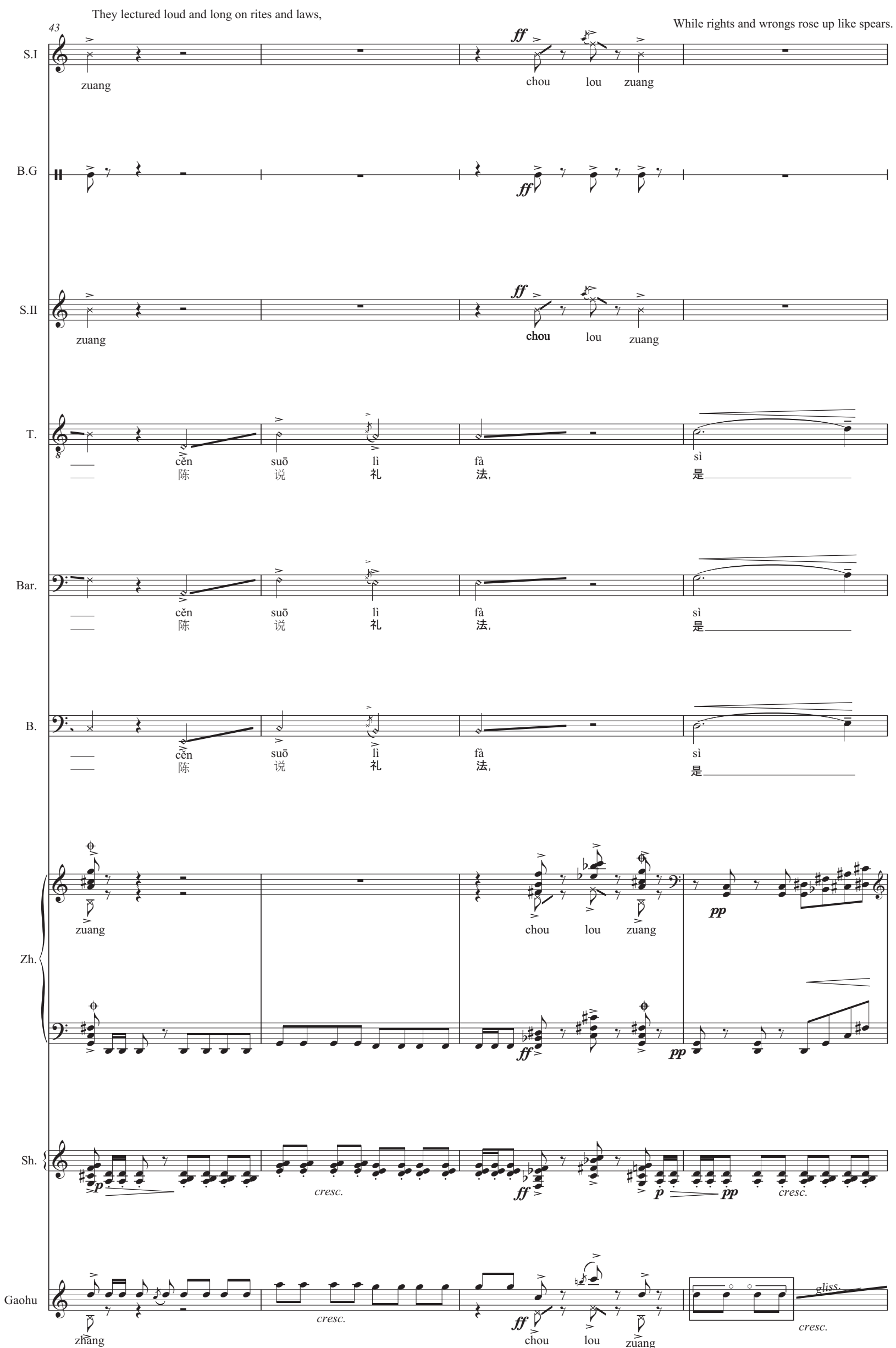

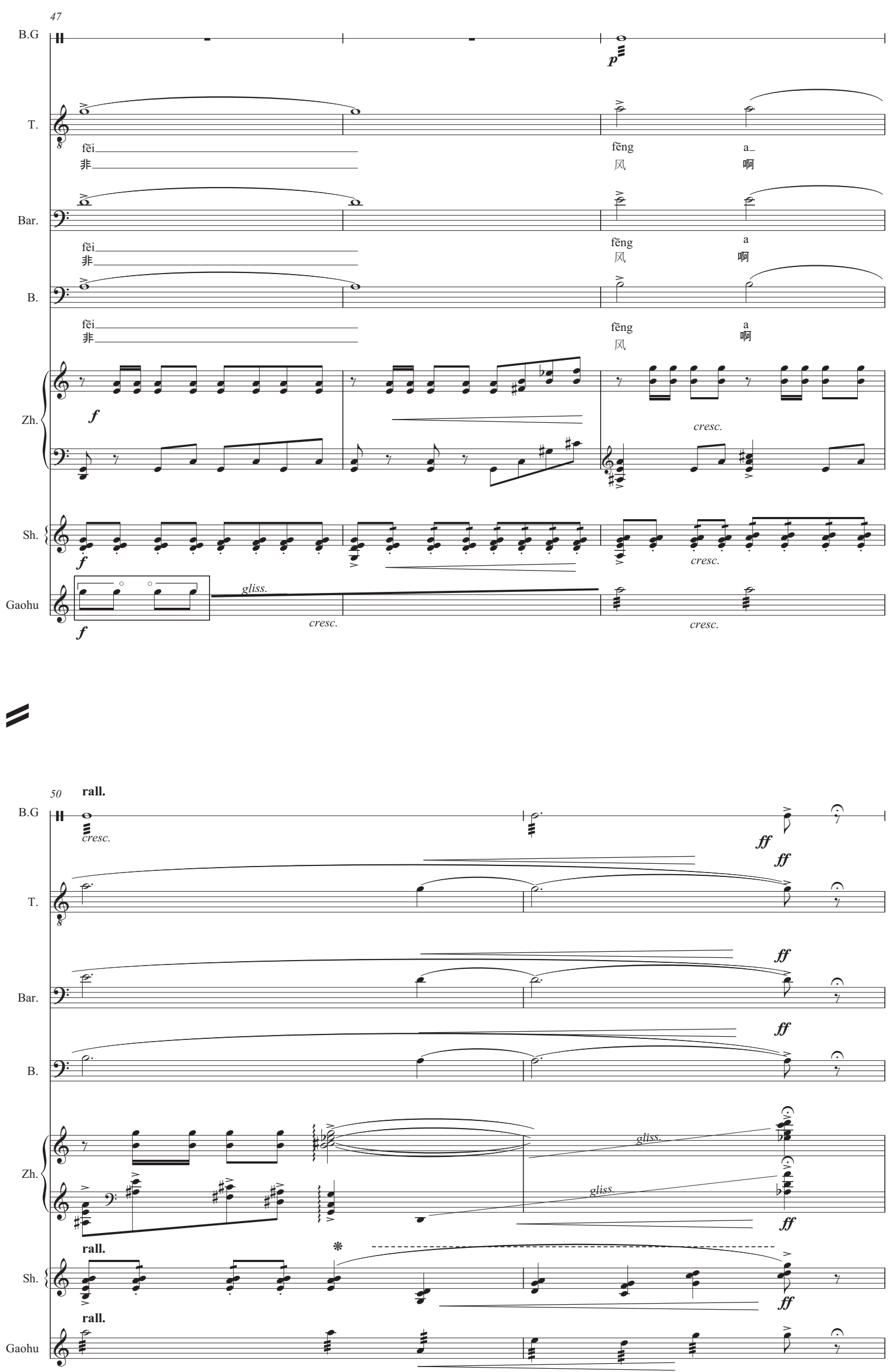

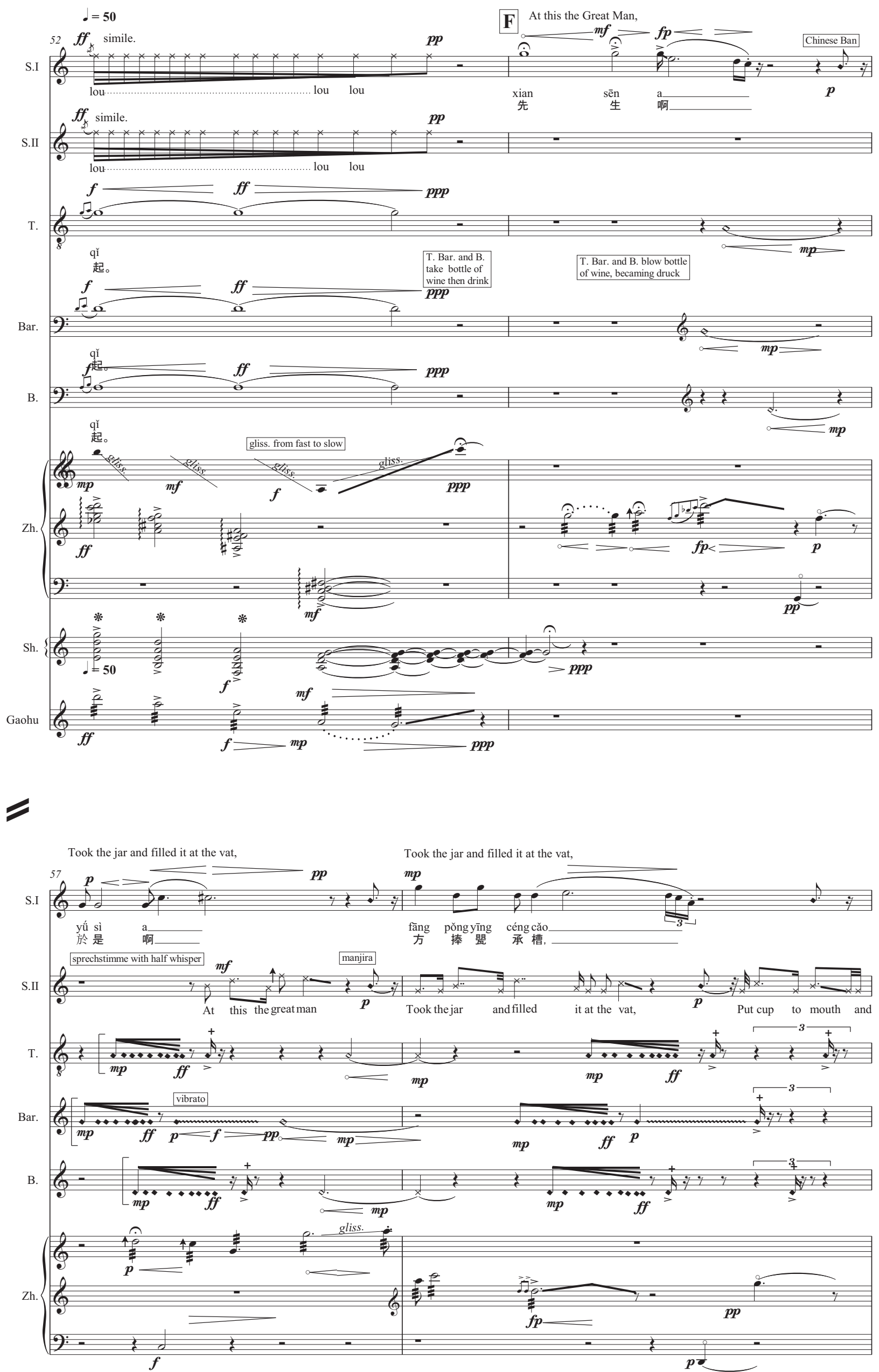

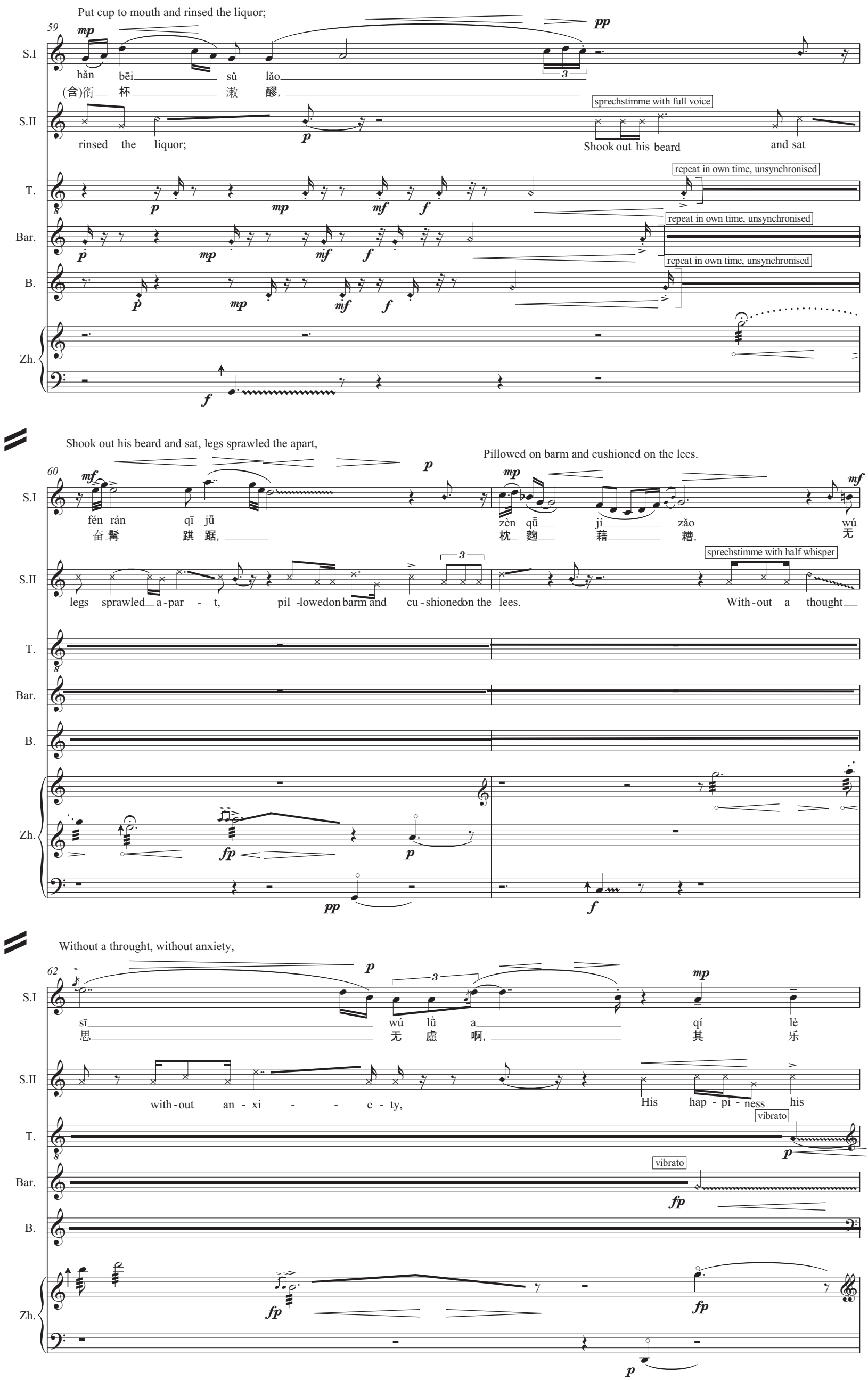


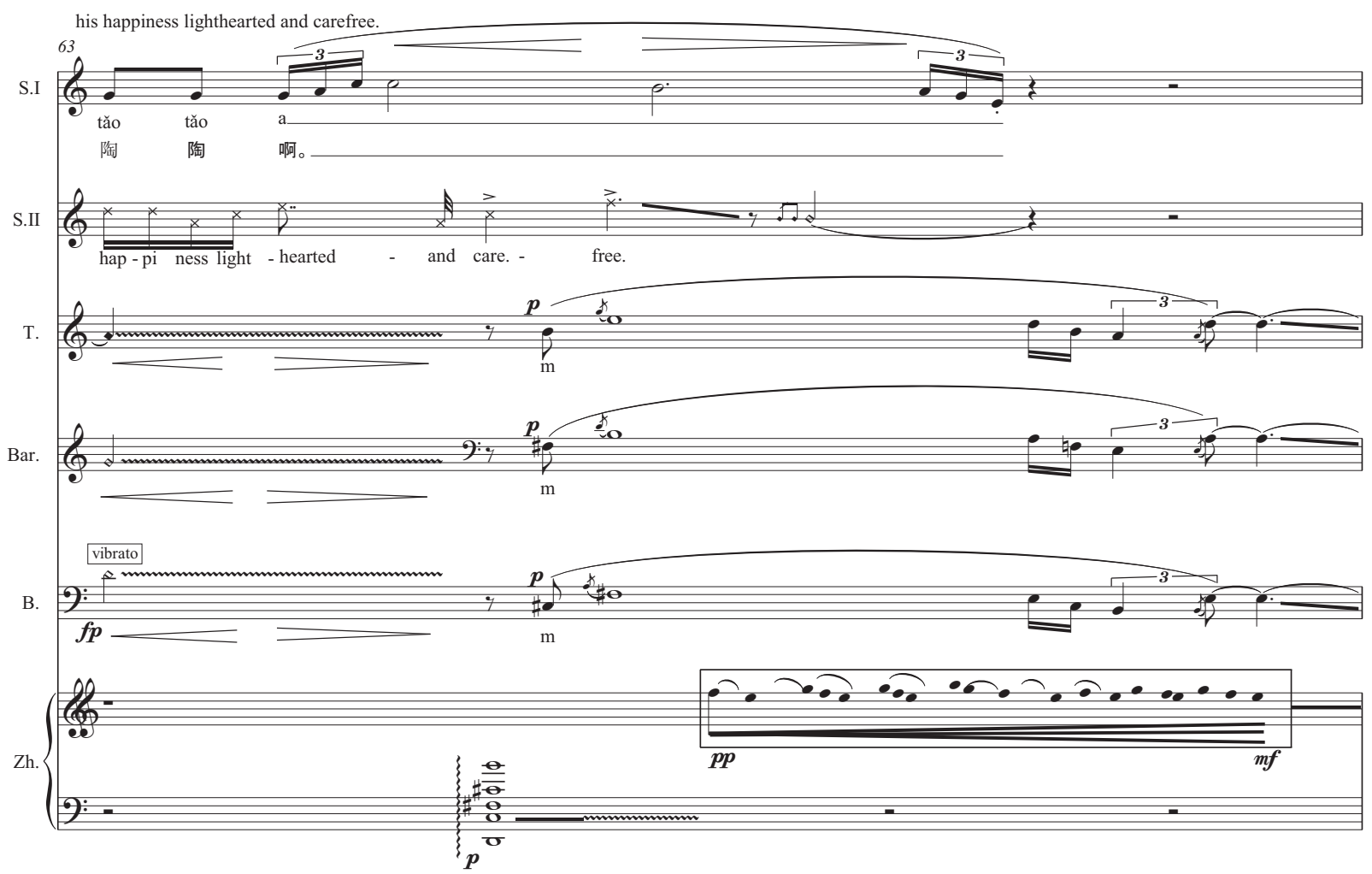

his happiness lighthearted and carefree

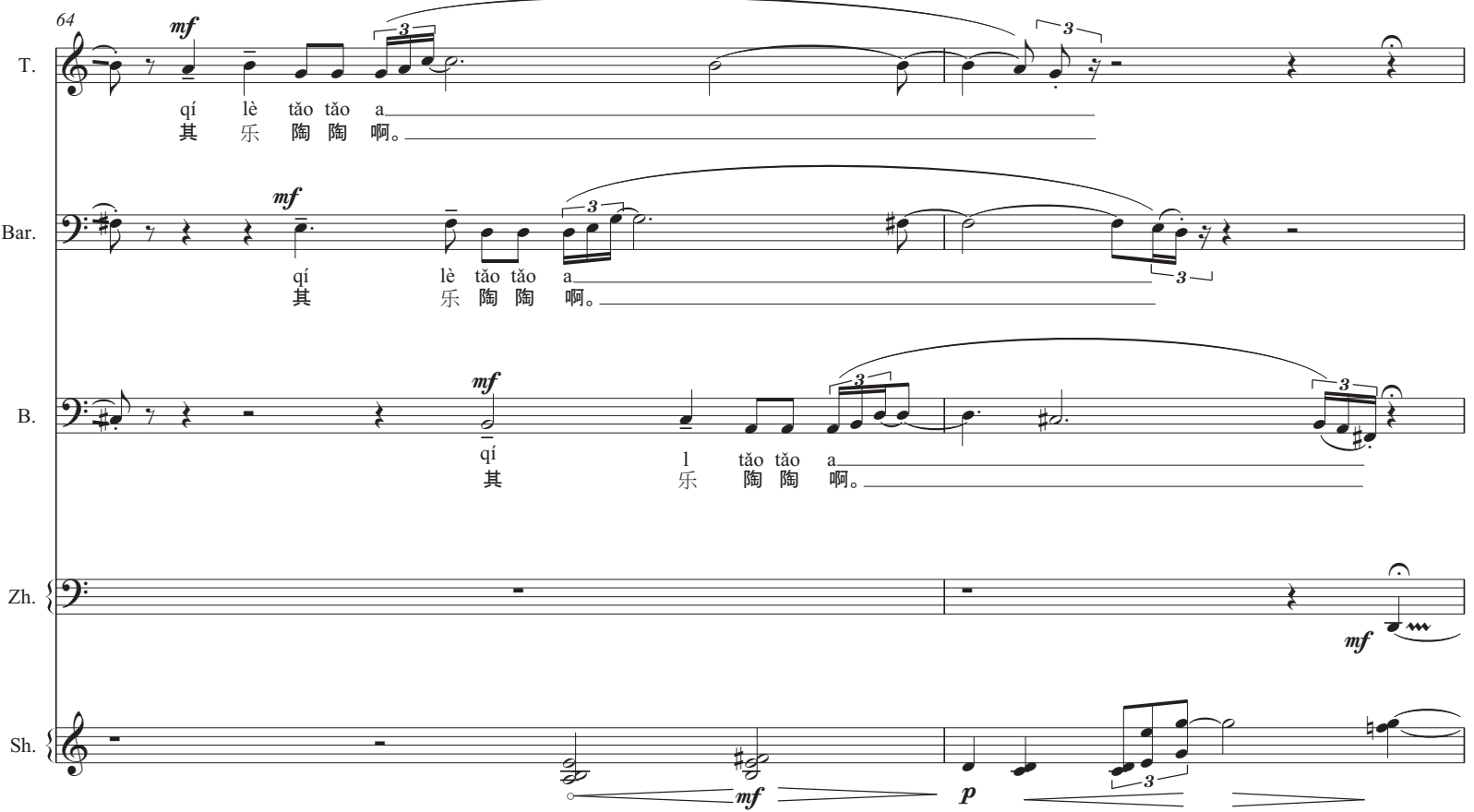



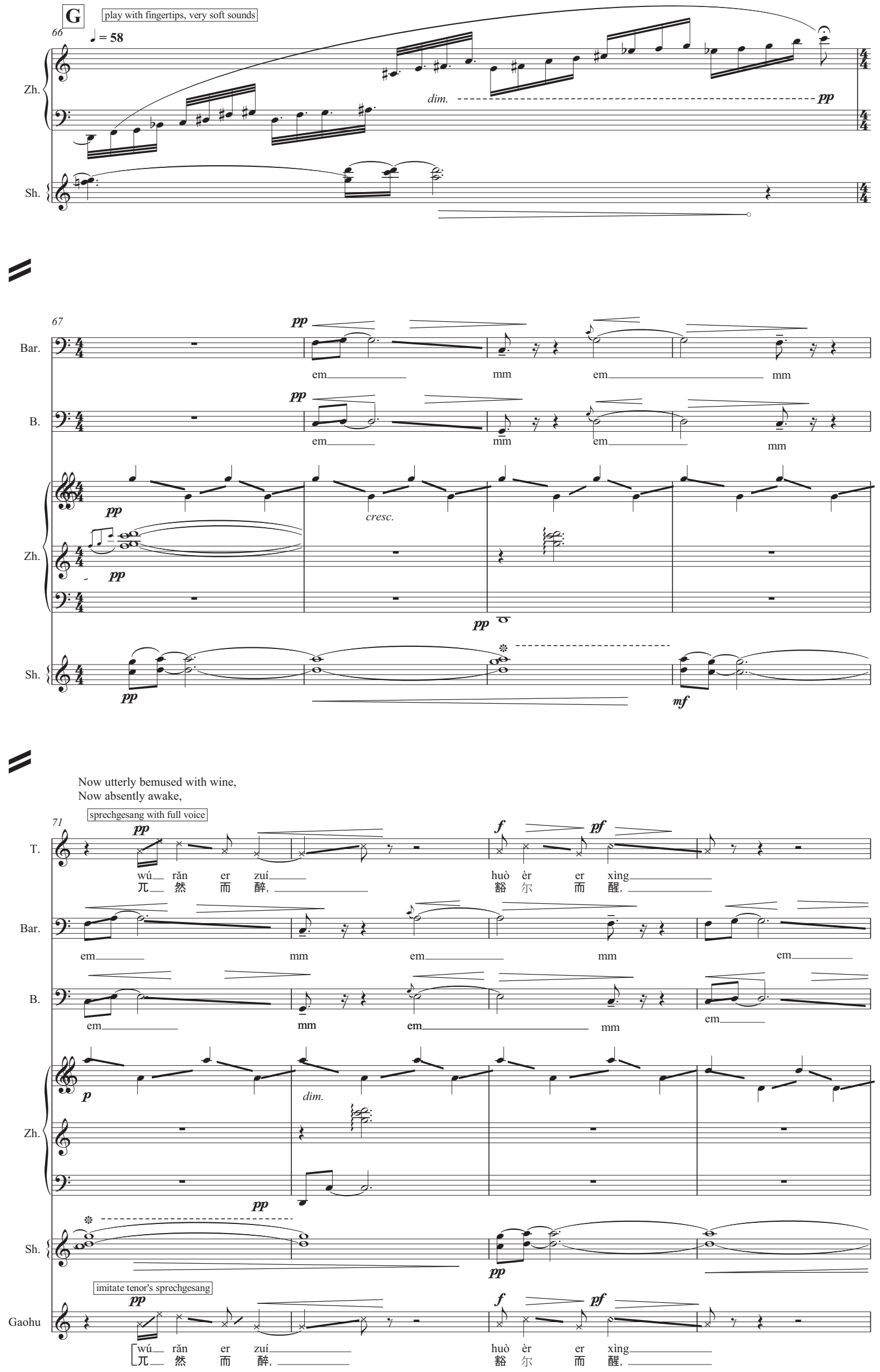
He calmly listened, deaf to thunder's crashing roar,

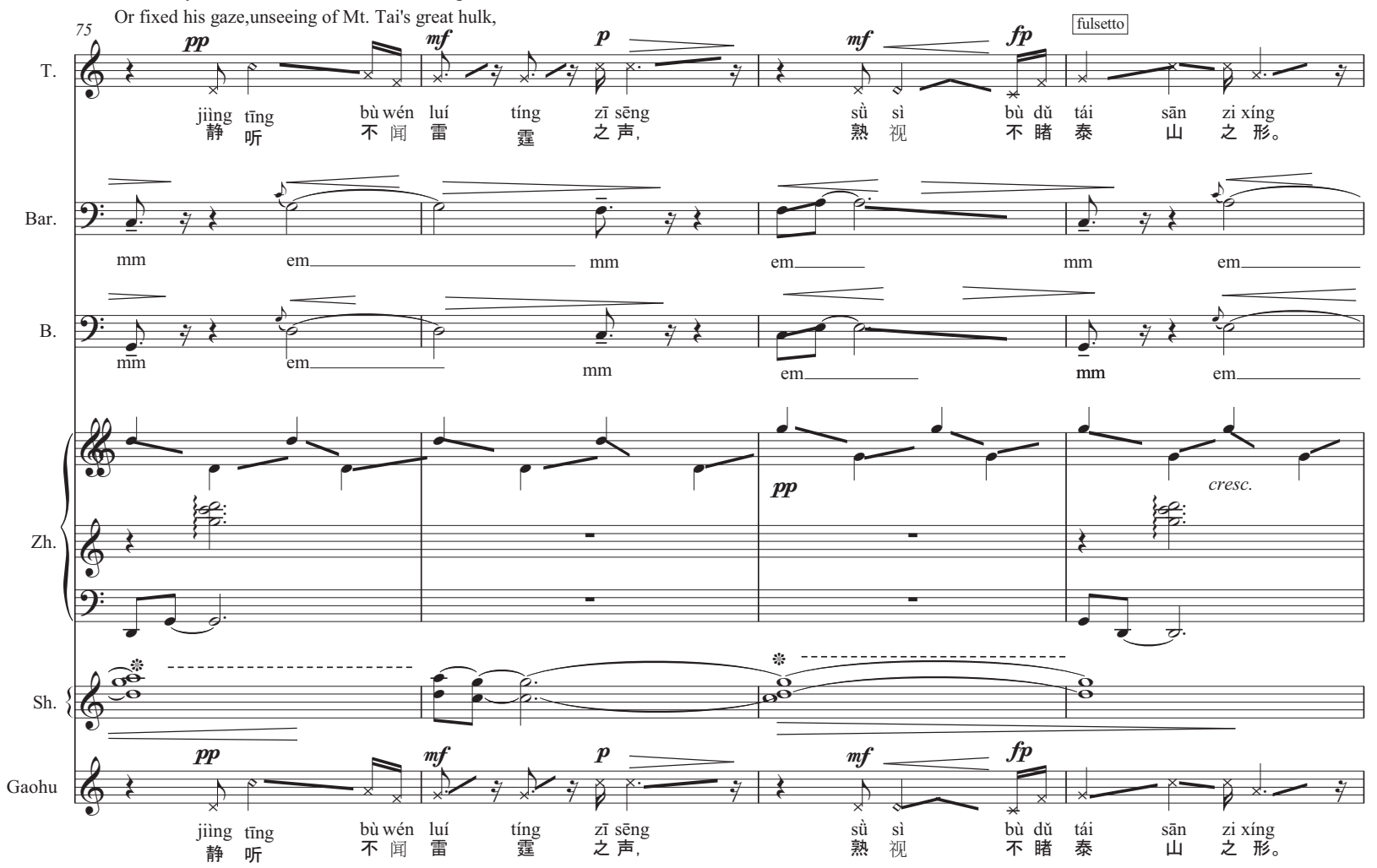

Of cold or heat he felt no fleshly pangs,

Of profit or desire no sensual stir;

He looked down on the myriad things, with all their fuss,

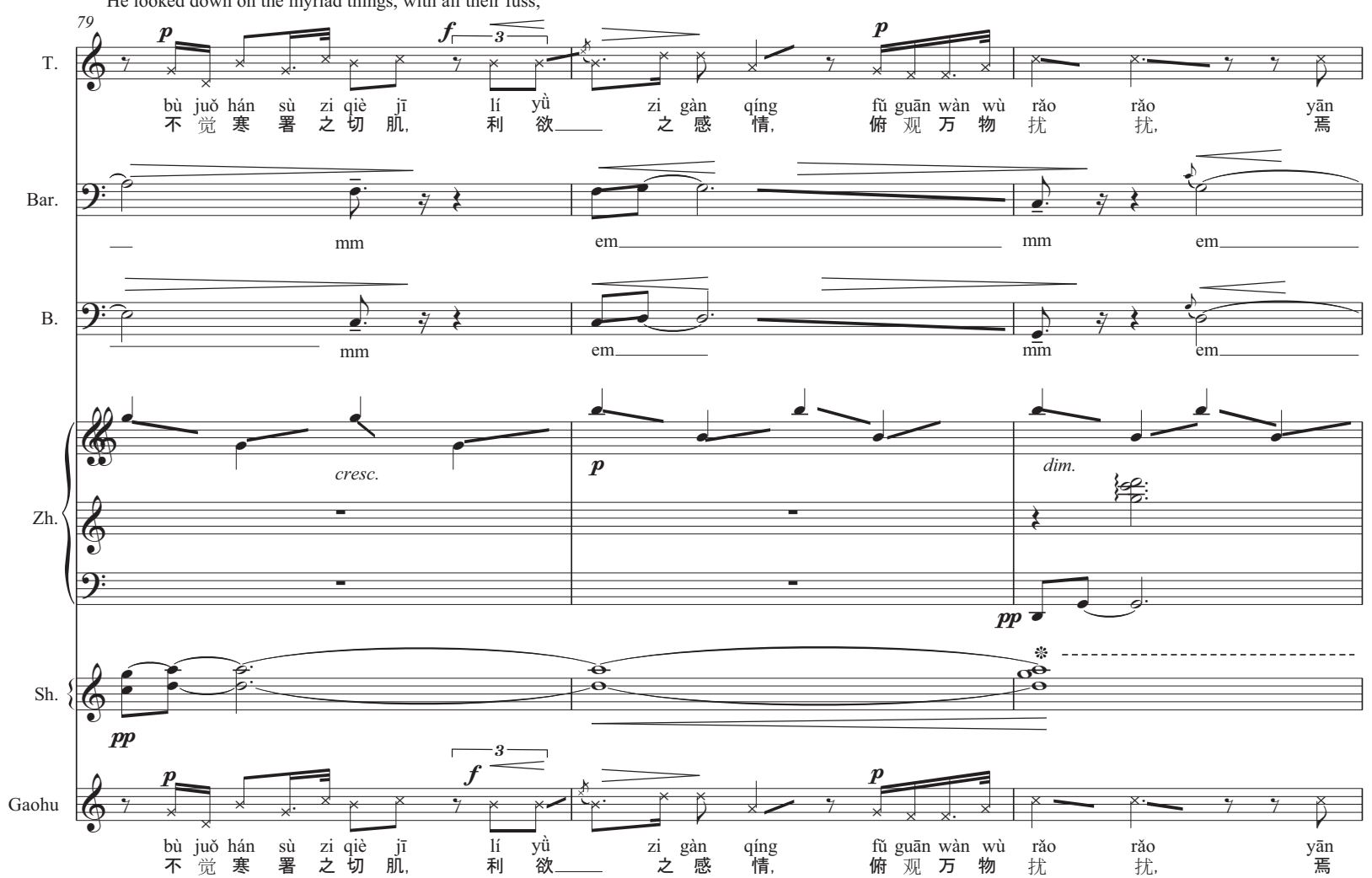


As on the Jiang and Han with floating weeds.

And those two stalwarts, waiting by his side-

How like to blacktail flies their busy buzz.
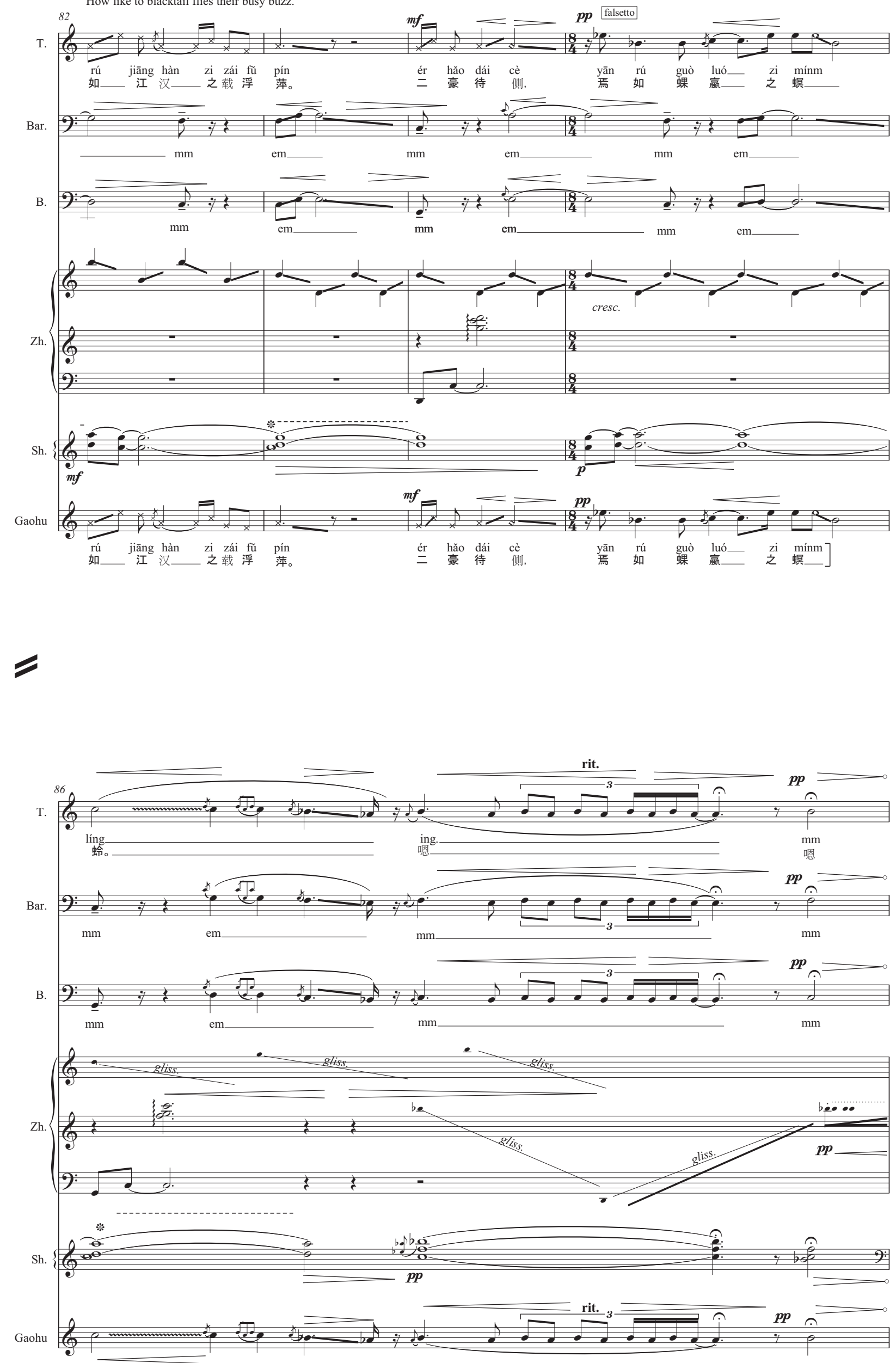
H There was a certain Mr. Great Man

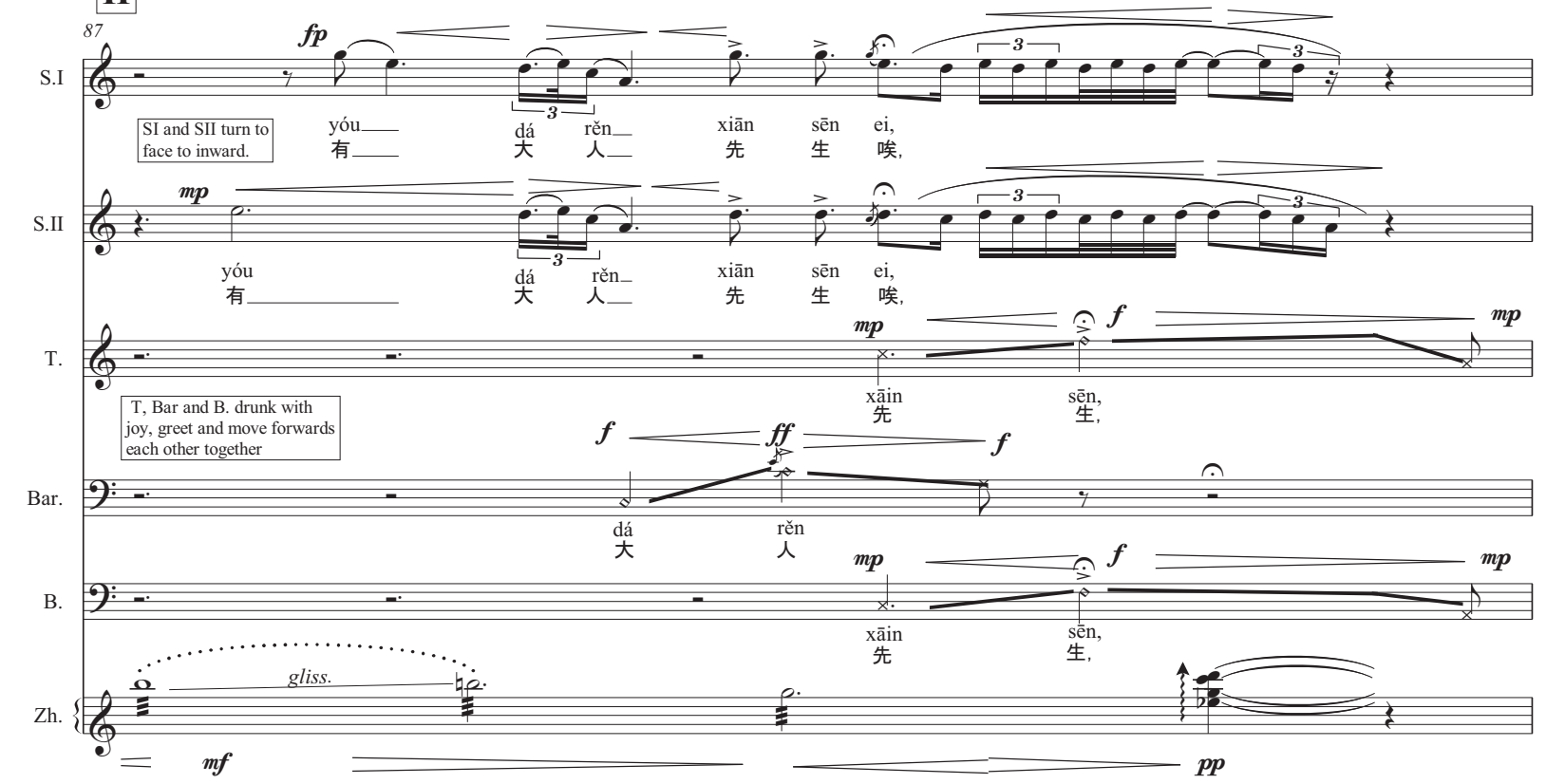

Heaven and Earth were but a morning's span,

A myriad ages but a flash of time;

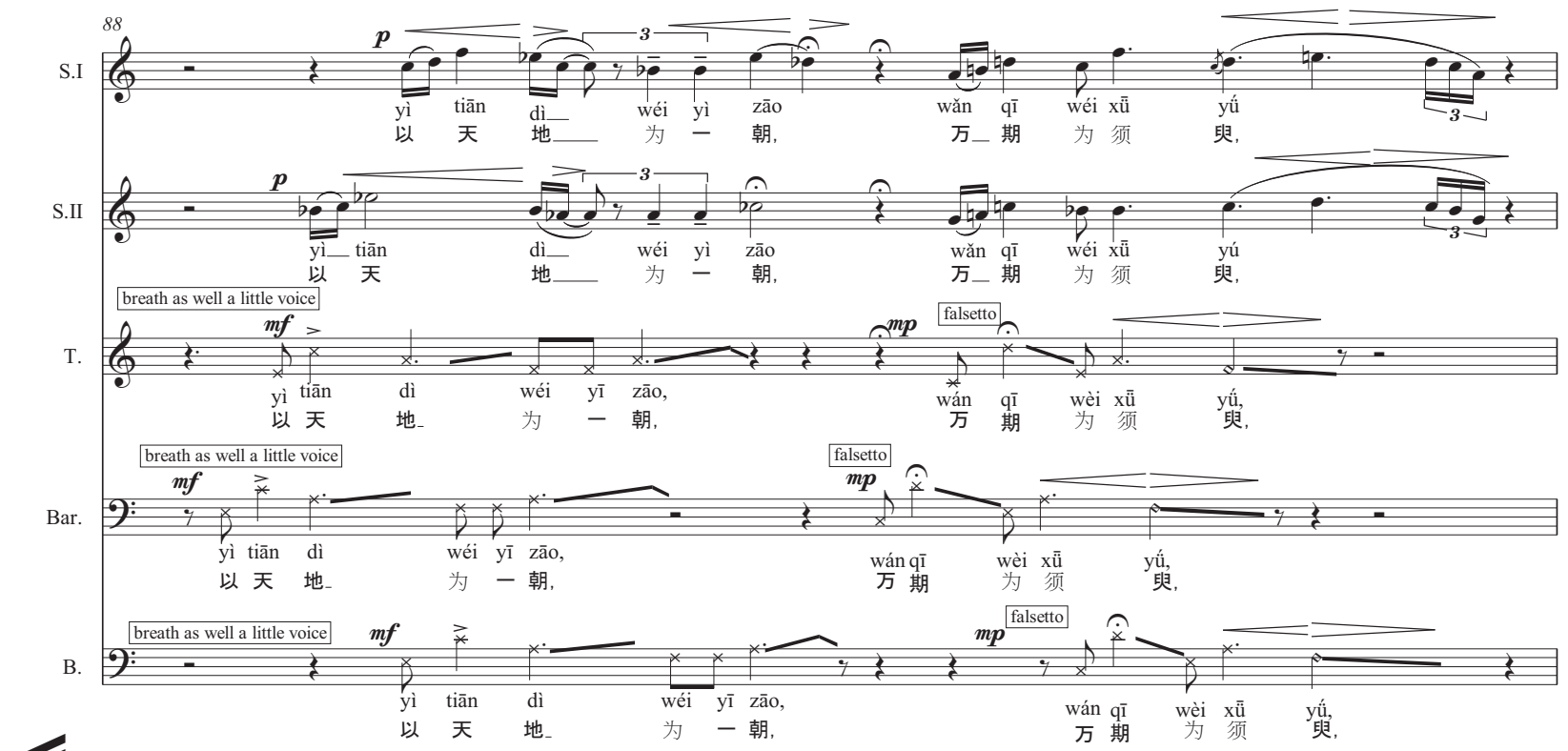

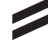

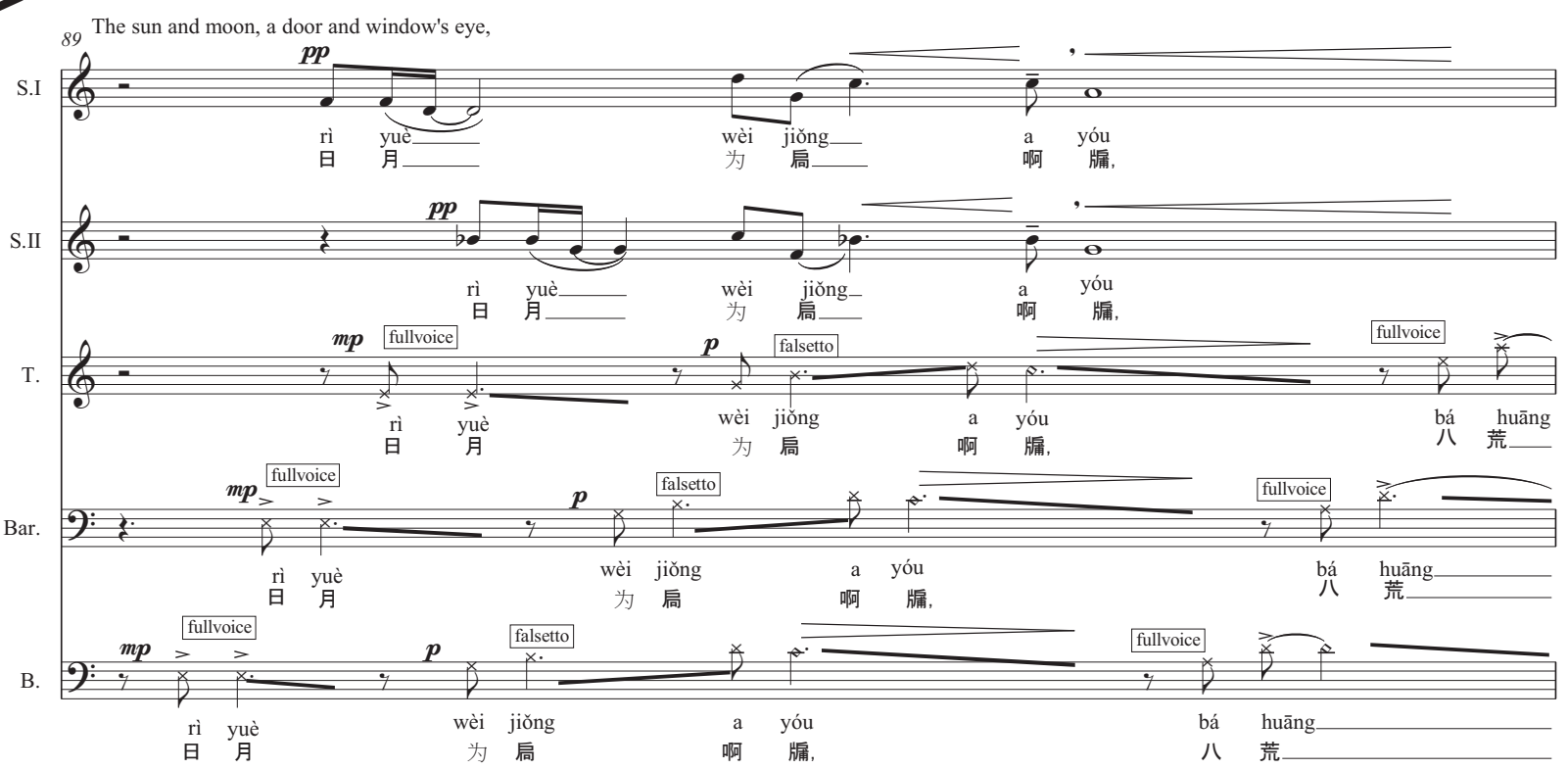



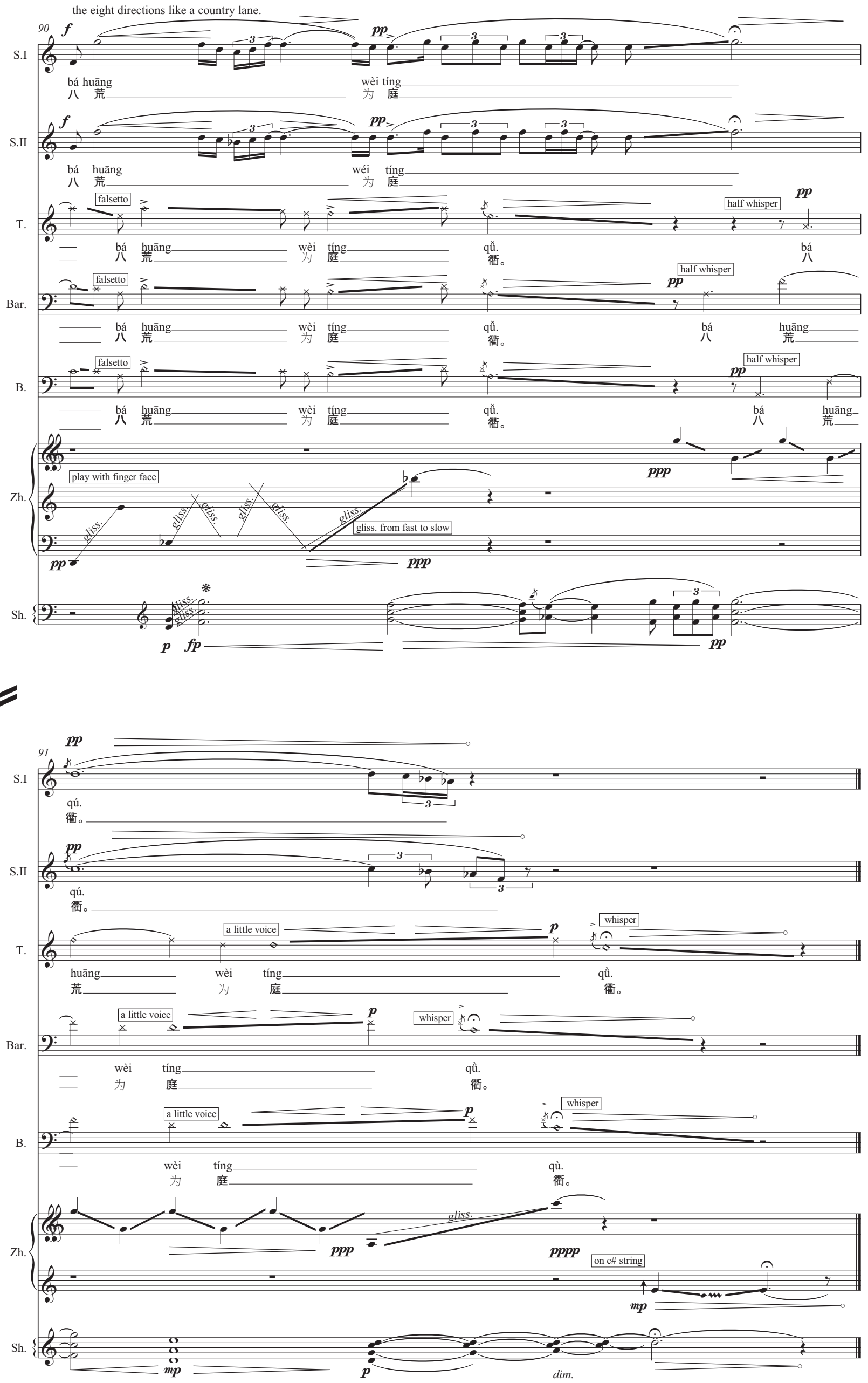


\subsubsection{Zuì (醉) Drunkenness}

Premiere and Performances Part of the

Liù Yǐngshì (六隐士) Six Hermits Project

Presented by The Song Company of Australia

26 October 2002 Sydeny Conservatorium of Music

27 October 2002 Reriverside Theatres Parramatta

27 October 2002 St Paul's Cathedral Melbourne

2 November 2007 Loke Yew hall, The University of Hong Kong

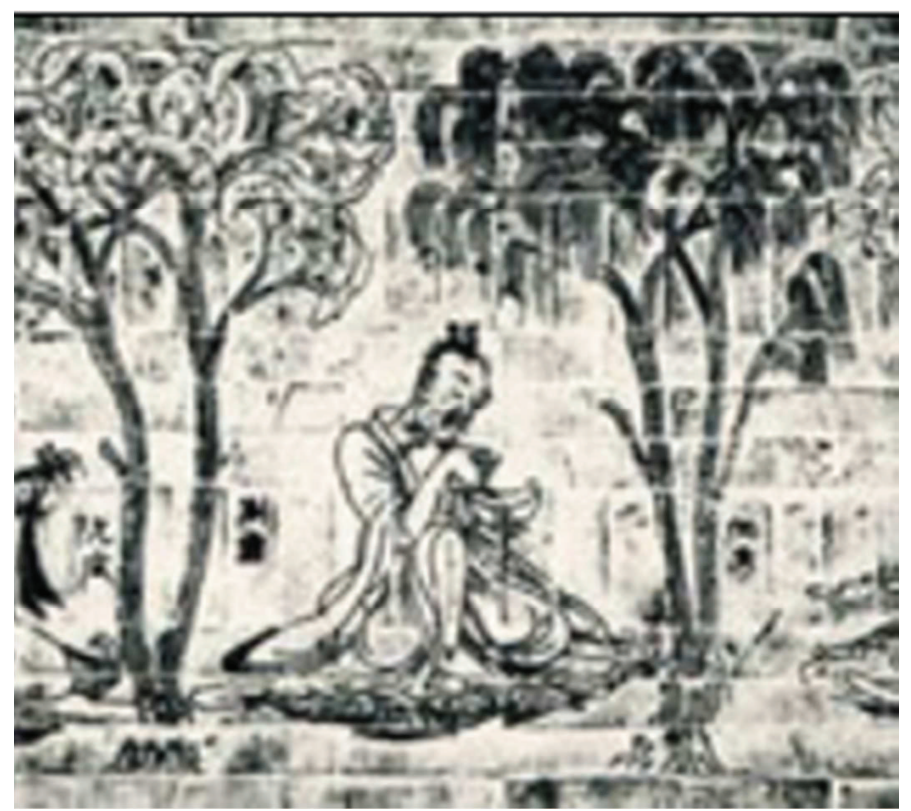

Liu Ling (c.225-280)

Chinese Music Virtuosi

Hiu-hung Ng zhēng solo

Clive Birch voice

(Live recording was from Sydney Conservatorium, October 2002. Produced by Malcolm Batty for ABC Classic FMABC Radio National, Australia) 


\section{DRUNKENNESS}

An interlude of Six Hermits
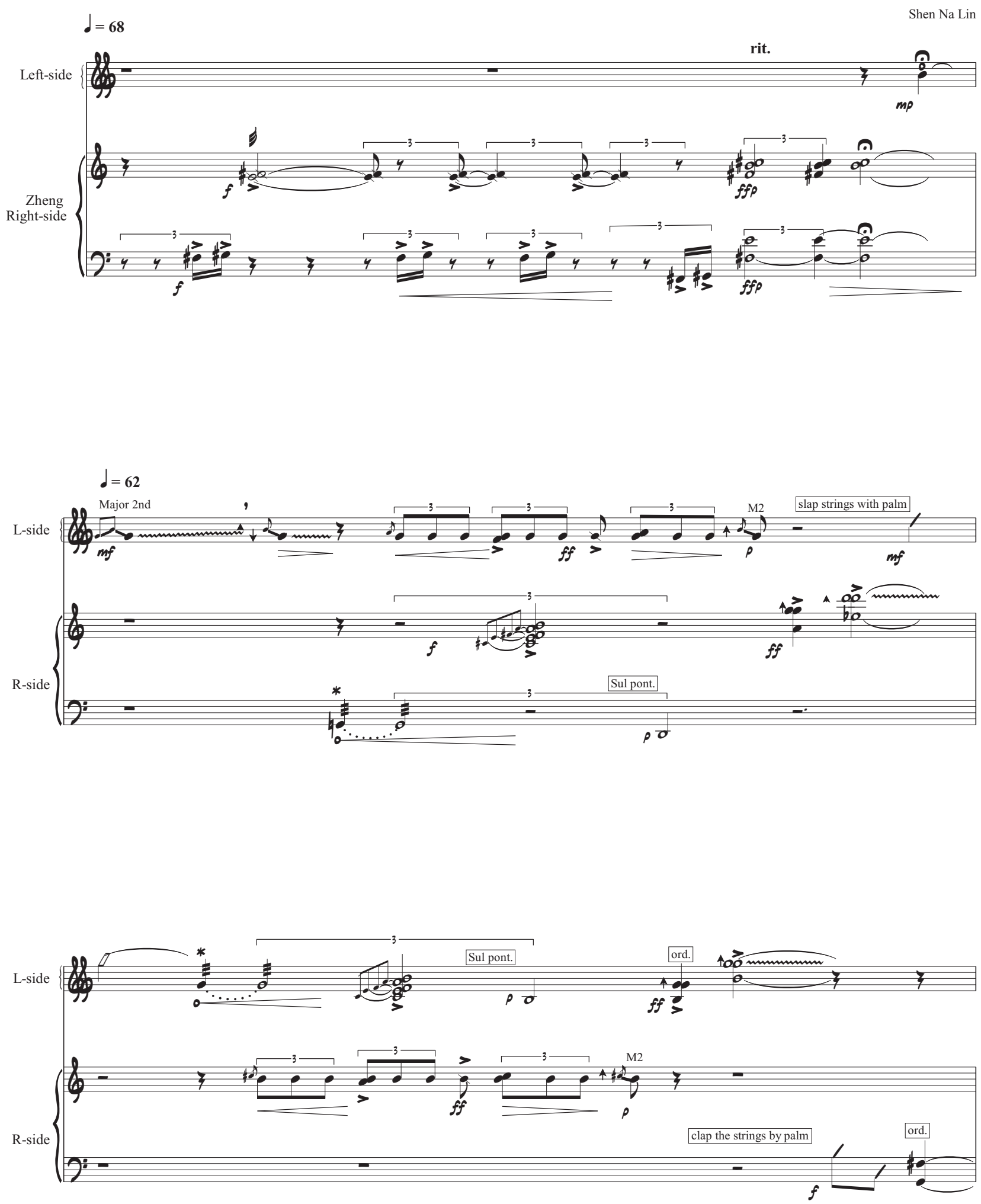

2002 Shen Na Lin 

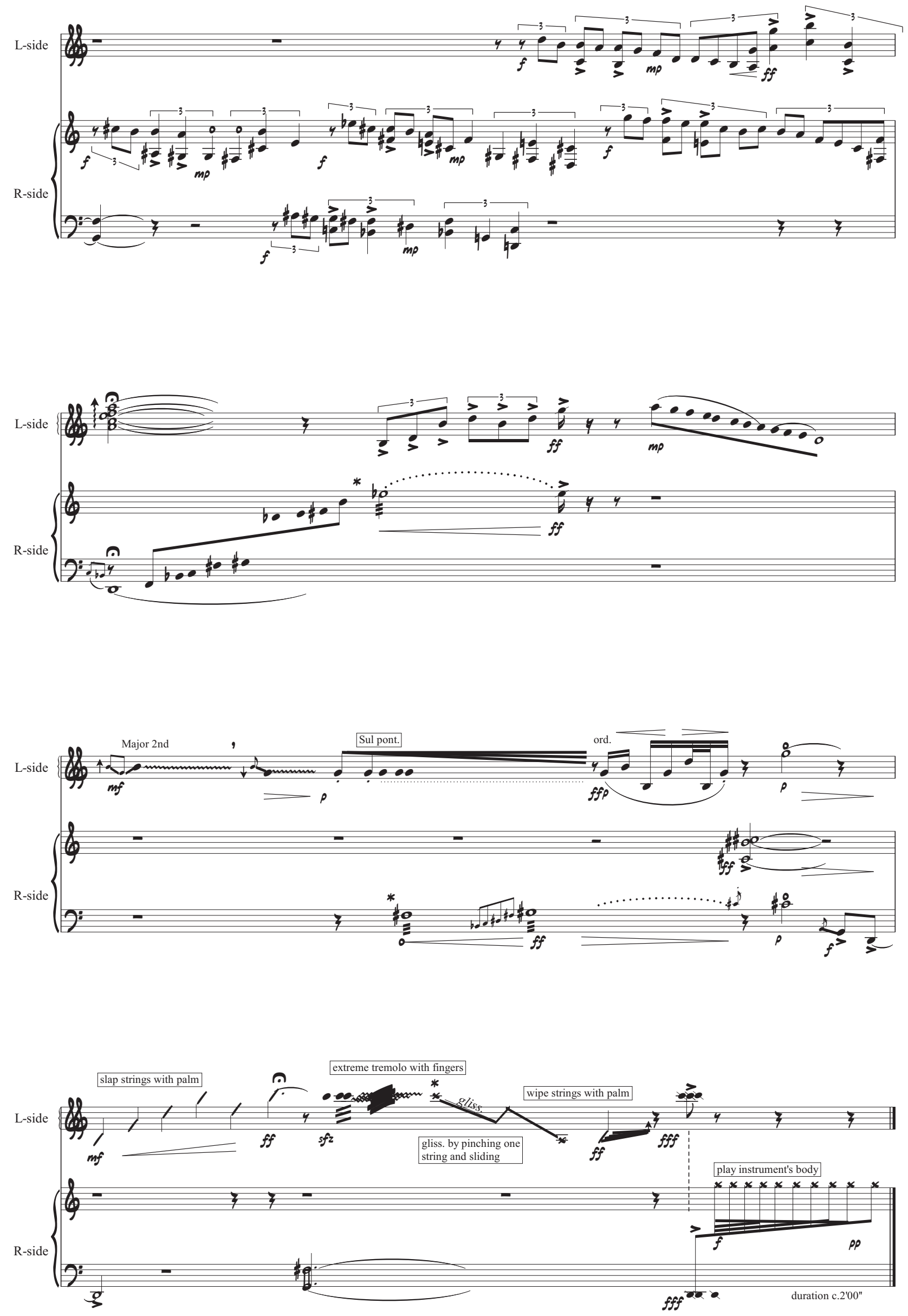


\subsection{Chüyè (初 夜) \\ Scene of the First Night}

An Asia Pacific Festival Production 2007

Te Whaea, National Dance and Drama Centre 12 February 2007

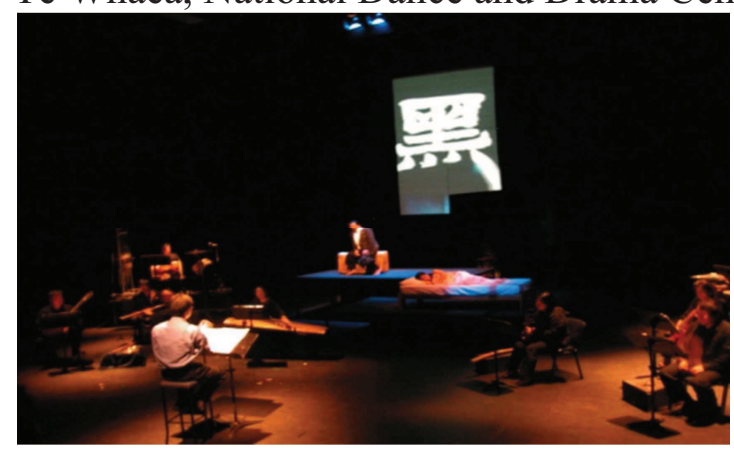

Prelude

Aria: Such a dark night

$03: 32$

Aria: Gazing at the moon through the window

Interlude

Duet: How many days since last saw you

Lullaby: My dearest son

Children's chant: One's good

Chorus: The first light of dawn

Aria: I love you

Linden Loader

mezzo-soprano

Wang Xingxing

James Meng

soprano

Daniel Shen

tenor

boy soprano

Gao Ping

conductor

Sara Brodie

director

Andrew Brettell

audio visual design

Tamsin Lakeman

lighting design

Judy Huo

costume design

Laurence Walls

producer

\section{Contemporary Music Ensemble Korea}

$\begin{array}{ll}\text { Yi Ji-young } & \begin{array}{l}\text { gayageum } \\ \text { daegeum } \\ \text { Kim Woong-seung } \\ \text { park }\end{array} \\ \text { Lee Hyang-han } & \text { saenghwang } \\ \text { Kim Woo-jae } & \text { guitar } \\ \text { Kim Woong-sik } & \text { Korean percussion } \\ \text { Rhee Kyu-bong } & \text { Western percussion } \\ \text { Lim Myoung-jin } & \text { clarinet } \\ \text { Park jeung-min } & \text { cello }\end{array}$

(Live recording on 12 February 2007, at Te Whaea, National Dance and Drama Centre, Wellington, by Roy Carr and Pual Wolffram) 
Scene of the First Night

Librettist Shen Nalin

English trans. Duncan Campbell

Supervisor: Jack Body
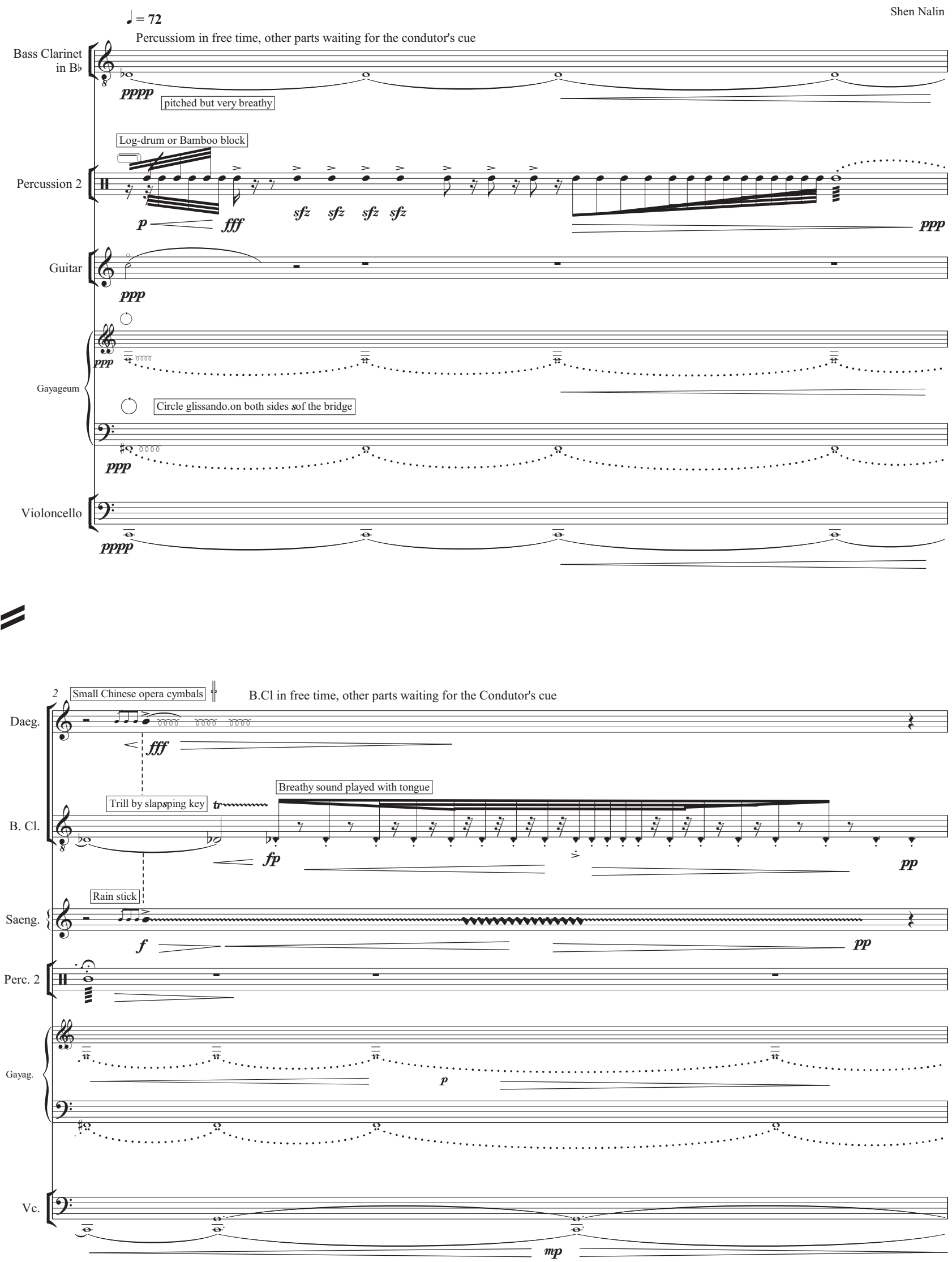

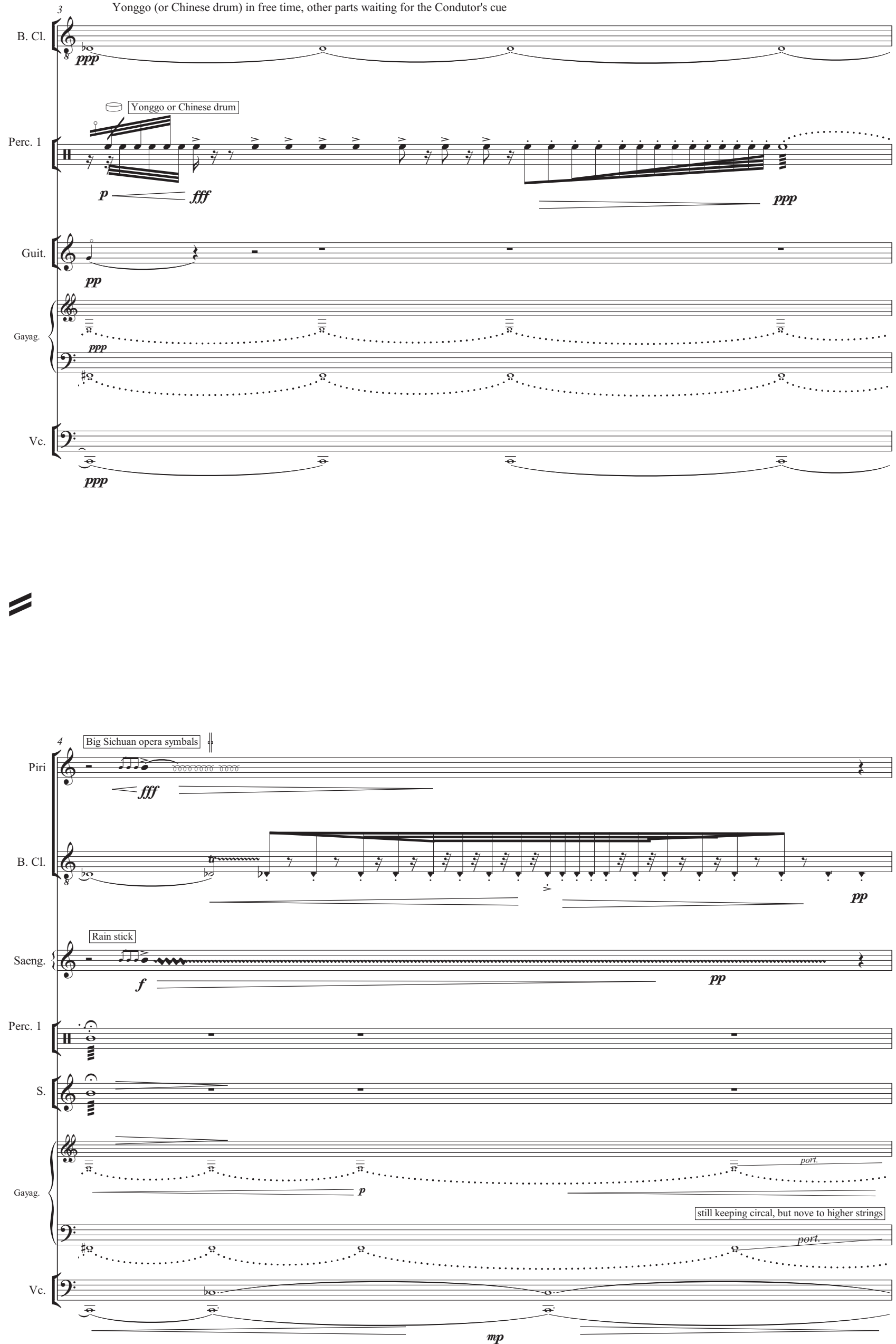

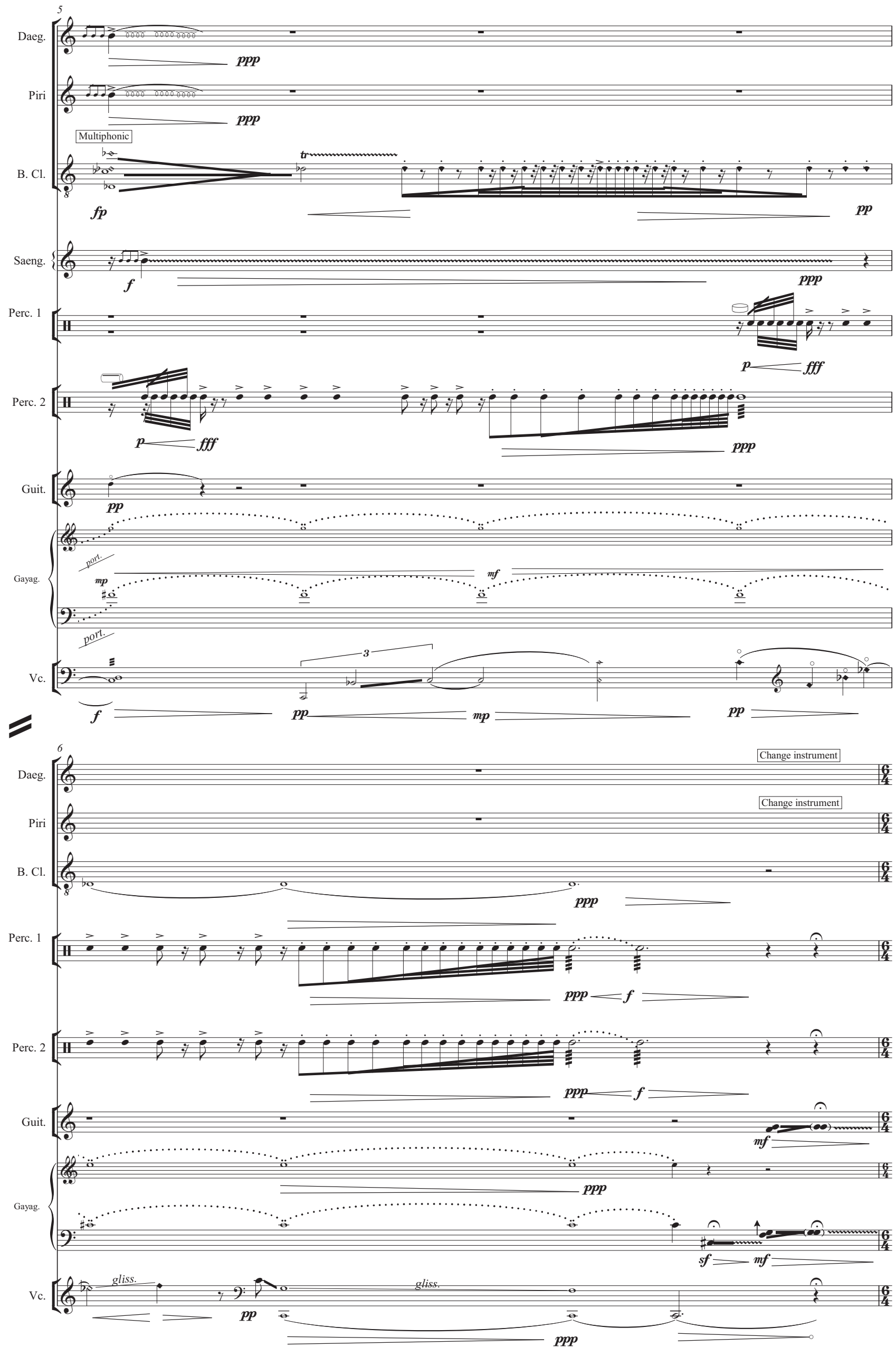

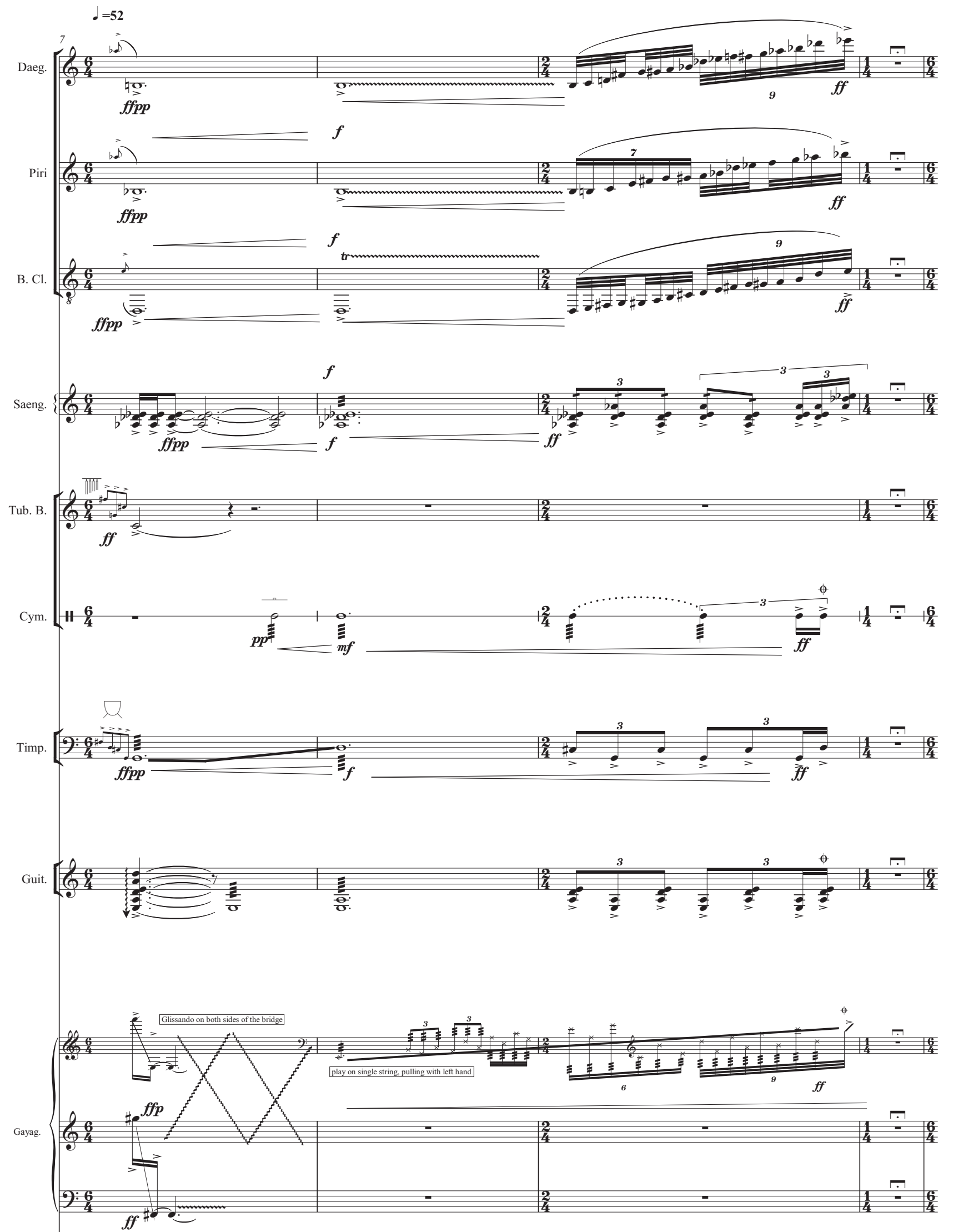

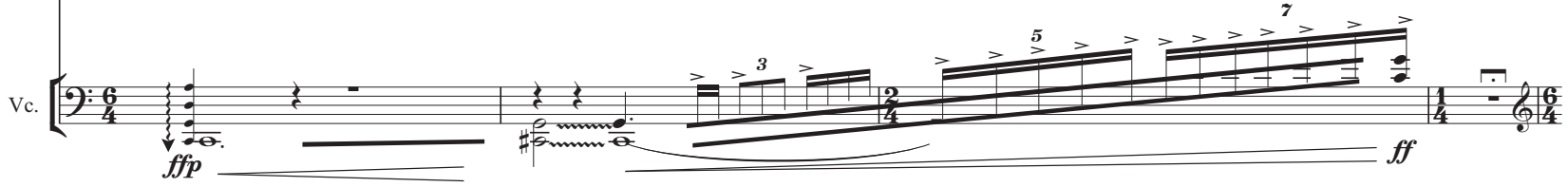




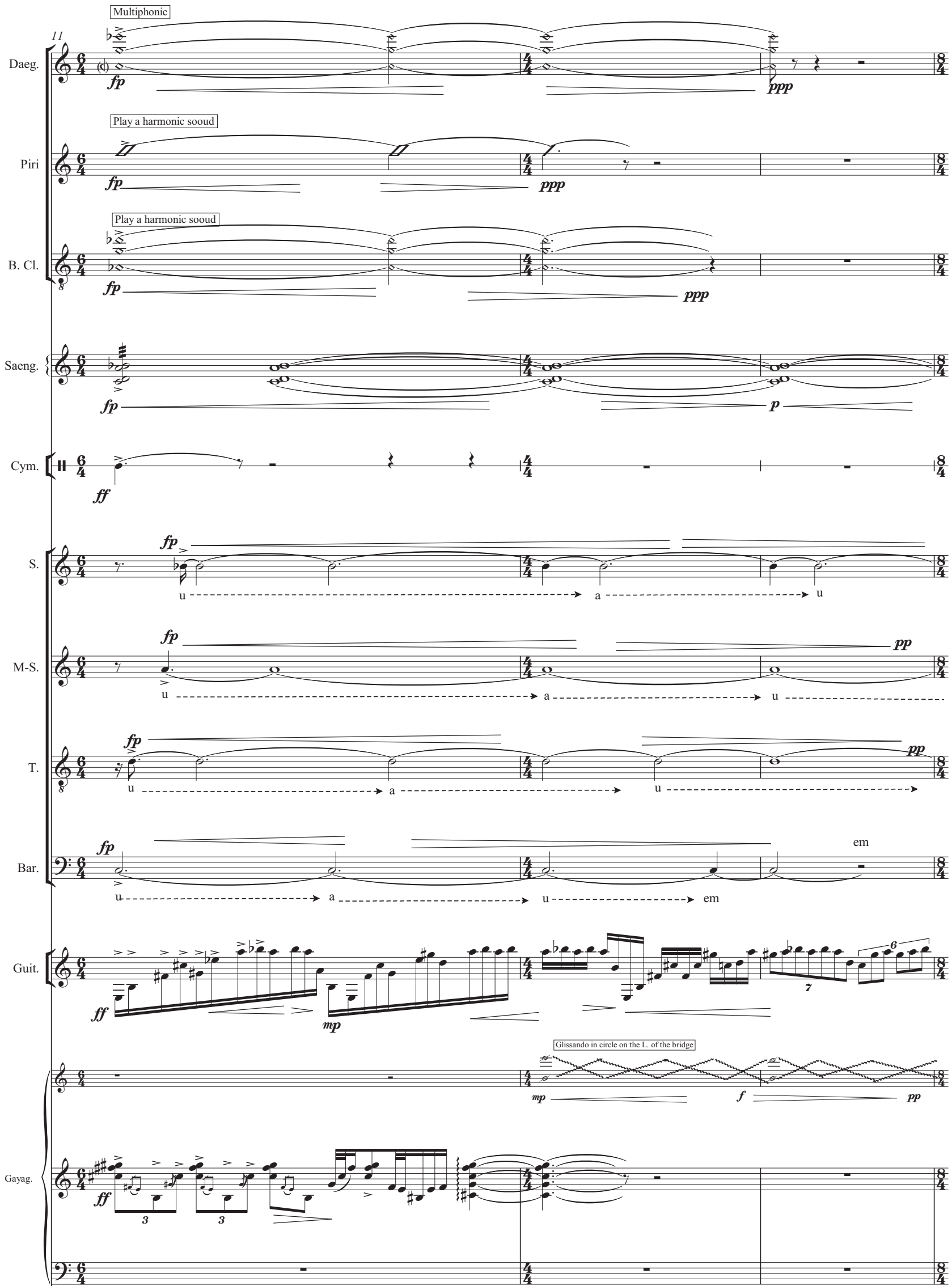

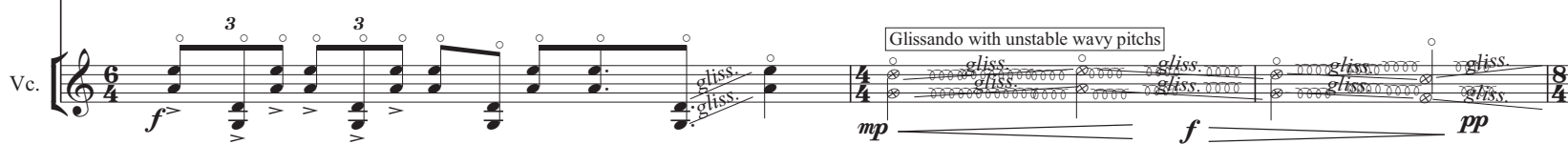



[Action 1: Yinger, hangs in front of the window.

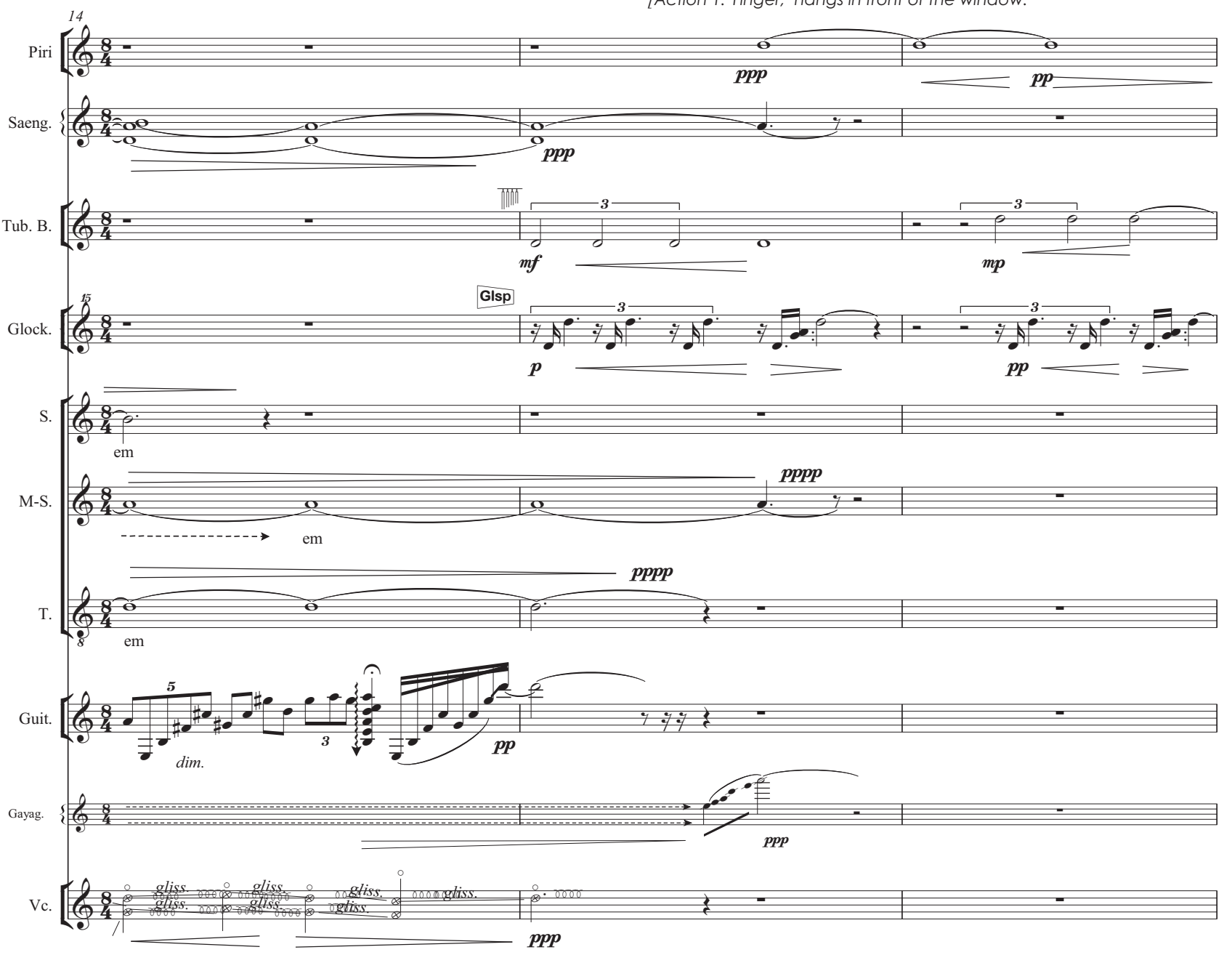

[Becoming aware of noise from the sitting room Yinger walks quietly towards the curtain of door, inclines her head to listen. Then, quickly,

she goes to turn off the bedside light

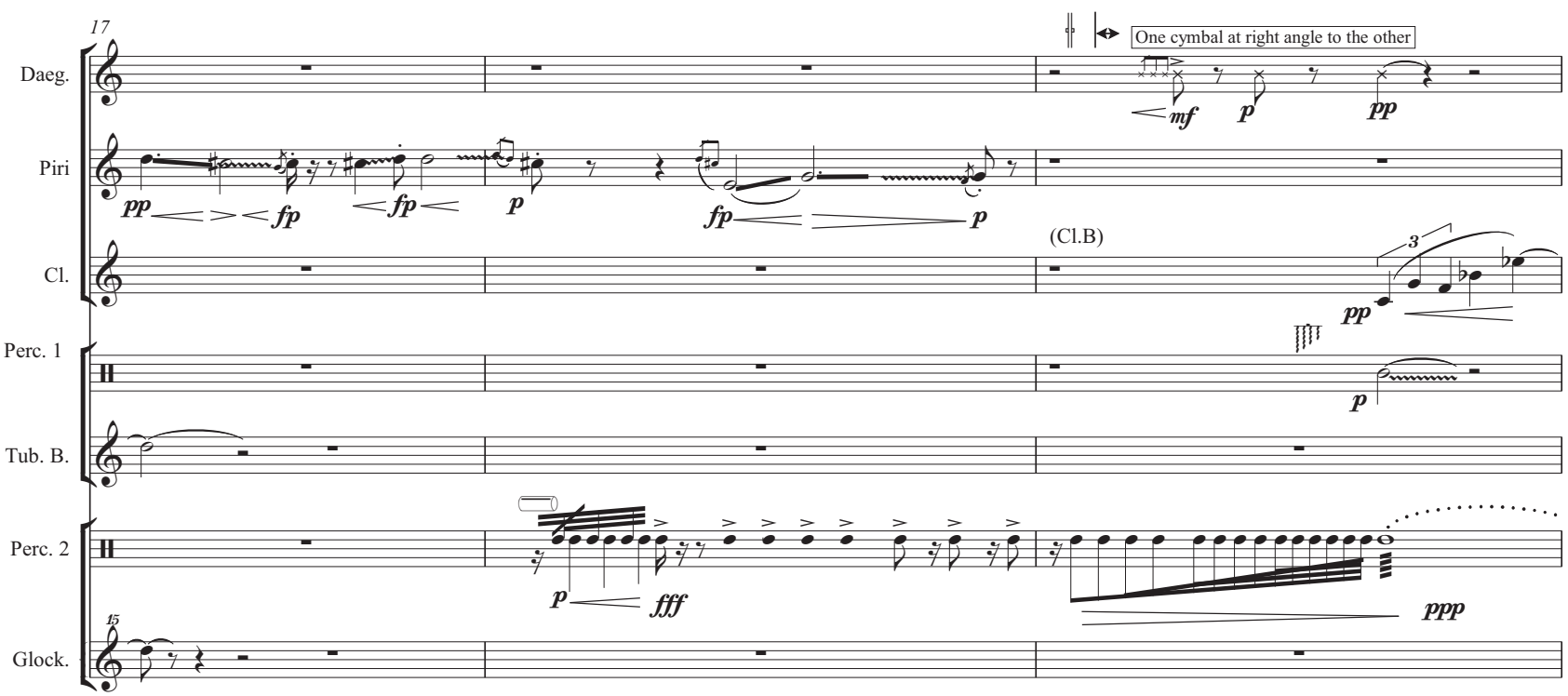



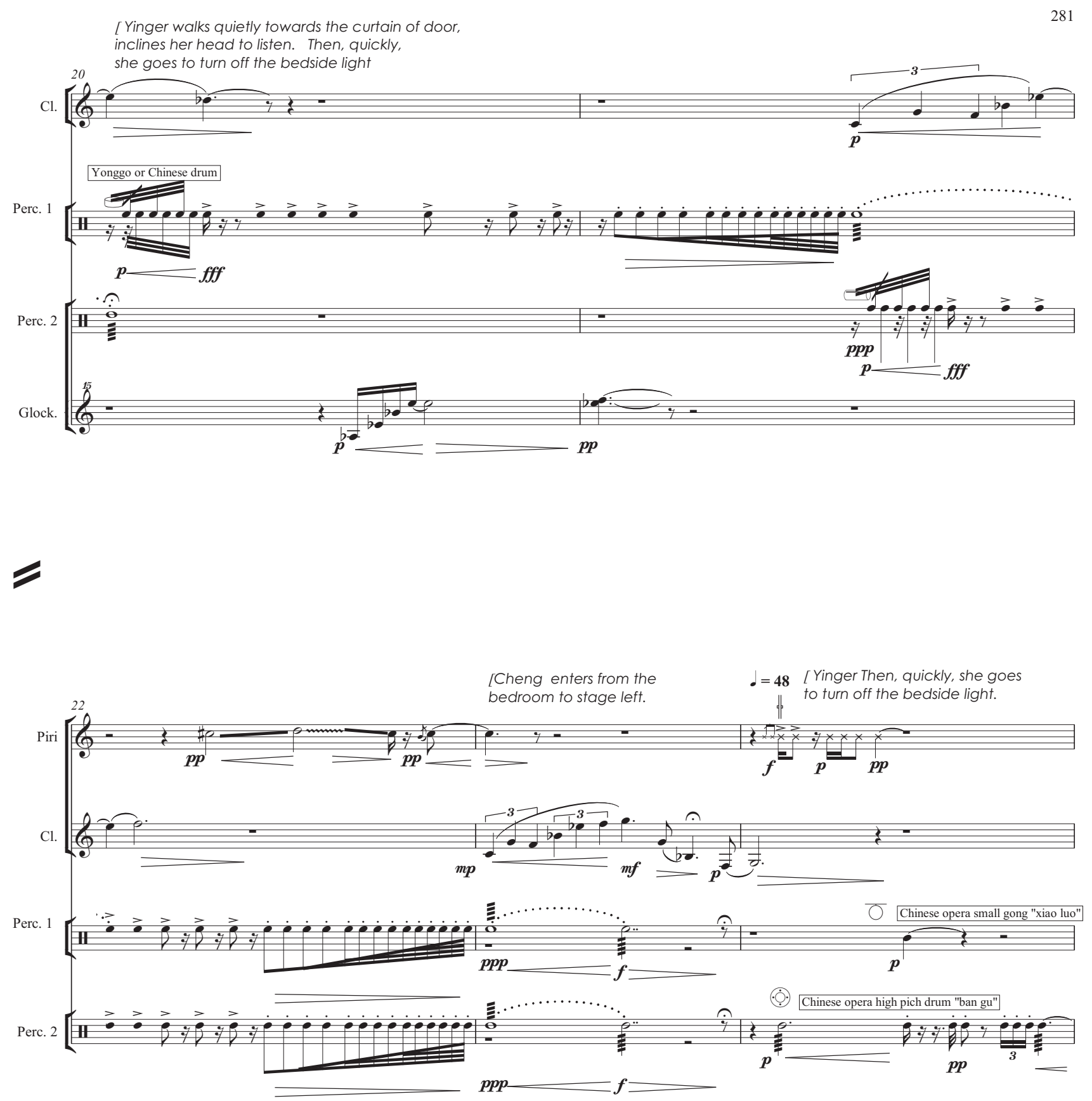

Gu Cheng's aria: "Such a dark night"

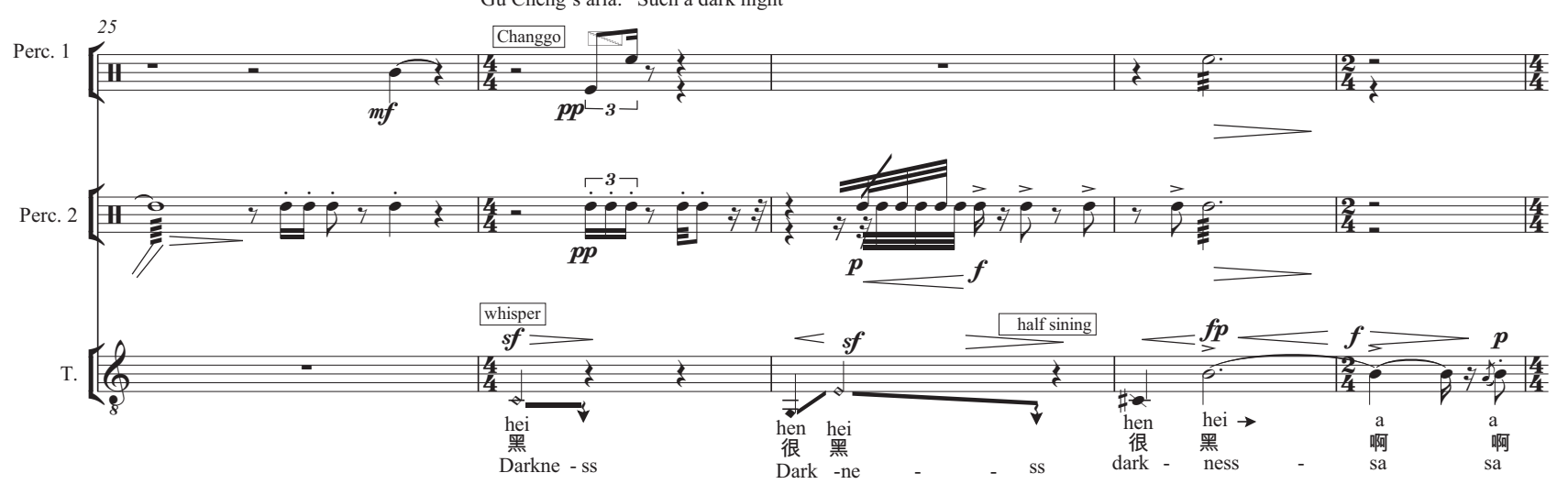




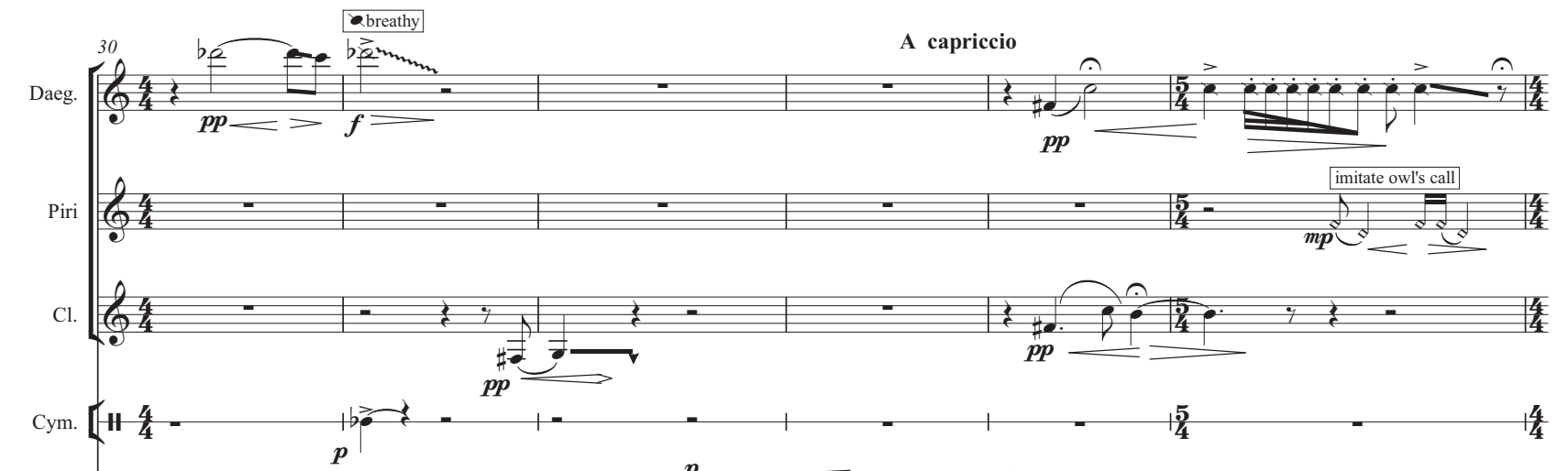

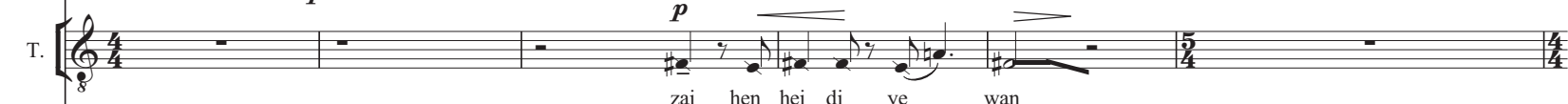

Guit.

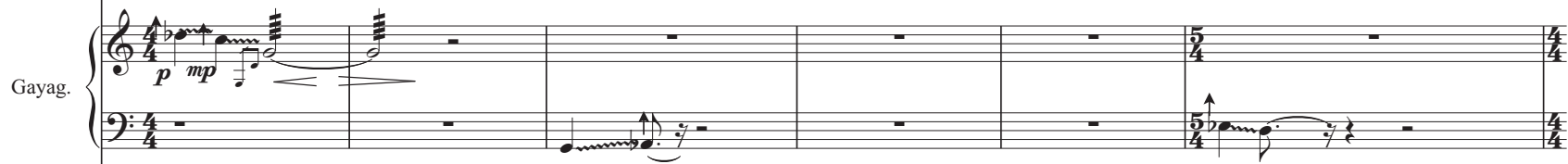

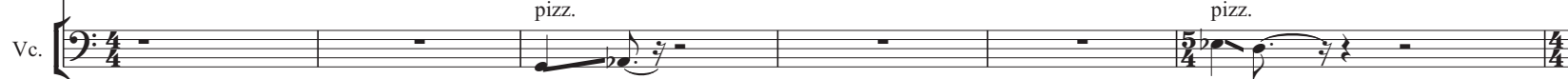

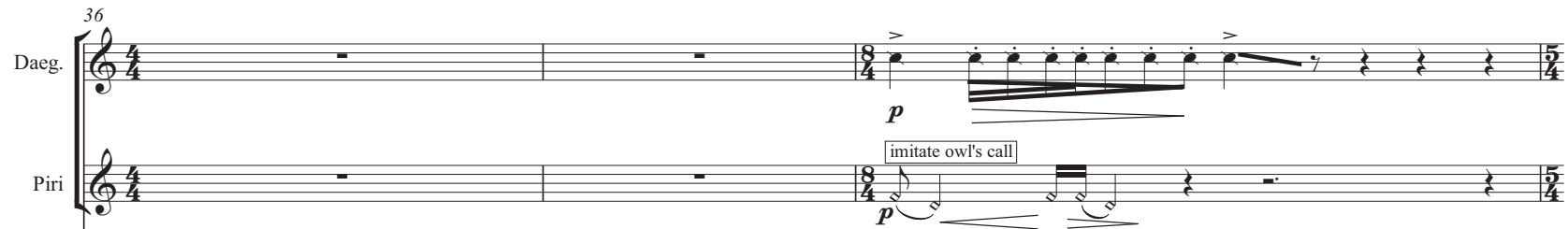

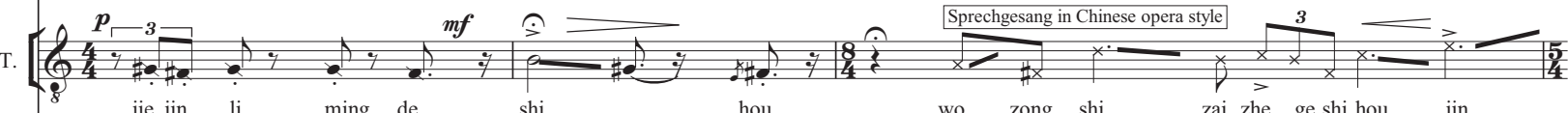

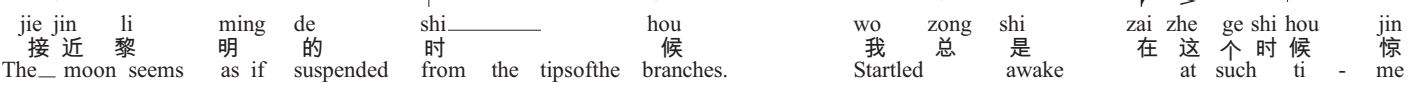

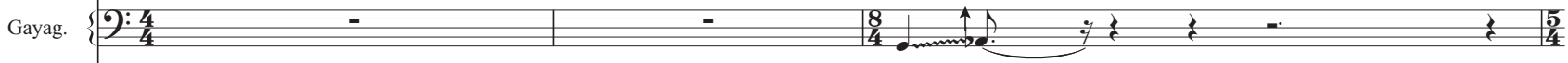

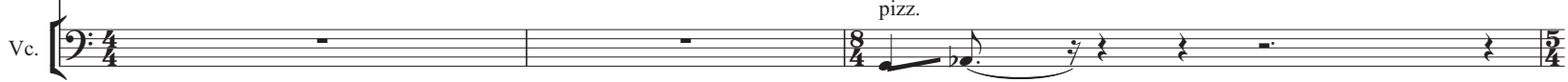

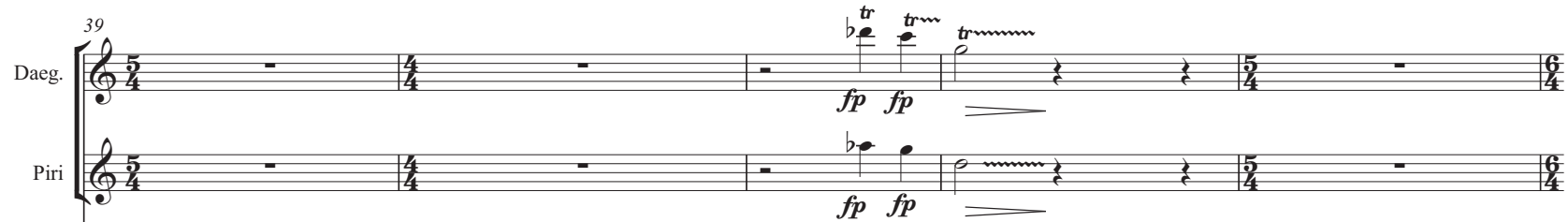

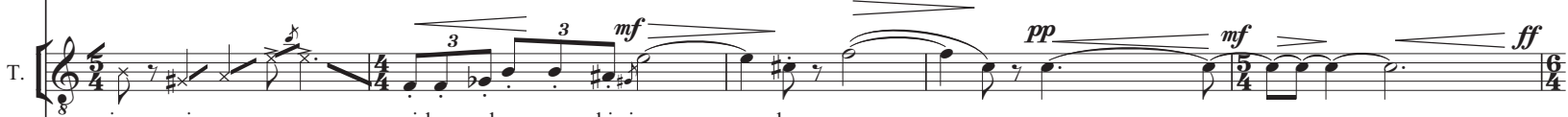

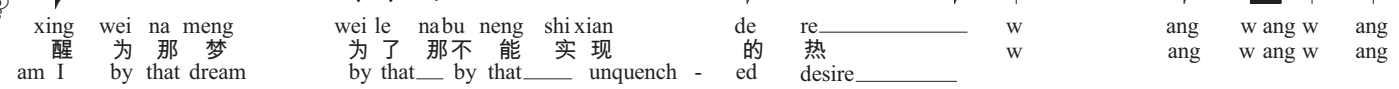

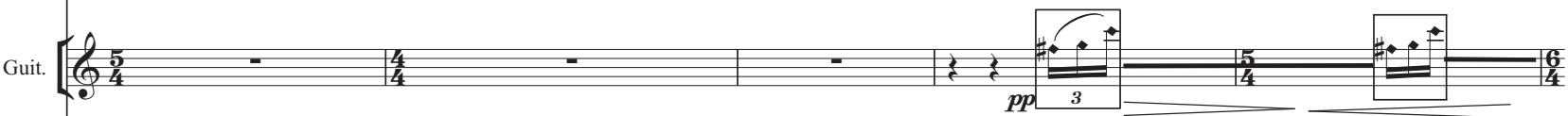

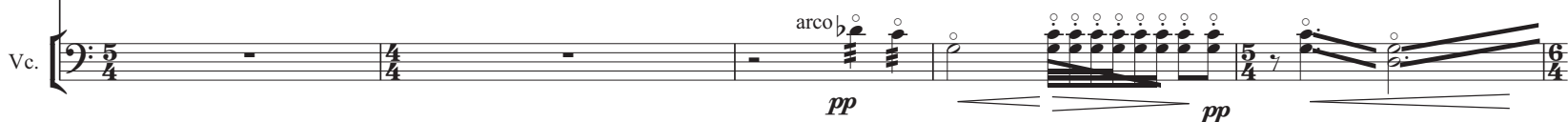



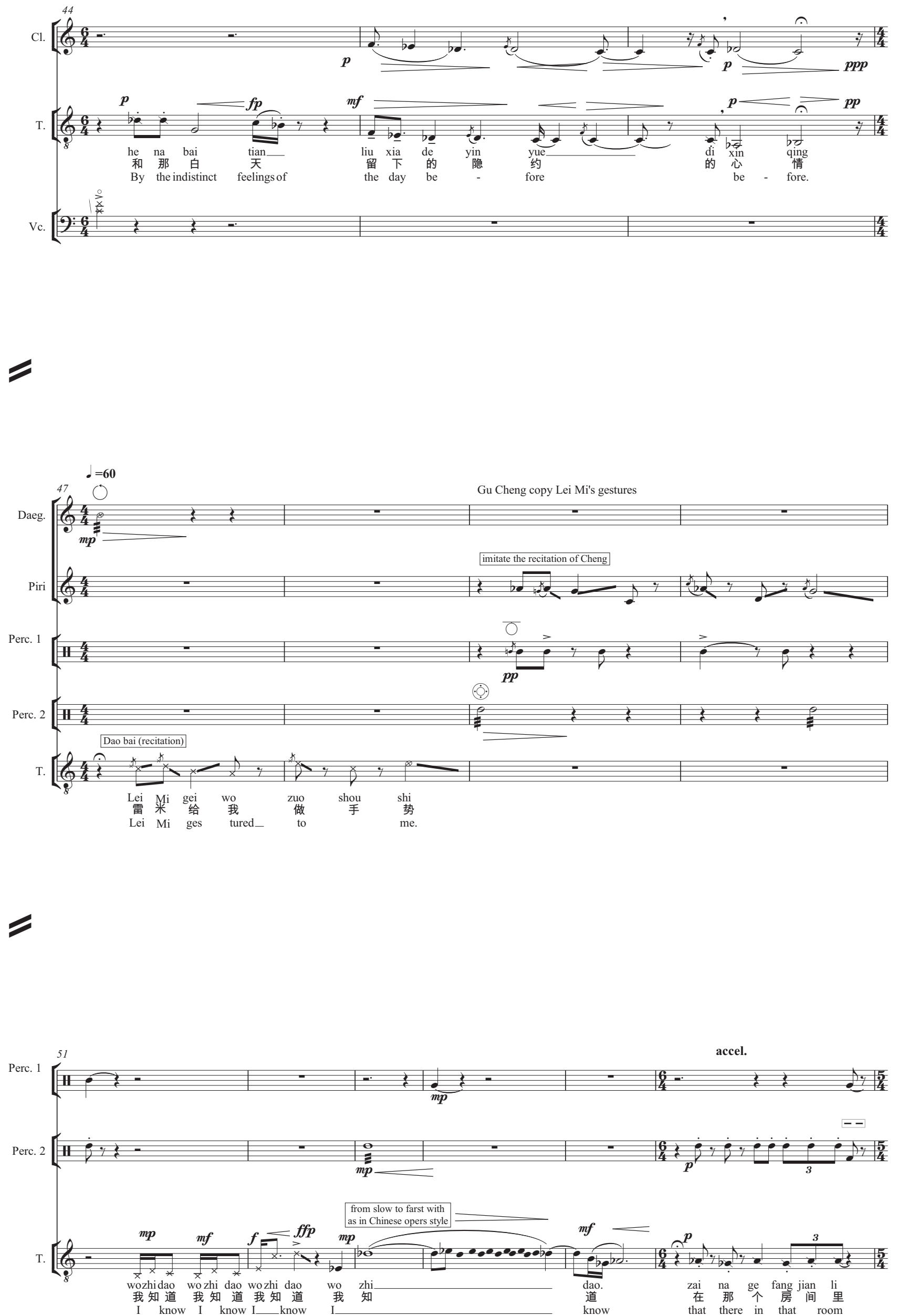

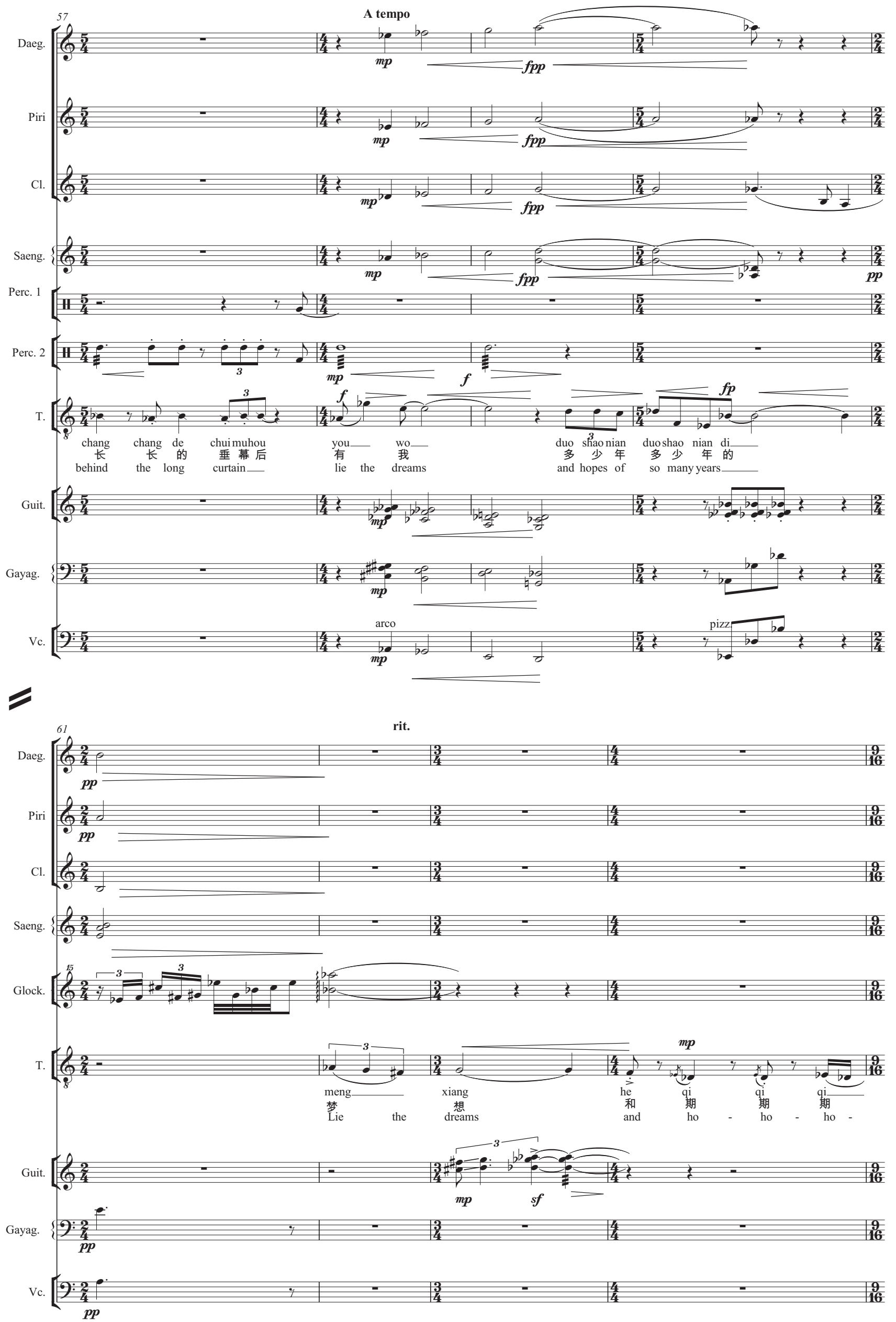

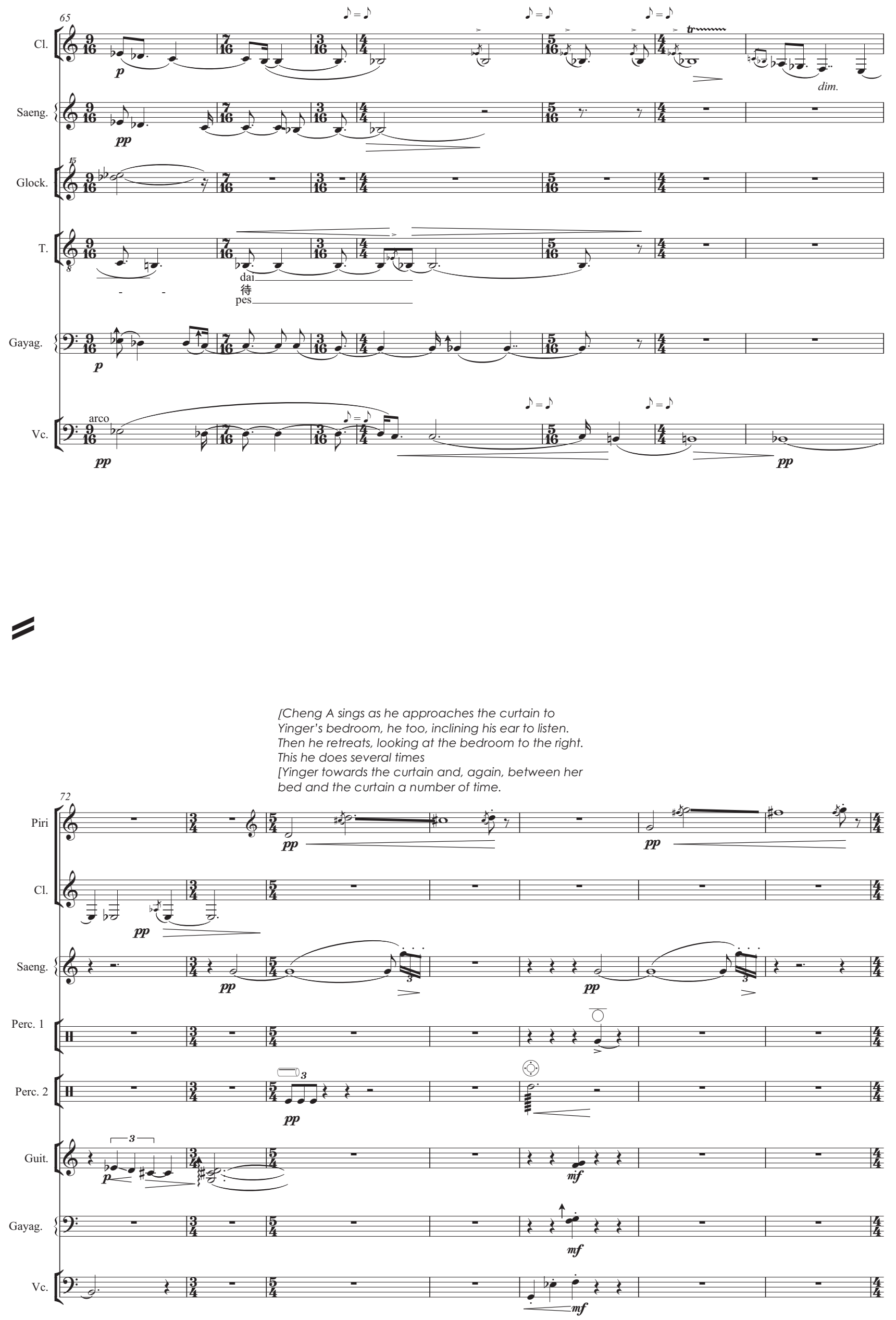


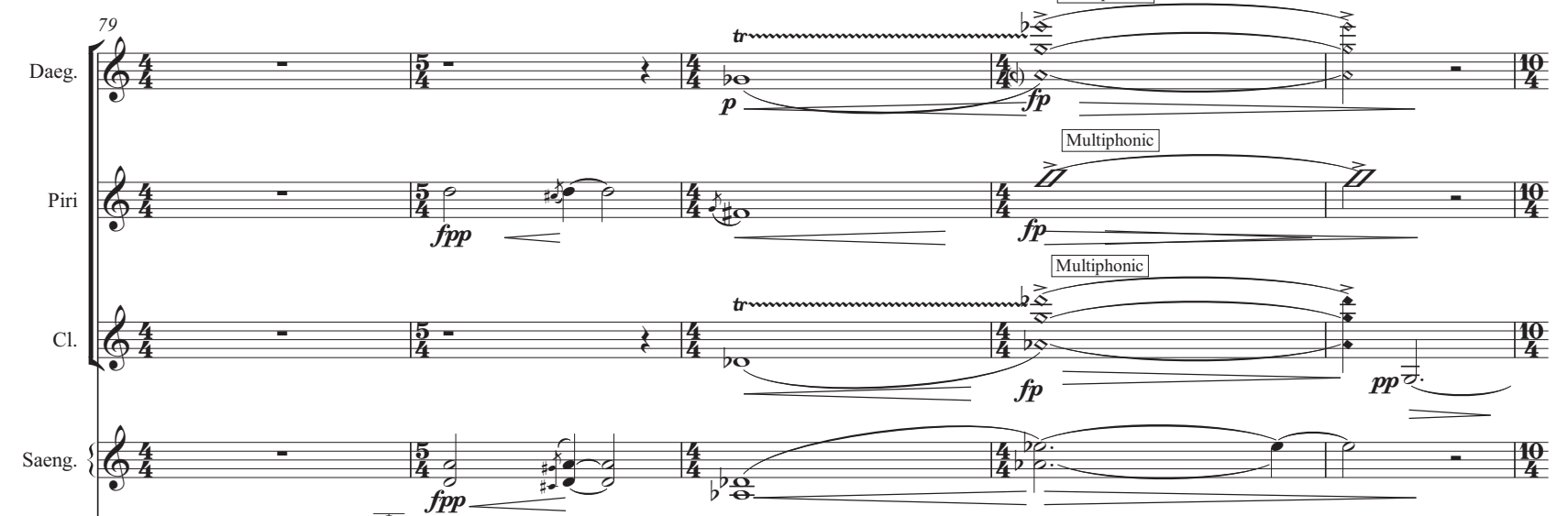

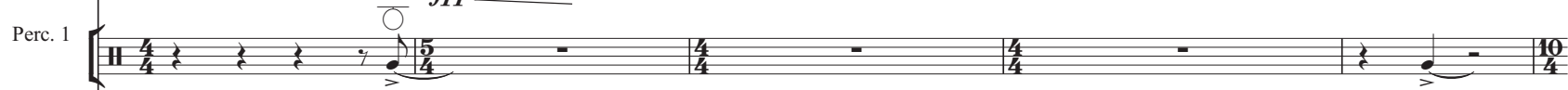

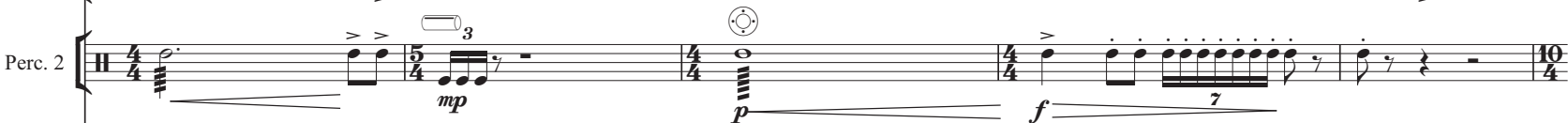

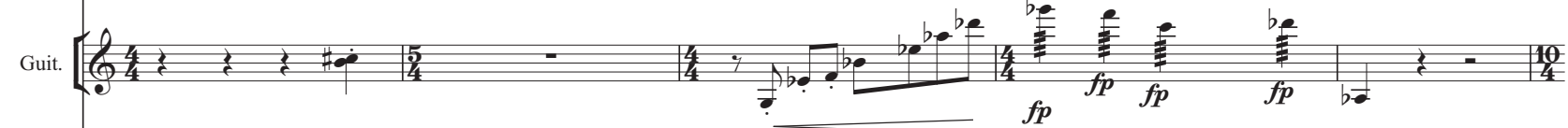

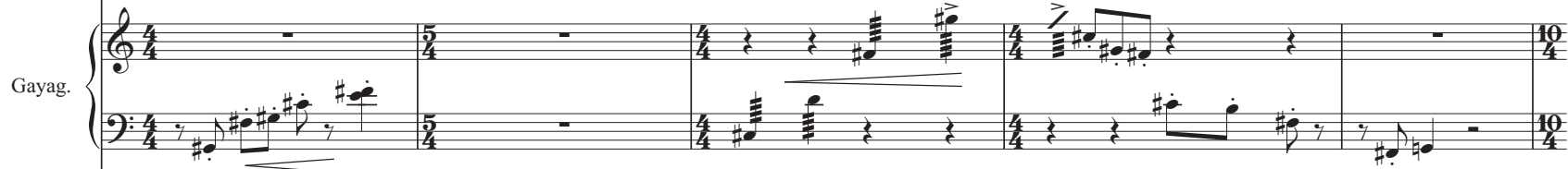

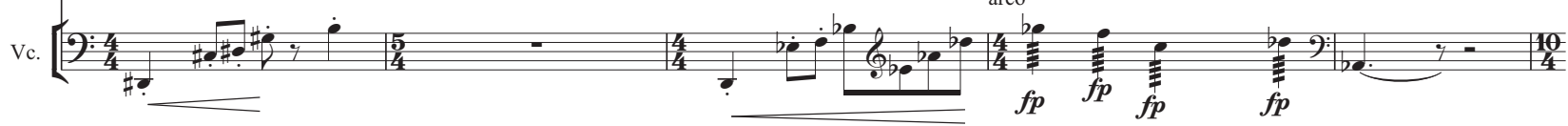

[Lighting: Gradually the bedroom becomes lighter.

[Cheng A gently approaches her bed and gazes at her reclining figure]

Gu Cheng's aria : "Gazing at the moon through the window"

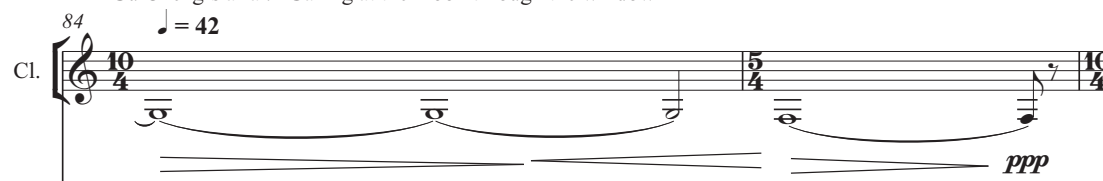

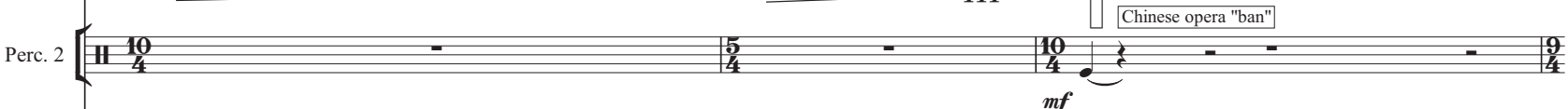

$\left[\frac{60}{80}\right.$

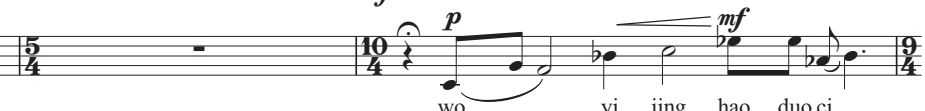
wo 我 yi jing hao duoci-

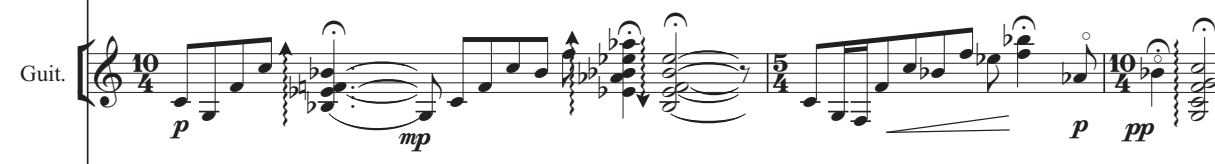

Gayag. $\left\{9: \frac{10}{4}\right.$

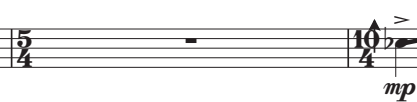

Vc. $\left[\frac{-10}{4}\right.$ 


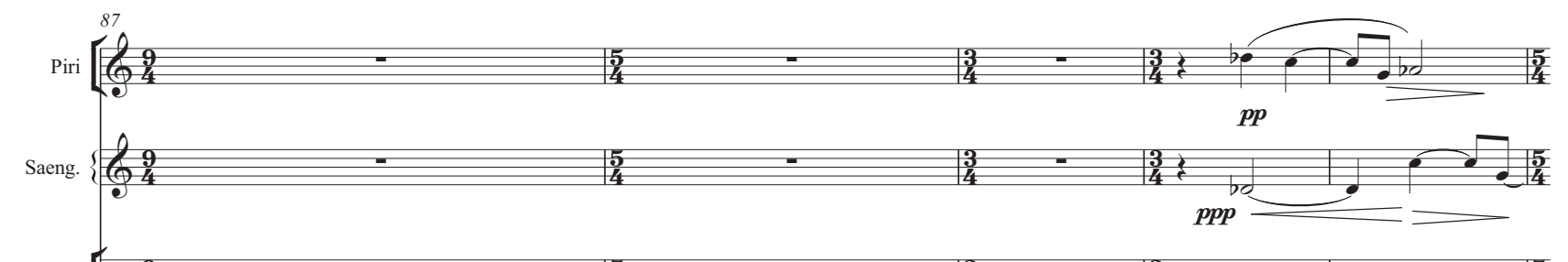

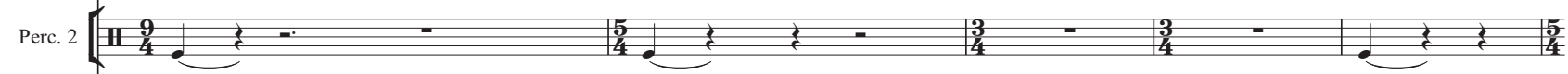

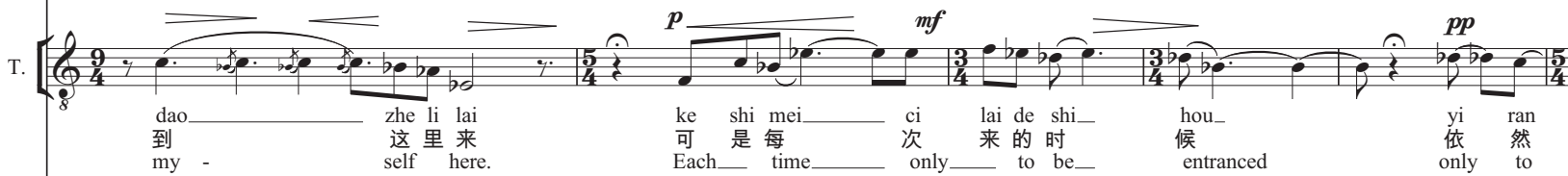

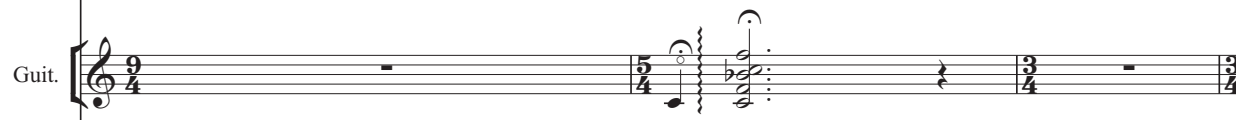

Gayag. $\{2: 9$

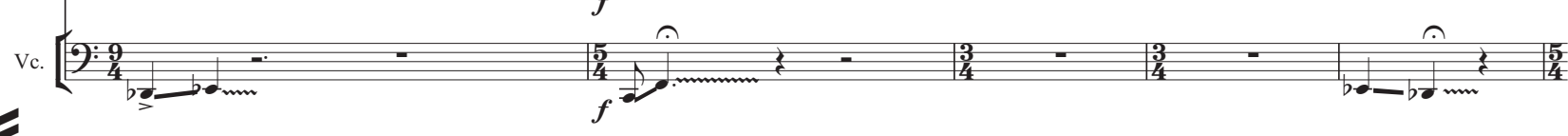

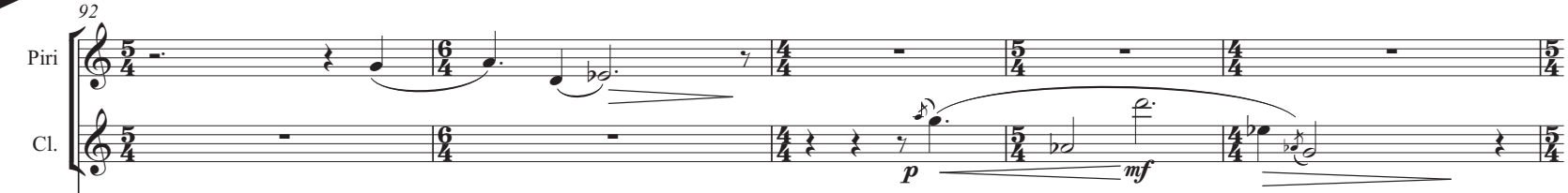

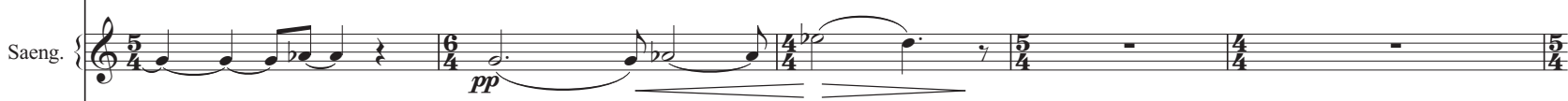

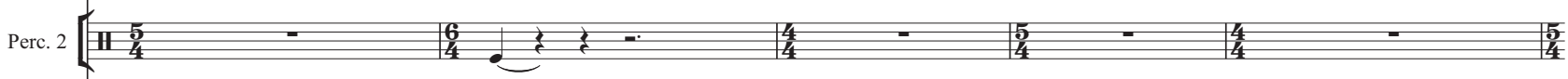

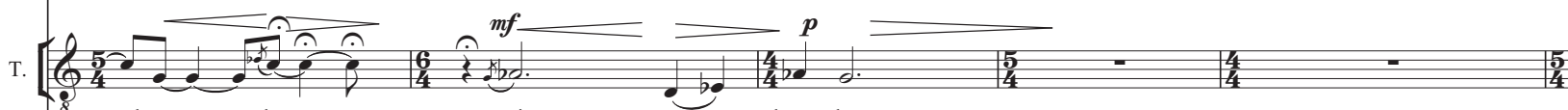

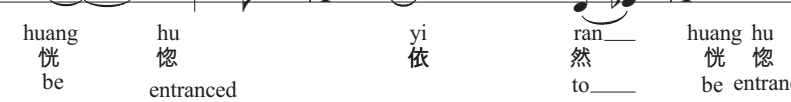

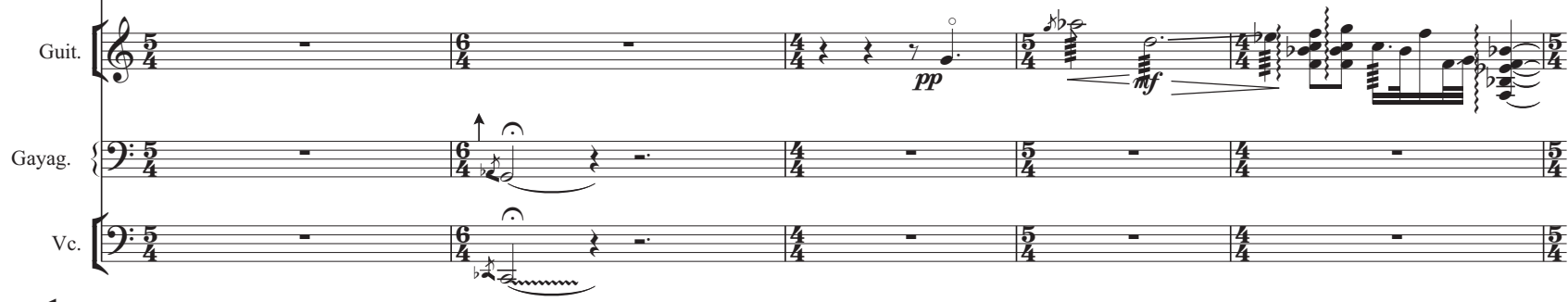

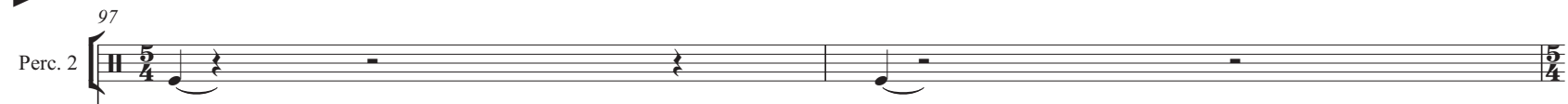
$m f$

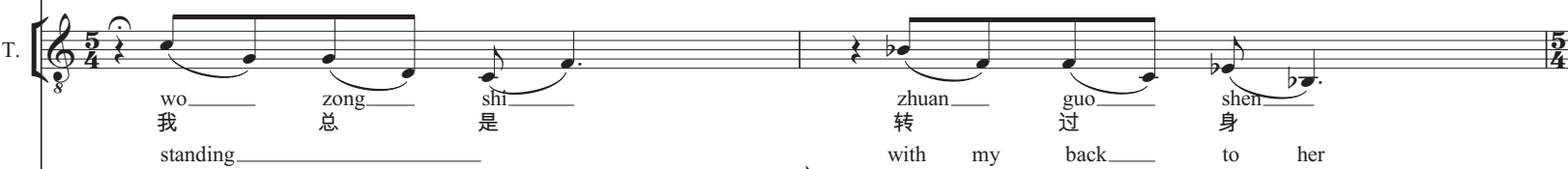

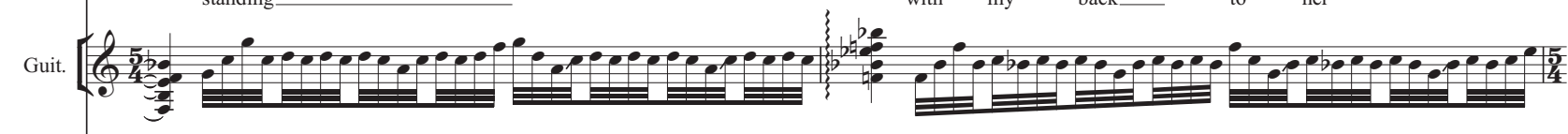

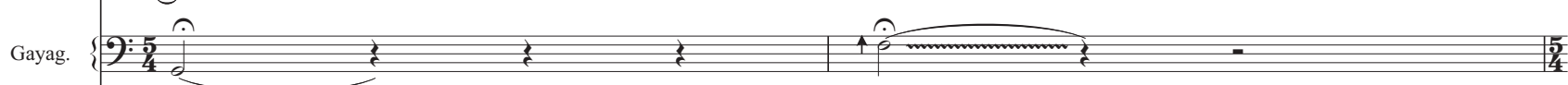

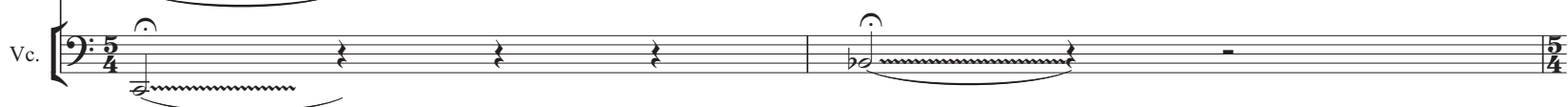



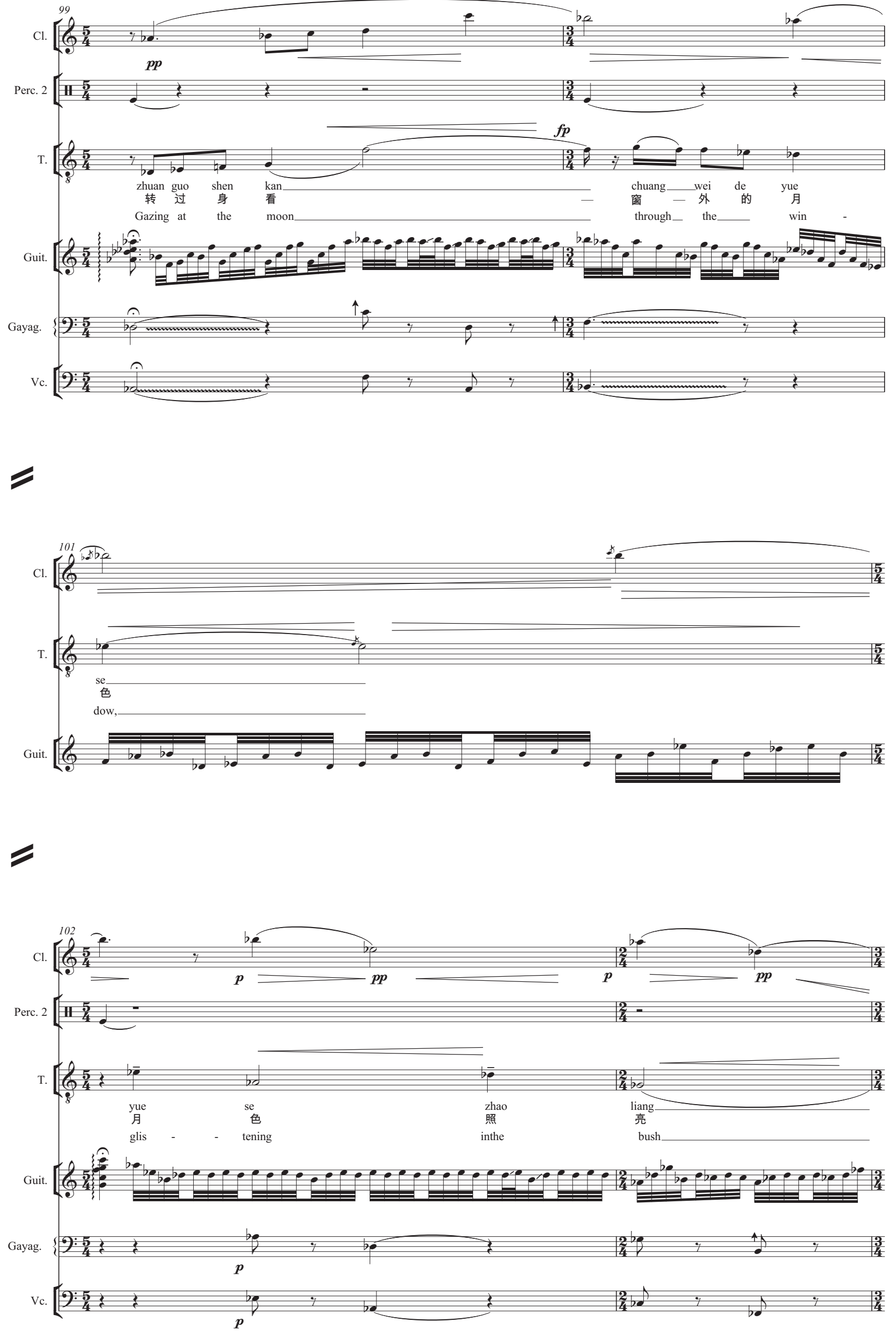


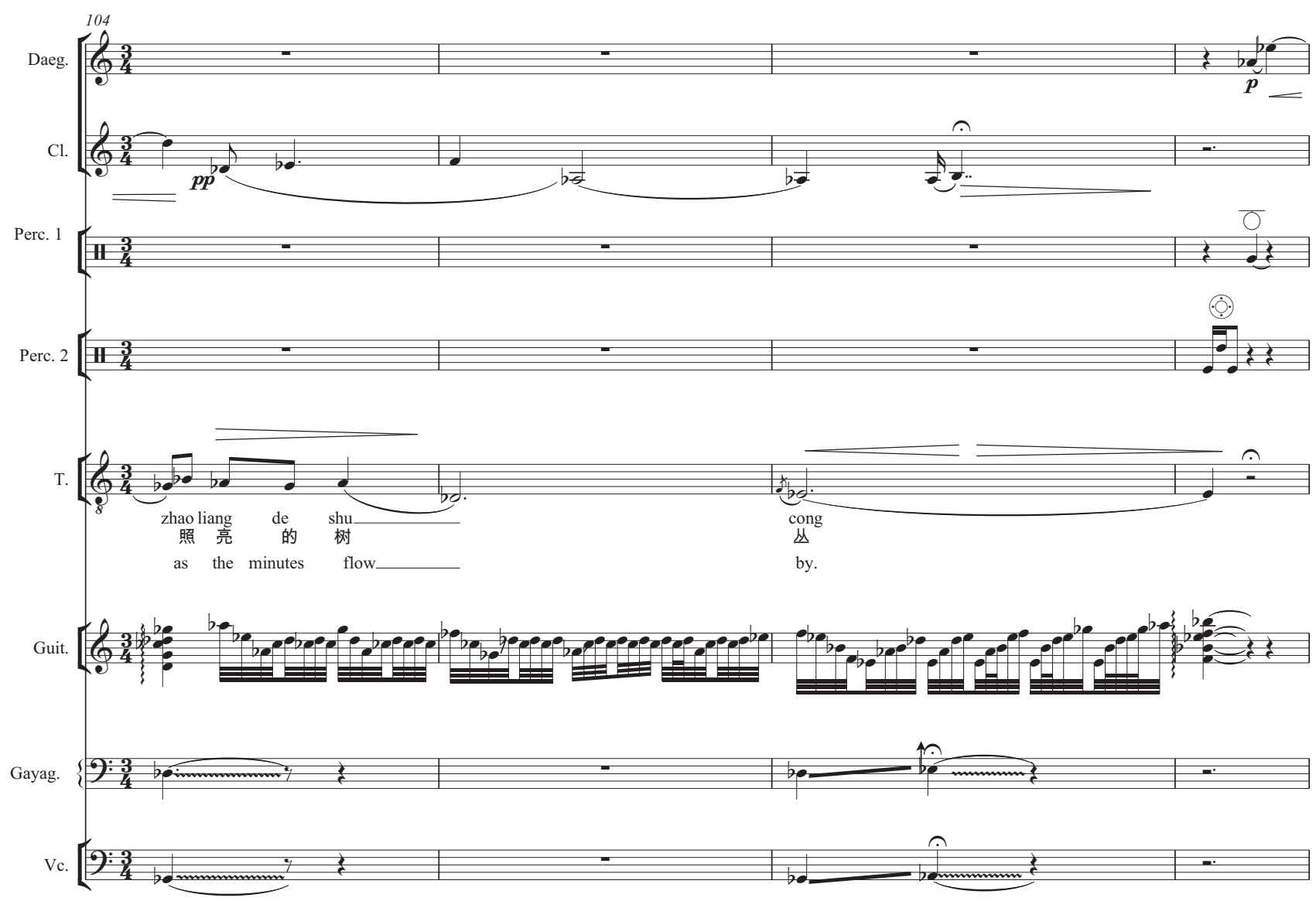

[Lei Mi enters the stage from the bedroom

and dashes towards the curtain to Yinger's bedroom.

In a moment, she has gained control of herself,

and she retreats step by step

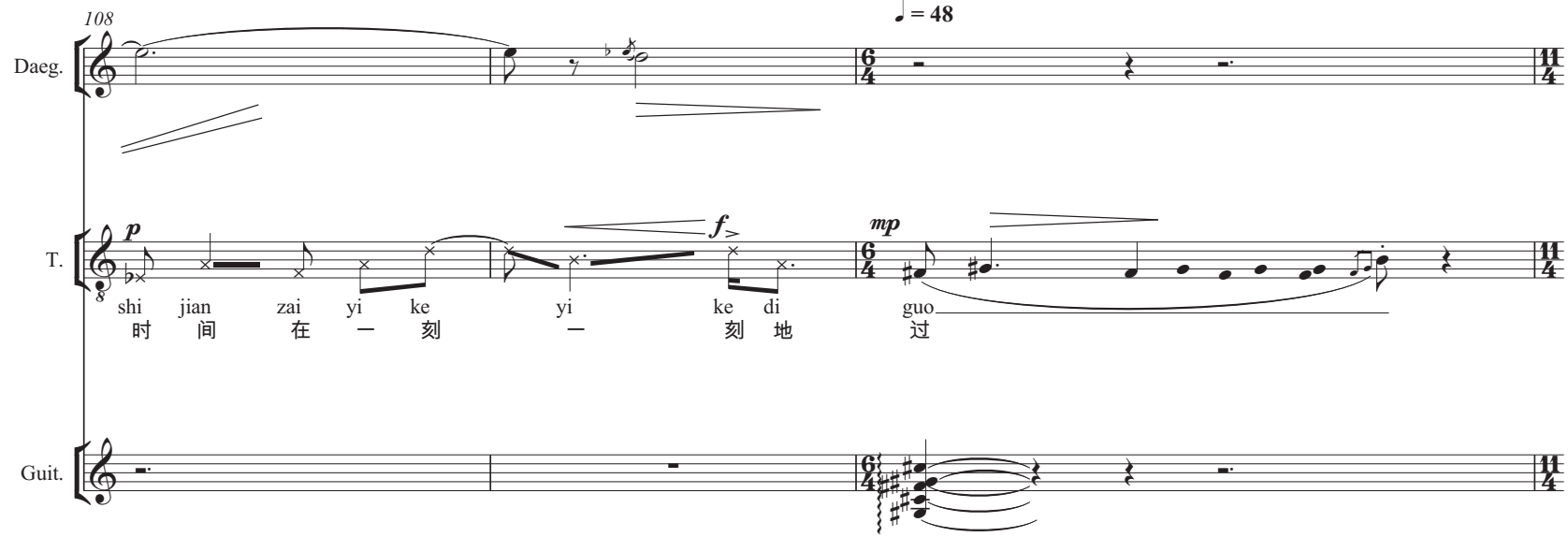




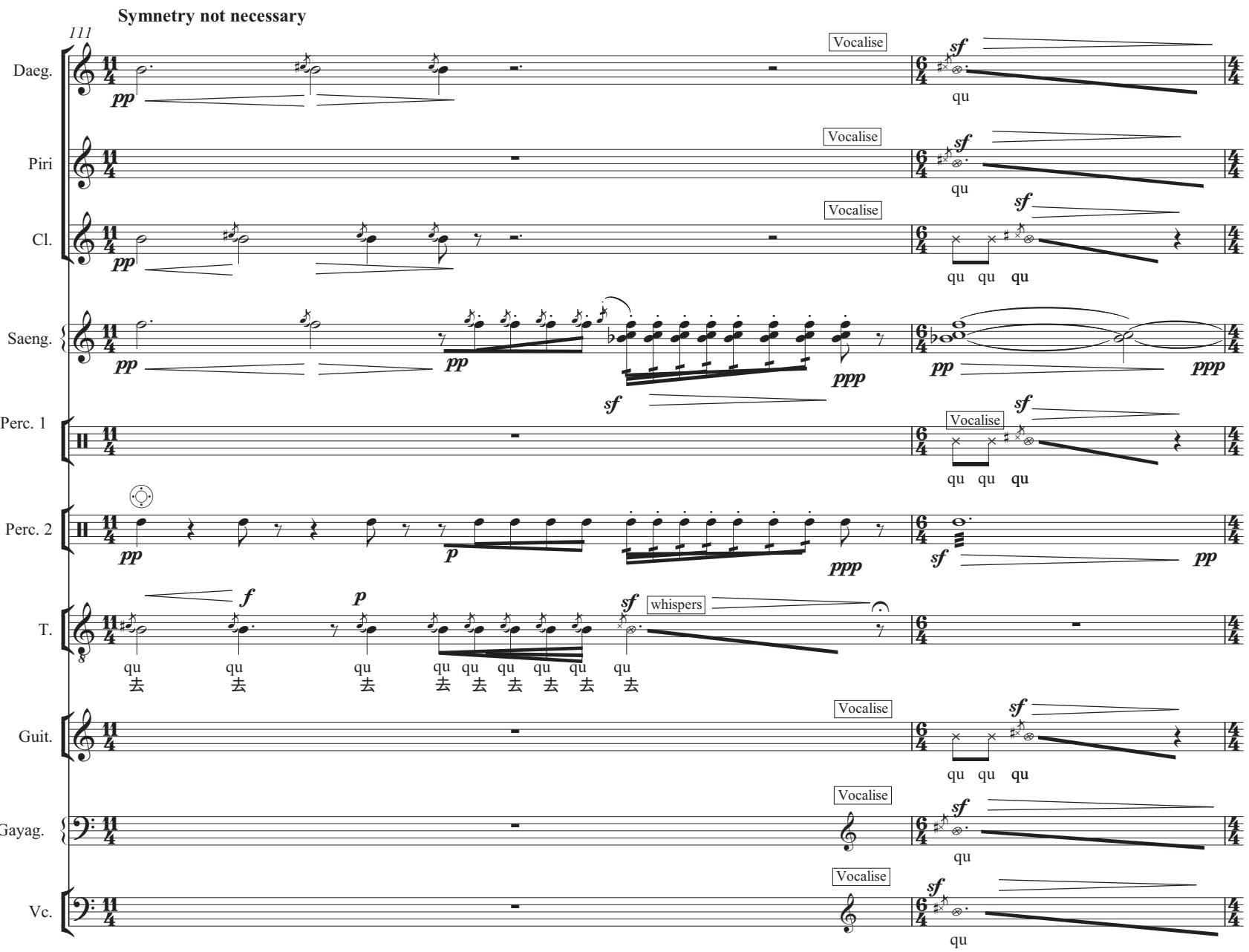

[Lighting: Gradually the bedroom becomes lighter.

[Cheng gently approaches her bed

and gazes at her reclining figure]
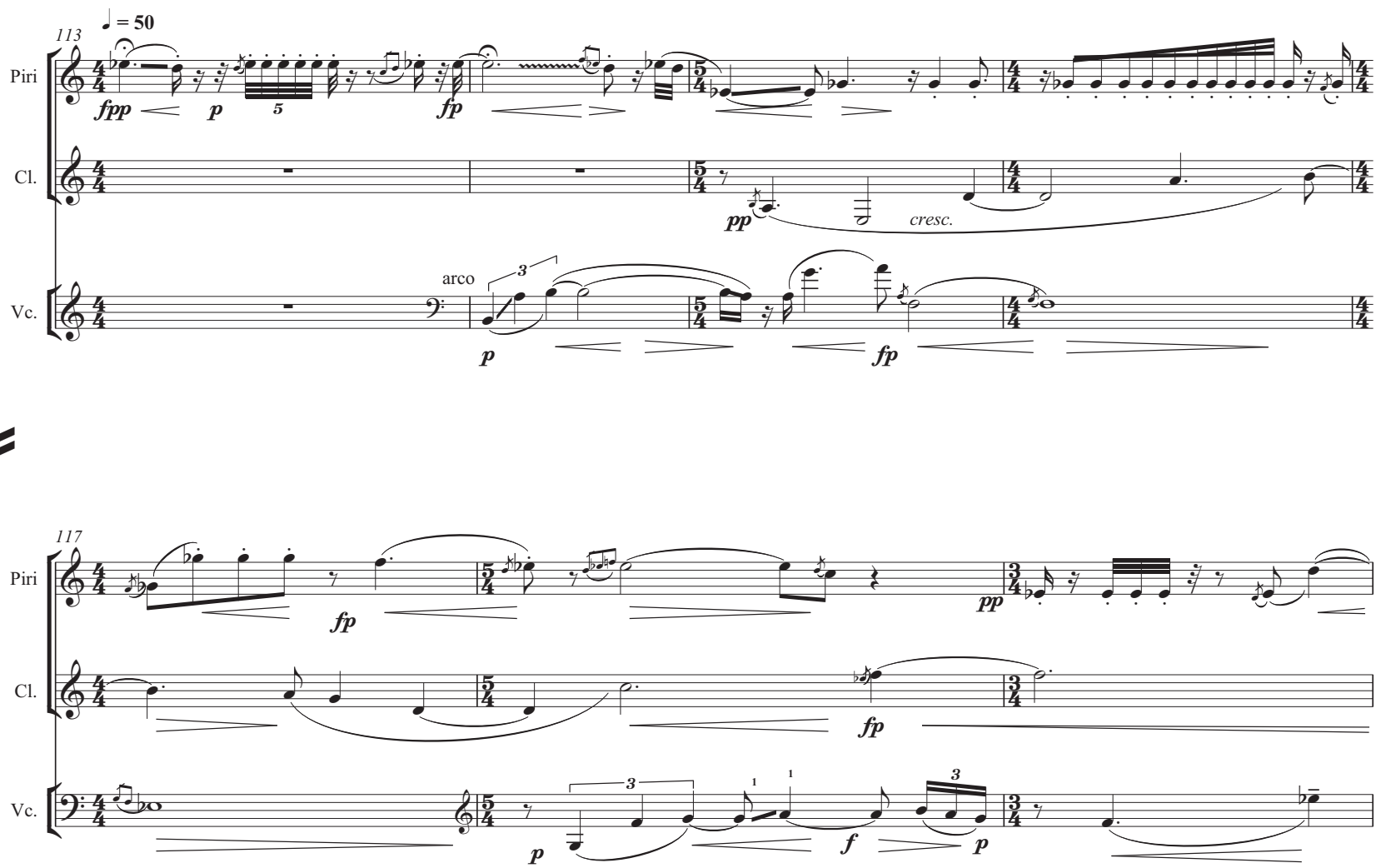

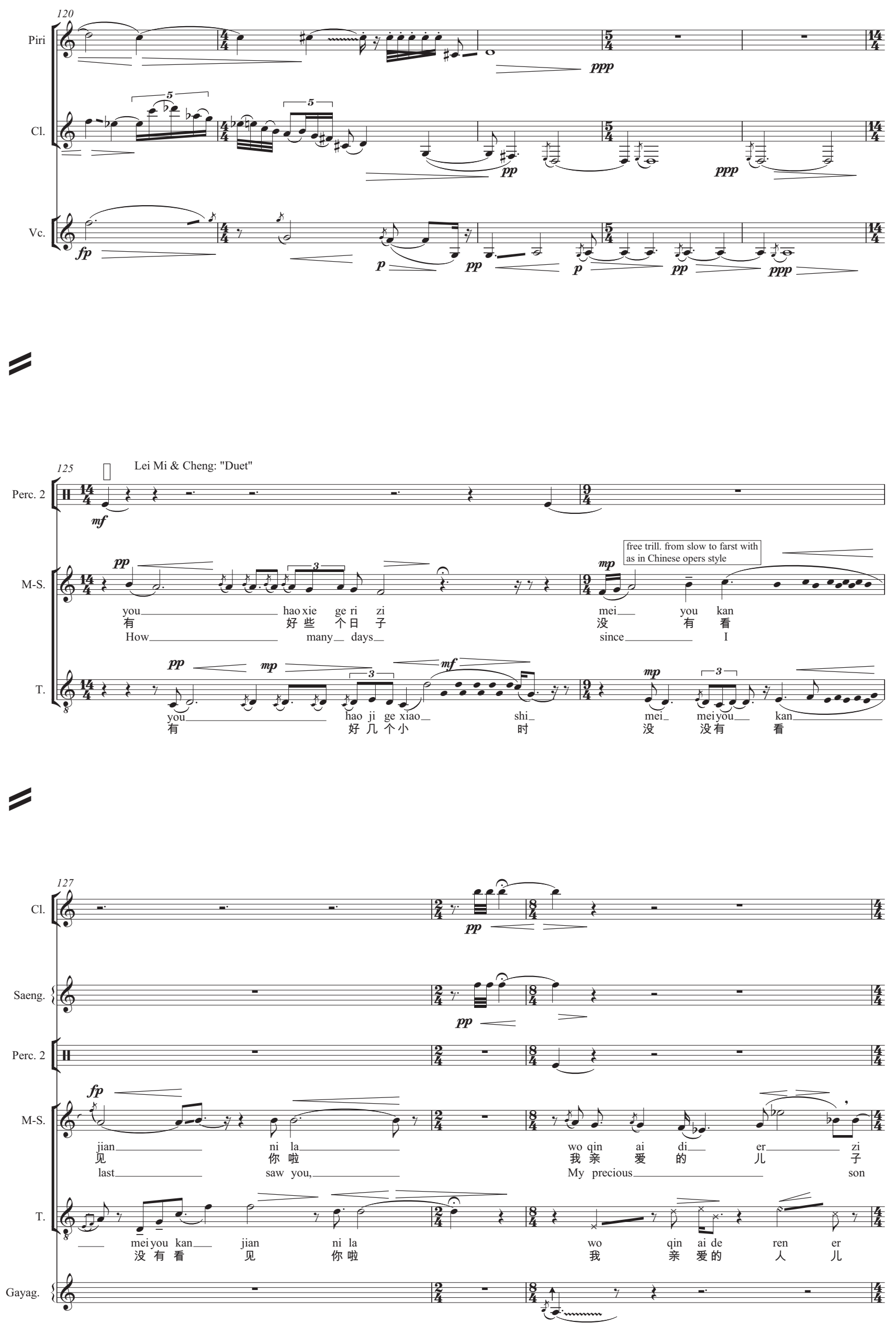


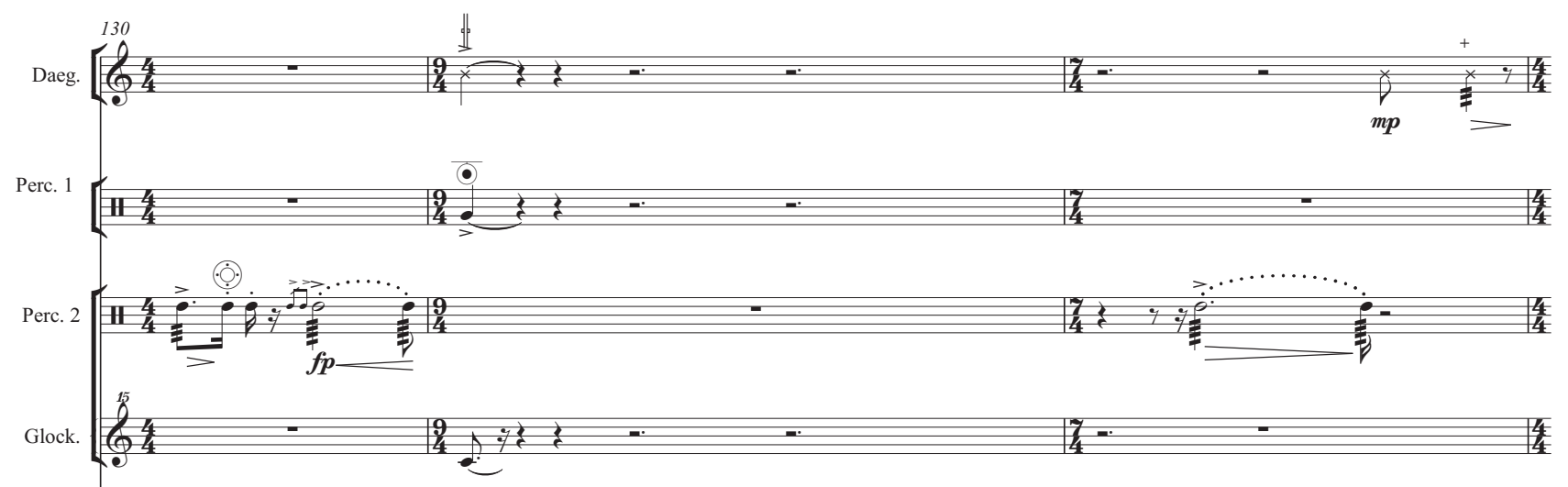

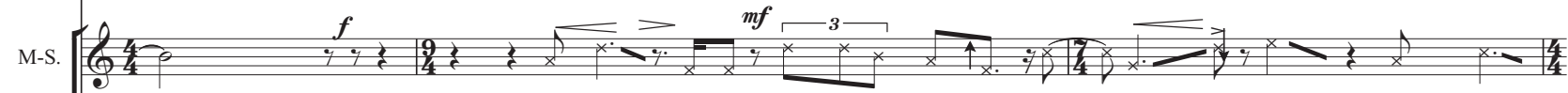

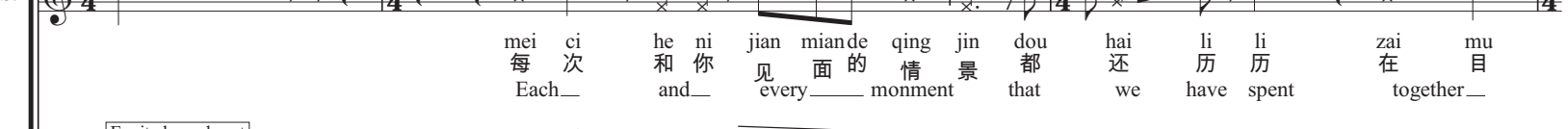

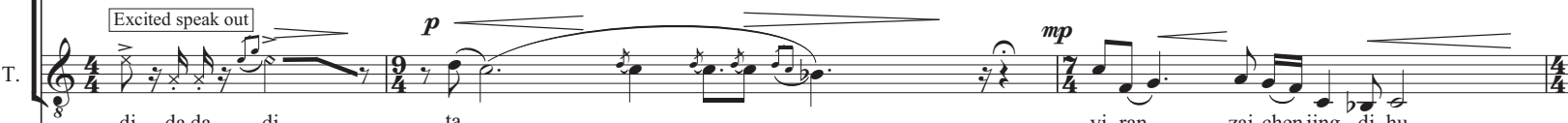

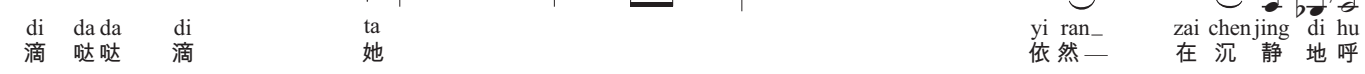

$\mathrm{Vc}$.

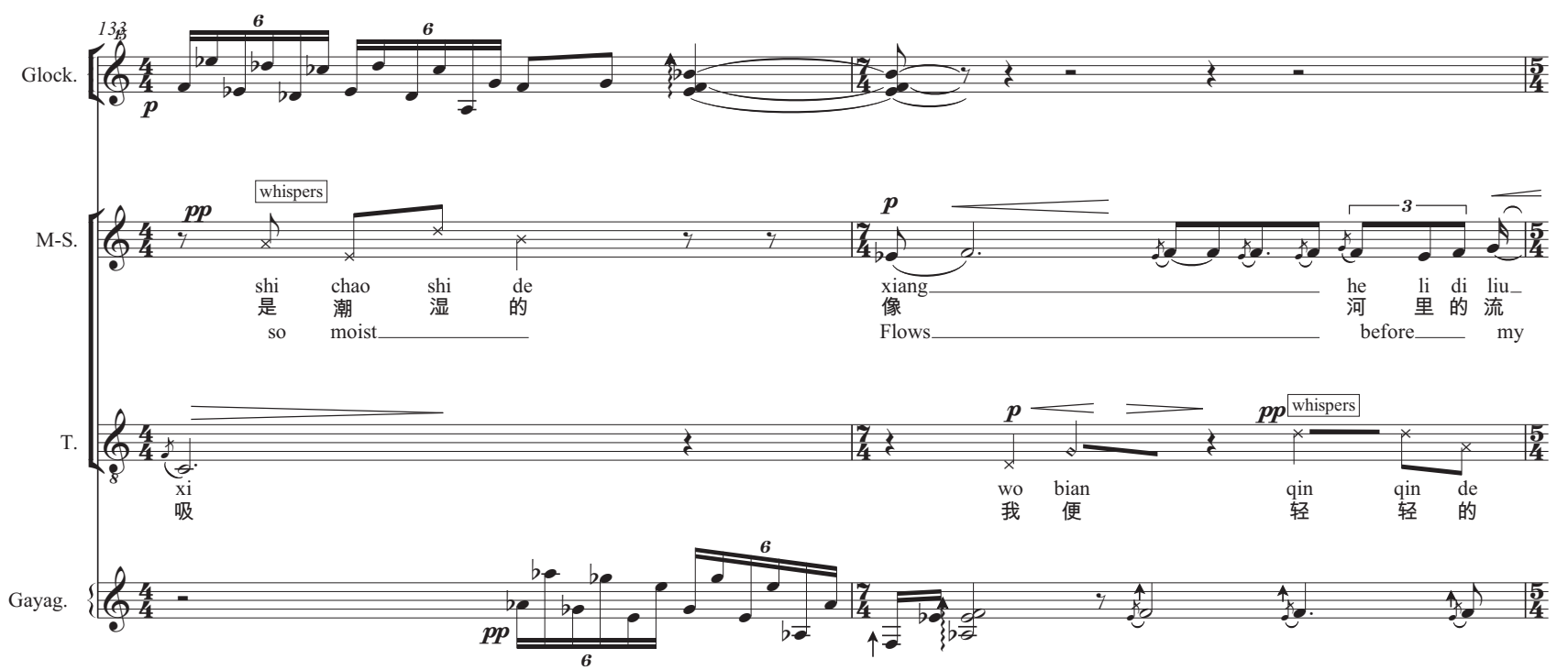



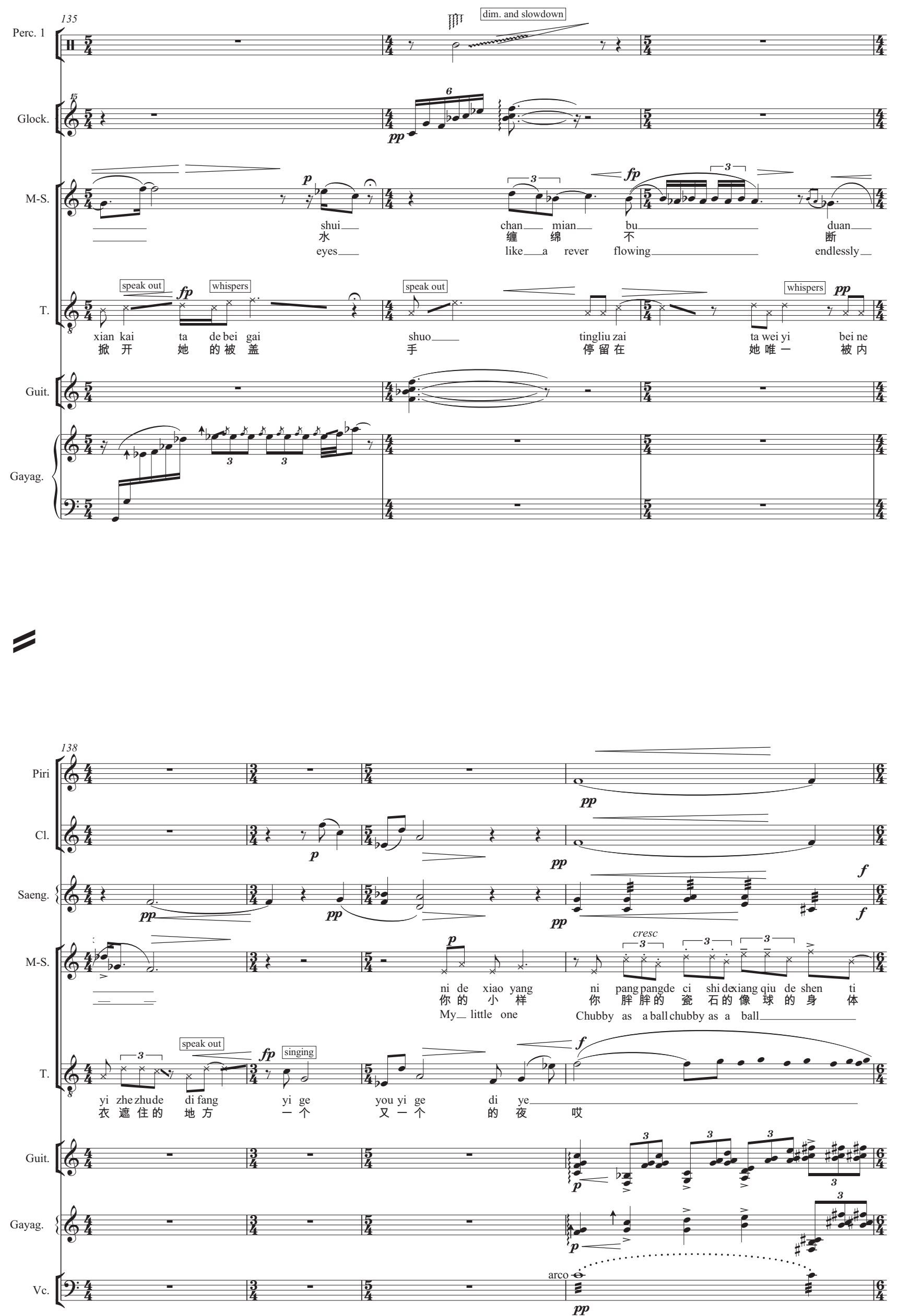


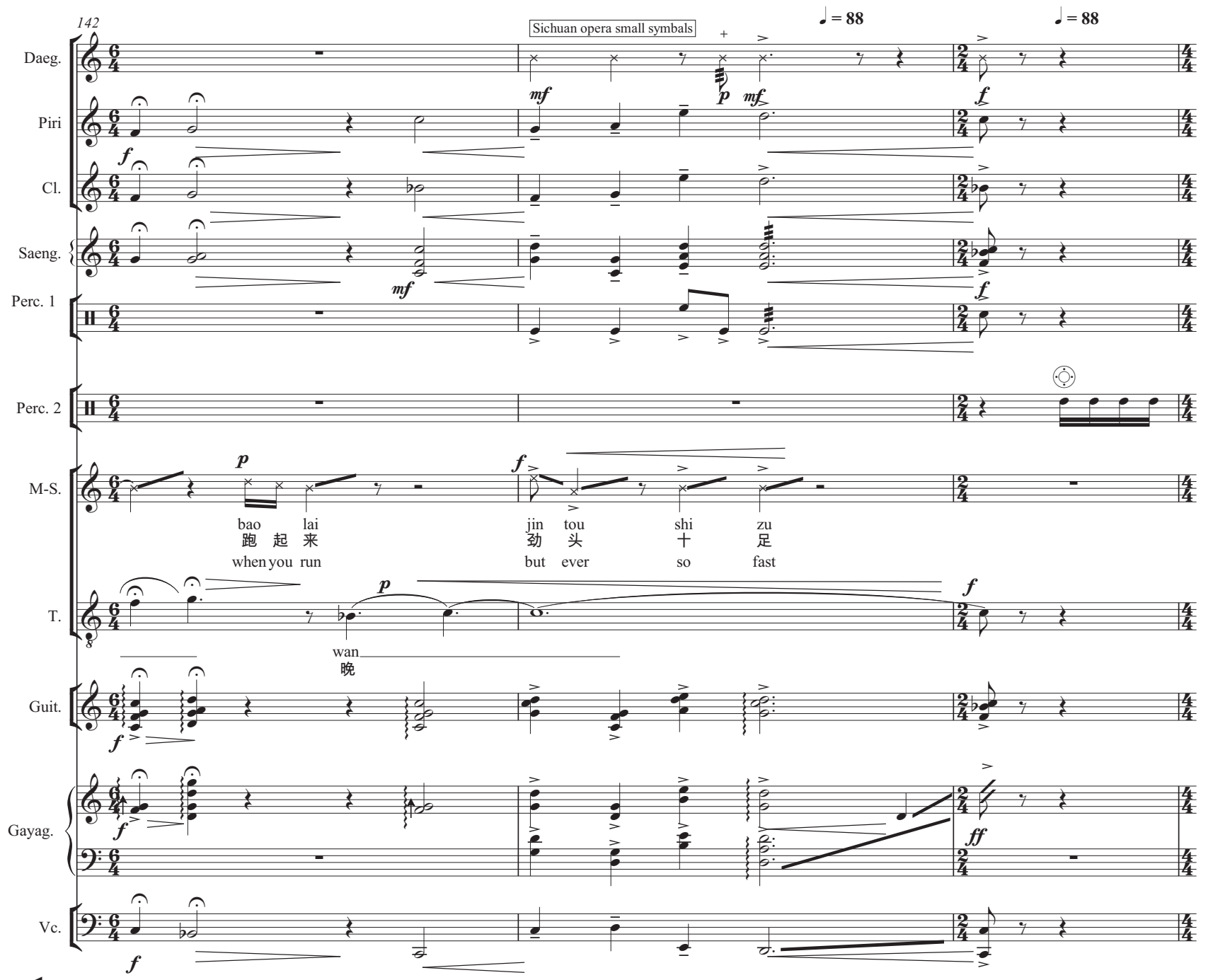

Daeg. $(2)$ Perc. 1 Perc. $2[114 \geq \geq \geq \cdots \cdots$ Glock. 

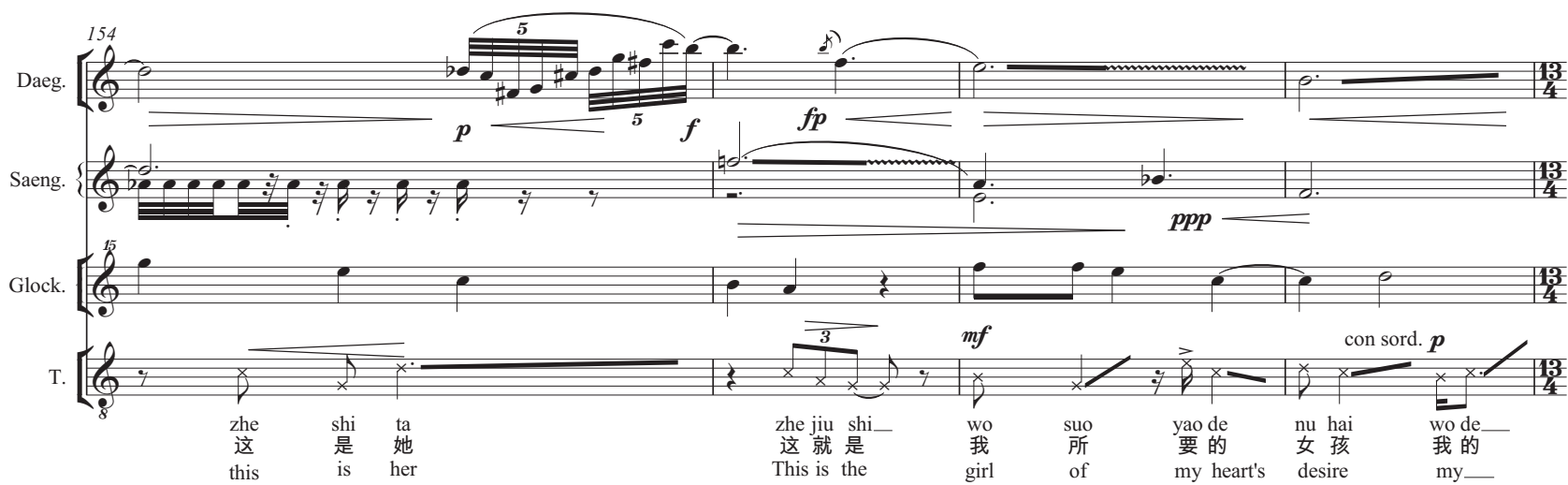

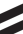

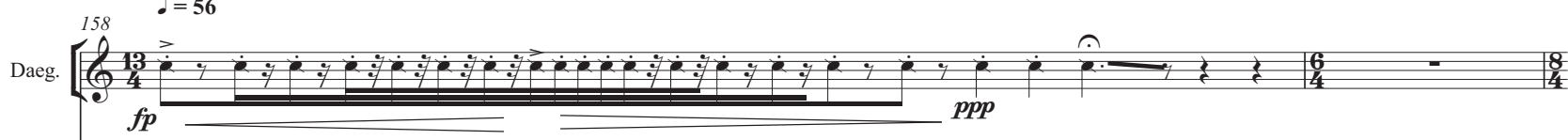

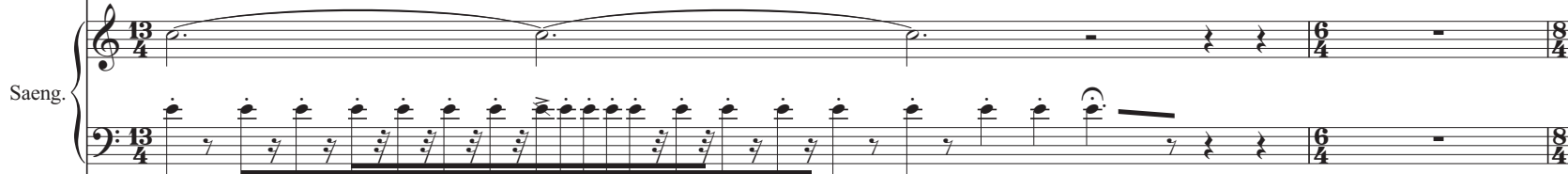

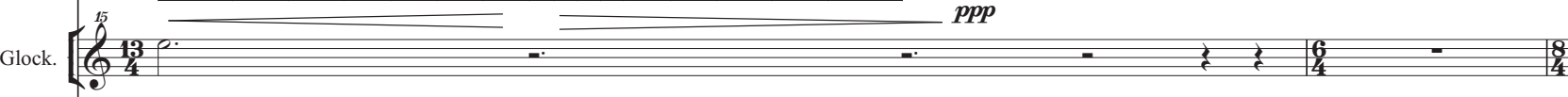

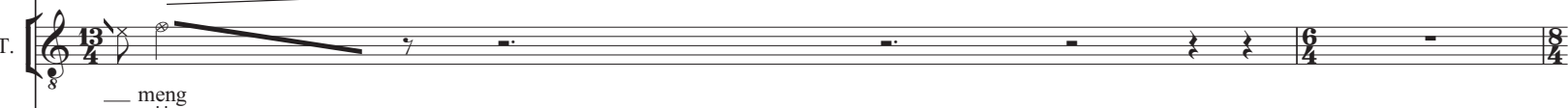
梦

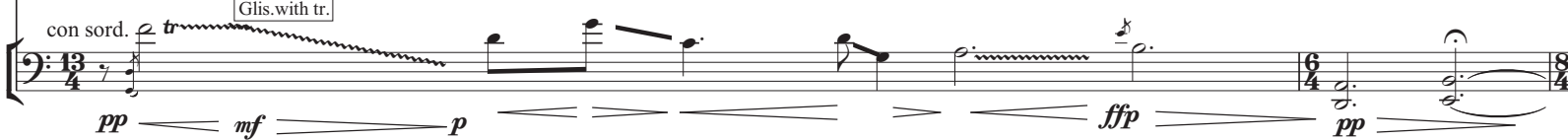

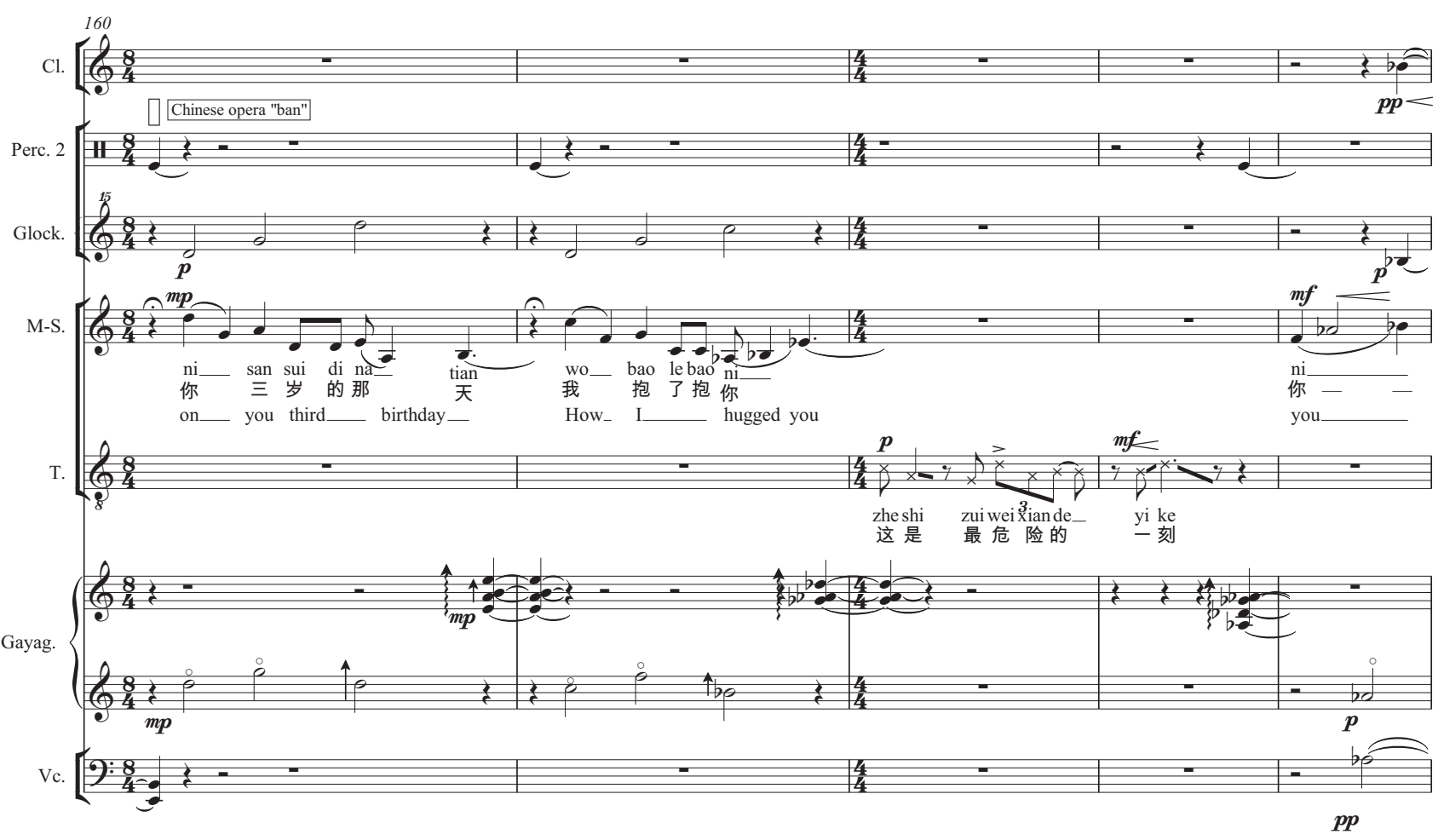


296
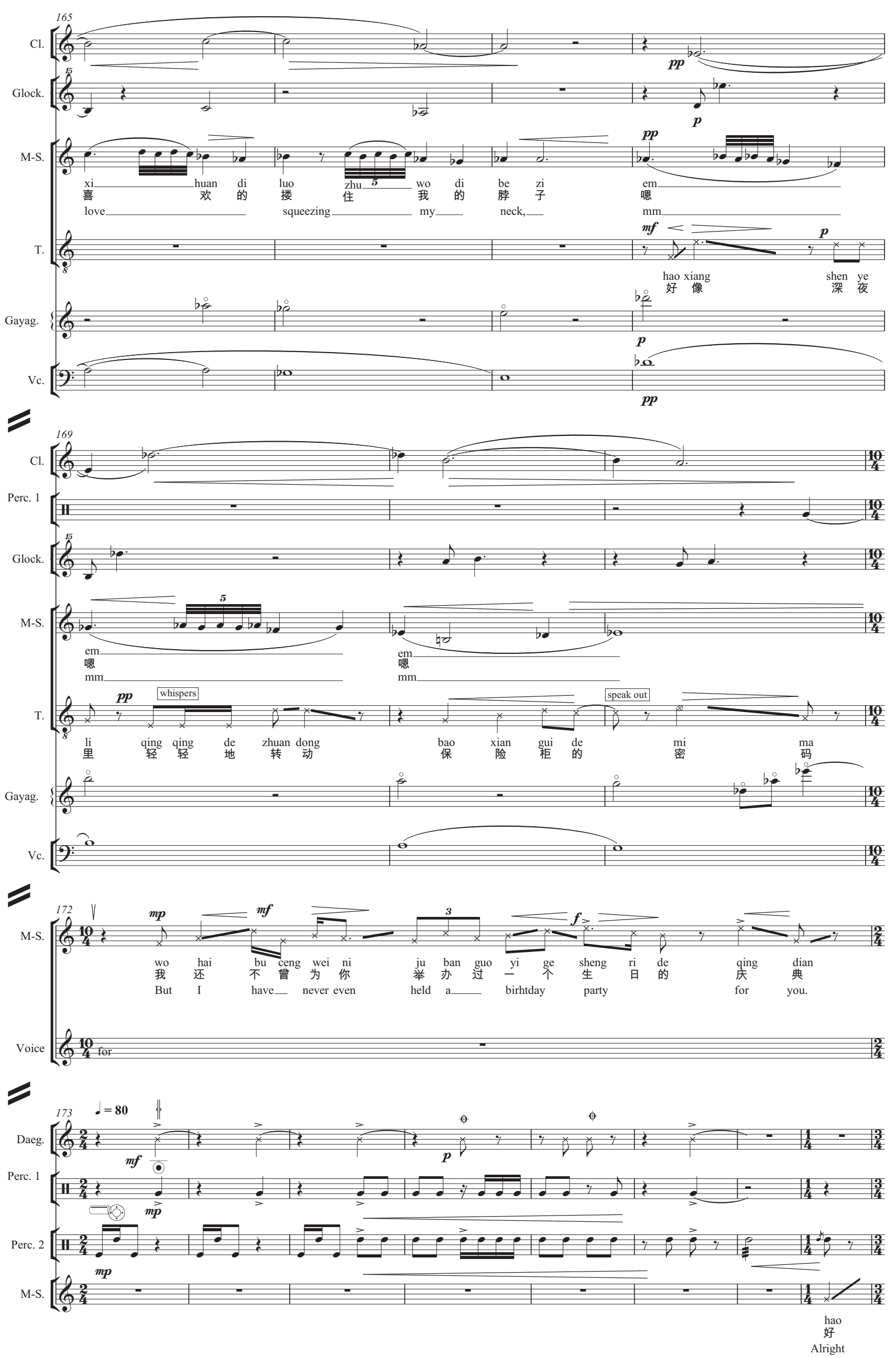
297

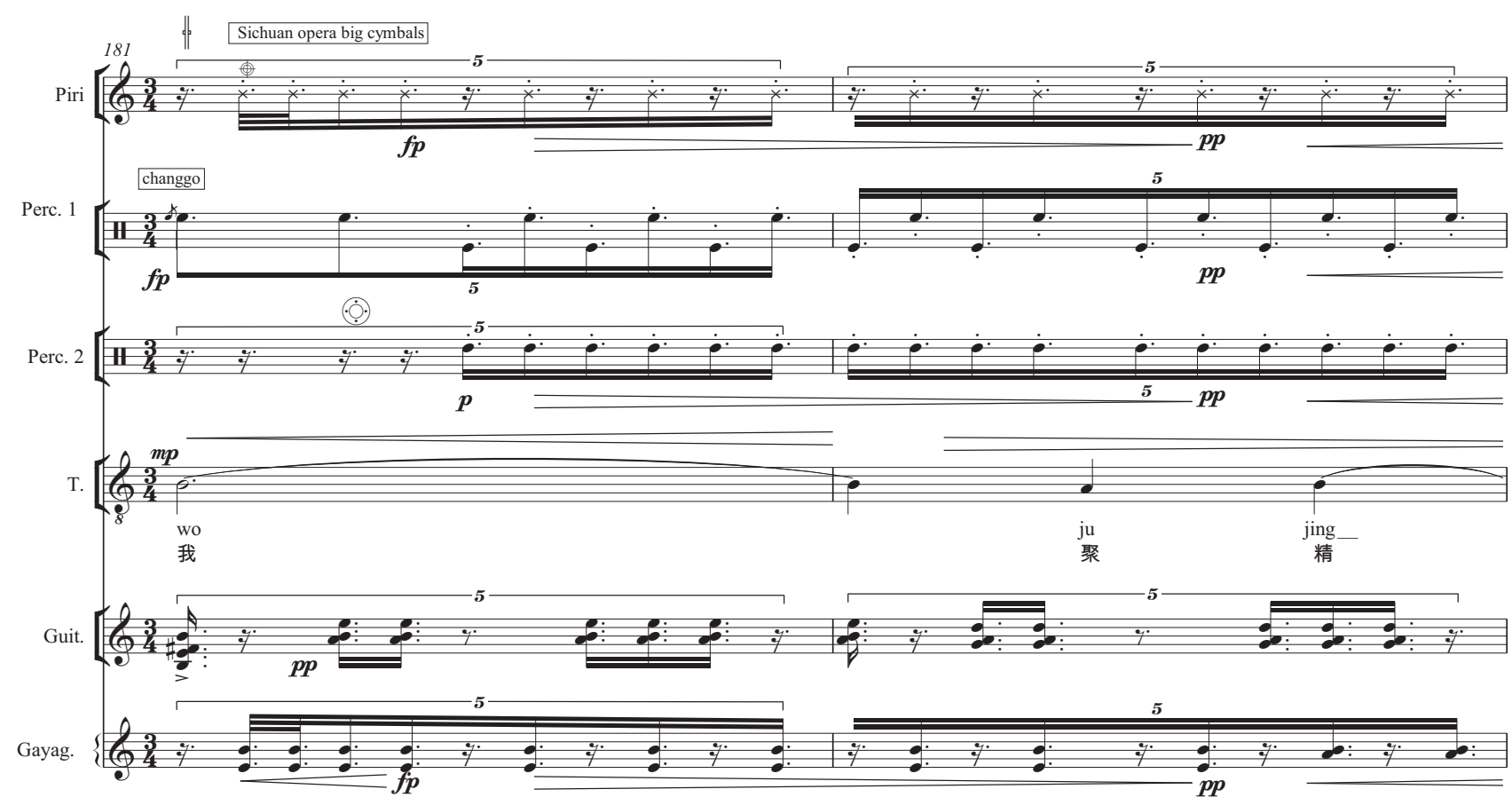

$$
=
$$

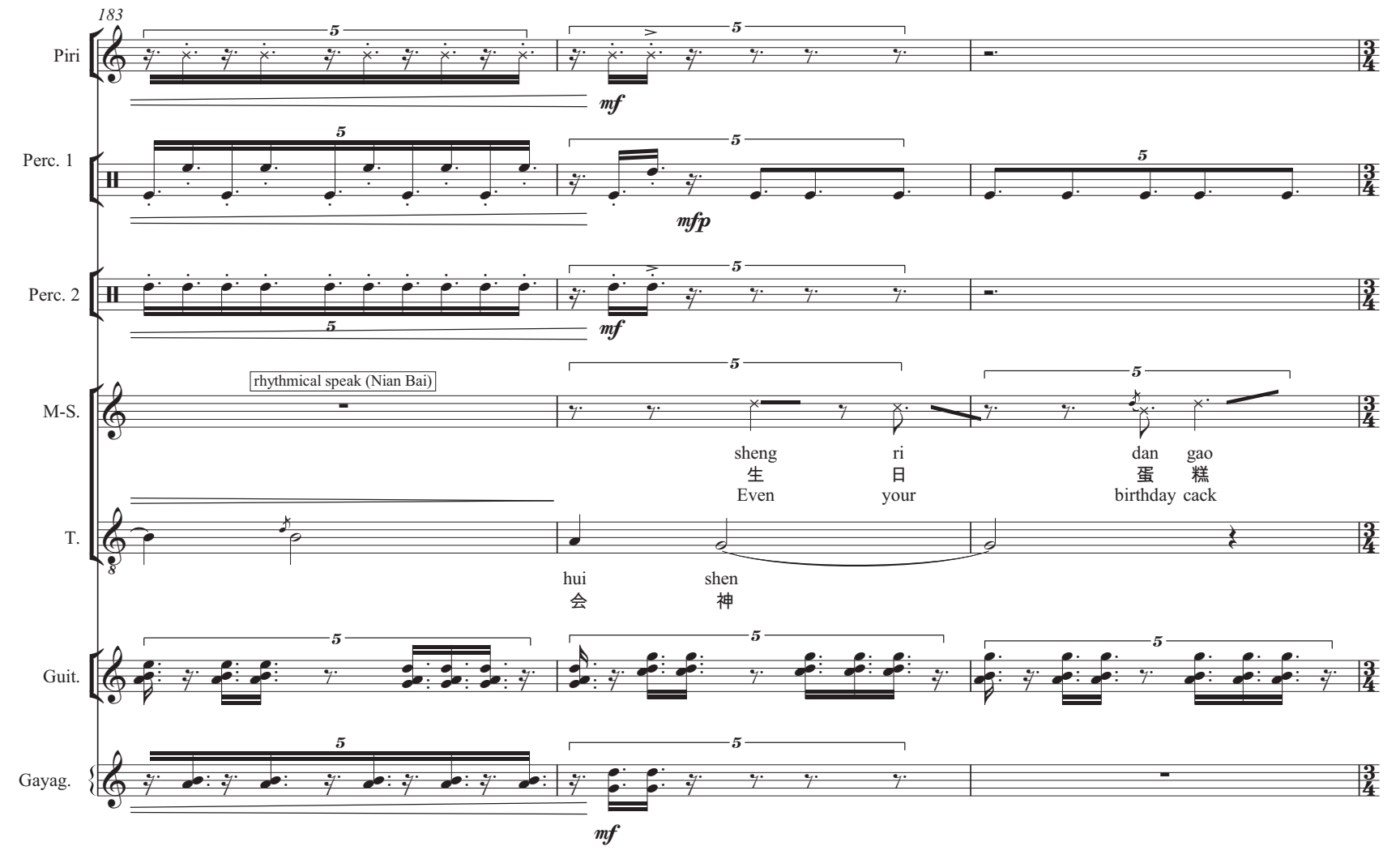




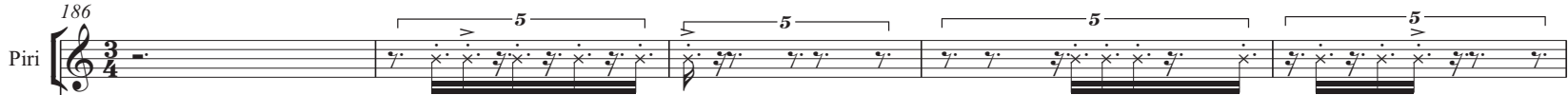

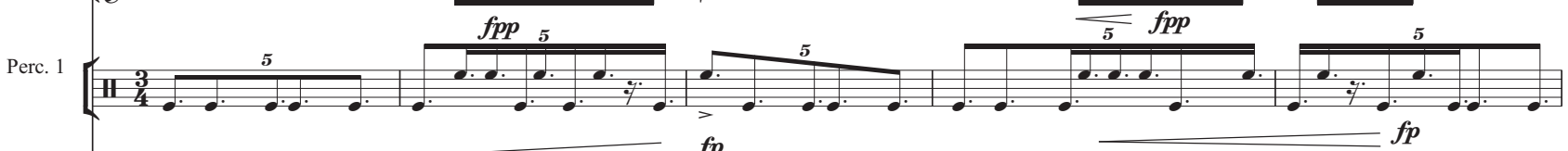

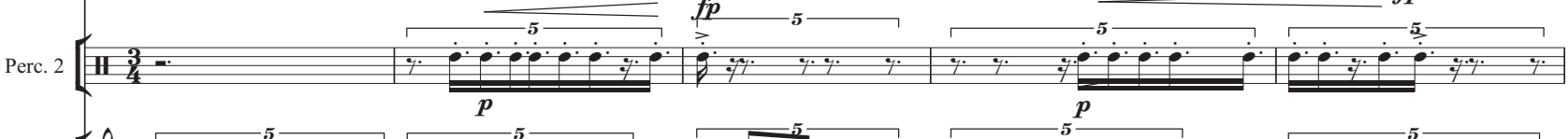

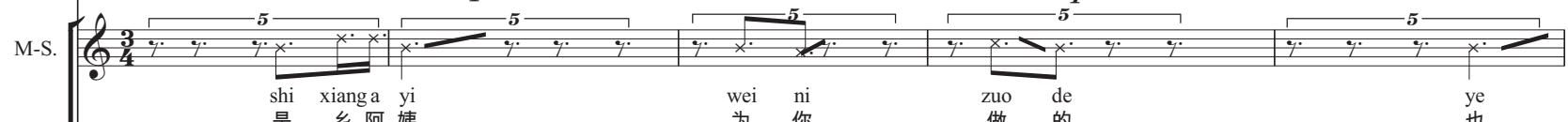

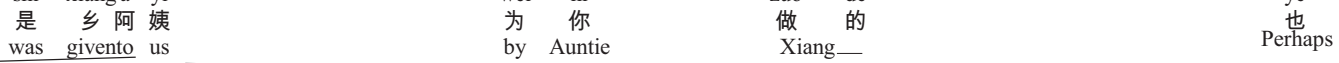

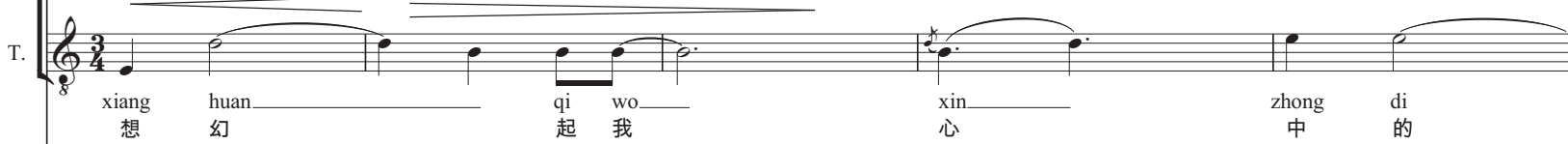

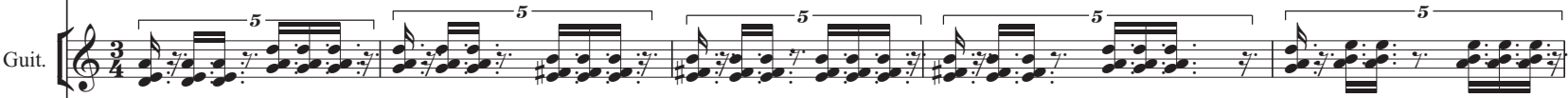

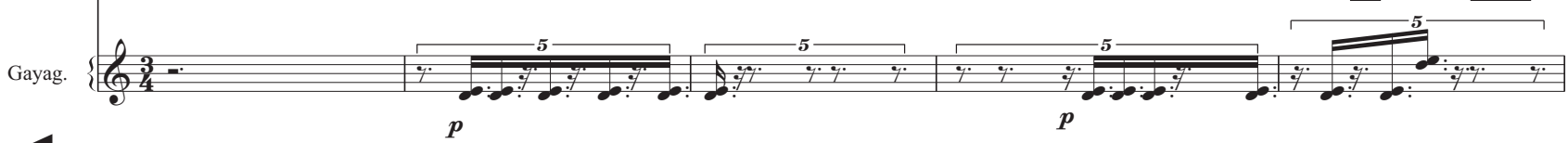

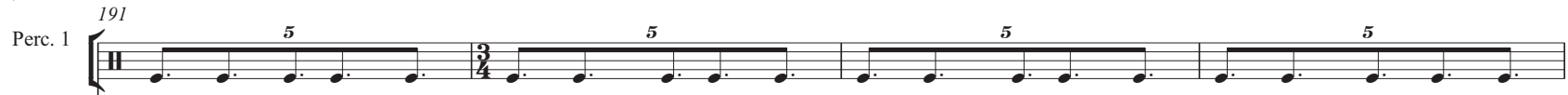

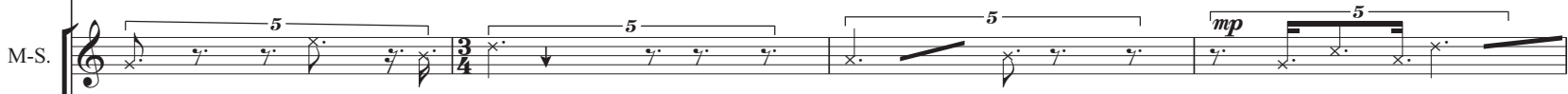

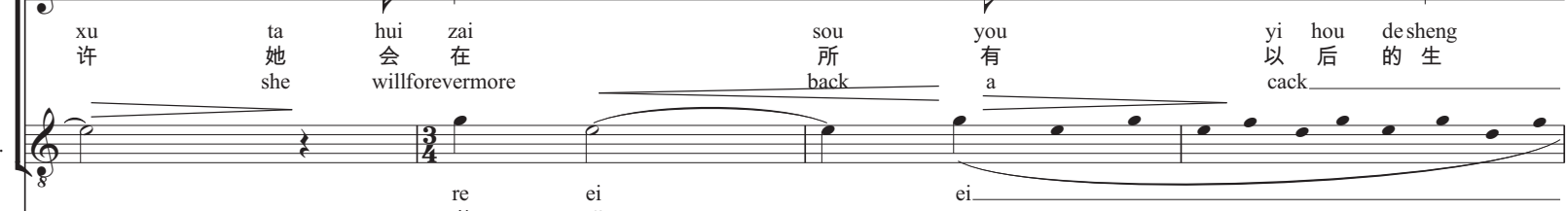

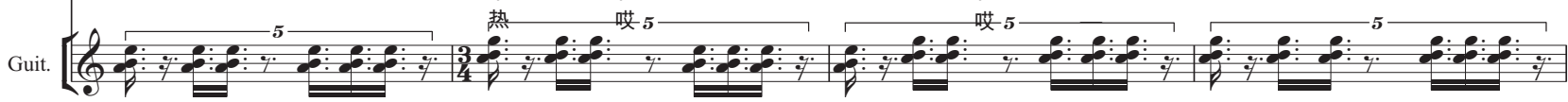
2

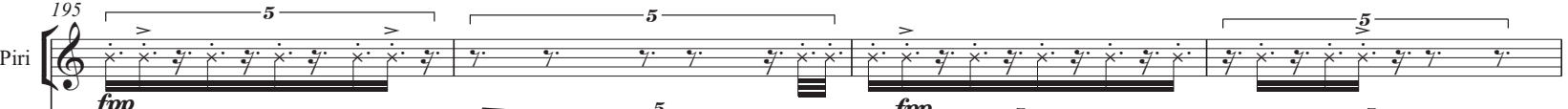

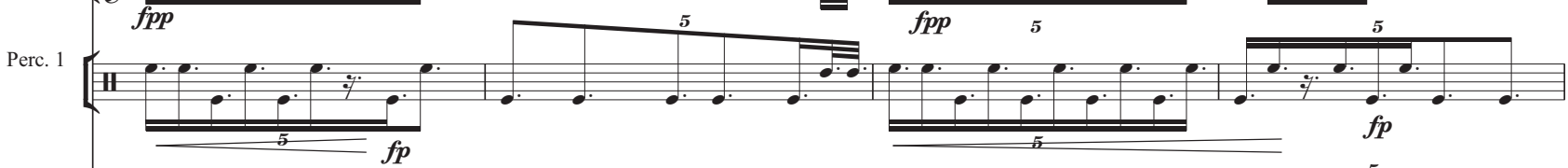

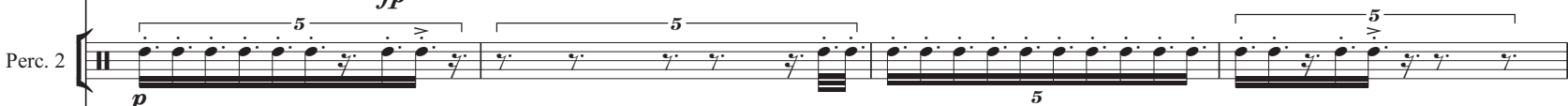

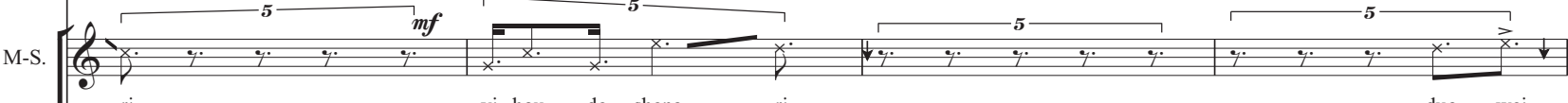
(1) 嗼

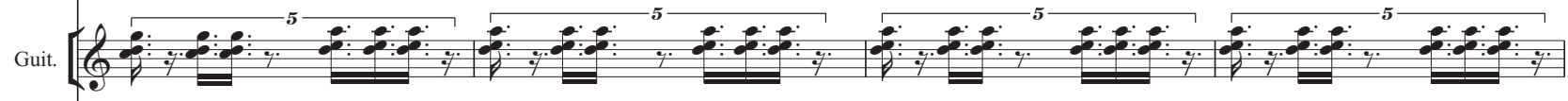

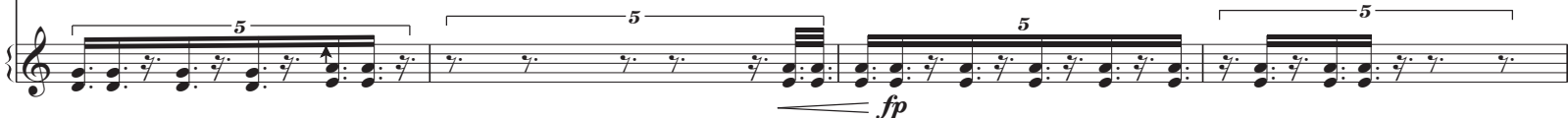


299
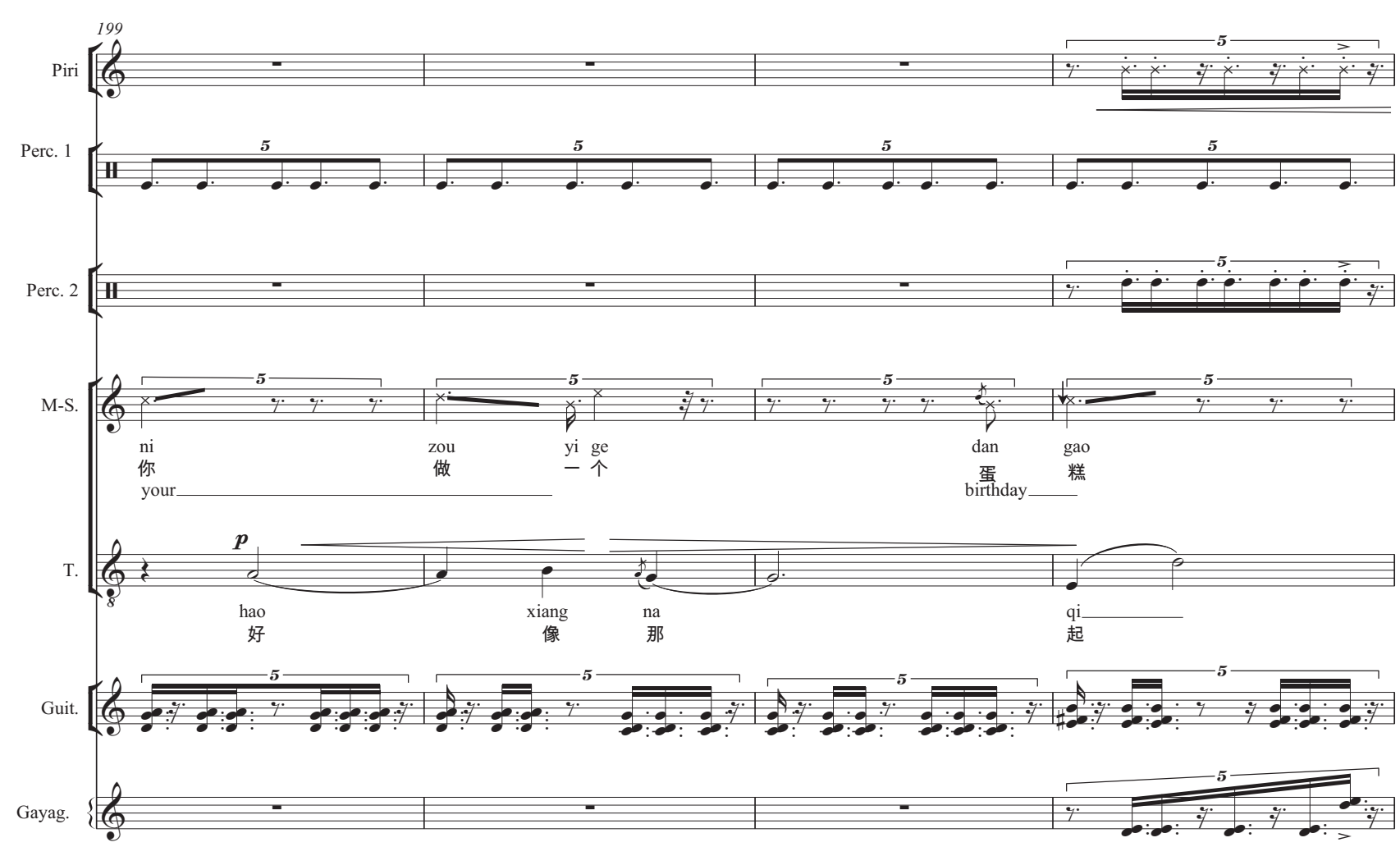

$=$

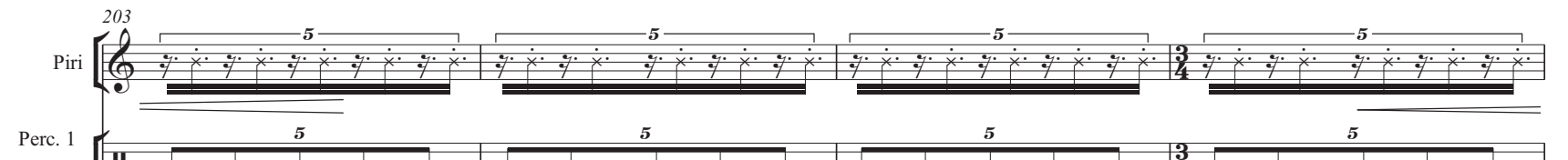

Perc. 1

Perc. 2

T.
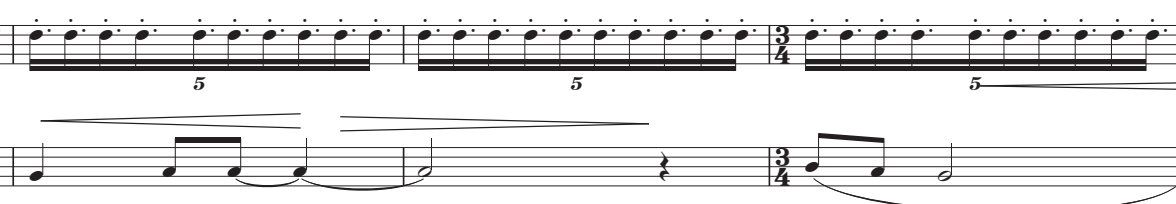

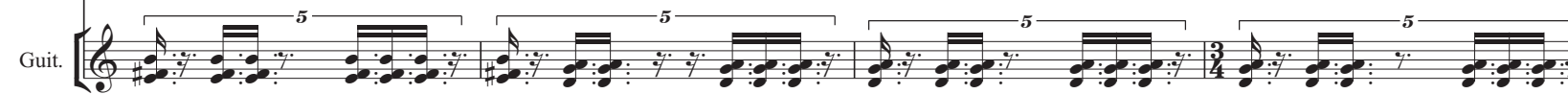

2

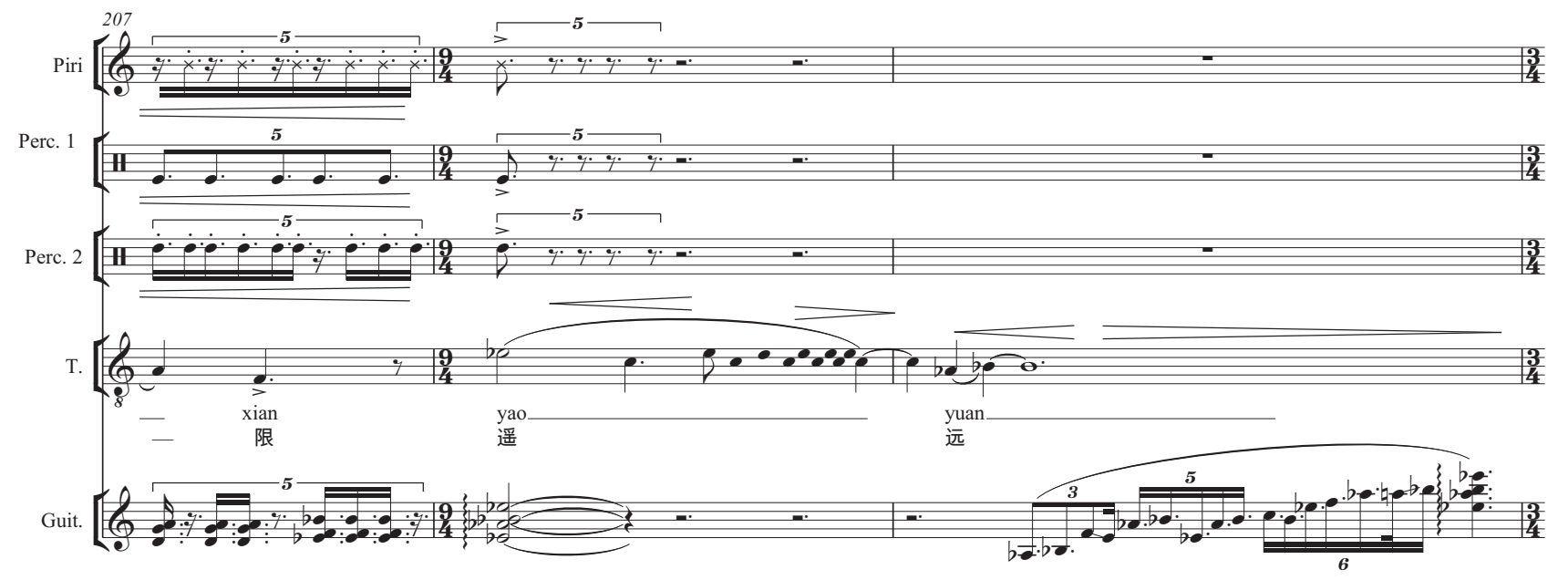



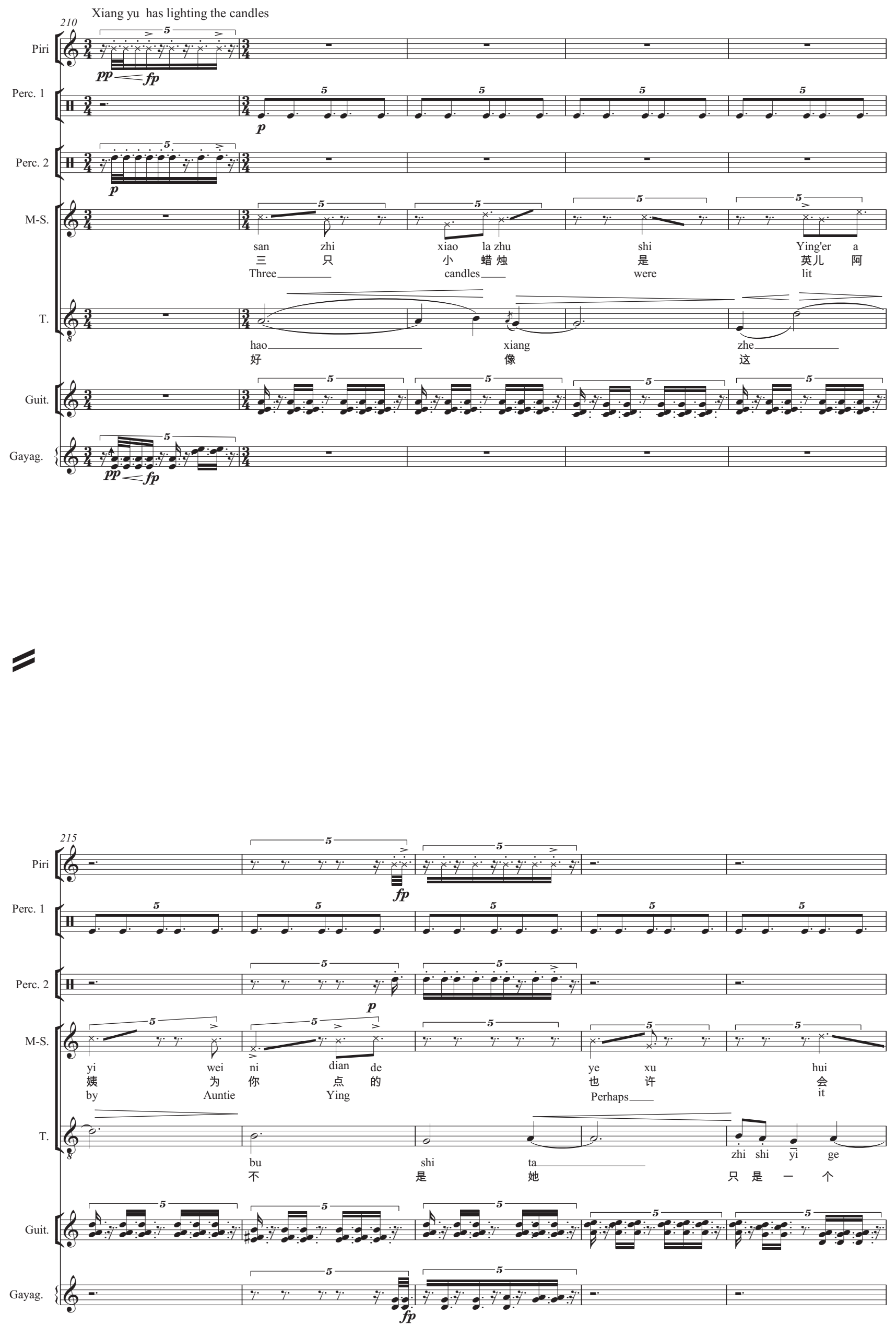
301

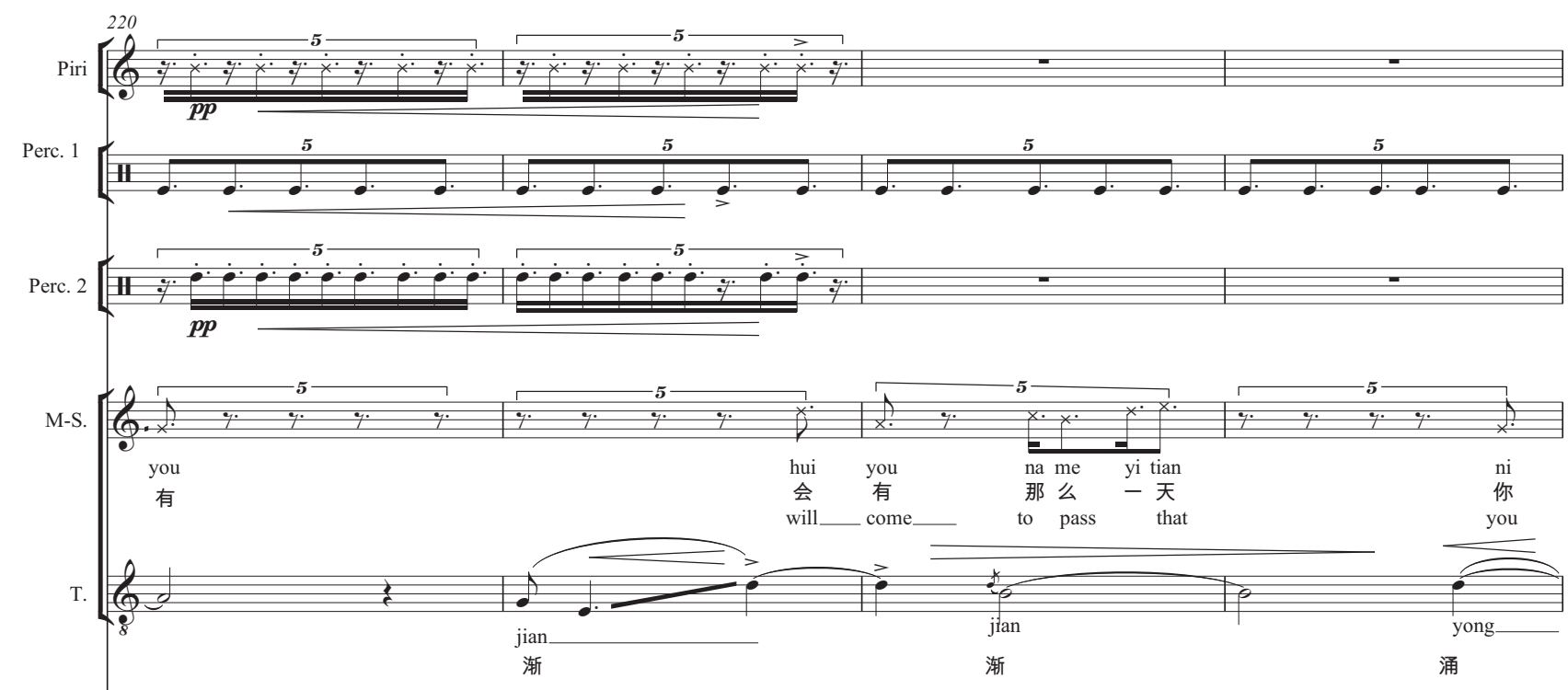

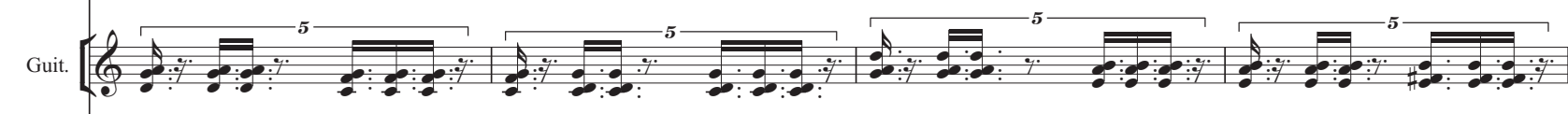

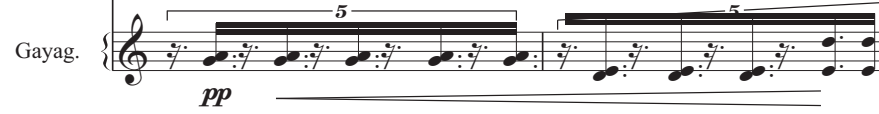

$=$

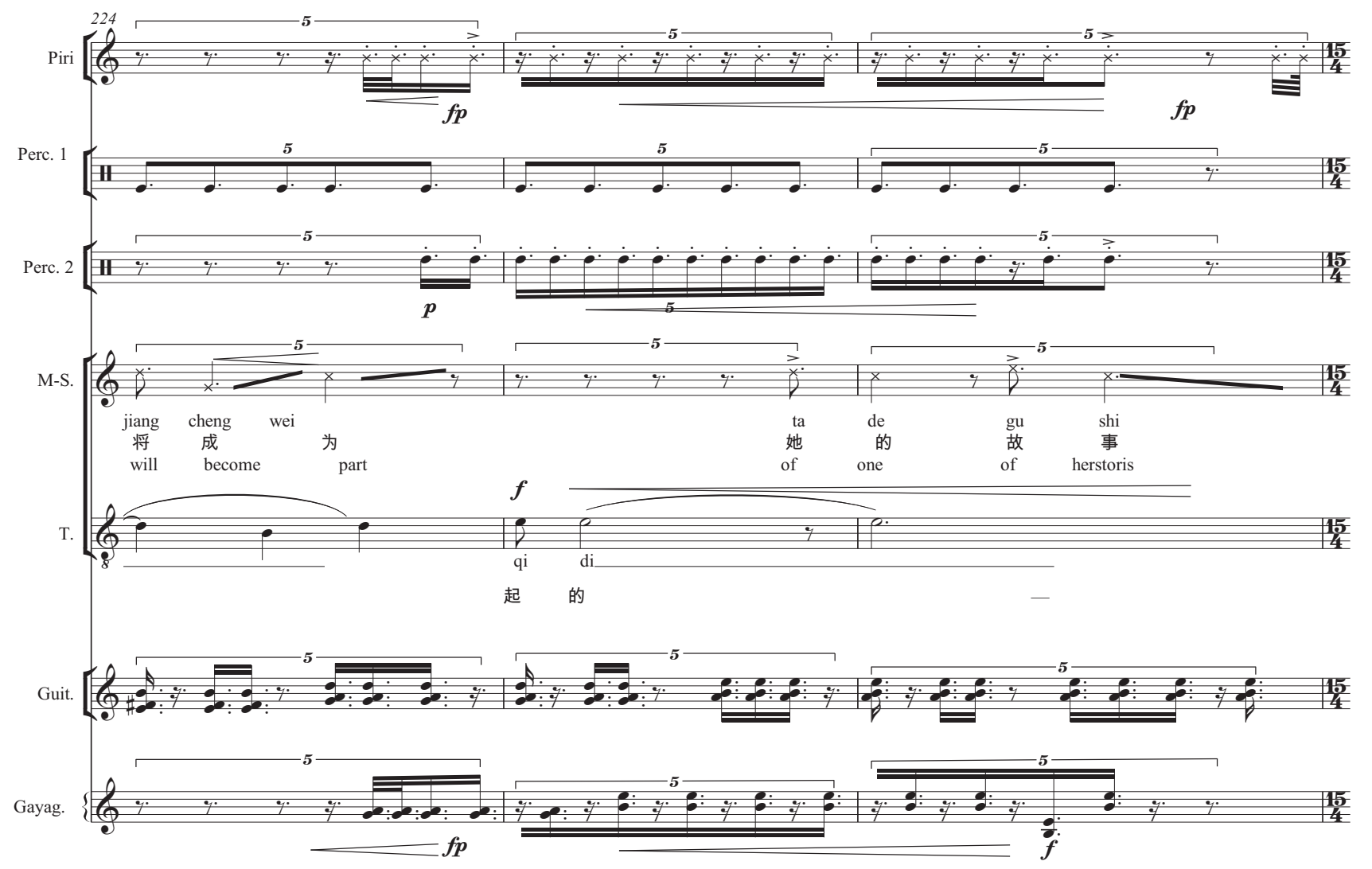



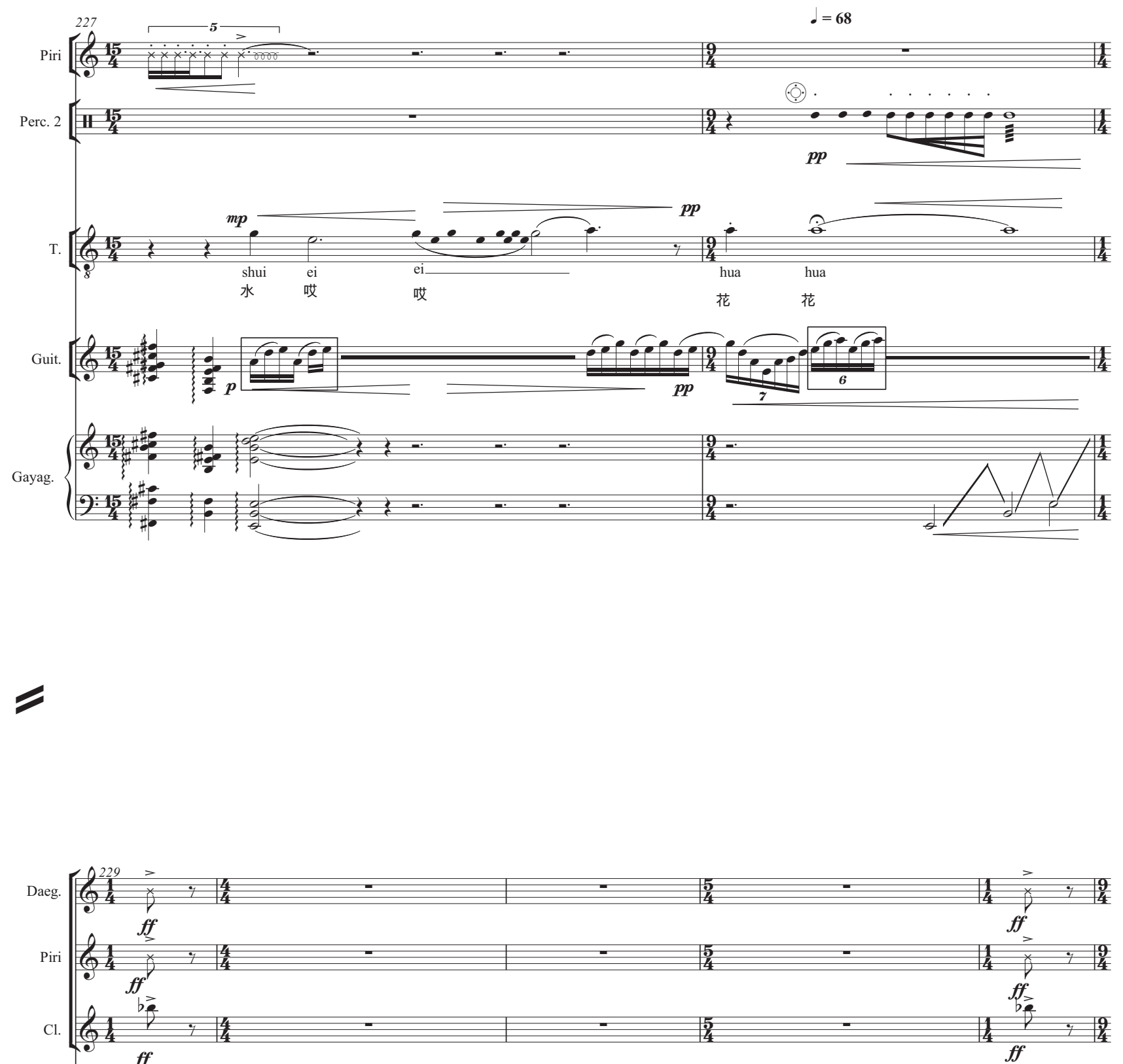

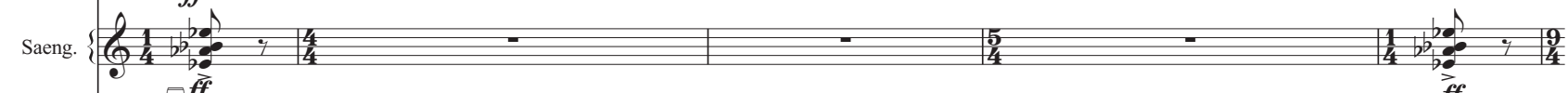

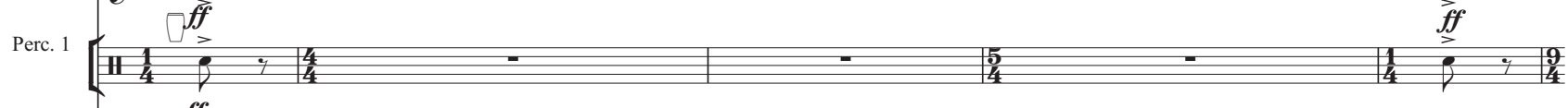

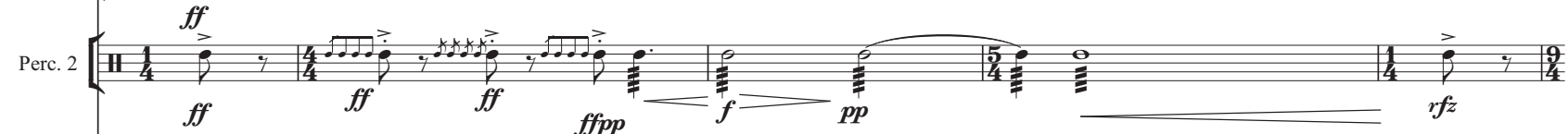

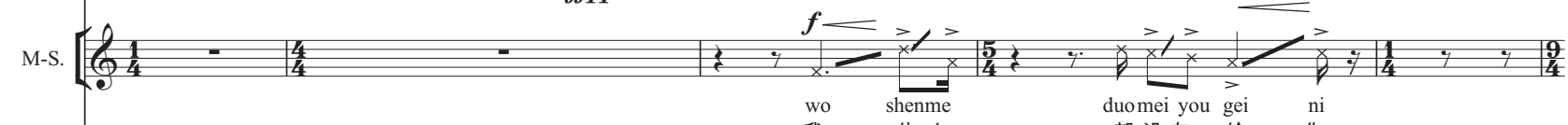

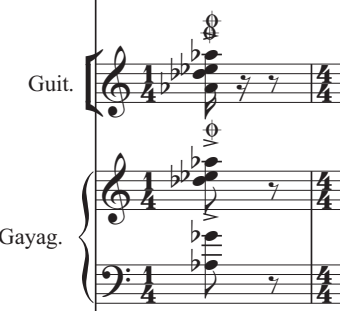

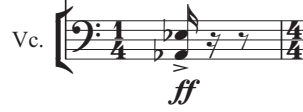

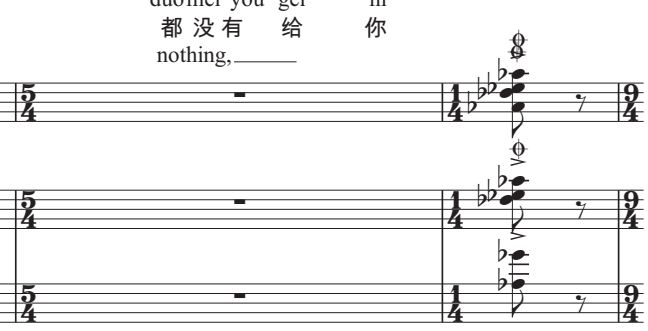



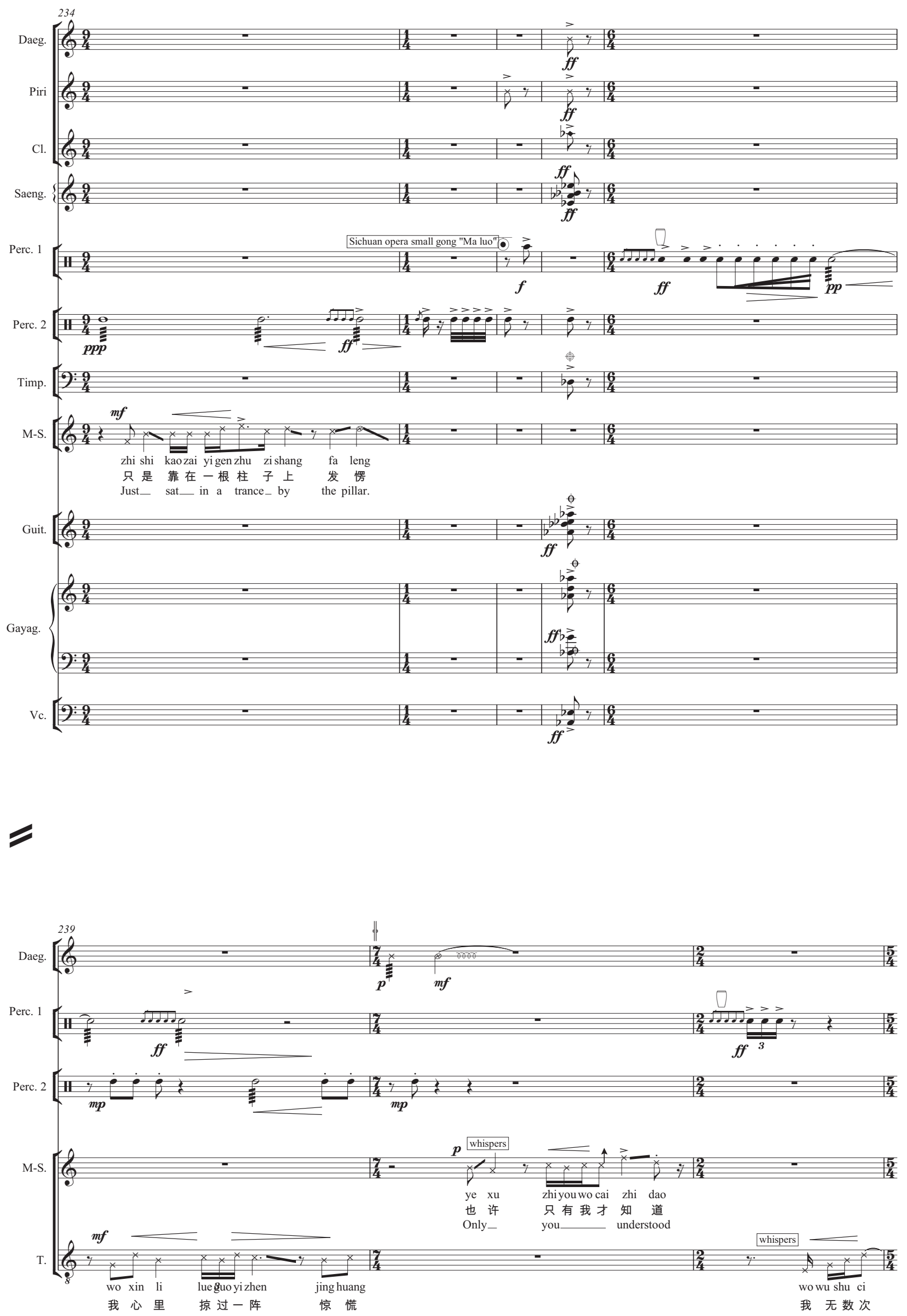

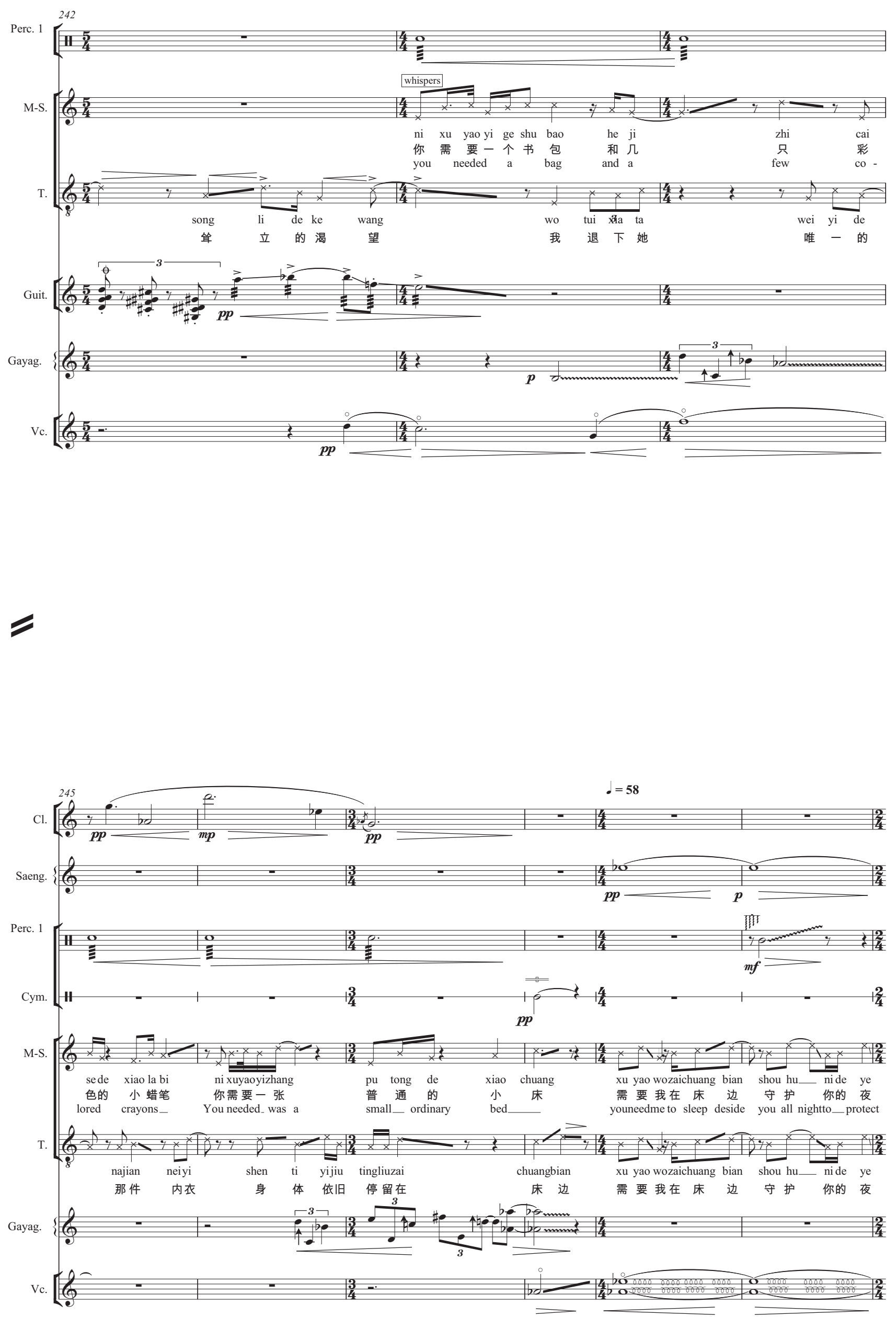

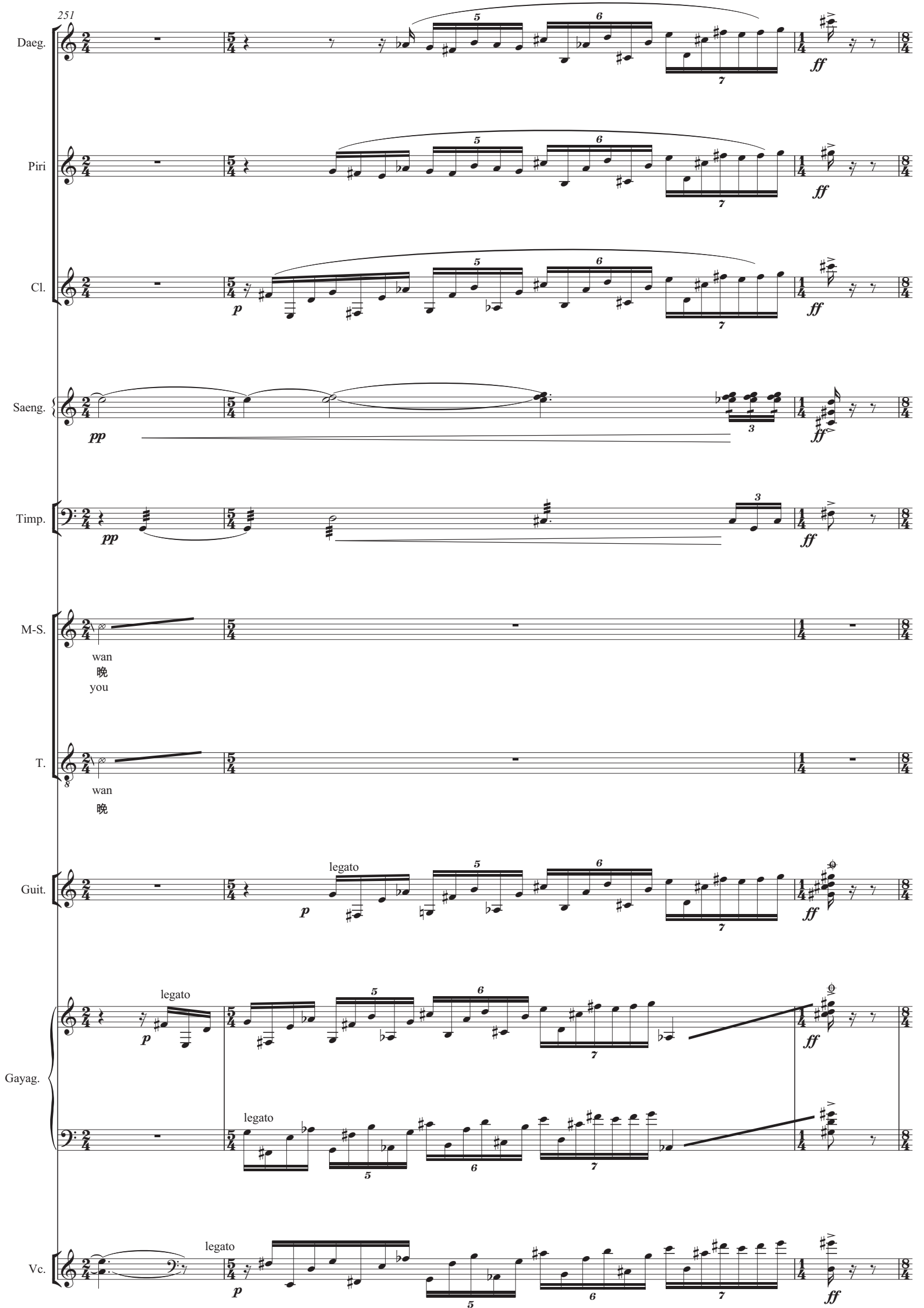

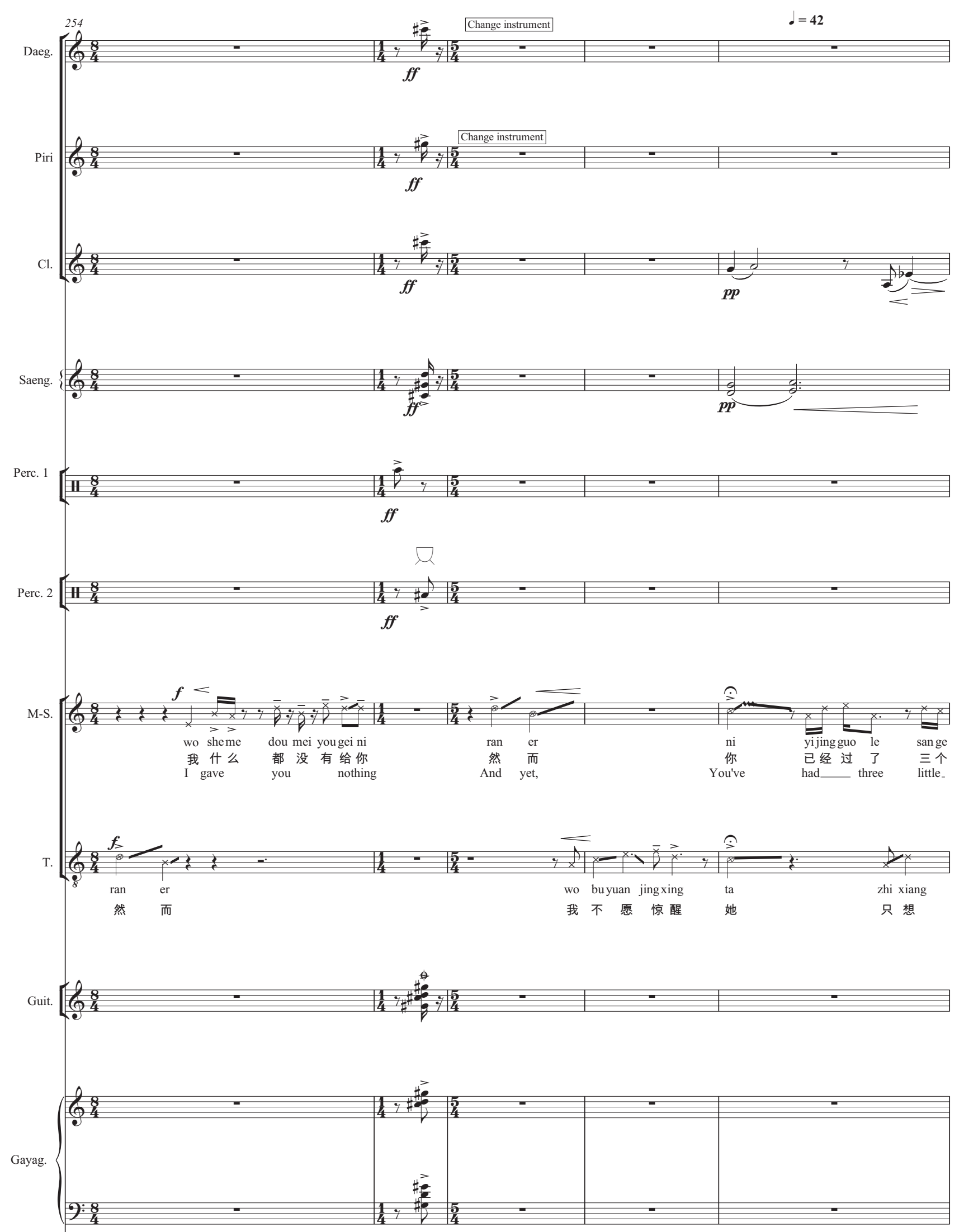

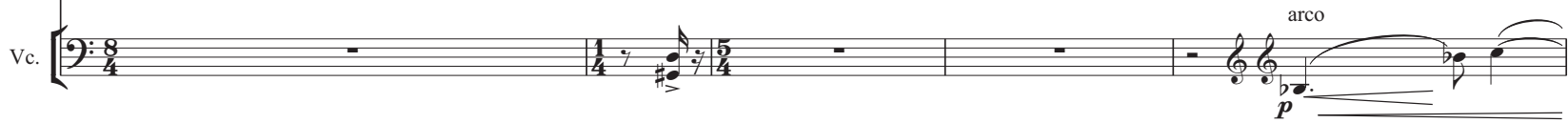



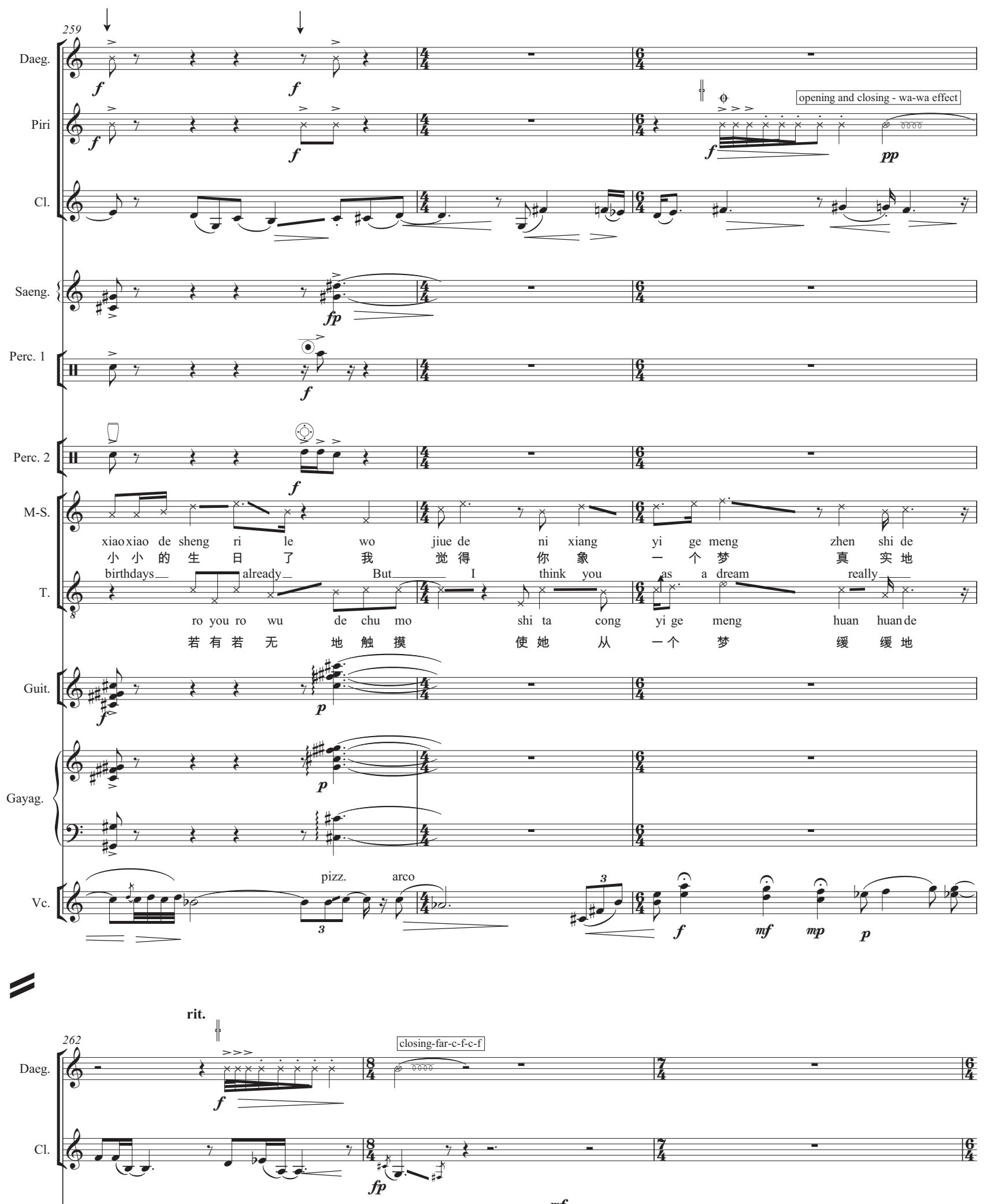
M-S.

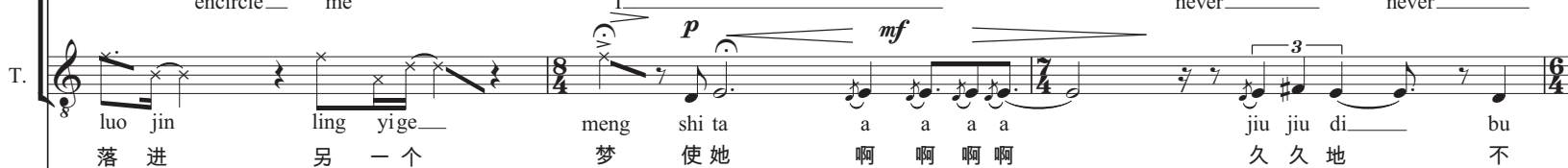

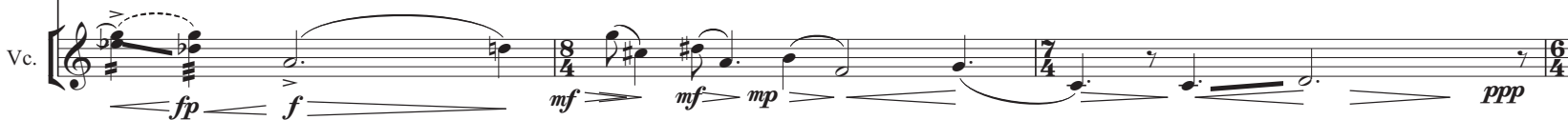



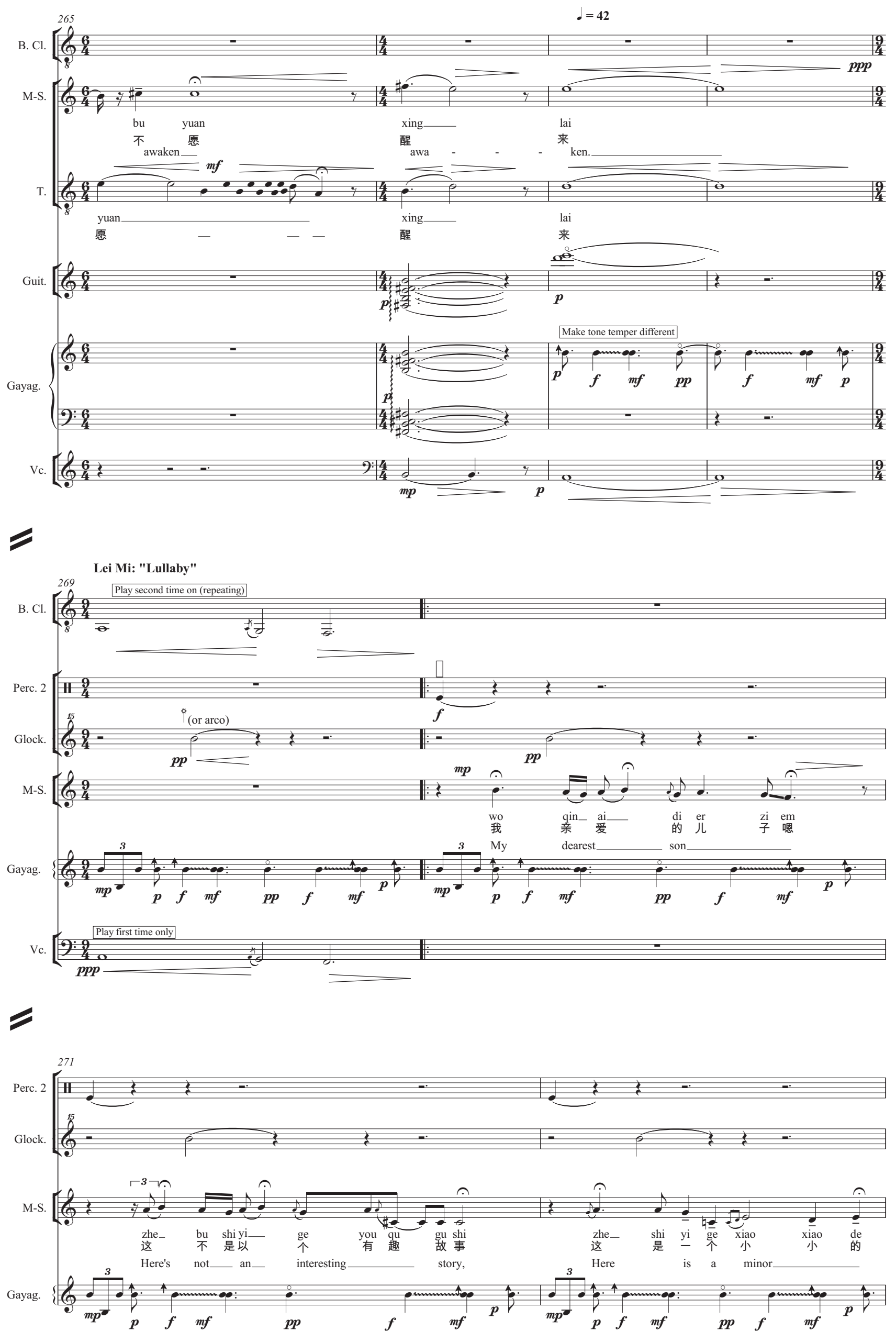


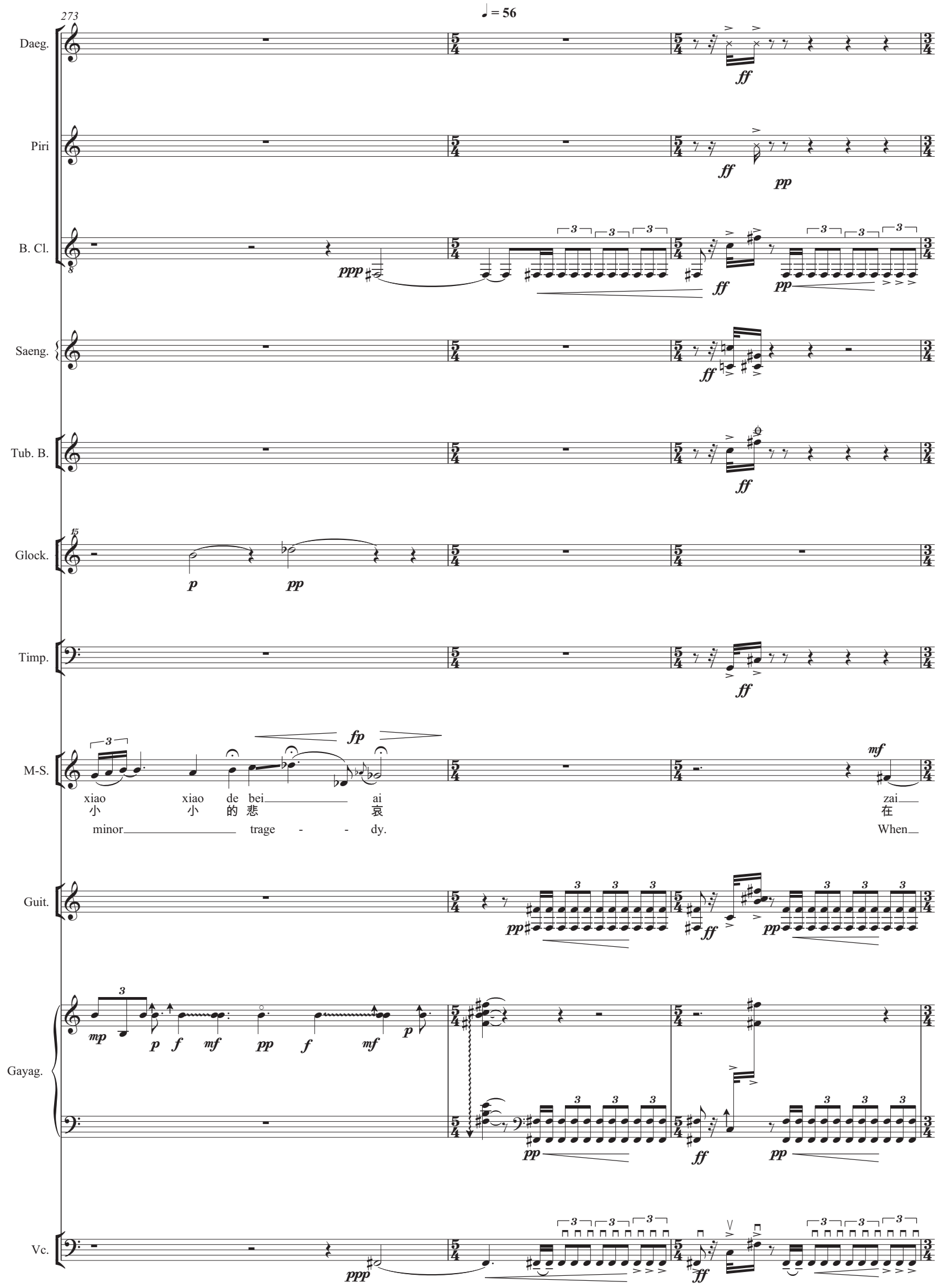




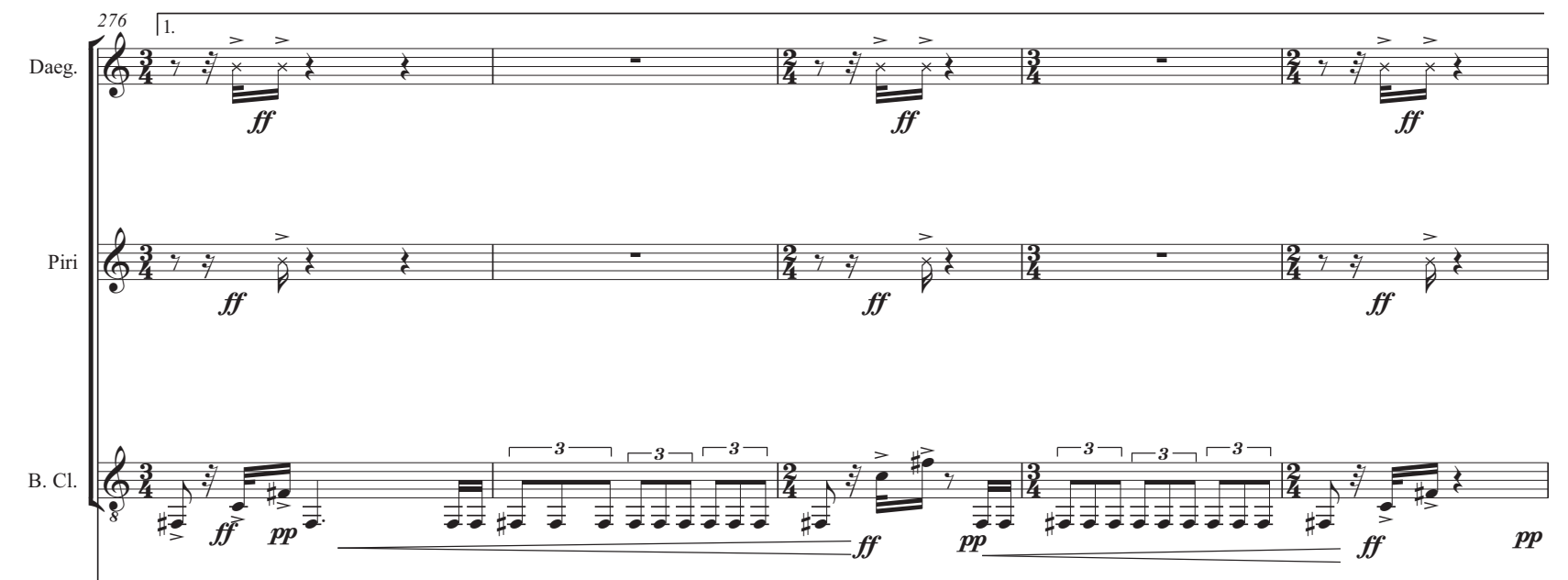

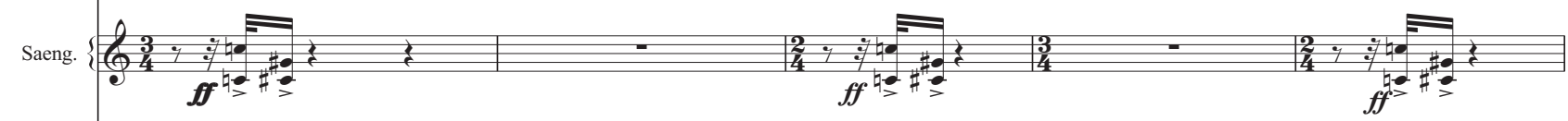

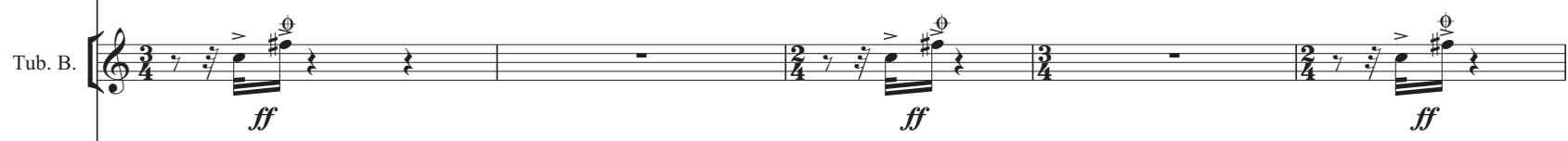
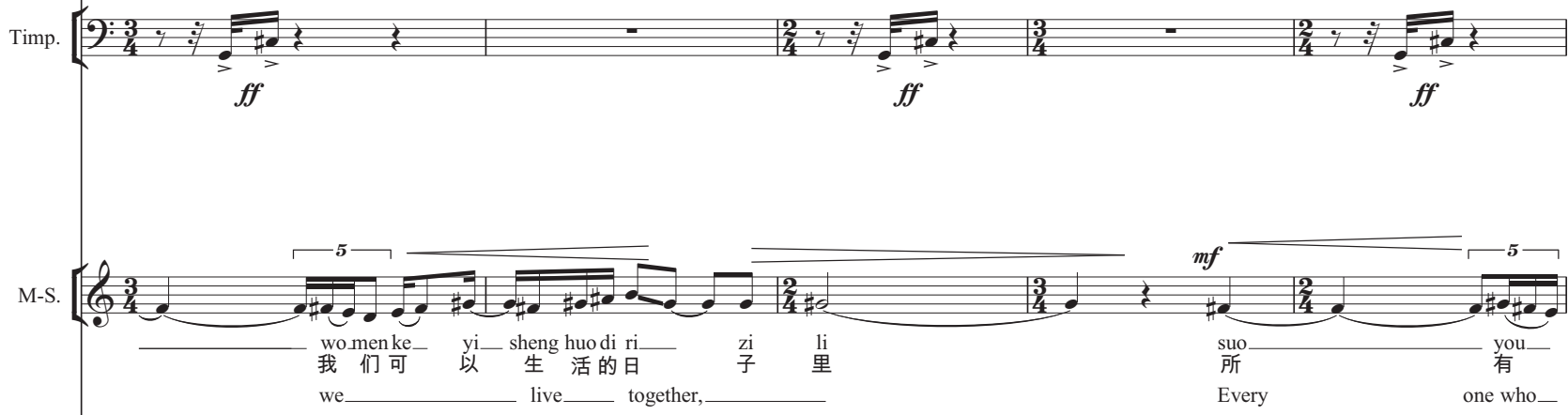

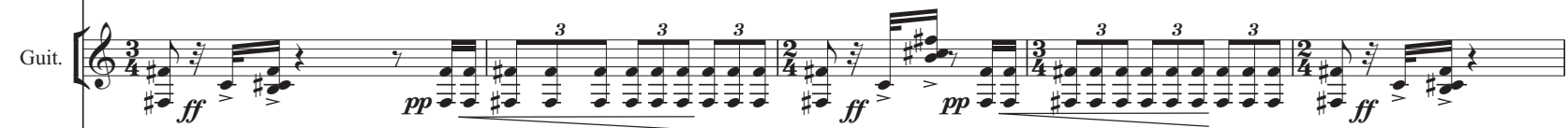

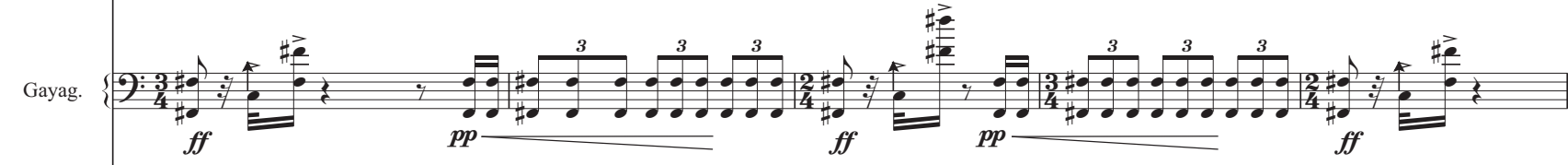

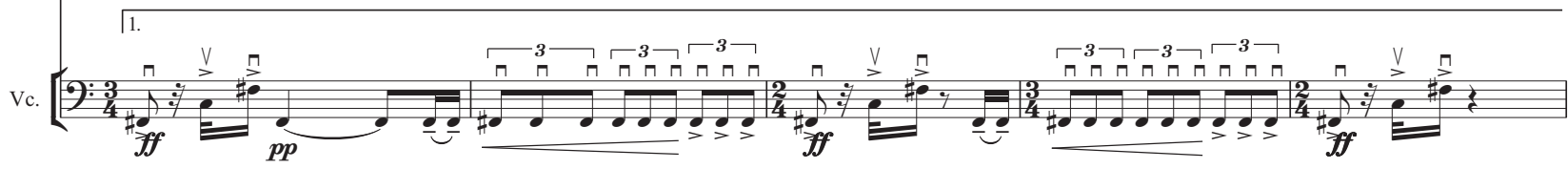




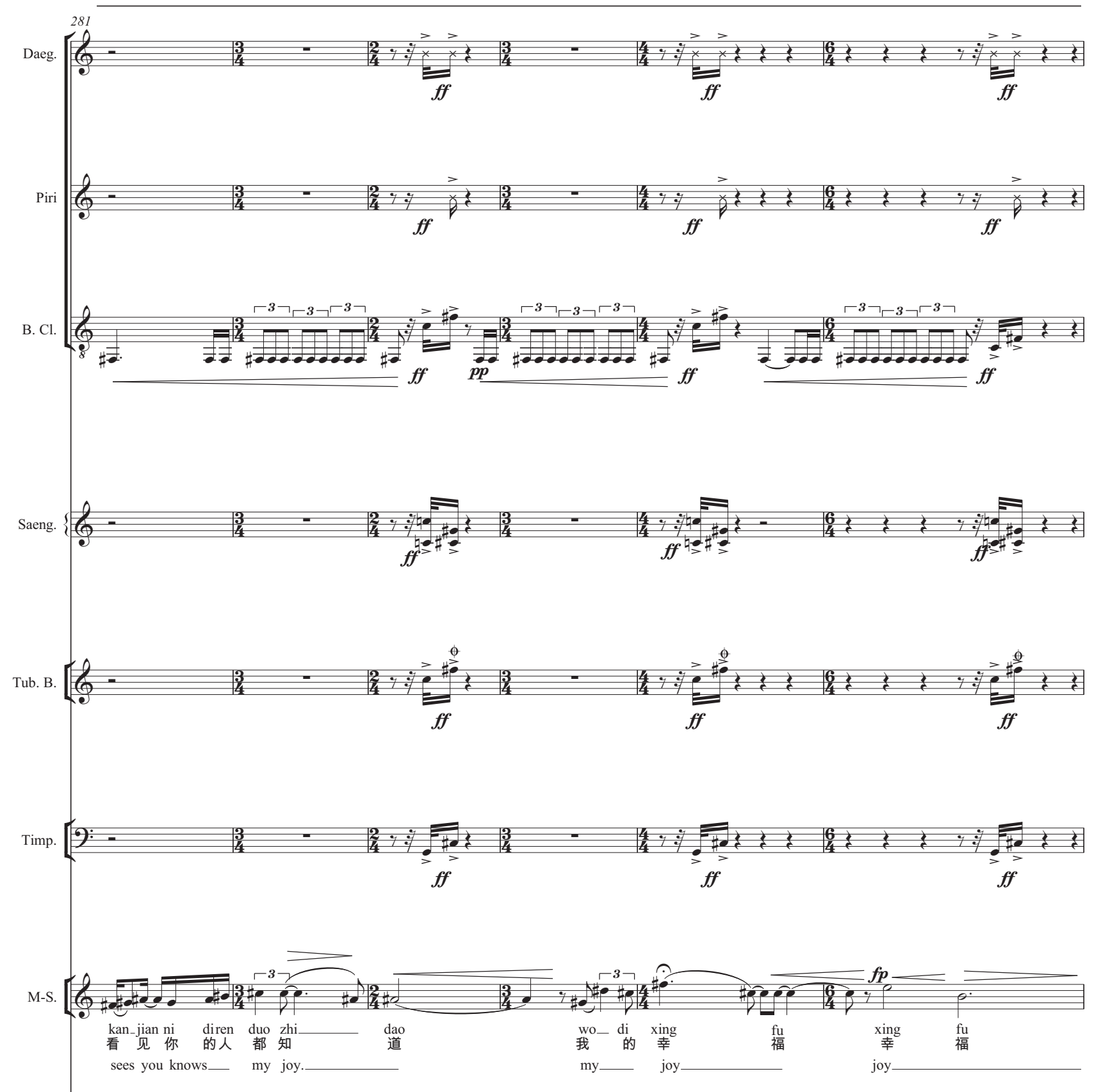

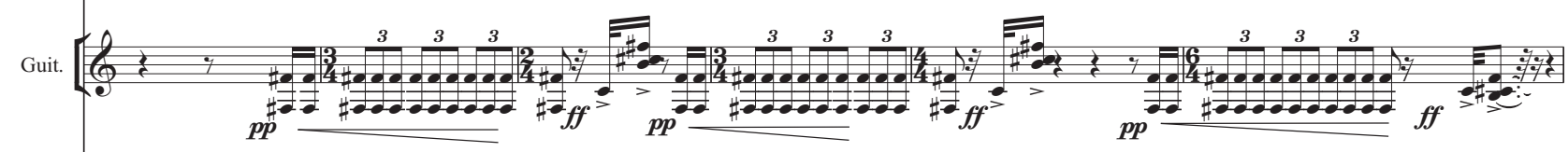

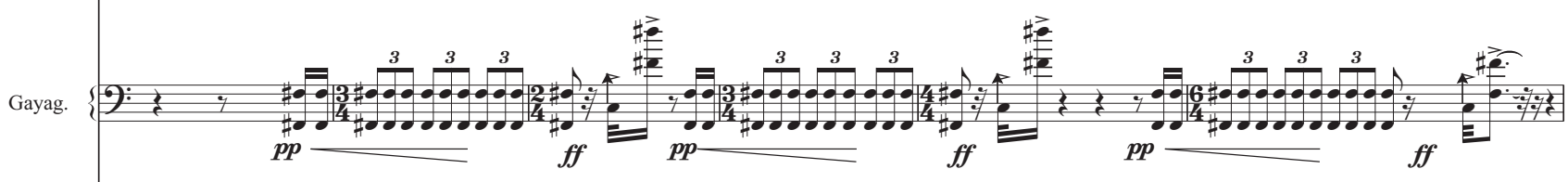

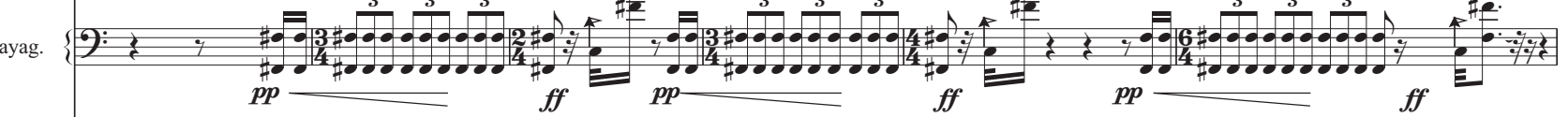

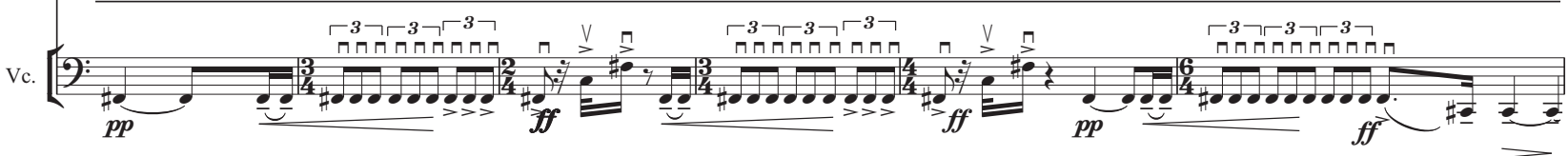



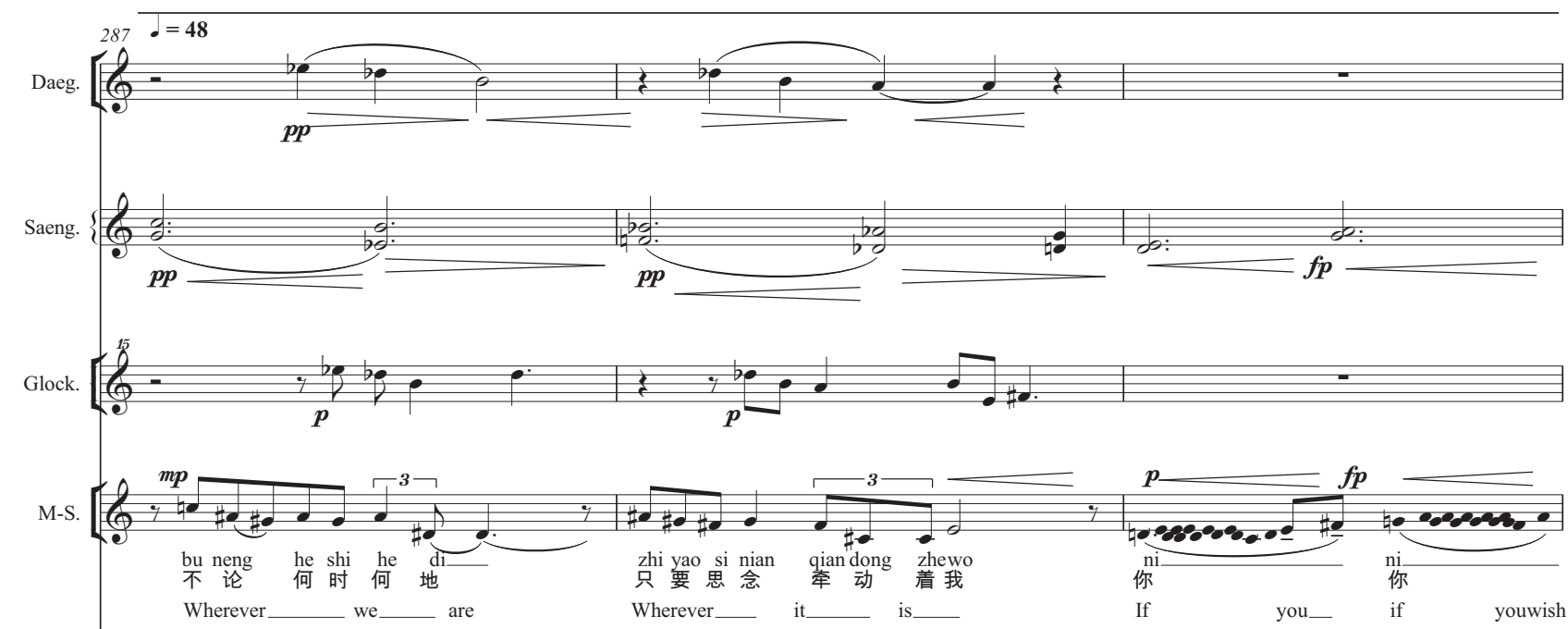

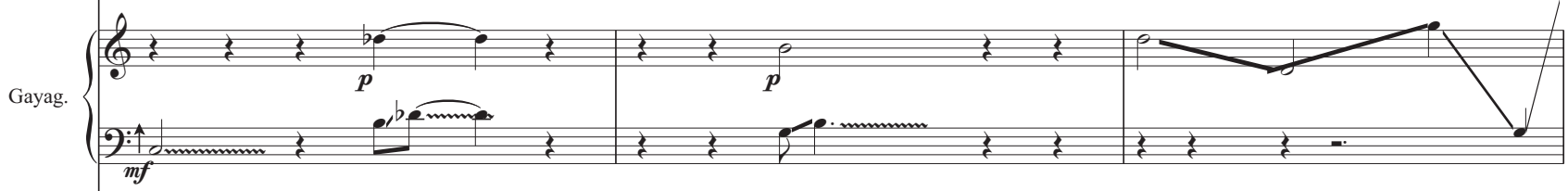
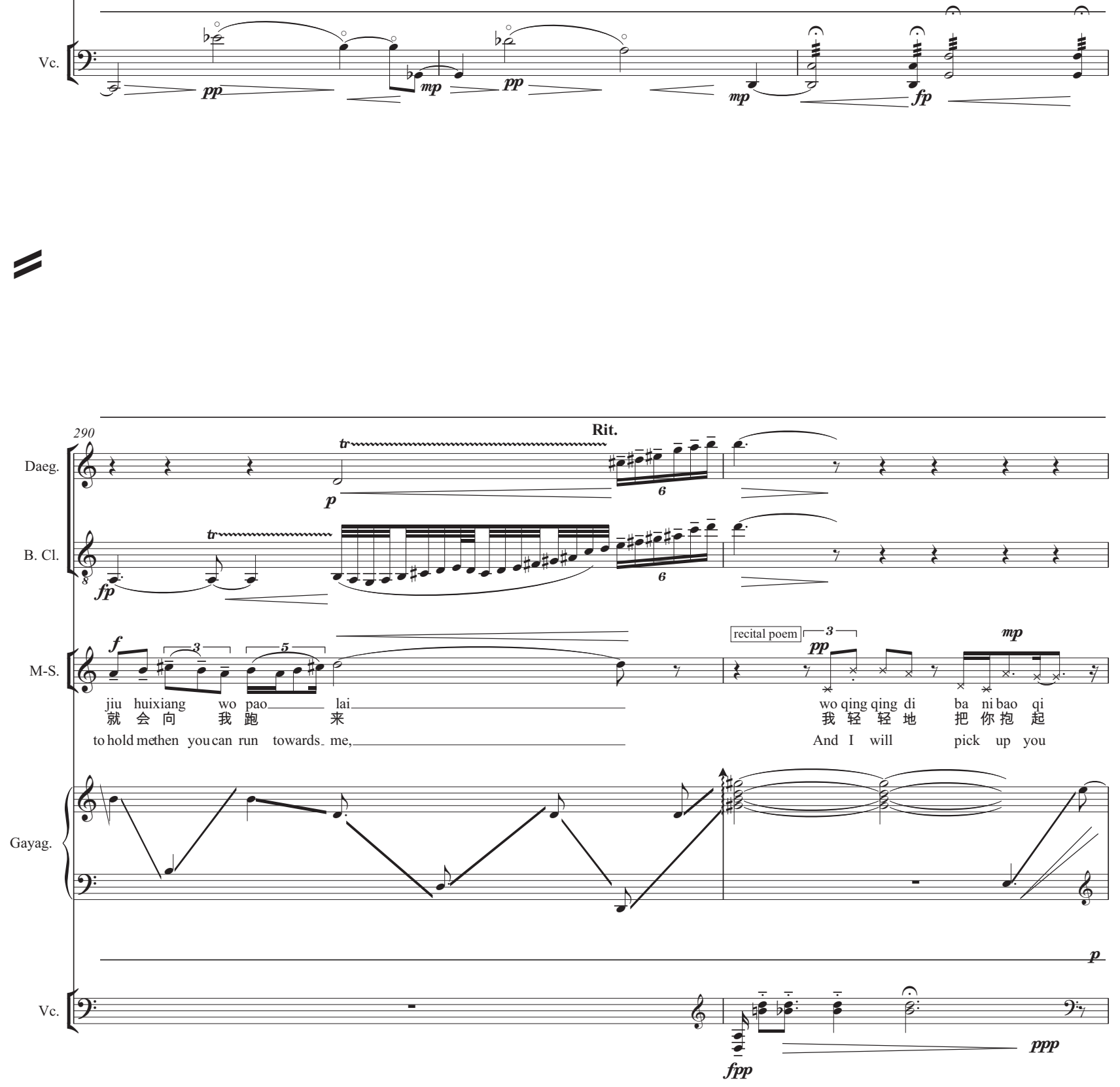

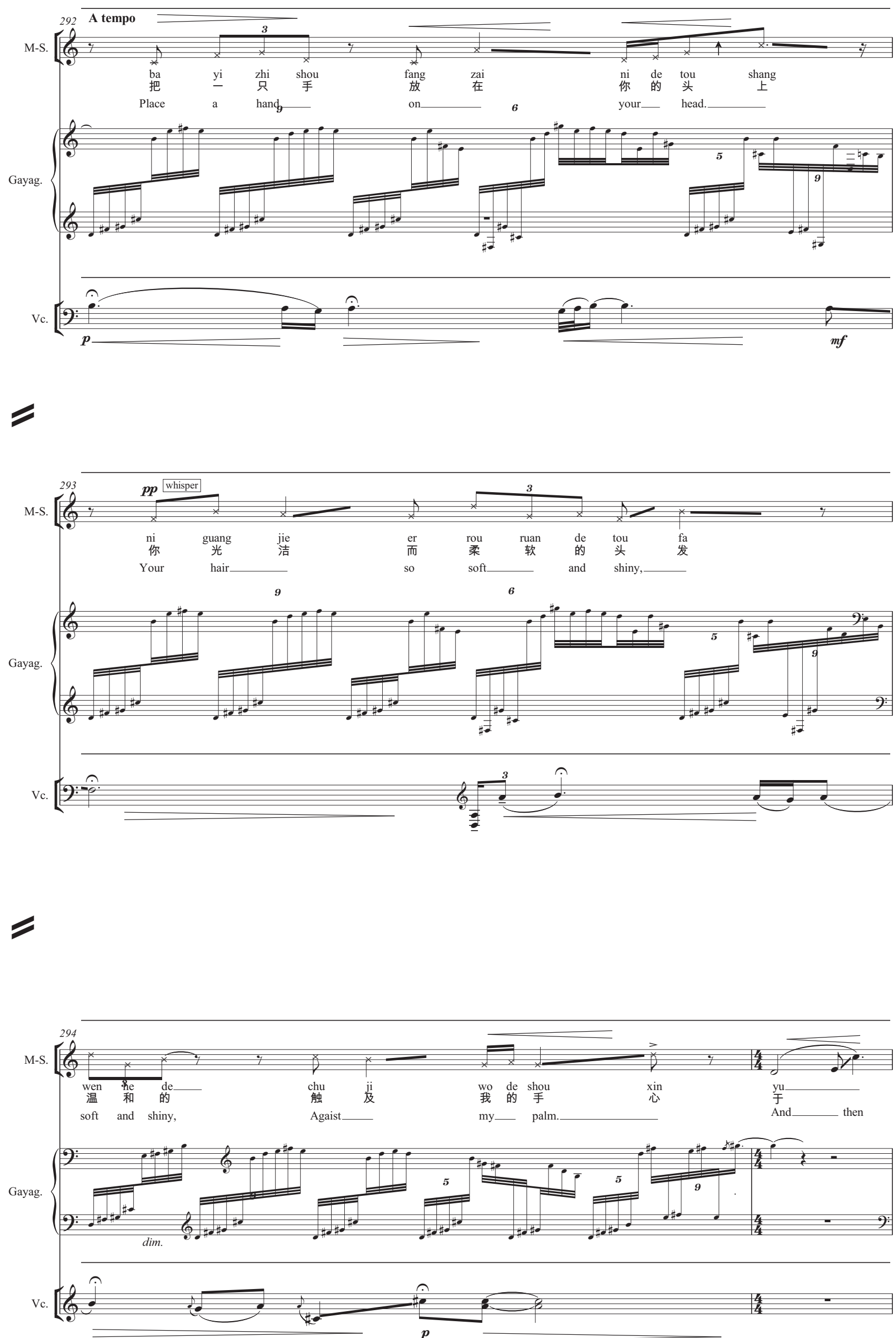


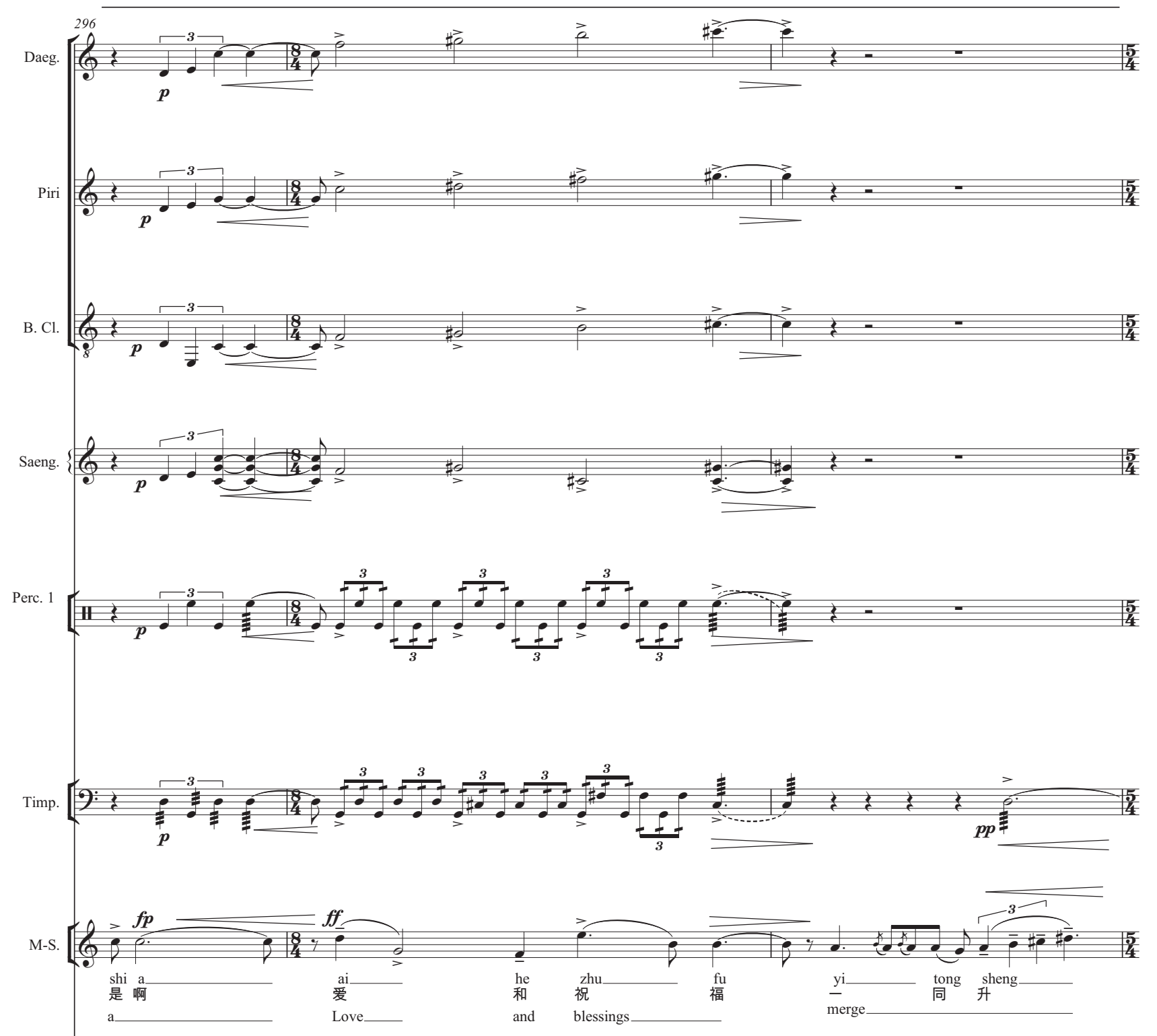

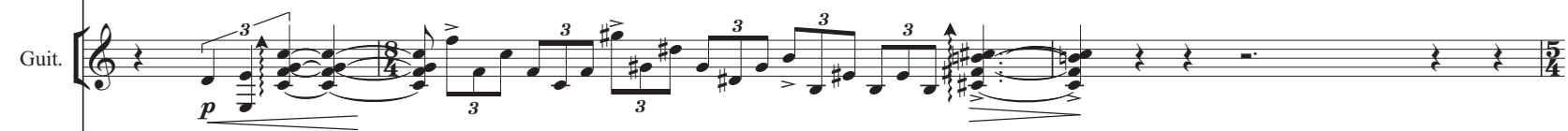

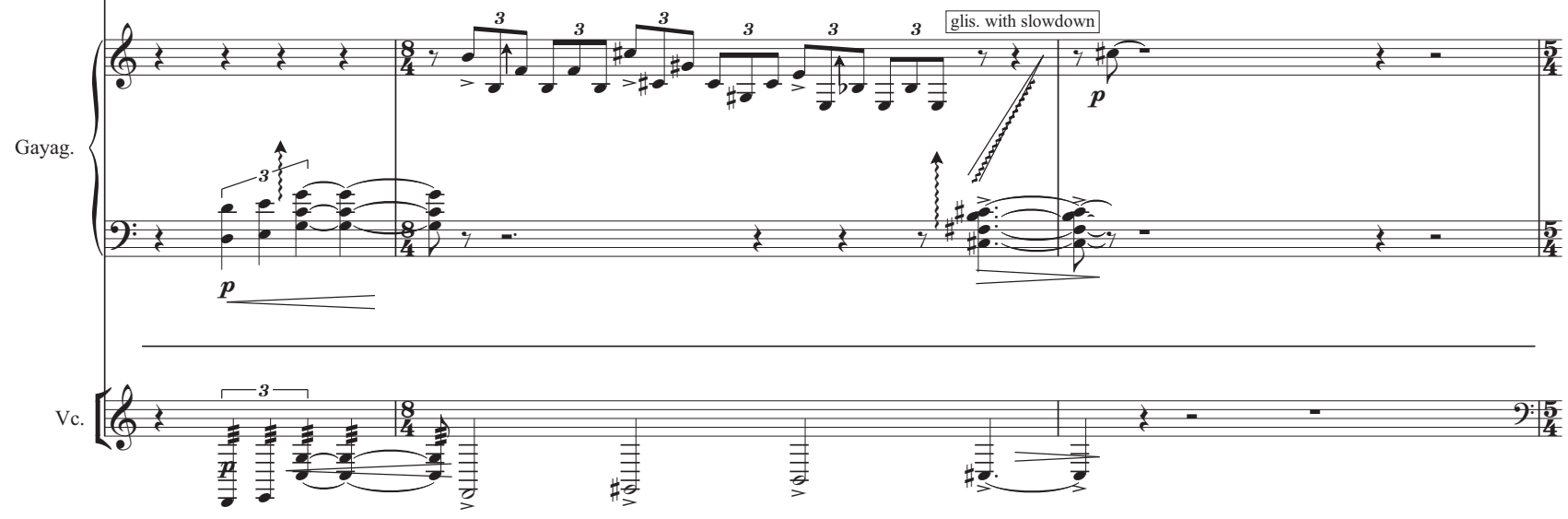




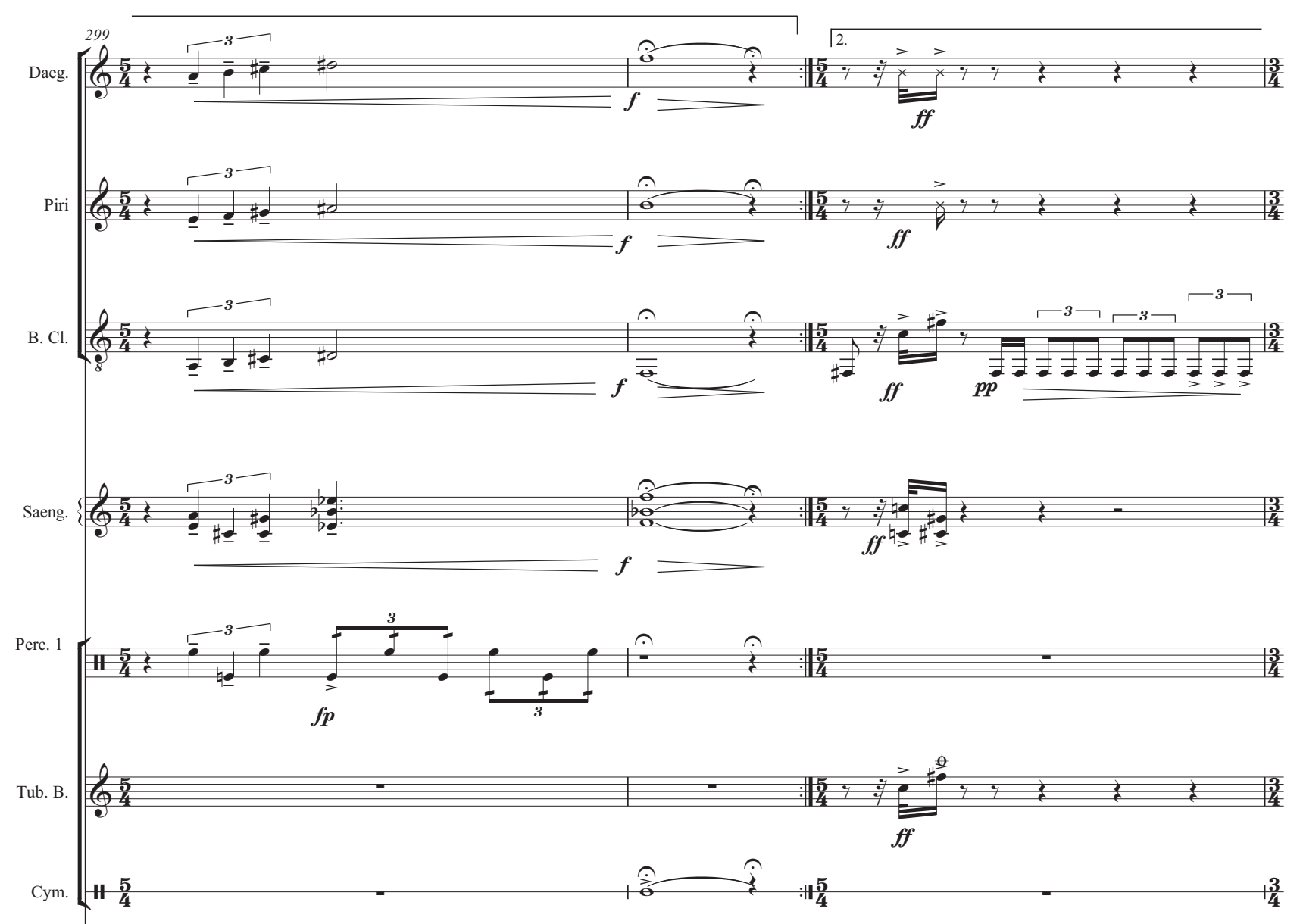

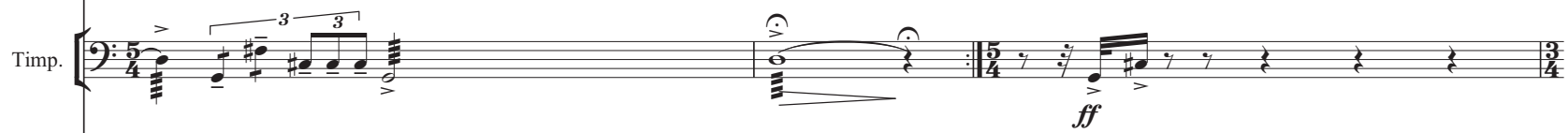

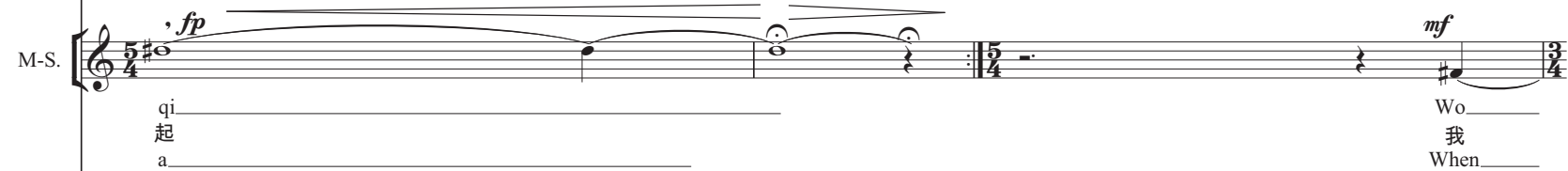

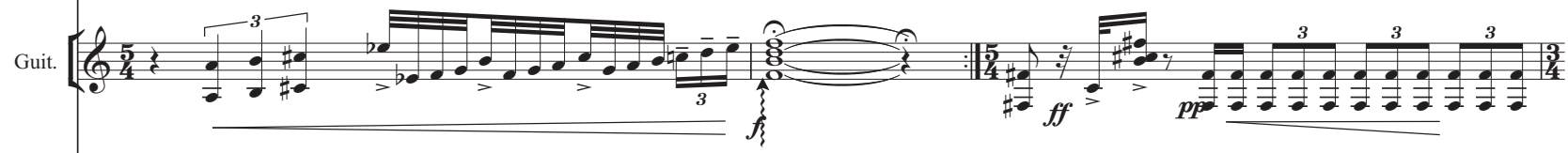

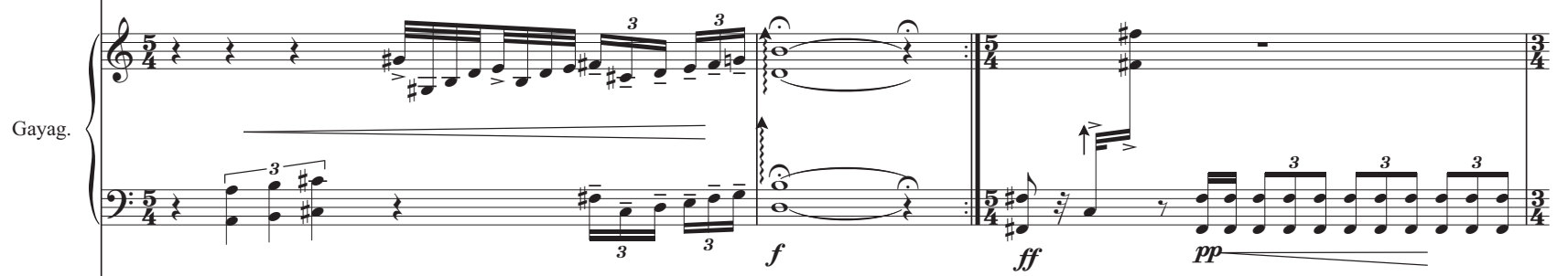

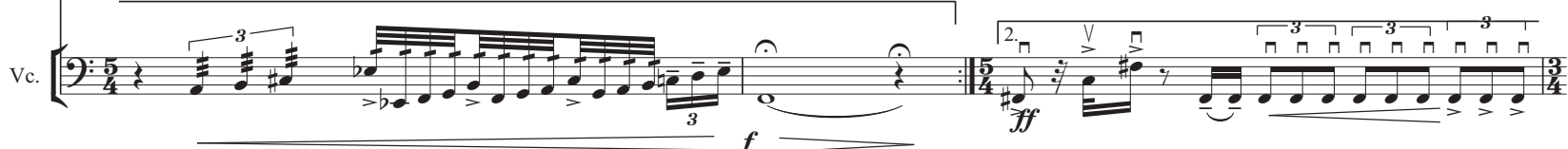




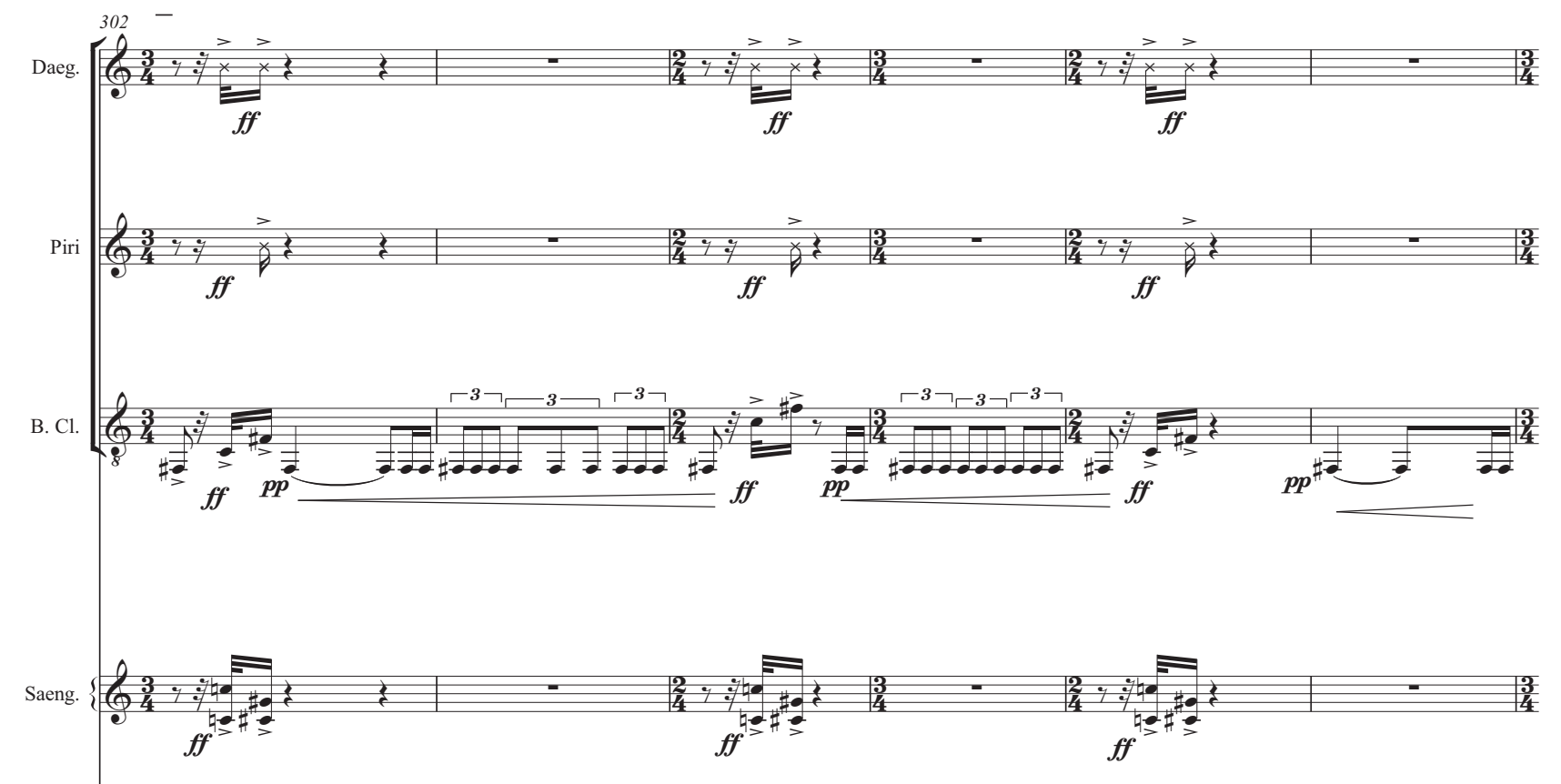

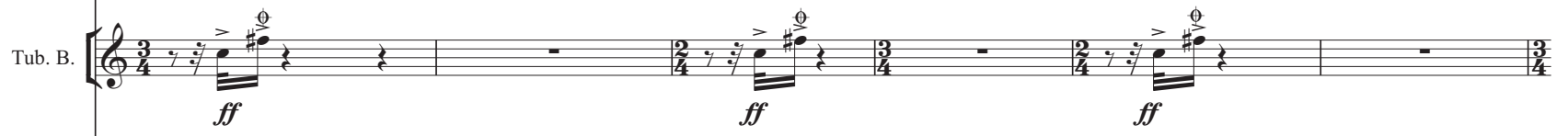

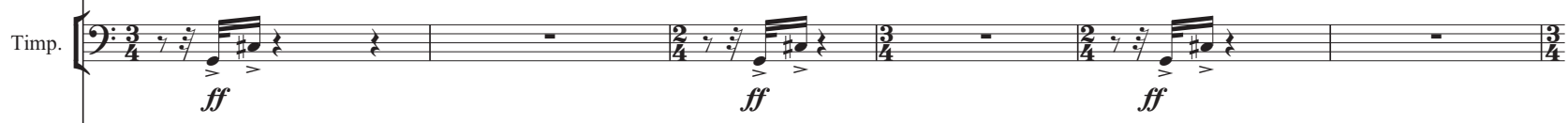
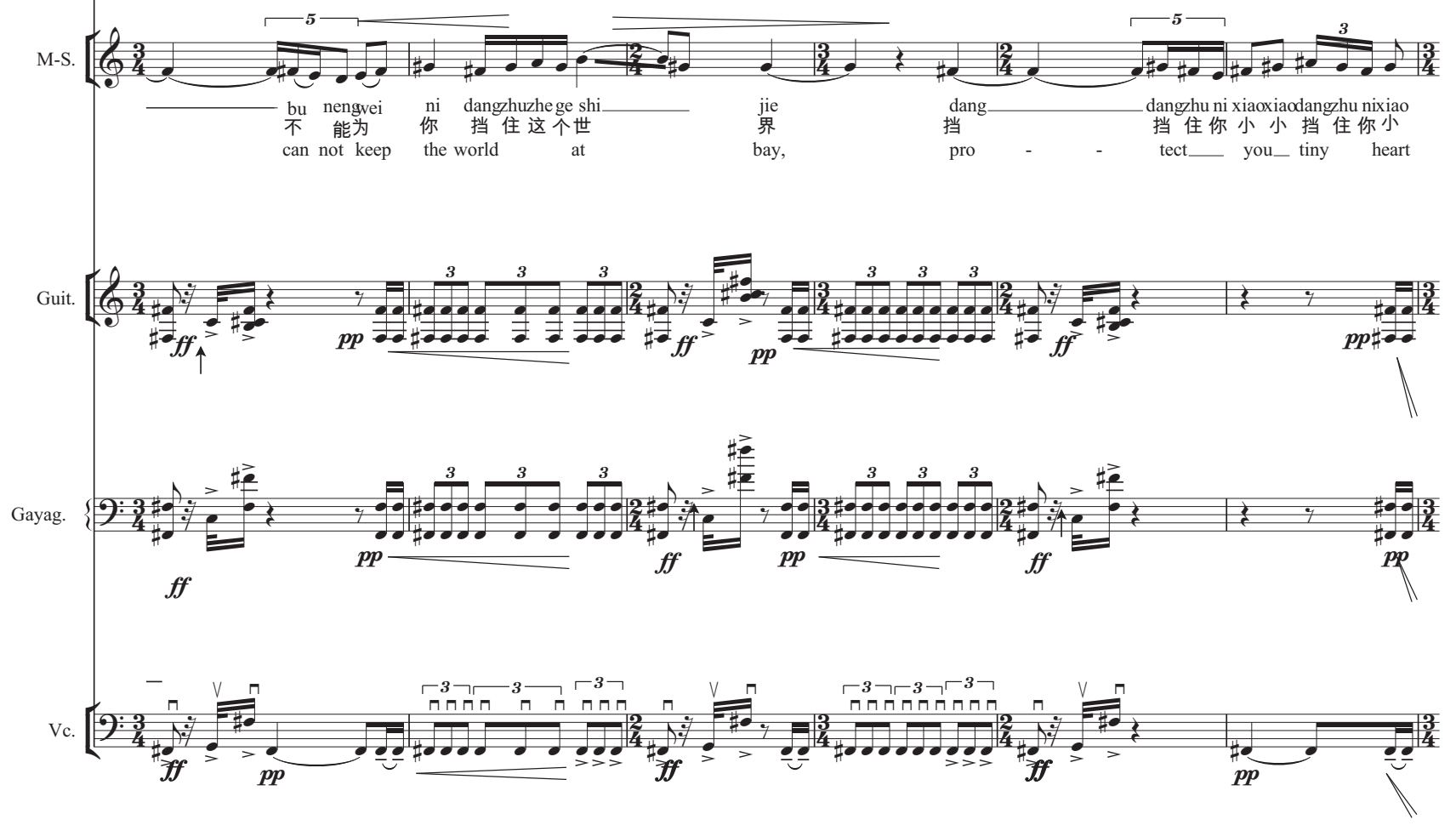


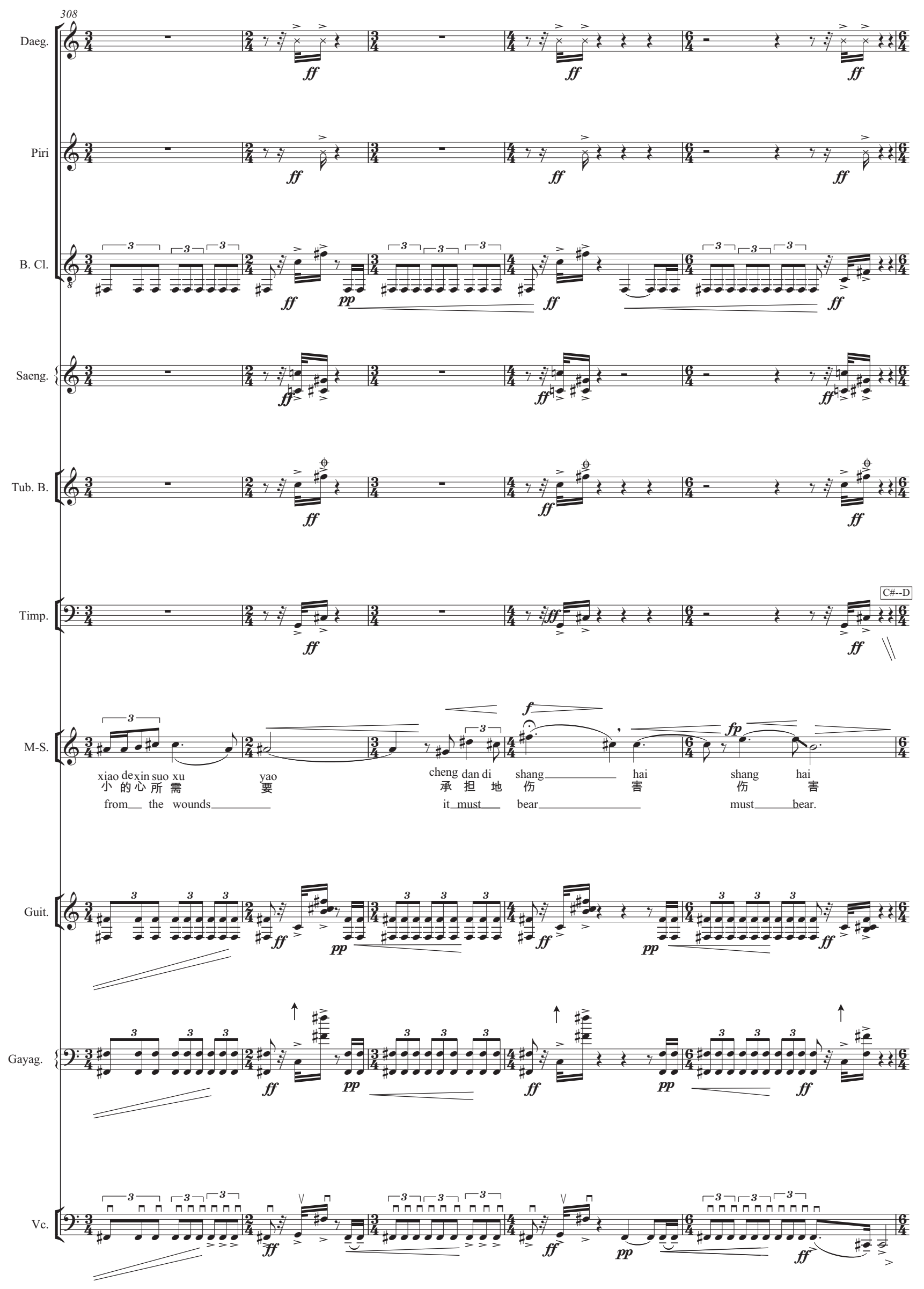



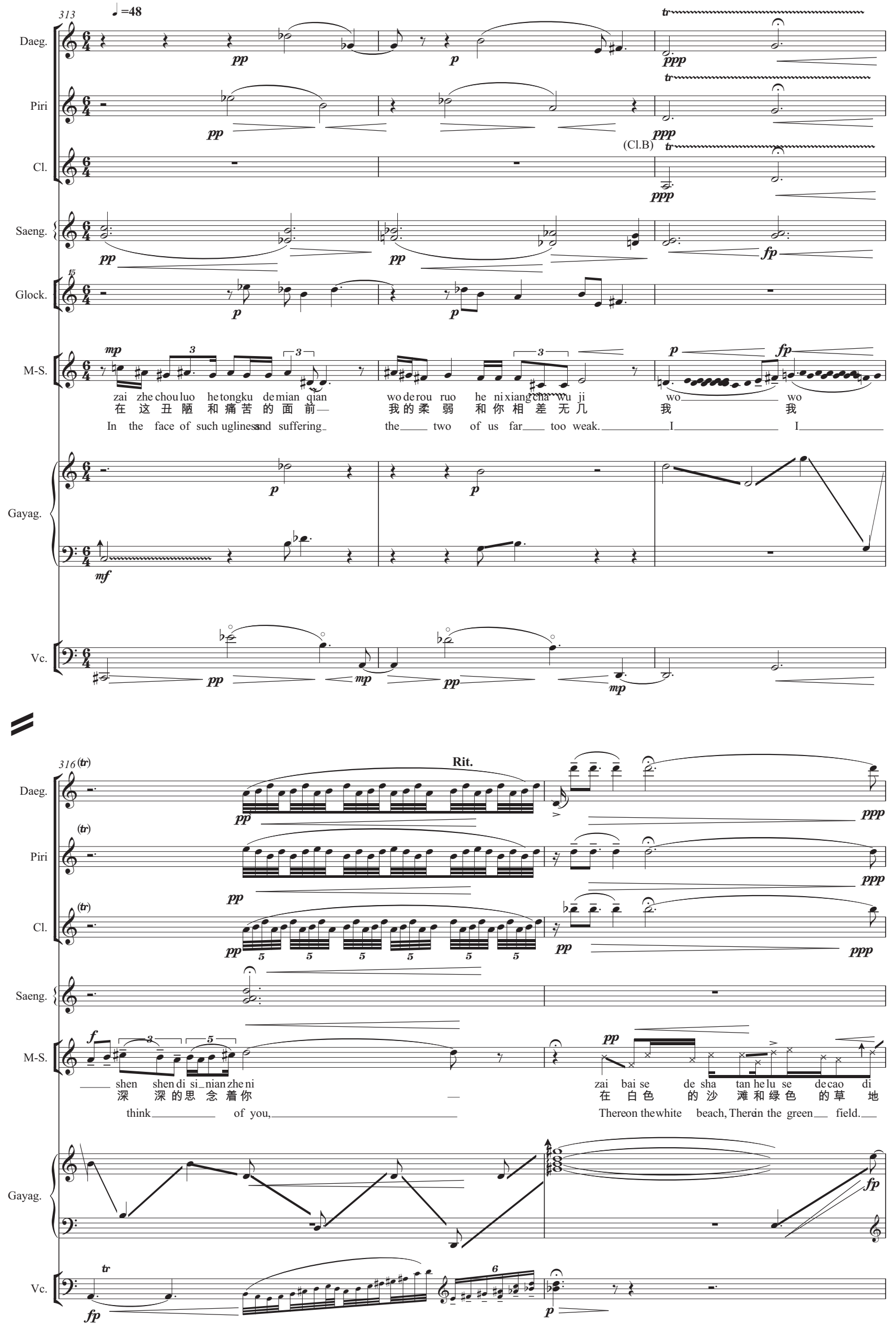

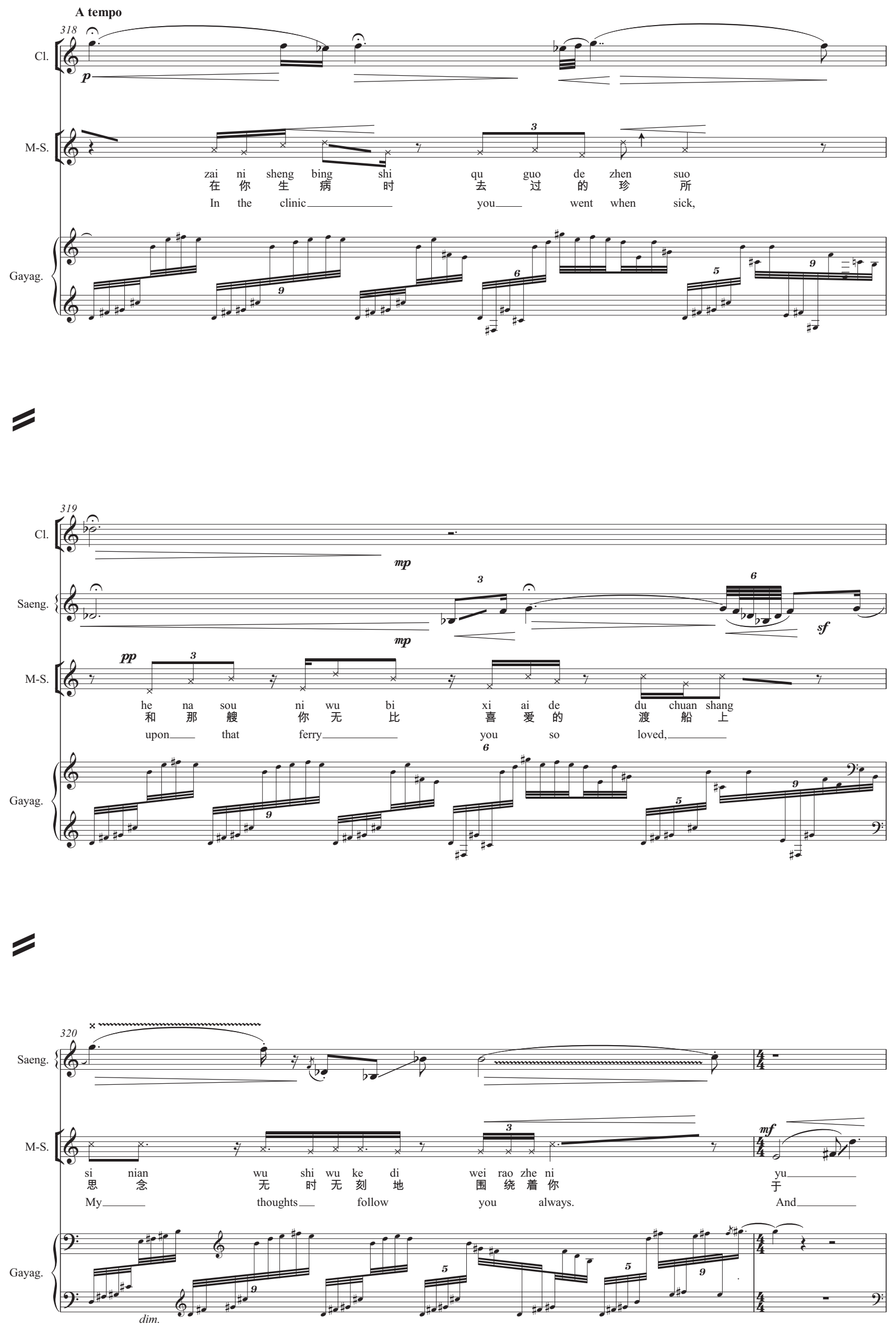


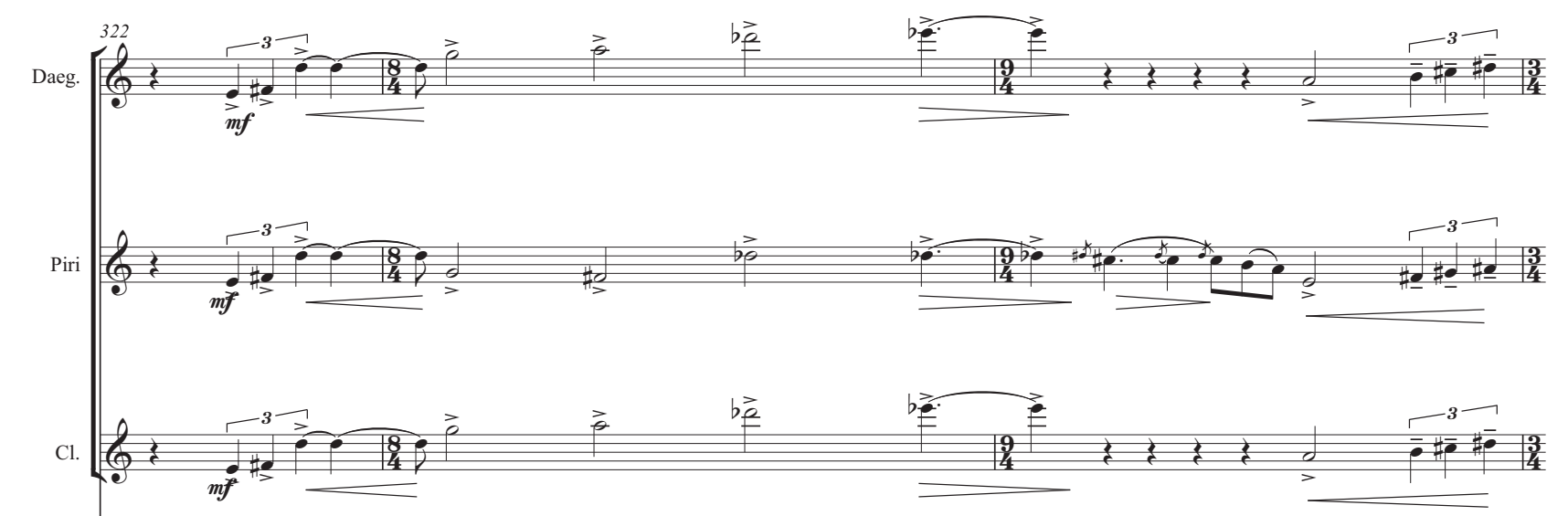

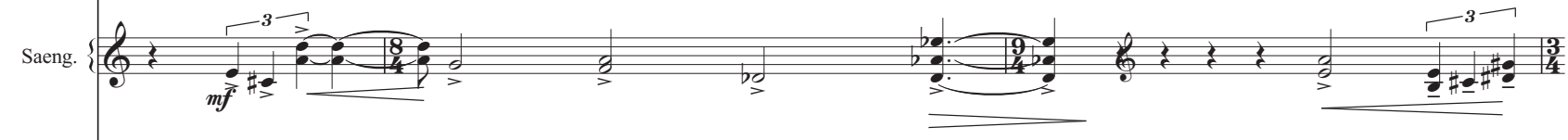
Perc. 1 (110)

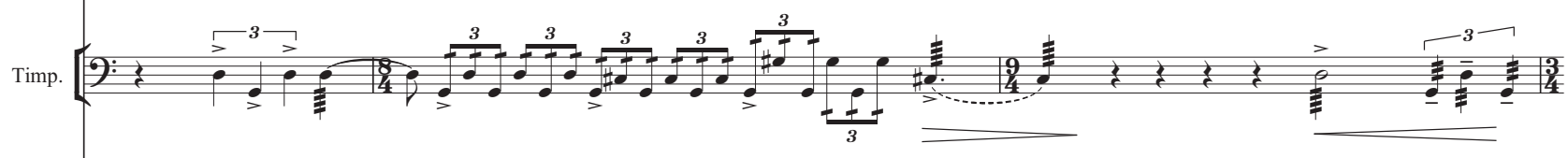

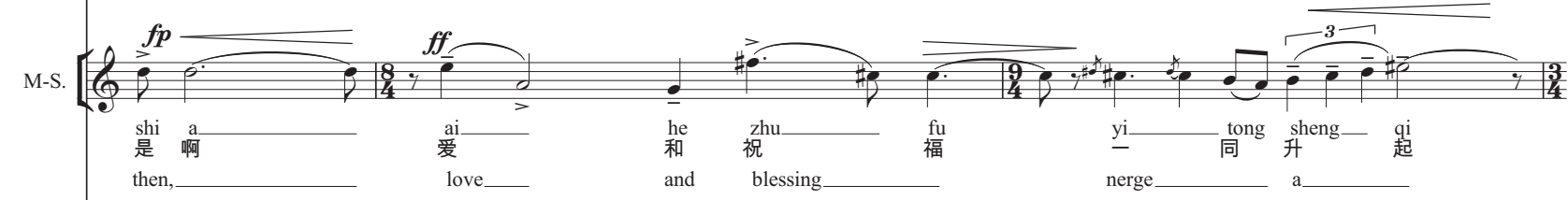
Guit. $\left\{b_{0}^{0}\right.$

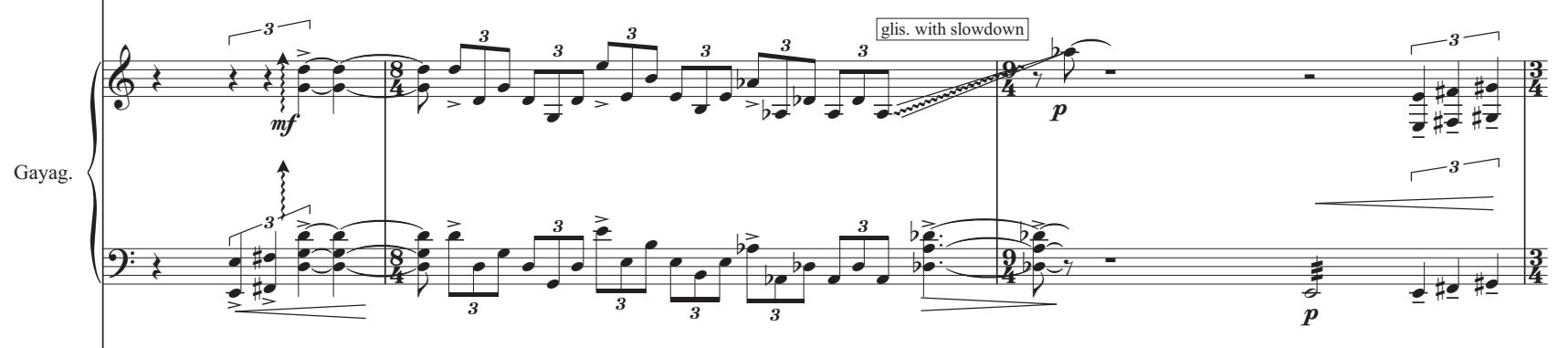

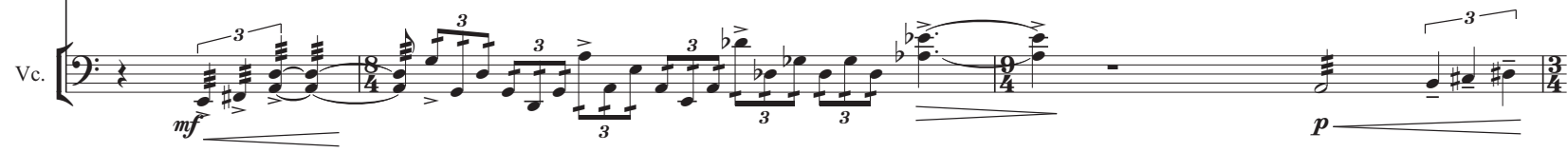



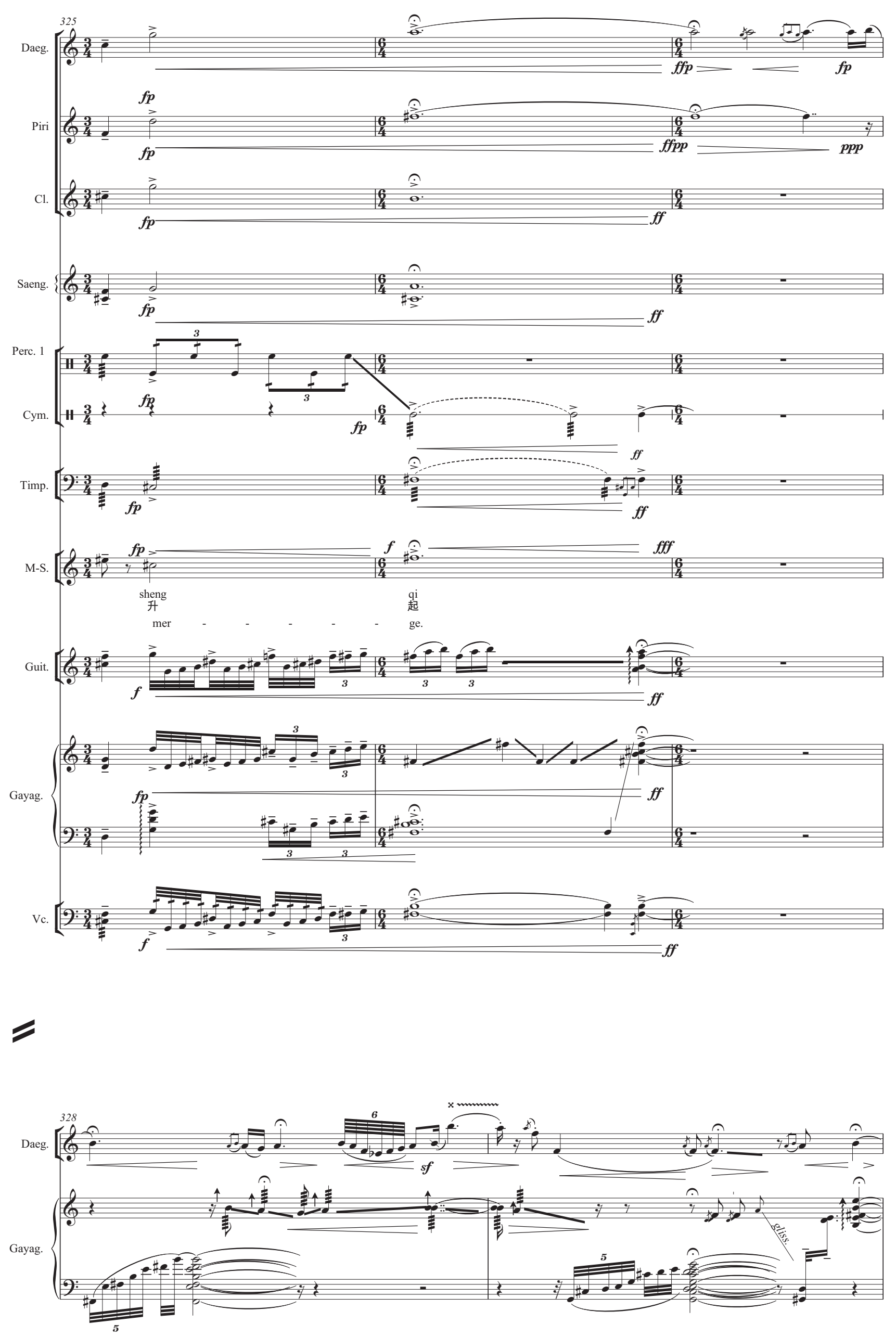


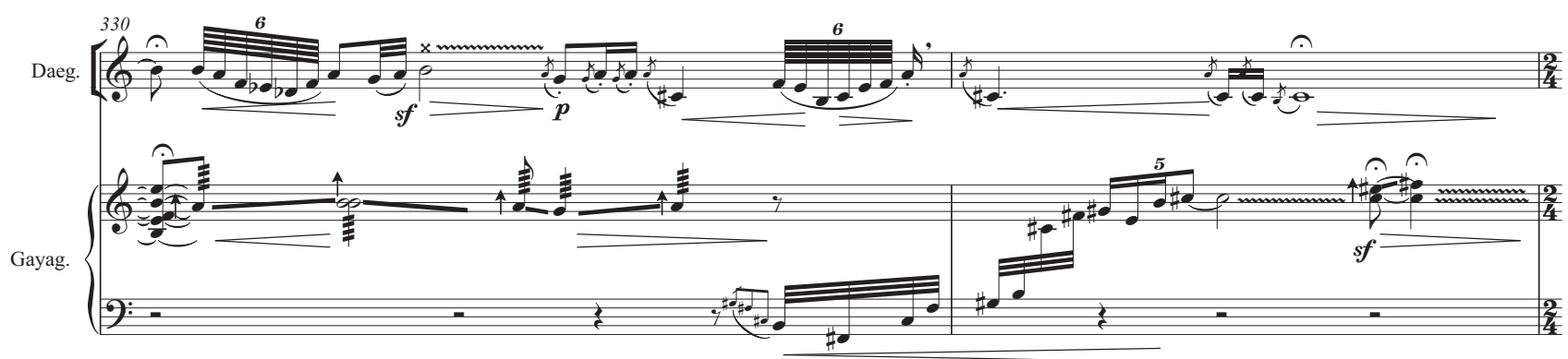

Lei Mi and the voice of Son in 'Kuaibanshu' style with Ensemble Children Chant: "Yige ren hao"
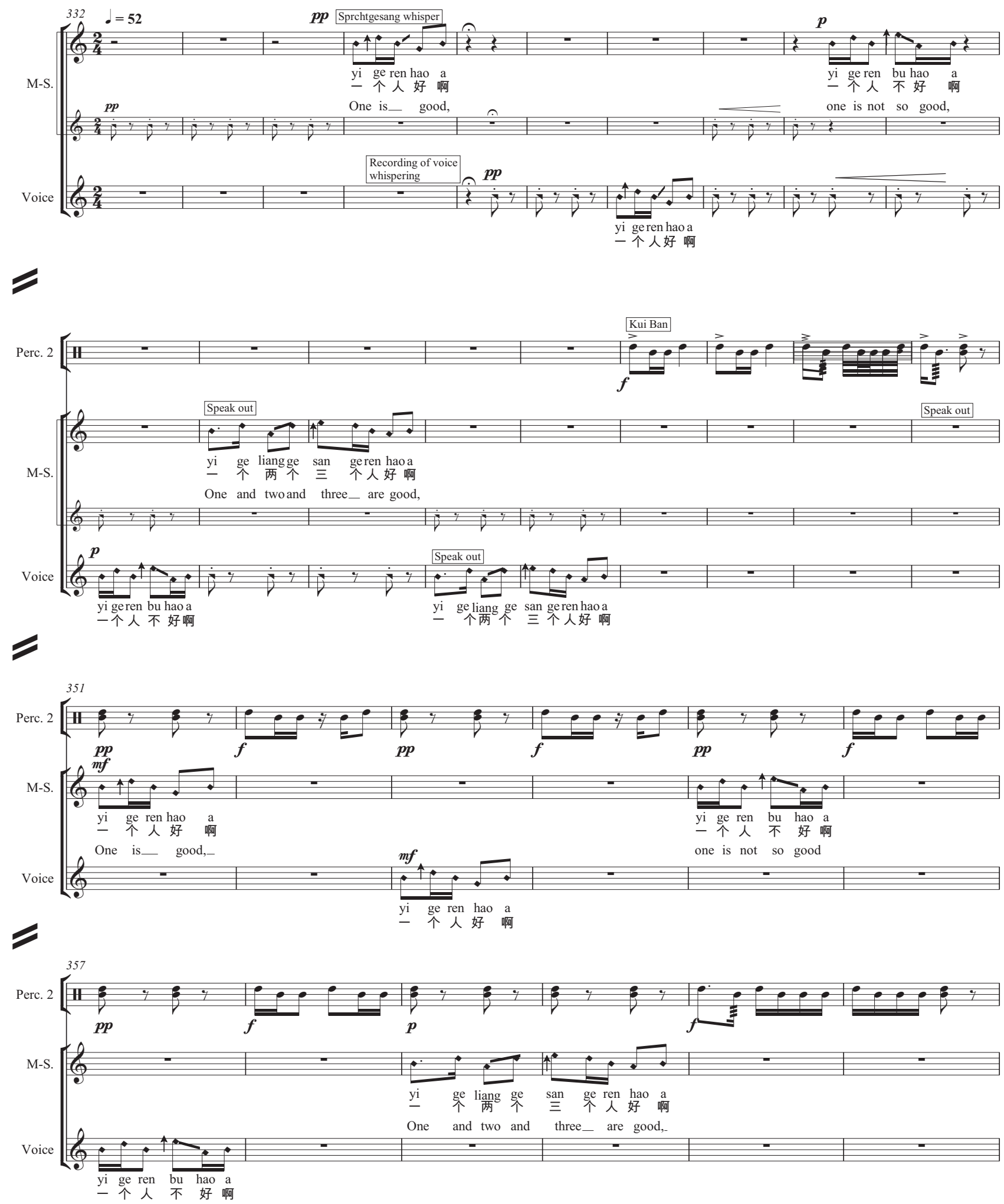


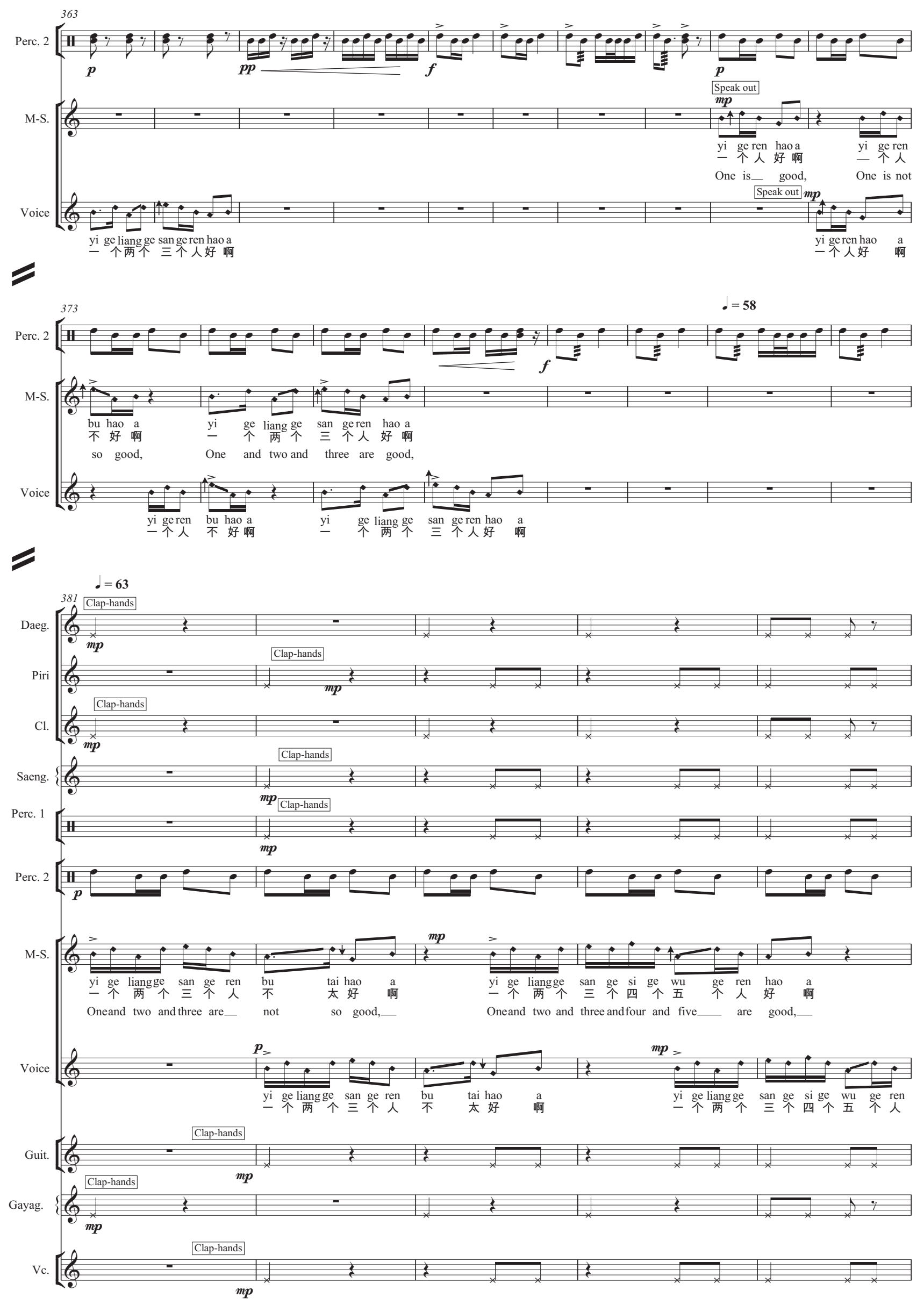




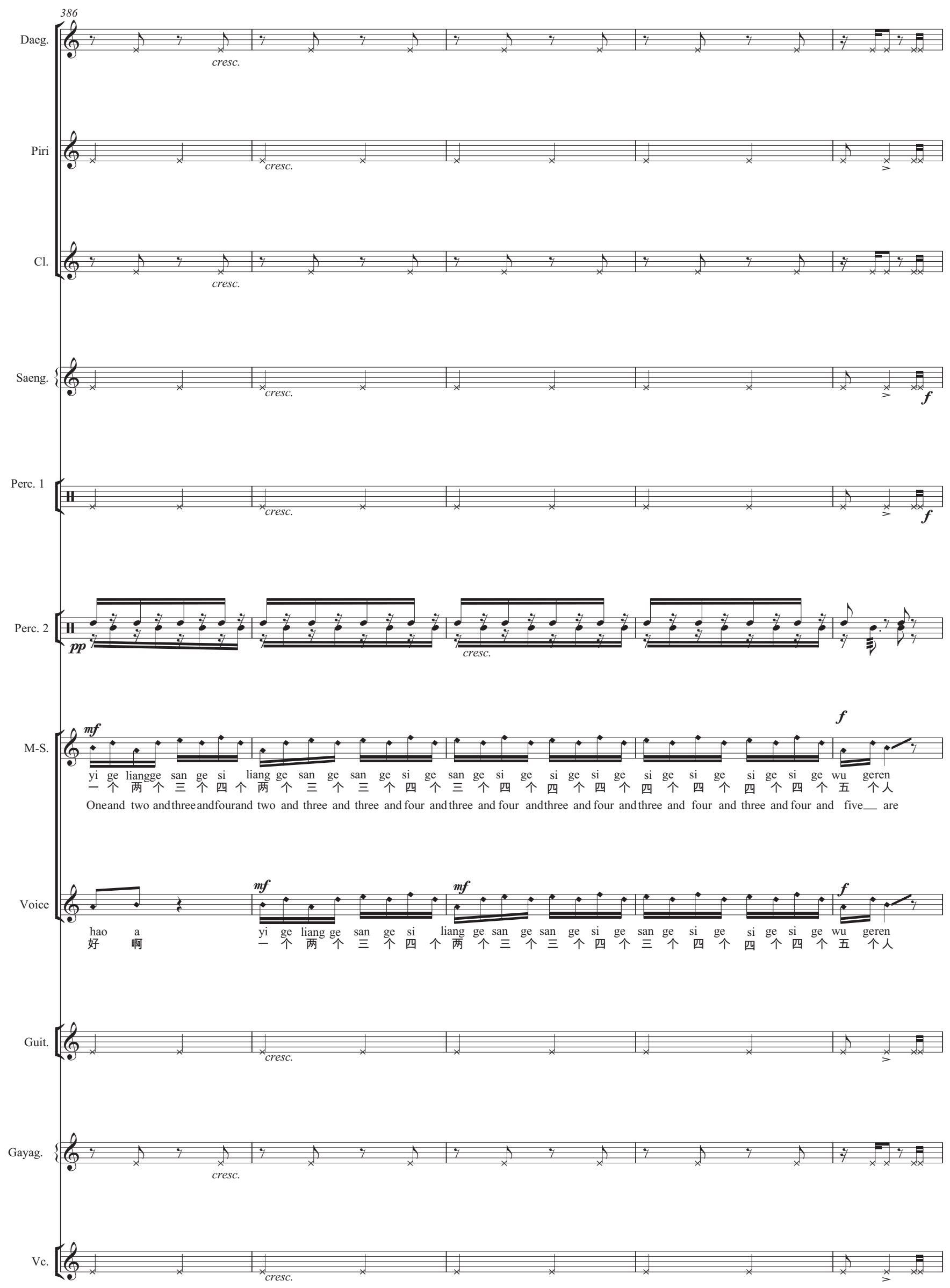




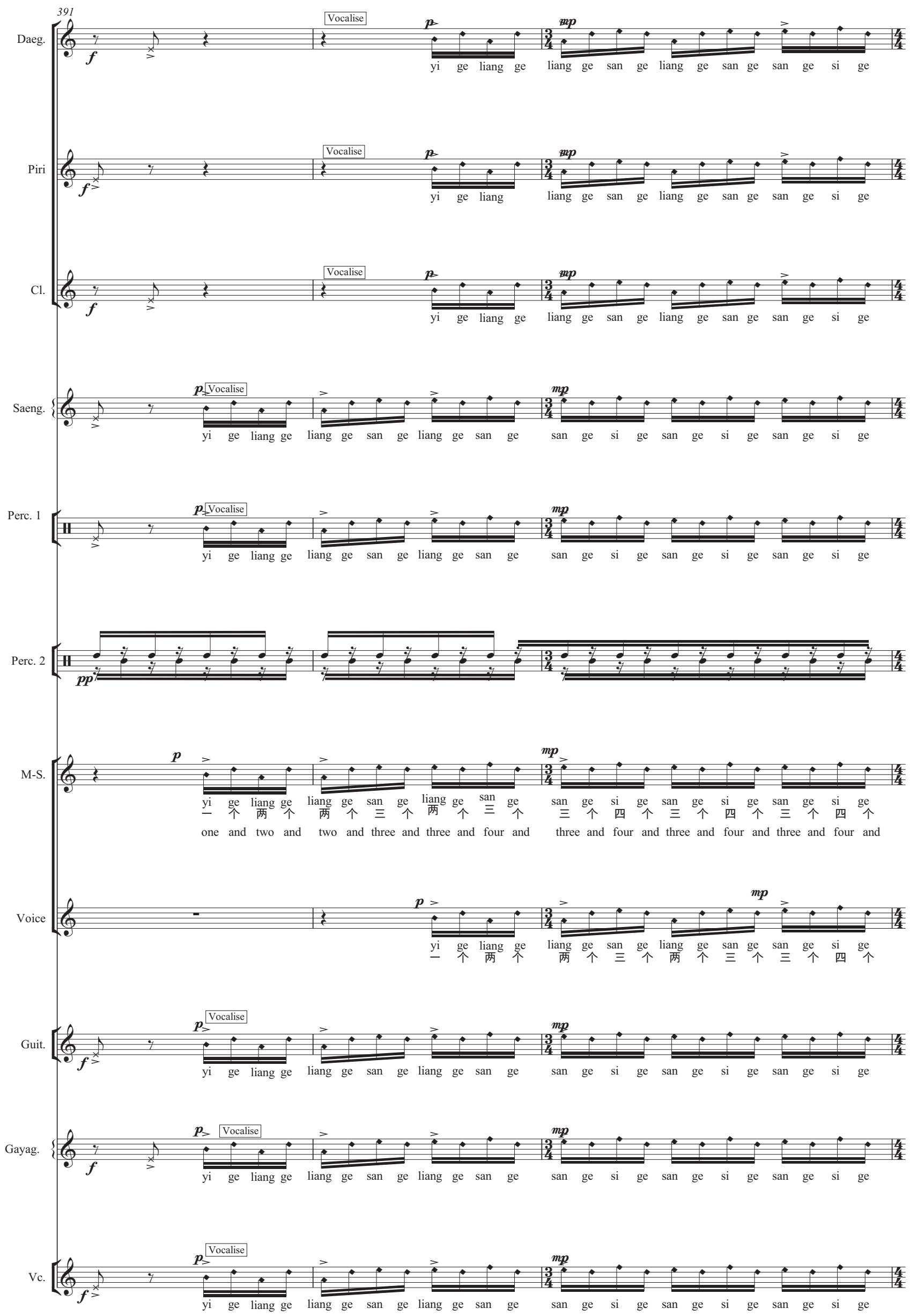




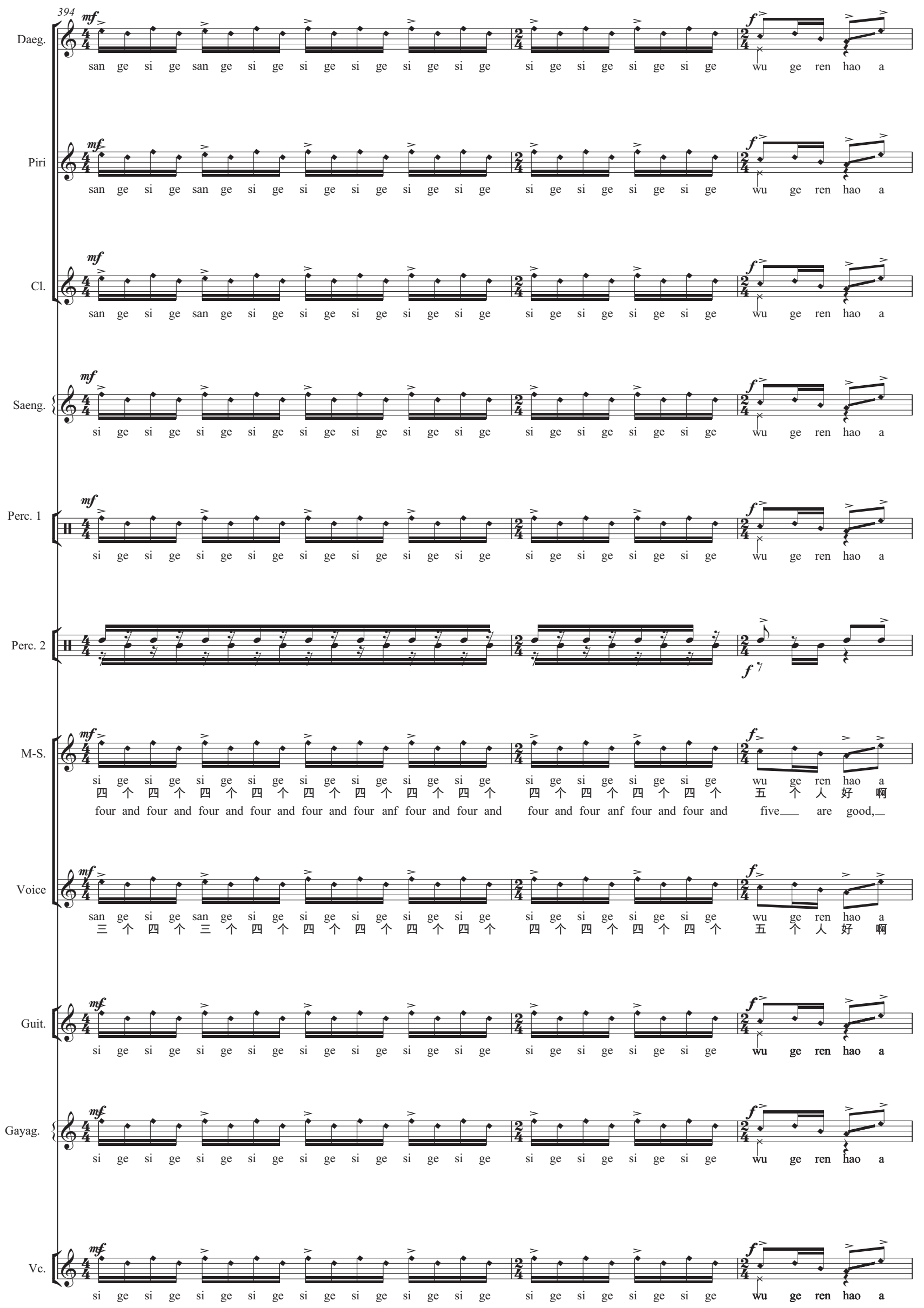




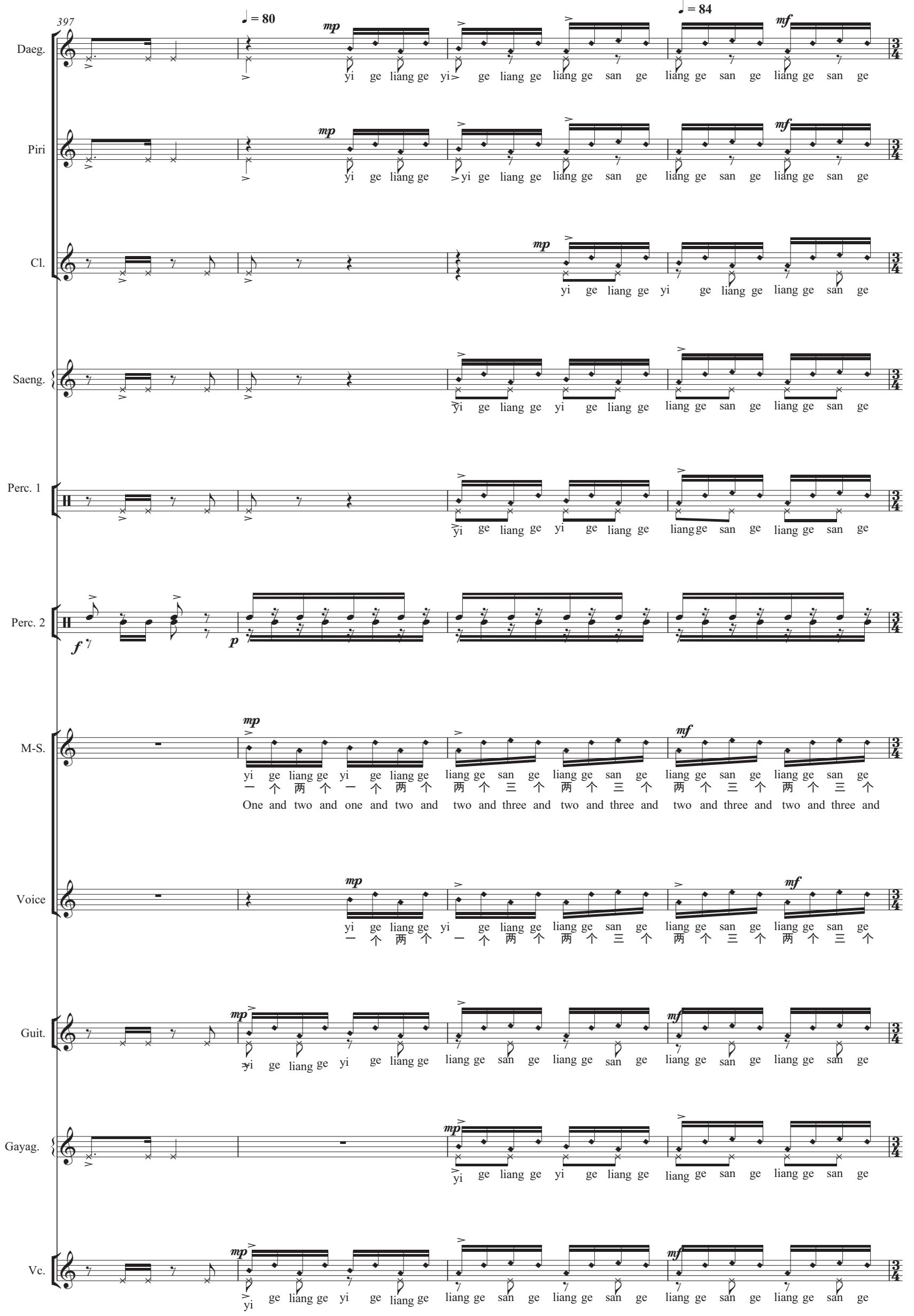



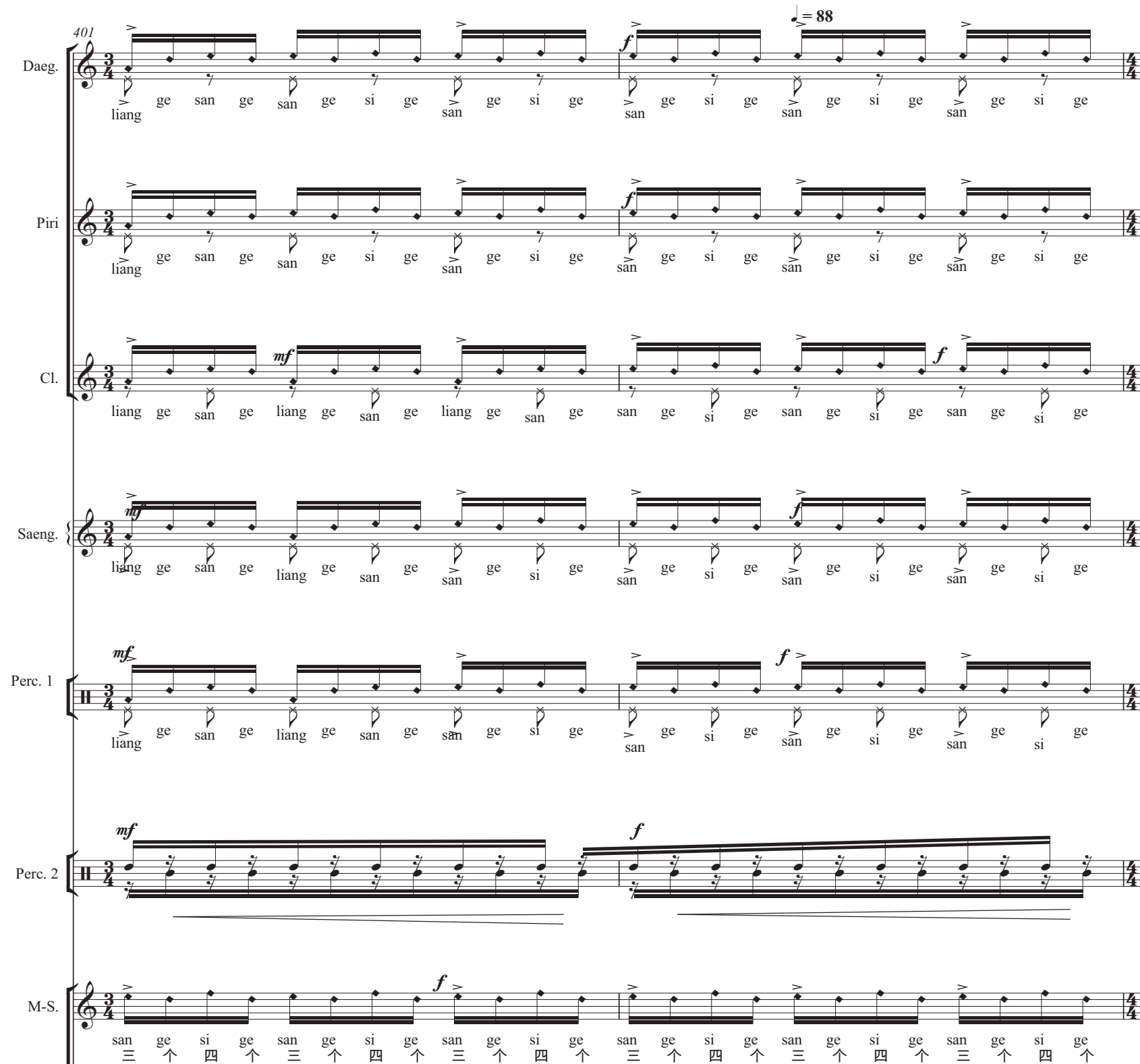
three and four and three and four and three and four and three and four and three and four and three and four and
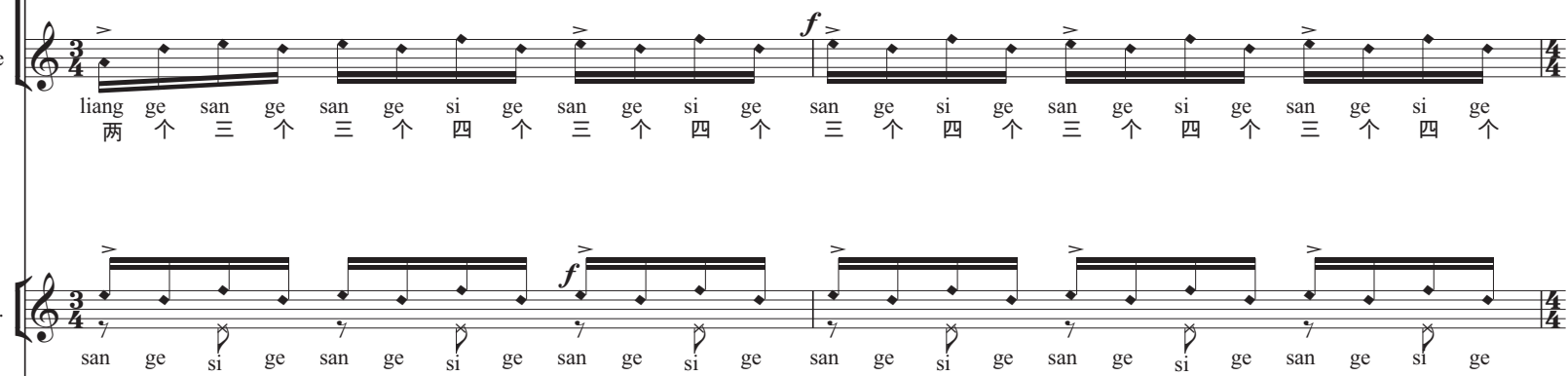

Gayag.
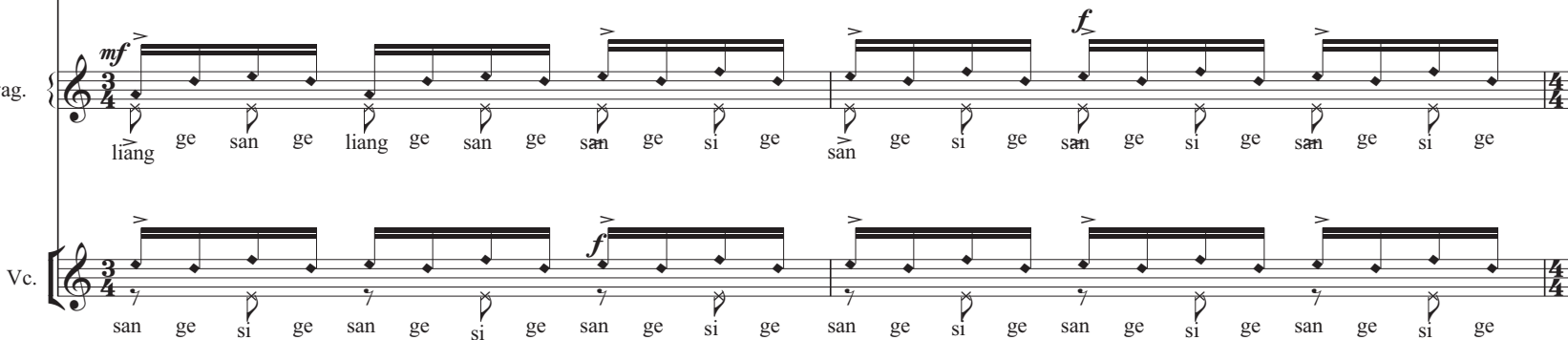


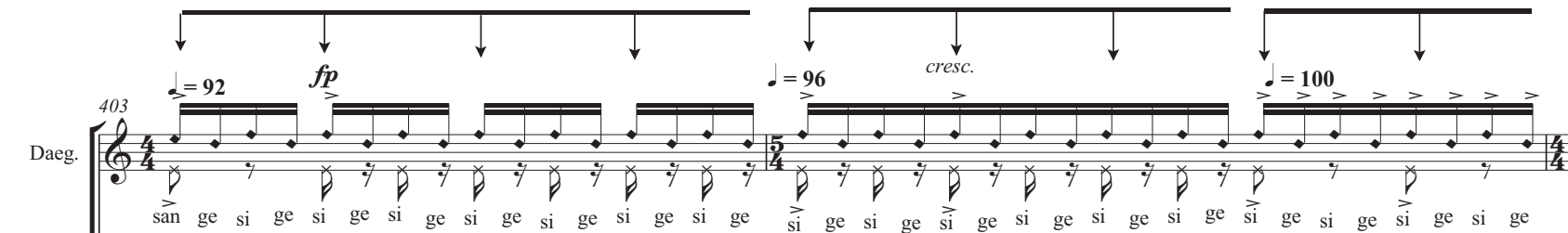

san ge si ge si ge si ge si ge si ge si ge si ge $\overrightarrow{s i}$ ge si ge $\overrightarrow{s i}$ ge si ge si ge si ge $\overrightarrow{\text { si }}$ ge si ge $\overrightarrow{\text { si }}$ ge si ge

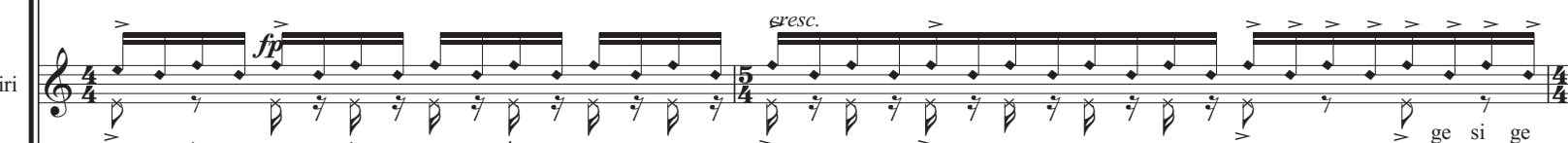

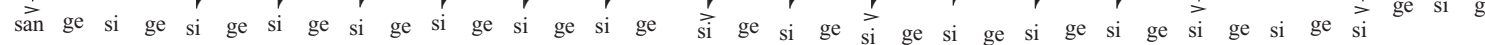

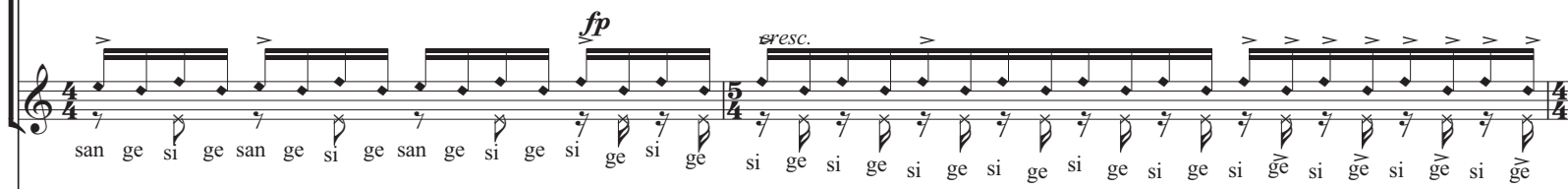

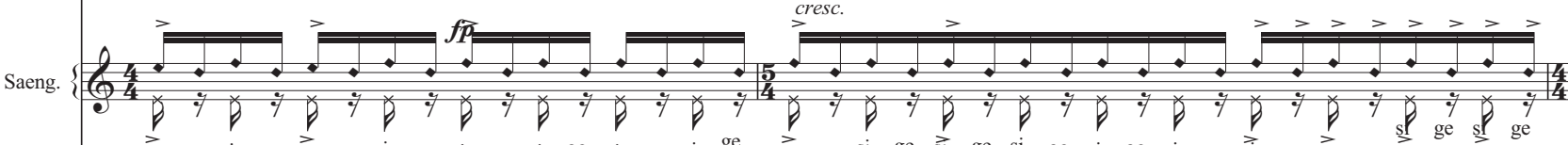
san ge si ge san ge si ge si ge si ge si ge si ge $\overrightarrow{s i}$ ge si ge $\overrightarrow{s i}$ ge si ge si ge si ge $\overrightarrow{s i}$ ge $\overrightarrow{\text { si }}$ ge

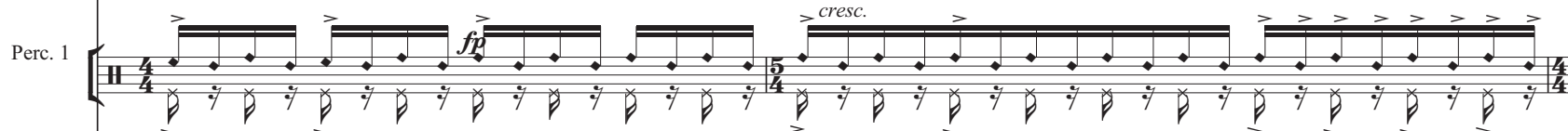

san ge si ge san ge si ge si ge si ge si ge si ge $\overrightarrow{s i}$ ge si ge $\overrightarrow{s i}$ ge si ge si ge si ge $\overrightarrow{\text { si }}$ ge $\overrightarrow{\text { si }}$ ge $\overrightarrow{\text { si }}$ ge $\overrightarrow{\text { si }}$ ge

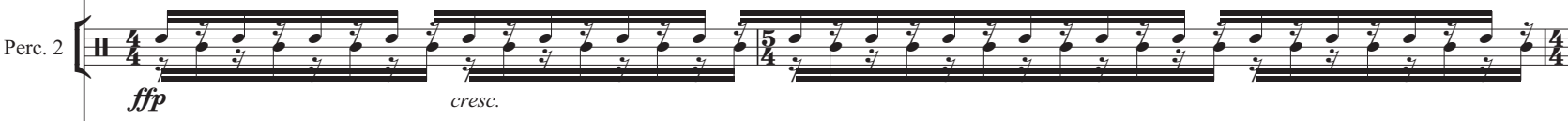

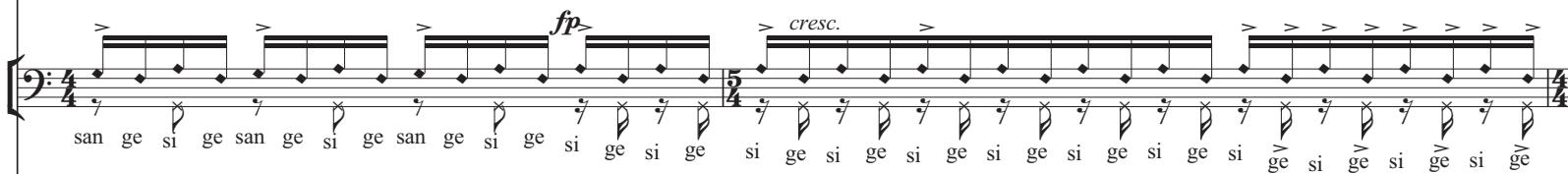
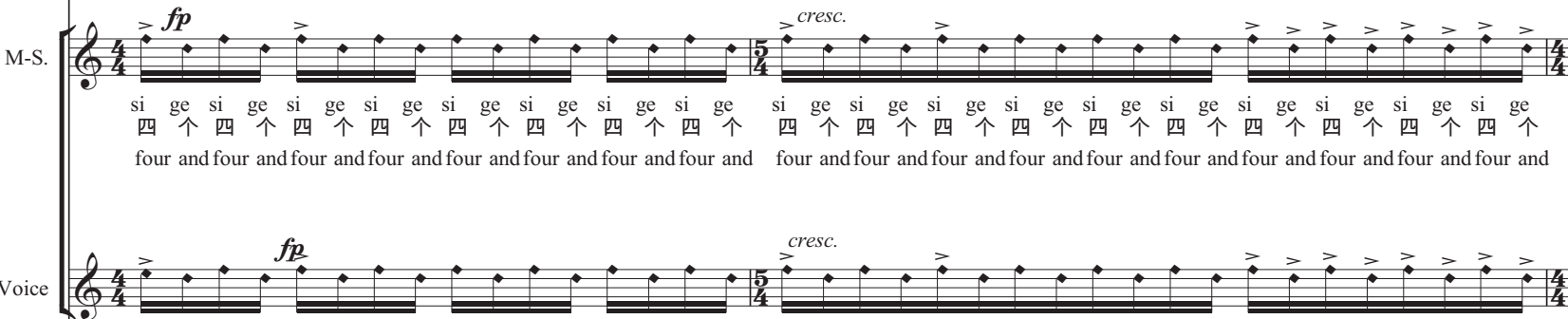

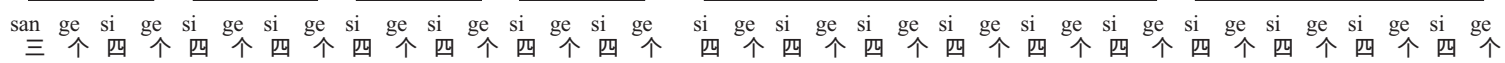

Guit.

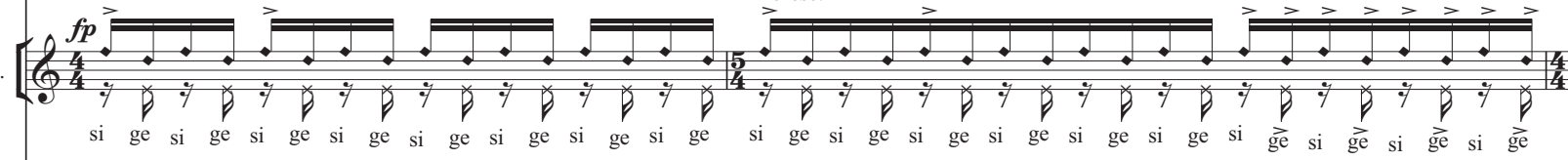

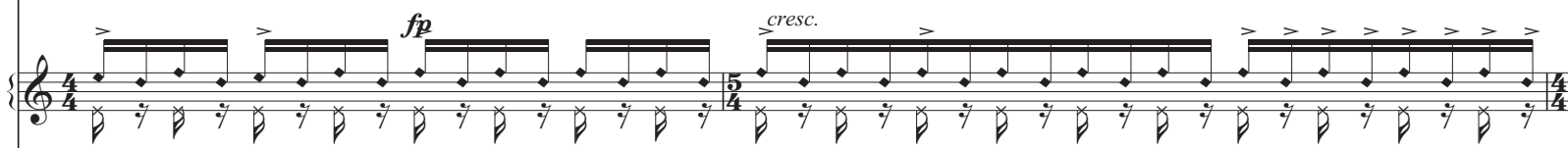
săn ge si ge san ge si ge si ge si ge si ge si ge $\overrightarrow{s i}$ ge si ge $\overrightarrow{s i}$ ge si ge si ge si ge $\overrightarrow{s i}$ ge $\overrightarrow{s i}$ ge $\overrightarrow{s i}$ ge $\overrightarrow{s i}$ ge

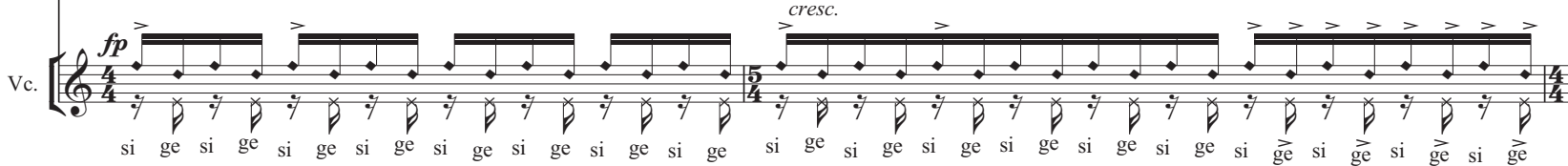



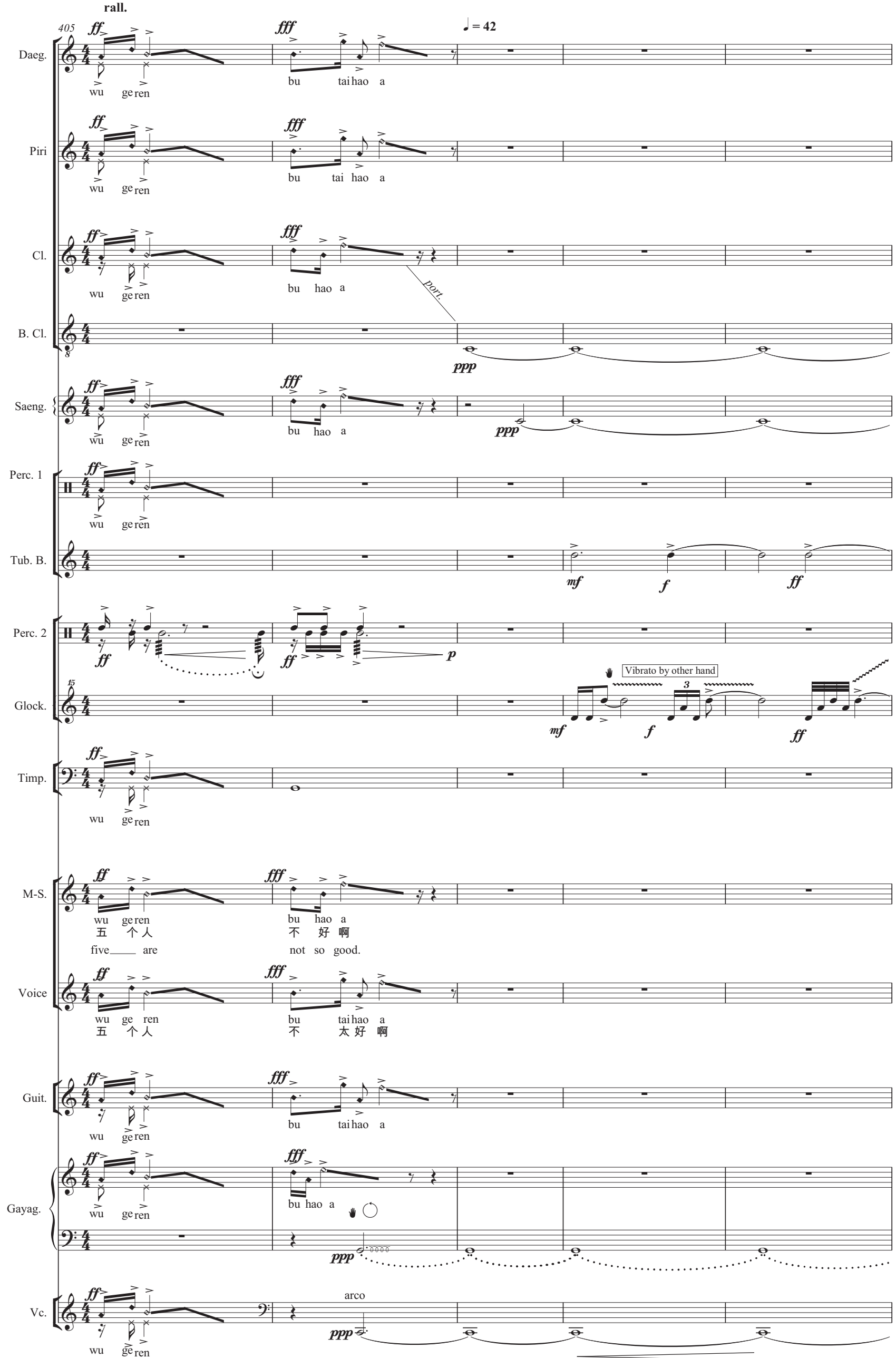


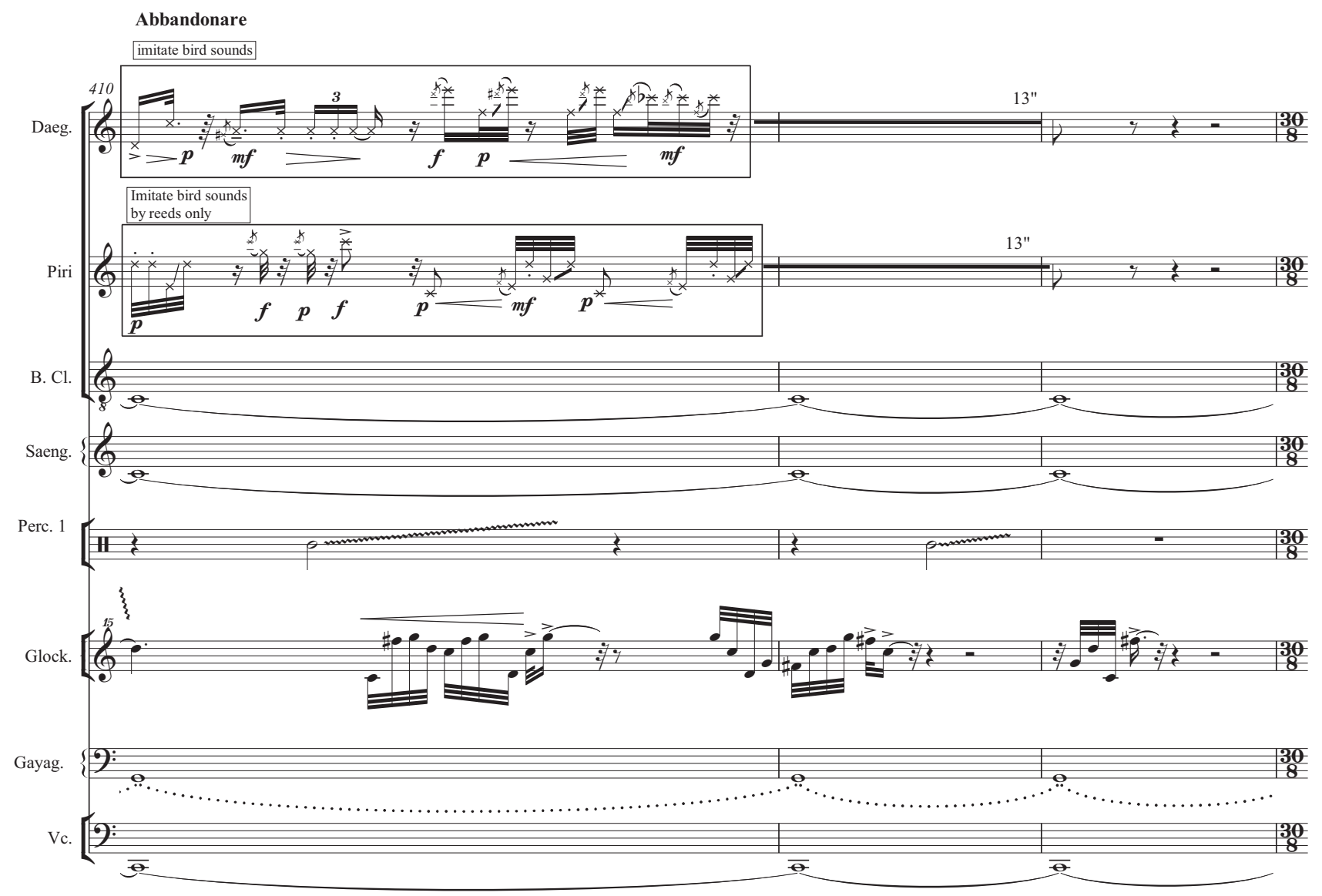

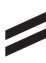

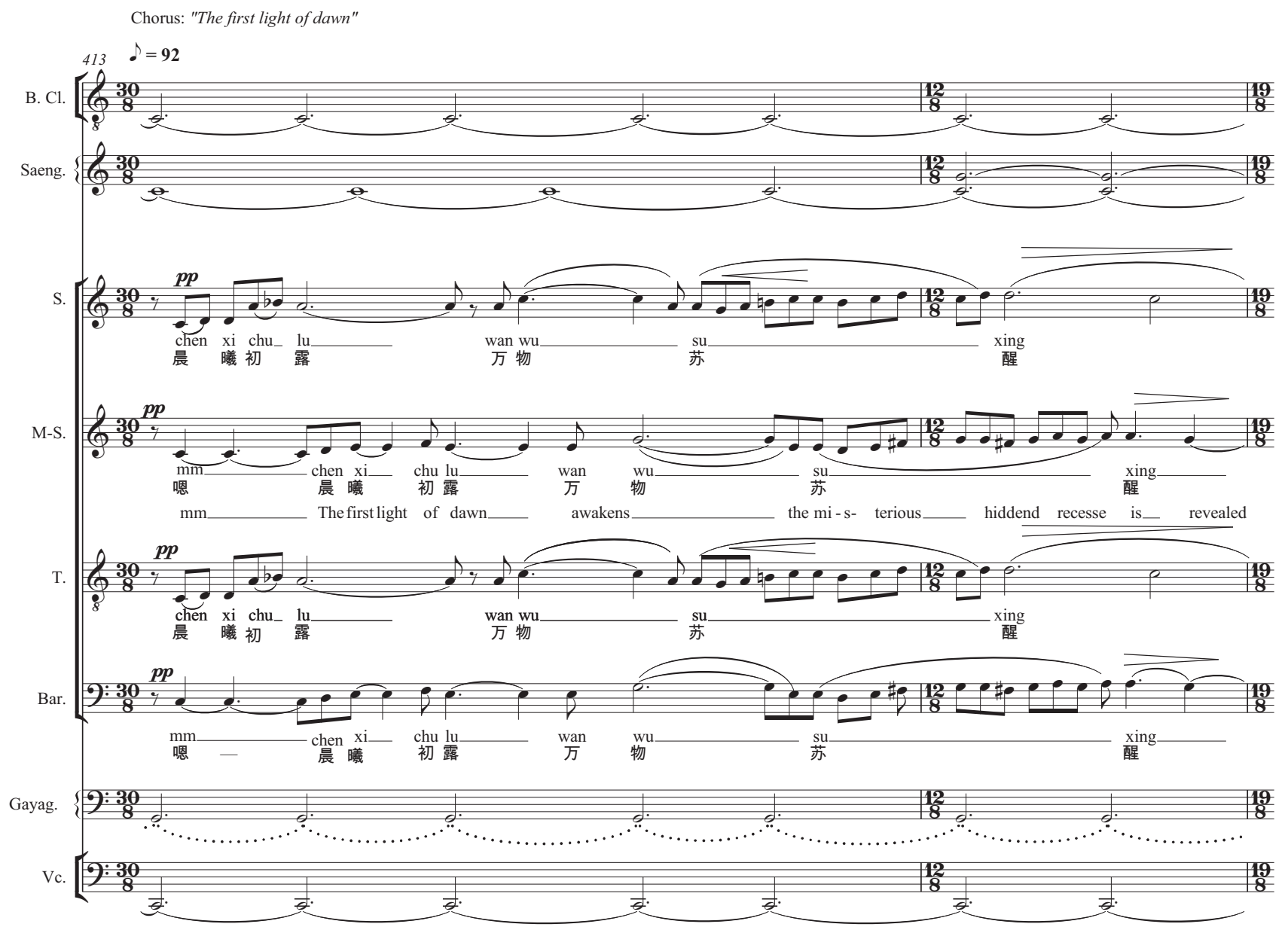



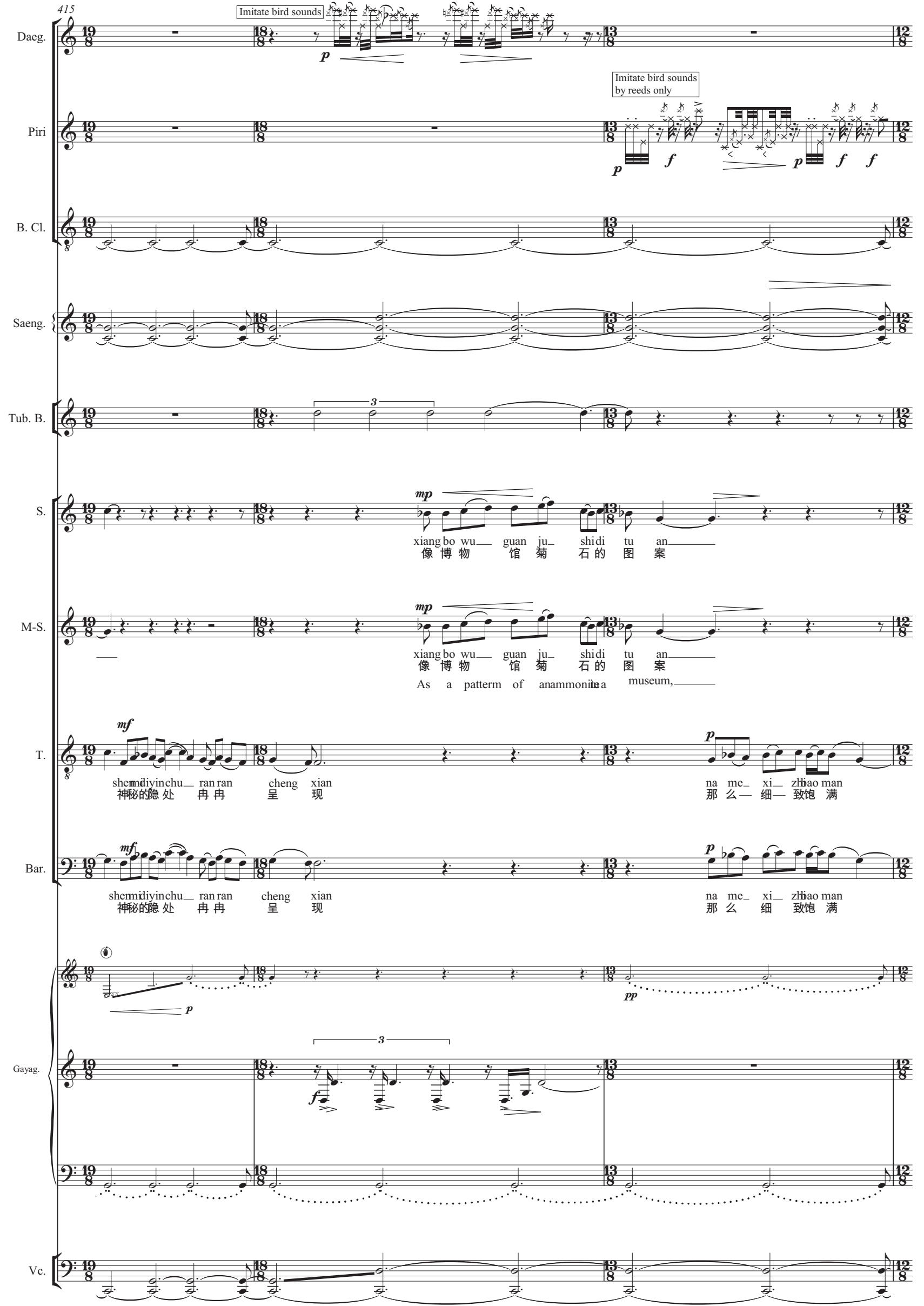


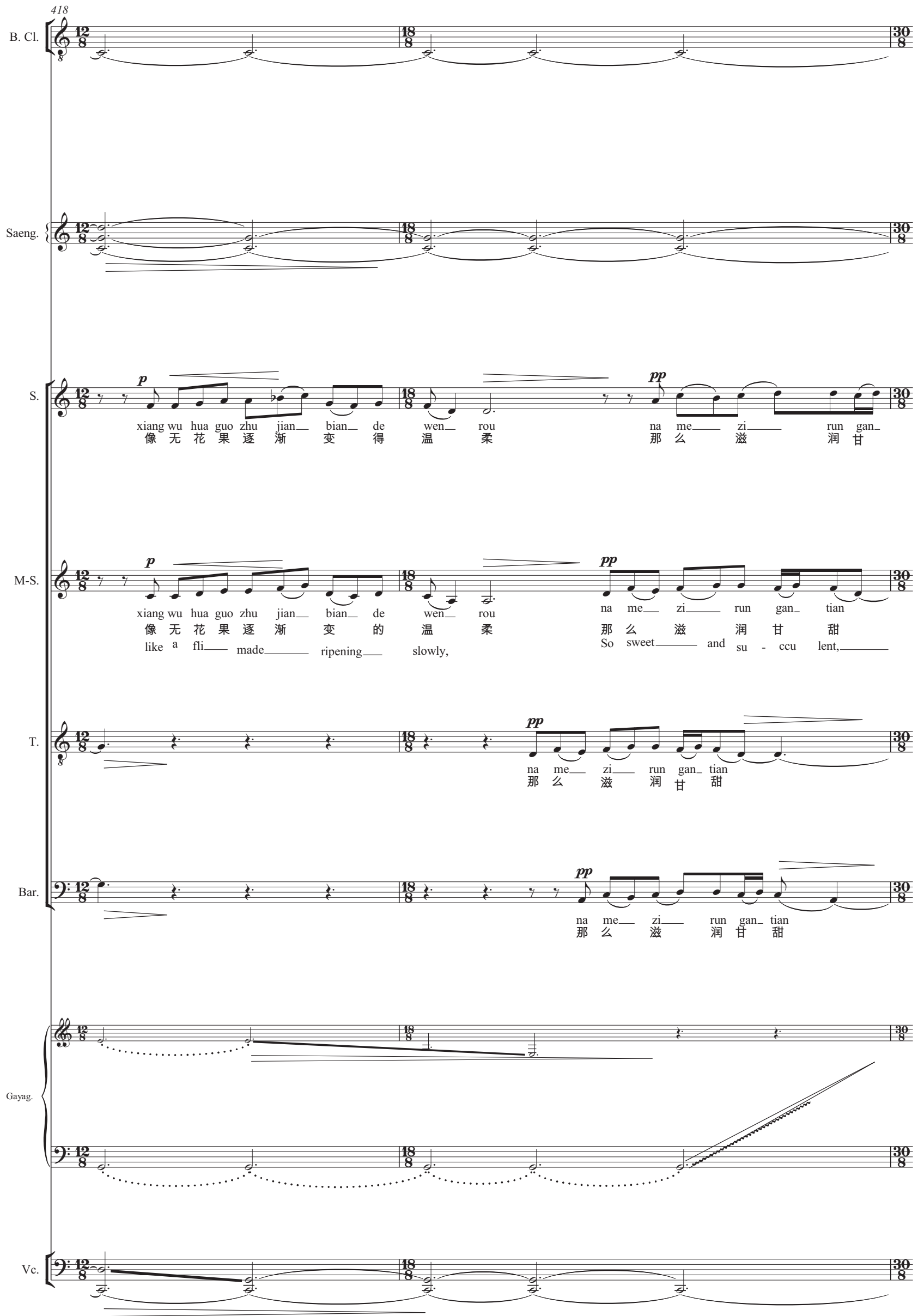




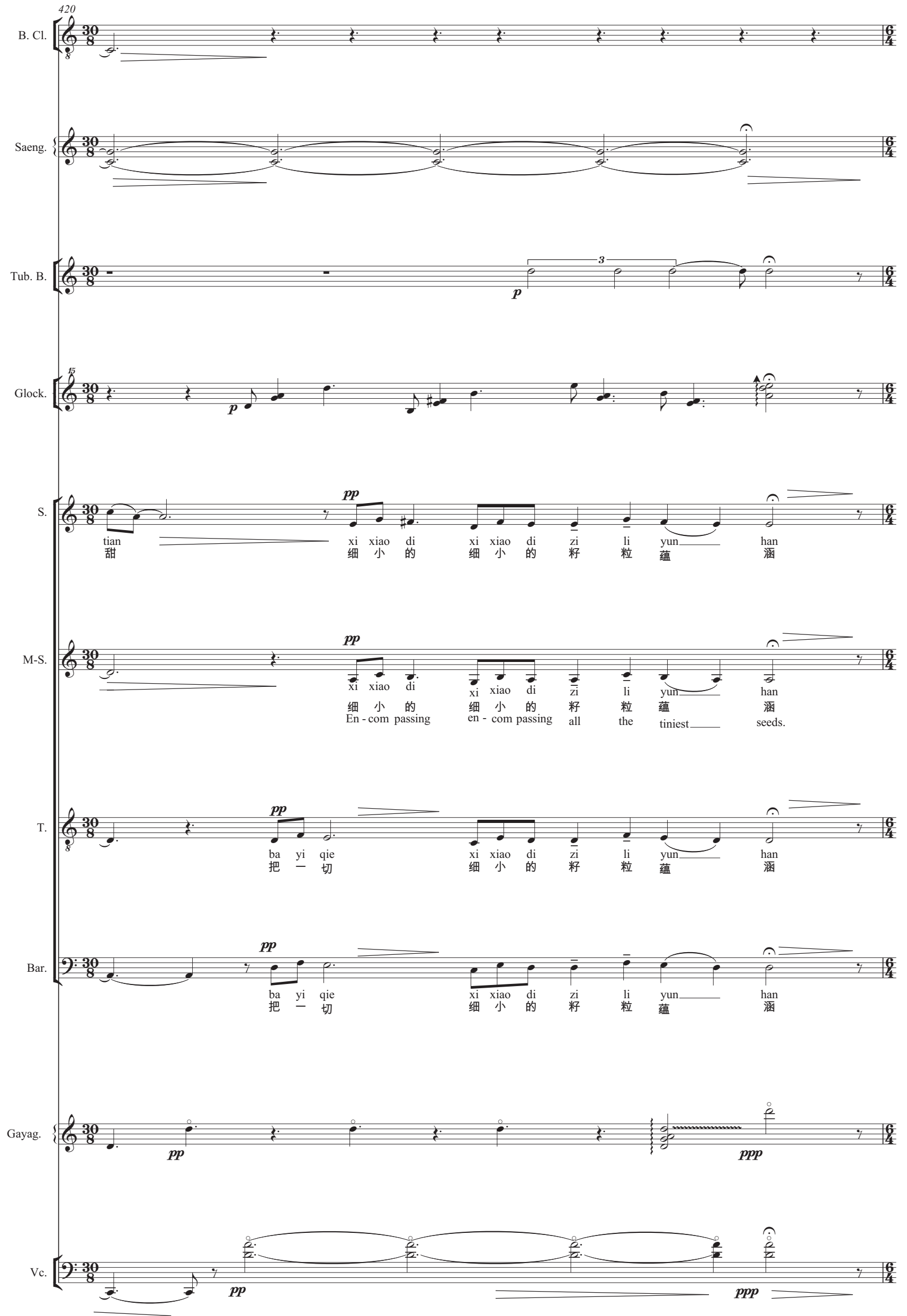




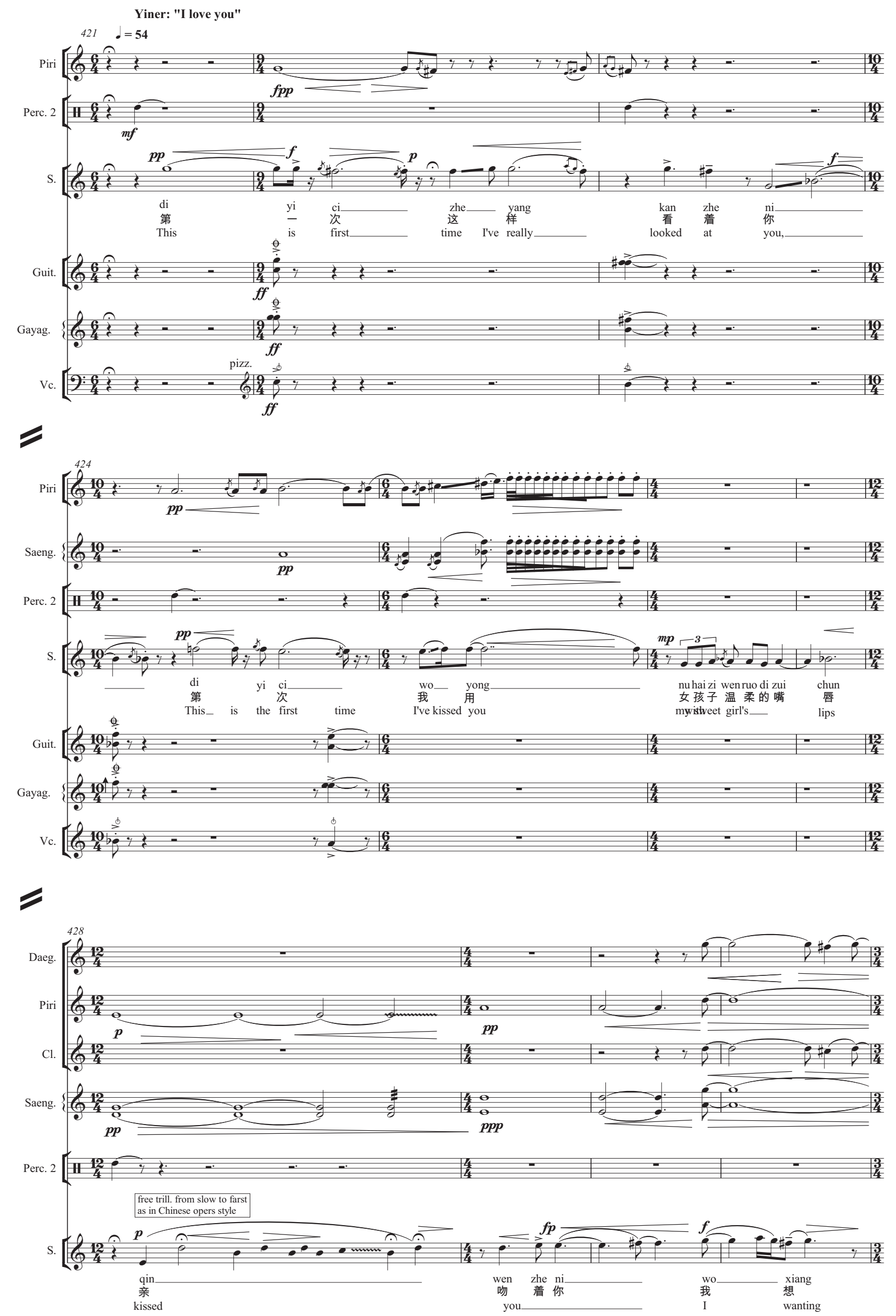



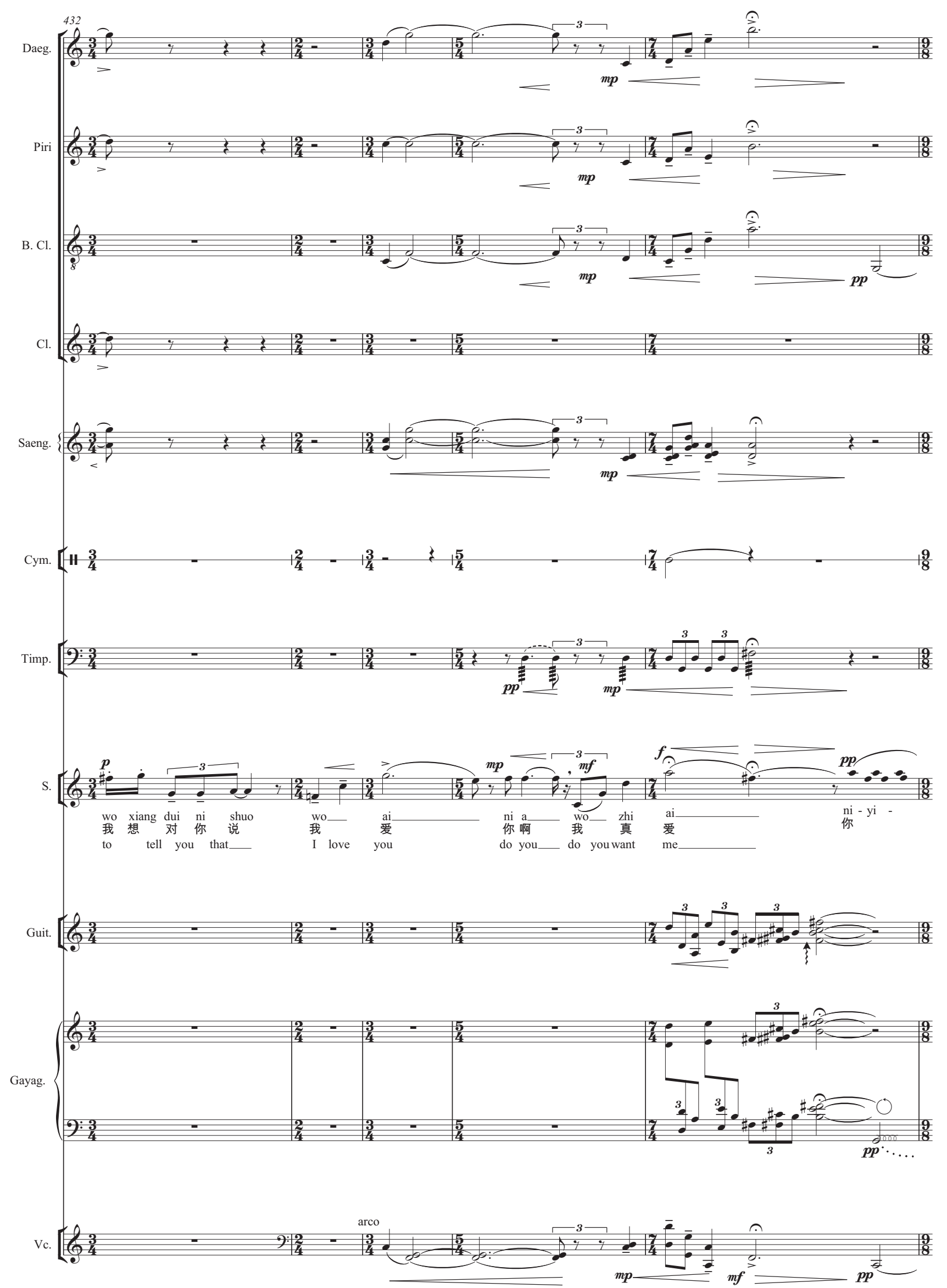


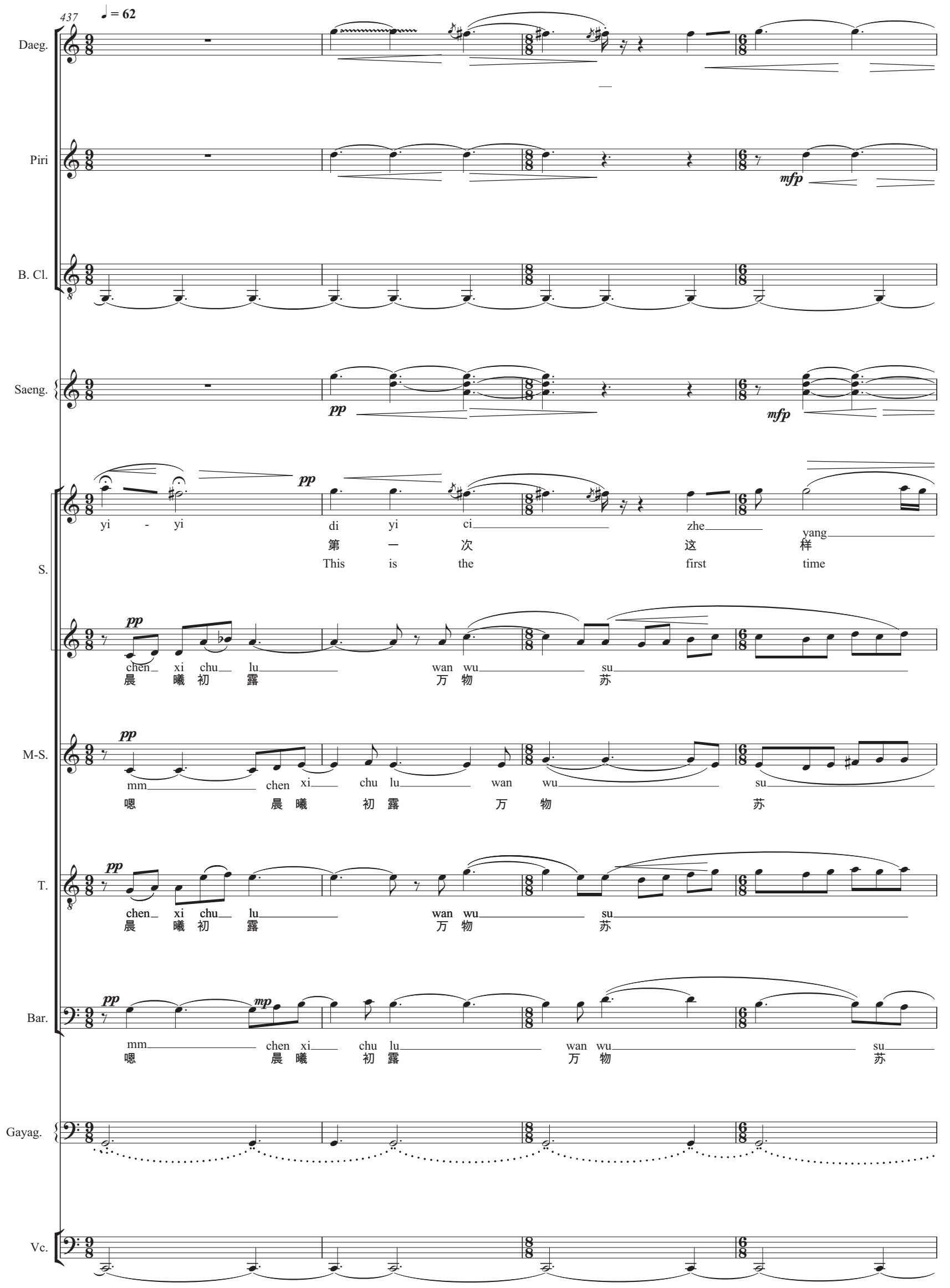



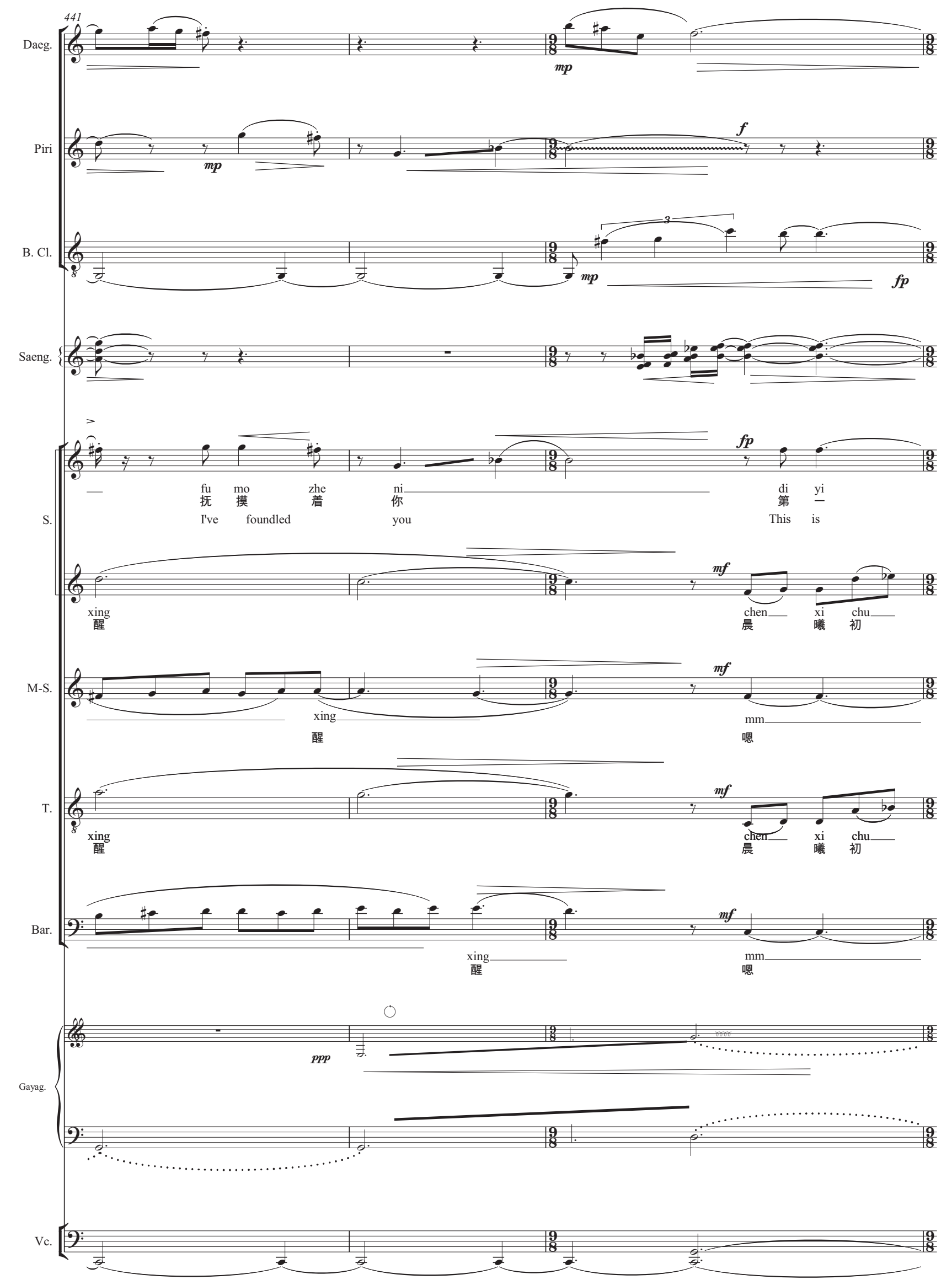

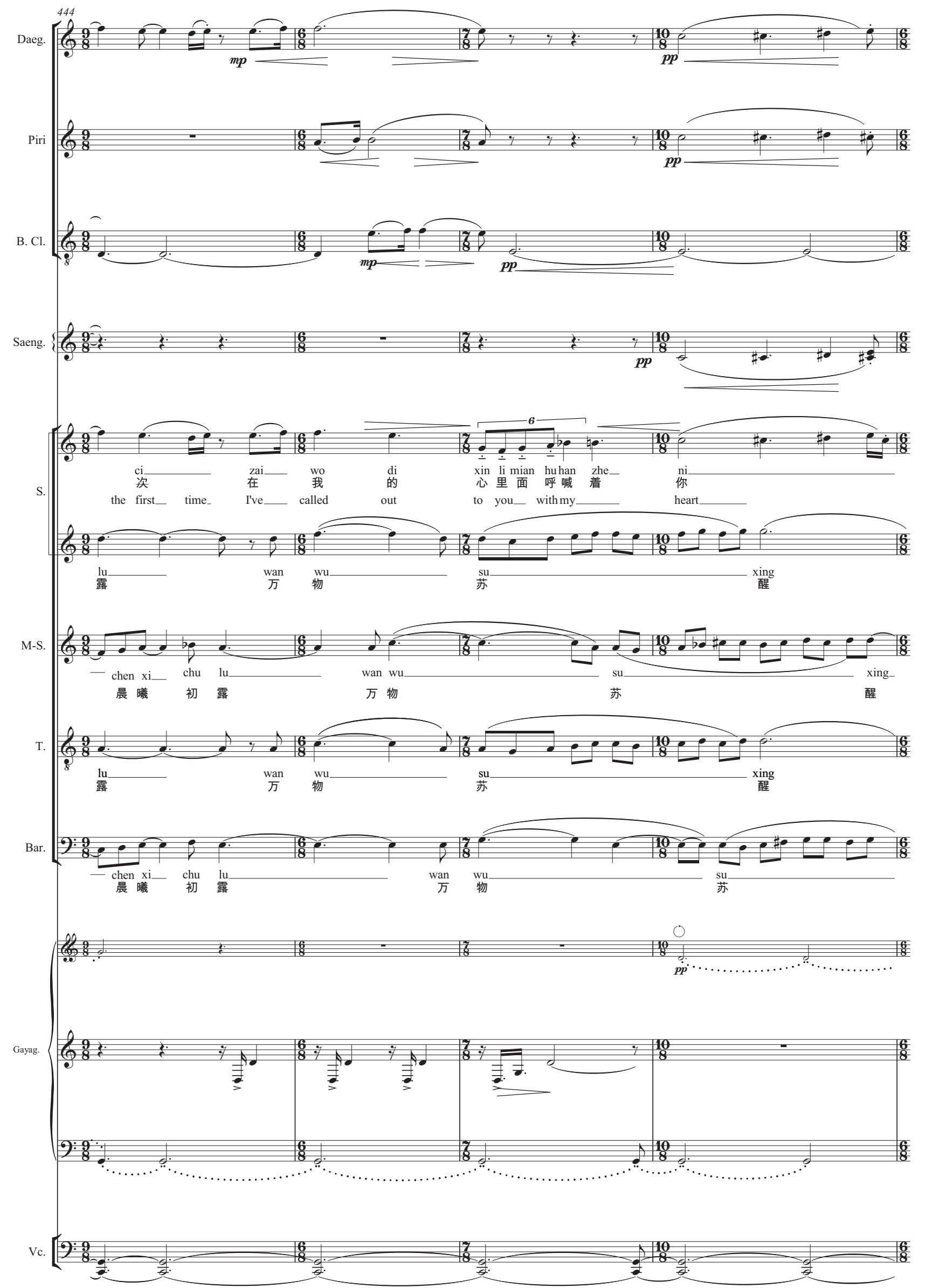

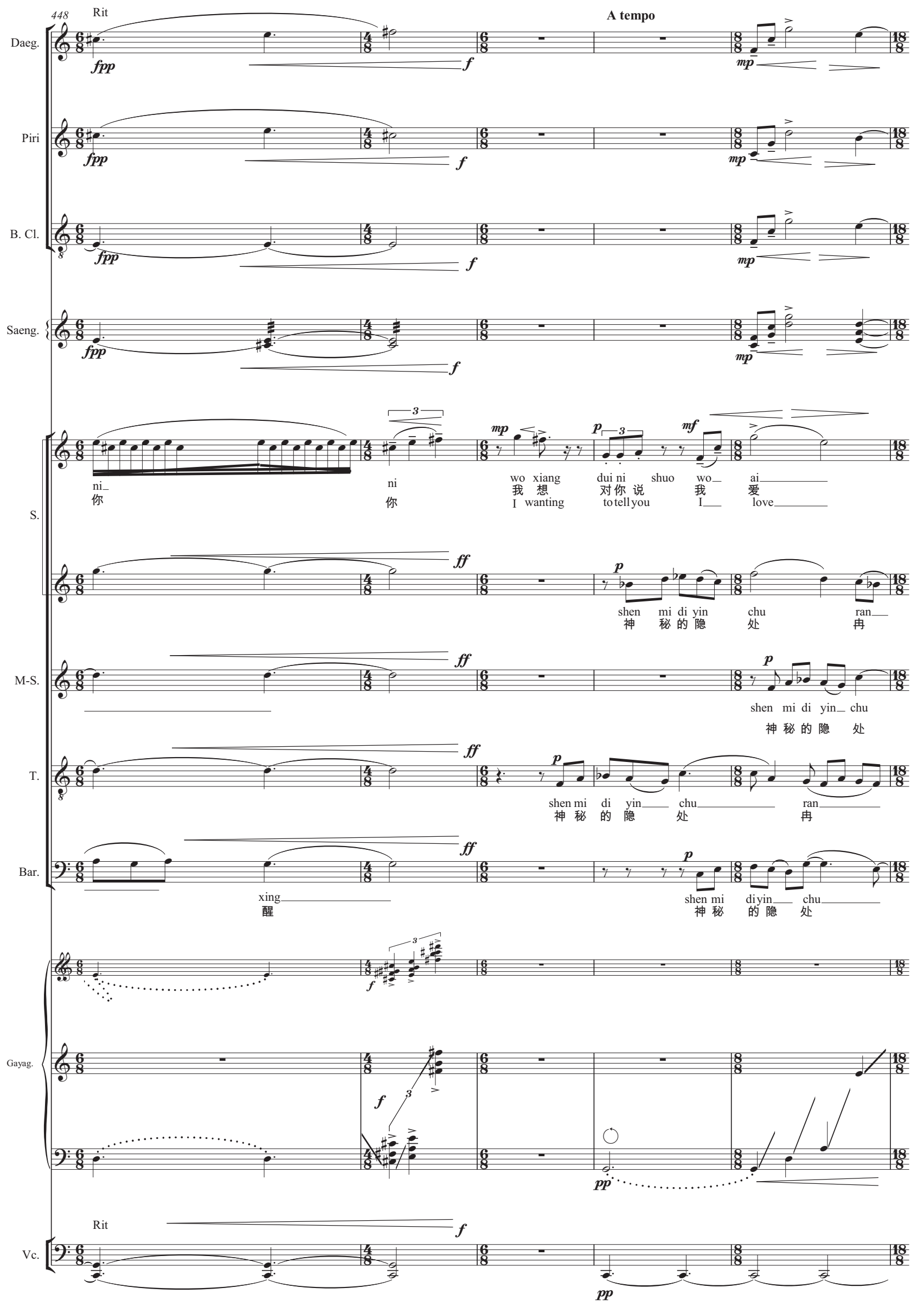


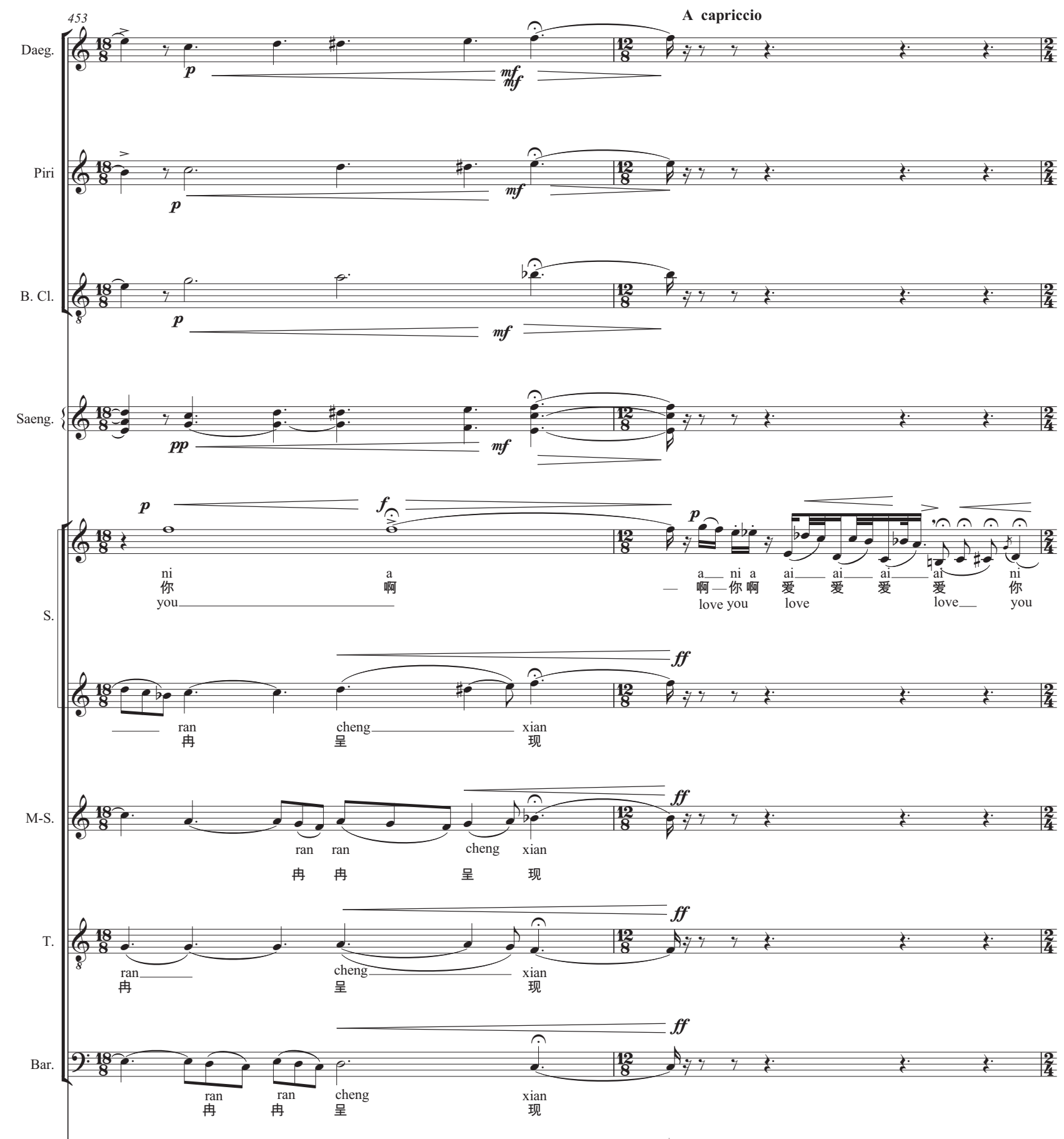

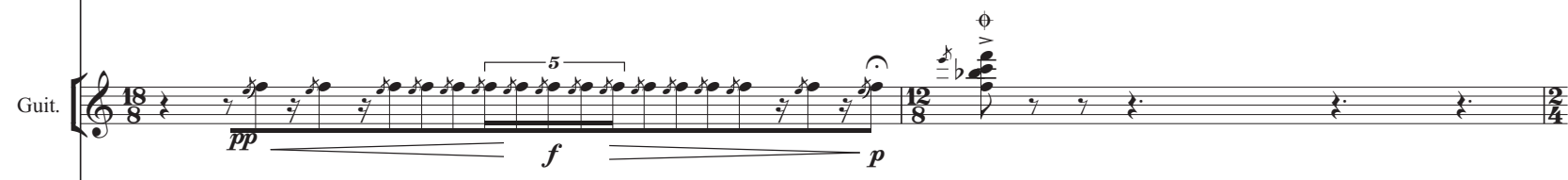

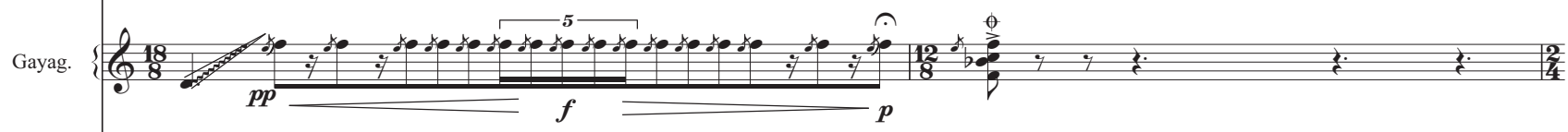

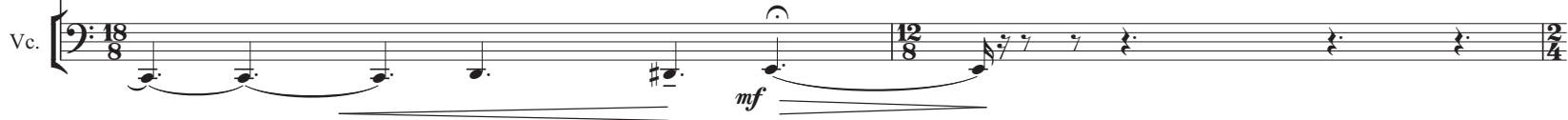



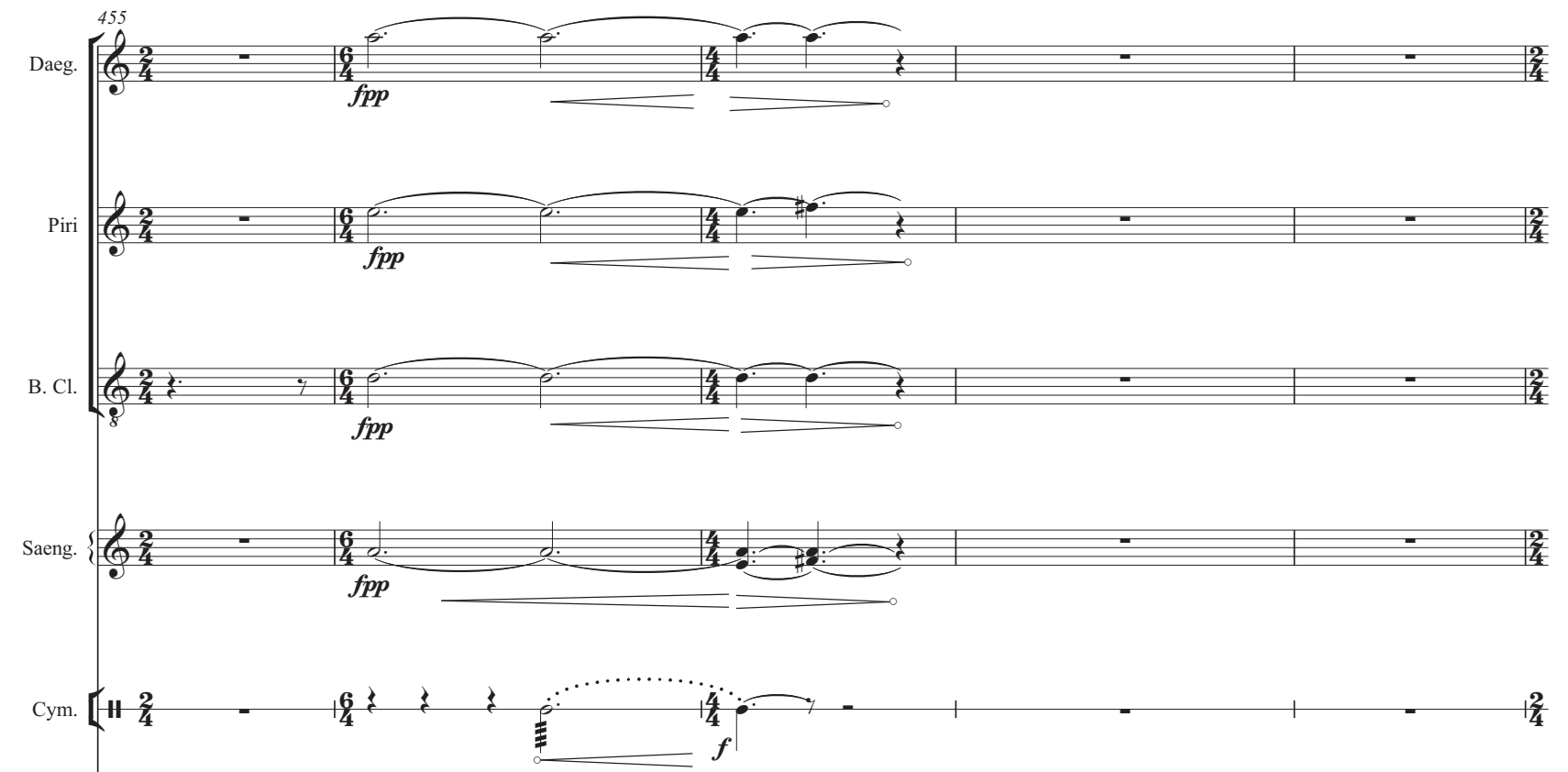

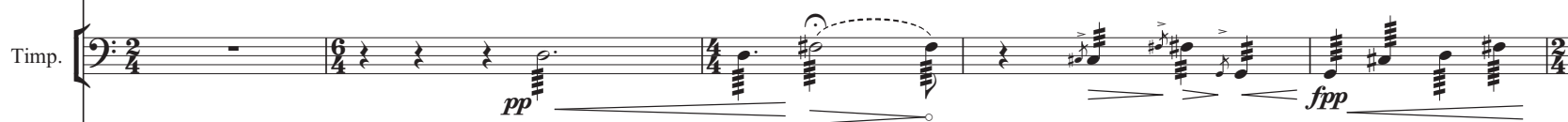

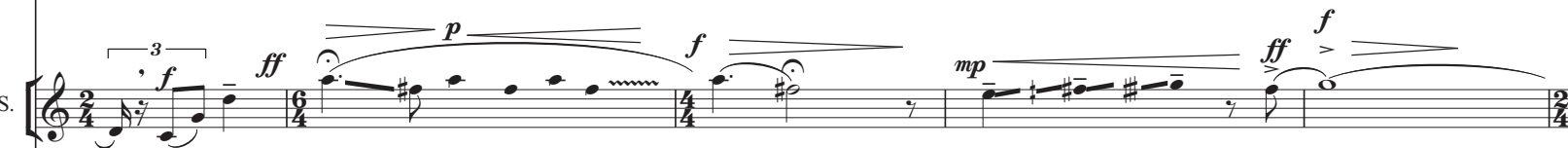
ni_-
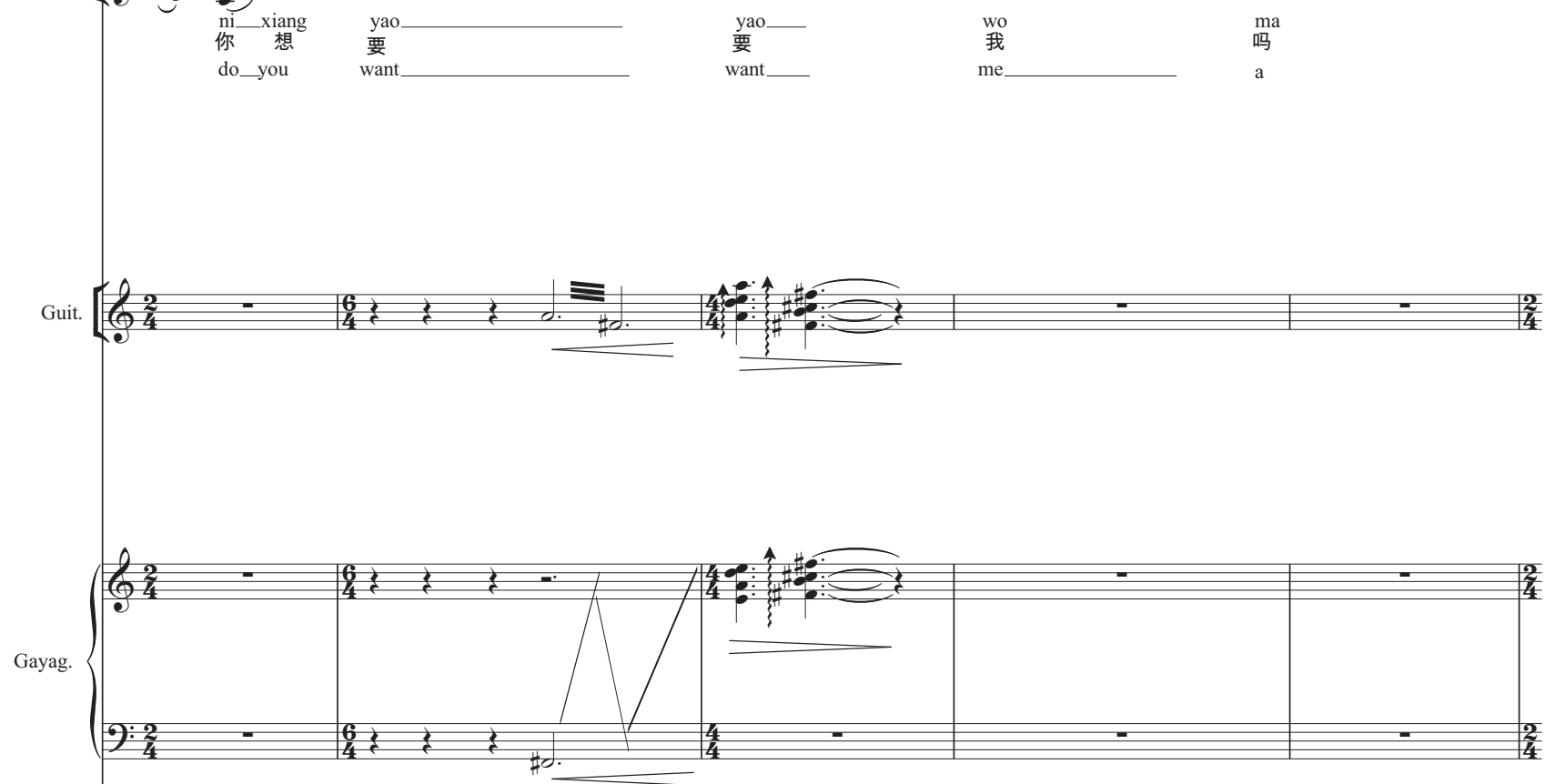

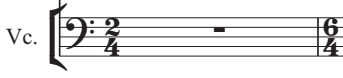

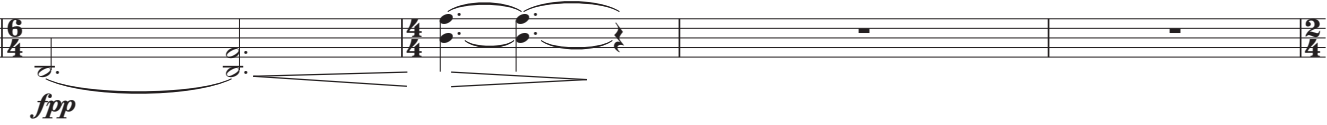




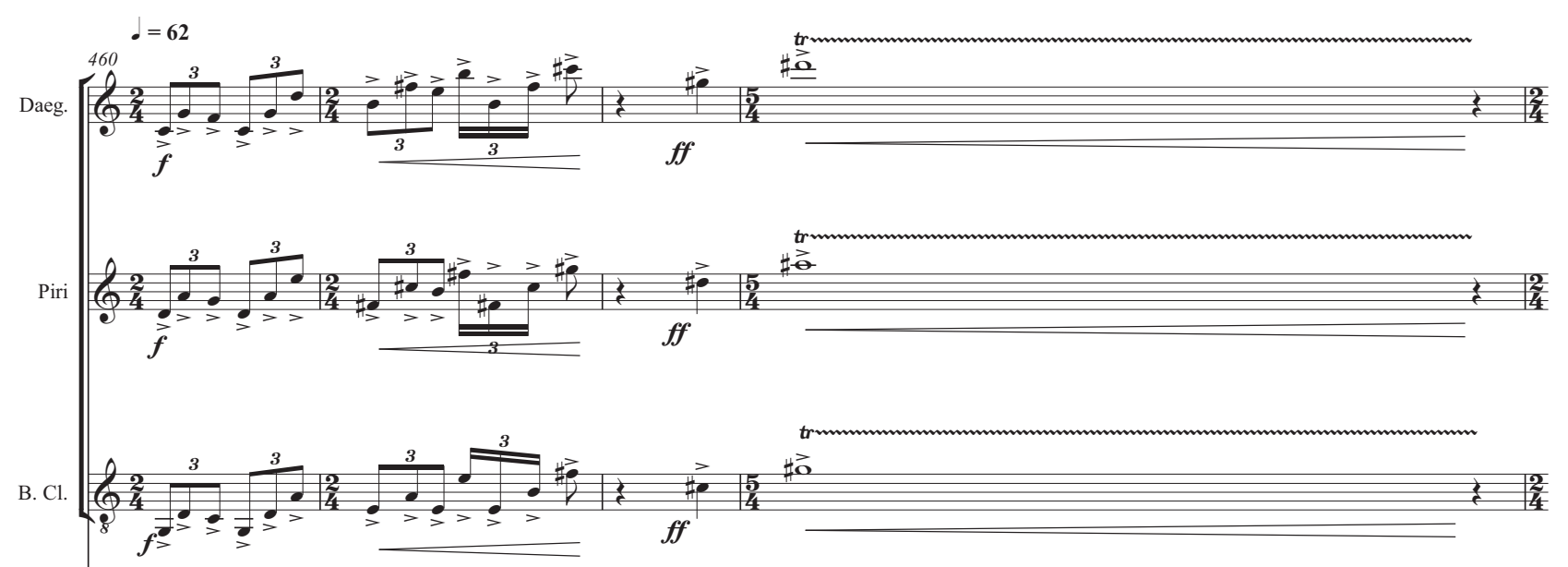

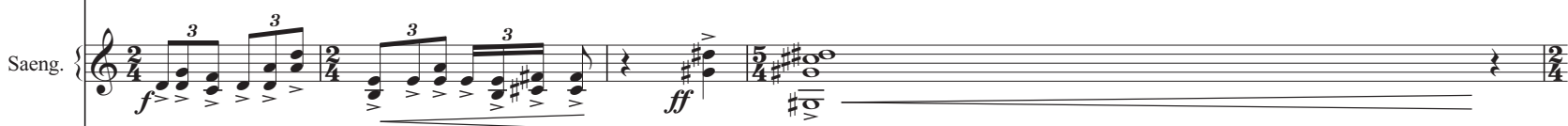

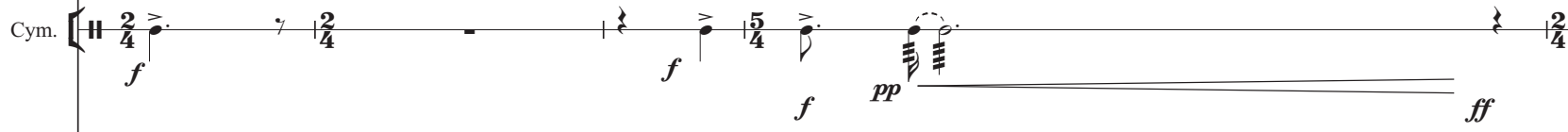

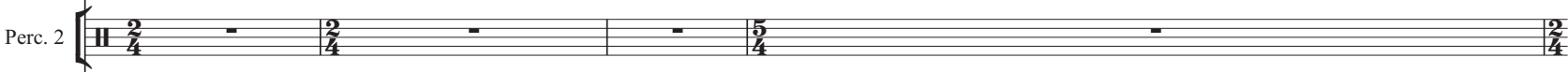

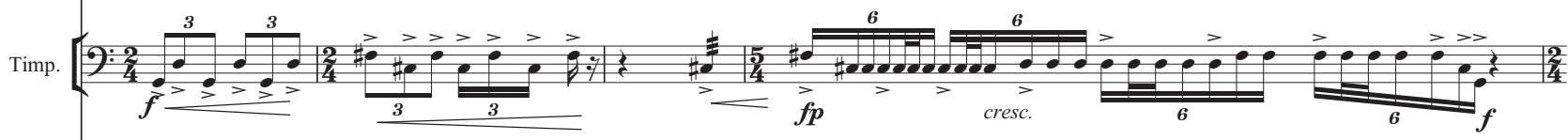

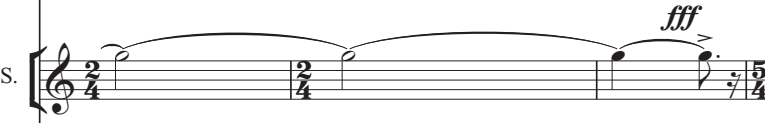

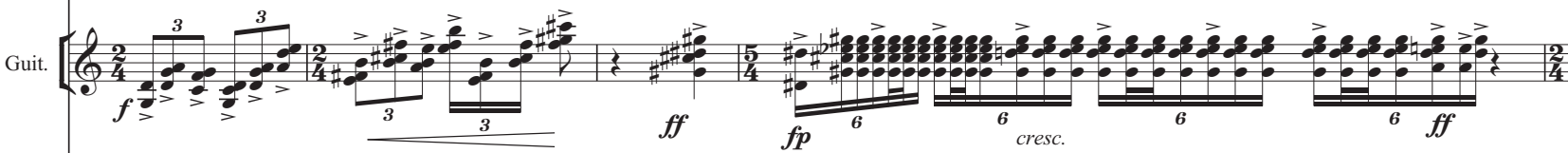

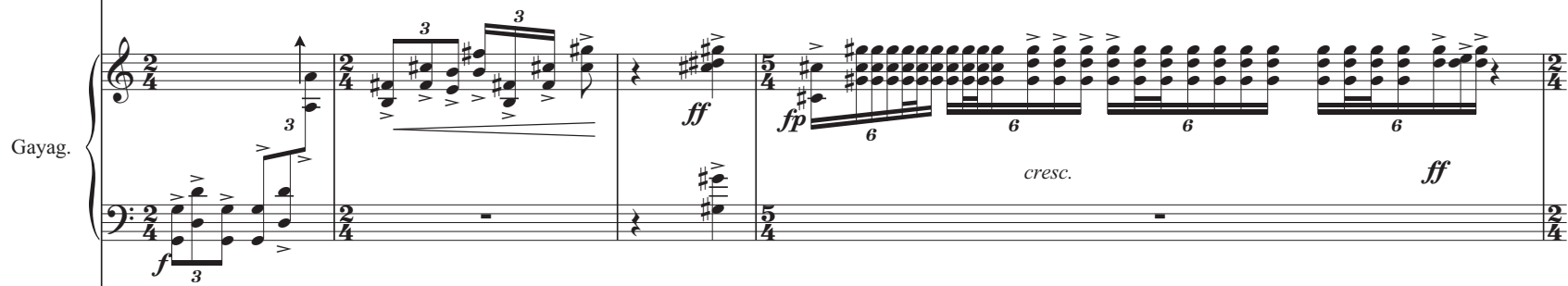

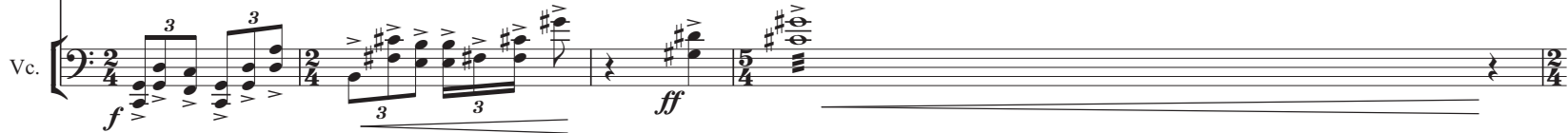




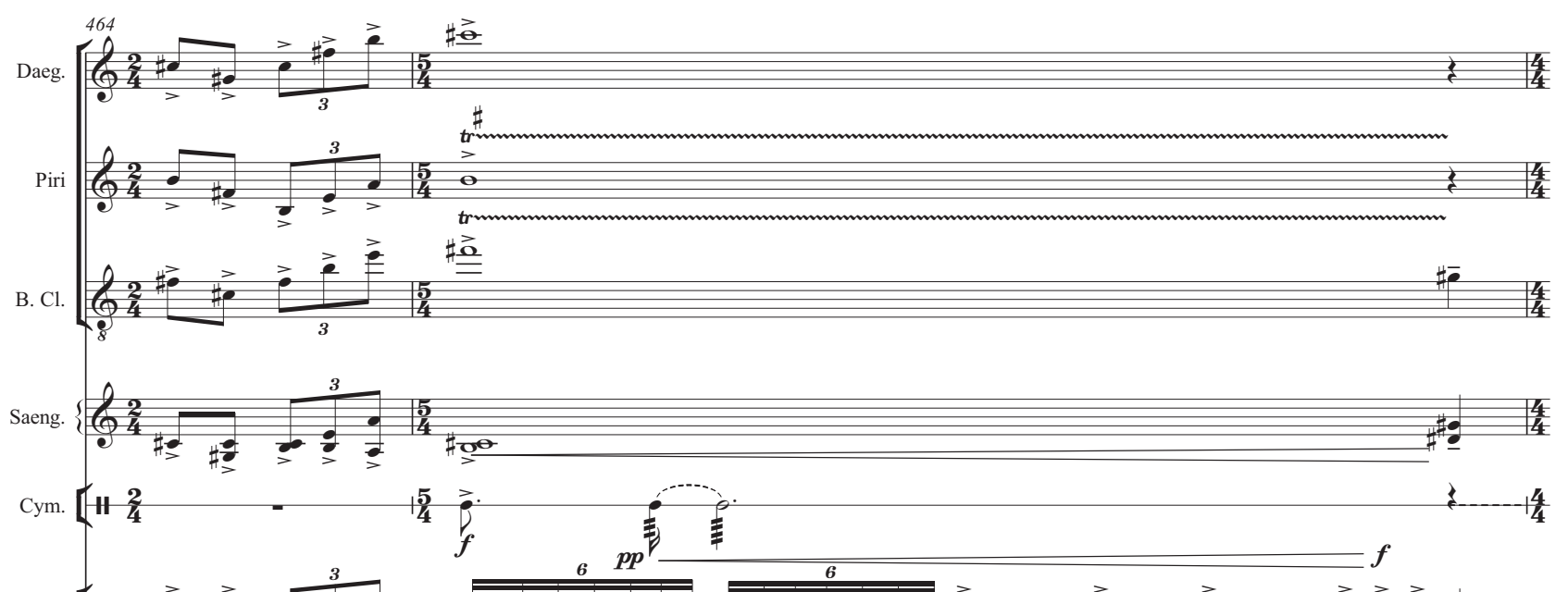

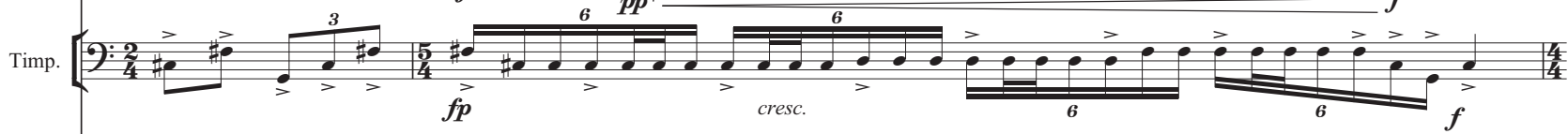

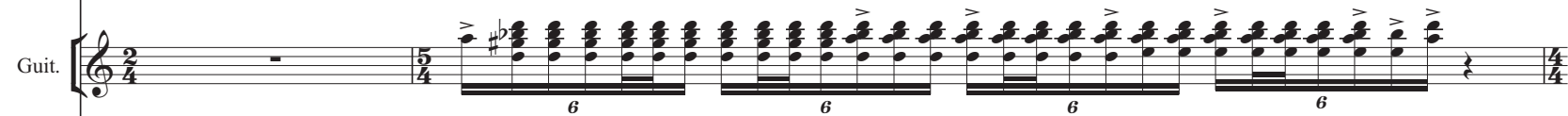

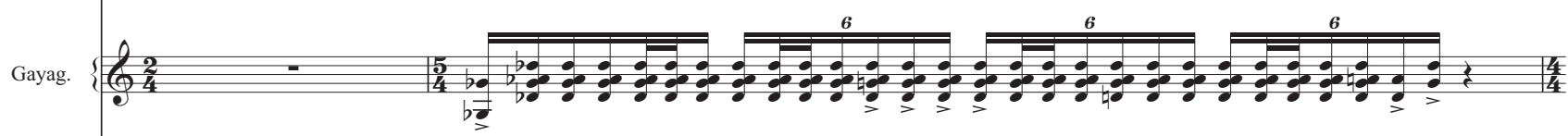

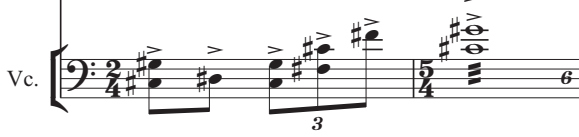

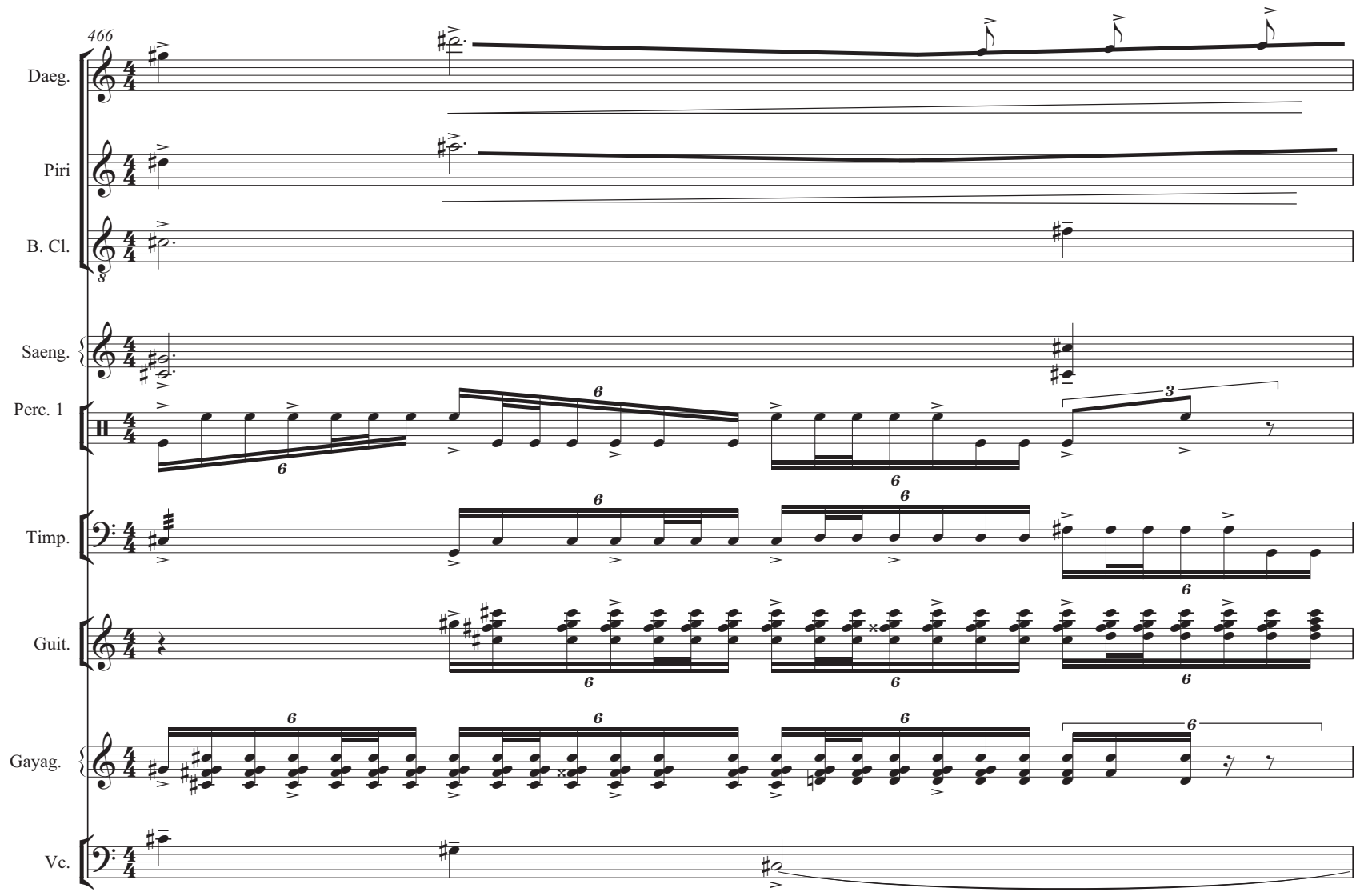



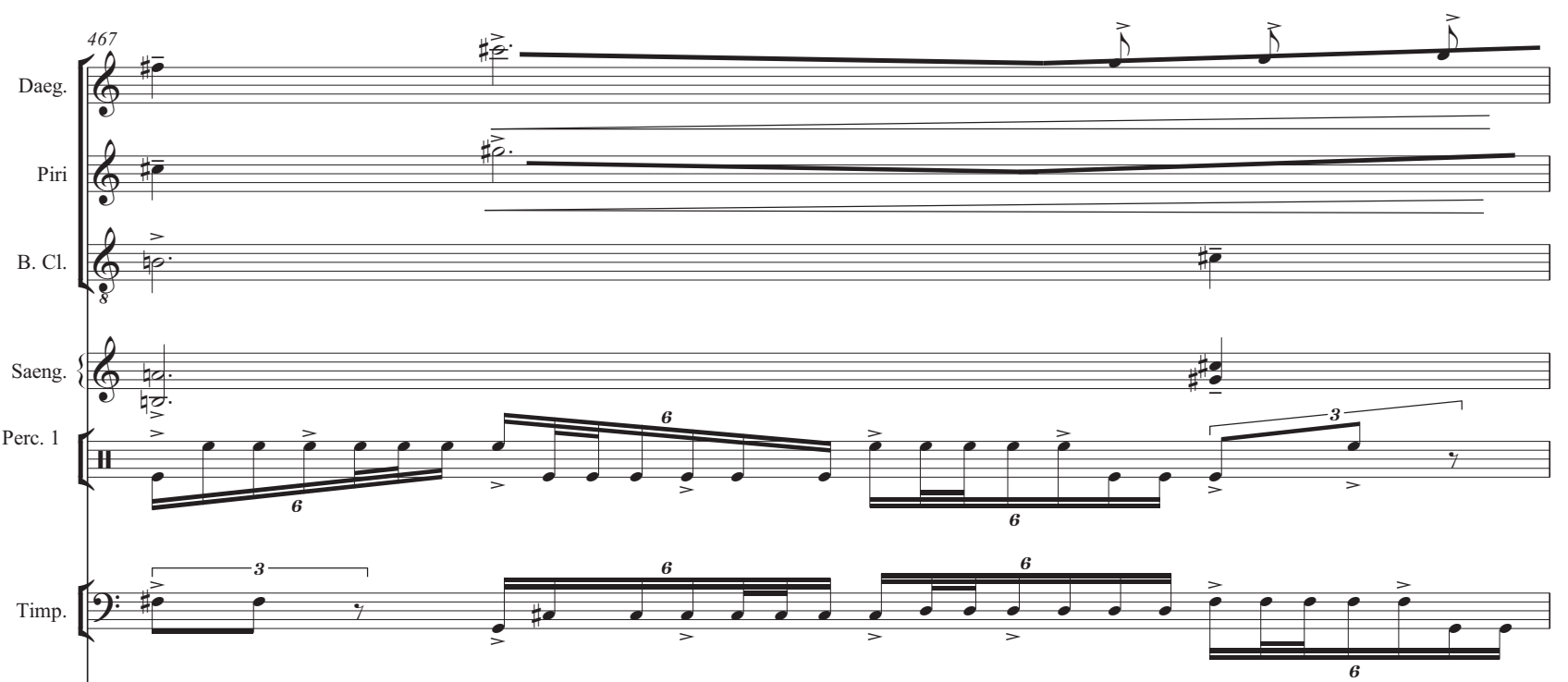

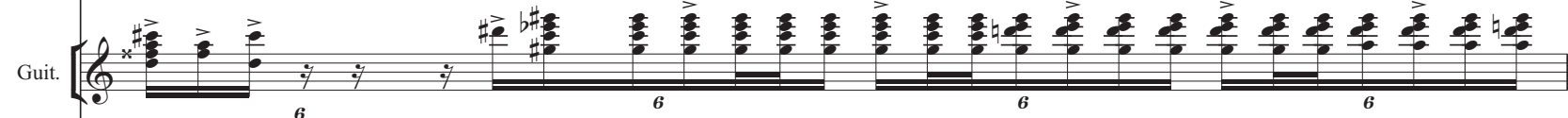

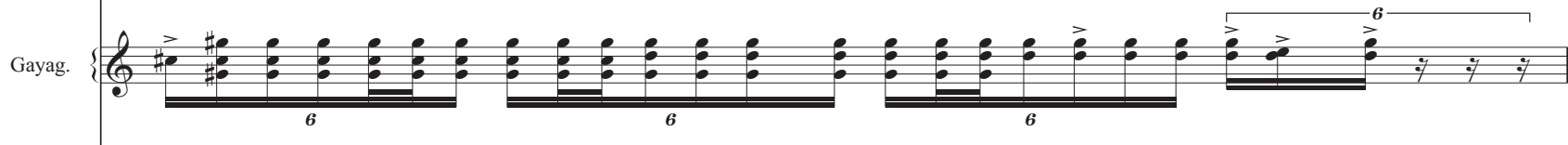
v.

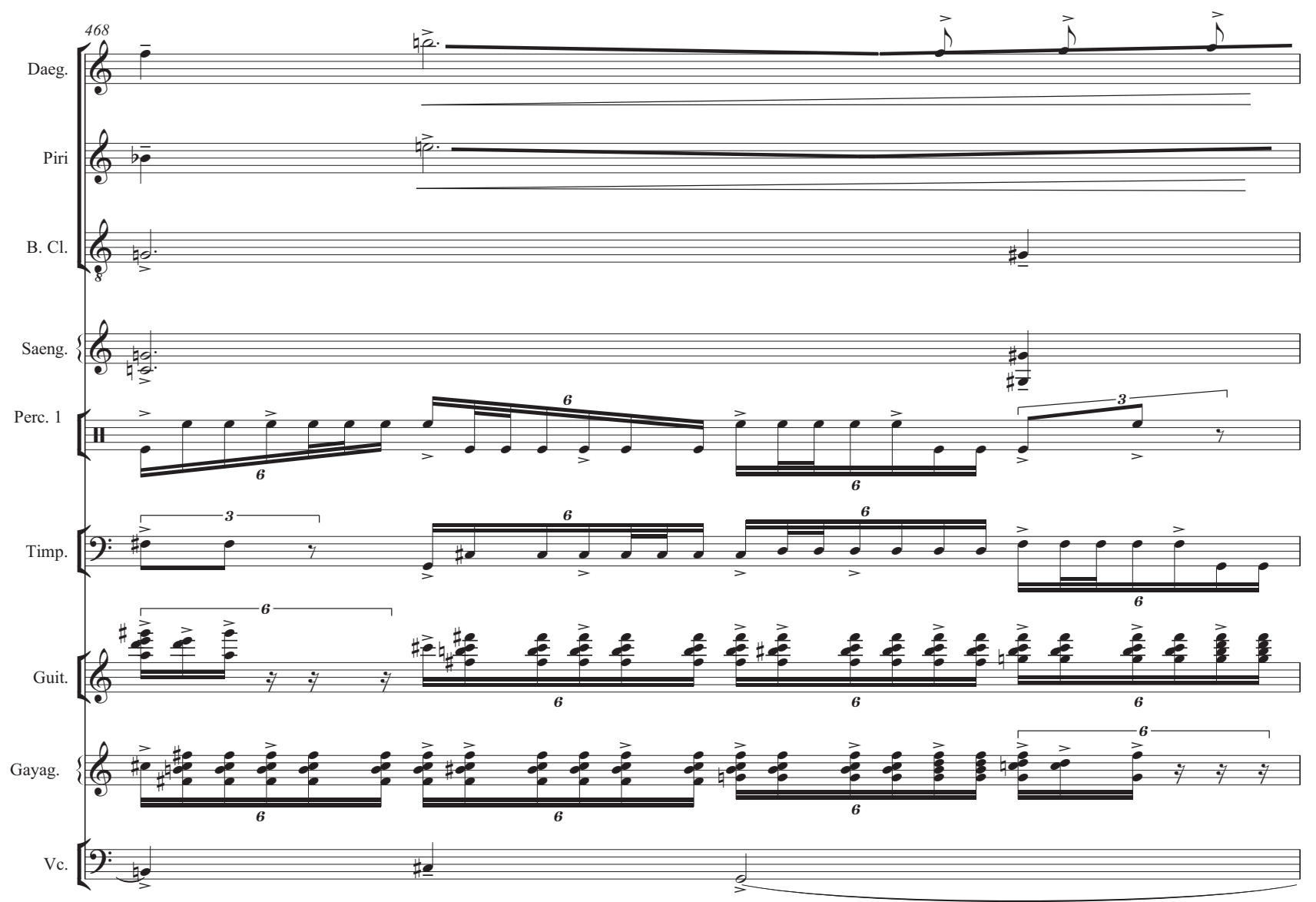




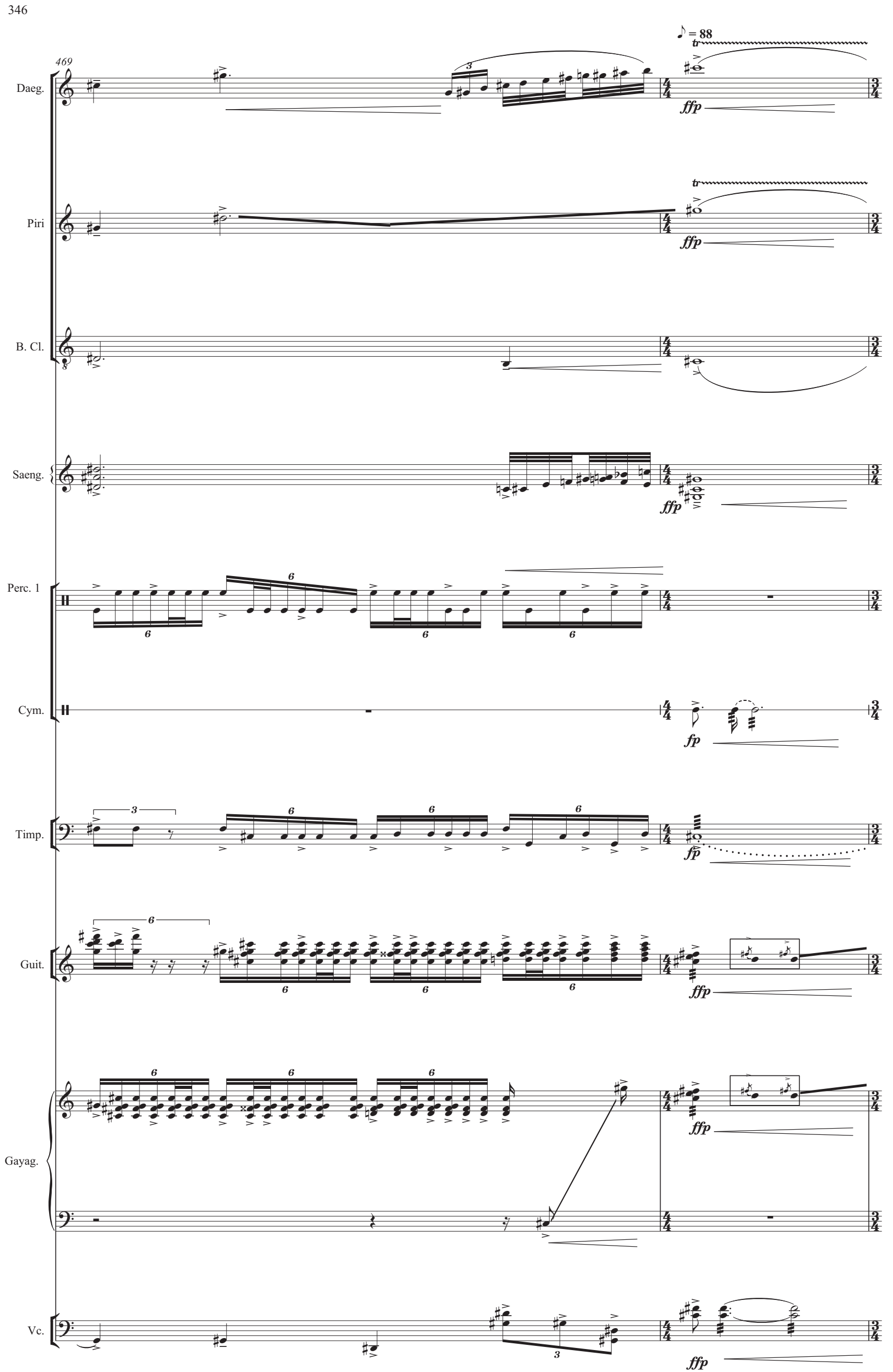



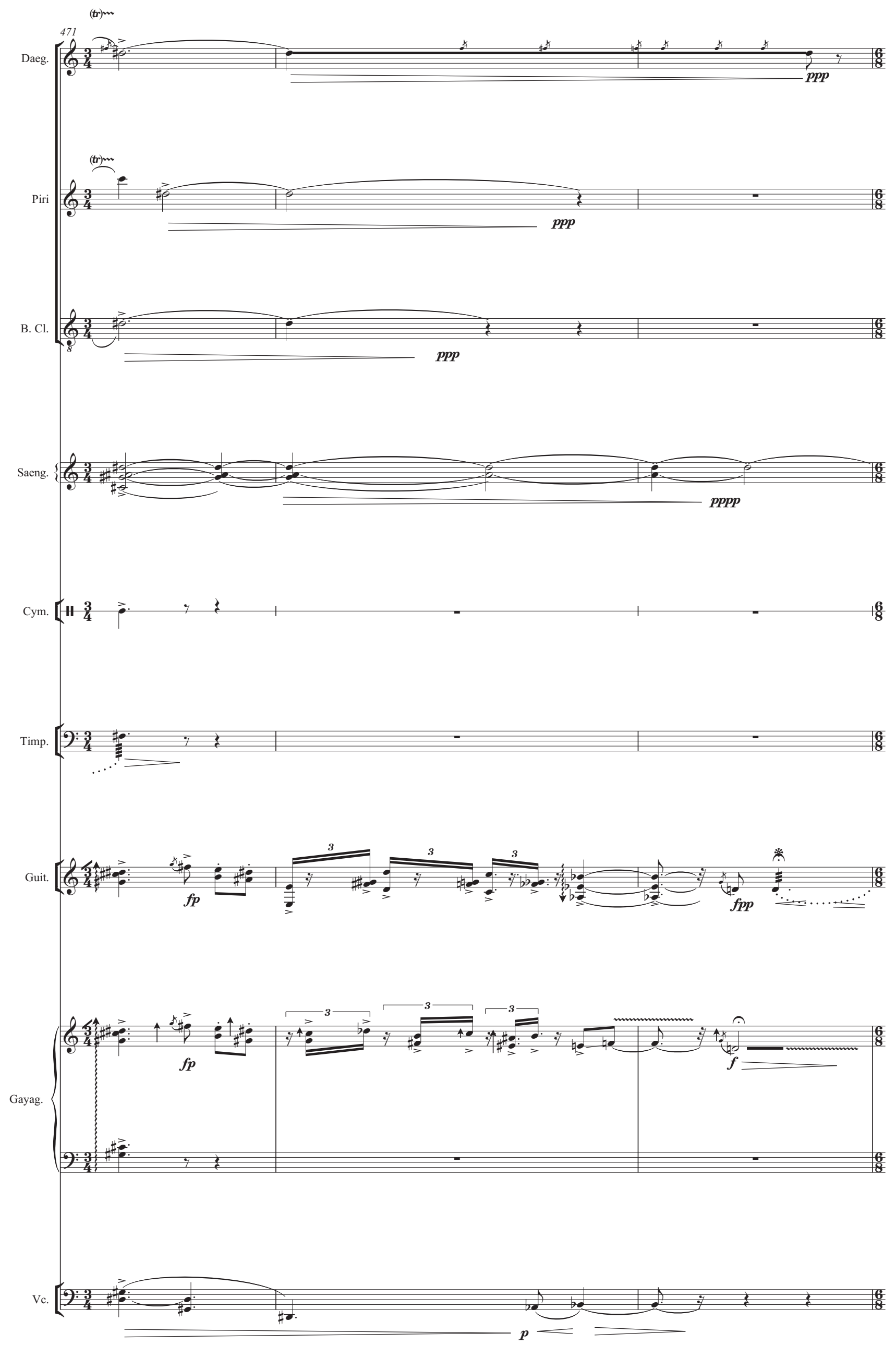

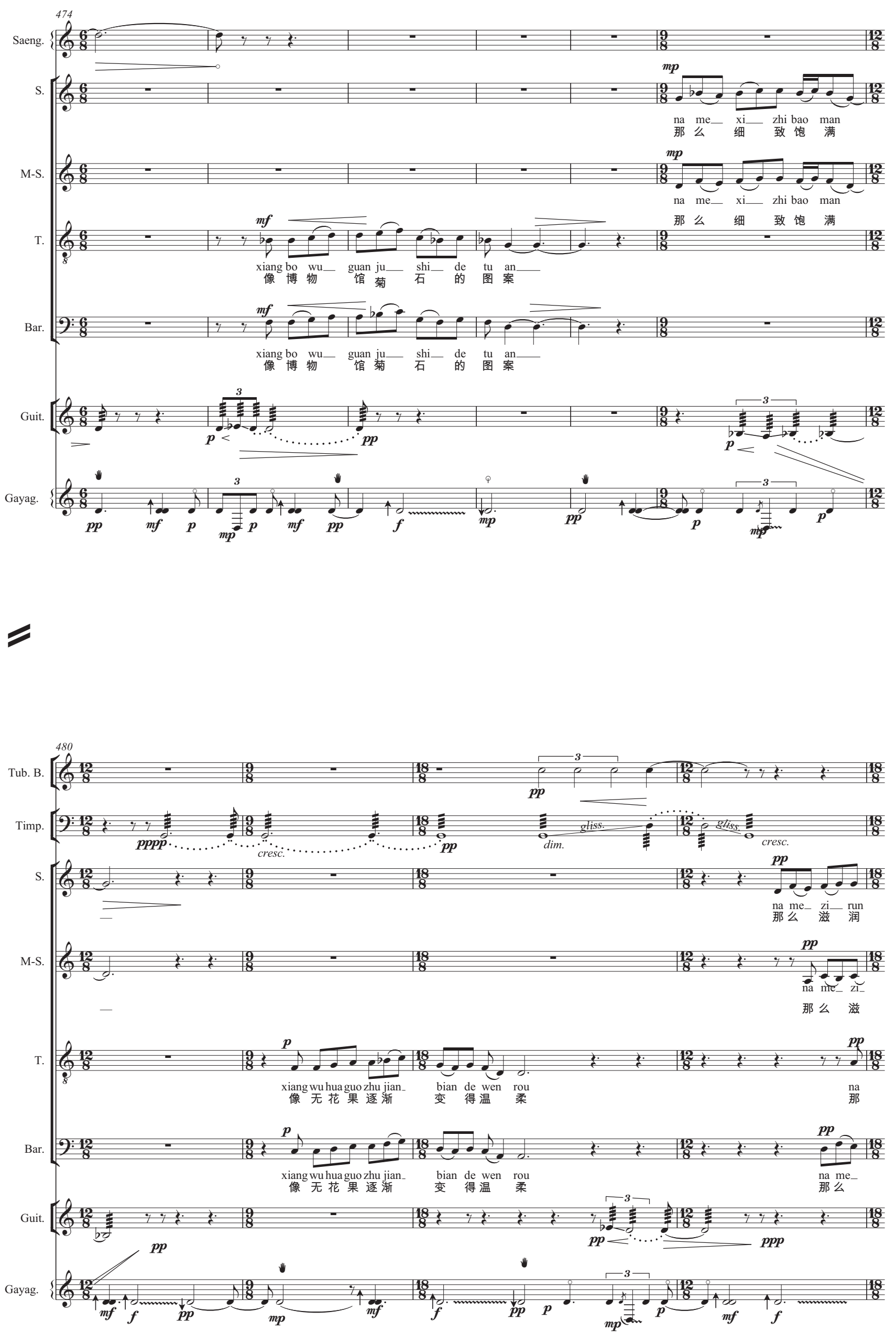

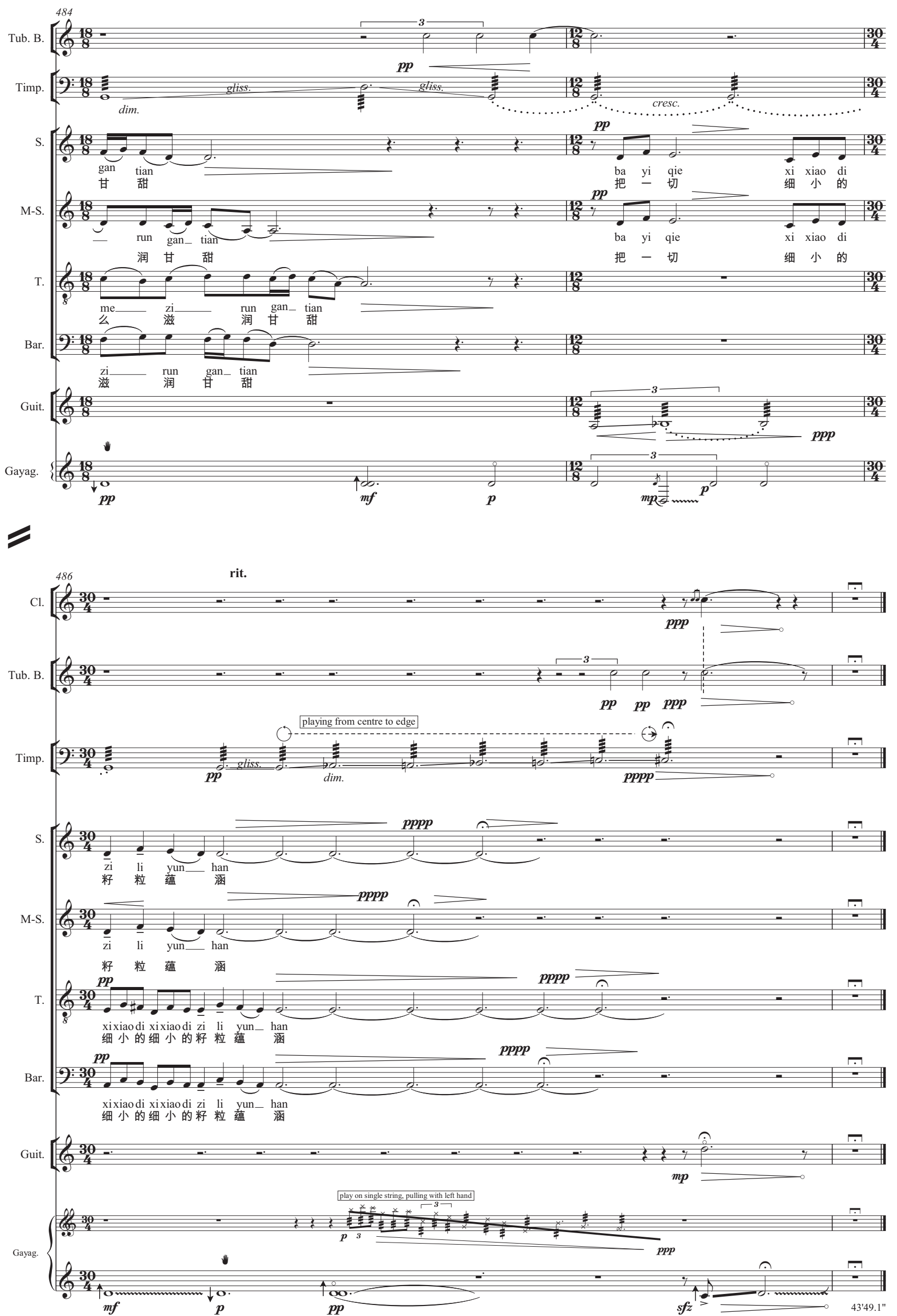